Miklós-Molnár Marianna:

A helyi önkormányzatok addicionalitásának biztosítása 
Pénzügyi Számvitel Tanszék

témavezető: Dr. Lukács János, Csc

CC Miklós-Molnár Marianna 
Budapesti Corvinus Egyetem Gazdálkodástani Doktori Program

Miklós-Molnár Marianna:

\section{A helyi önkormányzatok addicionalitásának biztosítása}

Ph.D. értekezés

Budapest

2012. 


\section{Tartalomjegyzék}

$\begin{array}{lr}\text { 1. Bevezetés - a kutatás határai és célja } & 8\end{array}$

2. A regionális politika elemei, hatása $\quad 12$

2.1. Regionális politika az Európai Unióban $\quad 12$

2.1.1. Történeti áttekintés $r$

2.1.2. Reformlépések a regionális politikában 13

2.1.3. Alapelvek és célrendszer az Európai Unió regionális politikájában 16

2.2. A regionális politika eszköztára $\quad 21$

2.2.1. Közösségi kezdeményezések, Kohéziós Alap, Strukturális Alapok 22

2.2.2. A 2000-2006 közötti programozási periódus forrás elosztásának alapelvei 24

2.2.3. A régiók mint beavatkozási területek 25

2.2.4. A strukturális politika jelene $\quad 26$

2.2.5. Kritikák az eszköztárban 28

2.3. A támogatások hatásának mérhetösége 28

$\begin{array}{lr}\text { 2.3.1. Mérhetöségi anomáliák } & 28\end{array}$

2.3.2. Hatásvizsgálat és elemzési lehetöségek $\quad 30$

2.3.3. A nemzetközi fejlesztési segélyektöl az európai támogatásokig 34

2.3.4. A támogatások hatásának mérése: a módszertani keretek kialakulása 39

2.3.5. A makrogazdasági mutatók változása Magyarországon 2004 és 2008 között 45

2.3.6. Módszerek értékelése, alkalmazhatósága, lehetöségek 49

2.4. Az addicionalitási szempontok érvényesülése más tagállamokban 50

2.4.1. Önkormányzatok lehetöségei európai uniós támogatás felhasználására 50

3. Magyarország az Európai Unióban $\quad 54$

3.1. A magyarországi intézményrendszer a 2004-2006-os programozási periódusban 55

3.1.1. Programozás és Nemzeti Fejlesztési Terv $\quad 55$

3.1.2. A megvalósitás intézményrendszere 2004-2006 között 56

3.2. A Strukturális Alapokból finanszírozott operativ programok pénzügyi lebonyolításának folyamatai 58

3.2.1. Finanszírozási kapcsolatok a tagállamon belül $\quad 58$

3.2.2. Elszámolás az Európai Bizottsággal $\quad 59$

3.2.3. Költségvetési kapcsolatok a támogatások igénybevételekor Magyarország és az Európai Unió között

4. Magyarországi helyi önkormányzatok mozgástere és az addicionalitás biztosítása 62

4.1. Az önkormányzatiság kialakulása Magyarországon 62

4.1.1. Helyi Önkormányzatok Európai Chartája $\quad 62$

4.1.2. A rendszerváltást követö időszak

4.2. Az önkormányzatok finanszírozási háttere $\quad 65$

4.2.1. Elméleti megközelitések a helyi adókra vonatkozóan 65

4.2.2. Magyarországi önkormányzatok gazdálkodása 1991-2000 között 67

4.2.3. Magyarországi önkormányzatok gazdálkodása 2000-2006 között 70

4.2.3.1. Az európai uniós csatlakozás kapujában

4.3. Eladósodási folyamatok $\quad 74$

4.3.1. Forrásbevonás lehetöségei $\quad 74$

4.3.2. Forrásbevonás és annak szabályozása Magyarországon $\quad 77$

4.3.3. Hitelfelvétel értékelése és kockázatai $\quad 79$

4.3.4. Az önkormányzati forrásszabályozással szemben megfogalmazott kritikák 83

4.3.5. A szabályozó környezet változása napjainkban 86

4.4. Az addicionalitási szempontok érvényesülése más tagállamokban 88 
4.5. A beszámolási rendszer kritikája és számviteli elszámolások az európai uniós támogatások folyamatában

4.5.1. Kritikák az önkormányzatok beszámolóinak információtartalmáról

4.5.2. Szavazati egység elmélet

4.6. Az európai uniós támogatások számviteli elszámolása

4.6.1. A támogatások nyilvántartása eredményszemléletü megközelitésben

4.6.2. A támogatások nyilvántartása módositott teljesités szemléletben

4.7. Az önkormányzatok mint kedvezményezettek számviteli elszámolása

\section{Hipotézisek megfogalmazása és a kutatás empirikus megalapozása}

6. A kutatás módszertana és a hipotézisek tesztelése

6.1. A kutatás empirikus megalapozása

6.1.1. Az adathalmaz eredete és az adatgyüjtés módja

6.1.2. Az adathalmaz feltáró elemzése

6.2. A hipotézisek tesztelése

6.2.1. A H1 hipotézis tesztelése

6.2.2. A H2 hipotézis tesztelése

6.2.3. A H3 hipotézis tesztelései

6.2.4. A H4 hipotézis tesztelése

6.2.5. A H5 hipotézis tesztelése

1. számú melléklet: A regionális politika célkitüzései

2. számú melléklet: A tagállamoknak támogatást nyújtó alapok (2000-2006 programozási periódus)

3. számú melléklet: Térkép az 1. célkitüzés szerint támogatható ás átmeneti támogatásban részesülö régiókról

4. számú melléklet: A Nemzeti Fejlesztési Terv (2004-2006) operatív programjai

5. számú melléklet: Strukturális Alapokból támogatott operatív programok magyarországi intézményrendszere 2004-2006

6. számú melléklet: Kifizetési folyamatok Strukturális Alapokból megvalósuló projektek esetében

7. számú melléklet: A hipotézisekben szereplö fogalmak operacionalizálása

8. számú melléklet: Könyvviteli mérlegek és költségvetési jelentések szerkezete

9. a) számú melléklet: A Központi Statisztikai Hivatal honlapjától letöltött adatok köre

9. b) számú melléklet: A Nemzeti Fejlesztési Ügynökség EMIR NFT adatbázisának kutatás szempontjából releváns változói

10. számú melléklet: Az adatbázis feltárásához kapcsolódó adatok

11. számú melléklet: A H2 hipotézis tesztelésének eredményei

12. számú melléklet: A H3 hipotézis tesztelésének eredményei

13. számú melléklet: A H3.1 hipotézis tesztelésének eredményei

14. számú melléklet: A H4 hipotézis tesztelésének eredményei

15. számú melléklet: A H5 hipotézis tesztelésének eredményei 


\begin{abstract}
Ábrajegyzék
1. számú ábra a regionális politika elveinek magyarországi viszonyairól 19

2. számú ábra az egy före jutó GDP változásáról 2004-2008 között, régiónként 46

3. számú ábra az egy före jutó GDP százalékos növekedéséröl, bázisévnek tekintve 2004-et 47

4. számú ábra a munkanélküliségi ráta változásáról 2004-2008 között, régiónként 49

5. számú ábra az elszámolás és átutalás igénylés folyamatáról 59

6. számú ábra a kifizetési folyamatokról Strukturális Alapokból megvalósuló projektek esetében 179
\end{abstract}




\section{Bevezetés - a kutatás határai és célja}

Magyarország európai uniós csatlakozásától számítva több mint hét év telt el, ami a támogatások igénybevétele szempontjából két programozási periódust jelent. Bár a 2004-2006 közötti időszakban felhasznált források nagysága töredéke a jelenlegi, 2007-2013-as időszakban felhasználhatónak, mégis az első programozási periódus meghatározó volt hazánk számára. Egyrészt tudástranszfernek tekinthető a tanulóidőszakként értelmezhető három év, másrészt pedig a források felhasználásával számos projekt valósult meg.

A támogatások felhasználásának értékelésére egy sor elméleti modell születettelsősorban az Európai Bizottság nyomására -, amelyek mind ex ante, mind ex post értelemben mérik, illetve mérhetik a támogatások hasznát, és ezáltal a fejlettségbeli különbségek mérséklődését, vagy éppen a további leszakadást. (White 1992), (Nagy 2008), (Kengyel 2003), (Dall'erba 2005), (Santos 2008), (Tatar 2010) A gyakorlatban használatos GDP és munkanélküliségi ráta mutatókon jelentősen továbblépő modellek nemcsak elméletben, hanem konkrét ország-példákon keresztül igazolták, hogy a támogatások folyósításának ellenére a fejlettségbeli különbségek egy-egy újonnan csatlakozó ország régiói között nem csökkennek, hanem nőnek. (Trón 2008), (Valentinyi 1995)

Az alkalmazott modellek többsége makroszintü megközelítést alkalmaz. Kevés módszer építkezik lentről felfelé, hiszen a megvalósítás programszerkezete miatt a projektszintű elemzés meglehetősen összetett. Ugyanakkor egy mikroszintü megközelítés nem feltétlenül vezet el közvetlen módon azokhoz - az évtizedek óta alkalmazott mutatókhoz, amelyek egy-egy régió fejlettségi szintjének megítélésére szolgálnak, és ezáltal a források szétosztásakor kulcsfontosságú szerepet töltenek be.

Az Európai Unióhoz 2004-ben és azt követően csatlakozott tagállamok - köztük Magyarország - esetében a fejlettségbeli különbségek csökkentésének egyik lehetséges eszköze a regionális politika által nyújtott eszköztár egészének hatékony felhasználása. A gazdasági fejlődés előmozdítása érdekében nem elegendő, ha a programokat alaposan megtervezik, ugyanilyen alaposságra van szükség azok végrehajtásakor és eredményeinek értékelésekor is. Mikro megközelítésben ez alatt azt érthetjük, hogy a nemes projektcél és 
a támogatói szándék mellett a potenciális kedvezményezettnek megfelelő erőforrásokkal kell rendelkeznie.

A kutatás középpontjában az európai uniós támogatások felhasználása és az addicionalitás alapelve közötti összefüggések állnak. Több szempontú, kitekintő jellegü elméleti megközelítéssel értekezésemben azt vizsgálom, hogy a támogatások felhasználása, a megvalósításhoz szükséges önerő, valamint a hitelfelvétel és eladósodás között milyen összefüggések körvonalazódhatnak.

A dolgozat tehát multidiszciplináris jellegü, mivel váltakoznak benne a regionális politikai, a gazdaságpolitikai és a számviteli megközelítésü gondolatok, amelynek szükségszerü következménye az, hogy nem lehet mindhárom megközelítés külön-külön, önmagában véve teljes. A dolgozat írásakor arra törekedtem, hogy egy-egy fejezeten belül a mondanivaló koherens legyen, és követhető módon épüljön fel.

Az európai uniós támogatások önmagukban nem értelmezhetők. Egyrészt minden tagállam gyakorlata más és más, másrészt a kedvezményezettek köre meghatározó a támogatások felhasználása szempontjából. Az addicionalitás alapelve értelmében a helyi szint aktív hozzájárulása - mind a tervezési folyamatokban, mind pénzügyi értelemben alapfeltétele annak, hogy az adott terület, illetve pályázó a támogatás jogosultjává váljon. $\mathrm{Az}$ addicionalitásnak tehát érvényesülnie kell mind kormányzati, mind pedig helyi szinten, melyek között kapocsként a dolgozat fókuszaként tárgyalt helyi önkormányzatok állnak.

Az addicionalitás vizsgálatához azonban meg kellett határoznom egy olyan mikroszintü elemzési egységet, amely a kutatás elméleti és gyakorlati része szempontjából is jól értelmezhető. Kiemelt célom, hogy az eredmények empirikus módon megfelelően, statisztikai értelemben stabilan alátámasztottak legyenek. Ehhez egyrészt olyan elemzési egységek választására törekedtem, amelyekkel kapcsolatosan számos kritika fogalmazódott meg a szakirodalomban, másrészt olyan számviteli adatok is rendelkezésre állnak, amelyek megbízhatók, mások által már ellenőrzöttek. Mivel az önkormányzatokat egyfajta kapocsnak tekintem az addicionalitás szempontjából, a választásom a magyarországi helyi önkormányzatokra esett.

A dolgozat bőséges elméleti felvezetőjét elsődlegesen nem a hipotézisekhez vezető út bemutatásának tekintem, hanem önálló - elsősorban szakirodalmi feldolgozásra épülő - 
kutatásom integráns részének. Arra törekedtem, hogy a dolgozat multidiszciplináris jellegének megtartása, és az egyes fejezetek tartalmának éles elkülönítése mellett logikus levezetéssel jussak el a hipotézisek megfogalmazásáig.

Az elméleti megalapozás egyik fő irányát az európai uniós támogatások felhasználásának módja képezi. Ennek megismerése érdekében indokoltnak tartok egy mélyebb, átfogó elméleti felvezetést egyrészt a regionális politika eszközrendszerének bemutatása, másrészt a támogatások hatásai mérhetőségének ismertetése, harmadrészt pedig a Magyarországon kialakított támogatási rendszer felvázolása érdekében. (2. fejezet)

A hazai támogatási rendszer átfogó, ugyanakkor leíró jellegü bemutatása (3. fejezet) két fő célt szolgál: egyfelől bemutatja azokat a szervezeti és pénzügyi kapcsolatokat, amelyek a támogatások által okozott hatások közötti logikai összefüggéseket világítják meg, másrészt pedig megalapozzák a támogatások folyósításának kezelését érintő dilemmákat a támogató és a támogatott szempontjából.

A kép az önkormányzatokat taglaló fejezetben (4. fejezet) közel sem lehet teljes: bár a fiskális föderalizmus meglehetősen szerteágazó elméletének tárgyalása, illetve a pénzügyi autonómia és hatékonyság kérdéseinek taglalása beleillene a gondolatmenetbe, mégsem részletezem azokat, mivel a támogatások hatását nem a centralizáció-decentralizáció és a hatalom koncentrációja szempontjából elemzem, hanem az addicionalitás biztosítására fókuszálok. Fentiekkel összefüggésben az önkormányzatiság tárgyalásakor hasonlóan nehéz megtartani az egyensúlyt az egyes önkormányzati szintek között, ugyanis a kérdés tárgyalása jóval túlmutat a dolgozat keretein, az önkéntes szerveződésektől a regionális önkormányzatok koncepciója, valamint a regionális térszerkezeti alternatívák felé vinné az elméleti megalapozást, ami bár - mind hazai, mind nemzetközi - szakirodalmát tekintve jól kutatható elméleti téma, de a kutatás tervezett empirikus elemeitől meglehetősen messze áll.

Az önkormányzatok esetében az addicionalitás elvének érvényesülése csak a jogi- és gazdasági környezetük összefüggéseinek ismeretében értelmezhető. Az önkormányzatok gazdálkodását többféle megközelítésből elemző bőséges szakirodalomból azokat emeltem ki, amelyek akár érintőlegesen is, de tárgyalják az addicionalitással kapcsolatos kételyeket, illetve az eladósodási folyamatok hátterét. Bár az önkormányzatok finanszírozásával kapcsolatosan számos kritika megfogalmazódott (Pitti 2005), (Kassó 
2006a), (Romhányi 2007), ezek közül is azokra helyezem a hangsúlyt, amelyek a kutatás empirikus részével összekapcsolhatók, annak keretében értelmezhetők. A disszertációban rövidem elemzem gazdálkodásukat, forrásszerkezetüket, ezen belül is a hitelfelvételt mint az addicionalitás követelménye teljesítésének egyik lehetséges, ugyanakkor napjainkban vitatott témáját.

A kapcsolódó nemzetközi kitekintés bemutatásával feltérképezem, hogy az addicionalitás biztosítása milyen terheket ró a gazdaság szereplőire más tagállamok esetében.

Az egyes hipotézisek összegző, csokorban történő bemutatását (5. fejezet) elsősorban az indokolja, hogy az elméleti szakirodalomban bemutatottak alapján az egyes hipotézisek több tudományterületet érintenek, egymáshoz szorosan kapcsolódnak, ezért azok különkülön történő taglalása mind elméleti, mind empirikus értelemben - a dolgozatban felesleges ismétlődésekhez, redundanciához vezetne.

A kutatás elméleti megalapozásához és az empirikus vizsgálatok lefolytatásához (6. fejezet) sokat segített a doktori tanulmányok korábbi szakaszában készített többváltozós adatelemzési feladat, amelynek előkészítéséhez még 2006-ben megismerhettem azokat az adatbázisokat, amelyek összekapcsolása az empirikus elemzés alapjául szolgálhat. Olyan adatbázisként tekintettem akkor a - többek által meglehetősen erősen kritizált (Kopányi, Vigvári 2003), (Kassó 2006b), (Vigvári 2009b) - önkormányzati beszámolókból felépített adatállományra, mint egy feltáratlan, ugyanakkor kincseket rejtő szigetre. Bár kezdeti próbálkozásaim a jelenlegi kutatás szempontjából is hasznosnak bizonyultak, elméleti alapok nélkül nem jelentett többet, mint egyszerü szárnypróbálgatást, ezért a kutatásom módszerét induktív $\rightarrow>$ deduktív $\rightarrow>$ induktív irányba tereltem.

Kutatáshoz hasonló példát a külföldi szakirodalomban - vélhetően az európai uniós támogatások felhasználásában, az önkormányzatiságban és a hitelfelvételi szabályokban, valamint azok együttesében rejlő eltérések miatt - nagyon keveset találtam. Ennek ellenére valamennyi fejezet elméleti felvezetésénél igyekeztem felvázolni a nemzetközi tapasztalatokat még akkor is, ha azok csak érintőlegesen kapcsolódnak a témához. A kutatást időbeliségében a Nemzeti Fejlesztési Tervre, vagyis a 2004-2006 közötti időszakra szükítettem. Ennek oka elsősorban az, hogy ezen programozási periódushoz kapcsolódó statisztikai adatok, beszámolók már rendelkezésre állnak. 


\section{A regionális politika elemei, hatása}

\subsection{Regionális politika az Európai Unióban}

\subsubsection{Történeti áttekintés}

Az európai regionális politika kezdeti szakasza a Római Szerződésre (1957) nyúlik vissza, amelynek Preambulumában megjelenik a különböző régiók között meglévő különbségek, és a hátrányos helyzetủ régiók elmaradottságának csökkentése ${ }^{1}$, valamint az, hogy az integráció hátrányos következményei ellen intézkedéseket kell tenni. A fejlődésbeli eltérések ugyanis gátolják az áruk, a szolgáltatások, a tőke és a munkaerő szabad áramlását, és ezáltal korlátozzák a belső piacot.

Európa területi adottságainak és az egyes országok eltérő történelmének, kultúrájának következtében a gazdasági viszonyok eltérően alakultak az egyes térségekben, azonban az Európai Gazdasági Közösség tagállamaiban a regionális politika² iránti igény 1975 és 1988 között kezdett megfogalmazódni, ugyanis addig a tagállamok közel azonos fejlettségi szinten álltak, és meglehetősen nagy kohéziós képességgel bírtak. A hetvenes évektől kezdve növekvő mértékben jutott szerephez a közösség gazdasági és szociális kohézióját szolgáló regionális támogatási rendszer. (Illés 2002) A kevésbé fejlett és szerkezetváltozáson keresztülmenő régiók növekedési potenciáljának kiaknázása a tagállamok közös érdeke, hiszen ezek a régiók alapozhatják meg az európai gazdaság gyorsabb növekedését. (Kengyel 2007a)

Dánia, Írország és az Egyesült Királyság 1973-as csatlakozását követően, 1975-ben hozták létre az Európai Regionális Fejlesztési Alapot, amelynek célja a források átcsoportosítása volt a gazdagabb régiók felöl a szegényebb régiók felé, különösen infrastrukturális beruházások megvalósításával. A program első évtizedét a nemzeti kvóták meghatározása tett ki, míg a tagállamok - összhangban a szubszidiaritás elvével országon belül érvényesítették a regionális politika elveit. (Kende, Szücs 2002) Az Európai Közösségek Tanácsa 1979-ben létrehozta a közösségi finanszírozási programok rendszerét, és ún. programszerződések keretében a hanyatló ipari térségek és a határmenti régiók fejlesztésére a nemzeti kvótákon felül támogatást biztosított.

\footnotetext{
${ }^{1}$ A közös regionális politika ugyanakkor nem szerepelt a Római Szerződésben. (Kende, Szücs 2002)

2 A regionális politika már korábban, 1967-ben intézményi szintre emelkedett, amikor önálló fơigazgatóságot hoztak létre a regionális politika kezelésére.
} 
Elörelépést jelentett a szabályozásban, hogy 1984-ben meghatározták a közösségi támogathatóság kritériumait, általánossá tették a fejlesztési programok elkészítésének kötelezettségét, valamint növelték a programok átláthatóságát, a nemzeti kvóták terhére. (Szegvári 2002)

\subsubsection{Reformlépések a regionális politikában}

A bővítés, a mediterrán államok felvételének eredményeként a fejlett országokban a „hajtóerő túlzott területi koncentrációja indult meg”, míg a perifériák, az agrárnépesség növekedése, a munkanélküliek arányának emelkedése és az elmaradott térségben élők számának megduplázódása problémát jelentett a fejlett országoknak (Szörényiné Kukorelli 2000), és a jólét mértékének a különbsége is erősen polarizálódott, ugyanis a gazdasági teljesítőképesség elmaradottsága fejletlenebb térségekkel társult. A gazdasági és a szociális különbségek az egyes régiókban a jövedelemtermelő-képességben és a munkaerő-foglalkoztatási lehetőségek eltérésében testesültek meg, amely önálló területfejlesztési politika kialakítását tette szükségessé. (Szegvári 2002)

A gazdasági integráció önmagában nem lehetséges, az egyes területek közötti egyenlötlenségeket mint negatív jelenségeket mérsékelni, kezelni kell. Az egyenlőtlenségek kezelése olyan aktív eszközök biztosításával lehetséges, amelyekkel a jóléti nyereségek szétteríthetők, hiszen az integráció előnyei nem minden régióban jelentkeznek azonos mértékben, így aktív eszközök nélkül „,a fejlődés még inkább az EU központi régióiban koncentrálódik.” (Kengyel 2003)

Az európai integráció bővülésének korai szakaszaiban - az 1970-es évektől, amikor az integráció határain belül Írországgal megjelentek az első, az átlagosnál jóval alacsonyabb fejlettségű területek - a tapasztalat a konvergencia automatikus müködésére engedett következtetni: az EU-15 esetén még úgy tünt, hogy a különböző területek gazdasági fejlettsége - legalábbis az integráción belül - valóban valamely közös egyensúlyi állapot felé tart (Beugelsdijk, Eijffinger 2005); (Churski 2008).

A regionális politika fejlődésében mérföldkőnek és egyben reformnak tekinthető az Európai Egységes Okmány (1986), amely célként határozta meg a régiók közötti egyenlőtlenségek, a legkedvezőtlenebb helyzetü régiók lemaradásának csökkentését, és önálló politikaként nevezte meg a regionális politikát. Ennek eszközeként egyrészt a tagállamok gazdaságpolitikájának összehangolását, másrészt a Strukturális Alapok 
létrehozását jelölték meg. Az Európai Egységes Okmány szerint az Európai Regionális Fejlesztési Alap rendeltetése, hogy „elösegítse a Közösségen belüli legjelentősebb regionális egyenlőtlenségek orvoslását a fejlődésben lemaradt térségek fejlesztésében és strukturális alkalmazkodásában, valamint a hanyatló ipari térségek átalakításában való részvétel útján”. (Európai Egységes Okmány, 130c. cikk) A regionális politika reformjának keretében célként fogalmazódott meg olyan eszközök alkalmazása, amelyekkel - hosszú távú programok megvalósításán keresztül - tényleges gazdasági hatásokat lehet elérni, és partnerkapcsolatokat lehet kiépíteni egyes régiók, tagállamok között.

Az 1988-as reform eredményeként növelték a regionális politika jelentőségét, megemelték a rendelkezésre álló pénzügyi forrásokat, a projekt-finanszírozással szemben előtérbe került a programozás, valamint az addicionalitás, a decentralizáció és a partnerség elve. (Szegvári 2002) Ezzel lehetővé vált a legkedvezőtlenebb helyzetü régiók koncentrált, összehangolt, programozott fejlesztése, támogatása, melyet tovább erősített az is, hogy a tervezhetőség érdekében időszakokat, ún. programozási periódusokat ${ }^{3}$ (költségvetési tervezési időszak) határoztak meg, melyekben kijelölésre kerültek a fejlesztési prioritások, a rendelkezésre álló források összege, valamint azok felhasználásának módja is. Az Európai Szociális Alap is a regionális politika eszközei közé került, ugyanis a munkaerő fejlesztésével kapcsolatos támogatások befolyásolják a regionális fejlettségi különbségek alakulását. (Kengyel 2007a)

A regionális politika fejlődésének második főbb állomása a Maastrichti Szerződés (1992), amely Preambulumában megfogalmazta a megerősített kohéziónak és a környezetvédelemnek a keretében a gazdasági és társadalmi fejlődést, és célként tüzte ki a gazdasági és társadalmi kohézió megerősítését, ezzel előkészítette a Kohéziós Alap megteremtését. (Kende, Szücs 2002)

A 2000-2006 közötti programozási periódusra felkészüléskor, valamint a kelet-közép-európai országok csatlakozási tárgyalásainak előkészítésekor az 1999-ben elfogadott Agenda 2000 program tekinthető a regionális politika harmadik reformjának, amelynek előkészítésekor a nettó befizető és a nettó kedvezményezett tagállamok eltérő álláspontot képviseltek. Míg a nettó befizető tagállamok a kiadások stabilizálására törekedtek, addig a nettó kedvezményezettek a legmagasabb támogatást nyújtó év (1999)

${ }^{3}$ 1988-1993; 1994-1999; 2000-2006; 2007-2013 
támogatásait kívánták alapul venni a költségvetési keretek meghatározása során. Az Agenda 2000 legfőbb eredménye, hogy újraszabályozta a regionális politika alapelveit, a Strukturális Alapok és a Kohéziós Alap müködését, valamint létrehozta az ISPA és a SAPARD előcsatlakozási eszközöket. A koncentráció elvének érvényesülése érdekében a támogatandó célok számát háromra szűkítették, és az Európai Unió keleti bővítése miatt bevezették a támogatási jogosultságukat elveszítő régiók átmeneti támogatásának intézményét. (Iván 2001) Fentieken túl meghatározásra került a 2000-2006 közötti programozási periódus költségvetése is.

A dokumentum a gazdasági-társadalmi kohézió célkitüzéseit fogalmazza meg, azonban a koncentráció elvének megfelelően csökkentette a támogatásban részesülő térségek típusait ${ }^{4}$, és megkövetelte a tagállamoktól a nemzeti támogatás-politika irányelveinek összhangba hozását a közösségi regionális politika szempontjaival, figyelemmel az addicionalitás elvére.

Míg a 2000-2006 programozási periódust megelőzően a tagállamok a fejlesztési programok meghatározásában és a végrehajtás irányításában ágazati szempontokat vettek figyelembe, centralizált elosztási politikát alkalmaztak és a regionális hatóságok szerepe elenyésző volt, addig a fentiek a 2000-2006 közötti időszakban ellentétes irányba mozdultak. (Horváth 2001) A globális teljesítőképesség növelése és a regionális különbségek csökkentése érdekében már a 2000-2006 közötti programozás periódus előkészítésekor megfogalmazódott a régiók felelősségén nyugvó szubszidiaritás, és a régiók saját erőforrásainak hasznosítása mint kiemelt cél.

A kelet-közép-európai országok csatlakozásával a jóléti transzferek jelentős mértékben a keleti tagállamok felé mozdultak, vagyis a keleti bővítéssel a regionális politika újra nagy változáson ment keresztül, „valószínűsíthető, hogy a kohézió koncepciója 2007 és 2013 között érvényesül a legnagyobb mértékben” (Marján 2009), azonban a hatásai még nem értékelhetők. Az újonnan csatlakozott tagállamok kevésbé fejlett régióiban rejlő gazdasági potenciál kiaknázása nagy kihívást jelent az Európai Unió és egyben a regionális politika számára. (Kengyel 2008)

\footnotetext{
${ }^{4}$ A korábbi hat helyett három célkitűzés maradt. A kieső három célkitűzés bemutatásától eltekintek, mivel Magyarország akkor még nem volt tagja az Európai Uniónak. Lásd (Szörényiné Kukorelli 2000)
} 
Az Európai Unió keleti irányú bővítésével a leggazdagabb és legszegényebb régiók közötti jövedelemkülönbségek a csatlakozást megelöző 2,6-szoros értékről 4,4-szeresre nőttek, amely mutató Románia és Bulgária 2007-es csatlakozásával 5,3-szeres értékre emelkedett. A keleti irányú bővítést követően még erőteljesebb az igény a regionális szinten jelentkező kimagasló fejlettségi különbségek csökkentésére, és a gyorsabb gazdasági növekedés feltételeinek megteremtésére. (Kengyel 2007a) (Musyck és Reid, 2007)

A 2007-2013-as programozási periódus azért meghatározó, mert a versenyképességet befolyásoló tényezőket ebben a periódusban úgy kell alakítani, hogy a kevésbé fejlett régiók társadalmi és gazdasági szerkezetének átalakulása mellett a tőkevonzó képességük megnőjön, a vállalkozási kedv megélénküljön, ezáltal legyen biztosítva a lehetőség a hosszú távon érvényesülő fejlődési potenciál kiaknázásának, valamint a gazdasági növekedés gyorsabb beindításának. (Barca 2009)

A regionális politika a legösszetettebb szakpolitika, ugyanis aktívan szolgál számos más politikát, és fejlődése az európai integráció elmélyülésével párhuzamba állítható (Marján 2009), ugyanakkor a fejlődési perspektívák száma behatárolt. A pénzügyi szolidaritás hosszabb távon fennmaradhat, illetve háttérbe is szorulhat, azonban az Európai Unió tagállamaiban nem mutatkozik hajlandóság az uniós finanszírozás növelésére, ami számos kérdést - többek között a támogatások regionális szintről országok szintjére emelését - megnyit a regionális politika körében. (Szemlér 2007)

\subsubsection{Alapelvek és célrendszer az Európai Unió regionális politikájában}

A regionális támogatásokkal kapcsolatos alapkövetelmény, hogy támogatás csak a hátrányos helyzetü térségekben adható, melyek fő célkitüzése a régiók fejlesztése, elsősorban beruházások megvalósításához, illetve munkahelyek teremtéséhez. A támogatások felhasználásának alapelvei egymással kölcsönösen összefüggő rendszert alkotnak.

A szubszidiaritás és a transzparencia az Európai Unió egészének működésére vonatkozó alapelvek. A transzparencia megköveteli, hogy a programozási folyamat átlátható, a döntések szempontrendszere világos legyen, illetve - szükebb értelemben - a támogatások ellenőrizhetők legyenek. (Kengyel 2007a) 
A szubszidiaritás alapelve szerint az Európai Unió a közösségi strukturális politika eszközeivel nyújt támogatást, vagyis a kedvezményezettek önállósággal és felelősséggel rendelkeznek. A támogatásokat olyan célok elérésére kell használni, amelyek saját forrásból nem valósíthatók meg, továbbá a támogatások kiegészítő jellegủek, vagyis nem helyettesítik a nemzeti, regionális, helyi fejlesztéseket. (Szegvári 2002)

A Maastrichti Szerződés (1992) értelmében a Közösség csak akkor és abban a mértékben avatkozik be, „amennyiben a tervezett intézkedés célkitüzéseit a tagállamok nem tudják kellöen megvalósítani”.

A szubszidiaritás alapelve szoros összefüggésben van a decentralizáció alapelvével, ami szerint a helyi, illetve területi döntéshozók eszközrendszerének megerősítésére kell törekedni, azonban azoknál a területeknél, amelyeknél a helyi vagy a regionális szint nem kellően hatékony a megvalósításban, integrációs funkció jelenik meg. A hatáskörök decentralizációjának ${ }^{5}$ megfelelő mértéke az a szint (helyi, regionális, nemzeti), ahol az önrendelkezés még - vagy közvetlenül vagy választott képviselők útján - hatékonyan megvalósul.

A szubszidiaritás és a decentralizáció alapelvével is összefügg a partnerség, ami a programok előkészítésében, végrehajtásában és ellenőrzésében részt vevők együttmüködésére utal, vagyis kifejezi azt, hogy a területi politika többszereplős, a területfejlesztési ügyek nem rögzíthetők kizárólagos állami feladatként, és csak a partnerség elvének tiszteletben tartásával kialakított, az érdekeltek által közösen kidolgozott területi, kistérségi és regionális fejlesztési célkitüzések támogathatók. (Gyulai 2000) A partnerség tehát szükségszerüen megköveteli a nyilvánosság és részvétel elvének biztosítását, hiszen egyrészt a területfejlesztési döntések meghozatalához a helyiregionális-központi szint közötti folyamatos párbeszéd szükséges, másrészt a nyilvánosság erősítésével nagyobb társadalmi támogatottság érhető el. (Szegvári 2002), (Pálné Kovács 2004) in (Horváth et al. 2004)

Az alapelvek mellett a támogatási programok kialakításában meghatározó szerepe van egyes, az eljárásmódokkal és a finanszírozással kapcsolatos követelményeknek is, amelyekhez kapcsolódó elvek szoros összefüggésben vannak az alapelvekkel. A koordináció és kooperáció a közigazgatás szervezésében meghatározó, ugyanis annak

\footnotetext{
${ }^{5}$ Értsd döntések meghozatala és végrehajtása.
} 
hatékonysága jelentősen befolyásolhatja az érintett szereplők tevékenységét mind a helyi, mind a regionális, mind a nemzeti szinten, hatással van a források elosztására, valamint arra, hogy a területfejlesztés összehangolt módon müködjön más szakpolitikákkal. A komplexitás és tervszerüség követelménye értelmében a regionális politika beépül az állami eszköztárba, azonban annak sikeréhez biztosítani kell a területi szempontok érvényesülését az ágazati döntések meghozatalában és a gazdaságpolitikában, ami megköveteli a regionális célokat beépitö gazdasági pénzügyi szabályozásokat. A tervszerüség hozzájárul ahhoz, hogy az eredmények értékelésével a célkitüzéseket és az eszközrendszert módosítani lehet, egyfajta iterációként értelmezve annak érdekében, hogy a támogatások hatása növelhető, az adott térség fejlesztési programjához, céljaihoz illeszkedő legyen. A programba illeszkedés követelménye szerint szükséges, hogy a beruházás egy térség programjában szerepeljen, vagy abba illeszkedjen, ugyanis a komplexitás és tervszerüség követelménye szerint azok a fejlesztési programok támogatandók, amelyek komplex módon hatnak egy-egy terület fejlödésére, vagyis az egyes projektek finanszírozása helyett a hosszabb távú, a fejlődést jobban segítő célkitűzések és prioritások kerülnek a középpontba. A programok tervezése során a tagállamok a helyzetleírással együtt meghatározzák az elérendő célokat, megtervezik a finanszírozás, a végrehajtás és az értékelés módját és időszakát, vagyis a programozás a tagállam és az Európa Unió többéves együttműködésén alapul. A regionális programozásban kifejeződnek az integráció lényeges pontjai, vagyis a tervezhetőség, a költségvetési egyensúly, a rászorultság és a programfinanszírozás. (Fáyné Péter 2002)

A források felhasználásának koncentrálása és decentralizálásának követelménye szerint a szubszidiaritás elvével összhangban elsődlegesen helyi szinten kell a célokat meghatározni, és a hozzájuk kapcsolódó forrásokat elosztani, ugyanakkor a hatékonyság miatt célszerü a forrásokat közösen kialakított prioritások mentén, a leginkább rászoruló régiókra összpontosítani, koncentrálni. A többcsatornás finanszírozás követelménye szerint a közösségi támogatásokat összehangoltan kell biztosítani, azonban egyidejűleg több csatornán keresztül is lehet folyósítani. Eszerint a tagállamon belül egyidejűleg bevonhatók a nemzeti, a regionális és a helyi források - beleértve az önkormányzati forrásokat is -, valamint a vállalkozói tőke és az üzleti hitelek, míg az Európai Unió a közösségi támogatást egyidejüleg több alapból is juttathatja. Az addicionalitás követelménye a szubszidiaritással együtt értelmezendő: a helyi források bevonásával vagyis Magyarországon az önerő követelményének teljesítésével - biztosítható, hogy 
érvényesüljön a hozzájárulás elve, vagyis az, hogy a támogatások kiegészítésként szolgálnak egy-egy projekt, illetve fejlesztési program megvalósításához. Ezzel a kormányzat biztosítja a támogatást, ugyanakkor a helyi és regionális területfejlesztési programokat nem kizárólag központi költségvetésből fedezi. „A beruházások megalapozottságát, a helyi adottságokkal és szükségletekkel való összhangot az biztosíthatja, ha a támogatások a helyi erőforrások bevonására épülnek." A közösségi és a tagállami fejlesztési tevékenységek együttes eredményeként értelmezhető az Európai Unió regionális politikája, ami miatt az addicionalitás kiemelt elvnek tekinthető. (Szegvári 2002), (Udvari 2010) Az addicionalitás ugyanakkor egyfajta katalizátorszerepként is értelmezhető: eszerint a közösségi támogatás a tagállami szerepvállalást egészíti ki és ezáltal csökkenti a fejlesztések időhorizontját. (Kende, Szücs 2002)

Az alapelvek, valamint az eljárásmódokkal és a finanszírozással kapcsolatos követelmények egymással kölcsönhatásban vannak, azonban azok viszonyai tagállamonként - az adott ország közigazgatási helyzetének függvényében - változnak. A fenti elvek magyarországi kapcsolatainak - egy lehetséges értelmezését - a következő ábra szemlélteti.

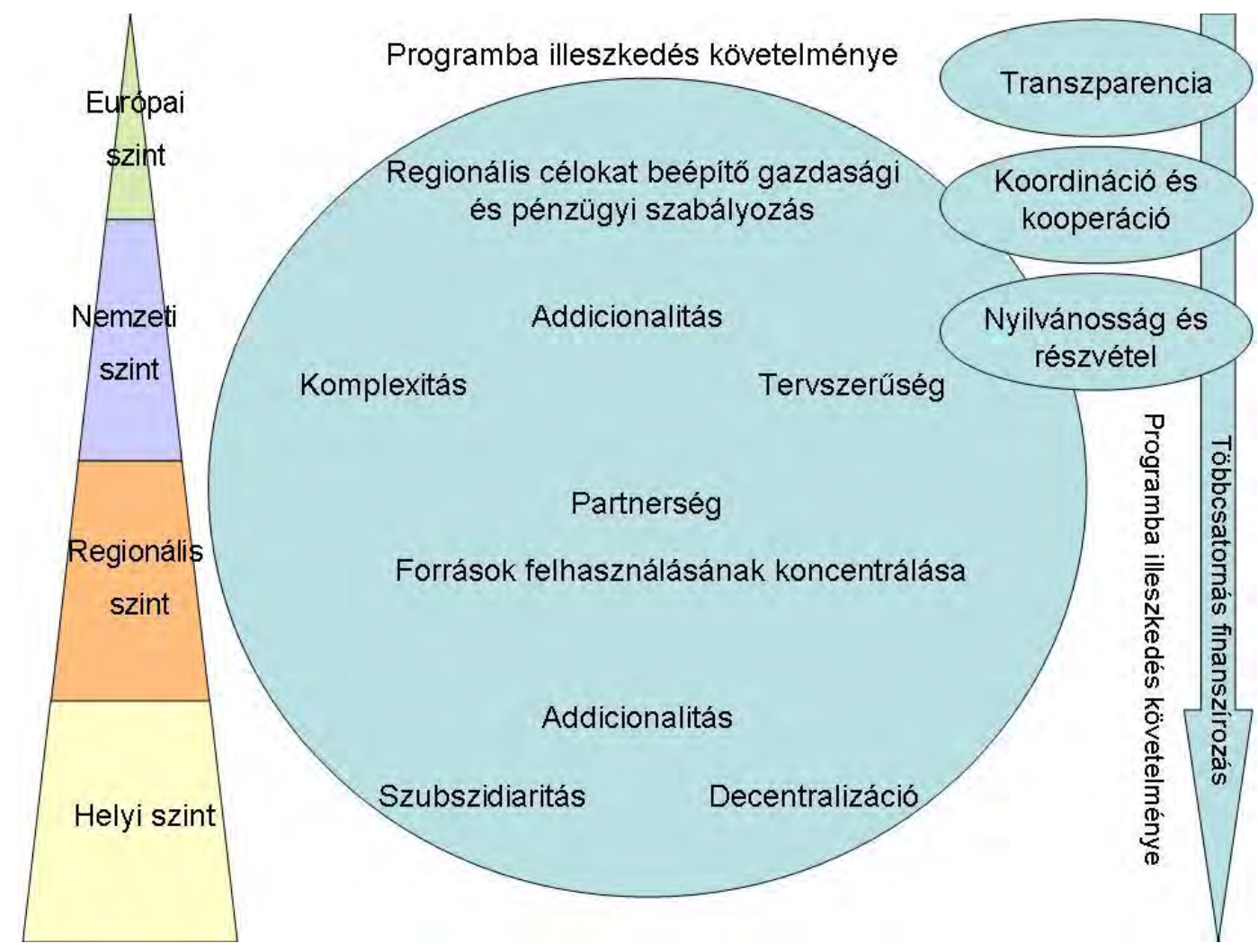

1. számú ábra a regionális politika elveinek magyarországi viszonyairól (saját készítésü ábra) 
A regionális fejlettségbeli különbségek nemcsak az egyes országok között, hanem egyes országokon belül is jelentősek, ezért a cél a térségek közötti különbségek csökkentése mind egy-egy tagállamon belül, mind a tagállamok között.

A regionális politika a helyi fejlesztési potenciál kiaknázásával, gazdaságilag releváns beruházásokkal - beleértve az infrastruktúra fejlesztését is - foglalkozik. ${ }^{6}$ Fő célkitűzése a térségi versenyképesség erősítése, ami egyrészt a térségi innovációra, másrészt a térségi felzárkóztatásra épül. Célja a regionális különbségek enyhítése, a strukturális problémákkal küzdő területek felzárkóztatása, valamint a nemzeti politikák támogatása és koordinálása (Szegvári 2002), ami egyrészt az Egységes Európai Okmányból, másrészt a Maastrichti Szerződésből következik. Az egységes piac előnyeinek kiaknázásához elengedhetetlen a „szerkezetváltási nehézségekkel” küzdő térségek versenyképességének tudatos javítása, ugyanis a fejlettségbeli különbségek csökkentését nem lehet kizárólag a piaci erökre építeni. (Kengyel 2008)

A gazdasági fejlödés javításának érdekében „fejleszteni kell az infrastruktúrát, emelni kell a munkaerő képzettségi szintjét, ösztönözni kell a vállalkozó kedvet.” (Kengyel 2003) A strukturális politika „az egyes célkitüzések összehangolt és hatékony megvalósítására törekszik az elmaradott térségekben" (Szegvári 2002), célja tehát az elmaradott régiók infrastruktúrájának, a helyi gazdaság diverzifikálásának, a munkaerő képzettségének, valamint a különböző gazdasági ágazatok termelékenységének fejlesztése.

A kelet-közép-európai országok csatlakozásával a regionális különbségek szükségszerüen növekednek, a korábbi kedvezményezett országok jogosultsága a támogatásokra csökken, ezért kevesebb forrást használhatnak. Ennek eredményeként az Európai Unió Agenda 2000 című dokumentumában első számú prioritásként a szociális és gazdasági kohéziót jelölte meg. (Horváth 2001) A regionális politika célkitüzéseit a dolgozat 1. sz. melléklete mutatja be.

\footnotetext{
${ }^{6}$ Bár dolgozatom tárgya szempontjából elsődlegesen a regionális politika releváns a közösségi politikák közül, tekintettel az Európai Szociális Alappal való szoros kapcsolatára, meg kell említenünk az európai szociális politikát is. A szociális politika elsődleges célja a munkanélküliség elleni küzdelem, a szakmai képességek fejlesztése, valamint munkahelyek és az esélyegyenlöség megteremtése; a fejlesztési potenciál kiaknázása érdekében szorosan összekapcsolódik a regionális politikával.
} 


\subsection{A regionális politika eszköztára}

A regionális politika eszköztára sokrétü. Dolgozatom terjedelmi korlátaira tekintettel elsődlegesen csak azokat az eszközöket és időszakokat emelem ki, amelyek a kutatás szempontjából meghatározóak.

Az Európai Unió a támogatásoktól a gazdasági és szociális kohézió erősödését várja. A támogatások valamennyi programozási periódusban három fő területre koncentrálódtak: emberi erőforrások fejlesztésére, vállalkozásoknak nyújtott támogatásokra, illetve infrastrukturális fejlesztésekre. Ezek eredményeként „csökken a munkanélküliség, emelkedik a jövedelem, javulnak az életkörülmények”, vagyis csökken a fejlettségi szintbeli különbség ${ }^{7}$. A képzettségi szint javítása közvetlenül és közvetetten is hatással van a vállalkozásokra: egyrészt fellendül az oktatás piaca, másrészt pedig a képzettebb munkaerő által javul a versenyhelyzet és csökken a munkanélküliség. Az infrastruktúra fejlesztésének hatása szintén közvetlenül és közvetetten is jelentkezik: egyrészt érinti a helyi vállalkozókat, másrészt pedig hozzájárul a termelési költségek csökkentéséhez, illetve bizonyos termelést korlátozó tényezőket megszüntet. Összességében tehát az infrastrukturális beruházásokkal javul a gazdasági környezet, ami növeli a régió vonzerejét. (Kengyel 2003)

A regionális politika elsődleges célja a gazdasági növekedés elősegítése, nem a jövedelem újraelosztása, tehát nem szociális transzferek és nem európai szintű jövedelemújraelosztás, hanem gazdasági növekedést elősegítő források szolgálnak a regionális politika eszközeként. A versenyképesség erősítésével és a gazdasági növekedéssel a fejlettségi különbségek mérséklődnek, hiszen az aktív regionális politika alkalmazásával kezelhetők az erőforrás-allokációból fakadó egyenlőtlenségek, az integrációból származó előnyök valamennyi régió számára érzékelhetővé válnak, az integráció elmélyül és hosszabb távon csökkenthetők az állami támogatások. (Kengyel 2008)

A regionális politika megköveteli, hogy a tagállamok többéves programokat készítsenek. Ezzel előtérbe kerülnek az integrált fejlesztéspolitikák, elmélyül a stratégiai tervezés, fejlődnek az értékelési módszerek, hiszen az Európai Unió alapkövetelményként fogalmazza meg az előrehaladás folyamatos monitoringját, és a programok előzetes, közbenső és utólagos értékelését is. A regionális politika nem mérhető hatása, hogy bár a

\footnotetext{
${ }^{7}$ Ezt a kijelentést jó néhány szerző vitatja, amelynek részletiről a dolgozat következő fejezete szól.
} 
fejlesztéspolitikák tartalma eltérő, vagyis ország-specifikus, azonban az azonos, tagállamokkal szembeni elvárás miatt a megközelítés módja és az időbeliség - a programozási periódusok ciklikussága miatt - az egyes tagállamok között azonos, ami előremutató az európai integráció tekintetében egy hasonló elvek mentén gondolkodó szakembergárda kialakulása szempontjából. Másrészről - például egy-egy határon átnyúló program miatt - megerősödik az együttmüködés az egyes tagállamok, illetve régiók között. A partnerség fejlődésével javul a fejlesztéspolitika átláthatósága, elmélyül a kooperáció és koordináció, ami hatással van a nemzeti fejlesztéspolitikák európaizálódására. A programok többéves tervezése pénzügyi szempontból is előremutató, hiszen a kiszámíthatóság stabilitást visz a megvalósítás folyamatába, amelynek pozitív hatása van a finanszírozás tervezhetőségére is. (Kengyel 2008)

A regionális politika forrásai három csoportba oszthatók: a Kohéziós Alapra, a Strukturális Alapokra, valamint a közösségi kezdeményezésekre, melyek közül a dolgozat - figyelemmel a vizsgált időszakra is - a Strukturális Alapokra fókuszál.

\subsubsection{Közösségi kezdeményezések, Kohéziós Alap, Strukturális Alapok}

\section{Közösségi kezdeményezések}

A támogatási alapot 1988-ban hozták létre, amely a nemzeti programok egyidejü végrehajtása mellett hasonló problémákkal küzdő - pl. határmenti - régiók célzott támogatását biztosította. A 2000-2006 közötti programozási periódusban a közösségi kezdeményezések olyan célokat szolgáltak, amelyek nemzetek közötti feladatokat oldottak meg. (Szegvári 2002) A Közösségi Kezdeményezések céljai a 2000-2006 közötti programozási periódusban a korábbiakhoz képest csökkentek, négy területre koncentrálódtak a következők szerint: a határon átnyúló, transznacionális és interregionális együttmüködéseket (INTERREG III.), a rurális fejlesztési célok megvalósítását (LEADER), a munkaerőpiacra jutás elősegítését (EQUAL), valamint a válságba került városok újjáélesztését (URBAN) támogatták. (Horváth 2001)

\section{Kohéziós Alap mint a regionális politika eszköze}

A Kohéziós Alapot a regionális politika második reformját követően, a Maastrichti Szerződés alapján hozták létre a gazdasági és társadalmi kohézió erősítése és előmozdítása, a régiók közötti egyenlőtlenség csökkentése, valamint a legkedvezőtlenebb 
helyzetü régiók - vagyis 1993-ban Görögország, Spanyolország, Portugália és Írország lemaradásának mérséklése céljából.

A Kohéziós Alap ${ }^{8}$ illeszkedik a strukturális politika céljaihoz és eszköztárához (Szegvári 2002), azonban a támogathatóság feltételét nem az egyes régiók mutatószámai adják, hanem a tagállam egészének jövedelemtermelö-képessége. A Kohéziós Alap - speciális módon, projektszinten - a környezetvédelem és a transz-európai közlekedésinfrastruktúra-hálózatok ${ }^{9}$ területén megvalósuló beruházásokhoz, 10 millió euró feletti nagyprojektekhez nyújt pénzügyi támogatást azokban a tagállamokban, amelyekben az egy före jutó bruttó nemzeti termék a közösségi átlag 90\%-ánál kevesebb. A projekteknek jelentős hatással kell lenniük a környezetvédelem területén, illetve a transzeurópai közlekedés-infrastruktúra hálózatok fejlesztésében. További követelmény, hogy a támogatások felhasználása összhangban legyen a közösségi politikákkal, azonban a támogatás mértéke összességében nem haladhatja meg a tagállam GDP-jének 10\%-át. (Kende, Szücs 2002)

A Kohéziós Alapból támogatott projektek az infrastruktúra fejlesztésével járultak hozzá a területfejlesztés fellendítéséhez, valamint a centrum-periféria közötti kapcsolatok erősítéséhez. (Szegvári 2002)

\section{Strukturális Alapok}

A Strukturális Alapok célja az elmaradott régiók infrastruktúrájának, a helyi gazdaság diverzifikálásának, a munkaerő képzettségének, valamint a különböző gazdasági ágazatok termelékenységének fejlesztése.

„Az európai szociális politika támogatására az Európai Szociális Alap már 1960-ban létrejött”, melyet 1962-ben az Európai Mezőgazdasági Tanácsadási és Garanciaalap követett, majd 1975-ben létrejött az Európai Regionális Fejlesztési Alap. Az Agenda 2000 szerint az Európai Unió költségvetésének több mint egyharmadát a Strukturális Alapok keretében kell felhasználni. (Szegvári 2002)

Az Agenda 2000 céljaival összhangban az Európai Bizottság célja a 2000-2006 közötti programozási periódusban az volt, hogy a tagállamokat és a régiókat érintő kohéziós

\footnotetext{
${ }^{8}$ A Kohéziós Alap szabályozása a 2007-2013-as programozási periódustól bekerült a közös szabályozási keretbe, és ezzel a projektszintű tervezés programszintűvé vált.

${ }^{9}$ A környezetvédelmi és a közlekedési projektek esetében a legmagasabb az átlagos megtérülési idő.
} 
politika, valamint a gazdasági és társadalmi kohézió erősítése a korábbinál hangsúlyosabban jelenjen meg. A forrásokat azokra a területekre ${ }^{10}$ kellett koncentrálni, melyek esetében az európai uniós fellépés hatékonyabb volt, mint a tagállami, és így a beruházásokkal szinergikus hatások voltak elérhetők. A fejletlenebb és fejlettebb régiókban nemcsak a támogatás mértéke, hanem a felhasználási célok is eltérőek voltak. A gazdagabb területeken a támogatások a versenyképességet segítő területekre (pl. kutatás-fejlesztés, oktatás), az elmaradottabb térségekben pedig többnyire az infrastruktúra-fejlesztésre koncentrálódtak. (Miklós-Molnár 2006a-d) A 2000-2006-os programozási időszakban a tagállamok által igénybe vehető támogatást nyújtó alapokat a dolgozat 2. számú melléklete mutatja be.

A Strukturális Alapok esetében az európai uniós szabályozás ${ }^{11}$ elsősorban a keretelveket határozta meg, míg a konkrét lebonyolítási szabályok megalkotása és betartatása tagállami hatáskör volt. Az alapok támogatásainak igénybe vételéhez valamennyi tagállam egy nemzeti fejlesztési terv keretében határozta meg a fejlesztési célokat, valamint felállította azt az intézményrendszert, amely a célok megvalósítását - mind stratégiai szempontból, mind operatív szinten - menedzselni tudja.

\subsubsection{A 2000-2006 közötti programozási periódus forrás elosztásának alapelvei}

Az Európai Unió regionális politikája egyrészt összehangolja az egyes közösségi politikákat, másrészt követi a nemzeti támogatások rendszerét a versenypolitikai elvek betartása érdekében, és pénzügyi ösztönzőket kínál a tagállamoknak a fejlesztések megvalósítása érdekében. (Szegvári 2002)

Az Európai Bizottság a támogatáspolitika szabályainak megalkotásakor alapelvként kezelte, hogy regionális támogatásokat indokolt esetben a legkedvezőtlenebb helyzetü térségeknek, koncentrált módon nyújtson az Európai Unió, összhangban az Agenda 2000ben foglaltakkal és a koncentráció elvével. Ezen alapelvek alapján születtek meg azok az objektív szabályok, amelyek - elsődlegesen statisztikai mutatószámok alapján meghatározzák a támogatásra jogosult területek körét és a célkitüzéseket az 1. sz. mellékletben bemutatottak szerint (Kende, Szücs 2002).

\footnotetext{
${ }^{10}$ Például közlekedés fejlesztés, energiagazdálkodás, vidékfejlesztés.

${ }^{11}$ 1260/1999/EK tanácsi rendelet, 438/2001/EK és 448/2001/EK bizottsági rendeletek.
} 
A célkitűzések koncentrálódása lehetővé teszi, hogy egy-egy beavatkozási területen magasabb források mozgósításával, összehangoltabb tervezéssel és programozással, koncentráltabban lehessen elérni a fejlesztési célokat, azonban az eredmények mérhetősége a nemzetközi szakirodalom alapján is vita tárgya. ${ }^{12} \mathrm{Az}$ eredmények mérhetősége Magyarországon még meglehetősen nehézkes. Ennek oka egyrészt az, hogy a 2004-2006-os programozási periódusban hazánk csak korlátozottan részesült támogatásban a csatlakozás 2004. május 1-jei időpontja miatt, másrészt a programok megvalósítása és a támogatások kifizetése 2009-ig elhúzódott, harmadrészt pedig azért,

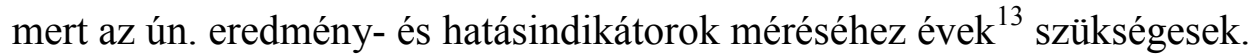

\subsubsection{A régiók mint beavatkozási területek}

Az EUROSTAT által kidolgozott Területi Statisztikai Nómenklatúra Rendszer (továbbiakban NUTS) alkalmas a regionális gazdasági kapacitások statisztikai vizsgálatára. A NUTS I-III regionális, míg a NUTS IV-V lokális szint, melyek jellemzően a lakosság száma, illetve a földrajzi elhelyezkedés alapján kerülnek meghatározásra. A NUTS rendszer kialakítása a kialakult közigazgatási struktúra figyelembe vételével az egyes tagállamok feladata, melynek célja - a statisztikai adatgyüjtés és elemzés megkönnyítésén túl - a regionális támogatások rendszerének kidolgozásakor a célterületek meghatározása. A regionális támogatások folyósításának alapjául a NUTS II régiók szolgálnak, amelyek az Európai Unió egészét tekintve eltérő közigazgatásiközhatalmi funkciókkal rendelkeznek. A tagállamok kizárólag normatív területeket határolhatnak le régióként, amelyek azonban nem szükségszerüen közigazgatási-területi egységek, lehetnek kizárólag tervezési-statisztikai egységek is. A NUTS II nagyrégiók a „gazdaság-fejlesztés, az innováció, a foglalkoztatáspolitika, az infrastruktúra-fejlesztés, a környezetvédelem állami feladatainak megvalósítási terepei és a területi versenyképesség megvalósításának eszközei is”, emellett pedig egyben elszámolási, forrás-szerző kategóriák. (Szegvári 2002)

Az Európai Unióban a regionális szintnek (értem ez alatt a NUTS II egységeket) tehát három fő funkciója van. Egyrészt statisztikai egységként szolgál a regionális szintü különbségek méréséhez, és ezáltal meghatározó része a támogathatóság követelményeinek megítélésének, másrészt segíti a regionális szintű különbségek

\footnotetext{
${ }^{12}$ Ennek taglalása a következő, 2.3. fejezet tárgya.

13 Például a talajvíz szennyezettségének csökkenésének mérése más eredményt ad a beruházás megvalósítását követő első héten, első évben és harmadik évben.
} 
mérséklését, a leszakadó régiók felzárkóztatását és a versenyképesség javítását, harmadrészt pedig biztosítja a központi és helyi szint közötti kapcsolatteremtést, a feladatok közötti közvetítést és a szolgáltatások megszervezését. (Szegvári 2002)

A NUTS rendszer kialakítása az egyes tagállamok felelőssége, így Magyarország is saját hatáskörében rendelkezett - még 1998-ban - a tervezési-statisztikai egységek kialakításáról. ${ }^{14}$ Mivel Magyarországon önkormányzati régiók nem működnek a helyi önkormányzatok önállósága miatt, adminisztratív régióként a megyék vehetők figyelembe, míg a NUTS II régiók elsődlegesen tervezési-statisztikai egységként funkcionálnak, önálló közhatalmi funkciókkal, gazdálkodási autonómiával nem rendelkeznek. A régiók lehatárolása Magyarországon normatív módon, vagyis a meglévő területi-közigazgatási berendezkedésnek megfelelően történt, nem pedig a természetföldrajzi adottság, vagyis az analitikus lehatárolás mentén.

A régiók mint statisztikai-tervezési egységek egyben forrás-szerző kategóriák és támogatási célterületek. Míg a Strukturális Alapok a NUTS 2 szintű egységeket, vagyis a régiókat támogatják, addig a Közösségi kezdeményezések esetében a NUTS 3 szintű régiók, vagyis a megyék is figyelembe vehetők mint speciális régiók, illetve ipari-szerkezeti átalakítási térségek és vidéki (rurális) térségek.

\subsubsection{A strukturális politika jelene}

A 2007-2013-as költségvetési időszakra vonatkozóan az Európai Bizottság céljai kissé megváltoztak. A jelenlegi programozási periódusban különös hangsúlyt kap a belső piac hatékony müködése, a természeti értékek megőrzése, a környezetvédelem és élelmiszerbiztonság szempontjai, az illegális migráció és szervezett bünözés elleni harc, valamint az Európai Unió tagállamainak egységes külső megjelenése és fellépése a harmadik országokkal való kapcsolatokban.

A jelenlegi programozási periódusban a célkitüzések megváltoztak, területük kibővült, és a korábban alkalmazott projektfinanszírozás helyett a programok megvalósítása került elötérbe, amely a magyar intézményrendszerben is változásokat okozott. Az új

\footnotetext{
${ }^{14}$ Eszerint NUTS1: Közép-Magyarország, Dunántúl, Alföld és Észak; NUTS2: 7 tervezési-statisztikai régió, amelyek a megyéket, mint közigazgatási egységeket csoportosítják (Közép-Magyarország, KözépDunántúl, Nyugat-Dunántúl, Dél-Dunántúl, Észak-Magyarország, Észak-Alföld, Dél-Alföld); NUTS3: 19 megye és a föváros; NUTS4: kistérségek; NUTS5: települési önkormányzatok.
} 
szabályozási környezet ${ }^{15}$ a tagállamoknak nagyobb szabadságot nyújt a támogatások felhasználásának tekintetében, viszont a kevésbé kötött, alapelveken nyugvó szabályrendszer miatt a tagállami felelősség megnőtt.

A regionális politikai támogatások felhasználására a jelenlegi programozási periódusban három prioritást határoztak meg. A vonzóképesség megteremtéséhez szükséges az infrastrukturális háttér fejlesztése, amely egyrészt a közlekedési infrastruktúra kiegyensúlyozott megoszlását - vagyis a transzeurópai közlekedési hálózat fejlesztését -, másrészt a gazdasági növekedés hosszú fenntarthatósága érdekében a környezeti (jellemzően hulladék- és szennyvíz-gazdálkodási) infrastruktúrát, harmadrészt az energiahatékonyság fejlesztését és a megújuló energiaforrások támogatását jelenti. A gazdaság elmozdítása a tudásalapú tevékenységek irányába, valamint a nemzeti és regionális kutatás-fejlesztési tevékenység elösegítése és a vállalkozások innovációs képességének előmozdítása a tudás és innováció prioritáshoz kapcsolódik. Ennek keretében támogatható a kutatási infrastruktúra fejlesztése, a kutatási együttmüködések előmozdítása, az e-kormányzat és az e-egészségügy fejlesztése. A több és jobb munkahely prioritása az emberi erőforrás fejlesztésére, a munkavállalók alkalmazkodóképességének javítására, az aktív munkaerő-piaci politikák megvalósítására, az oktatási és képzési rendszerek reformjára, valamint az egészségfejlesztésre és a betegségmegelőzésre irányulnak. A regionális politika területi dimenziójában cél a városi térségekben a vállalkozási szellem, míg a vidéki térségekben a gazdasági megújulás, valamint az idegenforgalmi szektorhoz kapcsolódó fejlesztések támogatása. (Kengyel 2007b)

A 2007-2013-as programozási periódus fő kihívása a 2004-ben és 2007-ben csatlakozott új tagállamok jövedelemszintbeli különbségeinek csökkentése. A támogatások mértéke egy tagállam esetében sem haladhatja meg a GDP 4\%-át, viszont minden tagállam a fejlettségi szintjének megfelelő arányú ${ }^{16}$ támogathatósági plafonra számíthat, ami az újonnan csatlakozott országoknak kedvez, hiszen a kedvezményezett országok számára a támogatások jelentős forrásokat képviselnek és a felzárkóztatásban számottevők. A kibővült Európai Unióban 2007-től megkétszereződtek a jövedelmi különbségek a csatlakozás előtti időszakhoz képest, ugyanakkor a 2007-2013-as programozási periódusban mégsem emelkednek ezzel arányosan a regionális politika kiadásai, azok aránya az unió bruttó nemzeti jövedelméhez viszonyítva csökkenni fog. Ez a szolidaritás

\footnotetext{
${ }_{15}^{15}$ 1083/2006/EK Tanácsi Rendelet, illetve 1828/2006/EK Bizottsági rendelet.

${ }^{16}$ Sávos módon meghatározott.
} 
alacsony fokának tekinthető, különösen úgy, hogy a transzferek jelentős része visszaáramlik a nettó befizető tagállamokba. (Kengyel 2007a)

\subsubsection{Kritikák az eszköztárban}

Az Európai Unió regionális politikájával kapcsolatosan megfogalmazódó kritikák három fő csoportra tagolhatók. Tisztán politikai kritikaként értelmezhető a nettó befizető tagállamok álláspontja, amelyek költségvetési okokból kérdőjelezik meg a kohéziós politika létét. Számos tanulmány (Churski 2008), (Santos 2008) vizsgálta a regionális politika hatékonyságát, azonban meglehetősen eltérő eredmények körvonalazódnak ki.

A kritika harmadik típusa elsősorban a bonyolult célrendszerre, a transzparencia, az átláthatóság és a flexibilitás hiányára összpontosul. A szakmai kritikák (Santos 2008). között megfogalmazódik, hogy a támogatások nem azokba a régiókba irányulnak, ahol a befektetések megtérülése a legmagasabb, illetve a régión belüli redisztribúció aránya magasabb, mint a régiók közötti redisztribúcióé.

A kutatások eredményei abban megegyeznek, hogy az egyes tagállamok közötti fejlettségi különbségek csökkentek, azonban egyes tanulmányok szerint a tagállamokon belül a régiók közötti különbségek nőttek, és rövid- és középtávon kedvezőtlen fejlődési időszakok is megfigyelhetők. (Kengyel 2007a) A csatlakozás időpontjában erősebb gazdasági potenciállal rendelkező régiók hatékonyabban használták fel a támogatásokat, mint a kevésbé fejlett régiók, így nehezen mutatható ki a regionális politika növekedésre gyakorolt hatása. (Marján 2009)

\subsection{A támogatások hatásának mérhetősége}

\subsubsection{Mérhetöségi anomáliák}

Az előző fejezetekben szemléltettem az európai integráció korai szakaszaitól kezdve jelen lévő törekvést a Közösségek ${ }^{17}$ tagállamai közötti, illetve az azokon belüli regionális fejlettségi különbségek felszámolására, illetve rövid áttekintést nyújtottam a regionális politika folyamatosan fejlődő eszköztáráról. Az integráció elörehaladtával - akár a

\footnotetext{
${ }^{17}$ Amikor az integráció korai szakaszairól beszélünk, az „Európai Közösségek”, „Közösségek”, illetve az „EK” megjelölést és az „európai integráció” összefoglaló elnevezést egymás szinonimájaként használjuk a későbbi Európai Unió elődjére utalva.
} 
tagállamok számának gyarapodását, akár az integráció mind mélyebb szintü megvalósítását értjük ez alatt -, a kérdés egyre sürgetőbb és kényesebb témájává vált az EK politikai agendájának. (Barca 2009) Ha a fent említett előrehaladást az első lehetőség szerint értelmezzük, akkor azért, mert az évtizedek során az átlagtól egyre különbözőbb fejlettségü régiók kerültek kívülről a Közösségek tagjai közé. Ha a másik értelmezést használjuk, akkor pedig azért, mert az integráció mélyebb szintjei ${ }^{18}$ a regionális különbségek minőségi átértékelését vonták maguk után (Churski 2008), (Balassa 1961) in: (Palánkai 2004).

Az európai kohéziós elképzeléseknek a regionális politika eszközén keresztül tervezett megvalósítása tehát fokozatosan felértékelődött, és máig kiemelt hangsúllyal szerepel az Európai Unió politikai napirendjén éppúgy, mint költségvetésében, amelynek majdnem egyharmadát a regionális politika eszközeinek csak egy részét (noha tetemes hányadát) jelentő Strukturális Alapok teszik ki (Santos 2008).

Régi közösségi politikáról lévén szó, az integráció kezdeti időszaka mellett már több költségvetési ciklus tapasztalatai is rendelkezésünkre állnak, a regionális politika - és az ennek legnagyobb részét képező Strukturális Alapok - értékelését azonban nagyban megnehezíti, hogy nemcsak az integráció szintje és a tagállamok száma változott viszonylag gyorsan az elmúlt néhány - de különösen az utolsó - évtized során, hanem a politika eszközei, és az azok mérésére alkalmazott módszerek is folyamatosan finomodnak.

Az Európai Unió 1999-2006-os költségvetési ciklusába 2004-ben bekapcsolódó, ekkor csatlakozó tíz tagállam - köztük Magyarország - számára a Strukturális Alapokból rendelkezésre álló források felhasználásának tanulóidőszaka vette kezdetét. A programozási periódus lezárultával nemcsak az új tagállamok kormányai, hanem a támogatások rendszerének többi szereplője is - az Európai Bizottság, a támogatások felhasználására felállított nemzeti intézményrendszer és a kedvezményezettek (legyenek azok költségvetési szervek vagy a magánszféra képviselői) - levonhatják a szükséges következtetéseket. (Sapir 2003) in: (Lóránd 2009)

\footnotetext{
${ }^{18}$ A vámuniót követő közös piac, majd gazdasági és egyes területeken esetlegesen megvalósuló politikai unió.
} 
A 2004-2006-os programozási periódus ugyanakkor nemcsak az ekkor csatlakozó országok, hanem a korábbi uniós tagállamok (EU-15) és az uniós politika formálói, a különböző uniós intézmények számára is komoly tanulságokat hordoz, hiszen a 2004-ben és az utána csatlakozó tagállamokkal radikálisan átrendeződött a regionális támogatások tagállamok közötti megoszlása és ezzel együtt a jövedelem térbeli eloszlása. Az új tagállamoknak gyakorlatilag minden régiója a Strukturális Alapok több mint kétharmadát kitevő, a „legfejletlenebb régiók felzárkóztatását” célzó 1. célkitűzés ${ }^{19}$ alá tartozik (Churski 2008), (Dall'erba 2007), (Dall'erba 2005).

A média, illetve a nemzeti gazdaságpolitika kritikusai részéről gyakran elhangzó panasz nevezetesen, hogy a kevéssé hatékony intézményrendszer és rossz gazdaságpolitika eredményeképpen Magyarország abszorpciós képessége jóval alulmúlja a támogatás elvileg elérhető mértékét, nemcsak egyetlen tényezőre szükíti az eredmények értékelését, hanem még e tényezőt is felszínesen vizsgálja (Banai 2010).

A dolgozat következő fejezetében a teljesség igénye nélkül körképet nyújtok a támogatások hatásának mérésére kialakított és alkalmazott számos módszer széles eszköztárából, az előnyök és hátrányok mérlegelése mellett kiemelve az értékelő esetleges személyes céljainak való megfelelést is. A támogatások hatékonyságának és hatásosságának mérése ugyanis az eddigi tapasztalatok szerint nemcsak a szereplők szándékai és várakozásai, hanem az eredmények tekintetében is módszerenként eltérő következtetésre vezet.

\subsubsection{Hatásvizsgálat és elemzési lehetőségek}

A következő fejezetek elsődleges célja nem a módszerek fejlődésének kronologikus áttekintése, hanem az eszköztár számunkra releváns elemeinek összehasonlító értékelésével azt szeretném mérlegelni, hogy a jelenleg használatban lévő módszertanok közötti mely különbségek vezetnek a különböző eredményekre és ennek folyományaképpen szerteágazó következtetésekre. Emellett értékelést is végzek: a különböző módszerek előnyeinek és hátrányainak értékelésével, a valóságban tapasztalt eredményeket az előre jelzetekkel összevetve körvonalazom, hogy a kutatás céljaihoz melyik módszer áll a legközelebb, melyik feleltethető meg leginkább.

\footnotetext{
19 A regionális politika 1988-as reformját követően a politika fö irányvonalait hat célkitűzés mentén fektették le. Ezek közül az 1. célkitüzés tette ki a strukturális alapok költségvetésének $68 \%$-át. E célkitüzés alá sorolták azokat a régiókat, amelyekben a vásárló erő paritáson számolt egy före jutó GDP értéke nem érte el a közösségi átlag 75\%-át (Dall'erba 2005).
} 
Mindenekelőtt meg kell határozni, hogy pontosan mit nevezünk a strukturális támogatások hatásának, mi az a mutató, amit a kutatás során, a Magyarországon a Nemzeti Fejlesztési Terv keretében 2004 és 2006 között igénybe vett támogatások tekintetében vizsgálni szeretnénk.

A hatékonyság ${ }^{20}$ az uniós terminológiában szintén használatos abszorpció fogalmával rokon. A rendelkezésre álló keret arányában azt mutatja meg, mekkora összeg került felhasználásra az adott szinten (az adott tagállam, egy operatív program viszonylatában vagy akár egyetlen projekt szintjén). A támogatások felhasználásának értelmezését árnyalhatjuk a lehívott, lekötött és esetlegesen visszafizetett összegek közötti különbségtétellel, de ez sem változtat a tényen, hogy a pusztán a hatékonyságot alapul vevő vizsgálat nem értékeli, hogy a támogatásokat értelmes célra, az elérhető legnagyobb hozzáadott érték szem előtt tartásával hasznosították-e (Nagy 2008).

A hatásosság vagy eredményesség ${ }^{21}$ ezzel szemben jóval összetettebb vizsgálati szempontrendszert takar, amelybe beleértjük a támogatás felhasználásának értékelését is. Talán a fogalom komplexitása, egyes figyelembe vett szempontok értékelésének nehézségei okozzák, hogy a hatásosság mérésére már jóval több módszer áll rendelkezésünkre, amelyek akár jelentős mértékben eltérő eredményre vezethetnek. A mérhetőség feltétele miatt a hatásosság mérésére gyakran olyan módszereket alkalmaznak, amelyek a támogatás hatására keletkező hozzáadott értéket vagy programok vagy tagállamok szintjén - a GDP hozzáadott növekedését veszik alapul (Nagy 2008).

A szakirodalomban hatásvizsgálatként vagy hatáselemzésként egyértelműen ez utóbbi változó vizsgálatát értjük valamilyen módszerrel. A hatásvizsgálat célja, hogy előzetesen becsült vagy utólag tapasztalt tényekre alapozva értékelje egy-egy társadalom- vagy gazdaságpolitikai beavatkozás eredményét, visszajelzéssel szolgálva ezzel az adott beavatkozásban érintettek számára, esetleges további lépések megalapozását célozva.

Ennek eléréshez a hatáselemzés az adott beavatkozás és a bekövetkezett változások közötti oksági kapcsolatok létét és erősségét vizsgálja (Futó 2009).

\footnotetext{
${ }^{20} \mathrm{Az}$ angol nyelvü irodalomban használt efficiency fogalom megfelelője.

${ }^{21}$ Angolul effectiveness.
} 
A szerteágazó hatásvizsgálati elméletek és módszerek közös pontjai után kutatva Bradley és szerzőtársai négy szakaszra tagolják az egyes módszerek alkalmazását (Bradley, Untiedt 2007). Mindenekelött behatóan tanulmányozni kell a kohéziós politika célterületeinek számító 1. célkitűzés alá eső régiók jellemzőit. Ezt követően áttekinthetjük az alapok felhasználása tematikus és pénzügyi tervezésének folyamatát, és a beruházások típusai (infrastruktúra, humán erőforrás, $\mathrm{K}+\mathrm{F}$, stb.) szerint csoportosíthatjuk a forrásokat. Az elméleti és megfigyelt háttér ismeretében fel kell állítanunk az alkalmazni kívánt módszertant ${ }^{22}$. Végül az eredmények ismeretében - gyakran valamilyen kontrollcsoport vagy egyéb viszonyítási alap meghatározásával - le kell vonnunk a szükséges következtetéseket. (Bradley, Untiedt 2007)

Vegyük sorra azokat az alapvető szempontokat, amelyek a hatásvizsgálat egyes típusait a vizsgálat időpontja és a vizsgált változók jellege szerint - megkülönböztetik.

Kezdjük az időbeliség aspektusával. Attól függően, hogy a támogatások felhasználásához képest előzetesen, a folyamat közben vagy a programok lezárulta után kívánjuk elvégezni elemzésünket, beszélhetünk ex ante (előzetes), mid term (a programozási időszak közben végzett) és ex post (utólagos) vizsgálatról. A különbség nemcsak a tapasztalati adatok elérhetőségében, hanem elsősorban a következtetések alkalmazhatóságában - és alkalmazásában - áll. Nagy hiba lenne összehasonlítanunk egy, a programok hatásának ex ante becslésére használt modell által adott eredményeket - még ha azok a programozási időszak elején minden szereplő szempontjából hasznos kiinduló adatokat szolgáltattak is -, és egy ex post hatásvizsgálati módszert, amely tapasztalati adatok alapján ad értékelést. (Trón 2008) A dolgozatban bemutatott kutatás az annak alapjául szolgáló - főleg számviteli jellegü - adatok természeténél fogva ex post jellegü, ezt az eredmények értékelésekor is figyelembe veszem.

A különböző vizsgálati módszereket abból a szempontból is csoportosíthatjuk, hogy milyen mutatókkal dolgoznak: a legáltalánosabban elterjedtek a makro mutatókat (például a GDP valamely nominális vagy reálértelemben vett értékét, növekedési ütemét, a reálbérrel, reálkamattal vagy a munkanélküliség alakulásával kapcsolatos indikátorokat) mérő eljárások. Nagy előnyük, hogy a makro mutatók könnyen számszerüsíthetők és matematikai értelemben jól kezelhetők, ezért az ökonometriai módszereket alkalmazó eljárások (modellek és különböző tanulmányok) alapját képezik. Ugyanakkor, a makro

\footnotetext{
${ }^{22}$ Bradley és szerzőtársai makromodellek alkalmazását javasolják (Bradley, Untiedt 2007).
} 
módszerek legtöbbje a vizsgált egységek tekintetében nem megy lejjebb az egyes államok szintjénél (top-down megközelítés), emiatt nehézségekbe ütközik alkalmazásuk olyankor, amikor például nem az egyes uniós tagállamok, hanem kisebb egységek - régiók, kistérségek vagy akár önkormányzatok - közötti konvergenciát vizsgálunk.

Erre a problémára keresnek - és kínálnak - megoldási alternatívát azok az egyre szélesebb körben elterjedt módszerek, amelyek mikro szintről - például az önkormányzatok vagy más kedvezményezettek oldaláról, régiók vagy még kisebb területi egységek szintjéröl - veszik a módszer alapját képező mutatókat (bottom-up megközelítés). Ezek a módszerek kiválóan alkalmasak arra, hogy egy szereplő - például kedvezményezett - támogatás-felhasználással kapcsolatos döntéseit vizsgáljuk, számszerü következtetések tekintetében azonban problematikusak lehetnek, ahogy erröl az alábbiakban még szót ejtünk. (Banai 2010), (Bradley et al. 2005), (Trón 2008) A mikro megközelítést alkalmazó vizsgálatokat már csak azért is meg kell különböztetni a makro elemzésektől, mert a nemzetközi gyakorlatban nem ritkán áll elő az a helyzet, hogy míg a makro hatások tekintetében a vizsgálatok negatív eredményt mutatnak - vagyis a támogatás nem éri el kitüzött célját -, addig mikro szinten pozitív eredményeket figyelhetünk meg (White 1992).

A mikro megközelítésekkel kapcsolatosan megfogalmazható egyik kritika, hogy ha azok pozitív eredményeket mutatnak, akkor nem szükségszerü, hogy a makro típusú megközelítések eredményei is kedvezőek legyenek. Mivel az Európai Bizottság az elemzései és értékelései során jellemzően makro megközelítést alkalmaz, a kutatás elméleti megalapozása során nem találkoztam olyan - Magyarországot érintő - mikro jellegü kutatással, amely az önkormányzatok nézőpontjából világította volna meg az elemzési lehetőségeket. Jelen dolgozatban a bottom-up megközelítést, annak is egyfajta szükítő, magyar helyi önkormányzatokra korlátozódó értelmezését alkalmazom, figyelemmel a kutatás rendelkezésére álló adatok jellegére is.

A módszerek csoportosításánál további szempont lehet, hogy a módszerrel a támogatások felhasználásának valamely kereslet-oldali aspektusát, vagy a kínálati oldalt kívánjuk vizsgálni. Ezen a ponton a vizsgálati módszer választása ismét attól is függhet, hogy a folyamatok mely szereplőjének az oldaláról közelítjük meg a támogatások felhasználásának kérdését: az Európai Bizottságot mint a donoroldal megtestesítőjét a kínálati, a támogatások kedvezményezettjeit ugyanakkor a keresleti oldalhoz sorolhatjuk 
(Nagy 2008). A keresleti és kínálati hatások az időbeliség tekintetében is elválnak: a támogatás rövid távú kereslet-oldali hatása általában a projekt megvalósítása során azonnal észlelhető, egyes kínálat-oldali hatások ezzel szemben a projektek befejezését követően is fennállnak - legalábbis az Európai Bizottság szándéka szerint ezt biztosítaná a fenntarthatóság kötelező szem elött tartását az egyes projektek megvalósításánál. (Bradley, Untiedt 2007)

A dolgozat következő fejezeteiben bemutatásra kerül az európai uniós támogatások hatásosságának vizsgálatára rendelkezésre álló eszköztár elméleti háttér, majd annak a gyakorlatban alkalmazott elemei - a fent ismertetett szempontok szerint.

\subsubsection{A nemzetközi fejlesztési segélyektöl az európai támogatásokig}

Az európai támogatások klasszikus megközelítése a donor oldalon szereplő intézményekhez köthető, amelyek megtestesítője gyakran az Európai Bizottság. A támogatásokat - és ezeken belül is a kutatás tárgyát képező Strukturális Alapokat - ebből a szemszögből úgy is értékelhetjük, mint a regionális konvergencia és a gazdasági növekedés kettős célkitüzésének eszközét (Cappelen et al. 2003), (Dall'erba 2005), (Santos 2008). A gazdasági növekedés biztosítása mellett az Európai Bizottság elsődleges célja tehát a régiók közötti különbségek csökkentése. Ez a két jelenség - a növekedés és a konvergencia - azonban a gyakorlatban ritkán jár együtt, olyannyira, hogy egyes szerzők egyenesen hibának tartják a kettő együttes, ugyanazon eszközön keresztül megvalósítandó feltevését (Santos 2008).

A következőkben röviden áttekintjük a gazdasági növekedés és a konvergencia feltevését meglapozó legfontosabb elméleteket, a fejlődés-gazdaságtani gyökerektől indulva egészen a modern, endogén növekedéselmélet és új gazdaságföldrajz talaján álló kritikáig.

A regionális támogatások elméleti alapjainak megértéshez vissza kell nyúlni a közösségi regionális politikánál valamivel nagyobb múltra visszatekintő növekedési elméletekhez, amelyek a nemzetközi segélyezés gyakorlatába is beépültek, és amelyek zöme az egy före eső GDP-t vagy annak növekedését veszi alapmutatónak. Az egyes, egymást követő elméletek felfüzhetők egy világos fejlődési vonal mentén, ahol az egyszerübb elméleti modelleket jellemzően felváltották azok, amelyek segítségével jobban - ha teljes körüen nem is - magyarázhatók a valóságban tapasztalt jelenségek. A megjelenő legújabb 
elméletek a korábbiak feltevésével szakítva már az automatikus konvergencia létét is megkérdőjelezik, és ilyen módon közelebb állnak a gyakorlatban tapasztalt jelenségekhez, viszont igen súlyos kérdéseket vetnek fel az uniós regionális politika alapfeltevéseinek vonatkozásában. (Valentinyi 1995).

Ha kiindulópontot keresünk a különböző növekedés-elméletek újdonságainak áttekintéséhez, akkor rövid úton a növekedés elméletek atyjának számító, az előző század első felében két szerző, az angol Roy Forbes Harrod és az orosz-amerikai Evsey David Domar által publikált modellhez jutunk. A modell legegyszerübb formája szerint a növekedést „palacknyakként”23 korlátozó egyetlen tényező a tőke, illetve a tőkebefektetések szükössége. A neoklasszikus közgazdaságtan keretein belül mozgó többi szerző ezt a modellt egészítette ki valamely tényezővel Ezt tették például Chenery és szerzőtársai, amikor a tőke (a megtakarítások) szűkösségéhez külkereskedelmi szempontokat adva megalkották a „kettős hiány”-ról ${ }^{24}$ szóló elméletüket. (White 1992); (Chenery, Bruno 1962) in: (White 1992) A neoklasszikus növekedéselmélet - amelyet a Harrod-Domar modell legismertebb továbbfejlesztője, az amerikai Robert Solow nevével szokás fémjelezni - alapvető jellemzője, hogy a gazdaság hosszú távú növekedését exogén, az egyes modelleken kívülről meghatározott változóként kezelik, továbbá a feltételezés, hogy a gazdasági növekedés a fejlettség egy pontján mintegy automatikusan be fog következni (Rostow 1960).

Éppen ezt a fenti két feltevést - miszerint a gazdasági növekedés exogén és automatikus érte a legtöbb kritika az 1980-as évektől kezdve. Az ekkor napvilágot látó endogén növekedéselmélet - ahogy a neve is mutatja - már nem tekinti adottságnak a gazdasági növekedést, és tekintetbe vesz egy sor politikai és egyéb befolyásoló tényezőt. (Dall'erba 2005), (Romer 2007) Ezeknek az újabb modelleknek nagy előnye, hogy alkalmasabbak a valóságban empirikus módon tapasztalt folyamatok magyarázatára, ugyanakkor jóval bonyolultabb, esetenként a mikro- és makro megközelítést integráló modellekkel számolnak. (Valentinyi 1995)

A fejlődés és felzárkózás mozgatórugójaként Kengyel ún. endogén és exogén fejlődést különböztet meg. Az exogén fejlődés külső tényezők hatására jön létre ${ }^{25}$, azonban csak

\footnotetext{
${ }^{23}$ Az angol közgazdasági nyelvben használatos bottleneck, illetve bottleneck effect kifejezések magyar megfelelője.

${ }^{24}$ dual gap theory, ld. (White 1992)

${ }^{25}$ Mint például technológiai transzfer, vagy jól képzett munkaerő.
} 
akkor tekinthető tartósnak, ha annak ok okozati láncolata teljes, vagyis az exogén tényezők hatására generálódik. ${ }^{26} \mathrm{Az}$ endogén fejlődést ezzel szemben belső okok kényszerítik ki: „az erős gazdasági alapoknak köszönhetően spontán módon alakul ki”, vagyis az endogén fejlődés önfenntartóvá válhat. Humán erőforrás- és az egyidejü infrastruktúra-fejlesztés „multiplikátor hatásokon keresztül fokozzák a keresletet és javítják a termelékenységet is.” (Kengyel 2003) Ezzel összefüggésben megfogalmazható ennek ellentettje is: vagyis a gazdaságszerkezeti okokon kívül a területi egyenlötlenségek alakulásában a termelékenységi és foglalkoztatási tényezők játszanak szerepet. A támogatások eredményeként az adott régió felzárkózik, csökkennek a jövedelmi különbségek az egyes régiók között, így az „integrált európai gazdaság versenyképességének erősítését a struktúrapolitikai alapelvek folyamatos fenntartásával párhuzamosan kell megoldani.” (Horváth 2001)

A növekedés előmozdítása mellett gyakran a nemzetközi segélyezési politikában is, az európai uniós regionális politikában pedig egyértelmüen a konvergencia támogatása áll a törekvések középpontjában. Automatikus-e a szegényebb régiók felzárkózása a gazdagabb területekhez? Milyen eszközökkel lehet előmozdítani a regionális fejlettségi különbségek csökkenését? Ilyen és hasonló kérdések mozgatják a konvergencia-elméletek kutatását. (Dall'erba 2005)

A konvergencia-modellek neoklasszikus értelmezésen alapulnak. Közös jellemzőjük a feltételezés, hogy az országok ${ }^{27}$ fejlettsége közeledik egymáshoz vagy - feltételes konvergencia esetén - valamely más viszonyítási ponthoz. Hogy pontosan mi az a mutató, ami közeledést mutat, illetve mihez képest, abban már különbségeket találunk az egyes elméletek között. (Ligeti 2002). A XX. század második felétől európai körökben is igen nagy népszerüségre számot tartó $\beta$-konvergenciaelmélet arra a megnyugtató feltevésre épül, hogy az alacsonyabb fejlettségi szintről induló régiók a gyorsabb növekedés révén előbb-utóbb utolérik a magasabb fejlettségi szinten lévőket.

A $\beta$-konvergencia feltételezésén túllépve a $\sigma$-konvergenciaelmélet értelmezésében a konvergencia nem pusztán a növekedési ütem közeledése formájában, hanem az abszolút fejlettségi szinteken valósulhat meg. A közgazdasági modell nyelvére lefordítva a

\footnotetext{
${ }^{26}$ Vagyis letelepülő vállalkozások folyamatosan megújítják a régió vonzerejét és ezzel újabb fejlödést generálnak.

${ }_{27}^{2}$ Általában ezt tekintik a vizsgálat alapegységének.
} 
konvergencia azt jelenti, hogy az egyes területek - akár országcsoportok vagy régiók fejlettségi mutatóinak szórása csökken (Dall'erba 2005), (Nemes Nagy 2004), (Ligeti 2002).

Népszerüsége miatt méltán megemlítendő elmélet még a feltételes konvergencia elmélete, amely szerint az egyes országok nem egymáshoz, hanem saját hosszú távú egyensúlyi állapotukhoz konvergálnak, eleget téve ezzel a $\beta$-konvergencia feltételeinek (Ligeti 2002).

A kérdés azonban az, hogy a fentiekben felvázolt elméleteket alátámasztják-e az elmúlt évtizedek világgazdasági történései? Vegyünk egy releváns példát. Az Európai Unióhoz 2004-ben csatlakozott tagállamok esetében megfigyelt trend a fent vázolt feltevésektől eltérő mintát mutat - és ennek következtében a strukturális támogatások értékelésére korábban felállított szempontrendszer radikális átalakítását vonja maga után. Itt az a jelenség figyelhető ugyanis meg, hogy miután a támogatásokra való jogosultság megítélését továbbra is a fejlettségi szint ${ }^{28}$ uniós átlaghoz való arányától teszik függővé, a teljes Európai Unió szintjén az újonnan csatlakozó tagállamok leggazdagabb régiói is az unió szegényebb területeiként szerepelnek, és így jogosultak strukturális támogatásra. Abban az esetben, amikor egy országon belül a gazdagabb és szegényebb régiók - vagy ennél is kisebb közigazgatási egységek, például önkormányzatok - ugyanolyan jogosultságokkal pályázhatnak támogatásra, a gazdagabbak előnyben vannak a szegényebbekkel szemben, különösen, ha figyelembe vesszük az addicionalitás alapelvét, amelyhez a szükséges forrásokat a gazdagabb egységek könnyebben előteremtik, mint a rosszabb helyzetben lévők (Churski 2008). Azokról a tényezőkről nem is beszélve, amelyek az anyagi források mellett mind a gazdagabb és nagyobb önkormányzatok előnyét erősítik: itt áll rendelkezésre a szükséges humán erőforrás, információ, kapcsolatok és lobbiképesség (Tatar 2010). Fenti gondolatmenetek szükített értelmü, kizárólag helyi önkormányzatokra vonatkozó leképezése egyes hipotézisem alapja, miszerint az önkormányzatok bizonyos paraméterei (területi elhelyezkedés, méret, forrásszerkezete) összefüggnek azzal, hogy mekkora támogatás használhatnak fel.

A fentiek, illetve a konvergencia gyakorlati megvalósulásának nehézségeire utaló egyéb tények számos kritikust arra a következtetésre vezettek, hogy a Strukturális Alapok jelenleg használatos formájukban nem váltják be a konvergencia tekintetében hozzájuk

\footnotetext{
${ }^{28}$ Értsd ennek mutatószámaként az egy före jutó GDP-t.
} 
füzött reményeket, és a politika eszközeinek esetleges átalakítása, vagy akár a célkitűzések átértékelése indokolt lehet (Santos 2008). A régiók közötti területi egyenlőtlenségek a konvergencia kezdeti szakaszaiban szükségszerüen növekednek, és csak az egyes államok felzárkózását követően kerülhet sor azok felszámolására (Williamson-hipotézis) (Cappelen et al. 2003), (MNB 2006) in: (Lóránd 2009)

A fent kifejtett probléma végig azon a feltevésen alapszik, hogy a konvergencia automatikusan bekövetkezö jelenség, amely csupán felgyorsul egy esetleges tőkeinjekció (pl. strukturális támogatás) hatására, de léte megkérdőjelezhetetlen. A konvergencia elméletek különböző válfajainak előretörésével párhuzamosan megjelenő kritikus hangok szerint azonban ez a feltételezés nem állja meg a helyét (Dall'erba 2005). A kritikusok zöme a gyakorlati tapasztalatokra hivatkozva azt hangsúlyozza, hogy a régiók felzárkóztatása korántsem ilyen egyszerü, és különösen nem automatikusan bekövetkező változás. A valóságban észlelt folyamatok számos olyan jelenséget foglalnak magukba, mint egyes régiók tartósan szegény volta vagy a térségi gazdasági klaszterek ${ }^{29}$ létezése (Sölvell et al, 2003) (Dall'erba 2005); (Porter 1996) in: (Nagy 2007). A neoklasszikus konvergencia-elméletek látszólag elégtelenek ezeknek a gyakorlatban megfigyelhető jelenségeknek a magyarázatára. Az európai regionális politika első néhány évtizedének tapasztalatai sem azt támasztják alá, hogy a strukturális támogatások hatása a kezdetben legfejletlenebb régiók esetében a legnagyobb (Trón 2008), (Dall'erba 2007).

A neoklasszikus konvergencia elméletek kritikusai gyakran egészen különböző kiindulási alapokra építve - például az endogén növekedés elméletéből eredeztetve vagy az új gazdaságföldrajz eszköztárát használva - és különböző érvekkel támadják a konvergenciát propagáló szerzőket. (Dall'erba 2005), (Valentinyi 1995) A biztos közös

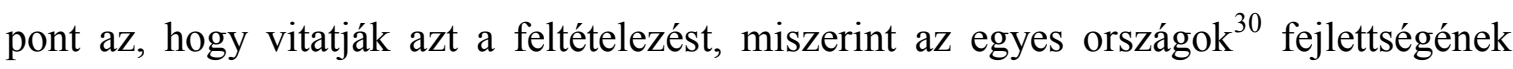
üteme vagy szintje automatikusan közeledne egymáshoz. Elméleteik gyakran különböző fejlődés-gazdaságtani gyökerekre épülnek, és az elmúlt évtizedek valóságban tapasztalt jelenségeinek vagy trendjeinek magyarázatára irányulnak (Dall'erba 2005). Ezek között találjuk a konvergencia-klubok kialakulásának elméletét vagy a centrum-periféria modellt (Durlauf, Johnson 1995) in: (Dall'erba 2005), (Krugman 1991) in: (Dall'erba 2005). Az alternatív elméletek közül a regionális politika tekintetében különös relevanciával bír az

\footnotetext{
${ }^{29}$ Ezt a kifejezést használja a szakirodalom arra a jelenségre, amely szerint a gazdag régiók más gazdag régiókkal, a szegények pedig a többi szegénnyel alkotnak közös halmazt, elsősorban gazdaságföldrajzi értelemben.

${ }^{30}$ Országcsoportok vagy területi egységek.
} 
endogén növekedéselmélet és új gazdaságföldrajz, amely két elmélet társítására több módszer keretein belül is kísérletet tesznek, ahogy ezt dolgozatom következő fejezetében bemutatom (Dall'erba 2007), (Valentinyi 1995).

Első látásra ezek a kritikai konstrukciók valóban alkalmasabbnak tűnnek az európai helyzet értékelésére is (Dall'erba 2005). Még ezek is túlzott egyszerüsítésekkel számolnak azonban, például a tekintetben, hogy a régiókat egymástól elszigetelt térségként kezelik, amelyek fejlettségi szintjét általában valamilyen külső vagy belső források függvényében változó, növekedési vagy jövedelmi mutatóként értelmezik.

Ezt a túlzott leegyszerüsítést igyekeznek kezelni az elmúlt időszakban folyamatos változáson keresztülment hatásvizsgálati módszerek, amelyek fó célkitüzése, hogy a régiók egymásra hatásának és egyéb tényezők figyelembe vételével reálisabb képet mutatnak a fejlesztési támogatások hatásáról, akár azon az áron is, hogy ennek következtében az elméleti modell vagy módszer matematikailag jóval összetettebbé válik. Ilyen módszerekkel dolgoznak az új gazdaságföldrajzon nyugvó, a dolgozat következő részeiben bemutatott térstatisztikai módszerek vagy a különböző ökonometriai tanulmányok (Dall'erba 2005), (Trón 2008).

\subsubsection{A támogatások hatásának mérése: a módszertani keretek kialakulása}

A nemzetközi szakirodalomban eltérő vélemények élnek az uniós strukturális politika két fő célkitüzése, a gazdasági növekedés és a konvergencia kapcsán: különösen az utóbbival kapcsolatban alakult ki heves vita a közelmúlt politikusai és a gazdasági szakemberei között. Ezért is van kiemelt jelentősége a támogatások hatását vizsgáló módszereknek. Választ adnak az alapkérdésre: vajon helyes célkitüzés-e a növekedés és konvergencia párhuzamosa megvalósítása; jó irányba halad-e az uniós regionális politika? (Santos 2008) (Barca 2009)

Az uniós regionális politika kiinduló szakaszában elsősorban a meglévő, különböző nemzetközi szervezetek vagy az Amerikai Egyesült Államok gazdaságpolitikusai által kidolgozott, a nemzetközi segélyezési gyakorlatban, illetve az Egyesült Államok belső regionális politikájában alkalmazott elméleti kereteket és módszertant alkalmazták az európai regionális politikára is (Sasaki 2006), (Sasaki 2007). Hamar nyilvánvalóvá vált azonban, hogy a speciálisan az Európai Unióra jellemző - alább felsorolt - sajátosságok miatt a Strukturális Alapokból társfinanszírozott támogatás lényeges jellemzőkben 
különbözik a klasszikus nemzetközi segélyektől, ami speciális vizsgálati módszerek kialakítását és azok elméleti megalapozását teszik indokolttá.

A nemzetközi fejlesztési segélyek hatásának vizsgálatára kialakított kereteket nem lehet változatlan formában alkalmazni az uniós regionális fejlesztési politikára. Ennek oka részben abban keresendö, hogy míg a klasszikus értelemben vett fejlesztési segélyek általában szociális transzferekre vagy fogyasztási céllal is felhasználhatóak, és ilyen értelemben a jövedelmek regionális, országos vagy akár globális szintü újraelosztását szolgálják, addig az uniós támogatások - azok közül is elsősorban a Strukturális Alapokból igénybe vehető közösségi hozzájárulás - egyértelmüen a gazdasági növekedés elősegítését célozzák. A Strukturális Alapok támogatásainak célja a gazdaság hosszú távú kínálati potenciáljának növelése (Nagy 2008).

A másik fontos különbség a támogatás felhasználásának feltételeiben rejlik. A Strukturális Alapokból rendelkezésre álló támogatás tekintetében ugyanis az Európai Unió nem egyszerüen úgy viselkedik, mint egy segélyt adó donor állam a nemzetközi gyakorlatban. Az uniós támogatások felhasználásának számos támogatás- és programspecifikus feltétele ${ }^{31}$ van, kezdve mindjárt az addicionalitás követelményén, amely eleve szükíti a potenciális kedvezményezettek körét. Ebből adódóan legalább alapvető szinten müködőképes, a támogatások felhasználást irányító és ellenőrző intézményrendszer hiányában egyetlen tagállam sem lenne képes a támogatás felhasználására (Beugelsdijk, Eijffinger 2005), (Tatar 2010), (White 1992).

A hatásvizsgálatra alkalmazott módszerek tekintetében az elméleti alaphoz hasonlóan a nemzetközi segélyezési gyakorlat jelenti a kiindulási pontot. A legtöbb nagy segélyező szervezetnek - gondoljunk a Világbankra, az OECD-re vagy az EuropeAid Együttmüködési Hivatalra - saját módszertana áll rendelkezésre a globálisan nyújtott segélyek hatásának vizsgálatára (Nagy 2008), amely eszközökből sok az európai támogatások esetében is alkalmazható. Ugyanakkor az elméleti alapok felállításához hasonlóan itt is igaz, hogy sok a szükítő tényező, ami miatt az európai támogatásokat csak szigorú feltételek kikötésével tekinthetjük a nemzetközi segélyek speciális változatának.

\footnotetext{
${ }^{31}$ Lásd még a dolgozat 2. 2. fejezetét!
} 
A hatásvizsgálati módszereket több szerző többféleképpen csoportosította (Bradley et al. 2005), (Trón 2008). A dolgozat céljának megfelelően az alábbiakban az előző fejezetben bemutatott szempontok mentén veszem sorra és értékelem az egyes módszereket.

Az európai uniós támogatások hatásának mérésére a legszélesebb körben alkalmazott eszközt a különböző - ökonometriai alapokon álló vagy egyszerübb feltevésekkel dolgozó - modellek jelentik. Ezek nagy előnye, hogy számszerüsíthető eredményekre, és ezek alapján messzemenő következtetésekre vezetnek, illetve, hogy nem korlátozzák a vizsgálatot kizárólag a fejezet elején említett szemszögek egyikére: ötvözhetik akár a mikro- és makro-, akár a keresleti és kínálati oldal mérésére szolgáló módszereket (Bradley et al. 2005). A strukturális támogatások hatásának mérésére alkalmazott modellekre ${ }^{32}$ általánosan jellemző, hogy - ha nem is egyforma módszertan alapján, de valamilyen módon, általában egy-egy másutt exogénnek tekintett változó endogénkénti figyelembevételén keresztül számításba veszik a tovagyürüzö hatásokat ${ }^{33}$ és a különböző externáliákat. Módszertani szempontból ehhez általában valamilyen ökonometriai számítást használnak (Dall'erba 2005), (Trón 2008) (Cooke 2009).

A modellszimulációk különösen jól használhatók a támogatások hatásainak ex ante becslésére, ezért az Európai Bizottság is előszeretettel alkalmazza őket valamely közösségi politika hatásainak előzetes felmérésére. A 2007-2013-as programozási periódusban a kohéziós politikai eszközök hatásának mérésére az Európai Bizottság három, különböző intézmények által fejlesztett modellt is megrendelt: a QUEST II, az ECOMOD és a HERMIN modelleket (Bradley, Untiedt 2007).

Az Európai Bizottság által alkalmazott modellek közös vonása, hogy neokeynesiánus gyökerekkel rendelkeznek, és általában kis nyitott gazdaságokkal számolnak, mint ami a legtöbb 1. célkitüzés alá tartozó ország. Mivel azonban a figyelembe vett változók és a mérésükre alkalmazott módszertan minden modell esetén speciális, az egyes modellek gyakran többé-kevésbé különböző eredményekre vezetnek, különösen a tovagyürüző hatások és externáliák hatásának becslése tekintetében, ennek megfelelően leginkább a hosszú távú kínálati hatások értékelése tér el (Bradley et al. 2005), (Bradley, Untiedt 2007). A legtöbb ex ante becslésre alkalmazott modell makromegközelítést alkalmaz,

\footnotetext{
${ }^{32}$ Különösen a makromodellekre.

${ }^{33}$ Angolul spill-over effects.
} 
és - a megrendelő szándékának megfelelően - sok esetben a legalább középtávú kínálati hatások vizsgálatára helyezi a hangsúlyt.

Azok a hatásvizsgálati módszerek, amelyek a támogatások hatásainak ex post feltérképezését és értékelését tüzik ki célul, bizonyos szempontból könnyebb helyzetben vannak, mint az ex ante modellek, hiszen itt nem kell találgatásokba és becslésekbe bocsátkozni. A tapasztalati adatok rendelkezésre állnak, a feladat „pusztán” annyi, hogy azokat értékelve levonjuk az egyedi esetre vonatkozó vagy általános következtetéseket. Már a hatások pontos meghatározása sem könnyü feladat, hiszen feltételként magában foglalja a „mi lett volna támogatás nélkül” szcenárió meghatározását. Az ezt követő mérlegelés és a következtetések levonása pedig gyakran különösen komplikált.

A Strukturális Alapokból származó támogatás hatásának utólagos bemutatására alkalmazott egyik legegyszerübb módszer az esettanulmány (Trón 2008). Ilyenek tömegével állnak rendelkezésre, minden 2004-ben vagy azóta csatlakozó EU-tagállam, de a regionális politika korábbi fö kedvezményezettjei - Görögország, Írország, Portugália és Spanyolország - esetében is (Banai 2010), (Barry, Bradley, Hannan 2001), (Churski 2008), (Tatar 2010). Az esettanulmányok beható elemzést nyújtanak egy-egy konkrét példán keresztül, ezért sok esetben jó kiindulópontul szolgálnak egy-egy jelenség megismeréséhez.

Jellegükből adódóan azonban legtöbbször megállnak a jelenségek bemutatásának és elemzésének szintjén, sem az értékelés számszerüsítése, sem a modellalkotás nem jellemző rájuk (Trón 2008). Az általános felfogás éppen ezért az, hogy az esettanulmányokból csak korlátozott relevanciájú következtetések vonhatók le, ezért gyakran azt javasolják, hogy csak kiindulópontul, vagy egy komplex modell részeként alkalmazzuk öket (Nagy 2008). Tekintettel azonban arra, hogy a támogatások felhasználása különféle közpolitikai eszközök komplex rendszerének keretében történik, és az egyedi projektektől kezdve az egyes intézkedéseken és prioritásokon át az operatív programokig sok szinten zajlik, az sem meglepő, hogy a hatások mérésére sem találunk egyszerü megoldást (Bradley, Untiedt 2007). Ha a követelményeket nem adjuk alább annál, hogy a Strukturális Alapok hatásait vizsgáló eszközünk komplex rendszerben tájékozódjon, ugyanakkor számszerüsíthető és összehasonlító eredményeket produkáljon, akkor nagy valószínüséggel valamely ökonometriai modell vagy tanulmány mellett tesszük majd le a voksunkat. Tekintsünk most át néhány ilyen eszközt, a makro 
módszerektől a - kutatás szempontjából inkább releváns - mikro megközelítést alkalmazó eszközök irányába haladva.

Az ökonometriai módszerek alkalmazásának lehetősége azért is érdekes, mert erős matematikai alapokon álló eredményeik nem ritkán szembe mennek a Strukturális Alapok felhasználása mögött álló politikai akarat által sugallt érvekkel - és a 2.3.2. és 2.3.3. fejezetben bemutatott általános elméletek kritikusait igazolják. A regionális politika célkitüzéseinek ismeretében első olvasatra meglepő lehet például az a következtetés, hogy a Strukturális Alapok infrastrukturális beruházásokra fordított részének legnagyobb nyertesei nem a legfejletlenebb régiók - hanem az 1. célkitüzés alá tartozó országok gazdagabb régiói (Trón 2008), (Dall'erba 2007).

Más szóval az országon belül, például régiók viszonylatában a $\beta$-konvergencia nem müködik, ahogy ezt a Williamson-hipotézis is feltételezi (Cappelen et al. 2003), (Lóránd 2009). Ilyen és hasonló következtetéseik miatt az ökonometriai módszerek az alternatív neoklasszikussal szembemenő - gazdasági elméleteket látszanak igazolni -, amelyek viszont nagymértékben építenek az ökonometriai eszköztárra. A fenti megközelítés illusztrálása céljából a makromutatók elemzésén keresztül a 2.3.5. fejezetben a magyarországi régiók példáján mutatom be a kritika létjogosultságát.

A többek között a térstatisztika eszköztárából forrásozó módszerekkel végzett tanulmányok egyik legnagyobb hozadéka, hogy szakítanak azzal a felfogással, hogy a vizsgálat egységét - legyen az állam, régió vagy kisebb területi egység - egymástól független entitásként kezelik, és figyelembe veszik, hogy a régiók térbeli közelségüknek megfelelően hatnak egymásra ${ }^{34}$. (Cappelen et al. 2003), (Dall'erba 2005) (Cooke 2009) Így lehetővé teszik a hatások vizsgálatát az egyes országokon belül például régiók szintjén, ugyanakkor alkalmat adnak arra, hogy gazdasági ágazatokra lebontva értékeljük a támogatások hatását, mérlegeljük, hogy mely operatív programok és tematikus elemek hatása a legelőnyösebb a kedvezményezett országok számára (infrastruktúra-fejlesztés helyett például érdemes lenne a humánerőforrás képzésére helyezni a hangsúlyt stb.). (Dall'erba 2007)

\footnotetext{
34 ezt a területi egységek között, mind társadalmi, mind gazdasági jelenségek tekintetében fennálló autokorrelációt nevezi Nemes Nagy József magyarul szomszédsági hasonulásnak (Nemes Nagy 2007)
} 
A 2007-2013-as uniós költségvetési periódus hatáselemzésére Magyarországon is kidolgozásra került a fenti alapokon - elsősorban az új gazdaságföldrajz feltevésein nyugvó ún. Geographic Macro and Regional (GMR) modell. A modell különböző rövid és hosszú távú egyensúlyi helyzetek leírásának rendszerével dolgozik, elsősorban a különböző - input, output - piacokon fennálló kereslet és kínálat egyezőségéből kiindulva, régiók és gazdasági szektorok szerinti bontásban. (Járosi et al. 2009)

A fent bemutatott gondolatmenet és modellek hibája, hogy elsősorban makromutatókat vizsgáló módszerek esetében müködnek, és gyakran ex ante becslésre alkalmazhatóak (mint a fent említett magyarországi GMR-modell). Ha a strukturális támogatásoknak a 2004-2006-os periódusban az önkormányzatokra kifejtett hatását szeretnénk értékelni, akkor elemzésünkhöz alkalmasabb lenne egy mikro megközelítést alkalmazó módszer, amely lehetőséget nyújt az egyes kedvezményezettek és a rendszer egyéb szereplői részéről meghozott döntések hatásainak utólagos összegzésére.

Áthidaló lehetőség az is, ha valamilyen, makro- és mikroelemeket integráló megközelítést használunk. (Bradley et al. 2005) in: (Trón 2008)

A fenti gyengeségek tudatában számos kísérlet történt már a negatív tulajdonságok kiküszöbölésére: elsősorban a módszertan lehetséges fejlesztési útjait, a statisztika és ökonometria eszköztárának a mikro megközelítésre való alkalmazását kutatják. Ennek eredményeképpen már lehetséges a hatások számszerüsíthető, ökonometriai elemzése.

Az elemzés során az egyik sarkalatos kérdés a „mi lett volna strukturális támogatás nélkül?" - kérdés megválaszolása. Erre kínál megoldást a párositás ${ }^{35}$ módszere, amelynek gyakorlati alkalmazását Magyarországon az NFT Gazdasági Versenyképesség Operatív Programjának példáján Béres Attila 2008-as hatástanulmánya mutatta be (Béres 2008). A párosítás módszere két csoport egyidejű vizsgálatán alapul: az egyik vizsgált csoport tagjai lehetnek például a strukturális támogatások kedvezményezettjei ${ }^{36}$, a másik, ún. kontrollcsoport pedig állhat olyan egyedekből, amelyek nem részesültek támogatásban. A hatásvizsgálat során a támogatásban részesült egyedek helyzetét hasonlítjuk össze a támogatásban nem részesültekével. A nehézséget az jelenti, hogy az egyedszintü összehasonlításhoz párokat, ún. statisztikai ikreket kell találnunk az egyedek

\footnotetext{
${ }^{35}$ Angolul: matching vagy pontos szóhasználattal propensity score matching.

${ }^{36}$ Vagy ezen belül azok az önkormányzatok, amelyek az NFT keretében 2004 és 2006 között strukturális támogatásban részesültek.
} 
között: olyanokat, amelyeknek egyik tagja a célcsoportba, másik tagja a kontrollcsoportba tartozik, miközben lehetőség szerint minél több egyéb tulajdonságban ${ }^{37}$ megegyeznek (Béres 2008); (Nagy 2006).

A statisztikai ikerpárok vizsgálatának módszerét árnyalhatja az ökonometriában alkalmazott különbségek különbsége ${ }^{38}$ módszer, amelynek használatával a vizsgált célcsoportunkat nemcsak egy kontrollcsoporthoz, hanem a célcsoport egyedeinek a támogatás igénybevételét megelőző állapotához is hasonlítjuk (Béres 2008).

\subsubsection{A makrogazdasági mutatók változása Magyarországon 2004 és 2008 között}

Az előző fejezetekben bemutattam a regionális politika mögött álló célkitűzések elérésére felállított eszközöket, és említést tettem a módszerek kritikusairól is, akik szerint a jelenleg alkalmazott eszközök nem, vagy csak részben alkalmasak a regionális politikai célok elérésére (Trón 2008), (Dall'erba 2007), (Cappelen et al. 2003), (Lóránd 2009). Ezen aggályok illusztrálására végeztem egy rövid elemzést a 2004-2008-as időszakra vonatkozóan a regionális politikai eszközök magyarországi hatásáról, makrogazdasági mutatókon keresztül.

A 2004-2006-os programozási periódus elszámolhatósági időszakának véghatárideje 2008. december 31-e volt, ezért a regionális politika eszköztárában mérésre leggyakrabban használt egy főre jutó GDP és munkanélküliségi adatok elemzésekor a 2004-2008-as időszakot vizsgálom. Az egy főre jutó GDP Magyarországon a vizsgált időszakban a következők szerint alakult:

GDP/fö (eFt)

\begin{tabular}{|l|r|r|r|r|r|r|}
\hline Területi egység & $\mathbf{2 0 0 4}$ & $\mathbf{2 0 0 5}$ & \multicolumn{1}{c|}{$\mathbf{2 0 0 6}$} & \multicolumn{1}{c|}{$\mathbf{2 0 0 7}$} & \multicolumn{1}{c|}{$\mathbf{1 0 0 8}$} & Különbség (2008-2004) \\
\hline Közép-Magyarország & 3291 & 3563 & 3924 & 4182 & 4424 & +1133 \\
\hline Nyugat-Dunántúl & 2139 & 2157 & 2353 & 2455 & 2594 & +455 \\
\hline Közép-Dunántúl & 1948 & 2041 & 2121 & 2319 & 2398 & +450 \\
\hline Dél-Dunántúl & 1462 & 1508 & 1587 & 1711 & 1825 & +363 \\
\hline Dél-Alföld & 1430 & 1476 & 1559 & 1652 & 1783 & +353 \\
\hline Észak-Magyarország & 1358 & 1429 & 1501 & 1599 & 1643 & +285 \\
\hline Észak-Alföld & 1343 & 1383 & 1483 & 1572 & 1657 & +314 \\
\hline
\end{tabular}

Forrás: Központi Statisztikai Hivatal (www.ksh.hu, letöltési idö: 2012. július 7.)

\footnotetext{
37 Pl. földrajzi elhelyezkedés, méret, vagyoni helyzet, vagy vállalatok esetén ágazat. Minél többet feltételként alkalmazunk, annál kevesebb olyan párt találunk, amely megfelel a kikötéseinknek.

${ }^{38}$ Angolul: difference in differences.
} 
Az egy főre jutó GDP értékének vizsgálatakor arra a következtetésre juthatunk, hogy valamennyi régió esetében nőtt az egy före jutó GDP, azonban a programozási periódus kezdetén a legmagasabb egy före jutó GDP-vel rendelkező régió (Közép-Magyarországi régió) esetén a növekedés kimagasló.

Megállapítható továbbá, hogy minél magasabb volt a régió egy före jutó GDP-je a programozási periódus kezdetén, annál nagyobb egy főre jutó GDP növekményt tudott elérni. Ez alól kizárólag Észak-Alföld és Észak-Magyarország jelent kivételt, ahol ugyanis a kedvezőbb helyzetből induló Észak-Magyarország egy főre jutó GDP növekménye kevesebb lett, mint a kedvezőtlenebb helyzetű Észak-Alföldé. Összességében arra a következtetésre juthatunk, hogy a programozási periódus kezdetén kedvezőbb helyzetben lévő régiók tovább tudták növelni előnyüket, így a fejlettségbeli olló tovább nyílt.

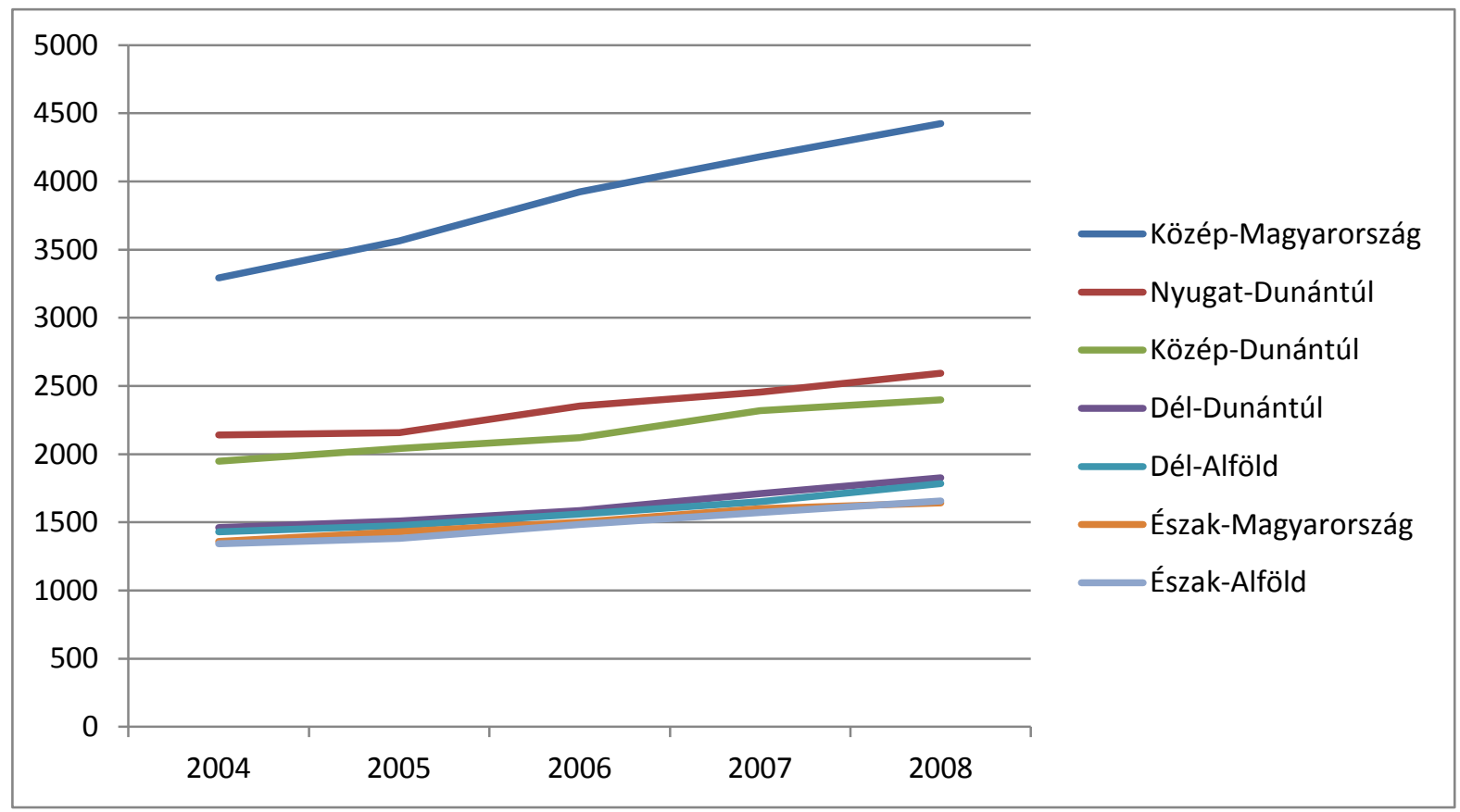

\section{2. számú ábra: Az egy före jutó GDP változása 2004-2008 között, régiónként} (saját készítésü ábra KSH adatok alapján)

A fenti képet árnyalhatja, ha nem az egy före jutó GDP-t vesszük figyelembe, hanem annak százalékos mértékben vett változását, bázisévnek tekintve 2004-et. Ekkor a következőkre juthatunk: 
GDP/fö százalékos növekedése (bázisév 2004)

\begin{tabular}{|l|r|r|r|r|}
\hline Területi egység & $\mathbf{2 0 0 5}$ & $\mathbf{2 0 0 6}$ & $\mathbf{2 0 0 7}$ & \multicolumn{1}{|c|}{$\mathbf{2 0 0 8}$} \\
\hline Közép-Magyarország & $8,26 \%$ & $19,23 \%$ & $27,07 \%$ & $34,43 \%$ \\
\hline Nyugat-Dunántúl & $0,84 \%$ & $10,00 \%$ & $14,77 \%$ & $21,27 \%$ \\
\hline Közép-Dunántúl & $4,77 \%$ & $8,88 \%$ & $19,05 \%$ & $23,10 \%$ \\
\hline Dél-Dunántúl & $3,15 \%$ & $8,55 \%$ & $17,03 \%$ & $24,83 \%$ \\
\hline Dél-Alföld & $3,22 \%$ & $9,02 \%$ & $15,52 \%$ & $24,69 \%$ \\
\hline Észak-Magyarország & $5,23 \%$ & $10,53 \%$ & $17,75 \%$ & $20,99 \%$ \\
\hline Észak-Alföld & $2,98 \%$ & $10,42 \%$ & $17,05 \%$ & $23,38 \%$ \\
\hline
\end{tabular}

Forrás: saját számitás KSH adatok alapján

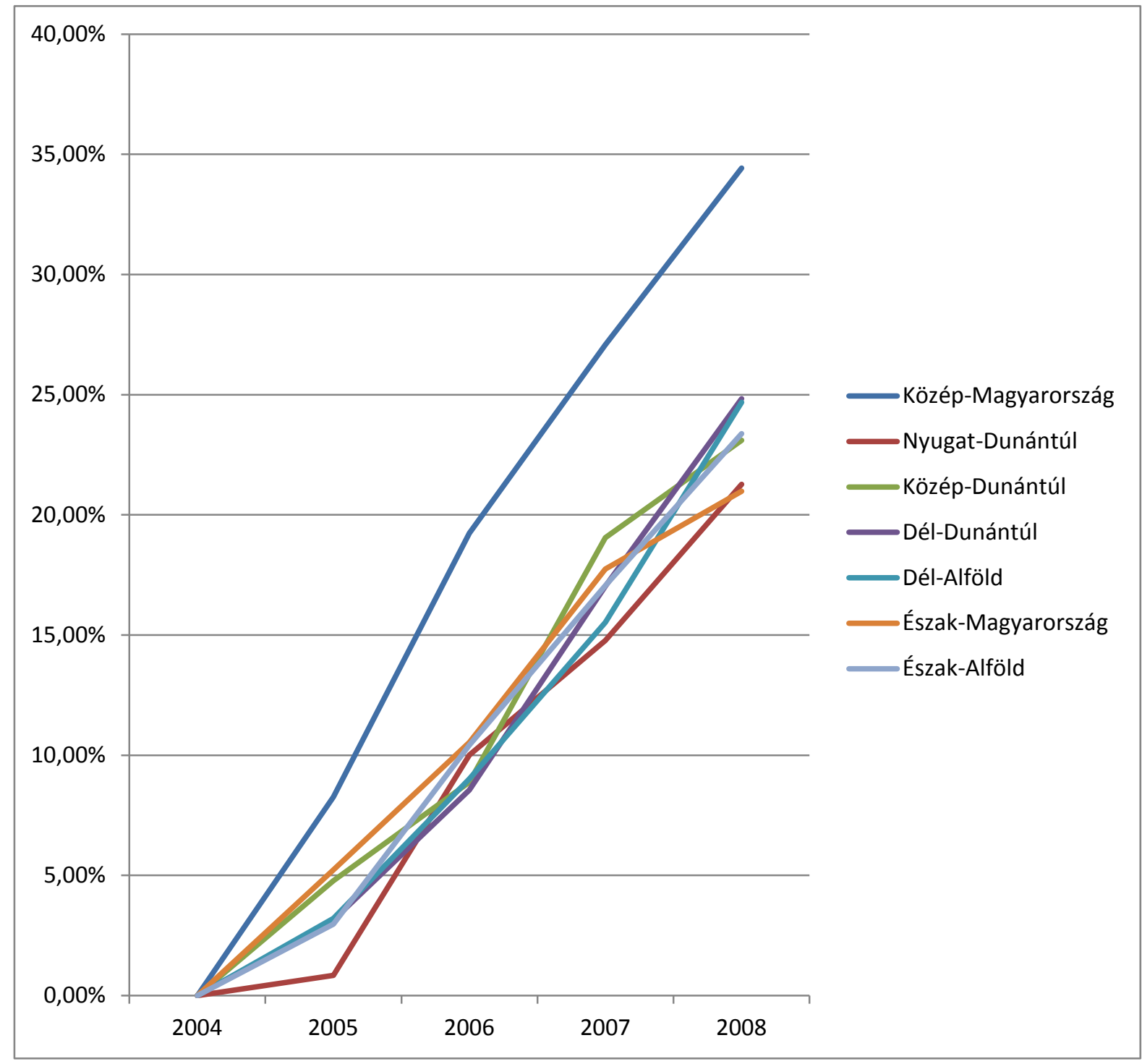

3. számú ábra: Az egy före jutó GDP százalékos növekedése, bázisévnek tekintve 2004-et (saját készítésü ábra KSH adatok alapján)

A fenti ábrából azt a következtetést vonhatjuk le, hogy a legfejlettebb régió (KözépMagyarország) messze a legmagasabb növekedést érte el, és a másik hat régió 
fejlődésének mértéke meg sem közelítette azt. A fejlődésbeli különbségek tehát KözépMagyarország és a másik hat régió vonatkozásában nem csökkentek, hanem nőttek.

Ha elemzésünk hatóköréből kizárjuk Közép-Magyarországot, akkor arra a következtetésre juthatunk, hogy a másik hat régió esetében az egy före jutó GDP százalékos változása kiegyensúlyozottabb növekedést és kisebb szórást mutat, tehát ennek a hat régiónak a vonatkozásában a fejlettségbeli különbségek kis mértékben ugyan, de csökkentek.

Ezt támasztja alá az is, hogy Nyugat-Dunántúli ${ }^{39}$ fejlődése nemcsak hogy kiugrónak nem tekinthető, hanem a legkisebb mértékü fejlődést mutató régiók egyike.

Az egy före jutó GDP mellett célszerủ megvizsgálni a regionális politika tárgyalásakor használt másik makrogazdasági mutatót, a munkanélküliségi rátát is. A munkanélküliség adatait a következő táblázat foglalja össze:

Munkanélküliségi ráta, \%

\begin{tabular}{|l|r|r|r|r|r|r|}
\hline Területi egység & \multicolumn{1}{|c|}{$\mathbf{2 0 0 4}$} & $\mathbf{2 0 0 5}$ & \multicolumn{1}{c|}{$\mathbf{2 0 0 6}$} & \multicolumn{1}{c|}{$\mathbf{2 0 0 7}$} & $\mathbf{2 0 0 8}$ & Különbség (2008-2004) \\
\hline Észak-Magyarország & 9,68 & 10,61 & 11,01 & 12,28 & 13,37 & 3,69 \\
\hline Dél-Dunántúl & 7,27 & 8,80 & 8,99 & 9,99 & 10,30 & 3,03 \\
\hline Észak-Alföld & 7,20 & 9,07 & 10,95 & 10,81 & 11,96 & 4,76 \\
\hline Dél-Alföld & 6,27 & 8,17 & 7,85 & 7,92 & 8,70 & 2,43 \\
\hline Közép-Dunántúl & 5,60 & 6,30 & 6,06 & 5,01 & 5,82 & 0,23 \\
\hline Nyugat-Dunántúl & 4,63 & 5,93 & 5,75 & 4,99 & 4,93 & 0,31 \\
\hline Közép-Magyarország & 4,54 & 5,16 & 5,10 & 4,74 & 4,61 & 0,07 \\
\hline
\end{tabular}

Forrás: Központi Statisztikai Hivatal (www.ksh.hu, letöltési idő: 2012. július 7.)

A munkanélküliségi ráta vizsgálatakor - sajnálatosan - arra a következtetésre juthatunk, hogy valamennyi régió esetében nőtt annak mértéke a vizsgált időszakban. A munkanélküliség nagysága szerint sorba rendezve a régiókat egy helyen mutatkozik (Észak-Alföld) különbség a 2004 és 2008-as adatok között. A munkanélküliség növekedésének mértékében kiugrónak rossznak tekinthető Észak-Alföld helyzete, míg ebből a szempontból legkedvezőbb helyzetü régióknak Közép-Magyarország és NyugatDunántúl tekinthetők. A munkanélküliség 2004 és 2008 közötti változását régiók szerinti bontásban a következő ábra szemlélteti.

\footnotetext{
${ }^{39}$ az egy före jutó GDP tekintetében a második legfejlettebb régió
} 


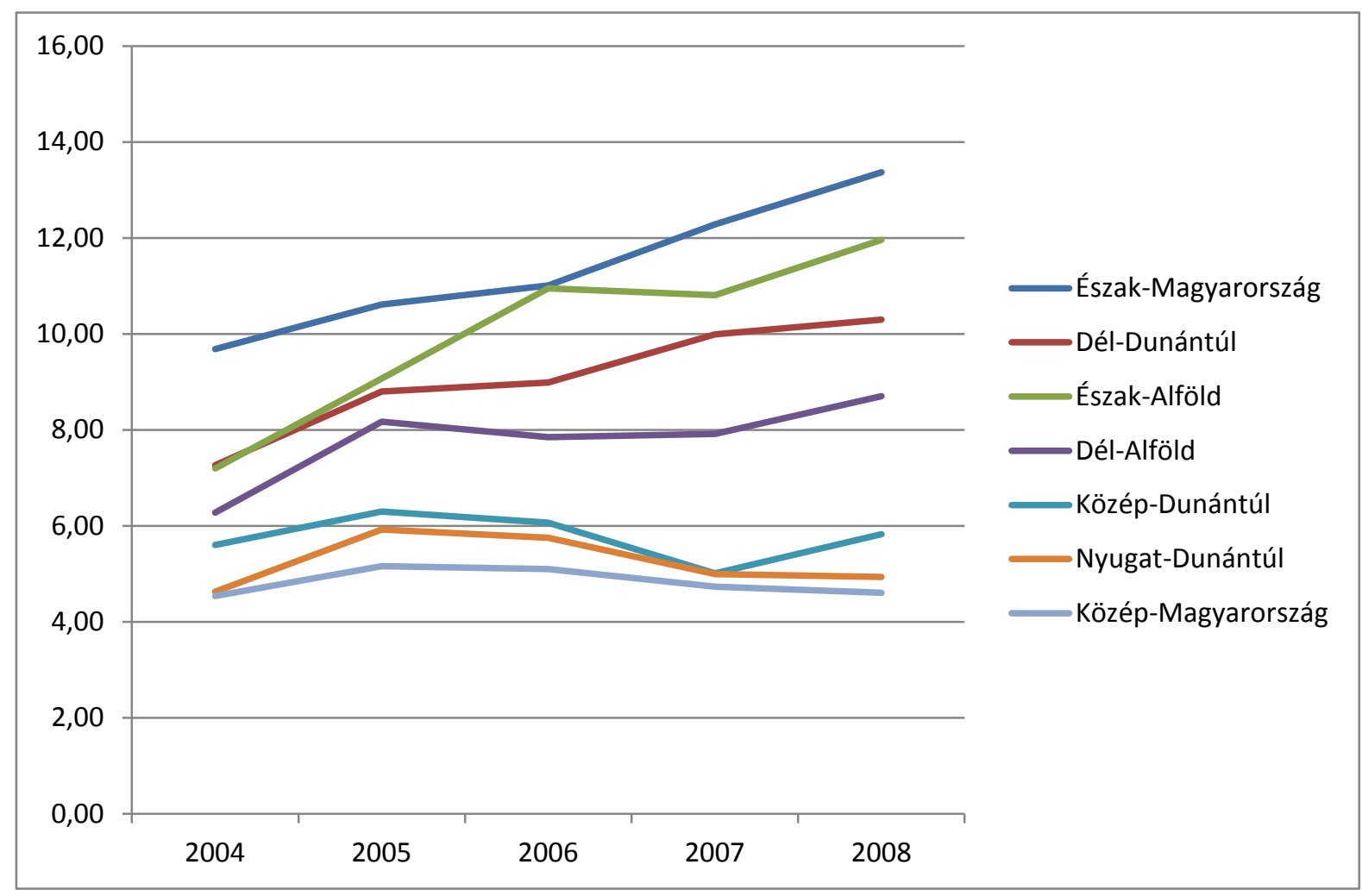

\section{4. számú ábra: A munkanélküliségi ráta változása 2004-2008 között, régiónként (saját készítésü ábra KSH adatok alapján)}

\subsubsection{Módszerek értékelése, alkalmazhatósága, lehetőségek}

Az eredmények értékelése és a következtetések levonása a hatásvizsgálatnak talán a legnehezebb szakasza. Mikro megközelítést alkalmazó vizsgálatoknál a releváns kérdés az lehet, hogy vajon strukturális támogatás nélkül a kedvezményezett a projektnek vagy fejlesztésnek mekkora részét valósította volna meg? Az erre a kérdésre kapott válaszok fényében három esetet különböztetünk meg:

- előfordulhat, hogy a fejlesztés valamilyen regionális vagy helyi fejlesztési terv részeként így is, úgy is megvalósult volna valamilyen állami vagy privát forrásból (teljes helyettesítés esete);

- a fejlesztés egy részét a kedvezményezett saját forrásból ${ }^{40}$ is megvalósította volna (részleges helyettesítés);

- a strukturális támogatás nélkül a fejlesztésből semmi nem valósult volna meg (zéró helyettesítés). (Bradley, Untiedt 2007); (Lóránd 2009)

\footnotetext{
${ }^{40}$ Saját forrás alatt ebben az esetben a kedvezményezett (pl. önkormányzat) részére a strukturális alapokon felül elérhető bármilyen helyi vagy állami költségvetési, illetve a magánszektorból származó forrást értünk.
} 
Magyarországi projektek viszonylatában a legtöbbször a harmadik eset a releváns, mivel a nemzeti fejlesztési politika gyakorlatilag kizárólag az európai uniós forrásokra, a közösségi támogatás hazai társfinanszírozásból történő kiegészítésére épül (Nagy 2006).

Tekintettel arra, hogy kutatás tárgyát kizárólag a 2004-2006-os programozási időszakban, Magyarországon, önkormányzatok által igénybe vett, Strukturális Alapokból finanszírozott támogatások képezik, a támogatások hatásának mérését is abból a szemszögböl értékeljük, hogy mennyire alkalmasak az általunk vizsgálni kívánt mutatók mérésére.

A megelőző fejezetek során fokozatosan haladtunk a dolgozatunk tárgyát kivizsgáló kutatás céljainak megfelelő módszerek felé. Így jutottunk a következtetésre, hogy céljainknak leginkább egy olyan módszer felelne meg, amely alkalmat nyit a Strukturális Alapok hatásainak utólagos mikro szintü elemzésére, lehetőség szerint értékelve az önkormányzatok vagyonváltozásában mutatkozó eredményeket.

Az elméleti felvezetést követően - a kutatás hatókörére fókuszálva és annak valamennyi összetevőjének megértése érdekében - a részletesen, gyakorlatorientált szemléletben bemutatásra kerülnek azok a 2004-2006-os programozási periódusban Magyarországon alkalmazott folyamatok, amelyek a támogatási rendszer alapjait adják. Mielőtt azonban erre rátérnék, tegyünk egy kitekintést az EU többi tagállamába - másutt hogyan érvényesülnek az addicionalitás dolgozatomban vizsgált szempontjai.

\subsection{Az addicionalitási szempontok érvényesülése más tagállamokban}

\subsection{1. Önkormányzatok lehetőségei európai uniós támogatás felhasználására}

Különböző intézményeinek politikáján keresztül az Európai Unió számos módon hatással van a tagállamok önkormányzatainak ${ }^{41}$ helyzetére. E befolyás egyik legkézzelfoghatóbb és legközvetlenebb - a dolgozat korábbi fejezeteiben már részletesen bemutatott formája, amikor az egyes helyi önkormányzatok strukturális támogatásban részesülnek. (Fleurke 2007) Az önkormányzatok európai uniós támogatás-felhasználási lehetőségei

\footnotetext{
${ }^{41}$ A 2.4. és 4.4. fejezet egészében önkormányzatok kifejezés alatt az Európai Unió területén lévő helyi önkormányzatokat értem.
} 
tekintetében csakúgy, mint a tényleges felhasználást tekintve azonban Európa-szerte rendkívül eltérő mintákat figyelhetünk meg.

Ez önmagában nem meglepő, hiszen a támogatások felhasználását számos - az önkormányzatok szempontjából kívülről adottnak tekinthető - tényező határozza meg. A következőkben kísérletet teszek arra, hogy e tényezők közül kiemeljem a legfontosabb, a magyarországi helyi önkormányzatok szempontjából is releváns elemeket.

Visszautalva a dolgozat 2.3 fejezetében említett jelenségre, miszerint a strukturális támogatásokra való rászorultságot regionális alapon ítélik meg, a támogatások döntő hányadát felölelő 1. célkitüzésből csak azok a régiók, illetve az azokban fekvő önkormányzatok részesülhetnek, amelyek GDP-je relatíve alacsony, vagyis nem haladja meg az uniós átlag meghatározott hányadát. Ennek következtében a régi ${ }^{42}$ tagállamokban, például Hollandiában egy önkormányzat aligha számolhat európai uniós támogatással fejlesztési tervének összeállításakor. (De Rooij 2002). A másik végletet az újonnan csatlakozott közép-kelet-európai államok jelentik, ahol, mint Észtországban vagy Magyarországon az állam közel teljes területét az 1. célkitüzés alá eső régiók alkotják. ${ }^{43}$ (Churski 2008; Dall'erba 2005) Ezekben az országokban aztán nem ritkán találkozunk azzal a jelenséggel, hogy az ország fejlesztési terve gyakorlatilag megegyezik az európai uniós támogatások felhasználására felállított koncepcióval, melynek oka azonban nem kizárólag gazdaságpolitikai döntésekben keresendő - arról sem szabad megfeledkeznünk, hogy az állam saját, fejlesztésre szánt forrásait sok esetben kimeríti a társfinanszírozás feltételének való megfelelés. (Tatar 2010)

A másik oldalról nézve ugyanakkor, a Strukturális Alapok pozitív hatása is éppen ezekben az országokban érzékelhető a legkézzelfoghatóbb módon. A szubnacionális közintézmények által megvalósított közvetlen befektetések Közép- és Kelet-Európában az ezredfordulót követő évtizedben gyors - évi átlag 8,1 százalékos - növekedést produkáltak, ennek oka pedig nem kis részben az uniós támogatásokból származó erőteljes tőkeinjekciónak köszönhető. A térség államaiban az európai uniós támogatások mérhető fellendítő hatást ${ }^{44}$ fejtenek ki. (DEXIA 2011) A 2000-2006-os programozási

\footnotetext{
${ }^{42}$ Régi tagállamok alatt az Európai Unióhoz 2004-nél korábban, új tagállamok alatt pedig 2004-ben, vagy azt követően csatlakozott országokat értek.

${ }^{43}$ A 3. számú mellékletben szereplő térkép az 1. célkitűzés szerint támogatható és átmeneti támogatásban részesülö régiókat mutatja be.

${ }^{44}$ Angolul leverage effect.
} 
időszakot megelőzően hasonló tapasztalatokban volt részük az Európai Unió akkor szegényebbnek számító régióinak, amelyek a kelet-európai bővítés következtében a támogathatóság megszűnését élik meg, ahogy arra a dolgozat 2.2. fejezetében már utaltam.

Ezeken a területeken a folyamat fájdalmas következményekkel, és az egész európai uniós tagság negatív aspektusainak felülkereskedésével, az euroszkeptikus nézetek elöretörésével jár a közvéleményben. (Kinnunen 2004; Fleurke 2007)

A fentiekből az is következik, hogy míg Nyugat-Európában a kohéziós politika rendeltetésének megfelelően kizárólag a legrosszabb gazdasági-szociális helyzetben lévő önkormányzatok juthatnak európai uniós támogatáshoz, addig Közép- és KeletEurópában a támogatások felhasználásával megvalósuló fejlesztéseket csak a „módosabb”, jobb erőforrásokkal rendelkező önkormányzatok engedhetik meg maguknak, - akik képesek az addicionalitás mint alapelv követelményének biztosítására, vagyis a társfinanszírozás előteremtésére - míg a legkomolyabb társadalmi-gazdasági problémákkal küszködők kohéziós források nélkül maradnak. (De Rooij 2002; Tatar 2010)

A fent említett jelenségek mellett természetszerüleg a nemzeti politikai, gazdasági és jogiszabályozási közeg szintén kulcsfontosságú szerepet tölt be az önkormányzatok támogatás-felvételénél. A vonatkozó nemzeti szabályozás alapvetően meghatározza az önkormányzatok döntési lehetőségeit. A kelet-európai országokra - köztük Magyarországra - általában a nyugat-európainál centralizáltabb területi berendezkedés jellemző, nemcsak a települési önkormányzatok, de a többi szubnacionális szereplő is korlátozott jogkörökkel bír. (Salamun 2007; Tabără 2010; Tatar 2010)

Ha az európai uniós és nemzeti politikai- gazdasági-szabályozási környezet meg is engedné egy önkormányzat számára a támogatás igénybevételét, akkor sem biztos, hogy az önkormányzat lehetőségei lehetővé teszik, hogy azt ténylegesen lehívja. A kedvezményezettek abszorpciós kapacitásával foglalkozó tanulmányok bemutatják a támogatások tényleges felhasználásának útjában álló akadályokat. Önkormányzati kedvezményezettekre értelmezve ezeket a tényezőket, alapvetően két csoportot állíthatunk fel: az egyik a pénzügyi források szükössége köré épül, vagyis amikor egy önkormányzat költségvetéséből nem telik az uniós projektek megvalósításához szükséges 
önrészre; a másik pedig alapvetően az önkormányzatoknál lévő adminisztratív kapacitás hiányához köthető. (Például, ha egy önkormányzatnál nem áll rendelkezésre a támogatás felhasználásához szükséges személyzet, technikai, illetve szakmai tudás vagy tapasztalat.) Utóbbi az Európai Unió történetében viszonylag új keletű probléma, ugyanis a keleteurópai bővítést megelőzően a szükséges humán-erőforrás és adminisztratív kapacitás rendelkezésre állása az akkori tagállamok esetében nem volt kérdés.

A fentiekből az a következtetés is levonható, hogy az önkormányzatok esélyei egyazon országon belül sem egyformák. (Oplotnik 2007) Az európai uniós támogatások hatását vizsgáló számos tanulmány foglalkozik azzal, hogy pontosan mely tényezők növelhetik a támogatásoknak a kedvezményezett önkormányzatokra kifejtett hatását. Ezeknek közös konklúziója, hogy - a támogathatóság alapvető kritériuma mellett, amelyet a fentiekkel összhangban a régió fejlettségi szintje határoz meg - az önkormányzat mérete (a hozzá tartozó lakosság nagysága) a legfontosabb befolyásoló tényező: egy önkormányzat annál jobb erőforrások felett rendelkezik, minél nagyobb a hozzá tartozó lakosság. A nagyobb önkormányzatoknál általában rendelkezésre állnak a támogatás-felhasználáshoz szükséges kapacitások: a humán erőforrás, valamint a technikai és szakmai tudás, vállalkozói készség és anyagi javak csakúgy, mint a szintén nélkülözhetetlen kapcsolatok és információk, melynek következtében az európai uniós támogatások felvételénél a legjobb erőforrásokkal, vagyis pénzügyi, illetve adminisztratív kapacitással rendelkező önkormányzatok vannak előnyben. (De Rooij 2002; Tatar 2010) 


\section{Magyarország az Európai Unióban}

A dolgozat jelen fejezetének elsődleges célja az, hogy a magyarországi támogatási rendszer alapjainak bemutatásával és az intézményrendszer szereplöinek meghatározásával a pénzügyi folyamatok áttekinthetővé váljanak, továbbá értelmezhető legyen a támogatások hatásának értékelése az intézményrendszer egyes szerepelőinek esetében. A kevésbé tudományos elemek bemutatása nélkül az egyes hipotézisek közötti kapcsolat csak korlátozottan értelmezhető, ezért jelen - elsődlegesen leíró - rész célja a folyamatok egymásra épülésének bemutatása. ${ }^{45}$ A fejezet megírásakor nagyban támaszkodtam a témában született, korábbi publikációimra.

Az Európai Unió regionális politikájának céljai és a hazai regionális politika célja - a támogatások igénybe vétele érdekében - szükségszerüen összhangban állnak. Magyarország a 2004-2006 közötti időszakban összesen 2,8 milliárd euró regionális támogatás felhasználására volt jogosult, ami a GDP 1,2\%-át tette ki, ez abszolút értékben és GDP, illetve lakosságarányosan is alacsonyabb - közel $1 / 3$ - volt, mint a regionális politika korábbi fö haszonélvezőinek (Görögország, Portugália) nyújtott támogatás. A relatív alacsony támogatottsági szint elfogadható, ugyanis mind intézményi, mind finanszírozási szempontból ez tekinthető felkészülésnek a 2007-2013-as programozási periódusra, amikor Magyarország 22,4 milliárd euró felhasználására jogosult. (Kengyel 2007b)

A támogatások felhasználásához és az intézményrendszer kialakításához szükséges elsődleges jogforrást a Strukturális Alapok esetében az Európai Unió rendeletei ${ }^{46}$ adják. A Tanácsi rendeletek az igénybe vétel feltételeit, a támogatható intézkedések körét szabályozzák, míg a Bizottsági rendeletek a programok végrehajtásának rendjét, az irányítási és ellenőrzési rendszerrel szemben támasztott követelményeket, a pénzügyi ellenörzés, valamint a kiadások igazolásának rendjét, és az értékelés és a tájékoztatás általános szabályait határozzák meg.

Az európai uniós jogforrások - mint keretszabályok - mellett a támogatások felhasználásának módját, az intézményrendszer felépítését, valamint a lebonyolításban

\footnotetext{
${ }^{45}$ Mivel a dolgozatnak nem témája a 2007-2013-as programozási periódus értékelése, így az intézmények és folyamatok bemutatása kizárólag 2004-2006-os időszakra korlátozódik.

${ }^{46}$ 1260/1999/EK Tanácsi rendelet, 438/2001/EK Bizottsági rendelet, 448/2001/EK Bizottság rendelet.
} 
részt vevő szervezetek feladat- és felelősségi körét tagállami hatáskörben szükséges szabályozni. $^{47}$

\subsection{A magyarországi intézményrendszer a 2004-2006-os programozási periódusban}

\subsubsection{Programozás és Nemzeti Fejlesztési Terv}

A 2004-2006-os programozási periódusban az 1. célkitűzés ${ }^{48}$ által érintett régiókra Közösségi Támogatási Keretet, a 2. és 3. célkitüzés alapján támogatott régiókra ún. Egységes Programozási Dokumentumot kellett készíteni a tagállamoknak. Mivel Magyarország egy före jutó GDP-je egyik régióban sem érte el az Európai Unió átlagának 75\%-át, így az ország teljes területe az 1. célkitüzés alá tartozott. A Közösségi Támogatási Keret, amely az Európai Unió és a tagállam közötti pénzügyi kötelezettségvállalás is - a Nemzeti Fejlesztési Terv alapján - az Európai Bizottság és Magyarország közötti tárgyalással került elfogadásra. (Kengyel 2007a)

A Nemzeti Fejlesztési Terv a tagállam fejlesztési célkitűzéseit és prioritásait tartalmazó nemzeti stratégiai dokumentum. Magyarország esetében az átfogó ex ante értékelést, makrogazdasági és szektoronkénti elemzést tartalmazott, bemutatta a stratégia és a prioritások közötti koherenciát és főbb pénzügyi adatokat, valamint rövid leírást tartalmazott az egyes operatív programokról, illetve a megvalósítás tervezett folyamatairól. (Nemzeti Fejlesztési Ügynökség 2007b)

A Nemzeti Fejlesztési Terv elkészítése nélkül a Strukturális Alapok támogatásaihoz nem lehetett hozzájutni, ezért annak elkészítése alapvető fontosságú feladat volt. (Kengyel 2007b) A Nemzeti Fejlesztési Terv stratégiai célja az életminőség javítása és az Európai Unió átlagától való lemaradás csökkentése, ami három specifikus részcélon ${ }^{49}$ versenyképes gazdaság, humán-erőforrás fejlesztése és foglalkoztatás növelése, a természeti erőforrások megóvása és a környezet védelme - keresztül valósulhat meg.

\footnotetext{
${ }^{47}$ Magyarországon a 360/2004. (XII. 26.) Korm. rendelet adta a szabályozás alapján a kutatás által érintett időszakban.

${ }^{48}$ Lásd még a dolgozat 2.2. fejezetét!

49 A részcélok négy prioritást foglalnak magukban: a termelőszektor versenyképességének javítását, a foglalkoztatás növelését és az emberi erőforrások fejlesztését, a megfelelőbb infrastruktúra és a tisztább környezetet, valamint a regionális és helyi potenciál erősítését. Utolsó, nem szakmai prioritásként megjelenik a technikai segítségnyújtás, ami a támogatások maximális felhasználását célozza.
} 
A stratégiai célok és a prioritások megvalósítása érdekében a Nemzeti Fejlesztési Tervben öt operatív program ${ }^{50}$ került megnevezésre, amelyek ugyan több prioritáshoz is kapcsolódtak, de jellemzően egy prioritás céljaira specializálódtak. A négy ágazati operatív program mellett a regionális operatív program céljai erősebben kötődtek a térségi fejlesztéshez, azonban az is az ország teljes területére vonatkozott. (Kengyel 2007b) Minden operatív programon belül - a különféle területek fejlettségét és a felzárkóztatási szempontokat figyelembe véve - prioritásokat, intézkedéseket és alintézkedéseket ${ }^{51}$ határoztak meg, melyekhez a 2004-2006-os programozási ciklusra vonatkozóan költségkereteket rendeltek.

\subsubsection{A megvalósítás intézményrendszere 2004-2006 között}

A dolgozatban a Strukturális Alapok intézményrendszerét mutatom be tekintettel arra, hogy a kutatás empirikus része a Strukturális Alapokból nyújtott támogatásra irányul. A Nemzeti Fejlesztési Terv végrehajtása érdekében felállított intézményrendszert, valamint a szervezetek közötti kapcsolati- és függőségi rendszert a dolgozat 5. számú mellékletében szereplő ábrák szemléltetik.

\section{Közösségi Támogatási Keret Irányító Hatóság}

A stratégiai, irányítási jellegü feladatok felelőse a Strukturális Alapok felhasználásának tekintetében a Nemzeti Fejlesztési Hivatalban felállított Közösségi Támogatási Keret Irányitó Hatóság volt, amelynek átfogó, teljes felelőssége volt a Nemzeti Fejlesztési Terv végrehajtsa tekintetében, valamennyi operatív programmal összefüggésben. A szervezeti egység feladatai kiemelkedtek a többi irányító hatóság feladatai közül, ugyanis ez a szervezet volt felelős a támogatások menedzselő intézményrendszer kialakításáért, fejlesztéséért, folyamatos működtetésért. Mivel a 2004-2006-os időszak a támogatások felhasználásának tekintetében - mind az intézményrendszer felkészülése, mind pénzügyi szempontból - egyfajta tanulóidőszaknak tekinthető (Pitti 2005), (Kengyel 2007b), így kiemelkedő jelentőséggel bírt a nemzeti szabályozások kialakításában és a kapcsolattartásban az Európai Bizottság illetékes főigazgatóságaival.

A támogatások felhasználásának alapvető követelménye, hogy a tagállam - statisztikai és pénzügyi - adatszolgáltatási kötelezettségeinek az Európai Bizottság felé eleget tudjon

\footnotetext{
${ }^{50}$ Az operatív programokra vonatkozó alapvető adatokat a 4. számú melléklet tartalmazza.

${ }^{51}$ A pályázatok kiírása alintézkedésenként történik.
} 
tenni. Az adatszolgáltatási kötelezettség teljesítése, az adatok naprakészségének biztosítása, a monitoring tevékenység előremozdítása, valamint a támogatások menedzsmentje elősegítésének érdekében már a csatlakozás előkészítése során megkezdődött az Egységes Monitoring Információs Rendszer (EMIR) kifejlesztése, amelynek adattartalma a kutatás empirikus részének alapját képezi, ugyanis szerepel benne valamennyi pénzügyi adat a nyújtott támogatásokra vonatkozóan.

\section{Monitoring Bizottság}

Az Irányító Hatóság - az európai uniós jognak megfelelően - a teljes szakmai és pénzügyi lebonyolítási folyamathoz kapcsolódóan Monitoring Bizottságot müködtet, melynek feladata a támogatott projektek végrehajtásának nyomon követése, az előrehaladás rendszeres felmérése, az eredmények áttekintése a kitűzött célok függvényében, valamint az Európai Bizottsághoz benyújtásra kerülő megvalósítási jelentések elemzése és jóváhagyása Az operatív program legfelsőbb szintű koordinációs és stratégiai döntéshozó testülete tehát a civil szervezetek tagjait is magában foglaló monitoring bizottság.

\section{Irányító hatóságok és közremüködő szervezetek}

A Magyarországon kialakított intézményrendszerben az irányító hatóságoknak stratégiai jellegü feladataik vannak, amelyek az illetékes szaktárcáknál működtek. Legfőbb feladataik az operatív program és a program-kiegészítő dokumentumok kidolgozása, az operatív program megvalósítása, az ahhoz szükséges eljárásrendek készítése, az elörehaladás értékelése, valamint a tájékoztatással és publicitással kapcsolatos kötelezettségek teljesítése. Az elszámolás szintje az Európai Bizottsággal a Strukturális Alapok esetében az operatív program, nem pedig az egyes projektek szintje volt.

Az irányító hatóság a projektek menedzselésével kapcsolatos operatív feladatok ellátására ${ }^{52}$ közreműködő szervezeteket bíz meg. Az irányító hatóság és a közreműködő szervezet közötti feladatok megosztása operatív programonként eltérő volt, a közremüködő szervezetek teljesítményének mérése, valamint müködésük nyomon követése az irányító hatóság feladata és felelőssége.

\footnotetext{
-52 Pályázatok érkeztetése, formai és tartalmi ellenőrzése, értékelése, értékelő bizottság működtetése, támogatási szerződések előkészítése, számlák ellenőrzése, kifizetése, engedélyezése, statisztikai és pénzügyi információ szolgáltatása, ad-hoc jelentések elkészítése, első szintű ellenőrzések lefolytatása stb.
} 


\section{Kifizetö hatóság}

A kifizető hatóság az Európai Unió és a tagállam közötti pénzügyi kapocsként értelmezhető. Felelős az egyes támogató alapok számlájára történő kifizetések rendezésért, az Európai Bizottság által a tagállam felé teljesített kifizetések fogadásáért, valamint - a kedvezményezetteknél ténylegesen felmerült költségek alapján - a lehívási kérelmek összeállításáért és benyújtásáért. A fordított irányú pénzügyi folyamatok, vagyis a visszafizetések korrekciója, illetve pénzügyi visszafizetése szintén a kifizető hatóság felelőssége.

\subsection{A Strukturális Alapokból finanszírozott operatív programok pénzügyi lebonyolításának folyamatai}

Az operatív programok lebonyolításának teljes szakaszában központi szerepe van a pénzügyi elszámolásnak az Európai Bizottsággal, ugyanis ez nagyban befolyásolja az előfinanszírozás mértékét a projektek megvalósítása érdekében, és ezáltal közvetlen hatással van a központi költségvetés helyzetére.

A programok megvalósításával kapcsolatos pénzügyi elszámolások két fô, egymástól nagyban eltérő csoportra tagolhatók. Külön érdemes megvizsgálni a tagállam és az Európai Bizottság közötti folyamatokat, illetve a tagállamon belüli - kedvezményezettet, szállítót, intézményrendszer szereplői közötti - elszámolásokat mind tartalmuk, mind technikájuk tekintetében.

\subsubsection{Finanszírozási kapcsolatok a tagállamon belül}

A Strukturális Alapok keretében megvalósuló projektek esetében a kivitelezési munkák elörehaladásával a szállítók benyújtják számláikat a kedvezményezettnek, ugyanis kizárólag velük állnak szerződéses kapcsolatban. A kedvezményezettek, illetve a szállítók sem az Európai Bizottságtól, sem a kifizető hatóságtól nem jutnak közvetlenül forráshoz.

A szállító és a kedvezményezett közötti elszámolás kétféle módon történhet. A kedvezményezettnek lehetősége van arra, hogy a szállítói számlát teljes egészében kiegyenlítse, valamint arra is, hogy a szállítóval közvetlenül csak az önrészt rendezze. Ennek oka az, hogy pl. infrastrukturális jellegű nagyprojektek esetében a számla teljes összegének kifizetése likviditási zavarokat okozhat a kedvezményezettnél. A kifizetési folyamat részletes leírását a dolgozat 6 . számú melléklete tartalmazza. 


\subsubsection{Elszámolás az Európai Bizottsággal}

A kifizető hatóság az Európai Bizottságtól érkező támogatások fogadására és továbbutalására operatív programonként, illetve finanszírozó alaponként euró bankszámlát nyit a Magyar Államkincstárban, amely felett az operatív program lezárásáig, és a végső egyenleg átutalásáig rendelkezik. Az operatív programok elfogadásakor a tagállam előlegre jogosult, amelyet a kifizető hatóság a közösségi hozzájárulások kifizetésére használ fel. Így a tagállam költségvetésének nem, vagy csak részlegesen kell előfinanszíroznia az egyes programokra jutó európai uniós támogatást. A Magyar Államkincstárban megnyitott számlák kamatoznak, a keletkező kamatok a tagállamot illetik, azonban azt a támogatások társfinanszírozására kell felhasználnia az addicionalitás jegyében.

A Strukturális Alapokból finanszírozott operatív programok esetében jogosult a tagállam előleg lehívására. A lehívott előleget a kifizető hatóság a közösségi hozzájárulások kifizetésére használja fel. A programok elörehaladásával az igazolt és ténylegesen kifizetett, elismerhető költségek figyelembe vételével közbenső átutalást kezdeményez a kifizető hatóság a Strukturális Alapokból finanszírozott operatív programok esetében a támogatás 95\%-áig. Az elszámolás és átutalás-igénylés folyamatát az Európai Bizottsággal a következő ábra - elsősorban 3. és 4. pontja - szemlélteti:

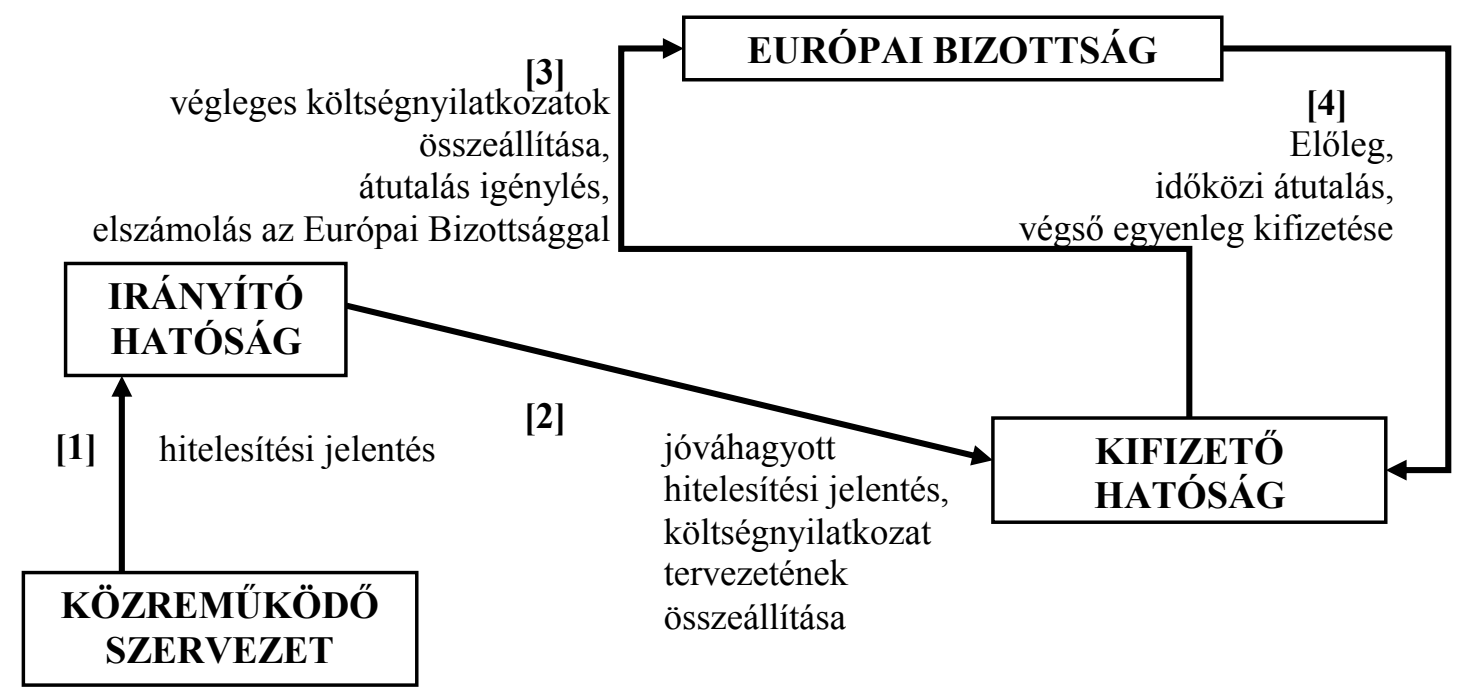

5. számú ábra az elszámolás és átutalás igénylés folyamatáról (saját készitésü ábra) 
1: A közremüködő szervezet elkészíti a hitelesítési jelentések tervezeteit, majd továbbítja az irányító hatóság felé.

2: Az irányító hatóság az operatív programok esetében prioritásonként jóváhagyja a hitelesítési jelentéseket, valamint összeállítja a költségnyilatkozat tervezetét és továbbítja a kifizető hatóságnak.

3: A kifizető hatóság összeállítja a végleges költségnyilatkozatot és igazolja, hogy a költségnyilatkozatok ténylegesen felmerült költségeken alapulnak, pontosak és megfelelőek, továbbá a közremüködő szervezetek és az irányító hatóság irányítási és ellenőrzési rendszerei a jogszabályi elöírásokkal összhangban vannak. Ezt követően a kifizető hatóság eljuttatja az átutalás igénylést az Európai Bizottságnak.

4: Az Európai Bizottság az igényelt támogatást átutalja a kifizető hatóságnak.

A végső egyenleget (fennmaradó 5\%) az Európai Bizottság csak az operatív program sikeres fizikai és pénzügyi lezárását követően, a zárónyilatkozat ${ }^{53}$ kibocsátását és annak Európai Bizottság általi jóváhagyását követően utalja át.

\subsubsection{Költségvetési kapcsolatok a támogatások igénybevételekor Magyarország és az Európai Unió között}

Az európai uniós támogatások közvetlen módon nem javítják a tagállamok költségvetését, hiszen a támogatások az azt közvetítő intézményrendszeren átáramlanak. A támogatások haszna - gazdasági fejlődés, munkanélküliség csökkenése, leszakadó régiók felzárkózása, gazdasági és társadalmi kohézió erösítése - a központi költségvetésben közvetett és közvetlen módon a támogatások folyósítását követően évek múlva jelentkezhetnek. Például megnövekedett adóbevételek formájában, vagyis közvetve az államháztartás egyenlegének javulásához hozzájárulnak.

A támogatások igénybe vételéhez azonban - összhangban a szubszidiaritás, illetve az addicionalitás elvével - minden esetben szükséges a nemzeti társfinanszírozás rendelkezésre bocsátása. Ez egyrészt lehet központi költségvetési forrás, másrészt a regionális, illetve a helyi szint hozzájárulása, valamint a kedvezményezett saját hozzájárulása. A regionális szint, illetve a helyi önkormányzatok hozzájárulása - az államháztartás egészét tekintve - többletkiadásnak tekinthető, vagyis a nemzeti

\footnotetext{
${ }^{53}$ A zárónyilatkozat kibocsátása az ellenőrzésért felelős szervezet feladata, melyben arról nyilatkozik, hogy a megvalósított programmal kapcsolatos elszámolás helyes, a költségeket alátámasztó ügyletek jog- és szabályszerüek.
} 
hozzájárulás egyes szintek (központi költségvetés, régiók szintje, helyi szint) közötti átcsoportosítása összességében nem változtatja az államháztartás egyenlegét. A magánszektor bevonása mérsékelheti az államháztartás azonnal jelentkező terheit, illetve időben szétterítheti a fejlesztések miatt jelentkező terheket. (Szemlér 2007) Ennek részlegesen ellentmond ugyanakkor, hogy az államháztartási hiány és a fejlesztési jellegü közkiadások közötti determinációs együttható Magyarországon megközelítette a 0,8-as értéket, vagyis az addicionalitási kiadások szintje a hiány mértékét nagyban befolyásolja. $\mathrm{Az}$ állam terheit növeli ugyanakkor az is, hogy a források lehető legmagasabb abszorpciója érdekében a tagállamnak magasabb kifizetési kötelezettséget ${ }^{54}$ kell vállalnia a kedvezményezettek felé, mint amekkora forrásra ténylegesen számíthat. Ennek hátterében az áll, hogy bizonyos projektek megvalósítása sikertelen, tehát a 100\%-os abszorpciós ráta eléréséhez a tagállamoknak 100\% feletti kötelezettségvállalással kell számolnia. Mindemellett a közösségi források gazdaságélénkítő hatása miatt az adóbevételek nőhetnek, ami idővel a költségvetési egyenleget javíthatja. (Banai 2008) A pótlólagos állami szerepvállalás más hazai szerzők szerint ugyanakkor eladósodáshoz vezethet, mivel „a költségvetés terhére folyósított állami támogatások növelésének természetszerü következménye a költségvetési hiányok, majd ezek halmozódása következtében az államadósság megugrása” (Pitti 2010) ugyanakkor a hétéves pénzügyi tervezés előnyeként a fejlesztésekre fordítandó terhek nagy biztonsággal, előre kalkulálhatók.

${ }^{54}$ Angolul overbook. 


\section{Magyarországi helyi önkormányzatok mozgástere és az addicionalitás biztosítása}

Ebben a fejezetben összegző módon bemutatom azokat a kockázatokat, amelyek a magyar önkormányzati rendszer gazdálkodásában jelen voltak a rendszerváltás óta eltelt időszakban. A logikai keret kialakítása érdekében összegző módon tárgyalom az önkormányzatiság kialakulását, a gazdálkodásban bekövetkező változásokat és azok hatásait. Az eladósodási folyamatok ugyan csak az uniós csatlakozásunkat követően erősödtek fel az önkormányzati rendszerben, mégis részletesen foglalkozom annak elméleti hátterével, figyelemmel az európai uniós támogatások igénybe vételéhez szükséges pénzeszközök biztosítására, összhangban az addicionalitás követelményével. A számviteli folyamatok bemutatását azért tartottam szem előtt, mert az empirikus tesztelés során alkalmazott adatok megértéséhez szükséges az egyes tételek mögötti mozgások részletes ismerete.

\subsection{Az önkormányzatiság kialakulása Magyarországon}

\subsubsection{Helyi Önkormányzatok Európai Chartája}

A Helyi Önkormányzatok Európai Chartája (1985) ${ }^{55}$ a szubszidiaritás elvének megfelelően rögzíti, hogy , a közfeladatokat általában elsősorban az állampolgárokhoz legközelebb álló közigazgatási szervnek kell megvalósítania. A feladatoknak más közigazgatási szervre történö átruházása a feladat természetétől és nagyságától, valamint hatékonysági és gazdaságossági követelményektöl függ." A Charta ${ }^{56}$ alapelvei szinte valamennyi európai uniós tagállam jogrendszerében alapvető önkormányzati értékként megjelennek. (Lóránt 2008a)

A charta a központi kormányzat és a települések közötti viszony alapelveit rögzíti, azonban

- mivel a szubszidiaritás elve alkalmazhatóságának feltétele a pénzügyi háttér megteremtése is (Gyulai 2000) - a finanszírozás módjára vonatkozó keretelveket is megállapít, amely szerint a pénzügyi források egy részét olyan adó és díjbevételek teszik ki, amelyek meghatározása az önkormányzatok hatásköre, és amelyek felett hatáskörük

\footnotetext{
${ }_{55}^{55}$ Magyarországon az 1997. évi XV. törvény hirdette ki.

56 A Helyi Önkormányzatok Európai Chartája mellett meg kell említeni a Regionális Önkormányzatok Európai Chartáját (1997), azonban mivel a kutatás nem a régiókra irányul, ennek bemutatásától eltekintek. A hazai szakirodalomban lásd (Forgácsné Orosz 2000); (Szegvári 2004).
} 
keretein belül szabadon rendelkeznek. A helyi önkormányzati gazdálkodási autonómia része a befolyt források relatíve szabad elköltése, ugyanakkor ,az állam által leosztott pénzeszközökhöz felhasználási kötelezettség társulhat." (Lóránt 2008a) A charta priorizálja a helyi adók használatát a kötött vagy részben kötött felhasználású támogatásokkal szemben, és rögzíti, hogy a támogatások juttatása nem korlátozhatja az önkormányzatok hatáskörükön belüli önálló döntéshozatali jogát. A helyi adók alkalmazása elősegíti az önkormányzati elszámoltathatóságot, míg a kötötten felhasználható támogatások gyengítik azt, a kiadások növelésére ösztönöznek, továbbá fellazítják a települések költségvetési korlátait. (Lotz 2009)

Nagyfokú hasonlóság figyelhető meg a helyi önkormányzatok bevételi szerkezete között az Európai Unió országaiban. A három fő finanszírozási forma - központi költségvetési támogatások normatív alapon vagy felhasználási kötöttséggel, megosztott vagy átengedett adók, saját jogon szedett bevételek ${ }^{57}$ - minden országban jelen van, azonban jelentős különbségek körvonalazódnak a bevételek szerkezetében, egymáshoz viszonyított aránya tekintetében, amely alapján a szakirodalom az észak-európai és a dél-európai modellt különbözteti meg. ${ }^{58}$ (Kusztosné Nyitrai, Barabás 1998), (Lóránt 2008a)

A helyi adóbevételek súlya és mértéke a tagállamokban eltérő, vegyes képet mutat. Az önkormányzati jövedelemkülönbségek mérséklésének horizontális és vertikális modellje különböztethető meg. A vertikális modell esetében az állam szükíti az önkormányzatok rendelkezésére álló források közötti negatív különbséget, míg a horizontális modell esetében az önkormányzatok között kiegyenlítési mechanizmus müködik, vagyis a pénzügyileg erősebb önkormányzatoktól jut forrás a pénzügyileg gyengébb önkormányzatokhoz. (Csipai, Vigvári 2009)

\subsubsection{A rendszerváltást követő időszak}

A rendszerváltás időszakában, valamint a piacgazdaságra történő áttérésben az önkormányzatiság kialakulása az átmenet integráns részét képezte, mind politikai, mind társadalmi értelemben. (Pickvance 2002), (Straussman, Fábián 1994) A rendszerváltást

\footnotetext{
${ }^{57}$ Helyi adók, díjak, vagyonból származó bevételek, hitelfelvétel stb.

${ }^{58} \mathrm{Az}$ észak-európai vagy skandináv modellben nagy méretü helyi önkormányzatok jellemzőek nagyfokú pénzügyi-gazdasági önállósággal és felelösséggel, míg a dél-európai modell a helyi önkormányzatok mérete föleg a történelmi hagyományokon múlik, azonban a pénzügyi rendszer centralizált, és jelentős az állami ellenőrzés. A francia, svéd, német önkormányzati modellek (ellátott közfeladatok, finanszírozás, ellenőrzés) részletes bemutatását lásd (Kusztosné Nyitrai, Barabás 1998).
} 
megelőző időszakban értékválasztás történt, miszerint - Alkotmányban rögzítetten és az önkormányzatokról szóló 1990. évi LXV. törvénnyel (továbbiakban önkormányzati törvény ${ }^{59}$ ) - minden település annak méretétől, elhelyezkedésétől függetlenül megkapta a helyi önkormányzásra való, valamint a helyi közügyek szabályozásához kapcsolódó jogot a társulási szabadság - mint lehetőség - mellett. (Fürcht 2009) Az új önkormányzati rendszer rendkívül nagy önállóságot és szabadságot biztosított az önkormányzatoknak a döntések meghozatalában (Jenei, Szalai 2002), ezzel az állami berendezkedés a hagyományos centralizációval szemben a decentralizáció útjára lépett. „A demokratikus intézményrendszer megteremtése, [...] a demokrácia megvalósulásának egyik legfőbb színtere azonban a helyi önkormányzat" (Gyulai 2000), melyet a Helyi Önkormányzatok Európai Chartája is megerősít.

A kialakított rendszerben a helyi szint és a központi szint között hierarchikus viszony nem állt fenn, a helyi önkormányzat önálló jogi entitás, amelynek vagyona van, és méretétől függetlenül azonos jogokkal bír, szabadon társulhat. (Jenei, Szalai 2002) (Straussman, Fábián 1994) (Goglio 2007) Mivel az önkormányzás joga a települési szintet illeti meg és ezáltal elaprózódott, a helyhatósági integráció helyett dezintegrált rendszer jött létre, az egy település egy önkormányzat modell valósult meg. (Vigvári 2009a) (Fürcht 2009) (Báger és Vigvári 2007) (Vigvári 2011a)

A helyi adókról szóló törvény ezzel párhuzamosan pedig megteremtette a lehetőséget és a jogszabályi kereteket ${ }^{60}$ az önkormányzatok részére a helyi adóztatásra (Lóránt 2008a). A korlátlan döntési szabadság már kezdetekben magában hordozta a pénzügyi egyensúlytalanság lehetőségét, beleértve a települések közötti fejlettségbeli különbségek növekedésének lehetőségét is. (Jókay et al. 2004), (Homolya-Szigel, 2008)

\footnotetext{
${ }^{59}$ A 2011. évi CLXXXIX. törvény az önkormányzatokkal kapcsolatos szabályozást új alapokra helyezte. A vizsgált idöszakban az 1990. évi törvény és annak módosításai voltak hatályban, így a dolgozatban önkormányzati törvény alatt azt értem.

${ }^{60}$ 1990. évi C. törvény a helyi adókról, amely alapján az önkormányzatok meghatározzák a helyi adóztatás részletszabályait, megállapítják az adók mértékét és a mentességeket, továbbá ellenőrzik az adóztatás folyamatát, ugyanakkor a helyi adók bevezetése nem kötelezö. A helyi adók három fö csoportra oszthatók: vagyoni típusú adók, kommunális jellegủ adók és helyi iparúzési adók.
} 


\subsection{Az önkormányzatok finanszírozási háttere}

\subsubsection{Elméleti megközelítések a helyi adókra vonatkozóan}

Az önkormányzatok jogi szuverenitásának megteremtését követően Magyarországon olyan finanszírozási rendszert kellett kialakítani, ami lehetővé tette az önkormányzatok gazdálkodási szabadságát.

„Örök igazság, hogy csak akkor beszélhetünk valós önkormányzati gazdálkodásról, ha helyben döntik el, mire, mennyit fordítanak." (Péteri 2005) A helyi adók bevezetését indokolta, hogy olyan széleskörü finanszírozási rendszer épüljön ki, ami egyrészt az önkormányzatok döntésén alapul, másrészt megteremti a kapcsolatot az önkormányzat által nyújtott szolgáltatások és a lakosság igényei között. Már a szabályozással kapcsolatos kezdeti tanulmányokban (Pitti, László, Pálné Kovács, Straussman) is két alapvető kérdéscsoport körvonalazódott: egyrészt az önkormányzati adóztatás jogi szabályozása mekkora szabadságot ad, másrészt pedig az újonnan létrejött önkormányzatok milyen mértékben tudnak élni a helyi adóztatás lehetőségével, illetve az adóztatással kapcsolatos közigazgatási, illetve szakmai feladataikat milyen színvonalon tudják ellátni, az adóigazgatás személyi és technikai feltételei milyen módon befolyásolják az adóztatást.

A rendszerváltást követő közvetlen időszakban az adóbevételek beszedése sem a központi költségvetés, sem az önkormányzatok esetében nem volt egyszerü feladat. Egyrészt meg kellett teremteni az adófizetés - politikai és közgazdasági dilemmákkal tarkított jogszabályi, valamint adminisztratív hátterét, másrészt gyakoriak voltak a csődesetek a vállalkozások esetében és az életszínvonal - a munkanélküliség és a szociális juttatások csökkentése miatt - romlott. (Kornai 1992)

A helyi adók bevezetése mellett és ellen is felsorakozott számos érv: a bevezetés mellett szólt a hiányzó források pótlásának megteremtése, illetve különféle fejlesztési programok megvalósítása, míg az adók bevezetésének halasztását támasztotta alá számos egyéb tényező. $^{61}$ A piacgazdaságba való átmenet magas munkanélküliséggel és inflációval párosult, a szociális háló meggyengült, ezért a helyi közösségek újjáélesztése kulcsfontosságúvá vált. (Straussman, Fábián 1994) A kritikusok szerint ((Pitti 1992) (László, Pálné Kovács 1993)) a helyi adóztatás bevezetése valójában nem lehetőség,

\footnotetext{
${ }^{61}$ Lakosság megváltozott életkörülményei, választási ígéretek, szakmai felkészületlenség.
} 
hanem kényszer az önkormányzatok számára, ugyanis míg az adók kivetése csak lehetőség, addig a feladatok ellátása - a költségek helyi szintü meghatározásával - az önkormányzatok kötelezettsége, és ilyen módon a kiadások megosztása a központi költségvetés és az önkormányzati alrendszer között.

A helyi adóztatás bevezetésének időszakában körvonalazódott már azonban, hogy „az aprófalvas térségek kisebb mértékben, a nagyobb település-méretü (gazdaságilag erősebb) térségek magasabb arányban tudnak élni a helyi adóztatás lehetőségével”, hiszen az iparüzési adó előnyeiből elsősorban a nagyobb települések profitáltak, ugyanakkor az adóbevételek súlya területenként nagymértékü szórást mutatott. A helyi adók - különösen az iparüzési adó - tehát az önkormányzatok bevételeit differenciálják. (Pitti 1992) (Hetényi 2004), (Péteri 2008) in (Sevic et al. 2008). Nem volt meglepő az az adat, miszerint a kisebb települések bevételi szerkezetében a helyi adókból származó bevételek nagyobb arányt képviseltek, mint a nagyvárosok esetében. Ugyancsak szembetünő, hogy az építményadó a 2000-es évek közepén az alacsonyabb komfortfokozatú, jellemzően falusi házakat terhelte az értékesebb városi lakásállomány helyett (Lóránt 2008a), hiszen míg a nagyobb, iparilag fejlettebb területeket a vállalkozásokat sújtó adók kivetése lehetőség volt a helyi önkormányzatok számára, addig a kisebb, illetve iparilag fejletlenebb településeken jellemzően a lakosságot adóztatta a helyi önkormányzat. Fentiek értékelése sem egységes a szakirodalomban, ugyanis a kritikus megközelítés szerint „a területi különbségeket és a szociálpolitikai problémákat nem képes a helyi adórendszer hatékonyan kezelni” (László, Pálné Kovács 1993), ugyanakkor a bevételi szerkezet eltérései méretgazdaságossági problémákon nyugodtak. (Bird, Wallich, Péteri 1995) Az önkormányzatok adóztatásával kapcsolatban megfogalmazott kritika volt, hogy a helyi adók bevezetését nem előzték meg feltáró elemzések, nem valósult meg a helyi sajátosságok érvényesítése. (Pitti 1992)

\section{Helyi iparüzési adó}

A helyi adók 1990-es bevezetése és a kutatás során vizsgált időszak között tendenciaként értékelhető, hogy a helyi adónemek száma és az adó mértéke folyamatosan növekedett, és az önkormányzatok bevételi szerkezetében meghatározó szerephez jutottak a saját bevételek. A helyi adók közül - a kutatás szempontjából - különösen fontos az iparüzési adó kezelése, egyrészt azért, mert jelentős hányadot képvisel az önkormányzatok saját 
bevételei között ${ }^{62}$, másrészt pedig azért, mert a gazdaságilag fejlettebb térségekben az iparüzési adó koncentrálódása jellemző. (Lóránt 2008a) Az iparüzési adó ugyanakkor érzékeny a konjunkturális változásokra, ezért a szektor „saját bevételi potenciáljának sebezhetőségét" (Vigvári 2009a) okozza, ami a kutatás szempontjából - összhangban a költségvetési egyensúly megteremtésének szükségességével - fontos tényező a hitelfelvételek ${ }^{63}$ szempontjából is.

Az iparüzési adó már a rendszerváltást követő kezdeti időszakban magas bevételekhez juttatta az önkormányzatokat, azonban annak beszedése felülmúlta azok adminisztratív és ellenőrzési kapacitásait. (Straussman, Fábián 1994), (Bird, Wallich, Péteri 1995) Az iparüzési adó jelzi azokat az aránytalanságokat, amelyek az ország térszerkezetében rejlenek, és emiatt az önkormányzatok adóerő-képesség mutatója számításának alapjává vált (Bende-Szabó, Gábor 2004) in (Horváth et al. 2004), (Lóránt 2008a), így mint a gazdasági fejlettséggel szorosan összefüggő mutatót a kutatás empirikus részében kiemelten kezelem.

\subsubsection{Magyarországi önkormányzatok gazdálkodása 1991-2000 között}

A hierarchikus tagozódás az önkormányzatok között megszünt, mellyel párhuzamosan teljessé vált a forrásszabályozás, kialakultak azok a gazdasági feltételek, amelyek biztosították a helyi közösségek autonóm gazdálkodását ${ }^{64}$ egyrészt azoknak a feladatoknak az ellátására, amelyeket a törvény kötelező feladatként ${ }^{65}$ nevesít, másrészt azokra, amelyeket az önkormányzat a helyi igényeknek és teljesítőképességének megfelelően ellát. A jogegyenlőség a hatáskörök és a feladatok telepítésében is megjelent, függetlenül a települések méretétől és közigazgatási teherbíró képességétől. (Pálné Kovács 1997)

Az önkormányzatok bevételi struktúrája így 1990 és 2000 között jelentősen módosult: míg a saját bevételek közel tízszeresen, a megosztott bevételek kilencszeresen, az állami

\footnotetext{
${ }^{62}$ A teljes helyi adó bevétel közel 80-85\%-át. (Jenei, Szalai 2002), (Goglio 2007), (Vigvári 2009a)

${ }^{63}$ A dolgozat elméleti felvezetőjében a hitel kifejezést nem a tényleges hitelfelvételre korlátozom, hanem beleértem a kötvénykibocsátást is, ami a hosszú lejárató hitelek felvételénél tipikusabb a magyar önkormányzati rendszerben tekintettel arra, hogy nem közbeszerzés-köteles tevékenység, míg a hitelfelvétel az.

${ }_{64}$ Ezzel egyidejűleg „a központi költségvetés jövedelemcentralizáló és újraelosztó szerepe is átértékelődött." (Pitti 2003)

${ }_{65}$ Egészséges ivóvíz ellátás és csatornázás, óvodai nevelés, alapfokú iskolai oktatás és nevelés, egészségügyi és szociális alapellátás, közvilágitás, helyi közutak és köztemető fenntartása, valamint a nemzeti és etnikai kisebbségek jogai érvényesülésének biztosítása.
} 
támogatások - nominálértéken számolva - négyszeresen növekedtek, addig a normatív juttatások a finanszírozási feltételek gyakori változása mellett alig kétszeresükre nőttek. Így a bevételi oldalon a saját bevételek, vagyis a helyi adók és a mobilizálható vagyon értékesítése kulcsfontosságú tényezővé vált. A helyi adókról szóló törvény 2006. évi módosításának ${ }^{66}$ következtében, továbbá az ellátandó feladatok növekedése miatt a helyi adókat bevezető önkormányzatok száma és a helyi adóbevétel nagysága is jelentősen növekedett. (Lóránt 2008a) A hitelek az önkormányzatok finanszírozásában - a magas kamatterhek miatt - nem játszottak jelentős szerepet, így az eladósodottsági szint nem volt magas. (Goglio 2007) Mivel ,az állami támogatások több mint négyötöde müködési célú juttatás, s alig egyötödös arányt képviselnek a fejlesztési célú támogatások” (Pitti 2003), az önkormányzatok fejlesztéseket - elsődlegesen - a ciklus első két évében felhalmozott saját bevételek terhére valósítottak meg, vagy elhalasztották azokat. (Kopányi, Vigvári 2003)

Az önkormányzatok kiadási szerkezete településtípusonként eltérő képet mutatott: míg a személyi jellegű ráfordítások súlya a megyék és városok esetében ${ }^{67}$ átlag feletti, addig a beruházási célú ráfordítások esetében a községek mutattak átlagon felüli részesedést. A beruházások jellemzően a közmühálózat fejlesztésére, szennyvízberuházásra, közvilágítás korszerüsítésére, fütéskorszerüsítésre irányultak. Valamennyi településtípus esetében jellemző, hogy a felhalmozási célú ráfordítások - a helyi önkormányzati választásokat megelőző évek tekintetében - ciklikusak, továbbá a hiteltörlesztés elhanyagolható nagyságrendet képvisel. (Pitti 2003), (Kopányi, Vigvári 2003), (Vigvári 2009b)

A vagyonosodási folyamatok három fö, azonban időben nem kiegyenlített szakaszra - vagyonszerzés ${ }^{68}$, vagyontárgyak nevesítése, társasággá alakítás, illetve privatizálás tagolhatók. A szabad vagyonelemek privatizálása, illetve fedezetkénti bevonása visszavetette az üzemgazdasági szemlélet meghonosodását. (Péteri 2008) in (Sevic et al. 2008)

Az Európai Tanács megbízásából elkészített, 14 országot $^{69}$ érintő kutatás eredménye szerint a helyi adókból származó bevételek jelentősége fokozatosan nőtt, ami a

\footnotetext{
${ }^{66}$ A központi mentességek köre csökkent, az alkalmazható adómérték emelkedett. (Lóránt 2008)

67 Vélhetően annak következtében, hogy a közfeladatok jelentős részét a városok látják el, és azok munkaerő-igényesek.

${ }^{68}$ Vagyis a vagyontárgyak az önkormányzat tulajdonába kerülnek.

${ }^{69}$ Magyarország is részt vett a felmérésben.
} 
decentralizáció erősödésére utal, ugyanakkor a helyi önkormányzatok növekvő feladatai miatt nőtt a központi forrásból finanszírozott, kötött felhasználású támogatások jelentősége is. A tanulmány nem erősítette meg azt, hogy az új feladatok ellátásához a települések a szükséges forrásokat ne kapnák meg a központi forrásokból, ugyanakkor felhívta a figyelmet arra, hogy a többletfeladatokért járó kompenzáció alapjául szolgáló indikátorok helytelen megválasztása pontatlan forráselosztáshoz vezet, függetlenül attól, hogy általános célú, vagy kötött célú-e a támogatás. (Lotz 2009)

A kompenzálási célú, kötött felhasználású támogatások gyakran, azonban nem kizárólagosan beruházási célokkal összefüggésben merülnek fel. Magyarországot a tanulmány a magas kötött felhasználású támogatású önkormányzati finanszírozási rendszerekhez sorolja, amelyet a kistérségi együttműködést ösztönző feladatmegosztás elősegítése, valamint a lakosság számára kötelezően nyújtandó közszolgáltatások teljesítése indokol.

A tanulmány szerint Magyarországon a helyi adóztatás megerősödésével a decentralizáció növekedése volt tapasztalható, azonban a helyi adók arányát a tanulmány az önkormányzatok saját bevételeinek tekintetében alacsonynak tartja. (Csipai, Vigvári 2009) Hasonló következtetésre jutott László is a rendszerváltást követő húsz év tapasztalatainak összegzésekor, miszerint az önkormányzatok helyi adóztatási politikáját a közgazdasági vészhelyzetek befolyásolták, nem pedig a helyi fejlesztési szükségletek. (László, Szebényi 2010)

A települési önállósághoz való jog érvényesült, a helyi közösségek vagyonhoz jutottak és forrásorientált szabályozás vált általánossá. A finanszírozási rendszer hátrányaként értelmezhető ugyanakkor, hogy a normatív szabályozás előtérbe kerülésével a térségi gondolkodás háttérbe szorult, továbbá és az önkormányzatok érdekeltsége a saját bevételek növelésére nem fokozódott. Ezek a tényezők nem kedveztek a településfejlesztésnek és következetes településpolitika kialakításának, ami jellemzően távlati gondolkodásmódot megkövetelő tevékenység. (Pitti 2003) Míg a jogszabály lehetővé tette az önkormányzatok közötti együttmüködést, a méretgazdaságosság jellemzően nem érvényesült a telepelülések közötti együttmüködés hiányában. (Jenei, Szalai 2002), (Pálné Kovács 2004) in (Kopányi, Wetzel, El 2004), (László, Szebényi 
2010) A települések kis mérete ${ }^{70}$ és az általuk ellátott feladatok széles köre miatt méretgazdaságossági problémák jellemzők Magyarországon, amelyek befolyásolják a közszolgáltatások hatékonyságát (Bird, Wallich, Péteri 1995), (Péteri 2008) in (Sevic et al. 2008), ugyanakkor a magyar jogrendszer lehetővé teszi az önkormányzatok társulását, illetve bizonyos feladatok ellátási kötelezettségét helyi önkormányzati szintről megyei önkormányzati szintre emelni. (Goglio 2007)

A hazai tanulmányok konklúziói eltérők a helyi adóztatás önállóságának, illetve kényszerüségének, valamint az önkormányzati döntések szabadságának tekintetében, egyetértés körvonalazódott viszont abban, hogy háttérbe szorultak a fejlesztési kiadások, illetve az önkormányzatok nem tudták összekapcsolni az egyes feladataikat a helyi adókkal. (Pitti 1992) (László, Pálné Kovács 1993)

\subsubsection{Magyarországi önkormányzatok gazdálkodása 2000-2006 között}

Az önkormányzatok költségvetésének bevételi szerkezetében nem volt jelentős változás abban a tekintetben, hogy a források döntő hányada a központi költségvetéstől származott.

A helyi adóztatás intenzitásának növelése, illetve a költségek jelentős mértékü csökkentése meglehetősen népszerütlen, ezért nem alkalmazott intézkedések. (Jenei, Szalai 2002) Az önkormányzati forrásszabályozás jellemzője az erőteljes jövedelemcentralizáció, melyben továbbra is központi szerepe volt az állami támogatásoknak és hozzájárulásoknak, valamint az átengedett központi bevételeknek. (Kovács, 2005)

A 2000-es évek elejére a külső forrásbevonási ${ }^{71}$ akciók háttérbe szorultak, a helyi adózás rendszere a teljesítőképesség határára került, ugyanis az ország egyes területeinek eltérő gazdasági szerkezete miatt különbségek hordozójává vált, illetve a szabályozásban növekvő hangsúlyt kapott az adóerö-képesség központi minősítése, ami jogi és szakmai szempontból egyaránt aggályosnak tűnt. A közfeladatok forrásigénye meghaladta a rendelkezésre álló helyi forrásokat, így a hazai szakirodalomban a 2000-es évek közepén számos tanulmány született, amelyek az önkormányzatok forrásbevonó-képességére

\footnotetext{
${ }^{70}$ Egyes empirikus tanulmányok szerint a hatékonyság alapfeltétele a legalább 5000 fős lakosságszám. Fox, W.F. (2004) in (Kopányi, Wetzel, El 2004)

${ }^{71}$ A forrásbevonás lehetőségeit a dolgozat 4.3.fejezete tagalja.
} 
vonatkoztak. (Kusztosné Nyitrai, Barabás 1998), (Pitti 2003),(Vigvári 2005) (Halmosi 2005)

A szakirodalomban (Pálné Kovács 2008), (Pitti 2005), (Fürcht 2009), (Vigvári 2009a) egyetértés van abban a tekintetében, hogy az önkormányzatok által ellátandó feladatok köre fokozatosan bővült, azonban az ehhez szükséges források nem, vagy csak részlegesen álltak az önkormányzatok rendelkezésére, ami eladósodáshoz vezethet. „A helyi önkormányzatok de jure alkotmányos önállóságát a valóságban jelentősen korlátozzák egyfelől azok az ágazati-szakmai törvények, amelyek maximalista, teljesíthetetlen követelményeket elöírva folyamatos jogsértésre késztetik/kényszerítik az önkormányzatokat.” (Állami Számvevőszék 2007)

Mivel a méretgazdaságossági szempontok sem érvényesültek és az általános szabályozási környezet nagy szabadságot biztosított az önkormányzatok gazdálkodásában, ez szükségszerüen oda vezetett, hogy a feladatok ellátása nem volt hatékony, a rendszer pénzügyileg nehezen fenntartható, és az önkormányzatok pótlólagos források bevonására kényszerültek.

\subsubsection{Az európai uniós csatlakozás kapujában}

Az európai uniós csatlakozást megelőző időszak kulcsfontosságú volt az önkormányzatok számára. A közösségi jog közvetlenül és közvetetten is hatással van az önkormányzatokra, így az aquis communautaire terjedelme miatt időben meg kellett kezdeni a csatlakozásra való felkészülést, melynek keretében az önkormányzati rendeletek - mint joganyag - áttekintése és átdolgozása vált szükségessé a közösségi jognak való megfelelés érdekében. (Barna 2003)

Az európai uniós csatlakozással kapcsolatos lehetőségként vették számba az államháztartás reformját, az önkormányzati feladat- és hatáskörök felülvizsgálatát, a szabályozás továbbfejlesztését, a meglévő szakmai tapasztalatokat, valamint az önkormányzatok müködésének változását. Ezzel egyidejüleg előrevetítették ugyanakkor azokat a veszélyeket és kockázatokat is, ami a társfinanszírozás biztosításának kötelezettségében rejlik, miszerint Magyarországnak kormányzati szinten fel kell készülnie a társfinanszírozásra, az önkormányzatoknak a saját erő előteremtésére, ami csak többéves - 2006-ig tartó - pénzügyi tervezéssel, illetve kötelezettségvállalással valósulhat meg. Javaslatként fogalmazódott meg a folyó- és felhalmozási típusú költségek 
eltérő költségvetési rendszerben kezelése többéves költségvetési tervezési eszközökkel. (Goglio 2007) (Kovács 2007) Ugyancsak veszélyként fogalmazódott meg az önkormányzatok vagyonvesztésének lehetősége is, mint a meggondolatlan hitelfelvételek következménye.

A változtatásokhoz Pitti lehetséges eszközként jelenítette meg - a nagy ellátó-rendszerek átfogó reformja mellett - az állam újraelosztó szerepének és a központi elvonásoknak a mérséklödését, a helyi adóalapok korlátozott szélesítését, valamint a feladat- és hatáskörök, illetve a finanszírozási rendszer felülvizsgálatát és a költséghatékony müködés feltételinek megteremtését mind a központi, mind az önkormányzati szinten. Pitti szerint az önkormányzati törvény módosításával újra kell gondolni az önkormányzatok ellátási kötelezettségeit, továbbá a törvénynek garanciát kell adnia a feladatokhoz kapcsolódó támogatások mértékére is. (Pitti 2003), (Pitti 2005) in (Vigvári et al. 2005)

A müködési feltételek biztosítása alapfeltétel ahhoz, hogy az európai uniós támogatások igénybe vételéhez szükséges saját erőt az önkormányzatok - akár hitelfelvétellel, akár állami garanciavállalás mellett - biztosítani tudják, és a térségi szemlélet ezzel párhuzamosan megerősödjön. A finanszírozási technikákra vonatkozóan konkrét javaslatként Pitti fogalmazta meg a saját bevételek körének és összértékének növelését a helyi adóztatás jogosítványainak bővítése, illetve a helyi adózás gyakorlatának átláthatóvá tétele $^{72}$ mellett. Ezzel párhuzamosan a központi és helyi adóterhek arányai közötti módosításra, illetve a megosztott bevételek körének bővítésére vonatkozó, érdekeltségi alapokon nyugvó szabályozási gyakorlat kialakítása mellett érvelt az adóerő-képességen alapuló és a normatív állami támogatások helyett. (Pitti 2003) Mások szerint az önkormányzati szektor adósságát növeli a hatáskörök decentralizációja, és a merev költségvetési szabályrendszer, valamint a helyi szint gyenge fiskális politikája okozza az önkormányzatok válságát. (Bences, István 2003) in (Lenkei et al. 2003), (Pálné Kovács 2004) in (Kopányi, Wetzel, El 2004), (Davey, Péteri 2004), (Halmosi 2005)

Magyarország európai uniós csatlakozását követően a Strukturális Alapokból származó források is megnyíltak az önkormányzatok mint kedvezményezettek elött. A helyi infrastruktúra modernizálásának lehetősége és ezzel párhuzamosan - a strukturális reformok végrehajtása érdekben - a költségek csökkentése összetett problémahalmaz

\footnotetext{
${ }^{72}$ Vagyis a számítás módját átláthatóvá és nyilvánossá kell tennie.
} 
megoldása elé állította az önkormányzati szektort, különösen az ország kevésbé fejlett területein, ott ugyanis - a fejlettségi különbségek csökkentése érdekében kulcsfontosságú volt a fejlődés beindítása beruházásokon keresztül. A közösségi források lehívásához azonban szükségessé vált, hogy a települési önkormányzatok egymással, illetve a központi költségvetéssel együttmüködjenek. (Goglio 2007)

A regionális szintű együttmüködésnek Magyarországon nincs történelmi múltja, és mind a megyék, mind a települések egymásnak inkább versenytársai voltak a rendszerváltást megelőző időszakban, mint kooperáló, együttmüködő szereplők. (László, Szebényi 2010) (Jenei, Szalai 2002) Több, külföldi tanulmány szerint (Pickvance 2002), (Bennett 1997) a helyi önkormányzatok jellemzően alulfinanszírozottak voltak a rendszerváltást követően a megnövekedett feladataikhoz képest, továbbá az egy település-egy önkormányzat modell miatt a méretgazdaságossági szempontok különösen nagy tőkebefektetést igénylő beruházások esetén nem tudtak maradéktalanul érvényesülni, a beruházások külső tényezőktől és forráslehetőségektől függtek, ami egyrészt a források differenciálódásához vezetett, másrészt pedig erősítette a kisebb önkormányzatok gazdasági függését a központi költségvetéstől. (Pickvance 2002) (László, Szebényi 2010) A közszolgáltatások hatékony ellátása, az adminisztratív költségek csökkentése és a beruházások megvalósítása érdekében a kistelepülések és a nagyvárosok közötti kooperáció erősítése indokolt: a támogatások sok esetben a lakosságszám bizonyos nagyságának eléréséhez kötöttek (Goglio 2007); azonban „,a társulási kényszer visszautasítása súlyos terhet jelent a rendszer számára.” (Vigvári 2009a)

Mindennek ellenére a regionális szint finanszírozási hiányosságai miatt a helyi önkormányzatok jellemzően nem maradt hosszú távon társulásokban, inkább egy-egy projekt megvalósításának időszakáig, majd az ön-kormányzás jóval drágább, azonban önálló módját választották. Ez ellentetében áll az Európai Unió által megkövetelt szemlélettel, miszerint transzparens, átlátható fejlesztési politika szükséges regionális szinten. (László, Szebényi 2010) 


\subsection{Eladósodási folyamatok}

A rendszerváltást követő időszakot elemző tanulmányok (Straussman, Fábián 1994) a forrásbevonási lehetőségek közül a hitelfelvételt nem is említették, hiszen abban az időszakban a saját bevételekbe beleszámítottak a privatizációs bevételek is, amelyet az önkormányzatokon lévő gazdasági nyomás fokozott, ugyanakkor felhívták a figyelmet az önkormányzatok túlzottan laza hitelfelvételi szabályozásában rejlő veszélyeire, holott az eladósodás még nem volt tipikus. (Bird, Wallich, Péteri 1995)

Az önkormányzatok nemzetközi összehasonlításban is egyre több közszolgáltatási feladatot láttak el a 2000-es évek elején, amelynek következtében a folyó költségvetési bevételekből nem tudták a beruházásokhoz szükséges fedezetet kigazdálkodni. (Jenei, Szalai 2002), (László, Szebényi 2010) A költségvetés egyensúlya csak pótlólagos forrásbevonással biztosítható, ami jellemzően hitelfelvételhez vezet, a hitelfelvétel vagy a folyó- vagy a tőkeköltségvetés hiányának finanszírozására szolgál. (Vigvári 2009a) A hitelfelvétellel egyrészt megteremthető a helyi költségvetés átmeneti (!) egyensúlya, ugyanakkor mind a hitelfelvétel, mind a törlesztés időszakában közvetett hatással bír a központi költségvetésre is.

\subsubsection{Forrásbevonás lehetőségei}

A hitelfelvétel veszélye, hogy annak hasznát azonnal realizálják, míg terhei később jelentkeznek. Erkölcsi kockázatként értelmezhető, hogy az önkormányzat a teherbíró képességénél nagyobb beruházásba kezd $^{73}$, míg a hitelező pénzintézet ezt nem gátolja meg, és mindkét szereplő bízik az állami szerepvállalásban az adósságszolgáltat nemteljesítése esetére. (Kopányi, Vigvári 2003) (Vigvári 2009a) Az önkormányzati eladósodás mértéke ugyanakkor szabályozási dilemmákat is felvet: a kontroll erősítése szükséges az egyes kormányzati szintek közötti eladósodási mértékek meghatározása érdekében. (Vigvári 2005)

Emiatt az ún. aranyszabály szerint csak beruházási kiadás okozhat költségvetési deficitet. Vagyis csak folyókiadásokra nem szabad hosszú távú hitelt felvenni, mert az elörehozott fogyasztás; a hitelfelvétel kizárólag beruházási kiadások esetében elfogadható, ugyanis annak koncentrált forrásigénye túlzottan megterhelné a megvalósítást végző generációt, vagy meghiúsítaná a beruházás megvalósítását. (Vigvári 2011a) (Gál 2010) Beruházási

\footnotetext{
${ }^{73}$ Ami hitelfelvételt gerjeszt. (Vigvári 2005)
} 
kiadások alatt azonban nemcsak a tárgyi eszköz állomány növekedése értendő, hanem azok

humántőke-beruházások is, amely „kiadásokat a statisztika nem felhalmozási, hanem folyó kiadásként veszi számba.” (Romhányi 2007) Az önkormányzatok hitelfelvételére vonatkozó szabályozás meglehetősen sokrétü, bizonyos országokban tiltott, másutt

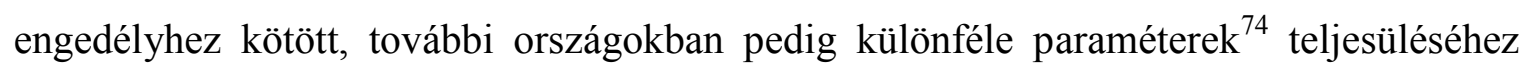
kötött. (Kopányi, Vigvári 2003) (Halmosi 2005) (Kassó 2006a) (Gál 2010) Nem tekinthető az aranyszabálytól való eltérésnek az az eset, amikor likviditási céllal vesz fel az önkormányzat rövid lejáratú hiteleket, hiszen bizonyos helyzetekben - például a regionális különbségek, strukturális problémák miatt - likviditási hitel nélkül egy-egy önkormányzat fizetésképtelenné válna. A hazai önkormányzat „pénzügyi architektúrája félkeménynek" tekinthető, ugyanis nem kizárt a folyó deficit finanszírozása tőkebevételből, illetve hitelfelvételből (Vigvári 2009a), vagyis az aranyszabály érvényesülését a jogszabályi környezet a kutatás által vizsgált időszakban nem kényszeríti $\mathrm{ki}^{75}$, és a költségvetés tervezése során nem különül el a folyó, illetve a beruházási kiadások tervezése. A költségvetési egyensúly megteremtése ugyanakkor a hatékonyságot szolgálja, hiszen megelőzi a deficit és ezáltal a túlzott hitelfelvétel által okozott káros hatásokat (költségvetési egyensúly felbomlása, túlzott kamatteher, fizetésképtelenség).

A beruházásokhoz kapcsolódó hitelfelvétel növeli az önkormányzatok önállóságát (Vigvári 2005) (Vigvári 2011a), és a korábbiakban elmaradt beruházások pótlását teszi lehetővé. Az önkormányzat költségvetésében a hitel egy későbbi visszafizetési kötelezettséggel terhelt bevétel, amelynek elköltésében a hitelfelvevő önkormányzat meglehetősen nagy szabadsággal rendelkezik, összességében a hitel egyrészt lehetőség, másrészt veszély az önkormányzatok gazdálkodása szempontjából. (Halmosi 2005) Szem előtt kell tartani ugyanakkor, hogy az állami/önkormányzati szerepvállalás hatékonysága nem ítélhető meg pusztán a vagyon nagyságának változásával. A vagyon növelése/csökkentése ,a helyzethez igazodó célrendszer függvényében” minősíthető, és

\footnotetext{
74 A folyó- és tőkekiadások között finanszírozása között nem, vagy csak részlegesen engednek átcsoportosítást, megállapítanak prudens müködést lehetővé tevő hitelarányt, a hitelfelvétel felső határát a pénzügyi kapacitáshoz kötik, részletes összehasonlítást ad (Halmosi 2005).

75 Az Állami Számvevőszék tézisgyüjteményében (Állami Számvevőszék 2007) javaslatot tesz az önkormányzatok esetében a folyó költségvetés kiegyensúlyozottságának, vagyis az aranyszabálynak az előírására, valamint a kezességvállalások és szállító tartozások hitelállományba történő beszámítására.
} 
összefüggésben áll az eladósodottság mértékének változásával, illetve a közszolgáltatások színvonalának változásával. (Kassó 2006a)

Az önkormányzatok forrásbevonó képességére vonatkozóan két modell különböztethető meg. A szabad piaci megoldás modellje szerint az önkormányzat mint hitelfelvevő nem különbözik más piaci szereplőktől ${ }^{76}$ és az adósságra vonatkozóan központi kezességvállalás nincs. A modell feltételezi, hogy az információ áramlása megfelelően biztosított és mind a hitelt nyújtó, mind a hitelt felvevő ésszerüen viselkedik. ${ }^{77}$ (Kopányi, Vigvári 2003) (Vigvári 2002), (Vigvári 2005) Az önkormányzatokat megkülönböztető modell szerint a hitelfelvétel engedélyhez kötött, vagyis a korlátozás mögött kontrollfunkciók $^{78}$ léteznek, azonban a központi (állami) garanciavállalás nem automatikus. (Kopányi, Vigvári 2003) Az önkormányzatok gazdasági önállóságát megmutatja a szabályozás mértéke, vagyis az, hogy a központi költségvetés az önkormányzat nemfizetése esetén milyen, - automatikusnak nem tekinthető - garanciális elemeket vállal, és ez mennyire csökkenti a hitelt nyújtók kockázatát. (Vigvári 2005) (Peterson 2000)

Magyarországon a két modell közötti különbség egyrészt a szabályozás tekintetében jelenik meg, másrészt figyelemmel kell lenni arra, hogy az önkormányzatok bevételeinek jelentős része - valamilyen transzfer útján - a központi költségvetésből származik. (Vigvári 2005) A modellválasztástól és a szabályozástól függetlenül azonban a hitelezés ténye miatt hitelezési kockázat merül fel függetlenül attól, hogy a hitel felvevője milyen gazdasági szereplő.

Az önkormányzati hitelezés kockázatai elsősorban erkölcsi kockázatokhoz kapcsolhatók. Egyrészt míg a hitelfelvétel időpontjában hatalom lévő testület élvezi a hitelfelvétel előnyeit, addig annak terheit - különösen nagyberuházások esetében - a következő testületeknek kell viselniük ${ }^{79}$, ezáltal a későbbi ciklusok pénzügyi mozgástere szükül.

Másrészt fennáll a veszélye annak, hogy az önkormányzat nem képes tartani a törlesztésekhez szükséges cash-flow tervét. (Vigvári 2005) (Kovács 2008a)

\footnotetext{
${ }^{76}$ Vagyis a hitelfelvevő ésszerủen viselkedik, a gazdaság szereplői információval megfelelően ellátottak.

77 A modell elméleti alapját a Tibout modell adja, melynek bemutatása mellőzhető a kutatás témája szempontjából.

${ }^{78}$ Aktív funkciók: hitelfelvétel jóváhagyása központi kormányzat, vagy lakosság által; passzív funkció: hitelösszeg korlátozása, hitel felhasználásának irányítása.

${ }^{79}$ „A pénzügyileg fenntarthatatlan feladatellátás, a jelen költségeit a jövő generációra hárító hitelfelvételi politika a prudencia hiányát jelenti." (Vigvári 2011a)
} 
A nemzetközi tendenciák és a magyarországi helyzet között párhuzamosságok körvonalazódnak: az önkormányzatok jelentős többletforrásokat kénytelenek bevonni a beruházások megvalósítása érdekében, ugyanis a rájuk háruló közfeladatok bevételeik döntő hányadát elveszik, így a költségvetésen kívüli források jelentős szerephez jutnak. (Vigvári 2005)

\subsubsection{Forrásbevonás és annak szabályozása Magyarországon}

A 2000-es évek közepére felhalmozódott beruházásigények teljesítése a tőke- és beruházás vonzás tekintetében a versenyképesség növelése szempontjából kulcsfontosságúvá vált. Magyarország európai uniós csatlakozásával a források megnyíltak, ugyanakkor fennállt a veszélye annak, hogy a „pályázati úton nyerhető EU-s támogatások társfinanszírozási igénye azt is jelenti, hogy a nem támogatott, de a különböző önkormányzatok preferencia skáláján élen lévő fejlesztésekre nem lesz forrás.” Az önkormányzati rendszer forrásbevonó képességével kapcsolatosan előnyként volt értékelhető, hogy a szabályozás mind a hitelfelvétel, mind a fizetésképtelenség esetére kialakult volt, továbbá az önkormányzati szektor eladósodottsága a 2000-es évek közepén még nem volt jellemző. Az önkormányzatok jelentős részénél ugyanakkor a saját bevételek, az adóbevételek és a tartalékok növelésére nem voltak további lehetőségek, így az önkormányzati szektor pénz- és tőkepiaci vérkeringésbe történő bevonása szükségszerü volt. (Kovács 2007), (Csiszárik 2008) Veszélyként jelent meg ugyanakkor, hogy az önkormányzatok átgondolatlan hitelfelvételei - a biztosítékok érvényesítése miatt - vagyonvesztést okozhatnak, illetve az utófinanszírozási logikával megvalósuló európai uniós projektek miatt a szektorban a likviditási kockázat nőni fog. (Kopányi, Vigvári 2003)

Mindemellett a magyarországi önkormányzati rendszerben jelentős - az önkormányzatoknak komoly többletterhet okozó - beruházási igények halmozódtak fel (Csiszárik 2008), (László, Szebényi 2010), amelyek egyrészt működési többletköltségeket okoztak, másrészt a beruházások tőkeigényének finanszírozása folyó bevételekből nem, vagy csak korlátozott módon volt lehetséges. (Bende-Szabó, Gábor 2004) in (Horváth et al. 2004), (Vigvári 2005) A felmerült beruházási igények európai uniós támogatásokból történő finanszírozásához, azonban az addicionalitás biztosítása érdekében 6-8 százalékponttal növelni kellett a beruházási célú kiadások arányát. Az abszorpciós 
képesség javításához a saját jogú bevételek növelése, illetve a hitelfelvétel szolgált eszközként. (Kopányi, Vigvári 2003) (Pitti 2003)

Az önkormányzati hitelkereslet modellezésének eredménye azt mutatta, hogy az önkormányzatok hitelfelvételében a politikai ciklikusság volt jellemző: míg a ciklusok első két évében tartalékokat képeztek, addig a második felében - jellemzően valamilyen hitel felvétele mellett - megvalósultak a beruházások az adósságállomány egyidejü megugrásával. (Báger és Vigvári, 2007) (Vigvári 2009a) Az önkormányzati szektor hitelfelvétele $^{80}$ ugyanakkor csak 2005-től nőtt jelentős mértékben. (Vigvári 2005) (Vigvári 2009a) A nemzetközi szakirodalomban is fellelhető hasonló tendenciákat bemutató kutatás, miszerint a politikai vezetés változása megváltoztathatja a költségvetés szerkezetét a választók bizalmának megszerzése érdekében, ami oda vezethet, hogy a helyi önkormányzatok kiadásai felülmúlják azok bevételeit. (Pinkowski 2004)

A magyarországi önkormányzatok vizsgált időszakbeli hitelfelvételét - elvi értelemben, de jure $^{81}$ a szabályozott adósságrendezés modelljével összhangban - korlátozhatja, hogy a helyi önkormányzat adósságot keletkeztető éves kötelezettségvállalásának (hitelfelvételének és járulékainak, valamint kötvénykibocsátásának, garancia- és kezességvállalásának, lízingjének) felső határa a korrigált saját folyó bevétel $70 \%$-a. ${ }^{82} \mathrm{~A}$ gyakorlatban azonban ez valódi hitelfelvételi korlátot nem jelentett, az önkormányzatok hitelfelvételét - és ezáltal a szektor eladósodását - elsődlegesen a bankok kínálata határozta meg. (Vigvári 2009a), (Jókay et al. 2004), (Homolya-Szigel, 2008) Szembetűnő tendencia azonban, hogy már 2006-tól „nőtt a működési célú hosszú lejáratú hitelek állománya is", továbbá számos önkormányzat a fizetőképességét folyószámla-hitelkeret emeléssel, valamint likvid hitelek felvételével tudta csak biztosítani, továbbá a kötvénykibocsátások korábbi hitelek visszafizetését szolgálták. (Kovács 2007) (Kovács 2008b)

\footnotetext{
${ }^{80}$ Melybe beleértjük a kötvénykibocsátást is.

81 „Az önkormányzatok eladósodásának hazai szabályozása leginkább a szabályalapú megközelítéshez igazodik." (Gál 2010)

${ }^{82}$ A szabályozás alapját az önkormányzati törvény 1996. január 1-től hatályos változata teremtette meg.
} 


\subsubsection{Hitelfelvétel értékelése és kockázatai}

A hitelfelvételi kockázatok elemzésekor figyelemmel kell lenni arra a tényre, hogy a hitelfelvétel és a magántőke bevonása hozzájárulhat a fejlesztési mozgástér bővítéséhez, továbbá a terhek generációk közötti megosztásához és a beruházás növeli az önkormányzat vagyonát. (Romhányi 2007), (Vigvári 2009a)

Az önkormányzatok hitelállománya 2005 és 2008 között jelentősen, közel kétszeresére nőtt. A felhalmozódott adósságállomány 87\%-a hosszú lejáratú kötelezettség volt, amelyből

63\%-ot a kötvénykibocsátások tettek ki. (László, Szebényi 2010) Az önkormányzatok bevételeinek összetételét is vizsgáló tanulmány (Lóránt 2008a) szerint 2005-től a kötvénykibocsátásoknak meghatározó szerep jutott, ugyanis míg 2005-ben 4,5 milliárd, addig 2007-ben 180 milliárd Ft értékü kötvénykibocsátás jellemezte az önkormányzati szektort. ${ }^{83} \mathrm{Az}$ önkormányzati alrendszer eladósodása mind a kötvényt kibocsátó önkormányzatok száma, mind a kibocsátott kötvények ${ }^{84}$ összegének tekintetében 2008 ban tovább nőtt (Kovács 2008b), és a gyorsuló eladósodással a „helyi önkormányzati szektor növekvő fiskális kockázatok hordozója” lett. (Vigvári 2009b) Lóránt szerint a kötvénykibocsátás mértékének jelentős növekedése - összhangban az aranyszabállyal csak akkor nem okoz hosszú távon pénzügyi nehézségeket, amennyiben azokat fejlesztésre használják fel, nem pedig müködési célok finanszírozására, vagy korábbi hitelek kiváltására.

A magyarországi önkormányzatok eladósodásának folyamatában jelentős szerep hárul a bankokra a jövőben. Míg korábban a bankok az önkormányzatokat jellemzően jó adósoknak minősítették, és ezért hitelkérelmeiket kedvezően bírálták el, addig a 2010 utáni időszakban kérdéses, hogy a piac önszabályozó mechanizmusa belép-e, vagyis amennyiben a hitelezési kockázatok miatt csökkentik a hitelkínálatot, akkor a szektor eladósodása lassulhat, amennyiben viszont a hitelkínálat fennmarad és szigorú szabályozás nem lép életbe, az önkormányzatok eladósodása - részben az európai uniós támogatások igénybe vételéhez szükséges önerő előteremtése miatt - fokozódhat. A hitelfelvételi kockázatok mérséklésének eszköze olyan központi kontrollok bevezetése is

\footnotetext{
${ }^{83}$ A kibocsátott kötvények jellemzően 3-5 éves tőketörlesztési moratóriummal és 15-18 éves futamidővel kalkuláltak, azokat többnyire a szervező bankok jegyezték. (Lóránt 2008), (Vigvári 2009a)

${ }^{84}$ A bankok a kötvények jegyzésével „komoly likviditást nyújtó szereplővé léptek elő”, azonban a kötvényeknek másodlagos piaca nincs. (Gál 2010)
} 
lehet, amelyek hitelfelvételi korlátokat adnak különféle szempontok - pl. hitelplafon, hitel futamidejének, céljának meghatározása - figyelembe vételével. (Vigvári 2009a)

Az önkormányzatok eladósodása Vigvári szerint atipikus (Vigvári 2009a), ugyanis a 2006-ot követően felvett hitelek egy részét az önkormányzatok tartalékként $^{85}$ (Homolya-Szigel 2008), (Kovács 2008a) (Vigvári 2009b) vagy arbitrázsmüveletekre használják, melyekből kamatbevétel származott (Vigvári 2011a), ugyanakkor a hiány növekvő komponense a folyó hiány. A pénzügyi kockázat forráshiányon ${ }^{86}$, likviditási kockázatokon, valamint bonitáshiányon alapul. A községi önkormányzatok esetében a fiskális kockázat jellemzően a forráshiányban jelenik meg, melyet „a kormányzat diszkrecionális eszközökkel” általában kezelni képes, ugyanakkor likviditáshiányukat hitelintézetek segítségével képesek kezelni. A nagyvárosok esetében azonban gyorsuló mértékü eladósodás volt jellemző, elsődlegesen devizában denominált kötvénykibocsátás formájában, amellyel nemcsak hosszú lejáratú kötelezettséget, hanem árfolyamkockázatot is vállaltak. (Vigvári 2010b) Vigvári szerint a kibocsátott kötvények egy része a működési hiányt fedezte, másik része pénztartalékként - későbbi beruházások megvalósítására - halmozódott fel, és csak kisebb részét használták fel ténylegesen, beruházási célokra. (Vigvári 2009b), (Dankó és Lóránt, 2010) A tanulmány szerint „az eladósodási folyamat eddig nem mutatott összefüggést az EU-s források abszorpciójával" és a jóváhagyott projektek és a kötvénykibocsátások között nincs közvetlen összefüggés. (Vigvári 2009b) Vigvári másik, ugyanabban az évben született tanulmánya szerint a kötvényeket kibocsátó önkormányzatoknak „sikerült függetleníteniük magukat a központi, sőt részben az európai uniós forrásoktól is", (Vigvári 2009a) és a kötvénykibocsátók jellemzően nem pályáztak európai uniós támogatásokra. A gondolatmenet alapján az arányszabály nem, vagy csak korlátozottan érvényesült.

Az eladósodás és az európai uniós támogatások felhasználásának makrogazdasági összefüggéseit vizsgálva Banai fentiekkel ellentétben arra a következtetésre jutott, hogy az államháztartási hiány szintje és a fejlesztési jellegü kiadások között magas $(0,8)$ determinációs együttható mutatható ki, vagyis „,a hiány szintjét alapvetően befolyásolja az addicionalitási kiadások szintje”. (Banai 2008) Az önkormányzatok hitelfelvételi

\footnotetext{
${ }^{85}$ betét, állampapír

${ }^{86}$ Forráshiány: a törvényekben rögzített feladatokhoz nem kapcsolódik megfelelő mértékü költségvetési forrás; bonitáshiány: az önkormányzat a vállalt kötelezettségeinek nem képes megfelelni. (Vigvári 2009a)
} 
kockázatának átfogó, banki szempontokat is elemző tanulmányában ${ }^{87}$ Homolya-Szigel részben megerősítették Vigvári atipikus önkormányzati eladósodás elméletét. Egyetértés mutatkozik a tanulmányokban abban, hogy az eladósodottság egy viszonylag szűk, kisszámú csoportot érint, és a hitelfelvétel alapvetően tartalékolási célú volt, tényleges finanszírozási igények nélkül. Míg Vigvári szerint az önkormányzatok a hitelt nem beruházási céllal vették fel, addig Homolya-Szigel értelmezésében „az eladósodás változása nem mutatott összefüggést az egyes önkormányzatok müködési költségeinek emelkedésével”, illetve az „EU támogatások hatására nem élénkültek az önkormányzati beruházások, így valószínűsíthető, hogy az EU által támogatott projektek nem teremtenek teljes egészében többletfinanszírozási igényt az önkormányzatok számára a korábbiakhoz képest." (Homolya-Szigel, 2008)

Az adósságállomány 2007 és 2008 között ugrásszerűen nőtt, a szektor eladósodottsági szintje ugyanakkor a nyugat-európai országokhoz képest relatíve alacsony, viszont mégis kockázatokat rejt magában néhány ok miatt: a felvett hitelek jellemző devizaneme svájci frank, míg az elhelyezett betéteké forint ${ }^{88}$, így az önkormányzat nyitott devizapozícióban van, (Homolya-Szigel, 2008), másrészt pedig fennáll a pénzbőség illúziója. (Vigvári 2010b) A kötvényforma elterjedése nemcsak annak a következménye, hogy nem közbeszerzés-köteles, hanem azé is, hogy míg a bankhitelek jellemzően beruházási projektekhez kötődtek, addig a kötvények esetében pontos cél meghatározása nem szükséges, tehát a felhasználása szabadabb. (Csiszárik 2008)

A tanulmány a kockázatokat nemcsak az adós, hanem a hitelező szempontjából is vizsgálta. A bankok becslése alapján a hitelek 10-30\%-a működési célt szolgál, kockázatot jelent a szektor finanszírozásának átláthatatlansága, jövőbeni pénzáramok tervezési nehézségei, azonban - a felmérés eredményei szerint - a bankok az önkormányzatok müködésének folytonosságában (és ezáltal a folyamatos cash flowban) bízva finanszírozzák az önkormányzati szektort. (Homolya-Szigel, 2008) „Hitelfelvétel esetén a hitelt nyújtók a visszafizetés egyik legfontosabb biztosítékának az önkormányzati adóbevételeket tekintik” (Vigvári 2011a)

\footnotetext{
87 A tanulmány taglalja az önkormányzatok többségi tulajdonában lévő vállalatok eladósodásával kapcsolatos kötelezettségeket is. Ehhez lásd még Hegedűs József-Tönkő Andrea (2006): Az önkormányzati gazdasági társaságok szerepe a helyi önkormányzatok vagyongazdálkodásában: feltételes kötelezettségvállalás in (Vigvári et al. 2007)

${ }^{88} \mathrm{Az}$ arbitrázsműveletekhez célszerünek tünt magas kamatozású forintbetétbe fektetni.
} 
Felmerülnek tehát a következő kérdések. Mi okozta a hitelfelvétel ugrásszerü növekedését úgy, hogy az sem beruházásokhoz, sem müködési költségekhez nem köthető? Mennyire racionális magatartás az önkormányzat részéröl a hitelfelvétel úgy, hogy a mögött tényleges finanszírozási igény nincs? Ez a magatartás hogyan illeszkedik az aranyszabályhoz? Összefüggésbe hozható-e azzal, hogy a 2007-2013-as programozási periódusban a Magyarország által felhasználható támogatás ugrásszerüen megnövekedik a korábbi programozási periódushoz képest, és annak addicionalitás igénye jelentkezik?

A táblázatban szerepelő 9 eset azt mutatja be, hogy milyen hatásai lehetnek a felhalmozási kiadások változásának az eladósodottságra abban az esetben, ha feltételezzük, hogy az eladósodottságot nem befolyásolja a költségvetés elsődleges hiánya, vagyis a müködési költségvetés egyensúlyban van.

\begin{tabular}{|c|c|c|c|c|c|}
\hline Vagyon & Eladósodás & Hatás & $\begin{array}{c}\text { A felhalmozási } \\
\text { kiadások } \\
\text { finanszírozása }\end{array}$ & \begin{tabular}{|c|} 
A \\
közszolgáltatások \\
finanszírozása
\end{tabular} & \begin{tabular}{|c|} 
Hitelfelvétel \\
aranyszabályának \\
érvényesülése
\end{tabular} \\
\hline \multirow{3}{*}{$\begin{array}{c}\text { Nem } \\
\text { változik }\end{array}$} & $\begin{array}{l}\text { Mértéke } \\
\text { nem } \\
\text { változik }\end{array}$ & $\begin{array}{l}\text { Egyensúly } \\
\text { helyzete }\end{array}$ & \multicolumn{2}{|c|}{\begin{tabular}{|c|} 
A vagyon pótlása és a \\
közszolgáltatások finanszírozása \\
folyó kiadásokból történik.
\end{tabular}} & - \\
\hline & Nő & Eladósodik & $\begin{array}{c}\text { A vagyon } \\
\text { pótlása nem a } \\
\text { folyó } \\
\text { kiadásokból, } \\
\text { hanem hitelböl } \\
\text { történik } \\
\text { és/vagy } \\
\end{array}$ & $\begin{array}{l}\text { túlzott mértékben a } \\
\text { közszolgáltatásokra } \\
\text { költ. }\end{array}$ & nem érvényesül \\
\hline & Csökken & Stabilizálódik & $\begin{array}{l}\text { A vagyon } \\
\text { pótlása, a folyó } \\
\text { kiadásokból } \\
\text { történik }\end{array}$ & $\begin{array}{l}\text { a közszolgáltatások } \\
\text { terhére. }\end{array}$ & - \\
\hline \multirow{3}{*}{ Nő } & $\begin{array}{l}\text { Mértéke } \\
\text { nem } \\
\text { változik }\end{array}$ & Fejlödik & \begin{tabular}{|c|} 
Beruházást \\
folyó kiadásból \\
finanszíroz
\end{tabular} & $\begin{array}{c}\text { a közszolgáltatások } \\
\text { terhére. }\end{array}$ & - \\
\hline & Nő & Eladósodik & $\begin{array}{l}\text { Beruházást } \\
\text { finanszíroz } \\
\text { hitelből } \\
\text { és/vagy }\end{array}$ & $\begin{array}{c}\text { túlzott mértékben a } \\
\text { közszolgáltatásokra } \\
\text { költ. }\end{array}$ & $\begin{array}{l}\text { vizsgálni kell az } \\
\text { aranyszabály } \\
\text { érvényesülését }\end{array}$ \\
\hline & Csökken & Stabilizálódik & $\begin{array}{c}\text { A beruházás } \\
\text { folyó kiadásból } \\
\text { történik }\end{array}$ & $\begin{array}{c}\text { a közszolgáltatások } \\
\text { terhére. }\end{array}$ & - \\
\hline
\end{tabular}




\begin{tabular}{|c|c|c|c|c|c|}
\hline Vagyon & Eladósodás & Hatás & $\begin{array}{c}\text { A felhalmozási } \\
\text { kiadások } \\
\text { finanszírozása }\end{array}$ & $\begin{array}{c}\text { A } \\
\text { közszolgáltatások } \\
\text { finanszírozása }\end{array}$ & $\begin{array}{c}\text { Hitelfelvétel } \\
\text { aranyszabályának } \\
\text { érvényesülése }\end{array}$ \\
\hline & $\begin{array}{c}\text { Mértéke } \\
\text { nem } \\
\text { változik }\end{array}$ & $\begin{array}{c}\text { Fokozatos } \\
\text { romlás }\end{array}$ & & $\begin{array}{c}\text { A } \\
\text { közszolgáltatások } \\
\text { szinten maradnak. }\end{array}$ & - \\
\cline { 2 - 3 } Csökken & Nő & Elszegényedés & $\begin{array}{c}\text { A vagyon } \\
\text { pótlása } \\
\text { semmilyen } \\
\text { forrásból nem } \\
\text { történik meg. }\end{array}$ & $\begin{array}{c}\text { a } \\
\text { közszolgáltatásokra } \\
\text { költött összeget } \\
\text { hitelböl } \\
\text { finanszírozzák. }\end{array}$ & nem érvényesül \\
& Csökken & Stabilizálódik & & $\begin{array}{l}\text { közszolgáltatások } \\
\text { szinten maradnak, } \\
\text { vagy csökkennek. }\end{array}$ & - \\
\hline
\end{tabular}

\section{Saját készítésü táblázat}

A helyi önkormányzatok eladósodási folyamata nem vitatható (Vigvári 2009a), (Homolya-Szigel, 2008), azonban kérdéses az, hogy az eladósodottság növekedése együtt jár-e a vagyon növekedésével, és az eladósodottságnak van-e bármilyen kapcsolata az európai uniós támogatások igénybe vételével.

A táblázatban felvázolt alapesetek egyike sem tekinthető egyértelmüen elutasítandónak, illetve követendőnek, azonban értékelhetők az aranyszabály szempontjából.

\subsubsection{Az önkormányzati forrásszabályozással szemben megfogalmazott kritikák}

Az önkormányzatok gazdálkodásával, forrásszabályozásával, müködésével, és a hozzájuk kapcsolódó jogszabályi környezet módosításával számos hazai és külföldi tanulmány foglalkozott.

A feladat- és hatáskörök közötti differenciálás az egyes településtípusok között elmaradt, ami az önkormányzati középszint gyengüléséhez vezetett, mellyel egyidejüleg az önkormányzati rendszer „konfliktuskonténerként” müködik „,a helyhatóságok túlhajtott alkotmányos önállósága, a közfeladatok erőteljes decentralizációja, az önkormányzáshoz füződő jog, a területi közigazgatás és a helyi közfeladat-ellátás kereteinek összemosódása" miatt. (Vigvári 2009a) (Vigvári 2009b) (Báger és Vigvári, 2007) Ezt a hatást felerősíti az is, hogy az önkormányzatok költségvetési szerkezete együtt mozgott a központi költségvetéssel a normatív támogatások rendszere miatt; egyes szerzők szerint - gazdasági értelemben - a függelmi viszont a központi szint és a helyi szint között 
fennmaradt. (Straussman, Fábián 1994), (Goglio 2007), (Fürcht 2009), (László, Szebényi 2010)

Vagyis elsődlegesen nem a finanszírozás módját illeti a kritika, hanem azt a tényt, hogy egyes, addig központi módon kezelt szociális feladatokat a települési önkormányzatok láttak el. Míg a szuverenitás jogi értelemben biztosított volt, addig „fokozódott az önkormányzatok gazdálkodási függősége materiális, illetve közgazdasági értelemben.” A helyi adóztatás ebben a megközelítésben gazdasági kényszer, és valódi önállóságot nem ad az adókivetés joga. Ezt támaszthatja alá az, hogy az önkormányzatok a társadalmi türőképességnek megfeleltethető helyi adókat alkalmaztak, továbbá az adók naturális vagyis alig vitatható - mutatókra épültek, és jelentős szerephez jutott a vagyon értékesítéséből származó bevétel is. (László, Pálné Kovács 1993) (Straussman, Fábián 1994)

A kritikusok szerint (László, Szebényi 2010), (Pálné Kovács 2004) in (Kopányi, Wetzel, El 2004), (Pitti 2005) a központi kormányzat és a helyi önkormányzatok közötti feladatmegosztás és az ahhoz kapcsolódó források rendszere húsz évvel a rendszerváltást követően sem tisztázott, ami befolyásolja az önkormányzatok gazdasági helyzetét. Míg az önkormányzatokról szóló törvény a helyi szint feladatait a helyi lakosság szükségleteinek, pénzügyi lehetőségeinek figyelembe vételével szabja meg, addig számos, ágazati törvény rendelkezik az önkormányzatok által ellátott feladatokról.

Lóránt szerint a rendszerváltás óta jellemző az a tendencia, miszerint a feladatdecentralizáció jellemző a központi szint és a helyi önkormányzatok között, ami csökkenti a helyi képviselö testületek tényleges, költségvetési döntési mozgásterét annak ellenére, hogy a helyi adók részaránya fokozatosan nőtt az önkormányzatok bevételi szerkezetében. (Lóránt 2008a)

A szabályozási mechanizmusok továbbfejlesztésére vonatkozóan a tervezett közigazgatási reform részeként - a feltárt kockázatok kezelésére - megoldási alternatívákat dolgoztak ki (Kopányi, Vigvári 2003), (Pitti 2005), (Kassó 2006b), (Kassó 2006a), (Vigvári 2005), (Romhányi 2007), (Vigvári 2009a) (Nagy 2002) a 2000-es évek közepén az önkormányzati szektor pénzügyi stabilitásának megteremtése, illetve hitelfelvételi képességének javítása érdekében. A tervezhetőségen, a tervezési 
gyakorlatok korszerüsítésén, a költségvetési tételek kontrollálhatóságán ${ }^{89}$ és a méretgazdaságossági szempontok érvényesítésén túl a hitelezési kockázatok csökkentése érdekében megjelent az elsődleges és másodlagos hitelbiztosítékok szabályozására vonatkozó javaslat, valamint esetleges passzív kontrollfunkciók (hitelfelvételi korlát differenciálása, önkormányzati adósságregiszter) beépítésének lehetősége.

A forrásbevonó kapacitás növelés érdekében az önkormányzatok prudens müködését előirányzó javaslatok születtek, amelyek egyrészt a beszámolási rendszer reformján és ezáltal a hitelezők informáltságának megteremtésén, a feladatfinanszírozású és nullbázisú tervezés alkalmazásán, másrészt kontrolling és ellenőrzési funkciók bevezetésén, harmadrészt pedig - az önkormányzatok hitelképességének megítélését segítő - átlátható, központi, önkormányzati adósságregiszter kialakításán alapultak. ${ }^{90} \mathrm{~A}$ fenti javaslatok célja egyrészt az önkormányzatok forrásbevonó-képességének növelése, másrészt pedig a hatékony és eredményes gazdálkodás alapjainak megteremtése a kormányzati szintek közötti feladatmegosztás újragondolásán, a differenciált feladat- és hatáskör telepítésen és a finanszírozási rendszer átrendezésén keresztül. (Kopányi, Vigvári 2003), (Halmosi 2005), (Pitti 2005) in (Vigvári et al. 2005), (Kassó 2006b), (Kassó 2006a), (Goglio 2007), (Péteri 2008) in (Sevic et al. 2008), (Kovács 2008b), (Vigvári 2009a), (Vigvári 2009b)

A közpénzek szabályozásával kapcsolatos problémákat az Állami Számvevőszék több tanulmány keretében vizsgálta, részben az ellenőrzések gyakorlati tapasztalataira, részben kutatási eredményekre alapozva. A „Közpéntek szabályozásának tézisei”, valamint az abban foglaltak tudományos alátámasztásául szolgáló „Államreform, közpénzügyi reform -Nemzetközi Trendek és hazai kihívások" tanulmányok a közpénzügyek átfogó korszerüsítésének koncepcióját mutatják be, részben a költségvetési fegyelem megerősítését szolgáló intézményrendszer létrehozásának felvázolásával. Ennek egyik kiindulópontja az, hogy a rendszerváltást követő időszakban a jogalkotó nem ügyelhetett „a közszektor eredményességét és transzparenciáját szolgáló mechanizmusok kiépítésére” (Báger és Vigvári 2007), ezért átfogó szabályozási megújulás szükséges. A tézisek alapján az új szabályozás célja olyan „technikai megoldások megtalálása, amelyek átláthatóbbá, kiszámíthatóbbá és hatékonyabbá teszik a közpénzekkel való gazdálkodást

\footnotetext{
${ }^{89}$ Ez legalább három szempontból értékelhető: az intézményi döntési szint, a kockázati tényezők jellege, és a tétel megszüntetéséhez szükséges minimális idő. (Romhányi 2007)

${ }^{90}$ Ennek egyik konkrét példája - elsősorban a nagyobb - önkormányzatok önkéntes hitelminősítésének lehetősége is.
} 
mind a nemzetgazdaság és az önkormányzatok, mind pedig az intézmények szintjén”. (Állami Számvevőszék 2007)

Az új szabályrendszer elveinek bemutatása mellett a tézisekben megjelenik a központi és a helyi szint kapcsolatainak stabil és átlátható szabályozására vonatkozó igény, valamint a költségvetési egyensúly mint a fenntartható fejlődés alapkövetelménye. A rendszer átfogó reformjához nem elegendő a szabályozás megújítása, hanem számszerüsített célok meghatározása, valamint a pénzügyi tervezés intézményes összhangjának megteremtése szükséges „egy átfogó, korszerü, jól koordinált nemzetgazdasági tervezési rendszer” kiépítésén keresztül. (Kovács 2009b)

Az önkormányzati rendszer reformja a központi és helyi szint közötti feladatok újraallokálásán (feladattelepítés, szolgáltatásszervezés módjai), valamint a finanszírozási háttér módosításán, tehát a centralizáció-decentralizáció-méretgazdaságosság szempontjából közelíthető. (Báger és Vigvári 2007) Előremutató, hogy javaslatot tesz a tanulmány az önkormányzatok finanszírozási egyensúlyának megtartására, valamint kiszámítható, középtávú tervezésre vonatkozóan is.

\subsubsection{A szabályozó környezet változása napjainkban}

A kutatás időbeli lehatárolása miatt a napjainkban zajló folyamatok, az átfogó közpénzügyi reform megvalósítása ugyan nem képezik a dolgozat témáját, mégis indokoltnak tartom a teljesség igénye nélkül legalább vázlatosan ${ }^{91}$ bemutatni azokat a jogszabályi változásokat, amelyek a mai magyar önkormányzatok szabályozó közegét jelentik, figyelemmel az eladósodási folyamatokra is.

Az önkormányzatok széleskörü gazdasági autonómiája miatt 2010-ig az állam nem korlátozta - gyakorlatilag semmilyen eszközzel -, hogy az önkormányzatok milyen önként vállalt feladatokat folytatnak, hogyan gazdálkodnak, mire vállalkoznak. A világgazdasági válsággal összefüggésben és a további eladósodás elkerülésére Magyarország Alaptörvénye egyértelmü szabályozást ad: egyrészt az országgyülés nem fogadhat el olyan költségvetési törvényt, amelynek eredményeképpen az államadósság a GDP 50\%-át meghaladná, másrészt pedig amíg a fenti mutató $50 \%$ felett van, addig csak olyan költségvetési törvény fogadható el, amely az államadósság csökkentését

\footnotetext{
${ }^{91}$ Az újonnan, 2010 és 2012 bevezetett jogszabályok áttekintő értékelésére jelen dolgozat keretében nem vállalkozom, ugyanis az egyrészt szétfeszítené a dolgozat kereteit, másrészt a jogszabályi változások hatásai az eltelt idő rövidsége miatt jelenleg nem, vagy csak nagyon korlátozottan értékelhetők.
} 
tartalmazza $^{92}$. (Magyarország Alaptörvénye 36. cikk) Ezen a ponton fontos kiemelni a Költségvetési Tanácsot, amely az Országgyülés tevékenységét támogató szerv és a központi költségvetés megalapozottságát vizsgálja. A Költségvetési Tanács Alaptörvényben rögzített joga és feladata az államadósságra vonatkozó szabályok betartásának ellenőrzése, melynek érdekében a Költségvetési Tanács ${ }^{93}$ előzetes hozzájárulása szükséges a központi költségvetés elfogadásához.

Az államadósság számításba a központi kormányzat és az egyéb kormányzati szervek mellett az önkormányzati alrendszer eladósodása is beleszámít, így nemzetgazdasági cél az önkormányzatok pénzügyi stabilitásának fenntartása, valamint az átlátható és transzparens gazdálkodási környezet és finanszírozási rendszer megteremtése.

Az önkormányzati autonómia és az Alaptörvényben megfogalmazott szigorú adósságszabályozása, valamint a közjogi szerepek változása miatt sarkalatos törvények sora rögzíti az önkormányzati gazdálkodás szabályait.

A gazdasági stabilitásról szóló törvény értelmében mind a kormányzati, mind az önkormányzati szektorban előzetes kormányzati engedélyhez kötött az eladósodás, annak érdekében, hogy az adósságcsökkentés feletti kormányzati kontroll érvényesülhessen, ugyanakkor a Kormány hozzájárulása nélkül lehetséges az európai uniós projektek önrészének és előfinanszírozásának biztosításához szükséges kötelezettségvállalás. A további önkormányzati eladósodás megakadályozása érdekében a szabályi szigorodtak: egyrészt müködési kiadásokra csak likvid hiteleket vehetnek fel, müködési hiány nem tervezhető, másrészt az eladósodás miatti fizetési kötelezettség felső határa a saját bevételek legfeljebb 50\%-a lehet az ügylet teljes futamidején keresztül. ${ }^{94}$

Az új önkormányzati törvény, valamint az államháztartási törvény egyaránt erősíti az átlátható és transzparens gazdálkodás megteremtését. Míg az önkormányzati törvény a

\footnotetext{
92 Fentiek alól kivételt jelent a nemzetgazdaság tartós és jelentős visszaesése, amely esetben a nemzetgazdasági egyensúly helyreállításához szükséges mértékben lehet eltérni. A gazdasági stabilitásról szóló törvény szerint tartós és jelentős a visszaesés, amennyiben a GDP negatív.

${ }^{93}$ A Költségvetési Tanács elemzési hatókörének szélesítésére ajánlást tett az Európai Tanács a Magyarországon fennálló túlzott költségvetési hiány megszüntetése érdekében. (Európai Tanács, 2012), letöltés ideje: 2012 . augusztus 1. http://eur-lex.europa.eu/LexUriServ/LexUriServ.do?uri=COM:2012:0104:FIN:HU:HTML

94 Az önkormányzati hitelfelvétel aktív és passzív kontrollja (Gál 2010) is megjelenik a szabályozásban, hiszen egyrészt a hitelfelvétel előzetes kormányzati jóváhagyáshoz kötött, másrészt a maximális hitelösszeg mértéke is meghatározott.
} 
központi és helyi erőforrásokat ${ }^{95}$, valamint a feladatok és hatáskörök megosztásának alapjait a települések teljesítőképességének függvényében differenciáltan szabályozza, addig az államháztartási törvény és annak végrehajtási rendelete az átláthatóságot és szabályszerüséget előmozdító pontosításokat tartalmaz. ${ }^{96}$

\subsection{Az addicionalitási szempontok érvényesülése más tagállamokban}

Közép-és Kelet-Európában gyakran éppen az európai uniós fejlesztési támogatásra leginkább rászoruló önkormányzatoknak esik nehezére a támogatások igénybevételéhez szükséges önerő előteremtése, ahogy azt a 2.3. fejezetben már bemutattam. Ha az önkormányzat saját forrásai erre a célra elégtelennek is bizonyulnak, még akkor is jó néhány lehetőség közül választhat forrásteremtésre, ezeknek a különböző eszközöknek az ára azonban - csakúgy, mint a haszon mértéke - eltérő lehet. Az eladósodás fenyegető veszélye gyakran visszariasztja az önkormányzatokat a legkézenfekvőbb megoldástól, vagyis a banki kölcsön felvételétől. A következő szakaszban az önkormányzatok számára elérhető forrásokat - azok jellemző előnyeit és hátrányait - teszem mérlegre.

A közép-kelet-európai államokra - Magyarországot is ideértve - általánosságban jellemző, hogy a rendszerváltás folyamatával, valamint a koppenhágai kritériumnak való megfeleléssel összhangban a helyi közigazgatás tekintetében is a nyugati standardok alkalmazásának irányába mozdultak el. Ezeknek a helyi közigazgatással kapcsolatos alapelvek egyfajta összegzését adja az Európa Tanács égisze alatt létrejött Helyi Önkormányzatok Európai Chartája, amelynek tartalmát a dolgozat korábbi fejezetei összefoglalják. Az addicionalitás elemzésekor azonban vissza kell utalnunk arra, hogy a Chartában egyértelműen a feladatok és felelösségi körök decentralizálásának követelménye jelenik meg a szubszidiaritás elvével összhangban. A gyakorlatban azonban ezt a fajta decentralizációt nem mindenütt kíséri a hatalom vagy az erőforrások átadása az államigazgatás alacsonyabb szintjére. Ennek megfelelően a legtöbb középeurópai önkormányzat küszködik azzal, hogy a hatályos szabályozásnak megfelelően költségvetése nagyon nagymértékben az állami transzferek függvénye. (Council of Europe 1985; Bilan 2008; Oplotnik 2007) A helyi pénzügyi autonómia hiányához szerencsétlen esetben a költségvetési fegyelem hiánya is társul: az olyan rendszerekben,

\footnotetext{
95 feladatfinanszírozás alapján

${ }^{96}$ Ilyennek tekinthető például, hogy a helyi önkormányzat által irányított költségvetési szervek bevételeit és kiadásait a helyi önkormányzat költségvetése elöirányzat szerinti bontásban tartalmazza, vagy például az, hogy a kötelező és önként vállalt feladatok a költségvetésben külön jelennek meg.
} 
ahol az adók beszedése jórészt az állam feladata, míg az önkormányzatokra csak a pénz elköltése hárul, nem ritkán szubnacionális adósságválságba torkollnak, melynek a következményeire később még kitérek. (Blankart 2006)

Az önkormányzatok rendelkezésére álló rendszeres bevételi források a legtöbb közép-és kelet-európai államban ugyanazok, mint Magyarországon, vagyis alapvetően két vagy három kategóriába sorolhatók. Különbséget kell tennünk az önkormányzat szuverén jogkörében beszedett saját források és a központi költségvetési transzferek között, továbbá sok országban - köztük Magyarországon is - harmadik csoportként elkülönülnek azok a „megosztott vagy átengedett bevételek”, amelyeket vagy a helyi önkormányzat, vagy a központi igazgatás gyüjt be, és aztán megosztásra kerülnek a két igazgatási szint között. (Municipum Magyarország Alapítvány 2003; Bilan 2008)

A fent felsorolt bevételi kategóriák mellé a gyakorlatban - ugyanúgy, mint Magyarországon - gyakran társul a hitelfelvétel mint rendkívüli bevételi forrás. (Oplotnik 2007; Bilan 2008) A közép-európai gyakorlatban az önkormányzatok ehhez az eszközhöz csak végszükség esetén nyúlnak, mert az eladósodás fenyegető veszélye meggondolásra készteti öket. Egyes pénzügyi szakemberek azonban arra is rámutatnak, hogy a hitelfelvétel következetes elutasítása nem mindig a legcélravezetőbb politika. Igaz ugyan, hogy az önkormányzat müködési költségeinek hitelből történő finanszírozása súlyos veszélyt jelent, bizonyos egyéb kiadások - elsősorban befektetések és infrastrukturális beruházások - fedezésére azonban kifejezetten jól alkalmazható.

A hitelfelvétellel megvalósuló befektetések még kecsegtetőbb lehetőségként tünhetnek fel, ha figyelembe vesszük az alternatívaként rendelkezésre álló európai uniós támogatások feltételeit, nevezetesen a társfinanszírozást és az utófinanszírozást, amelyek az egy adott pillanatban ténylegesen rendelkezésre álló forrásokra korlátozzák egy önkormányzat beruházási potenciálját. (Dafflon 2009) A közép-európai gyakorlatban olyan helyzetre is akad azonban példa, hogy egy helyi önkormányzat éppen az európai uniós forrásokhoz való hozzájutás - vagyis a társfinanszírozás biztosítása - érdekében vesz fel kölcsönt abban a reményben, hogy a befektetésböl származó fellendítő hatás hozadékából képes lesz a törlesztésre. (Oplotnik 2007) Az, hogy a fejlesztéspolitikájában az adott önkormányzat az egyik vagy másik megoldást alkalmazza, mindig eseti döntésének függvénye, jelen dolgozatban a felelös költségvetési- és gazdaságpolitika fontosságára szeretném felhívni a figyelmet, amely gyakorlat azonban csak átlátható és az 
államigazgatás különböző szintjei közötti felelösségi köröket világosan lehatároló szabályozás mellett valósulhat meg. (Blankart 2006)

A fent felsorolt forrásokra vonatkozó értékek ismeretében számos olyan mutatót állíthatunk fel, amelyek képet adnak egy-egy önkormányzat költségvetési helyzetéről, akár a bevételi, akár a kiadási oldalt tekintve. A leggyakrabban alkalmazottak az olyan mutatószámok, amelyek a fenti kategóriák egyikét (például az állami transzfereket vagy a helyi közbevételeket) viszonyítják valamilyen kumulált értékhez (például a teljes állami bevételhez vagy akár a GDP-hez). Érdekes információkkal szolgál a saját források összes helyi bevételen belül képviselt aránya, amelynek százalékban megadott értékét a helyi pénzügyi autonómia szintjeként is emlegetik. Ez a mutató Európában a jóléti skandináv államokban éri el a legmagasabb értéket: bizonyos államoknál meghaladja az összes bevétel négy ötödét. (Rusu 2008; Municipum Magyarország Alapítvány 2003) Magyarországon az EU-csatlakozás küszöbén a két fö kategória (saját bevételek és központi transzferek) majdnem egyenlő arányban oszlott meg az önkormányzati költségvetésen belül (42-43 százalék). (Kovács 2004) A közép- kelet-európai térség nem minden állama dicsekedhet azonban a nyugati normákhoz ilyen közel álló eredménnyel.

A román helyi önkormányzatok például mind költségvetési, mind politikai döntéshozatali tekintetben igen nagymértékben függnek az államtól, a volt szovjet köztársaságként pedig Észtországban is nehézséget jelent az önkormányzatok önállóságának kérdése. (Tabără 2010; Tatar 2010)

\subsection{A beszámolási rendszer kritikája és számviteli elszámolások az európai uniós támogatások folyamatában}

\subsubsection{Kritikák az önkormányzatok beszámolóinak információtartalmáról}

Az önkormányzatok pénzügyi beszámolórendszerének reformját sürgető tanulmányok már a 2000-es évek közepén megjelentek a hazai szakirodalomban. Ezen tanulmányok a döntések meghozatalához szükséges információhiány és a számviteli rendszerek összefüggéseit érintették, meglátásuk szerint szükséges a szektor pénzügyi beszámolórendszerét a számviteli törvény helyett az államháztartási törvény keretében szabályozni oly módon, hogy részleges eredményszemléletü beszámoló rendszer kialakításával a gazdálkodás, valamint a vagyoni és pénzügyi folyamatok átláthatóbbá 
váljanak, ezáltal a hitelképesség megítélése egyszerüsödjön. (Kopányi, Vigvári 2003) (Vigvári 2005)

Az eladósodási folyamatok elemzésével párhuzamosan Vigvári (Vigvári 2009b) (Vigvári 2011b) megfogalmazta azokat a javaslatokat is, amelyekkel az önkormányzatok pénzügyi kockázatai kezelhetők, melyek egyike az információrendszer korszerüsítése. A beszámolással kapcsolatos kritikaként megfogalmazta, hogy azokból a szektor vagyoni helyzete nem követhető, a nyilvántartások nem transzparensek, nem alkalmasak a döntések pénzügyi hatásainak mérésére, nem határozhatók meg egyes beruházások terhei sem, továbbá az informatikai rendszer fenntartása költséges, ezért eredményszemléletü könyvvezetés bevezetését javasolta. (Vigvári 2009b) A pénzforgalmi szemléletű számviteli megközelítés hiányosságát mutatta be Jókay is (Jókay et al. 2004), aki az önkormányzati csődesetek vizsgálatakor vonta le azt a következtetést, hogy a pénzforgalmi szemléletű számviteli megközelítés nem képes kezelni a jövőben esedékes törlesztésekkel járó terheket.

A beszámolórendszer kritikáját nem fogalmazta meg, ugyanakkor az információk hiányosságaira hívta fel a figyelmet tanulmányában Homolya-Szigel (Homolya-Szigel, 2008), miszerint az önkormányzatok jövőbeni kötelezettségvállalásáról nem állnak rendelkezésre teljes körű adatok, ami a valós pénzügyi helyzet megítélését nem teszi lehetővé. Kassó szerint a beszámolási kötelezettségek teljesítésére „,az intézményrendszer meglehetősen sok pénzt és energiát fordít”, vagyis a beszámolókkal rengeteg információ keletkezik. Az összehasonlítás és értékelés tehát nem a számviteli rendszer függvénye, hanem a célok egyértelmü meghatározásáé. (Kassó 2006a)

Az Állami Számvevőszék tézisgyüjteményében (Állami Számvevőszék 2007) kritikával illette a számviteli és beszámolási rendszert: egyrészt amiatt, hogy a költségvetési gazdálkodáson kívüli tételek ${ }^{97}$, és a jövőbeni kötelezettségek jellemzően nem jelennek meg a számviteli nyilvántartásokban, ami sérti a teljesség elvét és akadályozza az érdemi döntéshozatalt, másrészt pedig azért, mert a túlzottan részletes adatok a tényleges pénzügyi helyzet megismerhetetlenségét okozzák. ${ }^{98}$

\footnotetext{
${ }_{97}^{9}$ például a helyi önkormányzatok tulajdonában lévő vállalatok kötelezettségeire vonatkozó adatok

${ }^{98}$ „Ez a mai helyzet, amikor a prezentáció olyan, hogy a sok fától az erdőt nehéz látni.” (Állami Számvevőszék 2007)) Ugyanerre az anomáliára hívja fel a figyelmet Vigvári is. (Vigvári 2010)
} 
A magyar önkormányzati rendszer költségvetési és beszámolási szabályait meglehetősen élesen bírálta (Goglio 2007), miszerint a költségvetés megalkotása inkább jogi munka, nem pedig „budgeting” jellegü, ami miatt a közép- és hosszú távok célok meghatározása háttérbe szorul, és a költségvetésben nem különölnek el a müködési és beruházási célú kiadások. A helyi szint forráshiánya oda vezetett, hogy az önkormányzatok csak olyan projektek megvalósítását vállalták, amelyek részben valamilyen - jellemzően európai uniós - támogatásból valósultak meg. (László, Szebényi 2010) A tanulmány ezért szorgalmazta a többéves költségvetési tervezés bevezetését a költségvetési dokumentációhoz kapcsolódó nagyszámú, kevés információt tartalmazó dokumentáció helyett.

\subsubsection{Szavazati egység elmélet}

Kassó (Kassó 2006b) (Kassó 2006a) a hatalom gyakorlása és a kormányzás irányítása szemszögéből közelíti meg az államháztartási számvitel reformját. A szavazati egységet úgy definiálja, mint „feladatellátás kötelezvényt tartalmazó döntés, amelyhez szövegesen hozzárendelhetők a célok, elvárt eredmények, pénzügyi oldalról viszont meghatározza azt a kiadási plafont, ami a megvalósítás érdekében elkölthető", vagyis a költségvetési törvényben megállapított feladat teljesítése kötelező a költségkereteken belül. Így a teljesítményközpontú költségvetés bevezetésére tesz javaslatot, ami egyben alapja a számviteli rendszer reformjának.

Megközelítésében a számviteli rendszernek képesnek kell lennie arra, hogy az alapján a parlament és az adófizetők el tudják számoltatni a kormányzatot. Ez úgy valósulhat meg, ha a számvitel nemcsak a pénzköltést és a bevételeket mutatja ki, hanem ,azokat az ígérvényeket, hosszú távú kötelezettségeket is, amelyeket a kormányzatok jogilag felvállalnak, de az adott időszak elszámolásának pénzforgalmában még nem jelennek meg." A számviteli rendszerrel szemben támasztott követelményeket információbázisként ${ }^{99}$ tekinti, ami lényegesen tágabb, mint a terv és tényadatok összehasonlítása. Eszerint a számviteli rendszernek a tranzakciókat úgy kell kezelnie, hogy az adott szavazati egység érdekében felmerülő valamennyi esemény olyan részletezettséggel szerepeljen a nyilvántartásban, hogy a felhasznált erőforrások naturális értelemben is összevethetők és ellenőrizhetők legyenek. Ennek hátterében az áll, hogy a

\footnotetext{
${ }^{99}$ Ezzel párhuzamosan - összhangban Vigvárival - felvázolja, hogy a beszámolók és számviteli adatok előállítása meglehetősen költséges, ugyanakkor a rendelkezésre álló információ, ami valójában adathalmaz „kavalkád-szerü”. (Kassó 2006a; 2006b)
} 
költségvetési törvény elfogadásával a parlament egyfajta pénzköltési lehetőséget nyit meg a közigazgatás előtt azzal a céllal, hogy teljesítik azokat a feladatokat, amelyek kötelezettségüket képezik. A szavazati egységek szerinti beszámolás tehát nem támaszkodhat kizárólag a számviteli rendszerből nyerhető információkra; a számvitelnek ezzel azonban értékelő funkciója is keletkezne. A számviteli rendszer Kassó értelmezésében támogatja a költségvetés tervezését és a döntéshozók ellátását információkkal, túllép az események zárt rendszerű feldolgozásán és az adatok összehasonlításán. (Kassó 2006a)

A közszféra alulfinanszírozott és pazarló müködésének oka egyrészt a stratégiai megközelítés hiánya, a költséggazdálkodási kultúra, költséghatékonyság mérlegelésének hiánya, a szakmai és pénzügyi tervezés elkülönülésének hiánya, másrészt az, hogy „a számvitel és az információs rendszer nem támogatja a döntés-előkészítést és ezért a kormány objektív információk hiányában kénytelen kormányozni”. Önmagában a számviteli rendszer változtatása nem jelet megoldást, ezért az államháztartási pénzügyi beszámolási rendszert komplex módon célszerü értelmezi. Az államháztartási beszámoló rendszer önmagában vett reformja tehát nem értelmezhető: megújításának első lépése az államháztartás kereteinek újraszabályozása, a közszolgáltatásokat középpontba állító szemlélet megteremtése, valamint annak a közös intézményrendszernek a megteremtése, amely a költségvetési-tevezési-számviteli dimenziókat összeköti. (Kassó 2006b), (Kassó 2006a) Ezt a gondolatmenetet megerősíti az Állami Számvevőszék Tézisgyüjteménye (Állami Számvevőszék 2007), miszerint jól kialakított információs rendszerek szükségesek a mérlegen kívüli tételekben mutatkozó kockázatok feltárása, valamint az átláthatóság és a transzparencia elősegítése érdekében.

Az államháztartási számviteli beszámolási rendszer elsődlegesen az előirányzatok teljesítését, a tervezett bevételek és kiadások tényleges alakulását, valamint a közvagyon változását mutatja. Míg a vagyongyarapodás, illetve vagyonvesztés, az eredményesség a gazdálkodó szervezetek tevékenységének mutatója, addig a közszféra hasznát, és müködésének eredményeit nem lehet kizárólag számszaki módon megfogható mutatókkal értelmezni, az eredmények a társadalomban és a ,gazdaság egészében végbemenő változásokban testesülnek meg" A közpénzek egy hányada vagyonként nem materializálódik, hiszen minden időszakban újratermelődik azáltal, hogy a bevételekből közszolgáltatásokat nyújt az állam, másrészt bizonyos költségvetési tételek az emberi 
erőforrás fejlesztésére irányulnak, amelyek jelentős hatással vannak a gazdasági növekedésre, ugyanakkor eszközként nem realizálódnak. (Franco, Balassone, Francese 2003), (Kassó 2006b)

Az Állami Számvevőszék közpénzügyi téziseiben (Állami Számvevőszék 2007) (Báger és Vigvári, 2007) a közpénzek átfogó szabályozásának részeként megjelenik az államszámvitel korszerüsítésének igénye, ugyanis a költségvetés és a közpénzek felhasználásának átláthatóságát a pénzforgalmi szemlélet mellett eredményszemléletben (is) vezetett nyilvántartások biztosíthatják. A tanulmány részben a szavazati egység elméletre építve, azonban túllépve azon az eredményszemléletü, vagy részlegesen eredményszemléletű államháztartási számvitelt a tisztánlátás (értsd valós költség meghatározása, elhatárolás alapú megközelítés ${ }^{100}$ és a közpénzek átláthatósága hatékony eszközének tekinti, azonban annak gyakorlati bevezetési nehézségei miatt azonnali bevezetésére nem tesz javaslatot, ugyanakkor a szakmai viták indítására és a számviteli rendszer módosítási lehetőségeinek feltérképezésére igen ${ }^{101}$. Ezzel összhangban áll a tézisnek az az értelmezése is, miszerint az államszámvitelnek nem a szüken értelmezett számviteli tartalomra kell koncentrálnia, hanem információs bázisként át kell fognia az államháztartás gazdálkodási rendjét is.

A szakirodalomban egyetértés van abban, hogy az információs rendszer vagyis nem a szűken vett számviteli-beszámolási rendszer korszerüsítése kulcskérdés a költségvetési gazdálkodás minden területén, ezért a költség- és teljesítménymérés érdekében a pénzforgalmi szemlélettől az eredményszemlélet felé történő elmozdulás szükséges. (Györffi et al. 2009)

\footnotetext{
${ }^{100}$ A teljesség elvének érvényesülés érdekében a beszámolás keretében a mérleg alatti tételeket is be kellene mutatni, továbbá érvényesülnie kellene a számviteli értelemben vett konszolidációnak pl. az önkormányzat és a tulajdonában lévő vállalat tekintetében.

${ }^{101}$ pl. előzetes költség-haszon elemzés a bevezetés lehetőségeire vonatkozóan, valamint a bevezetés emberi erőforrás- és időigényének feltérképezése
} 


\subsection{Az európai uniós támogatások számviteli elszámolása}

A kutatásom során felhasználandó empirikus adatok egyrészt az önkormányzatok beszámolóiból, másrészt a Nemzeti Fejlesztési Ügynökség nyilvántartásából származnak, ezért - a későbbi megfelelő értelmezés érdekében - áttekintem az európai uniós támogatások számviteli elszámolásának hazai szabályrendszerét.

A számviteli szabályozás az egyes alapok pénzügyi mechanizmusaihoz igazodóan alakult ki. (Lilliné Fecz 2004) A számviteli elszámolások bemutatása - a kutatásom témájának megfelelően - a Nemzeti Fejlesztési Terv operatív programjainak vizsgálatára korlátozódik $^{102}$.

A pénzügyi folyamatok bemutatásakor körvonalazódott, hogy a támogatás lebonyolításának három fő szintje élesen elhatárolható egymástól. Számviteli értelemben ugyancsak meg kell különböztetni a kedvezményezett szintjét (1.), a központi költségvetésen keresztül a támogatás hazai szintjét (2.), illetve az elszámolást az Európai Unióval (3.).

Az európai uniós támogatások felhasználásáról nem kizárólag a hazai érdekhordozók felé kell beszámolni, hanem az Európai Bizottság felé is, így a könyvvezetési kötelezettség a teljes folyamatban két irányban jelenik meg: egyrészt a központi költségvetés információigényét kell kielégítenie, másrészt az Európai Bizottságét.

A kétféle nyilvántartás megközelítése eltérő. Míg a költségvetési tervezés, a kincstári információs rendszer miatt a tagállami adatszolgáltatáshoz módosított teljesítés szemléletü könyvvezetést és beszámolást kell teljesíteni, addig az Európai Bizottság felé eredményszemléletü könyvvezetési és beszámolási kötelezettségnek kell eleget tenni. (Lilliné Fecz 2004), ami ahhoz vezet, hogy a kétféle szemléletben vezetett nyilvántartás adategyeztetését is el kell látni.

A nyilvántartások elkülönített rendszerben vezetése szükségszerüen többletmunkát okoz, melynek alátámasztásául vázlatosan, összehasonlítási céllal bemutatom mind a módosított teljesítés szemléletü, mind az eredményszemléletű nyilvántartás alapvető összefüggéseit

\footnotetext{
${ }^{102}$ A támogatás volumene és az eltérő szabályozási elemek miatt a számviteli folyamatok értékelésekor nem kerülnek bemutatásra az előcsatlakozási támogatások (PHARE, SAPARD, Átmeneti Támogatás), a közösségi kezdeményezések, a Kohéziós Alap projektek, illetve az Új Magyarország Fejlesztési Terv operatív programjai sem.
} 
és magyarországi jogrendszerét annak demonstrálásaként, hogy viszonylag egyszerü, azonban többszintü támogatási rendszerben egy-egy gazdasági esemény nyilvántartásba vétele hány különböző érintettnél és milyen formában jelenik meg.

\subsubsection{A támogatások nyilvántartása eredményszemléletü megközelítésben}

Az Európai Bizottság elvárásainak megfelelően a támogatások útját követni kell a tagállami átutalástól egészen a kedvezményezett szintjéig, melynek egyik lehetséges eszköze a számviteli nyilvántartásokkal való alátámasztás. ${ }^{103}$ Az érdekhordozó ${ }^{104}$ tehát itt elsődlegesen az Európai Bizottság, amelynek információigénye (éves adatszolgáltatások, valamint éves pénzügyi jelentések) úgy elégíthető ki, ha a számviteli adatok eredményszemléletű megközelítésben állnak rendelkezésre.

Magyarország a beszámolási és az adatszolgáltatási kötelezettséget egyrészt számviteli nyilvántartásokkal, másrészt az Egységes Monitoring Információs Rendszerben (EMIR) szereplő pénzügyi adatokkal teljesítette a 2004-2006-os programozási periódusban. Az Európai Uniótól származó támogatásokhoz kapcsolódó, eredményszemléletű elkülönített számviteli nyilvántartási rendszer kialakítását és müködtetését a kifizető hatóság végezte, a saját müködésével kapcsolatos nyilvántartásoktól elkülönülten ${ }^{105}$.

Az eredményszemléletű számviteli nyilvántartás vezetésének célja egyrészt az adatszolgáltatás teljesítése az Európai Bizottság felé, másrészt a társfinanszírozott projektek megvalósításáról megbízható és valós kép nyújtása, valamint az ellenőrzési nyomvonal biztosítása.

A számviteli nyilvántartás nem különálló rendszer, hanem az EMIR rendszer integráns része, de míg a többi modul a projekt életútjával kapcsolatos adatokat (szerződéskötés, befogadott számlák, ellenőrzések stb.) gyüjti, addig a számviteli modul a ténylegesen jóváhagyott és kiutalt támogatásokat, illetve a visszakövetelt összegeket és azok pénzügyi teljesítését követi nyomon, zárt rendszerben.

\footnotetext{
103 A részletes szabályozást a tagállamok saját hatáskörükben hozzák meg, amely a 2004-2006-os programozási periódusban Magyarországon a 233/2003. (XII. 16.) Korm. rendelet, a 360/2004. (XII. 26.) Korm. rendelet volt, a 8017/2005., 8018/2005., 8008/2007. és a 8009/2007. Pénzügyminiszteri tájékoztatók voltak.

${ }^{104} \mathrm{Az}$ érdekhordozói elméletek összefoglaló áttekintését lásd (Baricz, Budapesti Közgazdaságtudományi Egyetem 1999).

105 Tehát ennek adatai nem keveredtek a Pénzügyminisztérium mint költségvetési fejezet számviteli nyilvántartásaival.
} 
A dolgozat 3. fejezetében, illetve a kapcsolódó 6. számú mellékletében részletesen bemutattam a pénzügyi folyamatot, amelyből következik, hogy a támogatások intézményrendszere meglehetősen összetett, azonban - eltekintve attól az esettől, ha ezen szervezetek a kedvezményezettek - a támogatás átáramlik a közvetítő rendszeren, és a kedvezményezettnél realizálódik. Az alkalmazott számviteli nyilvántartás a magyar számviteli törvény alapelveinek érvényesítésével készült, eredményszemléletü kettős könyvvezetés alkalmazásával. A könyvelés mérlegszámlákon és eredményszámlákon történt, figyelemmel azonban a támogatási rendszer logikájára, a támogatások elszámolásával kapcsolatos számviteli rendszer csak négy számlaosztályt ${ }^{106}$ tartalmaz. Míg a 3. és 4. számlaosztályhoz kapcsolódó müveletek teljes egészében megfeleltethetők a pénzügyi folyamatnak és egyfajta pénzforgalmi szemléletü megközelítést tükröznek, addig az időbeli elhatárolások megjelenítése ${ }^{107}$, valamint a rendkívüli ráfordítások és bevételek kezelésének rendszere eredményszemléletű megközelítést takar.

Annak érdekében, hogy az eltérő szemléletben (pénzforgalmi szemlélet vs. eredményszemlélet) vezetett számviteli nyilvántartások egyezősége biztosított legyen, rendszeres adategyeztetések történtek, melynek keretében - többek között - áttekintették a lebonyolítási számlák forgalmának számviteli kezelését mindkét nyilvántartási rendszerben, valamint az államháztartás részére történt európai uniós támogatások kifizetésének intézkedésenkénti bevételi nyilvántartásait a kifizető hatóság által vezetett, eredményszemléletű számviteli nyilvántartással.

\subsubsection{A támogatások nyilvántartása módosított teljesítés szemléletben}

A támogatások folyósításának átláthatósága érdekében a számviteli elszámolási és beszámolási rendszert úgy alakították ki, hogy a támogatások részletes megfigyelését lehetővé tegye. Ennek következtében a Strukturális Alapok esetében „operatív programon belül prioritásonként, illetve azon belül intézkedésenként kell a támogatást nyújtó államháztartási szervezetnek a főkönyvi könyvelésben elszámolnia, illetve a beszámolási kötelezettségét teljesítenie”. (Lilliné Fecz 2004) Az átláthatóságot biztosítja a 249/2000. (XII. 24.) Korm. rendelet 9. számú mellékletében szereplő, kötelezően alkalmazandó

\footnotetext{
106 3. számlaosztály követelések és pénzeszközök; 4. számlaosztály kötelezettségek, passzív időbeli elhatárolások, 8. számlaosztály ráfordítások, a ráfordításként elszámolt támogatás felhasználás nyilvántartására, valamint 9. számlaosztály bevételek, a bevételként elszámolt támogatások, illetve visszakövetelt összegek elszámolására.

107 A kialakított számviteli rendszer időbeli elhatárolásként kezelte az Európai Bizottság által átutalt, azonban a támogatást menedzselő intézményrendszer részére még tovább nem utalt összeget.
} 
számlakeret-tükör is, amely alapján biztosított az egyes támogatási programok elkülönített kezelése a számviteli rendszerben.

\section{A finanszírozó szervezetek európai uniós pénzeszközeinek számviteli elszámolása}

A Nemzeti Fejlesztési Terv operatív programjainak megvalósítása során ${ }^{108}$ a hazai jogszabályi környezet megkövetelte, hogy az európai uniós támogatásokhoz kapcsolódó előirányzat felhasználást minden esetben pénzeszköz átadással kell rendezi, ami év közben a bevételek és kiadások halmozódását okozza. A számviteli nyilvántartások vezetése szükségszerủen összhangban van a költségvetési törvényben foglaltakkal, hiszen „a forrásgazda [...] fejezeti kezelésű elöirányzatai közül az Európai Unióból érkező közösségi támogatásokhoz és a hozzájuk járuló nemzeti forrásokhoz (központi költségvetési támogatáshoz) kapcsolódó pénzforgalmi gazdasági események hatását a költségvetési törvényben elfogadott fejezeti kezelésű előirányzatonkénti tagolás szerint köteles elkülönítve elszámolni és nyilvántartani, mind a fökönyvi, mind az analitikus nyilvántartásban.” (Lilliné Fecz 2004)

A kialakított pénzügyi folyamatok, és az azokhoz kapcsolódó számviteli eljárások biztosítják, hogy a forrásgazda, valamint az irányító hatóságok és a közremüködő szervezetek a számviteli rendszerben zártan, elkülönítve tudják kezelni az egyes operatív programokon belüli prioritásokat, valamint a nemzeti és közösségi támogatás mértékét. $\mathrm{Az}$ európai uniós támogatással kapcsolatos kiadásokat mind közgazdasági, mind funkcionális osztályozás szerint el kell számolni.

\section{Strukturális Alapok támogatásának számviteli elszámolása (post-rata)}

\section{Elöleg elszámolása a támogatónál}

A projektek megvalósítása érdekében - a pénzügyi folyamatoknál bemutatottaknak megfelelően - a támogató a kedvezményezettnek elszámolási kötelezettség mellett előleget nyújthat. Az előleg átutalása kizárólag hazai forrás terhére történhet, a kifizető hatóságtól az európai uniós támogatás lehívása csak akkor kezdeményezhető, ha a kedvezményezett igazolni tudja a támogatások támogatási szerződés szerinti felhasználását.

\footnotetext{
${ }^{108}$ A Nemzeti Fejlesztési Terv kezdeti időszakában hatályban lévő 217/1998. (XII. 30.) Korm. rendelet 46. § (6) bekezdés d) pontja alapján.
} 
A kiutalt előleg a támogató oldaláról tehát költségvetési kiadásként jelenik meg, egyben egyéb követelés a tőkeváltozásokkal szemben. Az előleg elszámolásának időszaka - tárgyévi, vagy azt követő - befolyásolja annak számviteli rendezését a támogató könyveiben. Amennyiben az előleg elszámolása a tárgyévben megtörténik, ,a megfelelö pénzeszköz átadás-előirányzat teljesítési számlák közötti átrendezéssel végleges, elszámolt kiadásként kell kimutatni”, értelemszerüen az egyéb követelések tőkeváltozásokkal szembeni kivezetésével egyidejüleg. Amennyiben az elöleg elszámolása nem a tárgyévben történik, a pénzeszköz átadás elöirányzat teljesítése számlák közötti pénzforgalom nélküli átvezetés nem lehetséges, így csak a követeléseket kell rendezni a tőkeváltozásokkal szemben. Ha a kedvezményezett az előleggel nem, vagy csak részlegesen számol el (pl. a projekt meghiúsul, vagy szabálytalanság miatt visszafizetési kötelezettség keletkezik), akkor a különbözetet „a támogatási program előlegének visszatérüléseként pénzeszközátvétel-elöirányzat teljesítéseként kell nyilvántartásba venni.” (Nemzeti Fejlesztési Ügynökség 2007b)

\section{A támogatások pénzügyi elszámolásának követése a finanszírozó szervezeteknél}

A támogatási döntéssel egyidejüleg a támogatást mint kötelezettséget mérleg alatti tételként veszik nyilvántartásba, majd a hazai társfinanszírozási részt - a Magyar Államkincstár jóváírását követően - mint felügyeleti szervtől kapott támogatás elöirányzatának teljesítését.

A szállítói számlák benyújtását követően a közremüködő szervezet intézkedik a forráslehívásról, melyet a lebonyolítási számlára érkezéskor függő kiadásként kell elszámolni. A teljes támogatási összeg lebonyolítási számlára érkezésekor el kell végezni a támogatási programok idegen pénzeszközei, illetve a függő, átfutó bevételek közötti könyvelési tételeket. Az átutalást követően kedvezményezett részére a forrásgazda a korábbi függő kiadást elszámolja költségvetési kiadásként. (Nemzeti Fejlesztési Ügynökség 2007b)

$\mathrm{Az}$ európai uniós támogatás megérkezését a kifizető hatóságtól a forrásgazda támogatásértékü bevételként veszi nyilvántartásba a pénzforgalmi tételek egyidejü rögzítése mellett.

Szabálytalanságnak minősített kifizetéseket a forrásgazda követelésként - a kedvezményezett kötelezettségként - tartja nyilván, egészen annak pénzügyi rendezéséig. 
Ha szabálytalanság pénzügyi rendezése tárgyéven belül megtörténik, akkor azt a forrásgazda átadott pénzeszköz kiadásának csökkenéseként kezeli, és miután a pénzügyi rendezés megtörtént, a követelés kivezetésre kerül. Ezzel együtt a forrásgazda gondoskodik a szabálytalanul igénybe vett európai uniós támogatás visszautalásáról is, amelyet támogatásértékü bevétel csökkenéseként vesz nyilvántartásba. Amennyiben a szabálytalanság pénzügyi rendezése a tárgyévet követő évben történik meg, azt a forrásgazdánál támogatás értékü bevételként veszik nyilvántartásba, míg a forrásgazda által a kifizető hatóságnak visszautalt támogatásrészt végleges pénzeszközátadás kiadásaként kell nyilvántartásba venni. (Nemzeti Fejlesztési Ügynökség 2007b)

A fent leírt tételekkel a pénzügyi folyamat valamennyi lépése átlátható módon követhető, és teljesül az az alapelv, hogy az európai uniós támogatásokhoz kapcsolódó előirányzat felhasználást minden esetben pénzeszköz átadással kell rendezni, továbbá a támogatások elkülönített kezelése biztosítottá válik.

\subsection{Az önkormányzatok mint kedvezményezettek számviteli elszámolása}

A kutatás empirikus adatainak egy részét a Magyar Államkincstár szolgáltatja, melyek a helyi önkormányzatok beszámolóin alapulnak. Az adatok egységes értelmezése érdekében

- figyelemmel arra, hogy jelen dolgozatban a vizsgált időszakban az önkormányzatok számviteli szabályait tartalmazó hatályos kormányrendelet bemutatására nem kerül sor indokolt a dolgozatban bemutatni azokat a beszámoló-elemeket ${ }^{109}$, amelyek tartalmát az európai uniós támogatások felhasználása közvetve, vagy közvetlenül változtat.

\section{A Strukturális Alapokból származó támogatások elszámolása önkormányzati kedvezményezett esetében}

A pénzügyi folyamatok leírásánál bemutatottaknak megfelelően a Strukturális Alapok projektjeinek finanszírozása post-rata rendszerben történik.

\section{Elöleg számviteli kezelése}

Bizonyos operatív programok pályázati kírásai lehetőséget adnak arra, hogy a kedvezményezett részére elöleg folyósítására kerüljön sor, kizárólag hazai, költségvetési források terhére, ugyanis az európai uniós támogatás közvetett módon sem

\footnotetext{
${ }^{109}$ Elsődlegesen mérleg csoportokat.
} 
finanszírozhatja az államháztartás hiányát. Ennek figyelembe vételével indokolt az előleg kiemelt és elkülönített megfigyelése és nyilvántartása. (Lilliné Fecz 2004)

A kedvezményezettnek az elöleget elkülönített, ún. célelszámolási számlán kell kezelnie annak érdekében, hogy más, a pályázati céltól eltérő célra ne kerüljön felhasználásra (Antalóczy et al. 2010), mellyel egyidejüleg az elöleget mint rövid lejáratú kötelezettséget állományba veszi.

A projekt megvalósítása során a keletkező kiadásokat a kedvezményezett közvetlenül a célelszámolási számláról egyenlíti ki egészen addig, amíg elszámolási kötelezettségének a teljes előlegről nem tesz eleget. Értelemszerüen az előleg kötelezettségét csak akkor vezetheti ki könyveiböl a kedvezményezett, amennyiben a pénzügyi lebonyolítást menedzselő szervezet (közremüködő szervezet, vagy irányító hatóság) az előleg elszámolását jóváhagyta. „A végső kedvezményezett pénzeszközeiből a be nem fogadott szállítói számlákkal azonos összeget az értesítéssel egyidőben köteles átvezetni az elkülönített célelszámolási számlára, amelynek állománya mindig a támogatási szerződés megvalósítására utal, fel nem használt támogatási pénzeszközök nagyságát mutatja.”(Lilliné Fecz 2004)

\section{Támogatás elszámolásának számviteli kezelése a projekt megvalósitása során}

A számla befogadását követően a kedvezményezett a kötelezettségvállalást nyilvántartásba veszi, majd a szállító számláját pénzügyileg rendezi. ${ }^{110}$ Ezt követően a szállítói kötelezettség állományát csökkenti, majd gondoskodik a vásárolt eszközök állományba vételéről, amennyiben a beszerzés tárgyi eszközt keletkeztet. Amennyiben müködési költségek finanszírozására kapott támogatást - pl. valamilyen készség, képesség fejlesztésére, vagy nevesítetten a müködés finanszírozására -, akkor annak az elszámolását kell megtennie, de ez vagyonváltozással jellemzően nem jár. A szállítói számla kifizetésével a támogatás összege még nem rendeződött, ezért azt átmenetileg átfutó kiadásként kell nyilvántartásba vennie, majd annak megérkezését követően átvett pénzeszköz bevételeként kell nyilvántartásba vennie. (Lilliné Fecz 2009) Amennyiben a közremüködő szervezet a benyújtott elszámolást nem tartja jogszerünek, nem utalja át a visszautasított elemekre eső támogatást, így azt a kedvezményezettnek a saját előirányzatok terhére rendeznie kell. (Nemzeti Fejlesztési Ügynökség 2007b)

\footnotetext{
${ }^{110}$ A dolgozatban - az egyszerűsítés érdekében - azt az esetet nem mutatom be, amikor a kedvezményezett csak a számlára eső önerőt fizeti ki közvetlenül a szállítónak.
} 
Szabálytalannak minősített kifizetés esetén a kedvezményezettnek kötelezettsége keletkezik a támogatóval szemben. Amennyiben a szabálytalanság pénzügyi rendezése a tárgyévben megtörténik, akkor az az átvett pénzeszközök bevételének csökkenéseként jelenik meg az önkormányzat számviteli rendszerében, míg amennyiben a pénzügyi rendezés a naptári éven túl történik, azt támogatásértékü kiadásként veszi nyilvántartásba a kedvezményezett.

A támogatások utólagos elszámolása miatt a kedvezményezett megelőlegezi a teljes szállítói számla értéket, az előfinanszírozáshoz likviditási hitelt is felhasználhat. Ebben az esetben a likviditási hitel felvételét finanszírozási bevételként számolja el a likviditási hitel egyidejű állományba vétele mellett. A támogatások pénzügyi rendezését követően pedig a likviditási hitel törlesztésének elszámolása finanszírozási kiadásként történik a hitel állományának kivezetése mellett. (Antalóczy et al. 2010) 


\section{Hipotézisek megfogalmazása és a kutatás empirikus megalapozása}

\subsection{Az empirikus kutatás lehatárolása}

A dolgozat bevezetőjében jelzetteknek megfelelően a sokrétű elméleti felvezetést kutatásom integráns részének tekintem, ugyanis a feldolgozott szakirodalmi anyagok elemzésekor újszerü megközelítésre törekedtem: egymástól távol álló tudományterületek összekapcsolásával világítottam rá olyan összefüggésekre, amelyek az egyes részterületek külön-külön történő vizsgálatával nem körvonalazódnának.

A kutatás elméleti megalapozásánál többféle szempontból elemeztem az európai uniós támogatások és az önkormányzatok viszonyát. Felmerül egyrészt a támogatások hatásának mérhetősége, másrészt azok az addicionalitási szempontok, amelyek biztosítása alapkövetelmény a támogatások lehívásához. Látszólagos ellentmondás feszül a hazai szakirodalomban abban a kérdésben, hogy a fejlesztés és az eladósodás között milyen összefüggések körvonalzódnak. Míg Banai - az államháztartási hiány vizsgálatakor - arra a következtetésre jutott, hogy ,a hiány szintjét alapvetően befolyásolja az addicionalitási kiadások szintje" (Banai 2008), addig Vigvári atipikus önkormányzati eladósodás modellje szerint a kötvénykibocsátó - és ezáltal eladósodó - önkormányzatok jellemzően nem pályáztak európai uniós forrásokra. (Vigvári 2009a)

A kutatás során nem a fenti, látszólagos ellentmondás feloldását tüzöm ki célul, ugyanis annak mérhetősége a 2007-2013-as programozási periódust követően válik időszerüvé, hiszen, bár az eladósodás hatásai elvben mérhetők, az összehasonlíthatóság gerincét képező beruházási oldal viszont - a megvalósítás szakaszában lévő projektek miatt nem.

A fejlettségbeli különbségek mérésének egyik lehetősége az ún. bottom-up vagy mikro megközelítés, amelynek elemzési egységéül a helyi önkormányzatokat választottam. Bár a feldolgozott szakirodalomban meglehetősen sok utalás van arra, hogy a támogatások felhasználásában mitől lesz egy-egy település élenjáró, ennek igazolása még nem történt meg.

Az elemzés területeként olyan időszakot választottam, amely lezártnak tekinthető, ezért eredményeiről számszerüsíthető adatok állnak rendelkezésemre. Mivel azonban a 
Nemzeti Fejlesztési Terv 2004-2006-os programozási periódus elszámolhatósági időszaka - az Európai Bizottság egyetértésével - 2008. december 31-éig tartott, az empirikus tesztelést a 2004-2008-as időszakra, az európai uniós támogatások tekintetében pedig a strukturális alapokból finanszírozott operatív programokra, a megfigyelési egységek szempontjából pedig a helyi önkormányzatokra korlátozom. Az empirikus kutatásból azok erősen torzító hatása miatt a megyei jogú önkormányzatokat, valamint a fővárost és annak kerületeit kizártam.

\subsection{A hipotézisek megfogalmazása}

Az európai uniós támogatások felhasználása és a helyi önkormányzatok gazdálkodása közötti kapcsot az addicionalitás követelménye adja, vagyis az, hogy az önkormányzatoknak mint potenciális kedvezményezetteknek megfelelő önerővel kell rendelkezniük. Ehhez látni kell azt, hogy az önerő előteremtésére milyen források szolgálnak, milyen összefüggések körvonalazódnak a hitelfelvétel, eladósodás, saját bevételek, európai uniós források között.

H1: Magyarországon az aranyszabály nem teljesül: a helyi önkormányzatok hitelfelvétele nem kizárólag felhalmozási jellegü kiadásokat, hanem részben folyó (müködési) kiadásokat finanszíroz.

Az első hipotézis tehát kizárólag az aranyszabály érvényesülésével kapcsolatos, vagyis nem érinti az európai uniós támogatásokat, illetve annak kapcsolatát a hitelfelvétellel. Maga a hipotézis nem tekinthető újszerűnek, hiszen a 4. fejezetben bemutatott korábbi elméleti felvetések egyértelmüen kimondják és megerősítik azt, ugyanakkor annak teljes értékủ empirikus alátámasztására nem találtam szakirodalmi levelezetést. A hipotézisek második csoportjában a felhalmozási és beruházási jellegű kiadások, az európai uniós támogatások, valamint az addicionalitás tesztelése a fó cél.

H2: Az európai uniós támogatások a helyi önkormányzatok beruházásaiban meghatározó szerepet töltenek be: a felújítási és beruházási kiadások a folyósított európai uniós támogatásokkal pozitív kapcsolatban állnak.

Amennyiben a H2 hipotézis elfogadható, akkor arra a kérdésre kell választ találnom, hogy az addicionalitás követelményének a helyi önkormányzatok hogyan tettek eleget. 
Vizsgálandó a fejlesztés és a finanszírozás, valamint a települések saját bevételei közötti kapcsolat.

H3: A helyi önkormányzatok esetében az addicionalitás szabálya érvényesül: pozitív kapcsolat van a saját bevételek és a finanszírozás egyenlegének együttes összege, valamint a folyósított európai uniós támogatás között.

A H3 hipotézis elsődlegesen az addicionalitás tesztelésére fókuszál, nem ad választ arra a kérdésre, hogy az európai uniós támogatások és a helyi önkormányzatok kötelezettségeinek növekedése között léteznek-e kapcsolatok, és amennyiben igen, akkor azok milyen jellegüek. A disszertáció 4. fejezetében levezetettek alapján ugyanakkor az eladósodási tendencia egyértelmüen jellemzi a magyar helyi önkormányzatokat, ezért a hipotézist a kötelezettségvállalás növekedésére szükítem.

H3.1. Az európai uniós támogatások felhasználása eladósodáshoz vezet: a helyi önkormányzatok kötelezettségvállalásának növekedése, valamint a folyósított európai uniós támogatás egymással pozitív kapcsolatban áll.

A kutatást multidiszciplináris jellegünek szánom, azonban ha a H1-H3 hipotézisek megfogalmazásával zárulna a gondolatmenetem, felvetődne a kérdés, hogy miért szántam a dolgozat elméleti felvezetésének közel felét regionális politikai témákra, illetve a támogatások hatékonyságát mérő modellek bemutatására. A hipotézisem harmadik szük, de rendkívül összetett - csoportját olyan felvetések képezik, amelyek a támogatások elnyerése mögötti okokat és azok összefüggéseit keresik.

H4: A helyi önkormányzatok nagysága, területi elhelyezkedése, bevételi szerkezete együttesen olyan tényezők, amelyek meghatározzák az európai uniós támogatások igénybe vételét.

H5: Létezik a helyi önkormányzatoknak olyan nagyság, területi elhelyezkedés és bevételi szerkezet szerinti csoportja, amelyeknél az európai uniós támogatások felhasználása nem tipikus.

\section{A fogalmak operacionalizálása}

Az operacionalizálás az empirikus kutatással és a vizsgálandó változók pontos definiálásával teljes, ugyanakkor indokoltnak tartom a hipotézisekben használt fogalmak 
rövid operacionalizálását, mivel egyes kifejezéseknél eltértem mind a szakirodalomban, mind a köznyelvben általánosan használt megközelítéstől.

A hipotézisekben szereplő főbb fogalmak meghatározása egyrészt a 7 . számú mellékletben, másrészt a 8. számú mellékletben, harmadrészt az egyes hipotézisek részletes tesztelésének leírásánál található. 


\section{A kutatás módszertana és a hipotézisek tesztelése}

\subsection{A kutatás empirikus megalapozása}

A kutatás során induktív $\rightarrow>$ deduktív $\rightarrow>$ induktív megközelítést alkalmaztam, vagyis első lépéseként feltérképeztem azokat az adatbázisokat, amelyek a témában elérhetők, alaposan áttekintettem azok adattartalmát, és megpróbáltam egy szükebb adathalmaz alapján $^{111}$ feltérképezni a bennük rejlő összefüggéseket. Kellő elméleti ismeret hiányában azonban próbálkozásom kevés sikerrel járt. Ezt követően a nemzetközi és a hazai szakirodalom megismerésével megkezdtem önálló elméleti kutatásomat, melyet a disszertáció elméleti felvezető része tartalmazza. A hipotézisek megfogalmazása elsődlegesen a kutatás elméleti részén alapul. Empirikus tesztelés nélkül azonban a felállított hipotézisek pusztán elméleti levezetés alapján egyáltalán nem, vagy csak vitatható módon fogadhatók el, ezért a kutatás befejező részeként adatbázisok tesztelésén keresztül vizsgálom a hipotéziseket.

Mind a hipotézisek megfogalmazását megelőzően, mind a kutatás empirikus részének tervezésekor mélyinterjúkat is folytattam helyi önkormányzatok gazdasági szakembereivel, gyakorló könyvvizsgálókkal, valamint a Magyar Államkincstár és a Nemzeti Fejlesztési Ügynökség munkatársaival. Ezek a mélyinterjúk elsősorban az összefüggések feltárására és az egyes adatbázisokban szereplő változók gyakorlati értelmezésére szolgáltak, azonban nem tekinthetők strukturált mélyinterjúknak: elsősorban azokat a területeket tekintettük át, amelyek az adott interjúalany szűken vett szakmai területének tekinthetők. Mivel fentiek alapján a mélyinterjúk eredményei korlátozottak, azok eredményeinek bemutatásától eltekintek, és a hipotézisek alátámasztásához elsődlegesen a többváltozós adatelemzés matematikai-statisztikai módszereit hívom segítségül.

A kutatás során önálló kérdöív elkészítését nem tartottam indokoltnak tekintettel arra, hogy a következőkben bemutatásra kerülö, önmagukban egységes struktúrában készült adatbázisokban szerepel azon információk köre, amelyekre a hipotézisek alátámasztásához szükség van. Mind a Központi Statisztikai Hivatal, mind a Nemzeti Fejlesztési Ügynökség, mind a Magyar Államkincstár által szolgáltatott adatokat

\footnotetext{
111 A doktori képzés „Többváltozós adatelemzés matematikai-statisztikai módszerei” tárgy keretében az önkormányzatok 2004. évi költségvetési jelentéseit vizsgáltam.
} 
többszörösen - azok teljességét, koherenciáját - ellenőrzik, így megbízható és teljes adatforrásnak tekintem azokat.

Az adatbázisokban szereplő adatok elemzését és a hipotézisek tesztelését jellemzően két lépésben végeztem el. Az adatbázis belső szerkezetének feltárása érdekében első lépésben meghatároztam az egyes változók alapvető statisztikai paramétereit ${ }^{112}$, melyek részletes bemutatásától hipotézisenként külön-külön eltekintettem, ugyanakkor a föbb összefüggéseket külön mellékletben (10. számú melléklet) összegeztem. A hipotézisek tesztelésére szolgáló többváltozós adatelemzési, statisztikai eljárások megtervezése és lefolytatása az SPSS18 programmal történt. A dolgozatban szereplő ábrák, grafikonok szintén ennek a programnak az outputjai, ugyanis a kutatás dokumentálása, táblázatos és grafikus megjelenítése, valamint az eredmények értelmezése az SPSS segítségével történt.

\subsubsection{Az adathalmaz eredete és az adatgyüjtés módja}

A kutatáshoz kapcsolódóan három olyan magyarországi adatbázist ismertem meg, melyek adatai külön-külön nem, azonban együttesen elegendőek a hipotézisek empirikus teszteléséhez. A három adatbázis egyesítését megelőzően az egyes részeket külön-külön megvizsgáltam annak érdekében, hogy a kutatás szempontjából irreleváns változókat még az adatbázisok egyesítése elött - elkülönítsem. Ezzel elkerülhetővé vált a különben is ezres nagyságrendű változót tartalmazó adatbázis további, indokolatlan növelése.

\section{Központi Statisztikai Hivatal adatbázisa}

Az adatbázis összességében több mint ezer változót használ, melyek jelentős része közvetlenül nem kapcsolódik az önkormányzatok vagyoni, pénzügyi és jövedelmi helyzetéhez, eladósodottságához, illetve a folyósított európai uniós támogatások mértékéhez. A kutatás célját szem előtt tartva szükségszerünek tünt a változók körének jelentős mértékü szükítése. A kereskedelemre, oktatásra, egészségügyre, szociális ellátásokra, kultúrára vonatkozó naturális mutatók vizsgálata szociológiai jellegü kutatásoknál lenne érdekes, bár bizonyára találnának olyan összefüggéseket, amelyek a helyi önkormányzat fejlettségével kapcsolatosak, de ezen mutatókat mint változókat az elemzésből kizártam.

\footnotetext{
112 átlagát, szórását, eloszlását
} 
A Központi Statisztikai Hivatal településstatisztikai adatbázisának előnye, hogy a megfigyelési egységek a kutatás céljaihoz teljes egészében beazonosíthatók, ugyanis a megfigyelési egységek száma megegyezik azoknak a településeknek a számával, melyekben helyi önkormányzat müködik ${ }^{113}$, továbbá az adatok valamennyi vizsgált évre vonatkozóan (2004-2008), egységes szerkezetben letölthetők. Az adatbázis teljesnek tekinthető, mivel szerepel benne valamennyi magyarországi helységre vonatkozóan adat. Az adatbázisban szereplő információk alapján követhető, hogy a település területileg hol, melyik megyében helyezkedik el. Ezeknek az adatoknak a hozzáférése a Központi Statisztikai Hivatal honlapján keresztül biztosított volt ${ }^{114}$. (http://statinfo.ksh.hu/Statinfo, letöltés ideje 2011.október 13.)

\section{Nemzeti Fejlesztési Ügynökség Egységes Monitoring Információs Rendszere}

Az Egységes Monitoring Információs Rendszerben valamennyi, strukturális alapokból támogatott projektre vonatkozóan rendelkezésre állnak adatok. Mivel a rendszer a projektek teljes életciklusát követi a pályázat benyújtásától kezdve a fenntartási időszak végéig, így mind a projektek szakmai tartalmára vonatkozóan, mind azok pénzügyi folyamataira megfelelő információ áll rendelkezésre.

A Nemzeti Fejlesztési Ügynökséggel folytatott szakmai egyeztetést követően az adatbázist a kutatás céljaihoz illeszkedő adattartalommal, teljes körüen rendelkezésemre bocsátották. Az adatbázis valamennyi projektet tartalmazza, amelyre vonatkozóan kifizetés történt a 2004-2006-os programozási periódusban 2004 és 2008 között, tehát teljesnek tekinthető. Az adatbázis számos változót tartalmaz ${ }^{115}$, melyek közül a kutatás szempontjából elsődlegesen az egyes önkormányzati projektekre vonatkozó, 2004-2008 között teljesített kifizetések relevánsak.

Az adatbázis kezelés első lépéseként egyszerü Excel program segítségével strukturáltam a kutatás céljainak megfelelően az adatokat, melynek kezdeti lépése volt az adatbázisban szereplö változók értelmezése és helyi önkormányzatokra történő szükítése volt. A projektre vonatkozó adatokat elsődlegesen azok székhelye szerint vettem figyelembe.

\footnotetext{
${ }^{113}$ Az adatbázisban a megyei önkormányzatok és a fővárosi önkormányzat adatai is szerepelnek, azonban a kutatás hatókörét szükítettem, ezért ezek az adatok a kutatás szempontjából nem relevánsak.

${ }^{114}$ A KSH honlapjáról letöltött változók körét a dolgozat 9. a) számú melléklete tartalmazza.

115 Az NFÜ EMIR adatbázisának a kutatás szempontjából releváns változóit a dolgozat 9. b) számú melléklete tartalmazza.
} 
Összesen 7 projekt ${ }^{116}$ esetében nem volt ismert a székhely, ott a projekt megvalósításának helye szerinti települést vettem figyelembe. Az önkormányzatokra vonatkozó szűkítést az adatbázis „gazdasági forma” változója tette lehetővé.

\section{Magyar Államkincstár adatbázisa}

A vizsgált időszakban (2004-2008) hatályos magyar jogi szabályozásnak megfelelően az önkormányzatok a beszámolójukat minden évben kötelesek eljuttatni a Magyar Államkincstár területileg illetékes szervéhez. A beszámoló összesen 80 ürlapot foglal magában, melyek az önkormányzat vagyoni, pénzügyi és jövedelmi helyzetét mutatják be. A Magyar Államkincstár az adatokat a kutatás által lefedett időszakban évenként gyüjtötte, ami lehetővé teszi mind az egyes évek közötti összefüggések vizsgálatát, mind pedig az egyes éveket külön-külön vagy akár együtt kezelve. A Magyar Államkincstár adatbázisa teljes, valamennyi helyi önkormányzatra vonatkozó adatok, egységes szerkezetben találhatók meg benne.

A kutatás hatókörét a dolgozat elméleti felvezetésében a számviteli és nyilvántartási rendszerekkel megfogalmazott kritikával összefüggésben korlátozza, hogy „nincs információ az önkormányzat kvázifiskális szektoráról” (Vigvári 2010a), vagyis a helyi önkormányzatok beszámolói sem konszolidált módon, sem elkülönítve nem tartalmazzák az önkormányzati tulajdonban lévő gazdasági társaságok vagyonát, az azokkal kapcsolatos tulajdonosi kötelezettségeket ${ }^{117}$. Az önkormányzati gazdálkodásban jelentős szerepet játszó mérleg alatti tételek (pl. PPP projektekkel kapcsolatos hosszú távú kötelezettségek, többéves kötelezettséget jelentő lízingdíjak) a könyvviteli mérlegben kötelezettségként jellemzően nem jelennek meg, hanem azok összegző adatait a költségvetési jelentés folyó működési kiadások sorai tartalmazzák.

Fenti kockázat csökkentésének szándékát is szem előtt tartva első lépésként a 80 ürlap közül ki kellett választanom azokat, amelyek a kutatás szempontjából relevánsak. A megfogalmazott hipotézisek figyelembe vételével a Könyvviteli mérleg (01-es számú ürlap) és a Költségvetési jelentés (80-as ürlap) került kiválasztásra, ugyanis az azokban szereplő változók összevont információkat szolgáltatnak egyrészt a vagyonra és többéves adatokat vizsgálva annak változására vonatkozóan, másrészt pedig az önkormányzatok

\footnotetext{
116 A teljes EMIR NFT adatbázisban összesen 42858 projekt szerepelt, tehát a $7 \mathrm{db}$ meglehetősen alacsonynak $(0,02 \%)$ tekinthető.

${ }^{117}$ például garancia, kezességvállalás, harmadik féllel szembeni kötelezettségek
} 
bevételi és kiadási szerkezetére. A kutatást nehezítette az, hogy mindkét ürlap szerkezete és információtartalma - kis mértékben ugyan, de - változott, bővült a vizsgált időszakban. Az ürlapok tartalmát, vagyis a változók körét, valamint a változók kódolását a 8. számú mellékletek tartalmazzák.

A változók túlzottan magas száma az empirikus kutatást jelentősen nehezítette volna, ezért a három adatbázis összefüzését megelőzően a Magyar Államkincstár által szolgáltatott adatok esetében a változók számának csökkentése történt meg részben szakmai alapon, részben matematikai módszerekkel a következők szerint:

1. A Könyvviteli mérleg (01-es ürlap) esetében első lépésként annak tesztelése történt meg, hogy a folytonosság elve, vagyis a tárgyévi nyitó adatok és az azt megelőz év záró adatok közötti egyezőség a vizsgált időszakban teljesül-e. Ezt az elemzést elhagyhattam volna tekintettel arra, hogy a hatályos számviteli szabályok betartása mellett az egyezőség szükségszerü.

Véletlenszerüen kiválasztásra került a könyvviteli mérlegből 50 változó $^{118}$, amelyek esetében valamennyi vizsgált évre (2004-2008) vonatkozóan korreláció vizsgálatot végeztem. A korreláció 1-1 értékei alapján nagy valószínüséggel arra következtethetünk, hogy a folytonosság elve a gyakorlatban is érvényesült, így az adatbázisban redundanciát okozó változók szerepeltetése szükségtelen, ugyanis az az elemzést feleslegesen torzítaná. Fentiek figyelembe vételével a hipotézisek tesztelésére alkalmazott adatbázisban csak a 2004. évi nyitó és záró adatok, valamint a 2005-2008 évek záró mérlegadatai szerepelnek.

2. A költségvetési jelentés (80-as ürlap) esetében minden változóhoz három adat eredeti előirányzat, módosított előirányzat és tényleges teljesítés szerepel. Tekintettel arra, hogy a kutatás hatóköre nem terjed ki a tervezéskori és a ténylegesen megvalósult értékek közötti különbségek vizsgálatára, a változók közül kizárólag a tényleges teljesítést vettem figyelembe. Ezzel a lépéssel a költségvetési jelentéshez kapcsolódó változók száma harmadára csökkent.

Miután mindhárom adatbázist külön-külön megtisztítottam a kutatás szempontjából nem releváns, felesleges változóktól, előállt a hipotézisek tesztelésére alkalmas adathalmaz.

${ }^{118}$ a változók közel fele 


\subsubsection{Az adathalmaz feltáró elemzése}

A három adatbázis összekapcsolásával nominális, ordinális és arányskálán értelmezhető változók is szerepelnek.

Első lépésként részletesen vizsgáltam az átlagnépességet és a településszerkezetet. Ennek eredményeként ${ }^{119}$ arra jutottam, hogy a lakosság szórása magas, a pozitív ferdeség jobbra ferde eloszlást mutatott a csúcsosság magas pozitív értéke mellett, amelyből azt a következtetést vontam le, hogy extrém megfigyelések vannak a sokaságban. A korrigált átlagok (M-esztimátor) számításával az átlagérték csökkent, ami annak a következménye, hogy a nagyvárosok jóval kisebb számban fordulnak elö, mint az apró falvak, viszont a néhány kimagaslóan nagy lélekszámú város erősen felfelé húzta az átlagot. ${ }^{120}$ Ezt a megállapításomat alátámasztották további változók összefüggései is, miszerint voltak olyan változók, amelyek egyáltalán nem voltak jellemzőek bizonyos településtípusokra ${ }^{121}$.

A feltáró adatelemzés alapján levonhatjuk azt a következtetést, hogy az empirikus kutatás során az összes megfigyelési egység együttes elemzése nem, vagy csak nagyon nehezen vezethet célra, mivel a települések között jelentős eltérések vannak bizonyos változók tekintetében.

Kezdeti lépésként tehát meg kellett találnom azokat a csoportképzési ismérveket, amelyek mentén a helyi önkormányzatok mint entitások kezelhetők. Ezek a csoportképző ismérvek egyrészt a földrajzi elhelyezkedés, másrészt a lélekszám lehetne. A feltáró elemzés eredményeként azonban a gazdasági szerkezet jellemző értékek erősen függenek a lélekszámtól, ezért saját kategorizálást alkalmazok, mely egyrészt a területi elhelyezkedésen, másrészt a gazdasági szerkezet jellemzőin alapul.

\section{Földrajzi elhelyezkedés}

A vizsgálatok során figyelemmel a dolgozat regionális politikai részeire is célszerünek tünik a NUTS besorolás szerinti régiók figyelembe vétele, melynek részletes leíró statisztikai adatait, valamint térképes megjelenítését a 10. számú melléklet tartalmazza.

\footnotetext{
${ }^{119}$ Az eredményeket lásd a 10. számú melléklet a) pontjában.

${ }^{120}$ Ehhez lásd még (Hunyadi et al. 2001).

121 Ezek között voltak az európai uniós támogatások is bizonyos években, azonban ezt később, a H5 hipotézis tárgyalásánál részletesen kifejtem.
} 
A települések regiónkénti, illetve megyénkénti számából következően a NUTS1 és NUTS2 szintű tesztelés esetén a statisztikai stabilitás a többváltozós adatelemzés során teljesül, ugyanakkor a NUTS3 (megye) szintű bontás esetében azonban annak korlátai lehetnek. (lásd 10. számú melléklet o) pont) Ezt enyhíti ugyanakkor, hogy az adatbázis teljes, mintavételezésre nem kerül sor.

Mivel már a NUTS3 szintü bontás esetében is felmerül a statisztikai stabilitás kérdése, NUTS4 (kistérség) szintủ elemzéseket a hipotézisek tesztelése során nem alkalmazok.

A feltáró elemzés keretében megyék szerinti bontásban több lépésben megvizsgáltam az európai uniós támogatások és a települések területi elhelyezkedése közötti viszonyokat. ${ }^{122}$

A feltáró elemzés keretében megvizsgáltam Magyarország településszerkezetét abból a szempontból, hogy az egyes megyékben, illetve régiókban milyen lélekszámú települések jellemzőek. A 10. számú mellékletben szereplő adatok és diagramok alapján egyértelmüsíthető, hogy az ország településszerkezetében jelentős eltérések mutatkoznak, amelyeket az elemzések, és azok értelmezése során indokolt figyelembe venni. ${ }^{123}$

Magyarország nyugati megyéiben többségben vannak a kisebb lélekszámú települések, míg a keleti megyékben a több ezer fős települések a jellemzők. Figyelemreméltó az is, hogy az 500 fő alatti kitelepülések több, mint háromnegyede (75,8\%) Dunántúl NUTS1 nagyrégióban található ${ }^{124}$, a kistelepüléses szerkezet leginkább Baranya, Győr-Moson-Sopron, Somogy, Vas, Veszprém, Zala megyékre jellemző. (10. számú melléklet d-e) pont) Míg az 500 és 5000 fő lélekszámú települések NUTS1 nagyrégiók szerint arányosan oszlanak meg, addig 5000-50000 fö közötti települések többsége az Alföld és Észak NUTS1 nagyrégióban koncentrálódik. Az 50000 fő feletti nagyvárosok eloszlása egyenletesnek tekinthető. Figyelemreméltó ugyanakkor, hogy a NUTS1 szerinti besorolásban Közép-Magyarország településszáma jóval alacsonyabb, mint a másik két nagyrégióé. Ez, a szakmai szempontokon nyugvó besorolás elöremutató, ugyanakkor a települések számának aránytalansága miatt jelen kutatás eredményeit torzítaná.

A feltáró elemzéssel az volt a célom, hogy a megyéket figyelemmel a területi elhelyezkedésre is három csoportba rendezzem a NUTS1 és NUTS2 besorolástól

\footnotetext{
122 lásd 10. számú melléklet m-o) pont

${ }^{123}$ lásd 10. számú melléklet e) és q) pont

${ }^{124}$ Az Alföld és Észak régióban ez az érték mindössze 23,6\%.
} 
függetlenül olyan módon, hogy az egyes csoportok önmagukban a lehető leghomogénebbek legyenek, egymáshoz viszonyítva jellemzőikben ${ }^{125}$ pedig nagy eltéréseket mutassanak. A saját területi beosztást, valamint annak térképes megjelenítését a 10. számú melléklet f1-f2 pontja tartalmazza. A feltáró elemzés eredményeként a nyugati és a keleti csoportba sorolt megyék önmagukban hasonlóságot mutattak, míg az egyik csoportba sem sorolható megyék ${ }^{126}$ közös jellemzőt alig mutattak.

A saját besorolás alapján a lakosságszám településméretek közötti eltérései különösen az 500 fö alatti települések esetében élesednek figyelemmel arra, hogy az elemszámok az egyes kategóriákban egymáshoz közelednek. ${ }^{127}$ Ezzel az elemzések önmagukban homogénebb sokaságon folytathatók le, míg az egyes csoportok közötti különbségek élesebben kirajzolódnak. A saját besorolás további előnyének tekinthető, hogy az a támogatást elnyert helyi önkormányzatok szempontjából kiegyensúlyozott képet mutat az egyes besorolási kategóriák (Nyugat, Közép, Kelet) mentén.

A hipotézisek empirikus tesztelésekor a területi megbontás tekintetében valamennyi kategorizálást (NUTS szerinti, illetve saját bontás szerintit) használom.

\subsection{A hipotézisek tesztelése}

\subsubsection{A H1 hipotézis tesztelése}

H1: Magyarországon az aranyszabály nem teljesül: a helyi önkormányzatok hitelfelvétele nem kizárólag felhalmozási jellegü kiadásokat, hanem részben folyó (müködési) kiadásokat finanszíroz.

A kutatás elméleti részében bemutatottak alapján az feltételezhető, hogy a magyarországi helyi önkormányzatok hitelfelvétele mögött számos tényező áll. A szakirodalmi ismeretek alapján a hitelfelvételből származó bevételek egy részét a helyi önkormányzatok beruházásokra fordították, másik részét megtakarításként kezelték, harmadrészt pedig müködési kiadásokat finanszíroztak belőle.

\footnotetext{
${ }^{125}$ Ebben az egyik leginkább meghatározó tényező a lélekszám, ugyanis az magasan korrelál a kutatás szempontjából releváns többi változóval.

${ }^{126}$ Ezt átmeneti halmaznak is nevezhetnénk.

${ }^{127}$ Ez részben annak a következménye, hogy a NUTS1 besorolás szerinti Közép-Magyarország régió aránytalanul alacsony elemszámú volt. A saját besorolás szerinti „Közép” kategória Közép-Magyarország régión túl további megyéket is magában foglal, ami az egyes besorolás szerinti lélekszám kategóriákat kiegyensúlyozottabbá teszi. Lásd még 10. számú melléklet g) és 1) pont
} 
A hipotézis tesztelése során a 2004-2008 közötti időszak teljes egészét veszem figyelembe tekintettel arra, hogy az egyes évek közötti hitelfelvételek és törlesztések torzíthatnák a modellt, azonban az évek közötti különbségek öt év vizsgálatával már kisimulnak és a tendenciák megfigyelhetők. A hipotézis a változók értékének mozgásával ragadható meg, ezért a tesztelés alapadatai flow jellegüek, tehát a helyi önkormányzatok költségvetési jelentéseit veszem alapul. Az alkalmazott módszer nagyban épül az Állami Számvevőszék által a helyi önkormányzatok pénzügyi helyzetének és gazdálkodási rendszerének 2011. évi ellenőrzéseiről szóló összegzésben (Állami Számvevőszék 2012) alkalmazott CLF módszerre. A módszer lényege az, hogy a tárgyi pénzügyi helyzetet vizsgálja olyan módon, hogy a folyó és a felhalmozási költségvetés egyenlegeit ${ }^{128}$ következetesen elkülöníti egymástól, illetve a finanszírozás egyenlegétől is. ${ }^{129}$

Feltevésem szerint figyelemmel a kutatás elméleti részére is a következő kapcsolatok vélelmezhetők:

$\Delta H F \approx \Delta E ́ p+\Delta F e l h a l m+\Delta$ Müködés

ahol:

$\triangle H F$ : a hitelfelvétel változása, vagyis a vizsgált időszakban hitelfelvételből befolyt pénzbevétel és hiteltörlesztésre fizetett pénzkiadás különbsége,

$\Delta$ Ép: a vizsgált időszakban megvásárolt, illetve értékesített rövid és hosszú lejáratú értékpapírok különbözete

$$
\begin{gathered}
\Delta \text { Ép }=\sum_{2004}^{2008}(f o r g . \text { célú ép vásárlása - forg.célú ép értékesítése) } \\
+\sum_{2004}^{2008}(\text { hosszú lej. ép vásárlása - hosszú lej.ép értékesítése })
\end{gathered}
$$

$\Delta$ Felhalm: a felhalmozási kiadások és felhalmozási bevételek különbsége

$$
\Delta \text { Felhalm }=\sum_{2004}^{2008}(\text { Felhalmozási kiadások }- \text { Felhalmozási bevételek })
$$

\footnotetext{
${ }^{128}$ bevételek és kiadások különbözeteit

${ }^{129}$ A módszer részletes leírását lásd (Állami Számvevőszék 2012) 1. számú függelék.
} 
$\Delta M u ̋ k o ̈ d e ́ s:$ a működési kiadások és működési bevételek különbsége

$$
\Delta M \text { üködés }=\sum_{2004}^{2008}(\text { Müködési kiadások }- \text { Működési bevételek) }
$$

Az egyenlet átrendezésével a következökre jutunk:

$$
\frac{\Delta H F}{\Delta \text { Ép }+\Delta \text { Felhalm }+\Delta \text { Müködés }} \approx 1
$$

A hipotézis elfogadásához azonban nem elegendő a fenti egyenlet igazolása, szükséges alátámasztani azt is, hogy az egyenlet a müködési kiadások nélkül nem érvényes, tehát

$$
\frac{\Delta H F}{\Delta \text { Ép }+\Delta \text { Felhalm }} \neq 1
$$

Mindkét egyenlet együttes igazolásával bizonyítjuk, hogy a hitelfelvétel részben müködési kiadásokat szolgál.

A hitelfelvétel változását, vagyis a $\triangle H F$ - et kétféle módon értelmezem: először úgy, hogy a hitelfelvételbe a rövid lejáratú és likvid hiteleket nem értem bele, másrészt pedig úgy, hogy azokat is beleértem. A hipotézis tesztelése tehát két eseten keresztül, összesen négy lépésben történik, egymintás t-próba ${ }^{130}$ alkalmazásával azzal a feltétellel, hogy a nevező pozitivitását feltételezzük tekintettel az elméleti kutatás eredményeire ${ }^{131}$.

\section{A hitelfelvételbe a rövid lejáratú és likvid hiteleket nem értjük bele}

Ennél az esetnél hitelfelvétel alatt a helyi önkormányzatok által a vizsgált időszakban felvett hosszú lejáratú és külföldi hitelek felvételének és törlesztésének különbségét, forgatási célú és hosszú lejáratú értékpapírok kibocsátásnak ${ }^{132}$ és beváltásának különbségét, valamint az egyéb finanszírozás bevételeinek és kiadásainak különbségét együttesen értjük.

\footnotetext{
${ }^{130}$ Annak tesztelése, hogy az átlag egyenlő-e a hipotetikus várható értékkel.

${ }^{131}$ lásd 4.3.3. fejezet

132 vagyis kötvénykibocsátásnak
} 


$$
\begin{aligned}
\Delta H F_{1} & =\sum_{2004}^{2008}(\text { hosszú lej. hitel felvétel }- \text { hosszú lej. hitel törlesztés }) \\
& +\sum_{2004}^{2008}(k \ddot{u} l f \text { öldi hitel felvétel }-k \text { ülföldihitel törlesztés }) \\
& +\sum_{2004}^{2008}(\text { forg. célú ép kibocsátása - forg.célú ép beváltás }) \\
& +\sum_{2004}^{2008}(\text { hosszú lej.ép kibocsátása - hosszú lej.ép beváltás })
\end{aligned}
$$

A t-próba eredménye szerint 1122 elem bevonásával 0,929 átlag és 0,797-es szignifikancia szint mellett az egyenlettel leírt állítás nem vethető el.

\begin{tabular}{|c|r|r|r|r|r|}
\hline \multicolumn{6}{|c|}{ Teszt érték =1 } \\
\hline \multirow{2}{*}{$\mathrm{t}$} & $\begin{array}{c}\text { szabad- } \\
\text { ságfok }\end{array}$ & szignifikancia & Átlagos eltérés & \multicolumn{2}{|c|}{$90 \%$ konfidencia intervallum } \\
\cline { 5 - 6 } & 1121 & 0,797 & $-0,07095$ & $-0,5249$ & 0,3830 \\
\hline$-0,257$ & 1120 érték & felső érték \\
\hline
\end{tabular}

A fentiek a hipotézis alátámasztásának szükséges, de nem elégséges feltételei, ugyanis ok-okozati összefüggések ez alapján nem fogalmazhatók meg.

Mivel a hipotézis tesztelése során célom az aranyszabály cáfolata, következő lépésben azt

\begin{tabular}{|c|c|c|c|c|c|}
\hline \multicolumn{6}{|c|}{ Teszt érték $=1$} \\
\hline \multirow{2}{*}{$\mathrm{t}$} & \multirow{2}{*}{$\begin{array}{l}\text { szabad- } \\
\text { ságfok }\end{array}$} & \multirow{2}{*}{ szignifikancia } & \multirow{2}{*}{ Átlagos eltérés } & \multicolumn{2}{|c|}{$90 \%$ konfidencia intervallum } \\
\hline & & & & alsó érték & felső érték \\
\hline$-4,588$ & 2992 & 0,000 & $-0,76638$ & $-1,0412$ & $-0,4915$ \\
\hline
\end{tabular}
vizsgálom, hogy az összefüggés a müködési kiadások és bevételek különbségének számba vétele nélkül teljesül-e, tehát igaz-e a következő:

$$
\frac{\Delta H F_{1}}{\Delta \text { Ép }+\Delta \text { Felhalm }} \approx 1
$$

A t-próba eredménye szerint 2993 elem bevonásával 0,23 átlag és 0,00-s szignifikancia szint mellett az egyenlettel leírt állítás elvetendő. 
Fentiekből az a következtetés vonható le, hogy a hitelfelvétel szigorú értelmezése vagyis a rövid lejáratú és likvid hitelek figyelmen kívül hagyása - mellett nem érvényesül az aranyszabály a magyarországi helyi önkormányzatoknál, ugyanis a t-próba alapján csak akkor tartjuk meg a nullhipotézist, ha a müködési kiadások és bevételek különbségét is figyelembe vesszük.

\section{A hitelfelvételbe a rövid lejáratú és likvid hiteleket is beleértjük}

A tesztelés módszere teljes egészében azonos az 1. lépésnél leírtakkal, a különbség a hitelfelvétel mint változó értelmezésének tekintetében áll fenn. A hitelfelvételbe $\left(\Delta H F_{2}\right)$ most a következőket értem bele:

A helyi önkormányzatok által a vizsgált időszakban felvett likvid és rövid és hosszú lejáratú és külföldi hitelek felvételének és törlesztésének különbségét, rövid és hosszú lejáratú értékpapírok kibocsátásnak és beváltásának különbségét, valamint az egyéb finanszírozás bevételeinek és kiadásainak különbségét együttesen értem bele.

$$
\begin{aligned}
& \Delta H F_{2}=\sum_{2004}^{2008}(r o ̈ v i d \text { és likvid hitel felvétel }- \text { rövid és likvid hitel törlesztés) } \\
& +\sum_{2004}^{2008}(\text { hosszú lej. hitel felvétel - hosszú lej.hitel törlesztés) } \\
& +\sum_{2004}^{2008}(k \ddot{u} l f o ̈ l d i \text { hitel felvétel }-k \ddot{u} l f o ̈ l d i h i t e l \text { törlesztés }) \\
& +\sum_{2004}^{2008}(f o r g . \text { célú ép kibocsátása - forg.célú ép beváltás) } \\
& +\sum_{2004}^{2008}(\text { hosszú lej.ép kibocsátása - hosszú lej.ép beváltás) }
\end{aligned}
$$

A $\frac{\Delta H F_{2}}{\Delta \text { Ép }+\Delta \text { Felhalm+ } \Delta \text { Müködés }} \approx 1$ egyenletre vonatkozó t-próba eredménye szerint 1122 elem bevonásával 0,937 átlag és 0,838-as szignifikancia szint mellett az egyenlettel leírt állítás elfogadható. 


\begin{tabular}{|c|r|r|r|r|r|}
\hline \multicolumn{7}{|c|}{ Teszt érték =1 } \\
\hline $\mathrm{t}$ & szabad- \\
& ságfok & szignifikancia & Átlagos eltérés & $90 \%$ konfidencia intervallum \\
\cline { 5 - 6 } & 1121 & 0,838 & $-0,06288$ & \multicolumn{1}{c|}{ alsó érték } & felső érték \\
\hline$-0,205$ & 1120,5686 & 0,4429 \\
\hline
\end{tabular}

A $\frac{\Delta H F_{2}}{\Delta \text { Ép }+\Delta \text { Felhalm }} \approx 1$ 1egyenletre vonatkozó t-próba eredményei 2993 elem bevonásával 0,22 átlag mellett a következők, amely alapján azt elvetem:

\begin{tabular}{|c|r|r|r|r|r|}
\hline \multicolumn{7}{|c|}{ Teszt érték =1 } \\
\hline \multirow{2}{*}{$\mathrm{t}$} & $\begin{array}{r}\text { szabad- } \\
\text { ságfok }\end{array}$ & szignifikancia & Átlagos eltérés & \multicolumn{2}{|c|}{$90 \%$ konfidencia intervallum } \\
\cline { 5 - 6 } & & & \multicolumn{1}{c|}{ alsó érték } & felső érték \\
\hline$-4,383$ & 2992 & 0,000 & $-0,77926$ & $-1,0718$ & $-0,4867$ \\
\hline
\end{tabular}

Összességében az a következtetés vonható le, mind a hitelfelvétel szigorú, mind annak

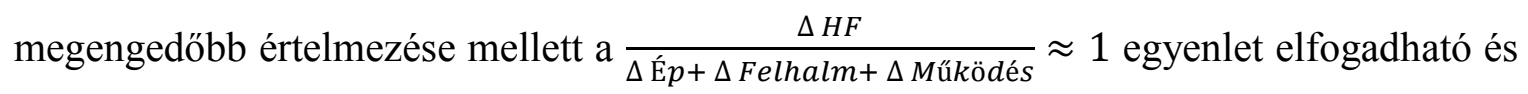
a $\frac{\Delta H F}{\Delta \text { É } p+\Delta \text { Felhalm }} \approx 1$ egyenlet elvetendö, tehát a hitelfelvétel során az aranyszabály a magyarországi helyi önkormányzatoknál nem érvényesült, ugyanis a hitelfelvétel részben működési kiadásokat finanszírozott. Fentiek alapján a hipotézist elfogadom.

\subsubsection{A H2 hipotézis tesztelése}

H2: Az európai uniós támogatások a helyi önkormányzatok beruházásaiban meghatározó szerepet töltenek be: a felújítási és beruházási kiadások a folyósított európai uniós támogatásokkal pozitív kapcsolatban állnak.

Az európai uniós támogatások folyósítása a meghosszabbított elszámolhatósági időszak miatt 2008 decemberéig releváns, ezért a hipotézist a teljes időszakra, együttesen tesztelem, nem pedig évenkénti bontásban. A hipotézis tesztelése során a felújítási és beruházási kiadások, valamint az önkormányzatok áfa elszámolási szabályaira tekintettel $^{133}$ a beruházásokhoz kapcsolódó áfa összegét, vagyis flow jellegű változókat vizsgálok az európai uniós támogatásokkal összefüggésben a 2004-2008 évek

${ }^{133}$ A helyi önkormányzatok gazdálkodásában az áfa jellemzően nem vonható le. 
tekintetében összevontan, a Magyar Államkincstár költségvetési jelentés űrlapjának alapadatai alapján. $^{134}$

A feltáró elemzés eredményeként körvonalazódik, hogy a lakosság száma meghatározó a változók tekintetében, ezért a hipotézis tesztelése során ezt figyelembe kell venni. Ezt megerősítik a változók közötti kapcsolatokat bemutató grafikus ábrák is, melyek a 11 . számú melléklet a1-a3 pontjaiban találhatók.

Első lépésként a változók közötti Pearson korrelációt vizsgálom országos szinten, illetve megyénként. (11. számú melléklet b1 és b2 pontok) Az eredmények alapján megállapíthatjuk, hogy a korreláció magas, a megyék többségében 0,9 körüli, két megye (Fejér és Pest) esetében alacsonyabb, de ott is 0,5 feletti. Mivel mindkét vizsgált változó népességgel való Pearson korrelációja magas, ezért kizárólag a kapcsolat pozitivitására vonatkozóan vonhatunk le következtetést. Ugyanakkor nem következik az az összefüggés, hogy a felújítási és beruházási kiadások, valamint az európai uniós támogatások között ok-okozati viszony van.

Második lépésként ezért parciális korrelációval megvizsgálom a két változó kapcsolatát a lakosság mint kontrollváltozó figyelembe vételével országos és megye szinten is. (11. számú melléklet c1 és c2 pontok) A kapott eredmények nem mutatják a hipotézis alátámasztásául szolgáló egyértelmü, erős pozitív kapcsolatot egymással. ${ }^{135}$

Az alkalmazott két megközelítés szélsőséges eredményei arra vezethetők vissza, hogy maga a megközelítés szélsőséges. Az első megközelítés kissé felületes, míg a második figyelmen kívül hagyja azt a szükségszerüséget, hogy a nagyobb települések több pénzből gazdálkodnak, nagyobb vagyonnal bírnak és magasabb európai uniós támogatásban részesülhetnek.

A fenti probléma feloldására olyan módszert kell alkalmazni, ami figyelembe veszi a lélekszámot, ugyanakkor nem mossa össze a lényegesen eltérő méretű településeket. A lélekszám alapján a településeket összhangban a KSH-nál is alkalmazott módszertannal rétegekre bontottam a következők szerint: 200 fő lélekszám alatti, 200-499, 500-4999, 5000-9999, 10 000-49 999, 50000 lélekszám feletti települések. Az egyes

\footnotetext{
134 Első lépésként tehát képeztem egy új változót, amely a következő: felújítási és beruházási kiadások $=$ felú $j_{\text {beruh }}=$ $\sum_{2004}^{2008}$ (felújítás + intézményi beruházási kiadások áfa nélkül + beruházások áfája) ${ }_{135}^{20}$ NUTS1, illetve NUTS 2 szerinti bontásban az eredmények hasonlóak, a hipotézist nem erősítik meg.
} 
rétegekben lévő elemszámok (lásd 11. számú melléklet d pont) figyelemmel arra is, hogy hány település részesült, illetve nem részesült európai uniós támogatásban a statisztikai stabilitás szempontjából megfelelőnek tünnek, azonban az elemek számossága nem elegendő ahhoz, hogy további területi bontást alkalmazzak a hipotézis tesztelése során.

A hipotézis teszteléséhez a következő megközelítést választottam: azt a feltételezést szeretném alátámasztani, hogy az európai uniós támogatásoknak hatása van a felújításokra és beruházásokra, amit olyan módon mutatok meg, hogy összehasonlítva vizsgálom az európai uniós támogatásban részesült, illetve nem részesült helyi önkormányzatokat.

A feltáró elemzés eredményeinek megfelelően a települések lélekszámával erős pozitív kapcsolatban van a helyi önkormányzatnak nyújtott európai uniós támogatás mértéke, így a nagyobb települések nagyobb arányban és magasabb értékü támogatást kapnak. A támogatásban részesült települések esetében azonban az egy fơre jutó támogatás a települések lélekszámának növekedésével csökken. ${ }^{136}$ Fentiekre, és egy-egy rétegen belül a települések méretében jelen lévő többszörös különbségre tekintettel a hipotézis tesztelése során tesztváltozónak már az egy före jutó felújítási és beruházási kiadásokat veszem számításba.

A hipotézis tesztelése során összehasonlítom, hogy a támogatásban részesült, illetve nem részesült helyi önkormányzatok esetében rétegenként milyen különbségek vannak az egy főre jutó felújítási és beruházási kiadásokban. Amennyiben szignifikáns különbség jelenik meg a támogatásban részesült, illetve nem részesült helyi önkormányzatok között a beruházási és felújítási kiadások tekintetében a támogatásban részesült települések javára, akkor az alátámasztja azt, hogy pozitív kapcsolat van a folyósított támogatás ténye és a beruházási és fejlesztési kiadások között. Ezt megerősíti az is, hogy az egy főre jutó támogatás mértéke a lélekszám növekedése mellett csökken, míg a teljes támogatás, valamint beruházási és felújítási kiadások nőnek. (11. számú melléklet e1 és e2 pont)

$\mathrm{Az}$ egy főre jutó beruházási és fejlesztési kiadások átlaga magasabb azoknak a településeknek az esetében, melyek részesültek európai uniós támogatásban. (11. számú

\footnotetext{
${ }^{136}$ Ez önmagában nem meglepő, hiszen a méretgazdaságosság bizonyos településméret felett érvényesül, ami hatással van a helyi önkormányzat bevételeinek és kiadásainak szerkezetére is.
} 
melléklet e1 pont) Az 50000 fö lélekszám feletti rétegben minden helyi önkormányzat részesült európai uniós támogatásban, ezért a vizsgálat ebben a rétegben nem releváns.

A támogatásban részesült, illetve nem részesült települések egy före jutó beruházási kiadásinak tesztelésére kétmintás t-próbát, illetve Welch próbát alkalmazok településméret szerint rétegenként külön-külön. A próbákkal azt tesztelem, hogy az egyes rétegeken belül az egy főre jutó beruházási és fejlesztési kiadások átlagai tekintetében tapasztalt különbség szignifikáns-e a támogatásban részesült, illetve nem részesült helyi önkormányzatok között.

A kapott eredmények (11. számú melléklet e3 pont) alapján megállapítható, hogy a 10000 - 49999 fő közötti lélekszámú rétegben nem fogadható el a vizsgált változó szórásának egyenlősége a támogatásban részesült, illetve nem részesült települések esetében, 0,017-es szignifikancia szint mellett (Levene teszt). Elvethetjük ugyanakkor, hogy az átlagban jelentkező különbség pusztán a véletlen műve, ugyanis a t-próbához tartozó szignifikancia szint 0,002 . Így a hipotézist a vizsgált rétegre elfogadom.

Az 5000 - 9999 fö, illetve az 1000 - 4999 fő közötti lélekszámú települések esetében (11. számú melléklet e3 pont) a szórások egyenlőségét a támogatásban részült és nem részesült települések esetében nem vetjük el, ugyanis a szignifikancia szint 0,281 , illetve 0,133. A t-próbához tartozó szignifikancia szint 0,1 , illetve 0,002 . Figyelembe véve, hogy a 90\%-os konfidencia intervallum egyik réteg esetében sem tartalmazza a 0 értéket, a hipotézist a két vizsgált rétegre elfogadom.

Az 500-999 fö közötti lélekszámú rétegben nem fogadható el a vizsgált változó szórásának egyenlősége a támogatásban részesült, illetve nem részesült települések esetében 0,05-ös szignifikancia szint mellett. Elvethetjük ugyanakkor, hogy az átlagban jelentkező különbség pusztán a véletlen müve, ugyanis a t-próbához tartozó szignifikancia szint 0,09 . Így a hipotézist a vizsgált rétegre elfogadom.

A 200 - 500 fö közötti lélekszámú települések esetében a szórások egyenlőségét a támogatásban részült és nem részesült települések esetében nem vetjük el, ugyanis a szignifikancia szint 0,878. A t-próbához tartozó szignifikancia szint 0,58 , továbbá a 90\%os konfidencia intervallum a 0 értéket tartalmazza, ami alapján a hipotézis a vizsgált rétegre nem lenne elfogadható. A települések vizsgálata során azonban (11. számú melléklet f pont) látható, hogy extrémen kilógó elemek szerepelnek a vizsgált rétegben, 
melynek kezelésére a felső rész 5\%-át, vagyis 36 elemet leválasztunk a sokaságból. A kétmintás t-próba eredményei (11. számú melléklet g pont) alapján arra a következtetésre juthatunk, hogy a szórások egyezőségét 0,00 szignifikancia szint mellett elvetjük, továbbá a t-próbához tartozó szignifikancia szint 0,006. Mivel a 95\%-os konfidencia intervallum nem tartalmazza a 0 értéket, a hipotézist a vizsgált rétegre is elfogadom.

A 200 fö alatti települések esetében figyelemmel kell lenni arra, hogy a települések jelentős része nem részesül európai uniós támogatásban. ${ }^{137}$ Biztosan állíthatjuk, hogy az egy főre jutó beruházási és felújítási kiadások magasabbak azoknál a településeknél, melyek európai uniós támogatásban részesültek. A t-próba eredménye alapján a szórások egyezőségének elfogadásától függetlenül a hipotézist a vizsgált rétegre nem fogadhatjuk el, ugyanis az eltérés nem tekinthető szignifikánsnak: a 90\%-os konfidencia intervallum tartalmazza a 0 értéket.

Összességében beszédes, hogy az egy före jutó beruházási és fejújítási kiadások minden vizsgált réteg esetében magasabbak a támogatásban részesült települések körében. A tpróba eredményei alapján arra jutottunk, hogy a 200 fö feletti települések esetében ez az eltérés szignifikáns. Mindezek alapján a hipotézist elfogadom.

\subsubsection{A H3 hipotézis tesztelései}

H3: A helyi önkormányzatok esetében az addicionalitás szabálya érvényesül: pozitív kapcsolat van a saját bevételek és a finanszírozás egyenlegének együttes összege, valamint a folyósított európai uniós támogatás között.

A hipotézist a teljes vizsgált időszakra (2004-2008), együttesen tesztelem, nem pedig évenkénti bontásban. A tesztelésnek ezt a módját megerősíti a támogatások folyósításának időszakán túl az is, hogy az addicionalitás biztosítása és a támogatás folyósítása nem feltétlenül esik egy naptári évbe, azok közötti időbeli eltolódások lehetnek: saját erő biztosítása nélkül a támogatás nem folyósítható, tehát a projektek sikeres lebonyolításához először a saját erőnek kell rendelkezésre állnia.

A hipotézis teszteléséhez a saját bevételek, a finanszírozás bevételei, valamint a finanszírozási kiadásai változók a vizsgált évekre vonatkozóan rendelkezésemre álltak,

${ }^{137} 39$ település részesült a vizsgált időszakban európai uniós támogatásban, míg 294 nem. 
ugyanis azokat a Magyar Államkincstár költségvetési jelentés ürlapja (80-as ürlap) külön nevesíti. Első lépésként a 2004-2008 közötti saját bevétel adatok összegzésével a hipotézis teszteléséhez szükséges „saját bevétel”változót előállítottam, majd a finanszírozási bevételek és finanszírozási kiadások különbségeként előállt a finanszírozás egyenlege változó, melynek 2004-2008 közötti adatait összegezve megkaptam a hipotézis teszteléséhez a „finanszírozás egyenlege” változót. ${ }^{138}$

Fontos megjegyezni, hogy a vizsgálandó változók (saját bevétel, illetve finanszírozás egyenlege) között bő egy nagyságrendnyi eltérés van, a saját bevétel bő tízszerese a finanszírozási egyenlegnek. Erre is figyelemmel a hipotézis tesztelése több lépésben történik.

Első lépésben változónként külön-külön áttekintem azok Pearson korrelációját a helyi önkormányzatoknak nyújtott európai uniós támogatás összegével egyrészt országos, másrészt területek szerinti bontásban, külön-külön vizsgálva valamennyi helyi önkormányzatot, illetve csak a támogatásban részesülteket. Ezt követően megvizsgálom a három változó összegével való korrelációját, majd a kapott eredményeket összehasonlítom és értékelem.

A vizsgált változók és a folyósított támogatás összegének grafikus megjelenítését a 12 . számú melléklet a-d pontjai tartalmazzák. A grafikonok áttekintésével láthatjuk, hogy van a településeknek olyan köre, amelyek viszonylag magas saját bevétel mellett sem részesültek európai uniós támogatásban. A támogatásban részesült települések esetében a diagramok alapján egyértelmű, közvetlen összefüggések nem korvonalazódnak, azonban tendencia-szerüen látható, hogy a saját bevétel növekedése és az elnyert támogatás között pozitív kapcsolatok vannak. A finanszírozás egyenlegének grafikus megjelenítéséből közvetlenül semmilyen összefüggés nem körvonalazódik. (12. számú melléklet e pont)

A helyi önkormányzatoknak juttatott európai uniós támogatások és a saját bevételek, valamint a finanszírozás egyenlege között korreláció-elemzést végeztem, melynek eredményei a 12. számú melléklet f pontjában találhatók. A korreláció értéke országos szinten valamennyi önkormányzat figyelembe vételével a saját bevétel tekintetében 0,757, a finanszírozás egyenlege tekintetében 0,684 , ami erős pozitív kapcsolatra utal.

\footnotetext{
${ }^{138}$ Finanszírozás egyenlege $=\sum_{2004}^{2008}$ (Finanszírozás bevétele - Finanszírozás kiadásai), a fogalmak értelmezéséhez lásd még a 7 . számú mellékletet.
} 
Hasonló eredményeket kapunk a támogatást elnyert települések vizsgálatával is, ahol a saját bevételekkel való korreláció 0,753 , míg a finanszírozás egyenlegével számított 0,683. A korreláció kis gyengülésének oka az, hogy nagyszámú támogatásban nem részesült települést zártunk ki az elemzésböl.

A korreláció pontosabb vizsgálata érdekében a NUTS1, NUTS2, NUTS3 és saját besorolás szerinti korreláció vizsgálatot is elvégeztem. A kapott eredmények egyértelműen alátámasztják, hogy erős a kapcsolat a vizsgált változók között: a saját bevétel esetében a megyék több, mint felénél a korreláció 0,9 feletti mind a támogatást elnyert helyi önkormányzatok, mind valamennyi helyi önkormányzat vizsgálatával. A finanszírozás egyenlege esetében az eredmények szintén jók: a korreláció a megyék közel felének az esetében 0,85 fölötti. Meglepő eredmények körvonalazódnak elsősorban Közép-Magyarország régióban, tehát Pest megyében, illetve Közép-Dunántúlon, Fejér megyében. Ezeknek a területeknek az esetében a vizsgált változók közötti korreláció 0,5 alatti értéket vesz fel, ami egyrészt jelentősen kilóg a többi terület közül, másrészt elméleti okot sem sikerült feltárni a mögöttes okok azonosítására. További kutatási irány lehet Fejér, illetve Pest megyék átfogó elemzése, mind a helyi önkormányzatok gazdálkodásának szerkezete, mind az elnyert európai uniós támogatások tekintetében.

A saját bevételek és a finanszírozás egyenlege külön-külön magasan korrelál a helyi önkormányzatoknak nyújtott európai uniós támogatás mértékével, ezért nagyon meglepő lenne, ha az együttes feltétel nem teljesülne, figyelemmel arra is, hogy a két változó között körülbelül bő egy nagyságrendnyi különbség van. A tesztelést szintén korreláció vizsgálattal végeztem el. A grafikus megjelenítést a 12. számú melléklet g-j pontjai, az eredményeket a 12. számú melléklet $\mathrm{k}$ pontjai tartalmazzák ugyanolyan területi bontásban, mint a változók külön-külön tesztelésekor.

A két változó együttes összegének és a helyi önkormányzatoknak nyújtott európai uniós támogatással való korrelációját vizsgálva megállapítható, hogy a korrelációban nincs szignifikáns elmozdulás, a korrelációs érték jellemzően továbbra is magas.

Mivel mind a saját bevétel, mind a finanszírozás egyenlege, mind a kettő együttesének esetében a korreláció a területi bontás figyelembe vétele mellett is erős, a $\mathbf{H 3}$ hipotézist elfogadom. 


\section{H3.1. Az európai uniós támogatások felhasználása eladósodáshoz vezet: a helyi önkormányzatok kötelezettségvállalásának növekedése, valamint a folyósított európai uniós támogatás egymással pozitív kapcsolatban áll.}

A hipotézis tesztelését azokra a helyi önkormányzatokra korlátozom, amelyek európai uniós támogatásban részesültek, hiszen az eladósodás és a támogatások közötti összefüggések ebben az alapsokaságban értelmezhetők.

A szakirodalmi levezetés alapján tendenciaszerü, hogy a helyi önkormányzatoknál 2004től eladósodás volt jellemzö, amely ugrásszerü növekedés mutatott különösen 2006 után. Az eladósodási folyamatok egyik alapvető mutatója mind a rövid lejáratú, mind a hosszú lejáratú kötelezettségek növekedése a mérlegben. A leíró statisztikai adatok alapján a vizsgált időszakban az eladósodás már jellemző, ezért a hipotézis teszteléséhez a mérlegadatokból kiindulva új változókat képeztem úgy, hogy a 2008. évi záróadatok és a 2004. évi nyitóadatok különbségét tekintettem változónak, hiszen ez a kötelezettségek tényleges változását mutatja. Amennyiben a változók értéke pozitív, akkor az eladósodási tendencia jellemző, amennyiben negatív, akkor a helyi önkormányzat adósságainak egy részét törleszti. A képzett új változókat a 13. számú melléklet a pontja tartalmazza.

Fontos megjegyezni, hogy a mérlegben szereplő összegző sorok közül a „hosszú lejáratú kötelezettségek összesen” és a „rövid lejáratú kötelezettségek összesen” sorokat nem vizsgálom külön változóként tekintettel arra, hogy azok összegző jellege miatt az eredmények torzulásához vezetne. A mérlegben ugyancsak összegző sor az egyéb rövid lejáratú kötelezettségek, azonban ezt vizsgálom külön változóként tekintettel arra, hogy az annak részét képező változók közül csak a hitelfelvételek törlesztésével kapcsolatos változókra koncentrálok. ${ }^{139}$

A hipotézis tesztelésének első lépéseként Pearson korreláció vizsgálatot végeztem a változók és a helyi önkormányzatnak folyósított európai uniós támogatások között, területi bontásban, melynek eredményeit a 13. számú melléklet b pontja tartalmazza ${ }^{140}$.

\footnotetext{
139 Nem képezi a vizsgált tárgyát a váltótartozások, a munkavállalókkal szembeni kötelezettségek, a költségvetéssel szembeni kötelezettségek, az iparüzési adó feltöltése miatt kötelezettségek, a helyi adó túlfizetés miatt kötelezettségek különbségeinek elemzése.

${ }^{140}$ A „múködési célú kötvénykibocsátás következö évben esedékes törlesztő részlete” változó korrelációja mind országos, mind NUTS1, NUTS2 és megye szintü bontásban is olyan alacsony értékeket mutat, hogy a faktoranalízis és klaszterelemzés során nem vizsgálom tovább.
} 
Az országos szinten számított korrelációs értékek jellemzően 0,5 alattiak, vagy a körüliek.

A NUTS1, valamint a saját területi besorolás szerint vizsgálva az elemzés KözépMagyarországtól eltekintve jellemzően magasabb korrelációs értékeket mutat, több változó esetében is, mint az országos szinten, azonban a hipotézis elfogadásához ez nem elegendő.

NUTS2 szinten vizsgálva a korrelációs értékeket megállapítható, hogy azok a régiók többségében lényegesen javulnak az országos szinthez képest, azonban a változékonyság alapján feltételezhető, hogy kisebb elemzései egységeket (megyéket) vizsgálva további eltérések körvonalazódnak. Figyelemreméltó, hogy több változó (fejlesztési célú kötvénykibocsátás, beruházási és fejlesztési hitelek) 4-5 régió esetében 0,5 feletti korrelációs értéket mutat.

Megyék szerint vizsgálva a korrelációt meglepő eredményekre jutunk. (13. számú melléklet $b$ pont) Az egyes megyék között nagy különbségek körvonalazódnak a korreláció tekintetében. Egyes változók (pl. szállító) -0,816 és 0,922 közötti értékekben korrelál a támogatással. Ebből azt a következtetést vonhatjuk le, hogy az egyes megyék teljesen eltérő jegyeket mutatnak az addicionalitás biztosítására vonatkozóan.

Megállapítható ugyanakkor, hogy majdnem minden megye esetében ${ }^{141}$ több vizsgált változó erősen, 0,7 feletti értékben korrelál a helyi önkormányzatoknak nyújtott európai uniós támogatással, amelynek alapján azt feltételezzük, hogy van kapcsolat az eladósodás és az európai uniós támogatások között. Az egyes megyékre jellemző korrelációs értékeket a faktor- és klaszteranalízis eredményével együttesen értékelem a könnyebb áttekinthetőség érdekében.

A korreláció vizsgálatot követően fökomponens elemzésre ${ }^{142}$ került sor olyan módon, hogy az 1-nél nagyobb sajátértékü faktorokat vontam be. ${ }^{143}$ A fökomponens elemzést követően varimax rotációt is alkalmaztam annak érdekében, hogy a magyarázott változók elkülönítése és értelmezése könnyebb legyen. A vizsgálatokat országos és megye szintü bontásban végeztem tekintettel arra, hogy a korreláció vizsgálat eredményei alapján a megyék közötti különbségek relevánsak, a NUTS1, illetve NUTS2 szintűek viszont nem.

\footnotetext{
${ }^{141}$ Pest és Nógrád megye kivételével

${ }^{142}$ A cél a dimenzió szám csökkentése olyan módon, hogy a kapott komponensek csökkenő sorrendben maximalizálják a magyarázott varianciát. (Sajtos és Mitev, 2007 253. o.) (Füstös et al. 2004)

${ }^{143}$ „Ha a sajátérték kisebb, mint 1, akkor elhanyagoljuk (mivel a faktor kevesebbet magyaráz, mint egy megfigyelt változó).” (Füstös et al. 2004, 256. o.)
} 
Az eredményeket a 13. számú melléklet c pontja tartalmazza. A vizsgálatok eredményét a korreláció vizsgálat és a klaszterelemzés eredményeivel együttesen értékelem.

A hipotézis tesztelésének utolsó lépéseként hierarchikus klaszterelemzést végeztem átlagos lánc módszerrel ${ }^{144}, \mathrm{Z}$ érték standardizálással. Az eredményeket országos szinten és megyénkénti bontásban a 13. számú melléklet d pontja tartalmazza. A klaszterelemzés célja elsődlegesen az volt, hogy azonosítható legyen az európai uniós támogatások viszonya a többi vizsgált változóhoz. Ugyancsak vizsgálom, hogy a korreláció vizsgálat és a faktoranalízis eredményei összhangban vannak-e a klaszterelemzés eredményével tekintettel arra, hogy a faktoranalízisnél és a klaszterelemzésnél nincs kitüntetett változó, míg a korreláció vizsgálatnál kitüntettük az európai uniós támogatásokat.

A fenti három vizsgálati módszer eredményeinek összevetését megyénként elkülönítve végeztem el figyelemmel azonban az egyes megyék közötti hasonlóságokra és különbségekre.

\section{A korreláció, a fökomponens elemzés és a klaszterelemzés együttes értelmezése}

\section{Országos szint}

Országos szinten a vizsgált változók korrelációja a helyi önkormányzatok részére juttatott európai uniós támogatásokkal meglehetősen alacsony, legmagasabb a beruházási és fejlesztési hitelek $(0,54)$ és a fejlesztési célú kötvénykibocsátás $(0,53)$. A fökomponens elemzés eredménye ez utóbbit megerősítette azzal, hogy a fejlesztési célú kötvénykibocsátás és a helyi önkormányzatok részére juttatott európai uniós támogatások változókhoz tartozó legnagyobb értékek közös faktorban szerepelnek. A klaszteranalízis eredményeként körvonalazódik továbbá az, hogy a helyi önkormányzatok részére juttatott európai uniós támogatások változóhoz a beruházási és fejlesztési hitelek hasonlít leginkább. Fentiekből a hipotézist alátámasztó következtetés még nem vonhatunk le, ugyanis a korreláció elemzés eredménye alapján az egyes megyék nagyon különbözőek.

\footnotetext{
144 „Átlagos láncmódszernél a két klaszter távolságát az összes megfigyelési egység páronkénti távolságának átlaga definiálja, ahol a pár egyik tagja az egyik klaszterbe, másik tagja pedig a másik klaszterbe tartozik." (Sajtos és Mitev 2007, 253., 295. o.)
} 


\section{Baranya megye}

A fejlesztési célú kötvény-kibocsátás, müködési célú kötvény-kibocsátás, beruházási és fejlesztési hitelek, szállító, egyéb rövid lejáratú kötelezettségek, valamint a beruházási és fejlesztési hitelek törlesztése változók és a helyi önkormányzatok részére juttatott európai uniós támogatások között magas, jellemzően 0,9 feletti korreláció van, továbbá a faktoranalízis ezeket első faktorként közös faktorba sorolja. A klaszterelemzés eredményei a fentieket megerősítik, a változók közös klaszterben szerepelnek. Baranya megyében tehát a korreláció vizsgálat, a faktoranalízis és a klaszteranalízis eredményei egyaránt azt mutatják, hogy a megyében eladósodás jellemző és ez egyértelmüen összefüggésben van a helyi önkormányzatok részére juttatott európai uniós támogatásokkal.

\section{Bács-Kiskun megye}

A háromféle elemzés szinte azonos eredményeket hoz. A fejlesztési célú kötvénykibocsátás, a beruházási és fejlesztési hitelek, a müködési célú hosszú lejáratú hitelek, az egyéb rövid lejáratú kötelezettségek, valamint a müködési célú hosszú lejáratú hitelek törlesztése és a helyi önkormányzatok részére juttatott európai uniós támogatások között magas, jellemzően 0,5 és 0,9 közötti korreláció van, továbbá a faktoranalízis mindegyiket a közös első faktorba sorolja. A dendogram alapján a fenti változók önálló ágat alkotnak.

\section{Békés megye}

A fejlesztési célú kötvény-kibocsátás, a beruházási és fejlesztési hitelek, az egyéb rövid lejáratú kötelezettségek, valamint a beruházási és fejlesztési hitelek törlesztése 0,5 feletti értékben korrelál a helyi önkormányzatoknak nyújtott európai uniós támogatással. A faktoranalízis eredménye és a dendogram ezt megerősíti a következő módon: első faktorként a helyi önkormányzatoknak nyújtott európai uniós támogatás és a fejlesztési célú kötvény-kibocsátás, valamint a beruházási és fejlesztési hitelek szerepelnek, és külön csoportot alkotnak az egyéb rövid lejáratú kötelezettségek, a beruházási és fejlesztési hitelek törlesztése és az egyéb hosszú lejáratú kötelezettségek. ${ }^{145}$ Fentiekből azt a következtetést vonhatjuk le, hogy a fejlesztési célú kötvény-kibocsátás, valamint a

${ }^{145145}$ Meglepő, hogy a faktoranalízisben és a dendogramban közel korrelálatlan változó is megjelenik. 
beruházási és fejlesztési hitelek szerepe különösen meghatározó az európai uniós támogatások szempontjából.

\section{Borsod-Abaúj-Zemplén megye}

A fejlesztési célú kötvény-kibocsátás, a beruházási és fejlesztési hitelek, valamint a rövid lejáratú hitelek, 0,88 feletti értékben korrelál a helyi önkormányzatoknak nyújtott európai uniós támogatással. A beruházási és fejlesztési hitelek törlesztése - 0,61 értékben korrelál az európai uniós támogatásokkal, valamint a faktoranalízisben ugyancsak az első faktor határozza meg, azonban a fenti változókkal ellentétesen. Vélhetően ennek a hátterében az áll, hogy a hitel törlesztését megkezdték, ami a szabad pénzeszközök lekötését eredményezte. A klaszteranalízis eredménye alapján az európai uniós támogatásokkal a fejlesztési célú kötvény-kibocsátás, a beruházási és fejlesztési hitelek, valamint a rövid lejáratú hitelek tartoznak egy csoportba, amelyből arra következtethetünk, hogy ezek szerepe meghatározó.

\section{Csongrád megye}

Több változó esetében jelenik meg erős korreláció az európai uniós támogatásokkal. Míg a beruházási és fejlesztési hitelek, az egyéb hosszú lejáratú kötelezettségek, a rövid lejáratú hitelek, az egyéb rövid lejáratú kötelezettségek, valamint a beruházási és fejlesztési hitelek és az egyéb hosszú lejáratú kötelezettségek törlesztése pozitívan korrelál az európai uniós támogatásokkal, addig $-0,73$ a korreláció a hosszú lejáratú kölcsönökkel. A faktoranalízis eredménye a változók közötti összefüggéseket megerősíti azzal, hogy azok mindegyikét az első közös faktorba sorolja. A dendogram eredménye alapján az európai uniós támogatások és az egyéb rövid lejáratú kötelezettségek, az egyéb hosszú lejáratú kötelezettségek törlesztése, a beruházási és fejlesztési hitelek és azok törlesztése, valamint a rövid lejáratú hitelek azonos ágon szerepelnek.

\section{Fejér megye}

Az európai uniós támogatásokkal a müködési célú hosszú lejáratú hitelek, valamint annak törlesztése erősen, 0,86 értékben korrelál. A többi változó esetében erős pozitív korreláció nem áll fenn. A faktoranalízis eredménye az eddigiektől eltérően csak második faktorként 
kezeli, azonban egyben a három változót. ${ }^{146}$ Összességében a faktoranalízis és a dendogram eredménye egyaránt megerősíti, hogy a fenti három változó együtt mozog.

\section{Györ-Moson-Sopron megye}

Az európai uniós támogatásokkal a beruházási és fejlesztési hitelek, valamint annak törlesztése erősen, 0,97, illetve 0,96 értékben korrelál. A többi változó esetében erős pozitív korreláció nem áll fenn. A faktoranalízis eredménye csak második faktorként kezeli a helyi önkormányzatoknak nyújtott európai uniós támogatást, azonban egyben a beruházási és fejlesztési hitelekkel. Ugyanennek a főfaktornak a része az egyéb rövid lejáratú kötelezettség, negatív előjellel, ami a korreláció-elemzésnél is megjelenik -0,76 eredménnyel. A dendogram eredménye megnyugtató azonban, ugyanis az európai uniós támogatásokat a beruházási és fejlesztési hitelekkel, valamint annak törlesztésével egy ágba sorolja. ${ }^{147}$

\section{Hajdó-Bihar megye}

Az európai uniós támogatásokkal erősen ( 0,9 felett) korrelál a beruházási és fejlesztési hitelek, valamint annak törlesztése, a fejlesztési célú kötvénykibocsátás törlesztése, és az egyéb rövid lejáratú kötelezettségek, valamint 0,7 feletti értékkel a szállító. Erős negatív korreláció jelenik meg ugyanakkor a hosszú lejáratú kölcsönöknél ${ }^{148}$. Ezeket az eredményeket a főkomponens elemzés eredménye is megerősíti azzal, hogy valamennyi változót az első főfaktorba sorolja magas abszolút értékkel. A dendogram eredménye alapján a változók a hosszú lejáratú kölcsön kivételével azonos ágon szerepelnek az európai uniós támogatással.

\section{Heves megye}

Heves megye rendkívül nagy hasonlóságot mutat Hajdú-Bihar megyével az érintett változók tekintetében. Egyedüli releváns különbségként az jelentkezik, hogy míg HajdúBihar megyében a szállítói finanszírozás tipikus, addig Heves megyében a rövid lejáratú

\footnotetext{
${ }^{146}$ Az első főfaktorban pozitív előjellel a beruházási és fejlesztési hitelek és annak törlesztése, valamint az egyéb rövid lejáratú kötelezettségek jelennek meg, míg negatív előjellel az egyéb hosszú lejáratú kötelezettségek, valamint a fejlesztési célú kötvénykibocsátás. A kutatás elméleti részében levezetettek alapján valószínüsíthető, hogy a hitelek kiváltása történt meg.

${ }^{147}$ Az egyéb rövid lejáratú kötelezettség annak negatív elöjele miatt nem ezen az ágon jelenik meg a dendogramban.

${ }^{148}$ A kutatás elméleti részében megfogalmazottak alapján vélelmezhető, hogy a hosszú lejáratú kölcsönök kiváltása történt meg beruházási és fejlesztési hitellel, amelyet megerősít -0,986 értékü korreláció is.
} 
hitelek a jellemzőek. A fökomponens elemzésből a dendogramból ugyanazok a következtetések vonhatók le, mint Hajdú-Bihar megyében, vagyis a változók azonos ágon szerepelnek az európai uniós támogatással.

\section{Komárom-Esztergom megye}

A korrelációs értékek alacsonyabbak ( 0,8 körüliek), mint az előzőekben vizsgált megyék esetében, kiemelendő ugyanakkor a beruházási és fejlesztési hitelek, valamint az egyéb rövid lejáratú kötelezettségek. A faktoranalízis eredménye az európai uniós támogatások szempontjából nem mutat egyértelmű képet, mivel a változó megoszlik az első két faktor között. Figyelemmel azonban arra, hogy a dendogram eredményei a második faktorban szereplő változókkal összhangban vannak, továbbá azonos ágon szerepelnek az európai uniós támogatással, a hipotézist nem vethetem el a megye esetében.

\section{Nógrád megye}

A korrelációs jóval értékek alacsonyabbak, mint az előzőekben vizsgált megyék esetében. Kiemelendő a rövid lejáratú hitelek szerepe, melynek európai uniós támogatással való korrelációja 0,66. A faktoranalízis eredménye eltérően alakul a korábbi tapasztalatokhoz képest: az európai uniós támogatások csak a negyedik faktorban jelennek meg, ott viszont magas $(0,88)$ értékkel, így az ebből levonható következtetések korlátozottan értelmezhetők. Ugyancsak ebben a faktorban szerepelnek a rövid lejáratú hitelek 0,77-es súllyal. A dendogram eredménye alapján az európai uniós támogatások és a rövid lejáratú hitelek azonos ágon szerepelnek. A fenti eredmények alapján a hipotézist nem vethetem el, azonban egyértelmüen nem erősíthetem meg.

\section{Pest megye}

A vizsgált változók és az európai uniós támogatás közötti korrelációs értékek nagyon gyengék. A legmagasabb korrelációs értéket a fejlesztési célú kötvénykibocsátás $(0,39)$ és a működési célú hosszú lejárató hitelek $(0,2)$ jelentik. A faktoranalízis eredménye szerint az európai uniós támogatások az ötödik faktorban vannak 0,76 értékkel, ezért az ebből levont következtetések meglehetősen bizonytalanok. Ugyancsak ebben a faktorban szerepel a müködési célú hosszú lejáratú hitel, 0,71-es értekkel. A dendogram eredménye a fentiek figyelembe vételével azt mutatja, hogy a helyi önkormányzatoknak nyújtott 
európai uniós támogatás önállóan szerepel, nem kapcsolódik eléggé szorosan egy vizsgált változóhoz sem. Mindennek következtében a hipotézist Pest megyére elvetem.

\section{Somogy megye}

$\mathrm{Az}$ európai uniós támogatásokkal erősen $(0,7$ felett $)$ korrelál a fejlesztési célú kötvénykibocsátás, a müködési célú kötvénykibocsátás, a beruházási és fejlesztési hitelek, az egyéb hosszú lejáratú kötelezettségek és annak törlesztése, valamint az egyéb rövid lejáratú kötelezettségek. Ezeket az eredményeket a főkomponens elemzés eredménye is megerősíti azzal, hogy valamennyi változót az első főfaktorba sorolja magas $(0,8$ feletti) értékkel. A dendogram eredménye alapján a változók mindegyike azonos ágon szerepelnek az európai uniós támogatással.

\section{Szabolcs-Szatmár-Bereg megye}

Az európai uniós támogatásokkal erősen $(0,85$ felett $)$ korrelál a fejlesztési célú kötvénykibocsátás, a rövid lejáratú hitelek, a szállító és az egyéb hosszú lejáratú kötelezettségek törlesztése. Ezeket az eredményeket a főkomponens elemzés is megerősíti azzal, hogy valamennyi változót az első főfaktorba sorolja magas ( 0,93 feletti) értékkel. A dendogram eredménye alapján a változók mindegyike azonos ágon szerepel az európai uniós támogatással.

\section{Jász-Nagykun-Szolnok megye}

$\mathrm{Az}$ európai uniós támogatásokkal erősen $(0,7$ felett $)$ korrelál a fejlesztési célú kötvénykibocsátás és annak törlesztése, valamint a beruházási és fejlesztési hitelek. A szállító és az egyéb rövid lejáratú kötelezettségek 0,6 felett korrelálnak az európai uniós támogatással. Erős negatív korreláció mutatkozik a hosszú lejáratú kölcsönök $(-0,91)$, valamint annak törlesztése tekintetében $(-0,83){ }^{149}$. Ezeket az eredményeket a főkomponens elemzés eredménye is megerősíti azzal, hogy valamennyi változót az első főfaktorba sorolja jellemzően magas ${ }^{150}$ abszolút értékkel. A dendogram eredménye alapján a változók a hosszú lejáratú kölcsönök és annak törlesztése kivételével azonos ágon szerepelnek az európai uniós támogatással.

\footnotetext{
${ }^{149}$ A kutatás elméleti részében megfogalmazottak alapján vélelmezhető, hogy a hosszú lejáratú kölcsönök kiváltása történt meg vagy fejlesztési célú kötvénykibocsátással, vagy beruházási és fejlesztési hitellel.

${ }^{150}$ A szállító és a beruházási és fejlesztési hitelek törlesztése esetében 0,65 és 0,54 az értékek.
} 


\section{Tolna megye}

A vizsgált változók esetében a korrelációs értékek gyengébb eredményeket mutatnak, mint a korábban vizsgált megyék többségében. A müködési célú kötvénykibocsátás 0,71 értékben korrelál az európai uniós támogatással, míg ugyanez az érték a fejlesztési célú kötvénykibocsátásnál 0,57 , a rövid lejáratú hiteleknél pedig $-0,68 .{ }^{151}$ A faktoranalízis eredménye a fentieket megerősíti. A klaszteranalízis eredménye alapján az európai uniós támogatások a müködési célú kötvénykibocsátással szerepel közös ágon.

\section{Vas megye}

Magas korrelációs érték tapasztalható az európai uniós támogatások és beruházási és fejlesztési hitelek és annak törlesztése (0,91 és 0,92$)$, valamint az egyéb rövid lejáratú kötelezettségek $(0,87)$ között. Negatív előjellel erős korrelációt mutat a szállító $(-0,82)^{152}$. A faktorelemzés eredménye a fentieket megerősíti azzal, hogy valamennyi változót az első főfaktorba sorolja magas abszolút értékkel. A dendogram eredménye alapján a beruházási és fejlesztési hitelek és annak törlesztése, valamint az egyéb rövid lejáratú kötelezettségek közös ágat alkotnak az európai uniós támogatással.

\section{Veszprém megye}

A beruházási és fejlesztési hitelek, valamint a rövid lejáratú hitelek magas korrelációt $(0,77$ és 0,78$)$ mutatnak a helyi önkormányzatnak nyújtott európai uniós támogatással. A faktoranalízis eredménye szerint ezek a változók az első főfaktorba sorolhatók, magas (0,9 körüli) értékkel. A dendogram eredménye alapján közös ágon szerepel az európai uniós támogatás, valamint a beruházási és fejlesztési hitelek és a rövid lejáratú hitelek.

\section{Zala megye}

Az európai uniós támogatások több változóval is erős korrelációt mutatnak. Míg a beruházási és fejlesztési hitelek, valamint annak törlesztése esetében a korreláció magas (0,93 és 0,85$)$, addig szintén indokolt figyelembe venni a rövid lejáratú kötelezettségeket $(0,76)$. A müködési célú hosszú lejáratú hitelek és annak törlesztése, valamint a hosszú lejáratú kölcsön törlesztése és az egyéb hosszú lejáratú kötelezettségek törlesztése is

\footnotetext{
${ }^{151}$ A rövid lejáratú hitelek és a müködési célú kötvények között erős negatív korreláció van, melynek értéke $-0,946$

${ }^{152}$ A szállító erős negatív korrelációt mutat a beruházási és fejlesztési hitelekkel, azonban a kutatás eredményeként ennek okát nem sikerült feltárni.
} 
magas korrelációt $(0,66)$ mutat. A faktorelemzés a fenti változókat két főfaktorba sorolja, amely eredmény a dendogramon is egyértelmüen megjelenik. Vitathatatlan, hogy ezeknek jelentős hatása van az európai uniós támogatásokra, azonban a vizsgálatok eredménye alapján nem körvonalazódik az, hogy milyen módon.

\section{Következtetés}

Figyelemmel arra, hogy a hipotézist 16 megye esetében egyértelmüen elfogadható, és 2 megye (Komárom-Esztergom, Nógrád) esetében nem vethető el, a hipotézist a konvergencia régióra szúkítve elfogadom, míg Pest megyére, vagyis a középmagyarországi régióra elvetem.

\subsubsection{A H4 hipotézis tesztelése}

\section{H4: A helyi önkormányzatok nagysága, területi elhelyezkedése, bevételi szerkezete együttesen olyan tényezők, amelyek meghatározzák az európai uniós támogatások igénybe vételét.}

A hipotézis vizsgálata során külön-külön értelmezem a nagyságot, a területi elhelyezkedést és a bevételi szerkezetet, mint tényezőket.

A hipotézis teszteléséhez a 2004-2008-as időszak egészét vettem figyelembe, ugyanis az önkormányzatoknak folyósított európai uniós támogatások évenként nem egyenletesek. Az önkormányzatok költségvetési jelentésében szereplő adatok (80-as ürlap) alapján új változókat képeztem, amelyek az éves adatok összegei. Mivel a hipotézis a bevételi szerkezetre irányul, a költségvetési adatok közül kizárólag a bevételi szerkezetre vonatkozókat teszteltem.

Az adatbázis feltáráshoz első lépésben Pearson korreláció vizsgálatot alkalmaztam az önkormányzatoknak juttatott támogatás és a bevételek között. A 0,5 feletti korrelációt mutató változókon hierarchikus klaszterelemzést végeztem, melynek eredményét a hipotézis tényleges teszteléséhez alkalmazott lineáris regresszióhoz alkalmazott változók szakmai alapon történő kiválasztásánál vettem figyelembe. 
A változók kiválasztásánál figyelemmel voltam arra a szempontra is, hogy az önkormányzat a támogatáshoz szükséges önerőt vélhetően milyen forrásból biztosítja. Ezek köre összhangban a kutatás elméleti részében kifejtettekkel a következő lehet:

1. készpénz állomány

2. központi költségvetéstől származó támogatások

3. átengedett és megosztott bevételek

4. már meglévő vagyoni elemek értékesítés

5. saját bevételek, adóztatás

6. hitelek felvétele

A bevételi szerkezetet leíró, főbb változók köre, valamint azok megnevezése a fentiek figyelembe vételével a következö:

1. pénzkészlet a tárgyidőszak végén (pénzkészlet)

2. önkormányzat költségvetési támogatása (költségvetési_tám)

3. személyi jövedelemadó bevételek (SzJA)

4. tárgyi eszközök, immateriális javak értékesítése (teért)

5. saját bevételek összesen; helyi adók; iparüzési adó; helyi adókkal kapcsolatosan kiszabott bírságok, kamatbevétel (sajátbev; helyiadoossz; IPAössz; adóbírság, kamatbevétel)

6. rövid lejáratú és likvid hitelek felvétele, forgatási célú értékpapírok kibocsátása és értékesítése; hosszú lejáratú hitelek felvétele, hosszú lejáratú értékpapírok értékesítése és kibocsátása, befektetési célú értékpapírok kibocsátása (rövidhitel; hosszúhitel)

A kiválasztott változók között részhalmaz-egészhalmazt jelentő változók is vannak, ilyen például a saját bevételek összesen, azon belül a helyi adók, azon belül a helyi iparüzési adó. Felmerül a kérdés, hogy ezek a változók hogyan értelmezhetők a lineáris regresszió esetében, illetve a modell eredményeit rontják-e.

A kérdés elsősorban akkor releváns, ha a becslésnél többi ilyen változó is a modell része, vagyis ezek közül legalább kettő bekerül a modellbe. Ebben az esetben az egészhalmaz a 
részhalmaz komplementereként értelmezendő, amelyet a lineáris regressziós modell a végső súlyok kialakításánál figyelembe vesz. ${ }^{153}$

\section{Nagyság értelmezése}

A bevételi szerkezetet leíró változók kiválasztását követően Pearson korreláció vizsgálattal arra a következtetésre jutottam, hogy az állandó népesség és a bevételi szerkezet közötti korreláció mind országos, mind regionális, mind megyei, mind az általam korábban képzett területi bontásban jellemzően magas. A korrelációra vonatkozó számításokat a 14. számú melléklet a) és b) pontjai tartalmazzák.

Fentiekből azt a következtetést lehet levonni, hogy a lakosságszám erősen determinálja a helyi önkormányzatok bevételi szerkezét leíró változókat, ennek következtében indokolatlan a lakosság számát a becslésnél felhasználni, mivel redundáns. Elfogadható viszont az az állítás, hogy amennyiben az empirikus tesztelés a bevételi szerkezetre vonatkozóan helytálló eredményeket ad, akkor a nagyságra vonatkozókat is elfogadhatom.

\section{Bevételi szerkezet, valamint elhelyezkedés értelmezése és tesztelése}

A fenti változókkal a megfigyelési egységek egészére lineáris regressziót számítok többféle módon, ahol mindegyik esetben függő változó a helyi önkormányzatoknak juttatott európai uniós támogatás összege. Az alkalmazott módszer stepwise ${ }^{154}$ lineáris regresszió. Az elemzés során figyelemmel követem azokat a változókat, amelyeknél a standardizált együtthatók a legmagasabbak, ezáltal legerősebben determinálják a támogatás értékét.

A terület szerinti rétegezésnél többféle lehetőség merült fel. A tesztelés NUTS1 és NUTS2 szerinti bontásban, valamint a feltáró elemzést követő saját kategorizálás alapján értelmezhető, azonban a megye, azaz a NUTS3 szintű vizsgálatot nem végeztem el annak korlátai miatt: 3151 elemü sokaság esetében a megye és támogatásban való részesülés

\footnotetext{
153 például: ha a modellben a saját bevétel 2 súllyal és azon belül a helyi adók 1,5 súllyal szerepel, akkor az azt jelenti, hogy a helyi adó valójában 3,5 súllyal szerepel, míg a helyi adón kívüli saját bevételek vagyis a komplementer halmaz 2 súllyal

154 A kutatás során a következőket alkalmaztam: a változót a módszer a modellbe belépteti, ha a szignifikancia szintje 0,05-nél kisebb, és a modellből eltávolítja, ha a szignifikancia szintje 0,1-nél nagyobb.
} 
szerinti bontásával az egyes rétegek elemszáma olyan alacsony lenne, amely nem biztosítaná a statisztikai stabilitást. ${ }^{155}$

\section{Valamennyi települési önkormányzat vizsgálata, területi elhelyezkedés figyelembe vétele nélkül}

A modell hat változó (költségvetési_tám, szja, teért, helyiadoossz, hosszúhitel, adóbírság) bevonásával közelítette $\left(\mathrm{R}^{2}=0,653\right)$ az önkormányzatoknak juttatott támogatás összegét, amelyek közül a költségvetési támogatás a legmeghatározóbb. Ez az eredmény a kapcsolat létezését alátámasztja ugyan, azonban a hipotézis igazolásához nem elegendö. Figyelemmel a feltáró elemzés eredményeire vélelmezhető, hogy a területi elhelyezkedés szerinti rétegezéssel az eredmények javulnak, vagy további összefüggések körvonalazódnak. (14. számú melléklet cI. pont)

\section{Valamennyi települési önkormányzat vizsgálata, a területi elhelyezkedés figyelembe} vételével

\section{II. a) Statisztikai nagyrégiók (NUTS1) szerinti bontásban}

A tesztelés eredményeként az kapjuk, hogy 2 régió esetében az országos szintü becslésnél pontosabb (Közép-Magyar $\mathrm{R}^{2}=0,7$; Alföld és Észak $\mathrm{R}^{2}=0,761$ ) becslést kapunk, míg a Dunántúl esetében $\mathrm{R}^{2}=0,613$, ami gyengébb eredmény, mint az országos esetében. Ez vélhetően a települések heterogenitására vezethető vissza. Megállapítható ugyanakkor, hogy a terület szerinti bontás vizsgálata releváns tényező különös tekintettel arra, hogy az ország szintü becslésünk során bevont változók közül csak a hosszú lejáratú hitelfelvétel jelenik meg mindhárom régióban, azonban eltérő súlyszámmal. A Közép-Magyarország régió esetében a meghatározó az adóbírság mértéke, ami kissé meglepő eredmény a kutatás elméleti eredményeihez képest. Dunántúl, illetve Alföld és Észak régiókban a saját bevételek, illetve a költségvetési támogatás meghatározóak. (14. számú melléklet cIIa. pont)

\footnotetext{
155 Ehhez lásd még 10. számú melléklet o) pontja „A helyi önkormányzatoknak juttatott európai uniós támogatás NUTS3 megye szerinti bontásban” címü táblázatát.
} 


\section{II. b) Statisztikai régiók (NUTS2) szerinti bontásban}

A modell eredményei különbözőnek tekinthetők régiónként. A becslés pontossága egy régiótól eltekintve (Közép-Dunántúl, ahol $\left.\mathrm{R}^{2}=0,473\right)$ javuló tendenciát mutat. $\left(0,681<\mathrm{R}^{2}\right.$ $<0,929)$ A becslés pontossága és a felhasznált változók száma, valamint köre jelentős változékonyságot mutat. A modell régiónként eltérő változókat vont be, azonban visszatérő változónak tekinthető ${ }^{156}$ a tárgyi eszközök értékesítéséből származó bevétel, valamint a saját bevétel/helyi adók/iparüzési adó változók valamelyike. A régiók közötti különbségek megjelennek, amiből arra következtetünk, hogy a területi elhelyezkedésnek szerepe van a támogatás értékének eloszlásában. (14. számú melléklet c)II.b pont)

\section{II. c) Saját besorolás szerinti bontásban}

Ezt az esetet a NUTS1 szintű eredményekkel célszerü összehasonlítani, ugyanis 3 hasonló kategóriát tartalmaznak. A kapott eredmények mindenhol pontosabbak, mint a NUTS1 szintű becslés eredményei.

A saját besorolás szerinti „közép” kategória a feltárás alapján átmenetet képez a viszonylag élesen elkülönülő „nyugat”-hoz, illetve „,kelet”-hez sorolt településekhez viszonyítva.

Az egymásnak megfeleltethető kategóriákban „Nyugat” vs „Dunántúl”, illetve „Kelet” vs „Alföld és Észak” az $\mathrm{R}^{2}$ eredmények javulnak. (Nyugat $\mathrm{R}^{2}=0,895$; Közép $\mathrm{R}^{2}=0,707$; Kelet $\mathrm{R}^{2}=0,781$ ) (14. számú melléklet c)II. c pont)

\section{Csak a támogatást elnyert települési önkormányzatok vizsgálata területi elhelyezkedés figyelembe vétele nélkül}

A modell eredménye nagyon hasonló az első esethez. Öt változó (szja, teért, költségvetési_tám, IPAössz, adóbírság) bevonásával közelítette $\left(\mathrm{R}^{2}=0,652\right)$ az önkormányzatoknak juttatott támogatás összegét. A magyarázó változók körében figyelemre méltó, hogy a tárgyi eszköz értékesítés szignifikáns változónak megjelenik, a költségvetési támogatás, valamint a személyi jövedelemadóból származó bevétel továbbra is meghatározó. Ez az eredmény a kapcsolat létezését alátámasztja ugyan, azonban a hipotézis igazolásához nem elegendő. Figyelemmel a feltáró elemzés eredményeire

\footnotetext{
${ }^{156}$ Közép-Magyarországon kívül valamennyi régióban megjelenik
} 
vélelmezhető, hogy a terület szerinti rétegezéssel az eredmények javulnak, vagy további összefüggések körvonalazódnak. (14. számú melléklet c)III. pont)

Figyelemre méltó ugyanakkor, hogy a modell eredményei lényegesen nem változtak attól, hogy csak a támogatást elnyert önkormányzatokat vonom az elemzés körébe. Az elemszám csökkenésével elvben szükségszerü lenne a javulás, azonban pont azokat az elemeket (támogatást nem nyert településeket) ${ }^{157}$ zárom ki, amelyek feltehetően jól becsülhetők. Ez összességében azt támasztja alá, hogy a becslésre használt változók megfelelőek.

\section{Csak a támogatást elnyert települési önkormányzatok vizsgálata a területi elhelyezkedés figyelembe vételével}

\section{IV. a) Statisztikai nagyrégiók (NUTS1) szerinti bontásban}

A modell eredményei hasonlóan alakulnak, mint a teljes adatbázisra vonatkozóak. Két régió esetében az országos szintű becslésnél pontosabb (Közép-Magyar $\mathrm{R}^{2}=0,747$; Alföld és Észak $\mathrm{R}^{2}=0,757$ ) becslést kapunk. A Dunántúl esetében $\mathrm{R}^{2}=0,621$, ami enyhén javuló eredmény.

A bevont változók esetében alig van változás. Továbbra is Közép-Magyarországnál az adóbírság, míg Alföld és Észak régióban a költségvetési támogatás a meghatározó. Dunántúl esetében a tárgyi eszköz értékesítés válik meghatározóvá. (14. számú melléklet c)IV.a pont)

\section{IV. b) Statisztikai régiók (NUTS2) szerinti bontásban}

A modell a II. b) esethez képest pontosabb képet mutat. Az $\mathrm{R}^{2}$ értékekben két régió kivételével jelentős javulás tapasztalható, és a bevont változók köre jóval szűkebb, ami a becslés átláthatóságát javítja, értelmezhetőségét segíti. Visszatérő változónak tekinthető a saját bevétel/helyi adók/iparüzési adó változók valamelyike, és megjelenik a hosszú lejáratú hitelfelvétel is. A NUTS1 szintű bontáshoz képest kevesebb változóval, és valamennyi modell közül a legjobb eredménnyel becsül, ami azt mutatja, hogy a területi bontás szerinti értelmezés indokolt. (14. számú melléklet c)IV.b pont)

157 ehhez lásd még a H5 hipotézis tesztelésének eredményeit is 


\section{$I V$. c) Saját besorolás szerinti bontásban}

Az R Rértékek javulása körvonalazódik mind a IV. a), mind a II. c) esethez képest. A változók közül a saját bevételek és a költségvetési támogatások meghatározó szerepet mutatnak. Az egymásnak megfeleltethető kategóriákban jelentős hasonlóság mutatkozik, ugyanakkor az $\mathrm{R}^{2}$ értékében „Nyugat”-on jelentős javulás van a IV. a) esethez, illetve „Közép”-en a II. c) esethez képest. Az eredmények alapján azt a következtetést vonhatjuk le, hogy a becslések közül ez tekinthető az egyik legpontosabbnak, ami igazolja azt is, hogy az adatbázis feltárás eredményes volt. (14. számú melléklet c) IV.c pont)

\section{Következtetés}

A bevételi szerkezet alapján a helyi önkormányzatoknak folyósított támogatás mértéke lineáris regresszióval viszonylag pontosan becsülhető, amit a magas $\mathrm{R}^{2}$ értékek mutatnak. A területi elhelyezkedés szerinti bontásban az eredmények minden esetben jelentős mértékben javultak, ami azt mutatja, hogy a területi elhelyezkedés is meghatározó az európai uniós támogatások felhasználása tekintetében. A fenti elemzésekre figyelemmel a H4 hipotézist elfogadom.

\subsubsection{A H5 hipotézis tesztelése}

H5: Létezik a helyi önkormányzatoknak olyan nagyság, területi elhelyezkedés és bevételi szerkezet szerinti csoportja, amelyeknél az európai uniós támogatások felhasználása nem tipikus.

A H1-H4 hipotézisek eredményeinek figyelembe vételével joggal feltételezhető, hogy a támogatásban részesült helyi önkormányzatok bevételi szerkezete eltér a támogatásban nem részesült helyi önkormányzatokétól. A H4 hipotézis vizsgálata során ezt az támasztotta alá, hogy a lineáris regressziós modell eredményei területi bontás esetében jellemzően javultak és a modellbe bevont változók is eltérőek voltak, amennyiben csak a támogatást elnyert helyi önkormányzatokat vizsgáltam.

A bevételi szerkezetet leíró változóknak ugyanazokat a változókat tekintem, mint amelyeket a H4 hipotézis esetében. Az együtthatók könnyebb kezelhetősége, valamint az eredmények pontosabb értelmezése érdekében az egyes változók mértékegységeit milliárd Ft-ban határozom meg. 
A leíró statisztikai elemzéskor elsődlegesen nem az elnyert támogatás mértékére fókusztálam, hanem annak bemutatására, hogy az önkormányzatok elnyertek-e európai uniós támogatást, vagy sem.

Változónként ország szinten vizsgáltam, hogy van-e lényeges különbség a támogatásban részesült, és a támogatásban nem részesült helyi önkormányzatok között. Ennek részleteit a dolgozat 15. számú mellékletének a és b pontjai tartalmazzák. A t-próbák alapján a változók kategóriák ${ }^{158}$ közötti egyenlőségének hipotézisét elvetettük, ami azt támasztja alá, hogy azoknak a modellben történő szerepeltetése indokolt. (15. számú melléklet c1 és c2 pontok)

\section{Nagyság értelmezése}

A hipotézisek vizsgálata során már láttuk, hogy a lakosságszám erősen determinálja a helyi önkormányzatok bevételi szerkezét leíró változókat, ennek következtében indokolatlan a lakosság számát a becslésnél felhasználni, mivel redundáns. Így jelen hipotézis tesztelésekor is elfogadom a nagyságra vonatkozó állítást, amennyiben az empirikus tesztelés a bevételi szerkezetre vonatkozóan helytálló eredményeket ad.

A vizsgálat időszakban a helyi önkormányzatok alig több, mint harmada részesült európai uniós támogatásban: a vizsgált 3151 településből 1108 helyi önkormányzata ${ }^{159}$, ami jelentős hatással van a becslésre. Megjegyzendő ugyanakkor, hogy a 2007-2013-as programozási periódus ÚMFT támogatások esetében a támogatást elnyert helyi önkormányzatok aránya lényegesen magasabb, ezért a jelen hipotézis vizsgálata keretében kapott eredmények nem általánosíthatóak a jelenleg is folyamatban lévő 20072013-as programozási periódusra. ${ }^{160}$

A hipotézis bevételi szerkezetre irányuló részének teszteléséhez bináris logisztikus regressziót (logit modell) alkalmazok, amely módszer bináris változó értékének becslésére alkalmas. Célom, hogy meghatározzak egy olyan kört, ahol a modell magas bizonyossággal becsüli, hogy egy település nem kapott európai uniós támogatást. A módszerrel a cél nem az előrejelzés, hanem olyan település-csoportok meghatározása,

\footnotetext{
158 vagyis támogatásban részesült, illetve támogatásban nem részesül helyi önkormányzatok

${ }^{159}$ Ehhez lásd még a 10. számú mellékletben szereplő adatokat.

160 A 2007-2013-as programozási periódusban feltehetően pontosabban becsülhetők azok a helyi önkormányzatok, amelyek támogatásban részesültek.
} 
amelyek körében a helyi önkormányzat részére folyósított támogatás ténye tipikus, illetve atipikus.

A leíró statisztikai eredmények alapján körvonalazódik (10. számú melléklet i) pont), hogy az 500 fő lélekszám alatti települések esetében a támogatásokból való részesedés atipikus, míg az 50000 fő feletti nagyvárosok kivétel nélkül részesültek támogatásban. A településméret növekedésével a támogatásban részesült helyi önkormányzatok aránya NUTS1 szintet tekintve minden régióban növekszik, NUTS2 szinten a fenti állítás néhány kisebb elemszámú esettől ${ }^{161}$ eltekintve szintén igaz. (10. számú melléklet i) pont)

Az alkalmazott módszer „forward selection conditional” logisztikus regresszió. Az eljárás a változókat egyesével építi be, illetve lépteti ki a modellbe, figyelemmel arra, hogy a változó mennyire szignifikáns az aktuális modell egészére ${ }^{162}$, tehát „lépésről lépésre szignifikáns változókkal bővíti”. (Kovács 2009) Szükséges megjegyezni ugyanakkor, hogy a hipotézis tesztelése során a logisztikus regresszió vizsgálatokat enter módszerrel is lefuttattam, azonban az eredmények közel ugyanazt mutatták, mint a fenti módszer esetében.

A logisztikus regresszió olyan osztályozó eljárás, amely egymást kizáró eredményekhez jelen esetben támogatásban részesül, vagy nem részesül - sorolja a megfigyelési egységeket egy osztályozó függvény által felvett érték alapján. A besorolási osztályt az előre, szabadon meghatározott vágópont és a függvényérték relációja határozza meg. ${ }^{163} \mathrm{~A}$ vizsgálatot két irányból, több lépésben végeztem el: egyrészt a támogatásban nem részesülők irányából, másrészt a támogatásban részesülők irányából közelítettem úgy, hogy a vizsgált osztály találati pontossága meghaladja a 80\%-ot. Ennek elérésére a vágópont értékét változtattam oly módon, hogy a 80\%-os találati pontosság megtartása mellett a lehető legtöbb elem kerüljön a vizsgált osztályba.

\footnotetext{
161 Nyugat-Magyarország esetében 5000-9999 fö lélekszámú településeknél $40 \%$ az arány, míg a 10000-49999 fö kategóriában 50\%, azonban az elemszám nagyon alacsony (2:3, illetve 4:5); Dél-Alföldön 5000-9999 fó lélekszámú településeknél 6,9\% az arány, míg a 10000-49999 fő kategóriában 15,8\%, azonban az elemszám nagyon alacsony (2:27, illetve 3:16).

162 A kutatás során a következőket alkalmaztam: a változót a módszer a modellbe belépteti, ha a szignifikancia szintje 0,05-nél kisebb, és a modellböl eltávolítja, ha a szignifikancia szintje 0,1-nél nagyobb. 163 Jelen esetben a vágópont alatti becslőfüggvény-értékkel rendelkező elemeket a modell a támogatásban nem részesült osztályba, míg a vágópont felettieket a támogatásban részesült osztályba sorolja.
} 
A hipotézis tesztelése során ugyanazt a sorrendiséget követtem, mint amit a H4 hipotézis esetében, mert az eredmények így egymással és a H4 hipotézissel is egyaránt összehasonlíthatók és könnyebben értelmezhetők lesznek.

Első lépésként a logisztikus regresszió vizsgálatot országos szinten végeztem el, melynek eredményeit a 15. számú melléklet d1 és d2 pontjai tartalmazzák. A mellékletben szereplő táblázatokban ,igen” jelöléssel azt az esetet tüntettem fel, amikor a támogatásban részesült osztályt vizsgáltam, míg „nem” jelöléssel azt, amikor a támogatásban nem részesült osztályt vizsgáltam. A kapott eredmények alapján levonhatjuk azt a következtetést, hogy a bevételi szerkezet alapján létezik a településeknek olyan köre (1813 darab), amelyeknél 80\%-os találati pontossággal (1461 település) igaz, hogy támogatásban nem részesült. Hasonló módon megállapíthatjuk, hogy létezik a településeknek egy olyan köre (294) is, ahol a támogatás igénybe vétele tipikus (238 település). Mindösszesen tehát a két becsléssel 1699 települést sorolunk helyesen. Következő lépésben annak alátámasztására törekszem, hogy a H4 hipotézis eredményeinek figyelembe vételével meghatározzam azt a területi rétegezést, ahol a modell eredményei tovább javíthatóak.

Második lépésként NUTS1 nagyrégió szinten folytattam az elemzést, melynek eredményeit a 15. számú melléklet e1 és e2 pontjai tartalmazzák. Nagyrégiónként eltérő becslőfüggvény alkalmazása mellett az eredmények javulnak: a támogatásban nem részesült osztályok 1476 esetben helyesen sorolnak, a támogatásban részesült osztályok pedig 283 esetben. Ebből azt a következtetést lehet levonni, hogy mind az ,igen”, mind a „nem” kategóriában ugyanolyan ( $80 \%$-os) pontosság mellett több elemet találunk el, tehát a nagyrégió szerinti területi rétegezéssel összességében enyhe, 3,5 \%-os javulást érünk el.

A NUTS 2 statisztikai régió szintű elemzés eredményeit a 15. számú melléklet f1 és f2 pontjai tartalmazzák. A tesztelés eredményeitől előzetesen jelentős javulást vártam figyelemmel arra, hogy az egyes régiók között fejlődésbeli különbségek vannak. A kapott eredmények meglepőek, ugyanis annak ellenére, hogy a támogatásban részesült településeket ${ }^{164}$ jobban becsüli a függvény (291), addig a „nem”-ek esetében a találati arány jelentősen, a NUTS 1 szintű becslés 1476-ról 1168-ra romlik. Ennek oka lehet azonban az is, hogy Dél-Alföld régió esetében nincs olyan vágópont, amellyel a 80\%-os találati pontosság elérhető lenne a „nem” kategóriában. Ez azt mutatja, hogy a modell

${ }^{164}$ vagyis az ,igen"-eket 
becslése erre az osztályra nagyon bizonytalan. Összességében azt a következtetést lehet levonni, hogy a NUTS1 szinthez képest 1759-ről 1459-re, vagyis 17 százalékkal romlik az eredmény.

Figyelemmel arra, hogy a NUTS1 szintü bontás az országos szinthez képest javuló eredményt mutatott, így a saját bontás szerinti vizsgálatot is elvégeztem, melynek eredményeit a 15. számú melléklet g1 és g2 pontjai tartalmazzák. Az „igen” osztály esetén az országos szinthez képest az eredmények 238-ről 288-ra javultak, ugyanakkor a „nem” osztály esetében 1461-ről 1416-ra romlottak. Összességében azt állapíthatjuk meg, hogy ez a bontás csak egy kicsit jobb, mint az országos szintü és alatta marad a NUTS1 nagyrégiók szerinti becslésnek.

A különböző területi bontások eredménye nem különbözött szignifikánsan az országos szintütől, a területi elhelyezkedés önmagában nem egyértelmüen befolyásolja a becslés helyességét, vagyis azt, hogy az adott település támogatásban részesült-e, vagy sem. Meg kell jegyezni ugyanakkor, hogy a területek között megjelenő eltérések a fentiek alapján abból fakadnak, hogy az adott területen milyen típusú értsd lélekszámú települések jellemzőek.

A területi bontás szerinti vizsgálat meglehetősen gyenge eredményeket mutat, így más irányból is teszteltem a hipotézist. A leíró statisztikák (10. számú melléklet i) pont) alapján az körvonalazódott, hogy az alacsony lélekszámú települések esetében a támogatás atipikus, míg a nagyvárosok esetében tipikus. A vizsgálatot ezért elvégeztem a települések lélekszám szerinti bontásának rétegezésével is a következők szerint:

1. 500 fő alatti települések

2. 500-999 fő lélekszámú települések

3. 1000 - 4999 fö lélekszámú települések

4. 5000 - 9999 fő lélekszámú települések

5. 10000 - 49999 fő lélekszámú települések

6. 50000 fő feletti települések

$\mathrm{Az} 500$ fö alatti települések esetében a logit modell a leíró statisztikához képest többleteredményt szükségszerüen nem hozhat tekintettel arra, hogy az 500 fó alatti települések több mint $80 \%$-a támogatásban nem részesült. Hasonlóan nem nyújt új információt a leíró statisztikához képest a logisztikus regresszió az 5-6 rétegben, vagyis 
10000 fő feletti településeknél, ugyanis azok jellemzően részesülnek támogatásban. (15. számú melléklet h pont)

A logisztikus regresszió a 2-3-as kategóriában gyengén becsli a támogatásban való részesülés tényét. (15. számú melléklet i pont) Az empirikus kutatás részeként további, méret, illetve területi elhelyezkedés szerinti alábontásokat is alkalmaztam, azonban azok eredményei sem érik el összességében a kívánt pontosságot.

Összegezve az állapítható meg, hogy a logisztikus regresszió eredményei az országos szint további alábontásával nem hoznak jelentősen pontosabb eredményt, területi elhelyezkedés nem meghatározó. A méret szerinti leíró statisztikai eredményekhez képest a modell többletinformációt nem ad. Mindezek alapján a hipotézist eredeti formájában elvetem. 


\section{Összegzés, következtetések, további kutatási irányok}

\section{Logikai keret}

A disszertáció utolsó, rövid fejezetével több célom van: egyrészt áttekintő szemléletben bemutatom azt a logikai keretet, amelyre a dolgozat épül, másrészt röviden, kissé kritikus szemléletben értékelem a kutatás eredményeit, harmadrészt pedig felvázolom a kutatás lehetséges további irányait.

Magyarország európai uniós csatlakozásával a cél összhangban az Európai Unió politikáival hazánk felzárkóztatása, vagyis a regionális különbségek csökkentése és a társadalmi és gazdasági kohézió erősítése. Ezen célok elérésének egyik más tagállamok példáira támaszkodva mondhatni bevált eszköze a regionális politika. A disszertációban szüken bemutattam a regionális politika múltját és jelenét, továbbá ezekben a dimenziókban elhelyeztem Magyarországot mint a 2004-ben csatlakozott új tagállamok egyikét. Az Európai Unió által nyújtott támogatások hozzájárulhatnak ahhoz, hogy egyegy lemaradó régió látványos fejlődésnek induljon, és ezáltal a fejlődésbeli különbségek csökkenhessenek.

Az Európai Unió támogatáspolitikájának alapelvei elvi szinten, ugyanakkor meglehetősen egyértelműen meghatározzák annak a mozgástérnek a határait, amelyben a támogatást igénybe vevő tagállamok mozoghatnak. A dolgozat számos fontos alapelv közül az addicionalitásra fókuszál: a hozzájárulásnak érvényesülnie kell mind a kormányzati, mind a helyi szinten annak érdekében, hogy a támogatások kiegészítésként járuljanak hozzá egy-egy projekt megvalósításához.

Összhangban a regionalizmus alapgondolatával az aktív helyi szintnek kell a döntéseket meghoznia a fejlődés érdekében, amelyhez kreatív elképzeléseken és terveken túl megfelelő források is szükségesek. Az addicionalitás vizsgálatánál a kutatás fókuszába a helyi szintet, azon belül is a magyarországi helyi önkormányzatokat helyeztem.

Régi mondás szerint: aki sokat markol, keveset fog. Bár ennek minden nehézségét és veszélyét érzékeltem a kutatás során, a dolgozatot mégis multidiszciplináris jellegünek szántam: a magyarországi helyi önkormányzatok mint kedvezményezettek körén keresztül vizsgáltam az addicionalitást, viszonylagosan szűken értelmezve. Ez a szűkített értelmezés is megkívánta ugyanakkor, hogy mind a regionális politika kapcsolódó 
elméleti hátterét, mind a magyarországi helyi önkormányzatok specifikumait bemutassam.

A dolgozatnak ez a kétarcúsága az elméleti felvezetésnél jelenik meg igazán, hiszen alapjaiban több, egymástól jelentősen eltérő tudományterület összekapcsolására tettem kísérletet, melyek külön-külön is egy-egy disszertáció és különálló kutatás részét képezhetnék. Így minden kapcsolódó szakirodalom alapos, mélyreható elemzése nem történhetett meg, törekedtem azonban - a föbb elméleti irányok részletes bemutatásával azoknak az összefüggéseknek a megvilágítására, amelyekkel a különbözö tudományterületek összekapcsolhatók.

A magyarországi helyi önkormányzatok vizsgálatakor a történeti háttér rövid bemutatását követően arra kérdésre fókuszáltam, hogy a helyi önkormányzatok milyen módon képesek előteremteni a fejlesztéshez szükséges forrásokat, és mi ennek az ára. A hazai szakirodalomban hangsúlyosan megjelenő eladósodási folyamatok tárgyalásától nem tekinthettem el, azonban a disszertáció fókuszában és a hipotézisek felállításában elsődlegesen nem az eladósodási folyamatok tárgyalása szerepel, hanem annak összefüggései az addicionalitással.

Mivel a regionális politika és az önkormányzatok közötti kapcsolatot az európai uniós támogatások felhasználásán mint gyakorlati területen keresztül teremtettem meg, ezért szükségszerüen a dolgozat integráns részét képezik gyakorlati irányú, összegző megközelítések is.

A hipotézisek megfogalmazásáig a dolgozat szerkezete túlzottan tagoltnak, az egyes fejezetek egymástól elszeparáltnak tünhetnek, ami nem a véletlen műve, hanem mondanivalóm felépítésének sajátos technikája. Míg mind a regionális politika, mind az önkormányzati gazdálkodás témájában külön-külön meglehetősen sok tanulmány született, azonban a két terület összekapcsolására sajnálatos módon kevés a szakirodalmi példa.

Az empirikus kutatással egyidejüleg az elméleti háttér további bővítésén is dolgoztam annak érdekében, hogy a két tudományterületi közötti átmenetet egyfajta hídként tudjam bemutatni. Kezdetektől fogva kockázatosnak tartottam a kutatást abban a tekintetben, hogy a hipotézisek empirikus tesztelésekor számtalan olyan elemzési eredmény körvonalazódhat, amely mögött rejlő okok egyelöre ismeretlenek. 


\section{Kutatási eredmények összegzése}

A hazai szakirodalomban többirányú elméleti levezetéssel és leíró statisztikai módszerekre építve már megfogalmazták (Vigvári), hogy Magyarországon az aranyszabály nem érvényesül. Ebben a tekintetben tehát a disszertáció H1 hipotézisét nem tekintem teljesen újszerü elméleti eredménynek. Az empirikus tesztelés során azonban (leíró egyenlet segítségével) igazoltam, hogy a helyi önkormányzatok hitelfelvételének változása a vizsgált időszak tekintetében összefüggésbe hozható az értékpapír állományban bekövetkezett változással, a felhalmozás egyenlegének változásával, valamint a müködés egyenlegének változásával. Az empirikus teszteléssel tehát megerősítettem azt az elméleti levezetést, miszerint a hitelfelvétel három fő célt szolgált: a felhalmozási kiadásokon keresztül elősegítette a beruházásokat, kiegyenlítette a müködési egyenleg deficitjét és részben megtakarítási célokat szolgált. Az empirikus tesztelés második lépéseként igazoltam, hogy a müködés egyenlegének figyelembe vétele nélkül a becslőegyenlet nem érvényes, tehát a helyi önkormányzatok a hitelfelvétel egy részét müködési célokra használták fel. Az empirikus tesztelés során a hitelfelvétel fogalmát kétféle módon operacionalizáltam: egy szükítő, és egy tágabb értelmezés szerint.

A H1 hipotézissel kapcsolatos további kutatási irány lehetne annak vizsgálata, hogy a szükítő értelmezésben definiált hitelfelvétel esetében újszerü összefüggéseket tárjak fel azokra a településekre, amelyek nem képezik a modell részét. Másik kutatási irányként értelmezhető, ha a becslőegyenletbe új változókat vonnánk be, vagy az egyes fogalmakat - hasonlóan a hitelfelvételhez eltérő módon értelmeznénk.

A hipotézis tesztelésének eredményeire is figyelemmel egyetértek a hazai kutatókkal (Vigvári) abban, hogy a magyarországi helyi önkormányzatok eladósodása atipikus, és az államháztartás átfogó reformja szükséges annak érdekében, hogy a folyamatok, a gazdálkodás módja átlátható, transzparens, és ezáltal az eredmények megfelelően mérhetők legyenek. Sajnálatos módon a kutatás empirikus részénél szembesültem a rendelkezésre álló adathalmaz elsősorban a helyi önkormányzatok által készített beszámolók konzisztenciájának hiányosságaival, valamint azzal a ténnyel, hogy a beszámolókból nem kaphatunk teljes képet egy-egy önkormányzat tényleges vagyoni, pénzügyi és jövedelmi helyzetéről, valamint annak jövőbeni kötelezettségeiről és mérleg alatti tételeiröl. 
A H2 hipotézissel több lépésben igazoltam, hogy a helyi önkormányzatok beruházásaiban az európai uniós támogatások meghatározó szerepet töltenek be. A változók közötti Pearson korreláció magas, ugyanakkor ez még nem támasztja alá az ok-okozati viszonyt. A hipotézis alátámasztásának érdekében az egy főre jutó beruházások átlagát vizsgáltam a támogatásban részesült, illetve a támogatásban nem részesült települések körében. A hipotézis tesztelése során rétegképző ismérvnek a lélekszámot tekintettem, amely rétegezéssel a lakosság mint mögöttes változó determinációját kezeltem ${ }^{165}$. A kapott eredmények alapján egyértelműen állítható, hogy a támogatásban részesült települések esetében az egy főre jutó beruházási és fejlesztési kiadások nagysága minden rétegben magasabb, mint a támogatásban nem részesült helyi önkormányzatok esetében. A különbség szignifikaciáját t-próbával, illetve Welch próbával teszteltem, melynek eredményeként megállapítottam, hogy a 200 fő alatti lélekszámú településektől eltekintve a különbség szignifikáns.

Összességében ez a hipotézis megalapozhat olyan feltevéseket, miszerint az európai uniós támogatásoknak hatása van a települések fejlődésére. Ezt jelen kutatás keretében nem állítom tekintettel arra, hogy az egy före jutó beruházási és fejlesztési kiadások vélhetően a méretgazdaságosság miatt a nagyvárosok esetében csökkenő tendenciát mutatnak. A disszertáció keretében igazolt hipotézis ugyanakkor makrogazdasági elemzési eszközökkel kiegészítve a fejlesztések és beruházások gazdaságosságának vizsgálatához alapot adhat.

A kutatás lehetséges további irányai sokrétüek, lehetőségként merült fel a földrajzi elhelyezkedés szerinti rétegképzés is. Ennek legfőbb korlátja az, hogy a területi bontás alkalmazásával az egyes rétegekben szereplő megfigyelési egységek száma jelentősen csökken, ami a statisztikai stabilitást már veszélyeztetné. Lehetséges lenne ugyanakkor más tagállamok hasonló fejlettségü régióival (pl. szomszédos országok határmenti régiói) összehasonlítani a magyar települések beruházási és fejlesztési kiadásait.

Az addicionalitás helyi önkormányzatok esetében történő érvényesülésének tesztelését célozta a H3 hipotézis. Pearson korreláció vizsgálattal igazoltam, hogy a helyi önkormányzatoknak folyósított európai uniós támogatás és a helyi önkormányzatok saját

\footnotetext{
${ }^{165}$ A képzett rétegek a következök voltak: 200 fö lélekszám alatti, 200-499, 500-4999, 5000-9999, 10 00049 999, 50000 lélekszám feletti települések. 50000 fö feletti települések mindegyike részesült támogatásban.
} 
bevétele, valamint finanszírozásának egyenlege között szoros pozitív kapcsolat áll fenn NUTS1 nagyrégió, NUTS2 régió és NUTS3 megye szintű bontásban egyaránt. A hipotézissel tehát azt igazoltam, hogy az addicionalitás alapelve a magyarországi helyi önkormányzatok szintjén teljesül. A hipotézissel kapcsolatos további kutatási irány, ha a korreláció vizsgálatot nem a területi elhelyezkedés szerinti bontásban, hanem lélekszám szerinti rétegezésben vizsgálnánk, illetve más változókat is (pl. pénzkészlet) az elemzés hatókörébe vonnánk.

A H3 hipotézis elfogadását követően indokolttá vált a H3.1 hipotézis tesztelése, miszerint az európai uniós támogatások felhasználása és a helyi önkormányzatok eladósodása között kapcsolatok vannak. Az önkormányzatok eladósodásának mutatójaként a kötelezettségvállalás növekedését vettem alapul a helyi önkormányzatok mérlegében szereplő stock típusú adatok 2008. évi záró és 2004. évi nyitó értékének különbségeként. Az empirikus kutatás részeként háromféle megközelítést alkalmaztam: egyrészt Pearson korreláció vizsgálattal teszteltem a kötelezettségvállaláshoz kapcsolódó változók és a folyósított európai uniós támogatás közötti kapcsolatot, majd fökomponens elemzéssel megvizsgáltam, hogy a folyósított európai uniós támogatás melyik változóval kerül egy faktorba. Harmadik lépésként pedig klaszteranalízis segítségével áttekintettem, hogy az európai uniós támogatás melyik változóval kerül egy ágra. Az elemzéseket megye szintű bontásban végeztem el, ugyanis a feltáró elemzés eredményeként az körvonalazódott, hogy megyénként eltérő összefüggések jellemzőek. A hipotézis 16 megye esetében egyértelműen elfogadható, 2 megye esetében nem vethető el, ugyanakkor Pest megyére nem teljesül.

A kutatás folytatásának első lépése elméleti irányultságú lehetne: szükséges feltérképezni azokat a mögöttes okokat (pl. gazdasági fejlettségbeli különbségek, iparosodottság, urbanizáció, politikai irányultság), amelyek alapján az egyes megyék közötti hasonlóságok és különbözőségek feltérképezhetők. Ezt követően kerülhetne sor újabb empirikus tesztelésre, azonban nemcsak megyei szinten, hanem annál nagyobb egységben, más csoportképző ismérvek alapján. Hasonlóan a többi hipotézishez, szintén kitekintő kutatási irány lehetne más tagállamok esetében a kötelezettségvállalás növekedésének vizsgálata, és összehasonlító elemzése a magyar helyi önkormányzatokkal. 
A H4 és H5 hipotézisekkel sikerült alátámasztani azt, hogy a helyi önkormányzatok nagysága, területi elhelyezkedése, bevételi szerkezete együttesen olyan tényezők, amelyek meghatározzák az európai uniós támogatások igénybe vételét, ugyanakkor elvetettem azt a hipotézist, miszerint létezik a helyi önkormányzatoknak olyan köre, ahol a támogatások felhasználása atipikus.

A H4 hipotézis tesztelésének első lépéseként lineáris regresszióval becslőfüggvényt képeztem országos szinten. Ezt követően különféle területi bontásban újabb becslőfüggvényeket képeztem, amelyekkel a helyi önkormányzat részére jutatott támogatás mértéke pontosabban becsülhető volt. A lineáris regresszió eredményeként a becslöegyenletbe bevont változók köre nem azonos, amelyböl összhangban a H3.1. hipotézissel - azt a következtetést is levonhatjuk, hogy a területi elhelyezkedés és a bevételi szerkezet meghatározó.

A hipotézis kapcsán további kutatási irányok körvonalazódnak: célszerü lenne kutatni, hogy a térbeli elhelyezkedés miért olyan meghatározó a bevont változók szempontjából, milyen mögöttes okok húzódhatnak meg az eltérő becslöfüggvények mögött. Az eredeti hipotézisen túllépve más változók bevonásával is alkalmazható lenne becslés, azonban az empirikus tesztelést további elméleti kutatásnak kellene megelőznie. Mivel a hipotézis tesztelésekor kumulatív módon értelmeztem a változókat, ezen a módszeren túllépve trendszámítási, illetve előrejelzési modelleket is lehetne képezni.

A H5 hipotézis tesztelését logisztikus regresszióval végeztem el, többféle módszer segítségével, ugyanazoknak a változóknak a bevonásával, mint a H4 hipotézis esetében. Meglepő eredménynek tartom, hogy a leíró statisztikai triviális eredményein - miszerint a 200 fö alatti települések esetében nem jellemző a helyi önkormányzatoknak folyósított európai uniós támogatás - nem sikerült túllépni a többváltozós adatelemzési módszerekkel, ezért a hipotézist eredeti formájában elvetettem.

Nem jelenthető ki ugyanakkor egyértelmüen az sem, hogy nem létezik a településeknek olyan nagyság, területi elhelyezkedés és bevételi szerkezet szerinti csoportja, amelyeknél az európai uniós támogatások felhasználása atipikus. Az elemzések során körvonalazódott, hogy a legkisebb települések helyi önkormányzatai esetében a 20042008 közötti időszakban viszonylag ritka volt a támogatásban való részesedés ténye, míg a nagyvárosok esetében szinte minden település helyi önkormányzata részesült európai 
uniós támogatásban. Ezek alapján triviális részállítások bizonyíthatók, azonban a két viszonylagosan szélsőségesnek tekinthető eseten túl a települések többségére érvényes következtetéseket nem tudtam megfogalmazni.

Lehetséges kutatási irány a szélsőséges esetek, vagyis a triviális halmaz kivétele az elemzés hatóköréből, majd valamilyen rétegképző ismérv alapján (pl. területi elhelyezkedés) más módszerrel történő elemzés. Mivel az eredeti hipotézis két értékre vonatkozik (támogatásban részesül-e vagy sem), más többváltozós adatelemzési technikák pl. klaszterelemzés csak korlátozottan tünnek alkalmazhatónak. Ezek alapján olyan más, de tartalmában hasonló hipotézist kellene első lépésként felállítani, ami a logisztikus regresszión kívül más többváltozós adatelemzési módszerrel tesztelhető. Ilyen lehet például, ha a leíró statisztika eredményei és a logisztikus regresszió jelen kutatás keretében körvonalazódott sikertelen eredményei alapján bizonyos lélekszámú (pl. 500 fő alatti) településekre vonatkozóan fogalmazzuk meg az eredeti hipotézist, és más többváltozós adatelemzési módszerrel teszteljük.

A H5 hipotézis kapcsán figyelemmel kell lenni arra is, hogy a vizsgált időszak nagyon meghatározó: jelen kutatás keretében a 2004-2008-as időszak adatait vettem figyelembe, míg a jelenleg is folyamatban lévő 2007-2013-as programozási periódus magasabb forrásai miatt vélhetően szükülni fog azoknak a településeknek a köre, amelyek helyi önkormányzatai egyáltalán nem jutnak támogatáshoz. A 2007-2013-as programozási periódus lezárásával célszerü lehet a két időszak együttes vizsgálata is.

További kutatási irány, ha a hipotézist nem szükítjük a helyi önkormányzatok körére, hanem a település egészére tekintjük vagyis beleértjük a magánszektor szereplőit is, és a település egészére jellemző mutatószámokkal (pl. munkanélküliek száma, aránya a településen, kifizetett segélyek összege, stb.) keressük az összefüggést. Ez azonban már jócskán túlmutatna jelen kutatás eredeti célján, vagyis a helyi önkormányzatok addicionalitásának vizsgálatán.

Bár a kutatás eredményeinek összegzésekor hipotézisenként külön-külön bemutattam a lehetséges további kutatási irányokat, a dolgozat multidiszciplináris jellege miatt számos olyan terület körvonalazódik, amelyekről szólni kell.

A jelenlegi kutatás keretében a hipotézisek empirikus tesztelése során a 2004-2008 éveket vizsgáltam mind az európai uniós támogatások, mind a helyi önkormányzatok beszámolói 
alapján. A hipotézisek többségénél az évek közötti ciklikusságok tompítása érdekében vagy összevontan, kumulatívan értelmeztem az adatokat, vagy pedig a vizsgált időszak záró és nyitóértékének különbségeként. Részben a feltáró elemzés eredményei, részben az egyes hipotézisek tesztelése során arra a következtetésre jutottam, hogy az időbeliség a vizsgált változók szempontjából hasonlóan az elméleti részben hivatkozott szakirodalomban megfogalmazottakhoz meghatározó lehet. ${ }^{166}$

A 2007-2013-as programozási periódus lezárultával már két támogatási időszak adatai fognak rendelkezésre állni. A 2004-2013-as időszak adatainak ismeretében a jelen dolgozat keretében alkalmazott módszerektől jócskán el lehet térni: trendvizsgálatokkal és idősor elemzésekkel is kutathatóvá válik az európai uniós támogatások területe. A jelenleg folyamatban lévő programozási periódus lezárását követően nemcsak a 20042013-as időszak egésze vonható elemzés alá, hanem a két programozási periódus is összehasonlítható lesz, vagyis vizsgálni lehet a folyamatokat a 2004-2006 és 2007-2013 időszakokra vonatkozóan külön-külön is. ${ }^{167}$ A klasszikus idősor elemzésen túlmutatva statisztikai értelemben megbízható becslöfüggvényeket is lehet majd készíteni, azonban ennek erőforrás igénye meglehetősen nagy. Egyszerübb kutatás keretében pedig megismételhető akár a jelenlegi kutatás is, csak más időszakra vonatkozóan, egyfajta panelvizsgálatként.

A kutatás során érzékeltem, hogy a területi elhelyezkedés, illetve a települések különféle szempontú rétegezése meghatározó lehet. Erre a tényre figyelemmel ki lehetne alakítani más rétegképző ismeréveket mind a területi elhelyezkedés, mind a nagyság tekintetében, továbbá figyelembe lehetne venni a települések rangját is.

\section{Kutatási irányok tág értelmezése}

Az addicionalitást a disszertáció keretében meglehetősen szüken értelmezve vizsgáltam, hiszen nemcsak a központi szint, hanem a magánszektor egészének vizsgálatától tekintettem el, azonban nem ok nélkül.

\footnotetext{
${ }^{166}$ példaként említhető a helyi önkormányzatok által kibocsátott kötvények ugrásszerü növekedése a vizsgált időszak végén

${ }^{167}$ Ez azért különösen érdekes kutatási téma, mert a jelenleg futó 2007-2013-as programozási periódusban a Magyarországra irányuló támogatás mértéke jóval magasabb, mint a kutatás keretében vizsgált időszak esetében, így a támogatottság mértéke és a támogatottak köre jellemzően bővül.
} 
A kutatás első szakaszában a nemzetközi szakirodalom feltérképezésével részletesen áttekintettem az elméleti megközelítések sokrétü tárházát és sajnálatos módon nem találtam sem a támogatás mérésének hatékonyságára, sem az addicionalitás biztosításának vizsgálatára készült átfogó, mikroszintről bottom-up irányba terjeszkedő kutatásokat. Jelen kutatás elméleti megalapozásának keretében ugyanakkor részletesen bemutattam a támogatások mérhetőségének anomáliáit és annak lehetséges módszertani kereteit.

Mindezek alapján úgy vélem, hogy pusztán az addicioanlitás szüken vett témakörén belül maradva is számos további iránya lehet a kutatásnak: kiterjeszthető az addicionalitás vizsgálata Magyarországon a kormányzati szintre, illetve a nem helyi önkormányzat kedvezményezettekre, gondolok itt elsősorban a magánszektorban müködő kis- és középvállalkozásokra, illetve társadalmi szervezetekre.

Magyarország irányából az Európai Unió más tagállamai felé elmozdulva szintén kiterjeszthető a kutatás: vizsgálni lehetne az addicionalitás kérdését mind a kedvezményezetti, mind a központi szinten más tagállamokban, akár a Magyarországgal egyidejüleg csatlakozott országokban, akár az Európai Unió teljes területén. A vizsgálat hatóköre irányulhatna egy-egy országra, de összehasonlító elemzés keretében is lefolytatható. Nyilvánvaló, hogy egy ilyen átfogó jellegü kutatás hatóköre nem állhatna meg az addicionalitás szüken vett vizsgálatánál, hanem kiterjedne a többi, hasonlóan fontos alapelv érvényesülésének kutatására. Az alapelvek átfogó kutatása mellett ugyanakkor az egyes tagállamok mélyreható gazdasági elemzése is szükséges velejárója lenne egy ilyen nagymérvü kutatásnak, hiszen a társadalmi, gazdasági, politikai berendezkedés Európában meglehetősen sokszínü. 


\section{Köszönetnyilvánítás}

A disszertáció kezdő pontja csupán egy kósza ötlet volt, talán kicsit mélyebb szakmai érdeklődés a magyarországi helyi önkormányzatok iránt. Az ötlet és a dolgozat összeállítása között azonban meg kellett másznom a hegyet. Szinte felsorolni is lehetetlen, hogy kik segítettek akár közvetlenül, akár közvetetten abban, hogy ez a munka elkészült. Mégis veszem a bátorságot arra, hogy név szerint is megnevezzem legfőbb segítőimet. Köszönet illeti témavezetőmet, Dr. Lukács Jánost, aki nemcsak szakmai javaslataival támogatta munkámat, hanem képes volt rábírni arra is, hogy néha távolabbról szemléljem a kutatást. Hálával tartozom az empirikus adatok összegyüjtésében nyújtott segítségért a Magyar Államkincstár és a Nemzeti Fejlesztési Ügynökség munkatársainak. Külön köszönet kollégáimnak, akik napról napra támogatták ötleteikkel, javaslataikkal a dolgozat elörehaladását. És végül köszönöm szépen férjemnek Istvánnak, gyermekeinknek Borinak és Pistinek, valamint Papinak, Anyának és a teljes családomnak, hogy elviselték a hiányomat és emberfeletti erővel támogatták munkámat. 


\section{Felhasznált irodalom}

\section{Tanulmányok, periodikák, elemzések}

Állami Számvevőszék (2012): Összegzés a helyi önkormányzatok pénzügyi helyzetének és gazdálkodási rendszerének 2011. évi ellenörzéseiről (No. 1282). Állami Számvevőszék, Budapest.

Állami Számvevőszék (2007): A közpénzügyek szabályozásának tézisei. Állami Számvevőszék, Budapest.

Antalóczy-Aradi-Bodor-Fülöp-Györffi- Győrffi-Lacó-Printz (2010): A számvitel idöszerü kérdései 2010. A könyvviteli szolgáltatást végzök kötelezö továbbképzéséhez. Perfekt, Budapest.

Báger, G. - Vigvári, A. (2007): Államreform, közpénzügyi reform. Nemzetközi trendek és hazai kihívások. Állami Számvevőszék Fejlesztési és Módszertani Intézet.

Balassa, B. (1961): The Theory of Economic Integration, Richard D. Irwin, Homewood, Illinois.

Balassone, F.-Franco, D.-Zotteri, S. (2004): Fiscal Rules for Subnational Governments: Lessons from the EMU. In: Kopits, G. (szerk.) Rules-Based Fiscal Policy in Emeging Markets. Background, Analysis and Prospects. Palgrave Macmillan kiadás, International Monetary Fund, London, 219-234. o.

Banai, P.B. (2010): 2004. május 1.-2009. december 31. - Több mint öt év az unió tagjaként: az első időszak pénzügyi mérlege. Külgazdaság, LIV. évf. 7-8. sz. 3-39. o.

Banai, P.B. (2008): Fejlesztés egyenlő eladósodás? Az addicionalitás szabálya és az államháztartási hiány kapcsolata. Fejlesztés és Finanszírozás. 2008. 4. sz. 55-63. o.

Barca, F. (2009): An Agenda for a Reformed Cohesion Policy. A place-based approach to meeting European Union challenges and expectations. European Commission.

Baricz, R. (1999): Mérlegtan. 3. átdolgozott kiadás, Aula, Budapest.

Barna, O. (2003): Önkormányzati Támogatások a Közösségi Jog Tükrében. Jogtudományi Közlöny. 58. évf. 10. sz.

Barry, F. -Bradley, J. -Hannan, A. (2001): The Single Market, the Structural Funds and Ireland's Recent Economic Growth. Journal of Common Market Studies, 39. évf. 3. sz. 537-552. o.

Benczes, I. (2003): Tétlenség vagy reform: releváns nemzetközi magyarázatok hazai viszonyok között. Stratek Füzetek, Miniszterelnöki Hivatal, 16. szám, 189-220. o. 
Bende-Szabó, G. (2004): Regionális önkormányzati feladat- és hatáskörök. In: Horváth M. Tamás (szerk.): A regionális politika közigazgatási feltételei : Variációk az uniós csatlakozás küszöbén. Magyar Közigazgatási Intézet, Budapest

Bennett, R.J. (1998): Local Government in post socialist cities. In: Enyedi Gy. (szerk.): Social Change and Urban Restructuring in Central Europe, Akadémiai Kiadó, Budapest, 35-54. o.

Bennett, R.J. (1997): Local government in post-socialist cities, LGI, Budapest.

Béres, A. (2008): A Nemzeti Fejlesztési Terv keretében a KKV-k számára megitélt technológiafejlesztési támogatásoknak a vállalkozások beruházásaira és növekedésére gyakorolt hatásának elemzése (GVOP 2.1.1), Nemzeti Fejlesztési Ügynökség, Budapest.

Beugelsdijk, M. -Eijffinger, S.C.W. (2005): The Effectiveness of Structural Policy in the European Union: An Empirical Analysis for the EU-15 in 1995-2001. Journal of Common Market Studies, 43. évf. 1. sz., 35-49. o.

Bilan, IrinaRusu, Elena (2008): Financing Local Infrastructure Investments in Romania and Other New Eu Member States. Annals of the University of Oradea, Economic Science Series, 17. évf. 3. sz. 97-102. o.

Bird, R.M.-Wallich, C.I. -Péteri, G. (1995): Financing local government in Hungary. In: Richard M. BirdRobert D. EbelChristine I. Wallich (szerk.): Decentralization of the socialist state : Intergovernmental finance in transition economies. The World Bank, Washington. 69116. o.

Blankart, C.B. Klaiber, A. (2006): Subnational Government Organisation and Public Debt Crises. Economic Affairs, 26. évf., 3. sz., 48-54. o.

Bradley, J. Untiedt, G. (2007): Do economic models tell us anything useful about Cohesion Policy impacts? A comparison of HERMIN, QUEST and ECOMOD. GEFRA, Münster.

Bradley, J. Mitze, T. Morgenroth, E. Untiedt, G. (2005): An Integrated Micro-Macro (IMM) approach to the evaluation of large-scale public investment programmes. The case of EU Structural Funds, GEFRA, Münster.

Cappelen, A. Castellacci, F. Fagerberg, J. Verspagen, B. (2003): The Impact of EU Regional Support on Growth and Convergence in the European Union. Journal of Common Market Studies, 41. évf., 4. sz., 621-644. o.

Chenery, H. Bruno, M. (1962): Development Alternatives in an Open Economy: the Case of Israel. Economic Journal, 77. évf. 285. sz. 79-103. o.

Churski, P. (2008): Structural Funds of the European Union in Poland - Experience of the First Period of Membership. European Planning Studies, 16. évf. 4. sz. 579-607. o. 
Cooke, P. (2009): The Knowledge Economy, Spillovers, Proximity and Specialisation. In: Pontikakis, D., Kyriakou, D., van Bavel, R. (Eds.): The Question of $R$ and $D$ Specialisation. Perspectives and Policy Implications. JRC Scientific and Technical Reports, European Commission DG for Research.

Csipai, M. Vigvári, A. (2009): A helyi pénzügyek fejlesztésének néhány nemzetközi tapasztalata. Pénzügyi Szemle. 54. évf. 23. sz. 451458. o.

Csiszárik-Kocsir Ágnes (2008): A magyar helyhatóságok eladósodása az ezredforduló után; Tér és Társadalom, 22. évfolyam, 2008/4, 81-95. oldal

Dafflon, B. (szerk.) (2002): Local Public Finance In Europe. Balancing the Budget and Controlling Debt. Edward Elgar, Cheltenham-Northampton.

Dafflon, B. Beer-Tóth, K. (2009): Managing Local Public Debt in Transition Countries: an Issue of Self-Control. Financial Accountability and Management, 25. évf. 3. sz. 305333. o.

Dall'erba, S. (2007): The Impact of EU Regional Support on Growth and Employment. Finance a úvěr - Czech Journal of Economics and Finance. 57. évf. 7-8. sz. 325-339. o.

Dall'erba, S. (2005): Distribution of regional income and regional funds in Europe 19891999: An exploratory spatial data analysis. Annals of Regional Science, 39. évf. 1. sz. 121-148. o.

Dankó, G. - Lóránt, Z. (2010): Az önkormányzati szabályozással szembeni kihívások. Pénzügyi Szemle. 55. évf. 3. sz. 493-499.

Davey, K. Péteri, G. (2004): Local government finance: General issues. In: M. KopányiD. WetzelD.S. El (szerk.): Intergovernmental Finance in Hungary. Co-publication of The World Bank and Opean Society Institute, Budapest, 135-145. o.

De Rooij, R. (2002): The impact of the European Union on local government in the Netherlands. Journal of European Public Policy, 9. évf. 3. sz. 447-467. o.

Domokos, L. (2012): Az önkormányzati ellenörzések tapasztalatai. Állami Számvevőszék, Budapest.

Durlauf, S.N. Johnson, P.A. (1995): Multiple regimes and cross-country growth behaviour. Journal of Applied Econometrics. 10. évf. 4. sz. 365-384. o.

Fáyné Péter Emese (2002): Integrált területfejlesztés az Európai Unióban Tanulságok hazánk számára. Humánpolitikai szemle. 13. évf. 7-8. sz. 19-26. o.

Fleurke, F. Willemse, R. (2007): Effects of the European Union on Sub-National Decision-Making: Enhancement or Constriction? Journal of European Integration. 29. évf. 1. sz. 69-88. o. 
Forgácsné Orosz, V. (2000): A Regionális Önkormányzatok Európai Chartájának tervezete és a magyar regionalizáció lehetőségei. In: Szigeti E. (szerk.): Régió, közigazgatás, önkormányzat. Magyar Közigazgatási Intézet, Budapest, 65-83. o.

Fox, W.F. (2004): Intergovernmental Finance: Summary and Evaluation. In: M. KopányiD. WetzelD.S. El (szerk.): Intergovernmental Finance in Hungary. Co-publication of The World Bank and Opean Society Institute, Budapest.

Franco, D. Balassone, F. Francese, M. (2003): Fiscal Policy in Europe: the Role of Fiscal Rules. In: National Tax Association (szerk.): Proceedings of the 95th Annual Conference of 2002 Washington, USA.

Fürcht, P. (2009): Sok a helyi önkormányzat Magyarországon!? Új magyar közigazgatás. 2. évf. 3. sz. 43-47. o.

Füstös, L. Kovács, E. Meszéna, G. Simonné Mosolygó, N. (2004): Alakfelismerés. Sokváltozós statisztikai módszerek. Új Mandátum Kiadó, Budapest.

Füstös, L. Simonné Mosolygó, N. Meszéna, G. (1986): A sokváltozós adatelemzés statisztikai módszerei. Akadémiai Kiadó, Budapest.

Futó, P. (2009): Az értékelés és a hatásvizsgálat módszereinek alkalmazása a kisvállalkozás-fejlesztési politikában. A közép- és kelet-európai országok gyakorlatából meritett esettanulmányokkal. Budapesti Corvinus Egyetem, Budapest.

Gál, E. (2010): Önkormányzatok és kereskedelmi bankok a pénz- és tőkepiac keresleti és kínálati oldalán. Hitelintézeti Szemle, IX. évfolyam, 3. szám, 290-306. oldal

Goglio, A. (2007): Encouraging Sub-National Government Efficiency in Hungary. OECD Papers, 7. évf. 7. sz. 1-36. o.

Győrffi, D. - Vigvári, A. - Zsugyel, J. (2009): A közpénzügyek nagy kézikönyve. CompLex, Budapest.

Gyulai P. (2000): Önkormányzatok az EU-csatlakozás folyamatában. EU Working Papers. 3. évf. 3. sz. 3-18. o.

Halmosi, P. (2005): Az önkormányzati hitelfelvétel szabályozásának motivációja az Európai Unió országaiban. Hitelintézeti szemle. 4. évf. 1. sz. 68-77. o.

Hegedüs, J. Tönkő, A. (2006): Az önkormányzati gazdasági társaságok szerepe a helyi önkormányzatok vagyongazdálkodásában: a feltételes kötelezettségvállalás problémája. Városkutatás Kft., Budapest.

Hetényi, I. (2004): Adózási dilemmák. Fejlesztés és finanszírozás. 2004. 3. sz. 53-62. o.

Homolya, D. Szigel, G. (2008): Önkormányzati hitelezés-kockázatok és banki viselkedés. MNB Szemle, szeptember. 
Horváth, Gy. (2001): Az Európai Unió regionális támogatási politikája a 2000-2006 közötti időszakban. Európai tükör. 6. évf. 2-3. sz. 75-105. o.

Horváth, M.T. Bende-Szabó Bilecz Horváth Pálné Kovács Perger Péteri Szigeti Winkler (2004): A regionális politika közigazgatási feltételei. Variációk az uniós csatlakozás küszöbén. Magyar Közigazgatási Intézet, Budapest.

Hunyadi, L. Mundruczó, G. Vita, L. Kerékgyártó, G. (2001): Statisztika. 4. kiadás, Aula, Budapest.

Illés, I. (2002): A területfejlesztés pénzügyi eszközei az Európai Unióban és Magyarországon. Pénzügyi szemle. 49. évf. 7-8. sz. 677-698. o.

Iván, G. (2001): A 2006 utáni közös regionális politika. Európai tükör. 6. évf. 2-3. sz. 106-128. o.

Járosi, P. Koike, A. Thissen, M. Varga, A. (2009): Regionális fejlesztéspolitikai hatáselemzés térbeli számítható általános egyensúlyi modellel: A GMRMagyarország SCGE modellje. MÜHELYTANULMÁNYOK 4. sz. Pécsi Tudományegyetem Közgazdaságtudományi Kar Közgazdasági- és Regionális Tudományok Intézete, Pécs.

Jenei, G. Szalai, Á. (2002): Modernizing local governance in a transitional nation Evaluating the Hungarian experience. Public Management Review. 4. évf. 3. sz. 367386. o.

Jókay, K. Szepesi, G. Szmetana, G. (2004): Municipal bankruptcy framework and debt management experiences 1996-2000. In: M. KopányiD. WetzelD.S. El (szerk.): Intergovernmental Finance in Hungary. Co-publication of The World Bank and Opean Society Institute, Budapest, 593 - 616. o.

Kassó, Zs. (2006a): Miért van szükség az államháztartás pénzügyi beszámolórendszerének megváltoztatására? In: Vigvári, A. (szerk.): Decentralizáció, transzparencia, elszámoltathatóság. Magyar Közigazgatási Intézet, Budapest. 83129. o.

Kassó, Zs. (2006b): Szükség van-e államszámviteli törvényre? Az államháztartás pénzügyi információs rendszere fejlődésének irányzatai, hazai feladatok. In: Vigvári, A. (szerk.): Vissza az alapokhoz! Tanulmányok a közpénzügyi rendszer reformjáról. Új Mandátum Kiadó, Budapest, 132-154. o.

Kende, T. Szücs, T. (2002): Az Európai Unió politikái, Osiris, Budapest.

Kengyel, Á. (2008): Az Európai Unió regionális politikai támogatásai és a nemzeti fejlesztéspolitikák "európaizálódása". In: Kotosz, B. - Pál, T. (szerk.): Közgazdaságtudományi Kar. Budapesti Corvinus Egyetem, Budapest, 39-53. o.

Kengyel, Á. (2007a): Európai uniós források a 2007-2013 közötti időszakban II. A regionális fejlesztési politika. CEO magazin. 8. évf. 1. sz. 14-24. o. 
Kengyel, Á. (2007b): Európai uniós források a 2007-2013 közötti időszakban III. A fejlesztési tervek tartalma - a magyar I. és II. NFT. CEO magazin. 8. évf. 2. sz. 1-12. o.

Kengyel, Á. (2003): A fejlettségi különbségek mérséklődése az Európai Unióban. In: Blahó, A. (szerk.): Elmaradottság - fejlödés - átalakulás: Tanulmányok Szentes Tamás akadémikus 70. születésnapja tiszteletére. BKÁE Világgazdasági tanszék, Budapest, 148-156. o.

Ketskeméty, L. Izsó, L. (2005): Bevezetés az SPSS programrendszerbe. ELTE Eötvös Kiadó, Budapest.

Kinnunen, J. (2004): Multilevel Governance. The Dynamics of EU Cohesion Policy. The Structural Funds as a Vector of Change in Finland. EU Framework $V$. University of Helsinki Centre for European Studies, Helsinki.

Kopányi, M. Vigvári, A. (2003): Az önkormányzati szektor forrásbevonó képességének növelésével kapcsolatos gazdaságpolitikai kérdések. Pénzügyi szemle. 48. évf. 11. sz. 1070-1088. o.

Kopányi, M. Wetzel El (2004): Intergovernmental Finance in Hungary. A Decade of Experience 1990-2000. OSI/LGI The World Bank, Bp., Washington DC.

Kornai, J. (1992): The postsocialist transition and the state: Reflections in the light of Hungarian fiscal problems. American Economic Review, 82. évf. 2. sz.

Kovács, Á. (2009b): Közpénzügyek, költségvetés - kihívások és lehetséges válaszok. In: Sándor, P. - Vass, L. (Eds.): Magyarország politikai évkönyve 2008-ról. DKMKA, Budapest.

Kovács, Á. (2008a): Az Önkormányzati rendszer müködése - a pénzügyi ellenör olvasata. Állami Számvevőszék.

Kovács, Á. (2008b): Önkormányzatiság és gazdálkodás. Állami Számvevőszék.

Kovács, Á. (2007): A helyi önkormányzatok 2007. évi költségvetése tervezésének néhány fontosabb kérdése. Állami Számvevőszék.

Kovács, Á. (2005): Az önkormányzati szerkezet számvevőszéki tapasztalatai. Állami Számvevőszék.

Kovács, B. (2004): A helyi önkormányzatok finanszirozási lehetöségei az EU csatlakozás tükrében, Budapesti Gazdasági Főiskola, Budapest.

Kovács, E. (2009): Pénzügyi adatok statisztikai elemzése. Egyetemi tankönyv. 3. bővített kiadás, Budapesti Corvinus Egyetem Pénzügyi és Számviteli Intézet, Tanszék Kft, Budapest.

Krugman, P. (1991): Geography and trade, The MIT Press, Cambridge, MA. 
Kusztosné Nyitrai, E. Barabás, Z. (1998): A helyi önkormányzatok és pénzügyeik. Consulting, Bp.

László, M. Pálné Kovács, I. (1993): Önálló-e az önálló helyi adózás? Pénzügyi szemle. 37. évf. 3. sz. 215-220. o.

László, M. Szebényi, A. (2010): The Economic Instruments of Local Government in Hungary. Megatrend Review. 7. évf. 1. sz. 47-67. o.

Lenkei, G. (szerk.) (2003): Euró, érvek és ellenérvek, Miniszterelnöki Hivatal. Kormányzati Stratégiai Elemző Központ, Budapest.

Ligeti, Z. (2002): Gazdasági növekedés és felzárkózás. Corvinus University of Budapest, Budapest.

Lilliné Fecz, I. (2007): Az államháztartás szervezetei beszámolási és könyvvezetési kötelezettségének 2007. évi változása. Számvitel, Adó, Könyvvizsgálat, 49. évf. 3. szám, március 100-105. o.

Lilliné Fecz, I. (2004): Az európai uniós támogatások elszámolása az államháztartás szervezeteinél. Számvitel, Adó, Könyvvizsgálat, 46. évf. 6. szám, március 254-261. o.

Lóránd, B. (2009): A fejlesztéspolitika sikerességét elősegítő tényezők és a kohéziós országok tapasztalatai Magyarország számára. Tér és társadalom. 23. évf. 2. sz. 213224. o.

Lóránt, Z. (2008a): Az államháztartás helyi szintje és a helyi adók. Pénzügyi szemle. 53. évf. 4. sz. 645-662. o.

Lóránt, Z. (2008b): Az önkormányzatiság jelene és jövője. Állami Számvevőszék.

Lotz, J. (2009): Is there conformity with the Council of Europe guidelines for local finances? Pénzügyi szemle. 54. évf. 2-3. sz. 474-482. o.

Marján, A. (2009): Gondolatok az EU regionális politikájának aktuális és jövőbeli kihívásairól. Európai tükör. 14. évf. 2. sz. 68-75. o.

Miklós-Molnár, M. (2006a): Hogyan csináljuk mi, magyarok? I. Szám Adó, XV. évf. 7. sz. 19-23. o.

Miklós-Molnár, M. (2006b): Hogyan csináljuk mi, magyarok? II. Szám Adó, XV. évf. 8. sz. 11-15. o.

Miklós-Molnár, M. (2006c): Hogyan csináljuk mi, magyarok? III. Szám Adó, XV. évf. 9. sz. 14-19. o.

Miklós-Molnár, M. (2006d): Hogyan csináljuk mi, magyarok? IV. Szám Adó, XV. évf. 10. sz. 14-19. o. 
Musyck, B. - Reid, A. (2007): Innovation and Regional Development, Do European Structural Funds make a Difference? European Planning Studies, European Briefing 15. évf. 7. sz.

Nagy, G. (2007): Divergencia vagy konvergencia - az átmenet gazdasági térfolyamatainak mérlege földrajzos szemmel. Tér és Társadalom. XXI. évf. 1. sz. 35-51. o.

Nagy, K. (2002): Önkormányzati adósságregiszter. Közigazgatás-fejlesztési füzetek 5. sz.

Nagy, S. Gy. (2008): Az európai uniós támogatások hatékonyságának mérése. Hatékonyság és hatásosság az európai uniós támogatások felhasználásánál 2004 és 2006 között Magyarországon az első Nemzeti Fejlesztési Terv keretében. Corvinus University of Budapest, Budapest.

Nagy, S. Gy. (2006): Az európai uniós támogatások hatékonyságának értelmezése és mérésének módszerei. Európai tükör. 11. évf. 2. sz. 100-111. o.

Nemes Nagy, J. (2007): Kvantitatív társadalmi térelemzési eszközök a mai regionális tudományban. Tér és Társadalom, XXI. évf. 1. sz. 1-19. o.

Nemes Nagy, J. (2004): Tagolt világ - a regionális fejlődés egyenlőtlenségei. II. Magyar Földrajzi Konferencia. G. Barton - G. Dormány (szerk.): SZTE TTK Természeti Földrajzi és Geoinformatikai Tanszék, Szeged, 2-4 September 2004.

Oplotnik, Ž. (2007): A Model of Local Financing in Theory and Practice: Lessons from Slovenia, New EU Member State. East European Quarterly, 41. évf. 4. sz. 429-452. o.

Palánkai, T. (szerk.) (2004): Az európai integráció gazdaságtana. Aula Kiadó, Budapest.

Pálné Kovács, I. (2008): Helyi kormányzás Magyarországon. Dialóg Campus, Budapest, Pécs.

Pálné Kovács, I. (2004): A regionális önkormányzatok és a regionális politika (területfejlesztés) irányítása. In: Horváth M. Tamás (szerk.): A regionális politika közigazgatási feltételei: Variációk az uniós csatlakozás küszöbén. Magyar Közigazgatási Intézet, Budapest, 57-96. o.

Pálné Kovács, I. (1997): Helyi önkormányzatok és végrehajtó hatalom. In: Balás István (szerk.): A demokrácia intézményrendszere Magyarországon. MTA, Budapest, 115130. o.

Péteri, G. (2008): Decentralisation under fiscal pressure: Local government finances in Hungary. In: Sevic, Zeljko (szerk.): Local public finance in Central and Eastern Europe. 183-208. o. Elgar, Cheltenham.

Péteri, G. (2005): Önkormányzati forrásszabályozás: Ideák és javaslatok. In: Vigvári, A. (szerk.): Félúton : Tanulmányok a helyi önkormányzatok finanszírozási rendszerének 
továbbfejlesztési lehetöségeiről. Települési Önkormányzatok Országos Szövetsége, Budapest, 115-123. o.

Péteri, G. (2004): Terítéken az önkormányzatok központi forrásszabályozási rendszere ahogy a kutatók látják. Elhangzott: „Félúton. A magyar önkormányzati rendszer az Európai Uniós csatlakozás folyamatában", a Belügyminisztérium IDEA csoportjának konferenciáján, Budapest, 2004. október 20.

Peterson, G. (2000): Building Local Credit Systems. Urban Background Series. 3. kiadás, The World Bank.

Pickvance, C. (2002): Settlement Type and Local Government Environmental Policy in Hungary: the Role of Local Economic Structure and Local Government Resources. European Environment: The Journal of European Environmental Policy (Wiley), 12. évf. 2. sz.

Pinkowski, J. (2004): Institutional Arrangements and State and Local Financial Forecasting. International Journal of Public Administration. 27. évf. 8. sz. 547-556. o.

Pitti, Z. (2010): A gazdasági válság és az EU közteherviselési gyakorlatának változása. Köz-gazdaság. 5. évf. 2. sz. 21-32. o.

Pitti, Z. (2005): Az önkormányzatok pénzügyi finanszírozásának modernizációja. Magyar Közigazgatás. 55. évf. 11. sz. 665-677. o.

Pitti, Z. (2003): Az önkormányzati finanszírozás korszerüsítése (vitaanyag). Magyar Közigazgatás. 53. évf. 6. sz. 327-345. o.

Pitti, Z. (1992): A helyi adók az adórendszerben és az önkormányzati gazdálkodásban 1. Pénzügyi szemle. 36. évf. 9. sz. 688-699. o.

Porter, M.E. (1996): Competitive advantage. Agglomeration economies and regional policy. International Regional Science Review. 19. évf. 1-2. sz. 85-94. o.

Rae, R. - Kovács, Á. (2010): Együttmüködés a ,jó kormányzás” kialakításában. Pénzügyi Szemle. 55. évf. 2. sz., 380-382. o.

Romer, P. (2007): Economic Growth. In: D.R. Henderson (szerk.): The Concise Encyclopedia of Economics. Liberty Fund.

Romhányi, B. (2007): Szempontok és javaslatok a magyar fiskális szabály- és intézményrendszer reformjához. Pénzügyi szemle. 52. évf. 2. sz. 335-370. o.

Rostow, W.W. (1960): The Stages of Economic Growth: a Non-Communist Manifesto. Cambridge University Press, Cambridge.

Rusu, Elena (2008): The Strenghtening of Romanian Local Financial Autonomy's Level in the Eu Context. Annals of the University of Oradea, Economic Science Series. 17. évf. 3. sz. 513-517. o. 
Sajtos, L. - Mitev, A.Z. (2007): SPSS kutatási és adatelemzési kézikönyv. Alinea, Budapest.

Salamun, M. (2007): The Laws on the Organization of the Administration in the Czech Republic, Hungary, Poland and Slovakia: A Comparative Analysis in the Context of European Integration. Review of Central \& East European Law. 32. évf. 3. sz. 267301. o.

Santos, I. (2008): Is structural spending on solid foundations? Bruegel policy brief. 2. sz. 1-8. o.

Sasaki, R. (2007): Addendum to "A Review of the History and the Current Practice of Aid Evaluation". Journal of MultiDisciplinary Evaluation. 4. évf. 7. sz. 108. o.

Sasaki, R. (2006): A Review of the History and the Current Practice of Aid Evaluation. Journal of MultiDisciplinary Evaluation. 3. évf. 5. sz. 55-88. o.

Sevic, Z. et al. (2008): Local public finance in Central and Eastern Europe. Elgar, Cheltenham.

Sölvell, Ö. - Lindqvist, G. - Ketels, C. (2003): The Cluster Initiative Greenbook. Ivory Tower AB, Stockholm.

Straussman, J.D. - Fábián, K. (1994): Local Government Finance in Hungary: Okun Revisited. Public Budgeting and Finance. 14. évf. 4. sz. 71-83. o.

Szegvári, P. (2004): Magyarország intézményi felkészülése az európai regionális poltika alkalmazására, a regionális demokráciára. Területi statisztika. 7. évf. 3. sz. 216-235. o.

Szegvári, P. (2002): Az Európai Unió és Magyarország regionális politikája. Európai közigazgatási szemle. 1-2. sz. 4-22. o.

Székelyi, M. - Barna, I. (2008): Túlélökészlet az SPSS-hez többváltozós elemzési technikákról társadalomkutatók számára. 4. kiadás, Typotex, Bp.

Szemlér (2007): Az EU- és a magyar költségvetés kapcsolatai, a kohéziós politika alakulása. In: Fóti-Rácz (szerk.): Az Európai Unió elött álló kihívásokról és a magyar érdekekröl. 59-71. o.

Szörényiné Kukorelli (2000): Az EU regionális politikája és a magyar területfejlesztés. In: Hahn Csaba (szerk.): A területfejlesztés feladatai az ezredfordulón és az információs társadalom. Hazai Térségfejl. Budapest, 37-40. o.

Tabără, V. (2010): The Income and Expenditure Budget of the Local Public Administration. Buletin Stiintific. 15. évf. 1. sz. 85-94. o.

Tatar, M. (2010): Estonian Local Government Absorption Capacity of European Union Structural Funds. Halduskultuur. 11. évf. 2. sz. 202-226. o. 
Ter-Minassian - Teresa-Craig, J. (1997): Chapter 7. In: IMF (szerk.): Control of subnational government borrowing in Fiscal Federalism in Theory and Practice. IMF, Washington.

Trón, Zs. (2008): Az európai uniós támogatások hatásának vizsgálata. Competitio. 7. évf. 1. sz. 83-101. o.

Udvari (2010): Aid for trade "Régi-új" fejlesztési eszköz az Európai Unióba. Európai tükör. 15. évf. 6. sz. 28-42. o.

Valentinyi, Á. (1995): Endogén növekedéselmélet. Közgazdasági szemle. XLII. évf. 6. sz. 582-594. o.

Vigvári et al. (2007): A családi ezüst Tanulmányok az önkormányzati vagyongazdálkodás témaköréböl. Magyar Közigazgatási Intézet, Budapest.

Vigvári et al. (2005): Félúton Tanulmányok a helyi önkormányzatok finanszírozási rendszerének továbbfejlesztési lehetöségeiröl. Települési Önkormányzatok Országos Szövetsége, Budapest.

Vigvári, A. (2011a): Kormányzati szerepvállalás a globalizálódó gazdaságban - pénzügyi nézőpontból. In: Pénz és társadalom. BGF, Budapest.

Vigvári, A. (2011b): Néhány javaslat a kialakitandó önkormányzati pénzügyi rendszerrel kapcsolatosan. Új Magyar Közigazgatás 4. évf. 10. sz., 38-42. o.

Vigvári, A. (2011c): Önkormányzati pénzügyek. Hazai kihívások és nemzetközi példák. Állami Számvevőszék Kutató Intézete, Budapest.

Vigvári, A. (2010a): Megtelt-e a konfliktuskonténer. Gondolatok a magyar önkormányzati pénzügyek korszerüsítéséhez. In: Államszerep válság idején: Magyary Zoltán emlékkötet. CompLex, Budapest.

Vigvári, A. (2010b): Megtelt-e a konfliktuskonténer. Pénzügyi Szemle. 55. évf. 3. sz., 465-487. o.

Vigvári, A. (2009a): Atipikus önkormányzati eladósodás Magyarországon. Közgazdasági szemle. 56. évf. 7-8. sz. 709-730. o.

Vigvári, A. (2009b): Pénzügyi kockázatok az önkormányzati rendszerben. Állami Számvevőszék Kutató Intézete, Budapest.

Vigvári, A. (2005): Az önkormányzatok hitelfelvétele. In: Vigvári et al.: Félúton Tanulmányok a helyi önkormányzatok finanszírozási rendszerének továbbfejlesztési lehetöségeiröl. Települési Önkormányzatok Országos Szövetsége, Budapest, 151167. o.

Vigvári, A. (2003): Források és hiányok (Fiskális mozgástér bővítésének lehetőségei az euró-övezethez történő csatlakozás időszakában). In Lenkei, G. (szerk.): Euró, érvek és ellenérvek. MEH Stratégiai Elemző Központ, Budapest, 221-247. o. 
Vigvári, A. (2002): Közpénzügyek, önkormányzati pénzügyek. KJK-Kerszöv, Budapest.

Warvasovszky, T. (2011): Új szemlélet az önkormányzati gazdálkodás ellenőrzésében. Állami Számvevőszék.

White, H. (1992): The macroeconomic impact of development aid: A critical survey. Journal of Development Studies. 28. évf. 2. sz.

Wormser, M. (2003): Guarantee Insruments. The World Bank.

\section{Jogszabályok és egyéb elsődleges források}

\section{Hazai jogszabályok}

Magyarország Alaptörvénye (2011. április 25.)

A helyi önkormányzatokról szóló 1990. évi LXV. törvény

A helyi adókról szóló 1990. évi C. törvény

A helyi önkormányzatok adósságrendezési eljárásáról szóló 1996. évi XXV. törvény

A Helyi Önkormányzatok Európai Chartájáról szóló, 1985. október 15-én, Strasbourgban kelt egyezmény kihirdetéséről szóló 1997. évi XV. törvény

Magyarország gazdasági stabilitásáról szóló 2011. évi CXCIV. törvény

Az államháztartásról szóló 2011. évi CXCV. törvény

A nemzeti vagyonról szóló 2011. évi CXCVI. törvény

Magyarország helyi önkormányzatairól szóló 2011. évi CLXXXIX. törvény

Az államháztartás működési rendjéről szóló 217/1998. (XII. 30.) Korm. rendelet

Az államháztartás szervezetei beszámolási és könyvvezetési kötelezettségének sajátosságairól szóló 249/2000. (XII. 24.) kormányrendelet

A Nemzeti Alapnak az ISPA keretében történő igénybevételéről szóló Együttmüködési Megállapodás, valamint a 2000. évi ISPA projektek pénzügyi megállapodásainak kihirdetéséről szóló 89/2002. (IV. 20.) Korm. rendelet

Az Európai Unió által nyújtott egyes pénzügyi támogatások felhasználásával megvalósuló programok monitoring rendszerének kialakításáról szóló 124/2003. (VIII. 15.) Korm. rendelet 
Az Európai Unió Strukturális Alapjai és a Kohéziós Alap támogatásainak fogadásához kapcsolódó pénzügyi lebonyolítási, számviteli és ellenőrzési rendszerek kialakításáról szóló 233/2003. (XII. 16.) Korm. rendelet

Az Európai Unió strukturális alapjaiból és Kohéziós Alapjából származó támogatások hazai felhasználásáért felelős intézményekről szóló 1/2004. (I. 5.) Korm. Rendelet

Egyes ISPA projektek pénzügyi megállapodásainak kihirdetéséről szóló 89/2004. (IV. 20.) Korm. rendelet

A Nemzeti Fejlesztési Terv operatív programjai, az EQUAL Közösségi Kezdeményezés program és a Kohéziós Alap projektek támogatásainak fogadásához kapcsolódó pénzügyi lebonyolítási, számviteli és ellenőrzési rendszerek kialakításáról szóló 360/2004. (XII. 26.) kormányrendelet

Az államháztartásról szóló törvény végrehajtásáról szóló 368/2011. (XII. 31.) Korm. rendelet

8017/2005. számú Pénzügyminiszteri tájékoztató a strukturális alapok számviteli elszámolása az irányító hatóságok és közremüködő szervezetek részére

8008/2007. számú Pénzügyminiszteri tájékoztató a strukturális alapok számviteli elszámolása az irányító hatóságok és közremüködő szervezetek részére 2005. 08. 15.-én kiadott 8017/2005. PM Tájékoztató módosításáról

8018/2005. számú Pénzügyminiszteri tájékoztató a Kohéziós Alap számviteli elszámolása az irányító hatóságok és közremüködő szervezetek részére

8009/2007. számú Pénzügyminiszteri tájékoztató a Kohéziós Alap számviteli elszámolása az irányító hatóságok és közremüködő szervezetek részére 2005.09.15.-én kiadott 8018/2005. PM Tájékoztató módosításáról 


\section{Európai uniós jogszabályok}

A Tanács 1994. május 16-i 1164/94/EK rendelete a Kohéziós Alap létrehozásáról

A Bizottság 1994. július 26-i 1831/94/EK rendelete a Kohéziós Alap finanszírozása keretében történt szabálytalanságokról és tévesen kifizetett összegek behajtásáról, valamint egy információs rendszer e téren történő létrehozásáról

A Tanács 1999. június 21-i 1264/1999/EK rendelete a Kohéziós Alap létrehozásáról szóló 1164/94/EK rendelet módosításáról

A Tanács 1999. június 21-i 1265/1999/EK rendelete a Kohéziós Alap létrehozásáról szóló 1164/94/EK rendelet II. mellékletének módosításáról

A Tanács 1999. június 21-i 1267/99/EK rendelete az Előcsatlakozási Strukturális Politikák Eszközének létrehozásáról

A Bizottság 2002. július 29-i 1386/2002/EK rendelete az 1164/94/EK tanácsi rendelet végrehajtására vonatkozó részletes szabályainak megállapításáról a Kohéziós Alappal nyújtott támogatások irányítási és ellenőrzési rendszere, valamint a pénzügyi korrekciós eljárás tekintetében

A Bizottság 2003. január 6-ai 16/2003/EK rendelete a Kohéziós Alap által részfinanszírozott intézkedések összefüggésében a kiadások támogathatósága tekintetében a 1164/94/EK tanácsi rendelet végrehajtására vonatkozó különleges részletes szabályok megállapításáról

A Tanács 1999. június 21-i 1260/1999/EK rendelete a strukturális alapokra vonatkozó általános rendelkezések megállapításáról

A Bizottság 2001. március 2-i 438/2001/EK rendelete a strukturális alapok keretében nyújtott támogatások irányítási és ellenőrzési rendszerei tekintetében az 1260/1999/EK tanácsi rendelet végrehajtása részletes szabályainak megállapításáról

A Bizottság 2001. március 2-i 448/2001/EK rendelete a strukturális alapok keretében nyújtott támogatások pénzügyi korrekciós eljárásai tekintetében az 1260/1999/EK tanácsi rendelet végrehajtása részletes szabályainak megállapításáról

1991/271/EGK Tanácsi irányelv a települési szennyvíz kezeléséről

1998/83/EK Tanácsi irányelv az emberi fogyasztásra szánt víz minőségéről

1999/31/EK Tanácsi irányelv a hulladéklerakókról 


\section{Egyéb elsödleges források}

Állami Számvevőszék (2008): 0822. sz. jelentés. Állami Számvevőszék, Budapest

Council of Europe (1985): European Charter of Local Self-Government.s Strasbourg.

DEXIA (2011): Subnational public finance in the European Union. DEXIA Crédit Local, July2011.

MNB (2006): Elemzés a konvergencia-folyamatokról. Magyar Nemzeti Bank, Budapest.

Municipum Magyarország Alapítvány (2003): A helyi önkormányzatok finanszírozása. Municipum Magyarország Alapítvány, Budapest.

\section{Internetes források}

Európai Bizottság: Térkép az 1. célkitüzés szerint támogatható ás átmeneti támogatásban részesülö régiókról. Elérhető: http://ec.europa.eu/regional_policy/ objective1/map_en.htm [Letöltés idöpontja: 2011. október 22.]

Európai Tanács (2012): A Tanács COM/2012/0104 sz. ajánlása a Magyarországon fennálló túlzott költségvetési hiány megszüntetéséről (2012). Elérhető: http://eurlex.europa.eu/LexUriServ/LexUriServ.do?uri=COM:2012:0104:FIN:HU:HTML [Letöltés idöpontja: 2012. augusztus 1.]

Központi Statisztikai Hivatal (2011): Tájékoztatási adatbázis. Elérhető: http://statinfo.ksh.hu/Statinfo/index.jsp. [Letöltés idöpontja: 2011. október 13.]

Nemzeti Fejlesztési Ügynökség (Ed.) (2007a): Nemzeti Fejlesztési Terv dokumentumai. Elérhető: http://www.nfu.hu/doc/128. [Letöltés idöpontja: 2012. július 9.]

Nemzeti Fejlesztési Ügynökség (2007b): A projektek számviteli elszámolása. Elérhető: www.nfu.hu/24_A\%20projektek\%20számviteli\%20elszámolása.pdf [Letöltés idöpontja: 2011. november 15.]

Sapir, A. et al. (2003): An agenda for a growing Europe. Making the EU Economic System Deliver, Elérhetö: http://www.euractiv.com/ndbtext/innovation/sapirreport.pdf. [Letöltés idöpontja: 2011. október 20.] 
Mellékletek 


\section{1. számú melléklet: A regionális politika célkitüzései}

1. célkitüzés: elmaradott régiók ${ }^{168}$, melyek egy főre jutó GDP-je a közösségi átlag 75\%-a alatt van, továbbá Finnország és Svédország alacsony népességü területei, valamint a tengerentúli francia megyék, a Kanári-szigetek, a portugál Azoriszigetek és Madeira.

Az 1994-1999 közötti programozási időszakban elmaradottnak minősülő, de az 1. célkitűzésnek - a növekedés miatt már nem - megfelelő területek ún. csökkenő átmeneti támogatásban részesülnek, melyek az ún. phasing-out régiók.

2. célkitüzés: strukturális nehézségekkel küszködő, gazdasági és szociális átalakulásra szoruló régiók ${ }^{169}$, ahol súlyos problémákat okoz a munkanélküliség, a szegény népesség, a károsodott környezet, a bűnözési ráta, az alacsony képzettség.

3. célkitüzés: humán erőforrásokkal kapcsolatos fejlödési nehézségekkel küzdő régiók, amelyek az 1. és 2. célkitüzésbe nem tartoznak, azonban a társadalmigazdasági kohézió biztosításához oktatási, szakképzési modernizáció szükséges.

\footnotetext{
${ }^{168}$ Itt: NUTS II régiók.

${ }^{169}$ Iparilag hanyatló területek, magas agrárfoglalkoztatottságú rurális térségek, halászati munkahelyekkel rendelkező területek.
} 


\section{2. számú melléklet: A tagállamoknak támogatást nyújtó alapok (2000- 2006 programozási periódus)}

A 2000-2006 közötti - vagyis a kutatás tárgyát képező - programozási periódusban a következő alapok támogatásait igényelhették a tagállamok ${ }^{170}$.

- Európai Regionális Fejlesztési Alap (ERFA): célja a társadalmi és gazdasági kohézió elősegítése a regionális egyenlőtlenségek csökkentésével, valamint az ipari szerkezetváltás és strukturális munkanélküliség miatti egyenlőtlenségek kezelése, melynek érdekében támogatást nyújt vállalkozások számára, hozzájárul az infrastruktúra ${ }^{171}$ kialakításhoz, valamint pénzügyi eszközökkel támogatja a regionális fejlődést.

- Európai Szociális Alap (ESZA): célja a humánerőforrás-fejlesztés támogatása, a munkaerő képzése, a munkanélküliség csökkentése, a foglalkoztatás elősegítése, a kirekesztés elleni küzdelem, az oktatási rendszer hatékonyságának növelése és az információs társadalom igényeinek támogatása a képzésen keresztül. Ennek érdekében támogatja többek között az élethosszig tartó tanulást, a hátrányos helyzetűek társadalmi integrációját és a diszkrimináció elleni küzdelmet.

- Európai Mezőgazdasági Orientációs és Garancia Alap orientációs részlege (EMOGA): célja a vidékfejlesztés, a mezőgazdaság termelékenységének növelése és a piacok stabilitásának megteremtése a mezőgazdaságban. Az alap 2007-től új néven - Európai Mezőgazdasági és Vidékfejlesztési Alap - müködik tovább az agrárpolitika keretein belül.

- Halászati Orientációs Pénzügyi Eszköz (HOPE): célja versenyképes halászati vállalkozások létrehozása, a fenntartható egyensúly megteremtése a halgazdálkodásban, valamint a halászati struktúrák modernizálása. Az alap 2007től Európai Halászati Alap néven müködik tovább a halászati politikán belül.

\footnotetext{
${ }^{170}$ Magyarország mind a négy alap támogatására jogosult volt 2004 és 2006 között a Nemzeti Fejlesztési Terv keretében.

${ }^{171}$ Kutatás-fejlesztés, környezetvédelmi, közlekedési hálózatok, energetikai beruházások
} 
3. számú melléklet: Térkép az 1. célkitűzés szerint támogatható ás átmeneti támogatásban részesülő régiókról

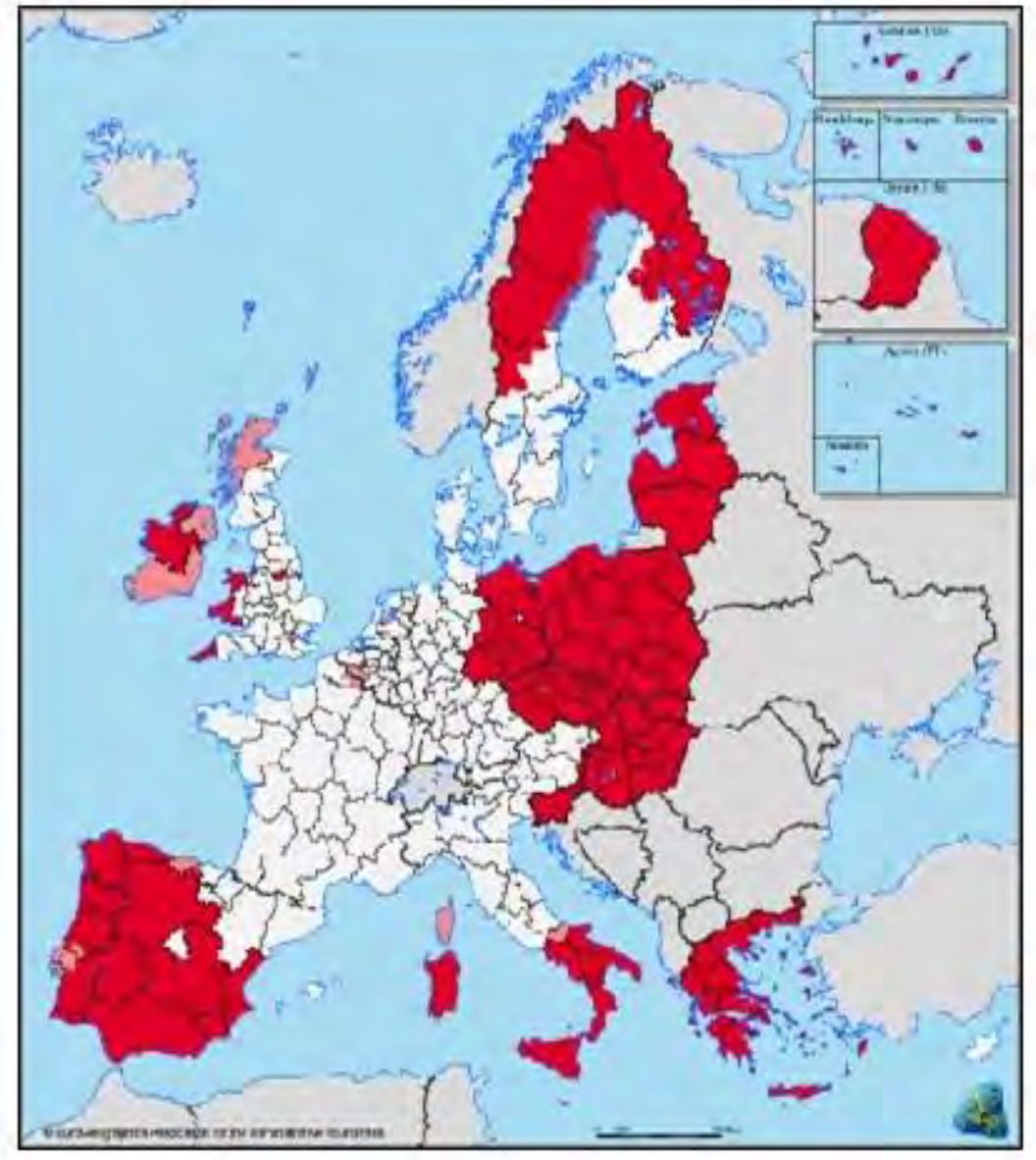

1. céllkitüzés szerint támogatható régiók

1. célkitüzés szerinti átmeneti támogatás

Svédország partvidéki területeinek támogatását célzó speciális program

Forrás: http://ec.europa.eu/regional_policy/objective1/map_en.htm; letöltés ideje 2011. október 22. 
4. számú melléklet: A Nemzeti Fejlesztési Terv (2004-2006) operatív programjai

\begin{tabular}{|c|c|c|}
\hline $\begin{array}{c}\text { Operatív program } \\
\text { megnevezése, fóbb } \\
\text { célok }\end{array}$ & $\begin{array}{c}\text { Operatív programon belüli } \\
\text { prioritások }\end{array}$ & Finanszírozó Alapok \\
\hline \multirow{4}{*}{$\begin{array}{l}\text { Agrár és Vidékfejlesztési } \\
\text { Operatív Program } \\
\text { (AVOP) } \\
\text { (Mezőgazdaság } \\
\text { modernizációjának } \\
\text { elősegítése és a vidéki } \\
\text { térségek felzárkóztatása) }\end{array}$} & $\begin{array}{l}\text { Versenyképes alapanyag } \\
\text { termelés megalapozása a } \\
\text { mezőgazdaságban }\end{array}$ & $\begin{array}{l}\text { Európai Mezőgazdasági } \\
\text { Orientációs és Garancia } \\
\text { Alap orientációs részlege } \\
\text { és Halászati Orientációs } \\
\text { Pénzügyi Eszköz }\end{array}$ \\
\hline & $\begin{array}{l}\text { Az élelmiszer-feldolgozás } \\
\text { modernizálása }\end{array}$ & \multirow{3}{*}{$\begin{array}{l}\text { Európai Mezőgazdasági } \\
\text { Orientációs és Garancia } \\
\text { Alap orientációs részlege }\end{array}$} \\
\hline & A vidéki térségek fejlesztése & \\
\hline & Technikai segítségnyújtás & \\
\hline \multirow{5}{*}{$\begin{array}{l}\text { Gazdasági } \\
\text { Versenyképesség } \\
\text { Operatív Program } \\
\text { (GVOP) }\end{array}$} & Beruházás-ösztönzés & \multirow{5}{*}{$\begin{array}{l}\text { Európai Regionális } \\
\text { Fejlesztési Alap }\end{array}$} \\
\hline & $\begin{array}{l}\text { Kis- és középvállalkozások } \\
\text { fejlesztése }\end{array}$ & \\
\hline & Kutatás-fejlesztés, innováció & \\
\hline & $\begin{array}{l}\text { Információs társadalom- és } \\
\text { gazdaságfejlesztés }\end{array}$ & \\
\hline & Technikai segítségnyújtás & \\
\hline \multirow{5}{*}{$\begin{array}{l}\text { Humánerőforrás- } \\
\text { fejlesztési Operatív } \\
\text { Program (HEFOP) } \\
\text { (foglalkozási szint } \\
\text { emelése, munkaerő } \\
\text { versenyképességének } \\
\text { javítása, társadalmi } \\
\text { beilleszkedés elősegítése) }\end{array}$} & $\begin{array}{l}\text { Aktív munkaerő-piaci } \\
\text { intézkedések támogatása }\end{array}$ & \multirow{3}{*}{$\begin{array}{l}\text { Európai Regionális } \\
\text { Fejlesztési Alap }\end{array}$} \\
\hline & $\begin{array}{l}\text { A társadalmi kirekesztődés } \\
\text { elleni küzdelem a munkaerő } \\
\text { piacra való belépés } \\
\text { elősegítésével }\end{array}$ & \\
\hline & $\begin{array}{l}\text { Az egész életen át tartó tanulás } \\
\text { támogatása és az } \\
\text { alkalmazkodóképesség javítása }\end{array}$ & \\
\hline & $\begin{array}{l}\text { Az oktatás, a szociális } \\
\text { szolgáltatások és az } \\
\text { egészségügyi ellátórendszer } \\
\text { infrastruktúrájának fejlesztése }\end{array}$ & Európai Szociális Alap \\
\hline & Technikai segítségnyújtás & $\begin{array}{l}\text { Európai Regionális } \\
\text { Fejlesztési Alap }\end{array}$ \\
\hline \multirow{3}{*}{$\begin{array}{l}\text { Környezetvédelmi és } \\
\text { Infrastruktúra-fejlesztési } \\
\text { Operatív Program } \\
\text { (KIOP) } \\
\text { (környezet állapotának } \\
\text { javítása és közlekedés } \\
\text { fejlesztése) }\end{array}$} & Környezetvédelem & \multirow[b]{3}{*}{$\begin{array}{l}\text { Európai Regionális } \\
\text { Fejlesztési Alap }\end{array}$} \\
\hline & $\begin{array}{l}\text { A közlekedési infrastruktúra } \\
\text { fejlesztése }\end{array}$ & \\
\hline & Technikai segítségnyújtás & \\
\hline
\end{tabular}




\begin{tabular}{|l|l|l|}
\hline Regionális Fejlesztési & Turisztikai potenciál erösítése & Európai Regionális \\
Operatív Program (ROP) & $\begin{array}{l}\text { Térségi infrastruktúra és } \\
\text { települési környezet fejlesztése }\end{array}$ & Fejlesztési Alap \\
\cline { 2 - 3 } (elmaradott térségek & $\begin{array}{l}\text { A régiók humán eröforrásának } \\
\text { fejlesztése }\end{array}$ & Európai Szociális Alap \\
\cline { 2 - 3 } $\begin{array}{l}\text { fejlesztése, regionális } \\
\text { gazdasági környezet } \\
\text { javítása) }\end{array}$ & Technikai segítségnyújtás & $\begin{array}{l}\text { Európai Regionális } \\
\text { Fejlesztési Alap }\end{array}$ \\
\hline
\end{tabular}

Operatív Programok Magyarországon 2004-2006 között (saját készítés, (Kengyel 2007b) alapján) 


\section{5. számú melléklet: Strukturális Alapokból támogatott operatív programok magyarországi intézményrendszere 2004-2006}

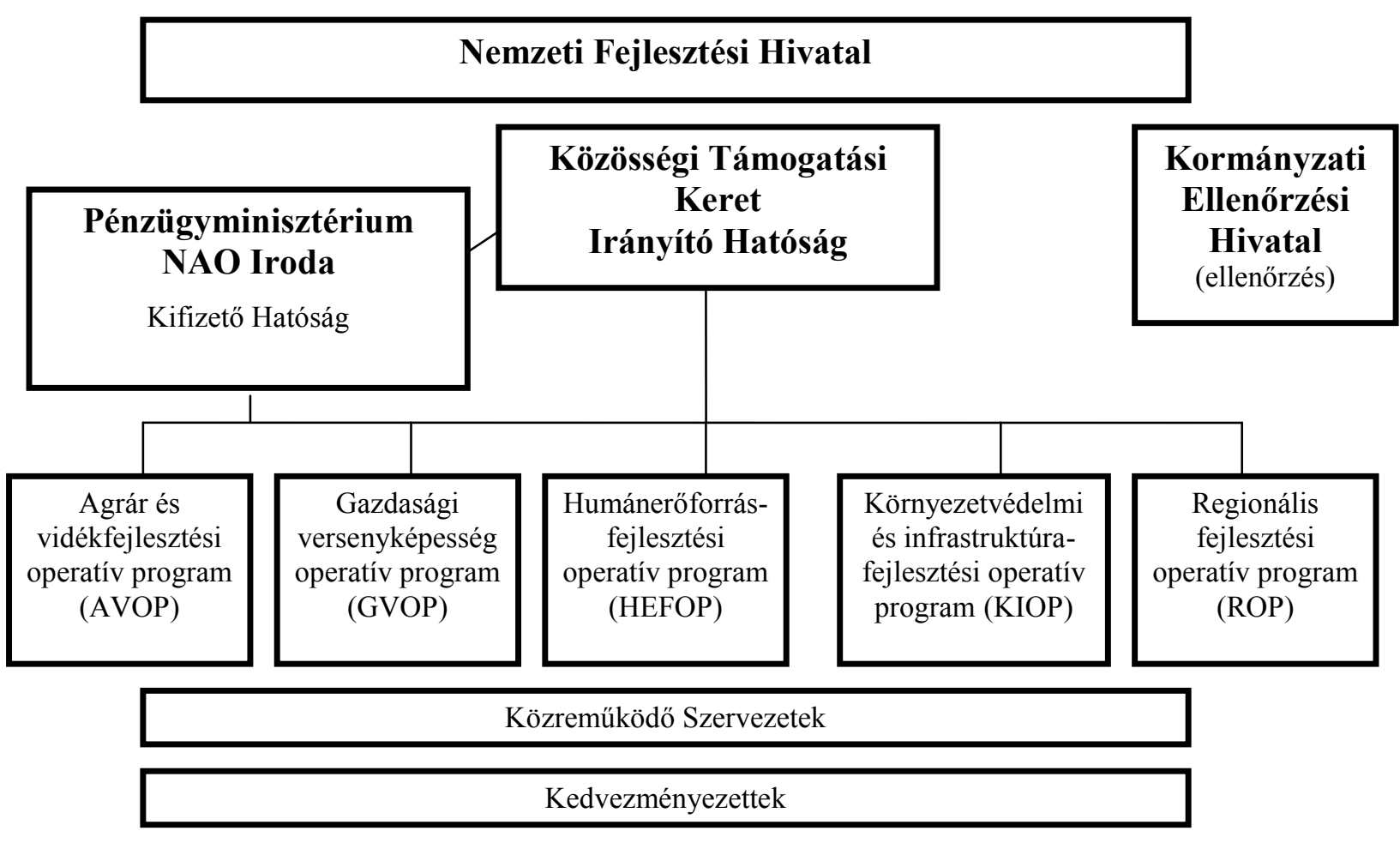




\section{6. számú melléklet: Kifizetési folyamatok Strukturális Alapokból megvalósuló projektek esetében}

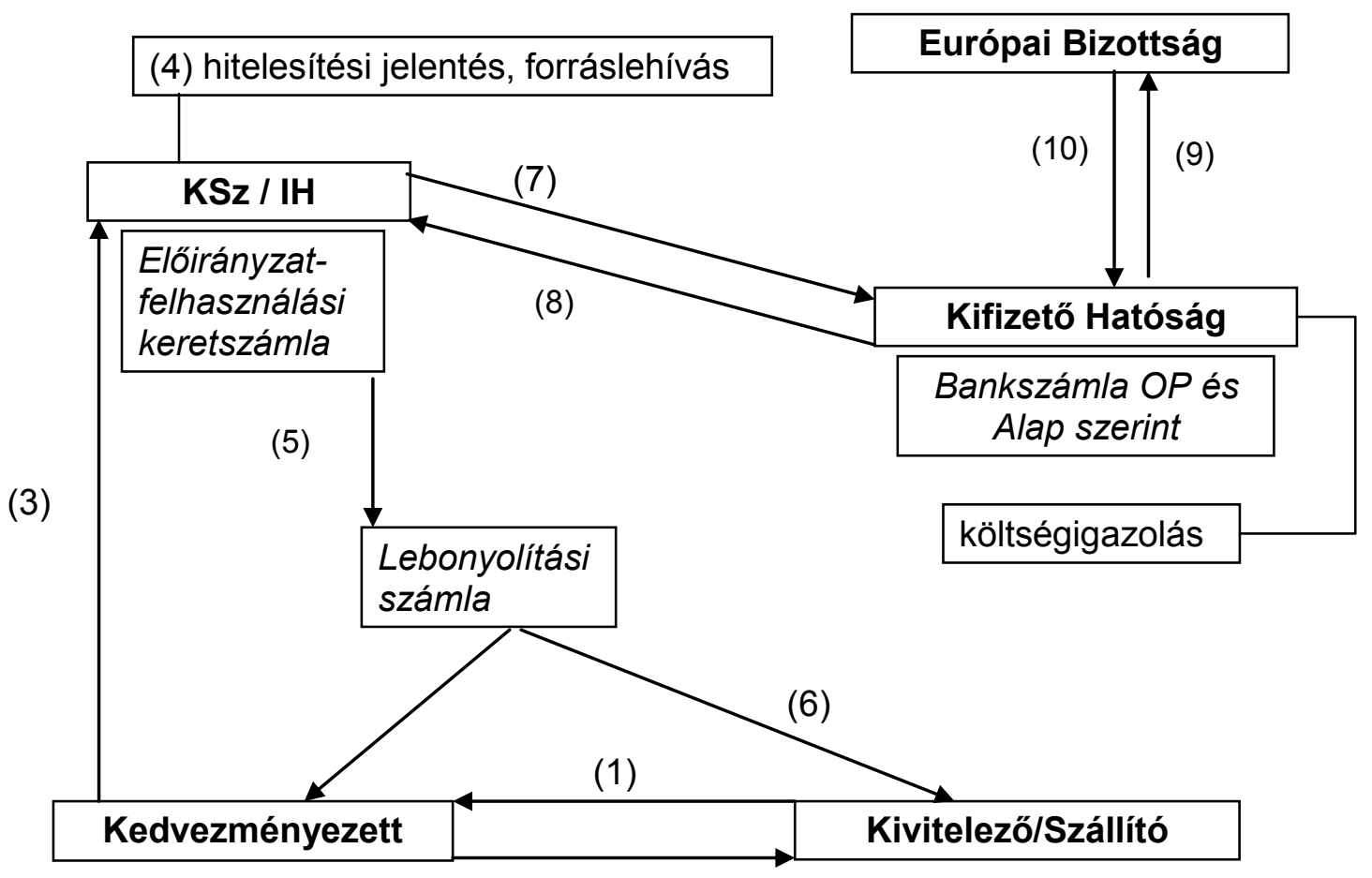

(2)

6. számú ábra a kifizetési folyamatokról Strukturális Alapokból megvalósuló projektek esetében (saját készitésü ábra)

A kifizetési folyamat lépései a következők:

1.: A szállító - a köztük lévő szerződésben foglaltaknak megfelelően - benyújtja számláját (vagy elöleg igényét) a kedvezményezettnek.

2.: A kedvezményezett a teljesítést igazolja, és kifizeti a szállítói számlát - vagy csak a rá eső önerőt, vagy a teljes összeget - a támogatási szerződésben foglaltaknak megfelelően.

3.: A kedvezményezett Projekt elörehaladási jelentést és kifizetési kérelmet küld a közremüködő szervezetnek, vagy az irányító hatóságnak. ${ }^{172}$ (továbbiakban KSz/IH)

4.: A KSz/IH a benyújtott kifizetési kérelem alapján hitelesítési jelentést készít és kezdeményezi a forráslehívást.

5.: A KSz/IH az előirányzat felhasználási keretszámláról a támogatás teljes összegét - kizárólag nemzeti forrásból - megelőlegezi, és az ún. lebonyolítási számlára utalja.

\footnotetext{
${ }^{172}$ Attól függően, hogy az irányító hatóság milyen feladatokat delegált az egyes közremüködő szervezeteknek.
} 
6.: A lebonyolítási számláról a támogatást folyósítják a szállítónak vagy a kedvezményezettnek attól függően, hogy a (2) lépésben a kedvezményezett a teljes szállítói számlát rendezte-e, vagy csak a rá eső részt.

Az első hat lépésben tehát megtörténik a szállítói számla rendezése, azonban az európai uniós támogatás elszámolása nem, tehát ha a folyamat itt megszakadna, akkor a támogatás kizárólag hazai forrásból származna. Megjegyzendő, hogy a pénzügyi elszámolás részeként elsődlegesen pénzforgalmi mozgások történnek, a vagyon keletkezésének helye a kedvezményezett.

7.: Az irányító hatóság elkészíti a közösségi hozzájárulás rendezéséhez szükséges iratokat, mellyel lehívja - a hazai forrásból megelőlegezett - európai uniós támogatást a kifizető hatóságtól. Az irányító hatóság negyedévente összeállítja a költségnyilatkozatot, ami az Európai Bizottságtól történő igénylés összeállításának alapjául szolgál és megalapozza a kifizető hatóság igazoló tevékenységét.

8.: A kifizető hatóság operatív programonként és alaponként bankszámlákkal rendelkezik, melyekről az európai uniós támogatást utólagosan átutalja az irányító hatóságnak a rendelkezésére álló elölegből.

\section{Elszámolás az Európai Bizottság és a kifizető hatóság között}

9.: A kifizető hatóság költségigazolást készít, és átutalási igénylést nyújt be az Európai Bizottság felé.

10.: Az Európai Bizottság időközi vagy végső kifizetés formájában ${ }^{173}$ átutalja az európai uniós támogatást.

${ }^{173}$ Értelemszerűen az előleg átutalása korábban megtörténik. 


\section{7. számú melléklet: A hipotézisekben szereplő fogalmak operacionalizálása}

Bevételi szerkezet: a helyi önkormányzat bevételein belül a saját bevételek, az átengedett bevételek, a felhalmozási és tőke jellegü bevételek, az állami hozzájárulások és támogatások, valamint a hitelek és értékpapírok egymáshoz viszonyított aránya.

Finanszírozás egyenlege: a helyi önkormányzatok finanszírozási bevételeinek és finanszírozási kiadásainak különbsége.

Finanszirozási bevételek: rövid lejáratú hitelek felvétele + likvid hitelek felvétele + hosszú lejáratú hitelek felvétele + forgatási célú belföldi értékpapírok kibocsátása + forgatási célú értékpapírok értékesítése + befektetési célú belföldi értékpapírok kibocsátása + hosszú lejáratú értékpapírok értékesítése + hosszú lejáratú külföldi értékpapírok kibocsátása + hitelfelvétel külföldről + egyéb finanszírozás bevételei

Finanszírozási kiadások: rövid lejáratú hitelek törlesztése + likvid hitelek törlesztése + hosszú lejáratú hitelek törlesztése + forgatási célú belföldi értékpapírok beváltása + forgatási célú értékpapírok beváltása + hosszú lejáratú belföldi értékpapírok beváltása + hosszú lejáratú értékpapírok vásárlása + hosszú lejáratú külföldi értékpapírok beváltása + hiteltörlesztés külföldre + egyéb finanszírozás kiadásai

Folyósított európai uniós támogatás: a Nemzeti Fejlesztési Terv keretében a helyi önkormányzat részére folyósított, strukturális alapokból származó támogatások együttes összege

Helyi önkormányzat: a község, város önkormányzata, amely a feladat- és hatáskörébe tartozó helyi közügyekben önállóan jár el és a 2004-2008. naptári évekre vonatkozóan a Magyar Államkincstár területileg illetékes részére beszámolóját eljuttatta. A kutatás során a vizsgálatnak nem képezi tárgyát a fővárosi és megyei önkormányzatok, valamint a főváros kerületi önkormányzatainak vizsgálata.

Helyi önkormányzatok nagysága: a települések élők lélekszáma

Helyi önkormányzatok területi elhelyezkedése: az a NURS1 nagyrégió, NUTS2 régió, NUTS3 besorolás szerinti megye, amelyben a település fekszik. 
Kötelezettségvállalás növekedése: A helyi önkormányzatok könyvviteli mérlegében szereplö hosszúlejáratú kötelezettségek, illetve rövid lejáratú kötelezettségek alá tartozó mérlegtételek értékének növekedése 2004 és 2008 között.

Saját bevételek: intézményi tevékenységek bevételei; kamatbevételek; ÁFA bevételek, illetékek; helyi adók; személyi jövedelemadó bevételek; egyéb átengedett adók; helyi adókkal kapcsolatos önkormányzatot illető bírságok és egyéb sajátos bevételek; adójellegü bevételek; osztalékok, koncessziós díjak 
8. számú melléklet: Könyvviteli mérlegek és költségvetési jelentések szerkezete a) Könyvviteli mérleg 2004

\begin{tabular}{|c|c|c|c|}
\hline $\begin{array}{l}\text { Változó } \\
\text { száma }\end{array}$ & ESZKÖZÖK & $\begin{array}{l}\text { Változó } \\
\text { száma }\end{array}$ & FORRÁSOK \\
\hline 01 & 1.Alapítás-átszervezés aktivált értéke & 61 & 1.Induló tőke \\
\hline 02 & 2.Kísérleti fejlesztés aktivált értéke & 62 & 2.Tőkeváltozások \\
\hline 03 & 3.Vagyoni értékü jogok & 63 & 3.Értékelési tartalék \\
\hline 04 & 4.Szellemi termékek & 64 & D.) SAJÁT TÖKE ÖSSZESEN $(61+62+63)$ \\
\hline 05 & 5.Immateriális javakra adott előlegek & 65 & 1.Költségvetési tartalék elszámolása \\
\hline 06 & 6.Immateriális javak értékhelyesbítése & 66 & tárgyévi költségvetési tartalék elszámolása \\
\hline 07 & I. Immateriális javak összesen & 67 & előző év(ek) költségvetési tartalékának elszámolása \\
\hline 08 & 1.Ingatlanok és a kapcsolódó vagyoni értékü jogok & 68 & 2.Költségvetési pénzmaradvány \\
\hline 09 & 2.Gépek, berendezések és felszerelések & 69 & 3.Kiadási megtakarítás \\
\hline 10 & 3.Jármüvek & 70 & 4.Bevételi lemaradás \\
\hline 11 & 4.Tenyészállatok & 71 & 5.Előirányzat-maradvány \\
\hline 12 & 5.Beruházások,felújítások & 72 & I. Költségvetési tartalékok összesen $(65+68+69+70+71)$ \\
\hline 13 & 6.Beruházásra adott előlegek & 73 & 1.Vállalkozási tartalék elszámolása \\
\hline 14 & 7.Állami készletek, tartalékok & 74 & tárgyévi vállalkozási tartalék elszámolása \\
\hline 15 & 8.Tárgyi eszközök értékhelyesbítése & 75 & előző év(ek) vállalkozási tartalékának elszámolása \\
\hline 16 & II. Tárgyi eszközök összesen & 76 & Vállalkozási tevékenység eredménye \\
\hline 17 & 1.Egyéb tartós részesedés & 77 & Vállalkozási tevékenység kiadási megtakarítása \\
\hline 18 & 2.Tartós hitelviszonyt megtestesítő értékpapír & 78 & Vállalkozási tevékenység bevételi lemaradása \\
\hline 19 & 3.Tartósan adott kölcsön & 79 & II. Vállalkozási tartalékok összesen $(73+76+77+78)$ \\
\hline 20 & 4.Hosszú lejáratú bankbetétek & 80 & E.) TARTALÉKOK ÖSSZESEN $(72+79)$ \\
\hline 21 & 5.Egyéb hosszú lejáratú követelések & 81 & 1.Hosszú lejáratra kapott kölcsönök \\
\hline 22 & 6.Befektetett pénzügyi eszközök értékhelyesbítése & 82 & 2.Tartozások fejlesztési célú kötvénykibocsátásból \\
\hline 23 & III. Befektetett pénzügyi eszközök összesen & 83 & 3.Tartozások müködési célú kötvénykibocsátásból \\
\hline 24 & 1.Üzemeltetésre, kezelésre átadott eszközök & 84 & 4.Beruházási és fejlesztési hitelek \\
\hline 25 & 2.Koncesszióba adott eszközök & 85 & 5.Müködési célú hosszú lejáratú hitelek \\
\hline 26 & 3.Vagyonkezelésbe adott eszközök & 86 & 6.Egyéb hosszú lejáratú kötelezettségek \\
\hline 27 & 4.Vagyonkezelésbe vett eszközök & 87 & I. Hosszú lejáratú kötelezettségek összesen $(81+\ldots . . . .86)$ \\
\hline 28 & $\begin{array}{l}\text { 5.Üzem-re, kezelésre, koncesszióba, vagyonkezelésbeli eszközök } \\
\text { értékhelyesbítése }\end{array}$ & 88 & 1.Rövid lejáratú kölcsönök \\
\hline 29 & IV.Üzem-re,kezelésre,koncesszióba,vagyonkezelésben lévö eszközök & 89 & 2.Rövid lejáratú hitelek \\
\hline 30 & A.) BEFEKTETETT ESZKÖZÖK ÖSSZESEN (07+16+23+29) & 90 & 3.Kötelezettségek áruszállítás-,szolgáltatásból(szállítók) \\
\hline 31 & 1.Anyagok & 91 & - tárgyévi költségvetést terhelő szállítói kötelezettségek \\
\hline 32 & 2.Befejezetlen termelés és félkész termékek & 92 & - tárgyévet követő évet terhelő szállítói kötelezettségek \\
\hline 33 & 3.Növendék-, hízó és egyéb állatok & 93 & 4.Egyéb rövid lejáratú kötelezettségek \\
\hline 34 & 4.Késztermékek & 94 & - váltótartozások \\
\hline 35 & 5/a Áruk,betétdíjas göngyölegek,közvetített szolgáltatás & 95 & - munkavállalókkal szembeni különféle kötelezettségek \\
\hline 36 & 5/b Követelés fejében átvett eszközök, készletek & 96 & - költségvetéssel szembeni kötelezettségek \\
\hline 37 & I. Készletek összesen & 97 & - iparüzési adó feltöltés miatti kötelezettségek \\
\hline 38 & 1.Követelések áruszállításból és szolgáltatásból (vevők) & 98 & - helyi adó túlfizetés \\
\hline 39 & 2.Adósok & 99 & - szabálytalan kifizetések miatti kötelezettségek \\
\hline 40 & 3.Rövid lejáratú kölcsönök & 100 & - hosszú lejáratra kapott kölcsön köv.évi törlesztése \\
\hline 41 & 4.Egyéb követelések & 101 & - felhalm.célú kötv.kibocs-ból szárm. tartoz. köv.évi tör.részl. \\
\hline 42 & kölcsönböl mérlegforduló napot követő évbeni részlet & 102 & működési célú kötv.kib.szárm. tart. köv.évi törlesztése \\
\hline 43 & támogatási program előlegek & 103 & - beruházási, fejlesztési hitelek köv. évet terhelő tör.részletei \\
\hline 44 & támogatási programok szabálytalan kifizetése miatti követelés & 104 & - működési célú hosszú lejáratú hitelek köv. évi törlesztése \\
\hline 45 & II. Követelések összesen & 105 & - egyéb hosszú lejáratú kötelezettség köv. évi törlesztése \\
\hline 46 & 1. Egyéb részesedés & 106 & - tárgyévi költségvetést terhelő rövid lejáratú kötelezettségek \\
\hline 47 & 2. Forgatási célú hitelviszony megtestesító értékpapírok & 107 & - egyéb különféle kötelezettségek \\
\hline 48 & III. Értékpapírok összesen & 108 & II. Rövid lejáratú kötelezettségek összesen \\
\hline 49 & 1.Pénztárak, csekkek, betétkönyvek & 109 & 1.Költségvetési passzív függő elszámolások \\
\hline 50 & 2.Költségvetési bankszámlák & 110 & 2.Költségvetési passzív átfutó elszámolások \\
\hline 51 & 3.Elszámolási számlák & 111 & 3.Költségvetési passzív kiegyenlítő elszámolások \\
\hline 52 & 4.Idegen pénzeszközök & 112 & 4.Költségvetésen kívüli passzív pénzügyi elszámolások \\
\hline 53 & IV. Pénzeszközök összesen & 113 & Költségvetésen kívüli letéti elszámolások \\
\hline 54 & 1.Költségvetési aktív függő elszámolások & 114 & Nemzetközi támogatási programok deviza elszámolása \\
\hline 55 & 2.Költségvetési aktív átfutó elszámolások & 115 & $\begin{array}{l}\text { III. Egyéb passzív pénzügyi elszámolások összesen } \\
(109+\ldots+112)\end{array}$ \\
\hline 56 & 3.Költségvetési aktív kiegyenlítő elszámolások & 116 & F.) KÖTELEZETTSÉGEK ÖSSZESEN \\
\hline 57 & 4.Költségvetésen kívüli aktív pénzügyi elszámolások & 117 & F O RRÁ SOK ÖS SZESEN \\
\hline 58 & V. Egyéb aktív pénzügyi elszámolások összesen & \multirow{3}{*}{\multicolumn{2}{|c|}{ A1: nyitó ért }} \\
\hline 59 & B.) FORGÓESZKÖZÖK ÖSSZESEN & & \\
\hline 60 & ESZKÖ Z Ö K Ö S S Z E S E N & & \\
\hline
\end{tabular}


b) Könyvviteli mérleg 2005 és 2006 (azonos szerkezet)

\begin{tabular}{|c|c|c|c|}
\hline $\begin{array}{l}\text { Változó } \\
\text { száma }\end{array}$ & ESZKÖZÖK & $\begin{array}{l}\text { Változó } \\
\text { száma }\end{array}$ & FORRÁSOK \\
\hline 01 & 1.Alapítás-átszervezés aktivált értéke & 63 & 1.Induló tőke \\
\hline 02 & 2.Kísérleti fejlesztés aktivált értéke & 64 & 2.Tőkeváltozások \\
\hline 03 & 3.Vagyoni értékü jogok & 65 & 3.Értékelési tartalék \\
\hline 04 & 4.Szellemi termékek & 66 & D.) SAJÁT TŐKE ÖSSZESEN $(63+64+65)$ \\
\hline 05 & 5.Immateriális javakra adott elölegek & 67 & 1.Költségvetési tartalék elszámolása \\
\hline 06 & 6.Immateriális javak értékhelyesbítése & 68 & tárgyévi költségvetési tartalék elszámolása \\
\hline 07 & I. Immateriális javak összesen & 69 & előző év(ek) költségvetési tartalékának elszámolása \\
\hline 08 & 1.Ingatlanok és a kapcsolódó vagyoni értékü jogok & 70 & 2.Költségvetési pénzmaradvány \\
\hline 09 & 2.Gépek, berendezések és felszerelések & 71 & 3.Kiadási megtakarítás \\
\hline 10 & 3.Járművek & 72 & 4.Bevételi lemaradás \\
\hline 11 & 4.Tenyészállatok & 73 & 5.Elöirányzat-maradvány \\
\hline 12 & 5.Beruházások,felújítások & 74 & I. Költségvetési tartalékok összesen $(67+70+\ldots 73)$ \\
\hline 13 & 6.Beruházásra adott előlegek & 75 & 1.Vállalkozási tartalék elszámolása \\
\hline 14 & 7.Állami készletek, tartalékok & 76 & tárgyévi vállalkozási tartalék elszámolása \\
\hline 15 & 8.Tárgyi eszközök értékhelyesbítése & 77 & előző év(ek) vállalkozási tartalékának elszámolása \\
\hline 16 & II. Tárgyi eszközök összesen & 78 & Vállalkozási tevékenység eredménye \\
\hline 17 & 1.Egyéb tartós részesedés & 79 & Vállalkozási tevékenység kiadási megtakarítása \\
\hline 18 & 2.Tartós hitelviszonyt megtestesítő értékpapír & 80 & Vállalkozási tevékenység bevételi lemaradása \\
\hline 19 & 3.Tartósan adott kölcsön & 81 & II. Vállalkozási tartalékok összesen $(75+78+79+80)$ \\
\hline 20 & 4.Hosszú lejáratú bankbetétek & 82 & E.) TARTALÉKOK ÖSSZESEN $(74+81)$ \\
\hline 21 & 5.Egyéb hosszú lejáratú követelések & 83 & 1.Hosszú lejáratra kapott kölcsönök \\
\hline 22 & 6.Befektetett pénzügyi eszközök értékhelyesbítése & 84 & 2.Tartozások fejlesztési célú kötvénykibocsátásból \\
\hline 23 & III. Befektetett pénzügyi eszközök összesen & 85 & 3.Tartozások müködési célú kötvénykibocsátásból \\
\hline 24 & 1.Üzemeltetésre, kezelésre átadott eszközök & 86 & 4.Beruházási és fejlesztési hitelek \\
\hline 25 & 2.Koncesszióba adott eszközök & 87 & 5.Működési célú hosszú lejáratú hitelek \\
\hline 26 & 3.Vagyonkezelésbe adott eszközök & 88 & 6.Egyéb hosszú lejáratú kötelezettségek \\
\hline 27 & 4.Vagyonkezelésbe vett eszközök & 89 & I. Hosszú lejáratú kötelezettségek összesen $(83+\ldots . . . .88)$ \\
\hline 28 & $\begin{array}{l}\text { 5.Üzem-re, kezelésre, koncesszióba, vagyonkezelésbeli eszközök } \\
\text { értékhelyesbítése }\end{array}$ & 90 & 1.Rövid lejáratú kölcsönök \\
\hline 29 & IV.Üzem-re,kezelésre,koncesszióba,vagyonkezelésben lévö eszközök & 91 & 2.Rövid lejáratú hitelek \\
\hline 30 & A.) BEFEKTETETT ESZKÖZÖK ÖSSZESEN (07+16+23+29) & 92 & 3.Kötelezettségek áruszállítás-,szolgáltatásból(szállítók) \\
\hline 31 & 1.Anyagok & 93 & - tárgyévi költségvetést terhelö szállítói kötelezettségek \\
\hline 32 & 2.Befejezetlen termelés és félkész termékek & 94 & - tárgyévet követő évet terhelő szállítói kötelezettségek \\
\hline 33 & 3.Növendék-, hízó és egyéb állatok & 95 & 4.Egyéb rövid lejáratú kötelezettségek \\
\hline 34 & 4.Késztermékek & 96 & - váltótartozások \\
\hline 35 & 5/a Áruk,betétdíjas göngyölegek,közvetített szolgáltatás & 97 & - munkavállalókkal szembeni különféle kötelezettségek \\
\hline 36 & 5/b Követelés fejében átvett eszközök, készletek & 98 & - költségvetéssel szembeni kötelezettségek \\
\hline 37 & I. Készletek összesen & 99 & - iparüzési adó feltöltés miatti kötelezettségek \\
\hline 38 & 1.Követelések áruszállításból és szolgáltatásból (vevők) & 100 & - helyi adó túlfizetés \\
\hline 39 & 2.Adósok & 101 & - támogatási program előlege miatti kötelezettség \\
\hline 40 & 3.Rövid lejáratú kölcsönök & 102 & - szabálytalan kifizetések miatti kötelezettségek \\
\hline 41 & 4.Egyéb követelések & 103 & - garancia és kezességvállalásból származó kötelezettség \\
\hline 42 & kölcsönből mérlegforduló napot követő évbeni részlet & 104 & - hosszú lejáratra kapott kölcsön köv.évi törlesztése \\
\hline 43 & Hosszú lejáratú követelésből mérleg fordulónapot követő évbeni részlet & 105 & - felhalm.célú kötv.kibocs-ból szárm. tartoz. köv.évi tör.részl. \\
\hline 44 & \begin{tabular}{|l|} 
támogatási program előlegek \\
\end{tabular} & 106 & - müködési célú kötv.kib.szárm. tart. köv.évi törlesztése \\
\hline 45 & támogatási programok szabálytalan kifizetése miatti követelés & 107 & - beruházási, fejlesztési hitelek köv. évet terhelő tör.részletei \\
\hline 46 & - garancia és kezességvállalásból származó követelések & 108 & - müködési célú hosszú lejáratú hitelek köv. évi törlesztése \\
\hline 47 & II. Követelések összesen & 109 & - egyéb hosszú lejáratú kötelezettség köv. évi törlesztése \\
\hline 48 & 1. Egyéb részesedés & 110 & - tárgyévi költségvetést terhelő rövid lejáratú kötelezettségek \\
\hline 49 & 2. Forgatási célú hitelviszony megtestesítő értékpapírok & 111 & $\begin{array}{l}\text { - tárgyévet követő évet terhelő egyéb rövid lejáratú } \\
\text { kötelezettségek }\end{array}$ \\
\hline 50 & III. Értékpapírok összesen & 112 & - egyéb különféle kötelezettségek \\
\hline 51 & 1.Pénztárak, csekkek, betétkönyvek & 113 & II. Rövid lejáratú kötelezettségek összesen \\
\hline 52 & 2.Költségvetési bankszámlák & 114 & 1.Költségvetési passzív függő elszámolások \\
\hline 53 & 3.Elszámolási számlák & 115 & 2.Költségvetési passzív átfutó elszámolások \\
\hline 54 & 4.Idegen pénzeszközök & 116 & 3.Költségvetési passzív kiegyenlítő elszámolások \\
\hline 55 & IV. Pénzeszközök összesen & 117 & 4.Költségvetésen kívüli passzív pénzügyi elszámolások \\
\hline 56 & 1.Költségvetési aktív függő elszámolások & 118 & Költségvetésen kívüli letéti elszámolások \\
\hline 57 & 2.Költségvetési aktív átfutó elszámolások & 119 & Nemzetközi támogatási programok deviza elszámolása \\
\hline 58 & 3.Költségvetési aktív kiegyenlítő elszámolások & 120 & $\begin{array}{l}\text { III. Egyéb passzív pénzügyi elszámolások összesen } \\
(114+\ldots+119)\end{array}$ \\
\hline 59 & 4.Költségvetésen kívüli aktív pénzügyi elszámolások & 121 & F.) KÖTELEZETTSÉGEK ÖSSZESEN \\
\hline 60 & V. Egyéb aktív pénzügyi elszámolások összesen & 122 & F ORRÁSOK ÖS SZESE N \\
\hline 61 & B.) FORGÓESZKÖZÖK ÖSSZESEN & & \\
\hline 62 & E S Z K Ö Z Ö K Ö S S Z E S E N & & \\
\hline
\end{tabular}

A2: záró értékek, csak ezek szerepelnek változóként a kutatásban 


\begin{tabular}{|c|c|c|c|}
\hline $\begin{array}{l}\text { Változó } \\
\text { száma }\end{array}$ & ESZKÖZÖK & $\begin{array}{l}\text { Változó } \\
\text { száma }\end{array}$ & FORRÁSOK \\
\hline 01 & 1.Alapítás-átszervezés aktivált értéke & 64 & 1.Induló tőke \\
\hline 02 & 2.Kísérleti fejlesztés aktivált értéke & 65 & 2.Tőkeváltozások \\
\hline 03 & 3.Vagyoni értékü jogok & 66 & 3.Értékelési tartalék \\
\hline 04 & 4.Szellemi termékek & 67 & D.) SAJÁT TŐKE ÖSSZESEN $(64+65+66)$ \\
\hline 05 & 5.Immateriális javakra adott előlegek & 68 & 1.Költségvetési tartalék elszámolása \\
\hline 06 & 6.Immateriális javak értékhelyesbítése & 69 & tárgyévi költségvetési tartalék elszámolása \\
\hline 07 & I. Immateriális javak összesen & 70 & előző év(ek) költségvetési tartalékának elszámolása \\
\hline 09 & 2.Gépek, berendezések és felszerelések & 72 & 3.Kiadási megtakarítás \\
\hline 10 & 3.Jármüvek & 73 & 4.Bevételi lemaradás \\
\hline 11 & 4.Tenyészállatok & 74 & 5.Elöirányzat-maradvány \\
\hline 12 & 5.Beruházások,felújítások & 75 & I. Költségvetési tartalékok összesen $(68+71+\ldots 74)$ \\
\hline 13 & 6.Beruházásra adott előlegek & 76 & 1.Vállalkozási tartalék elszámolása \\
\hline 14 & 7.Állami készletek, tartalékok & 77 & tárgyévi vállalkozási tartalék elszámolása \\
\hline 15 & 8.Tárgyi eszközök értékhelyesbítése & 78 & előző év(ek) vállalkozási tartalékának elszámolása \\
\hline 16 & II. Tárgyi eszközök összesen & 79 & Vállalkozási tevékenység eredménye \\
\hline 18 & 2.Tartós hitelviszonyt megtestesítő értékpapír & 81 & Vállalkozási tevékenység bevételi lemaradása \\
\hline 19 & 3.Tartósan adott kölcsön & 82 & II. Vállalkozási tartalékok összesen $(76+79+80+81)$ \\
\hline 20 & 4.Hosszú lejáratú bankbetétek & 83 & E.) TARTALÉKOK ÖSSZESEN (75+82) \\
\hline 21 & 5.Egyéb hosszú lejáratú követelések & 84 & 1.Hosszú lejáratra kapott kölcsönök \\
\hline 22 & 6.Befektetett pénzügyi eszközök értékhelyesbítése & 85 & 2.Tartozások fejlesztési célú kötvénykibocsátásból \\
\hline 23 & III. Befektetett pénzügyi eszközök összesen & 86 & 3.Tartozások müködési célú kötvénykibocsátásból \\
\hline 24 & 1.Üzemeltetésre, kezelésre átadott eszközök & 87 & 4.Beruházási és fejlesztési hitelek \\
\hline 25 & 2.Koncesszióba adott eszközök & 88 & 5.Müködési célú hosszú lejáratú hitelek \\
\hline 26 & 3.Vagyonkezelésbe adott eszközök & 89 & 6.Egyéb hosszú lejáratú kötelezettségek \\
\hline 27 & 4.Vagyonkezelésbe vett eszközök & 90 & I. Hosszú lejáratú kötelezettségek összesen 84+.......89) \\
\hline 28 & $\begin{array}{l}\text { 5.Üzem-re, kezelésre, koncesszióba, vagyonkezelésbeli eszközök } \\
\text { értékhelyesbítése }\end{array}$ & 91 & 1.Rövid lejáratú kölcsönök \\
\hline 29 & IV.Üzem-re,kezelésre,koncesszióba,vagyonkezelésben lévö eszközök & 92 & 2.Rövid lejáratú hitelek \\
\hline 30 & A.) BEFEKTETETT ESZKÖZÖK ÖSSZESEN (07+16+23+29) & 93 & 3.Kötelezettségek áruszállítás-,szolgáltatásból(szállítók) \\
\hline 31 & 1.Anyagok & 94 & - tárgyévi költségvetést terhelő szállítói kötelezettségek \\
\hline 32 & 2.Befejezetlen termelés és félkész termékek & 95 & - tárgyévet követő évet terhelő szállítói kötelezettségek \\
\hline 33 & 3.Növendék-, hízó és egyéb állatok & 96 & 4.Egyéb rövid lejáratú kötelezettségek \\
\hline 36 & 5/b Követelés fejében átvett eszközök, készletek & 99 & - költségvetéssel szembeni kötelezettségek \\
\hline 37 & I. Készletek összesen & 100 & - iparüzési adó feltöltés miatti kötelezettségek \\
\hline 38 & 1.Követelések áruszállításból és szolgáltatásból (vevők) & 101 & - helyi adó túlfizetés \\
\hline 39 & 2.Adósok & 102 & - nemzetközi támogatási programok miatti kötelezettségek \\
\hline 40 & 3.Rövid lejáratú kölcsönök & 103 & - támogatási program előlege miatti kötelezettség \\
\hline 41 & 4.Egyéb követelések & 104 & - szabálytalan kifizetések miatti kötelezettségek \\
\hline 42 & kölcsönből mérlegforduló napot követő évbeni részlet & 105 & - garancia és kezességvállalásból származó kötelezettség \\
\hline 43 & $\begin{array}{l}\text { egyéb hosszú lejáratú követelésböl mérleg fordulónapot követö évbeni } \\
\text { részlet }\end{array}$ & 106 & - hosszú lejáratra kapott kölcsön köv.évi törlesztése \\
\hline 44 & nemzetközi támogatási programok miatti követelések & 107 & - felhalm.célú kötv.kibocs-ból szárm. tartoz. köv.évi tör.részl. \\
\hline 45 & támogatási program elölegek & 108 & - müködési célú kötv.kib.szárm. tart. köv.évi törlesztése \\
\hline 46 & támogatási programok szabálytalan kifizetése miatti követelés & 109 & - beruházási, fejlesztési hitelek köv. évet terhelő tör.részletei \\
\hline 47 & - garancia és kezességvállalásból származó követelések & 110 & - müködési célú hosszú lejáratú hitelek köv. évi törlesztése \\
\hline 48 & II. Követelések összesen & 111 & - egyéb hosszú lejáratú kötelezettség köv. évi törlesztése \\
\hline 49 & 1. Egyéb részesedés & 112 & - tárgyévi költségvetést terhelö rövid lejáratú kötelezettségek \\
\hline 50 & 2. Forgatási célú hitelviszony megtestesítő értékpapírok & 113 & $\begin{array}{l}\text { - tárgyévet követö évet terhelö egyéb rövid lejáratú } \\
\text { kötelezettségek }\end{array}$ \\
\hline 51 & III. Értékpapírok összesen & 114 & - egyéb különféle kötelezettségek \\
\hline 52 & 1.Pénztárak, csekkek, betétkönyvek & 115 & II. Rövid lejáratú kötelezettségek összesen \\
\hline 53 & 2.Költségvetési bankszámlák & 116 & 1.Költségvetési passzív függő elszámolások \\
\hline 54 & 3.Elszámolási számlák & 117 & 2.Költségvetési passzív átfutó elszámolások \\
\hline 55 & 4.Idegen pénzeszközök & 118 & 3.Költségvetési passzív kiegyenlítő elszámolások \\
\hline 56 & IV. Pénzeszközök összesen & 119 & 4.Költségvetésen kívüli passzív pénzügyi elszámolások \\
\hline 57 & 1.Költségvetési aktív függő elszámolások & 120 & Költségvetésen kívüli letéti elszámolások \\
\hline 58 & 2.Költségvetési aktív átfutó elszámolások & 121 & Nemzetközi támogatási programok deviza elszámolása \\
\hline 59 & 3.Költségvetési aktív kiegyenlítő elszámolások & 122 & $\begin{array}{l}\text { III. Egyéb passzív pénzügyi elszámolások összesen } \\
(114+\ldots+119)\end{array}$ \\
\hline 60 & 4.Költségvetésen kívüli aktív pénzügyi elszámolások & 123 & F.) KÖTELEZETTSÉGEK ÖSSZESEN \\
\hline 61 & V. Egyéb aktív pénzügyi elszámolások összesen & 124 & FORRÁSOK ÖSSZESEN \\
\hline 62 & B.) FORGÓESZKÖZÖK ÖSSZESEN & & \\
\hline 63 & E S Z K Ö Z Ö K Ö S S Z E S E N & & \\
\hline
\end{tabular}


d) Költségvetési jelentés 2004

\begin{tabular}{|c|c|}
\hline 01 & Rendszeres személyi juttatás \\
\hline 02 & Nem rendszeres személyi juttatás \\
\hline 03 & Külső személyi juttatások \\
\hline 04 & Személyi juttatások \\
\hline 05 & TB., munkaadói járulék, és táppénz-hozzájárulás \\
\hline 06 & Egészségügyi hozzájárulás \\
\hline 07 & Dologi kiadások ÁFA nélkül és realizált árfolyamveszteségek \\
\hline 08 & Dologi kiadások ÁFÁ-ja \\
\hline 9 & Egyéb folyó kiadások (kamatkiadások, előző évi maradvány visszafizetése nélkül) \\
\hline 10 & Előző évi maradvány visszafizetése \\
\hline 11 & Ellátottak pénzbeli juttatásai \\
\hline 12 & Müködési célú pénzeszköz átadás központi költségvetési szervnek \\
\hline 13 & Müködési célú pénzeszköz átadás fejezeti kezelésű elöirányzatnak \\
\hline 14 & Müködési célú pénzeszköz átadás elkülönített állami pénzalapnak \\
\hline 15 & Müködési célú pénzeszköz átadás társadalombiztosítási alapnak \\
\hline 16 & Müködési célú pénzeszköz átadás helyi önkormányzatnak \\
\hline 17 & Múködési célú pénzeszköz átadás Római sz. 87. cikk önkormányzati többségi tulajdonú egyéb vállalkozásoknak \\
\hline 18 & Müködési célú pénzeszköz átadás Római sz. 87. cikk nem önkormányzati többségi tulajdonú egyéb vállalkozásoknak \\
\hline 19 & Müködési célú pénzeszköz átadás Római 87. cikk, egyéb vállalkozásnak (17+18) \\
\hline 20 & Müködési célú pénzeszköz átadás önkormányzati többségi tulajdonú egyéb vállalkozásoknak (nem 17. sor alatt) \\
\hline 21 & Müködési célú pénzeszköz átadás nem önkormányzati többségi tulajdonú egyéb vállalkozásoknak (nem 18. sor alatt) \\
\hline 22 & Müködési célú pénzeszköz átadás egyéb vállalkozásnak (19+20+21) \\
\hline 23 & Müködési célú pénzeszköz átadás pénzügyi vállalkozásoknak \\
\hline 24 & Müködési célú pénzeszköz átadás háztartásoknak \\
\hline 25 & Működési célú pénzeszköz átadás non-profit szervezeteknk \\
\hline 26 & Múködési célú pénzeszköz átadás külföldre \\
\hline 27 & Társadalom-, és szociálpolitikai juttatások \\
\hline 28 & Tervezett maradvány, eredmény tartalék \\
\hline 29 & Egyéb müködési célú támogatások, kiadások $(12+\ldots \ldots+16+22+\ldots+28)$ \\
\hline 30 & Kamatkiadások \\
\hline 31 & Felújítás \\
\hline 32 & Intézményi beruházási kiadások ÁFA nélkül \\
\hline 33 & Beruházások ÁFÁ-ja \\
\hline 34 & Felhalmozási célú pénzeszköz átadás központi költségvetési szervnek \\
\hline 35 & Felhalmozási célú pénzeszköz átadás fejezeti kezelésű előirányzatnak \\
\hline 36 & Felhalmozási célú pénzeszköz átadás elkülönített állami pénzalapnak \\
\hline 37 & Felhalmozási célú pénzeszköz átadás társadalombiztosítási alapnak \\
\hline 38 & Felhalmozási célú pénzeszköz átadás helyi önkormányzatoknak \\
\hline 39 & Felhalmozási célú pénzeszköz átadás Római sz. 87. cikk, önkormányzati többségi tulajdonú egyéb vállalkozásoknak \\
\hline 40 & Felhalmozási célú pénzeszköz átadás Római sz. 87. cikk, nem önkormányzati többségi tulajdonú egyéb vállalkozásoknak \\
\hline 41 & Felhalmozási célú pénzeszköz átadás Római 87. cikk egyéb vállalkozásnak (39+40) \\
\hline 42 & Felhalmozási célú pénzeszköz átadás nem önkormányzati többségi tulajdonú egyéb vállalkozásoknak (40. sor nélkül) \\
\hline 43 & Felhalmozási célú pénzeszköz átadás önkormányzati többségi tulajdonú egyéb vállalkozásoknak (39. sor nélkül) \\
\hline 44 & Felhalmozási célú pénzeszköz átadás egyéb vállalkozásoknak $(41+42+43)$ \\
\hline 45 & Felhalmozási célú pénzeszköz átadás pénzügyi vállalkozásoknak \\
\hline 46 & Felhalmozási célú pénzeszköz átadás háztartásoknak \\
\hline 47 & Felhalmozási célú pénzeszköz átadás non-profit szervezeteknek \\
\hline 48 & Felhalmozási célú pénzeszközátadás külföldre \\
\hline 49 & Felhalmozási kiadások $(31+\ldots .38+44+\ldots \ldots .48)$ \\
\hline 50 & Kölcsönök nyújtása államháztartáson belülre \\
\hline 51 & Kölcsönök nyújtása államháztartáson kívülre \\
\hline 52 & Kölcsönök törlesztése államháztartáson belülre \\
\hline 53 & Pénzügyi befektetések kiadásaiból részesedések vásárlása \\
\hline 54 & Felügyelet alá tartozó költségvetési szerveknek folyósított támogatás \\
\hline 55 & KIADÁSOK $(04+\ldots \ldots+11+29+30+49+\ldots \ldots .54)$ \\
\hline 56 & Intézményi müködési bevétel ÁFA nélkül \\
\hline 57 & ÁFA bevételek, visszatérülések \\
\hline 58 & Kamatbevételek \\
\hline 59 & Gépjármủadó \\
\hline 60 & Helyi adók \\
\hline 61 & ebböl: Építményadó \\
\hline 62 & ebböl: Telekadó \\
\hline 63 & ebből: Vállalkozók kommunális adója \\
\hline 64 & ebböl: Magánszemélyek kommunális adója \\
\hline 65 & ebböl: Idegenforgalmi adó tartózkodás után \\
\hline 66 & ebből: Idegenforgalmi adó épület után \\
\hline 67 & ebből: Iparüzési adó állandó jelleggel végzett iparúzési tevékenység után \\
\hline 68 & ebböl: Iparüzési adó ideiglenes jelleggel végzett iparüzési tevékenység után \\
\hline 69 & Illetékek \\
\hline 70 & Személyi jövedelemadó \\
\hline 71 & Egyéb átengedett adók, adójellegü bevételek \\
\hline 72 & Bírságok és egyéb sajátos bevételek \\
\hline 73 & Müködési célú pénzeszköz átvétel társadalombiztosítási alaptól \\
\hline 74 & Működési célú pénzeszköz átvétel elkülönített állami pénzalaptól \\
\hline 75 & Költségvetési kiegészítések, visszatérülések \\
\hline 76 & Működési célú pénzeszköz átvétel központi költségvetési szervtől \\
\hline 77 & Működési célú pénzeszköz átvétel fejezeti kezelésủ előirányzattól \\
\hline 78 & Müködési célra átvett pénzeszközök helyi önkormányzatoktól \\
\hline 79 & Müködési célra átvett pénzeszközök vállalkozásoktól \\
\hline 80 & Múködési célra átvett pénzeszközök pénzügyi vállalkozásoktól \\
\hline 81 & Müködési célra átvett pénzeszközök háztartásoktól \\
\hline 82 & Müködési célra átvett pénzeszközök non-profit szervezetektől \\
\hline 83 & Múködési célra átvett pénzeszközök nemzetközi szervezetektől \\
\hline 84 & Müködési célra átvett pénzeszközök egyéb külföldi forrásból \\
\hline 85 & Egyéb müködési célú pénzeszközátvétel, bevételek $(75+\ldots . .84)$ \\
\hline
\end{tabular}




\begin{tabular}{|c|c|}
\hline 86 & Felhamozási célú pénzeszközátvétel a TB. alapoktól és kezelöitől \\
\hline 87 & Felhamozási célú pénzeszközátvétel az elkülönített állami alapoktól \\
\hline 88 & Tárgyi eszközök, immateriális javak értékesítése \\
\hline 89 & Felhalmozási célú pénzeszközátvétel központi költségvetési szervtől \\
\hline 90 & Felhalmozási célú pénzeszközátvétel fejezei kezelésű előirányzattól \\
\hline 91 & Felhalmozási célú pénzeszközátvétel helyi önkormányzatoktól \\
\hline 92 & Felhalmozási célra átvett pénzeszközök vállalkozásoktól \\
\hline 93 & Felhalmozási célra átvett pénzeszközök pénzügyi vállalkozásoktól \\
\hline 94 & Felhalmozási célra átvett pénzeszközök háztartásoktól \\
\hline 95 & Felhalmozási célra átvett pénzeszközök non-profit szervezetektől \\
\hline 96 & Felhalmozási célra átvett pénzeszközök nemzetközi szervezetektől \\
\hline 97 & Felhalmozási célra kapott juttatások EU-tól \\
\hline 98 & Felhalmozási célra kapott juttatások kormányoktól \\
\hline 99 & Felhalmozási célra kapott juttatások külföldről (nem nemzetközi szervtől) \\
\hline 100 & Felhalmozási célra átvett pénzeszközök külföldi forrásból $(96+\ldots+99)$ \\
\hline 101 & Önkormányzati lakások, egyéb helyiségek értékesítése, cseréje \\
\hline 102 & Privatizációból származó bevételek \\
\hline 103 & Vállalatértékesítésből származó bevételek \\
\hline 104 & Vagyoni értékủ jog értékesítéséből, egyéb vagyonhasznosításból származó bevétel \\
\hline 105 & Felhalmozási bevételek $(88+\ldots \ldots 95+100+\ldots \ldots+104)$ \\
\hline 106 & Kölcsönök visszatérülése államháztartáson belülröl \\
\hline 107 & Kölcsönök visszatérülése államháztartáson kívülről \\
\hline 108 & Kölcsönök igénybevétele államháztartáson belülröl \\
\hline 109 & Osztalékok, üzemeltetési és koncessziós díjak \\
\hline 110 & Pénzügyi befektetések bevételeiből részesedések \\
\hline 111 & Saját bevételek $(56+\ldots+60+69+\ldots \ldots 74+85+86+87+105+\ldots+110)$ \\
\hline 112 & Önkormányzat költségvetési támogatása \\
\hline 113 & Felügyeleti szervtől kapott támogatás \\
\hline 114 & Tárgyévi kiadások és bevételek egyenlege ) 55-111-112-113) \\
\hline 115 & Előző évi előirányzat-maradvány, pénzmaradvány igénybevétele \\
\hline 116 & Rövid lejáratú hitelek törlesztése \\
\hline 117 & Hosszú lejáratú hitelek törlesztése \\
\hline 118 & Rövid lejáratú értékpapírok beváltása \\
\hline 119 & Rövid lejáratú értékpapírok vásárlása \\
\hline 120 & Hosszú lejáratú értékpapírok beváltása \\
\hline 121 & Hosszú lejáratú értékpapírok vásárlása \\
\hline 122 & Hosszú lejáratú külföldi értékpapírok beváltása \\
\hline 123 & Hiteltörlesztés külföldre \\
\hline 124 & Egyéb finanszírozás kiadásai \\
\hline 125 & Finanszírozási kiadások $(116+\ldots .+124)$ \\
\hline 126 & Rövid lejáratú hitelek bevételei \\
\hline 127 & Hosszú lejáratú hitelek bevételei \\
\hline 128 & Rövid lejáratú értékpapírok kibocsátása \\
\hline 129 & Rövid lejáratú értékpapírok értékesítése \\
\hline 130 & Hosszú lejáratú belföldi értékpapírok kibocsátása \\
\hline 131 & Hosszú lejáratú értékpapírok értékesítése \\
\hline 132 & Hosszú lejárató külföldi értékpapírok kibocsátása \\
\hline 133 & Hitelfelvétel külföldröl \\
\hline 134 & Egyéb finanszírozás bevételei \\
\hline 135 & Finanszírozási bevételek $(126+\ldots+134)$ \\
\hline 136 & Finanszírozás összesen $(115-125+1359=(114)$ \\
\hline 137 & Pénzkészl/pénztár, bank, változása $(111+112+113+28-55-125+135)$ \\
\hline 138 & Pénzkészlet január 1 -jén 1 \\
\hline 139 & Pénzkészlet a tárgyidőszak végén $(137+138)$ \\
\hline 140 & Foglalkoztatottak létszáma (fö) - időszakra \\
\hline 141 & Munkajogi létszám a tárgyidőszak végén \\
\hline
\end{tabular}


e) Költségvetési jelentés 2005

\begin{tabular}{|c|c|}
\hline 01 & Rendszeres személyi juttatás \\
\hline 02 & Nem rendszeres személyi juttatás \\
\hline 03 & Külső személyi juttatások \\
\hline 04 & Személyi juttatások \\
\hline 05 & TB., munkaadói járulék, és táppénz-hozzájárulás \\
\hline 06 & Egészségügyi hozzájárulás \\
\hline 07 & Dologi kiadások ÁFA nélkül és realizált árfolyamveszteségek \\
\hline 08 & Dologi kiadások ÁFÁ-ja \\
\hline 9 & Egyéb folyó kiadások (kamatkiadások, előző évi maradvány visszafizetése nélkül) \\
\hline 10 & Elöző évi maradvány visszafizetése \\
\hline 11 & Ellátottak pénzbeli juttatásai \\
\hline 12 & Müködési célú pénzeszköz átadás központi költségvetési szervnek \\
\hline 13 & Működési célú pénzeszköz átadás fejezeti kezelésű előirányzatnak \\
\hline 14 & Müködési célú pénzeszköz átadás elkülönített állami pénzalapnak \\
\hline 15 & Müködési célú pénzeszköz átadás társadalombiztosítási alapnak \\
\hline 16 & Müködési célú pénzeszköz átadás helyi önkormányzatnak \\
\hline 17 & Müködési célú pénzeszköz átadás Római sz. 87. cikk önkormányzati többségi tulajdonú egyéb vállalkozásoknak \\
\hline 18 & Müködési célú pénzeszköz átadás Római sz. 87. cikk nem önkormányzati többségi tulajdonú egyéb vállalkozásoknak \\
\hline 19 & Müködési célú pénzeszköz átadás Római 87. cikk, egyéb vállalkozásnak (17+18) \\
\hline 20 & Müködési célú pénzeszköz átadás önkormányzati többségi tulajdonú egyéb vállalkozásoknak (nem 17. sor alatt) \\
\hline 21 & Müködési célú pénzeszköz átadás nem önkormányzati többségi tulajdonú egyéb vállalkozásoknak (nem 18. sor alatt) \\
\hline 22 & Müködési célú pénzeszköz átadás egyéb vállalkozásnak (19+20+21) \\
\hline 23 & Müködési célú pénzeszköz átadás pénzügyi vállalkozásoknak \\
\hline 24 & Müködési célú pénzeszköz átadás háztartásoknak \\
\hline 25 & Müködési célú pénzeszköz átadás non-profit szervezeteknk \\
\hline 26 & Müködési célú pénzeszköz átadás külföldre \\
\hline 27 & Társadalom-, és szociálpolitikai juttatások \\
\hline 28 & Tervezett maradvány, eredmény tartalék \\
\hline 29 & Egyéb múködési célú támogatások, kiadások $(12+\ldots \ldots+16+22+\ldots+28)$ \\
\hline 30 & Kamatkiadások \\
\hline 31 & Felújítás \\
\hline 32 & Intézményi beruházási kiadások ÁFA nélkül \\
\hline 33 & Beruházások ÁFÁ-ja \\
\hline 34 & Felhalmozási célú pénzeszköz átadás központi költségvetési szervnek \\
\hline 35 & Felhalmozási célú pénzeszköz átadás fejezeti kezelésű előirányzatnak \\
\hline 36 & Felhalmozási célú pénzeszköz átadás elkülönített állami pénzalapnak \\
\hline 37 & Felhalmozási célú pénzeszköz átadás társadalombiztosítási alapnak \\
\hline 38 & Felhalmozási célú pénzeszköz átadás helyi önkormányzatoknak \\
\hline 39 & Felhalmozási célú pénzeszköz átadás Római sz. 87. cikk, önkormányzati többségi tulajdonú egyéb vállalkozásoknak \\
\hline 40 & Felhalmozási célú pénzeszköz átadás Római sz. 87. cikk, nem önkormányzati többségi tulajdonú egyéb vállalkozásoknak \\
\hline 41 & Felhalmozási célú pénzeszköz átadás Római 87. cikk egyéb vállalkozásnak (39+40) \\
\hline 42 & Felhalmozási célú pénzeszköz átadás nem önkormányzati többségi tulajdonú egyéb vállalkozásoknak (40. sor nélkül) \\
\hline 43 & Felhalmozási célú pénzeszköz átadás önkormányzati többségi tulajdonú egyéb vállalkozásoknak (39. sor nélkül) \\
\hline 44 & Felhalmozási célú pénzeszköz átadás egyéb vállalkozásoknak $(41+42+43)$ \\
\hline 45 & Felhalmozási célú pénzeszköz átadás pénzügyi vállalkozásoknak \\
\hline 46 & Felhalmozási célú pénzeszköz átadás háztartásoknak \\
\hline 47 & Felhalmozási célú pénzeszköz átadás non-profit szervezeteknek \\
\hline 48 & Felhalmozási célú pénzeszközátadás külföldre \\
\hline 49 & Garancia-kezességvállalásból származó pénzeszköz átadás államháztartáson belül \\
\hline 50 & Garancia-kezességvállalásból származó pénzeszköz átadás államháztartáson kívül \\
\hline 51 & Felhalmozási kiadások $(31+\ldots .38+44+\ldots \ldots .50)$ \\
\hline 52 & Kölcsönök nyújtása államháztartáson belülre \\
\hline 53 & Kölcsönök nyújtása államháztartáson kívülre \\
\hline 54 & Kölcsönök törlesztése államháztartáson belülre \\
\hline 55 & Pénzügyi befektetések kiadásaiból részesedések vásárlása \\
\hline 56 & Felügyelet alá tartozó költségvetési szerveknek folyósított támogatás \\
\hline 57 & KIADÁSOK $(04+\ldots \ldots+11+29+30+51+\ldots \ldots .56)$ \\
\hline 58 & Intézményi müködési bevétel ÁFA nélkül \\
\hline 59 & ÁFA bevételek, visszatérülések \\
\hline 60 & Kamatbevételek \\
\hline 61 & Gépjármüadó \\
\hline 62 & Helyi adók \\
\hline 63 & ebböl: Építményadó \\
\hline 64 & ebből: Telekadó \\
\hline 65 & ebből: Vállalkozók kommunális adója \\
\hline 66 & ebből: Magánszemélyek kommunális adója \\
\hline 67 & ebből: Idegenforgalmi adó tartózkodás után \\
\hline 68 & ebböl: Idegenforgalmi adó épület után \\
\hline 69 & ebből: Iparüzési adó állandó jelleggel végzett iparüzési tevékenység után \\
\hline 70 & ebből: Iparüzési adó ideiglenes jelleggel végzett iparüzési tevékenység után \\
\hline 71 & Illetékek \\
\hline 72 & Személyi jövedelemadó \\
\hline 73 & Termöföld bérbeadásából származó jövedelemadó \\
\hline 74 & Egyéb átengedett adók, adójellegü bevételek \\
\hline 75 & Talajterhelési díj \\
\hline 76 & Bírságok és egyéb sajátos bevételek \\
\hline 77 & Müködési célú pénzeszköz átvétel társadalombiztosítási alaptól \\
\hline 78 & Működési célú pénzeszköz átvétel elkülönített állami pénzalaptól \\
\hline 79 & Költségvetési kiegészítések, visszatérülések \\
\hline 80 & Müködési célú pénzeszköz átvétel központi költségvetési szervtöl \\
\hline 81 & Müködési célú pénzeszköz átvétel fejezeti kezelésű előirányzattól \\
\hline 82 & Müködési célra átvett pénzeszközök helyi önkormányzatoktól \\
\hline 83 & Müködési célra átvett pénzeszközök vállalkozásoktól \\
\hline 84 & Müködési célra átvett pénzeszközök pénzügyi vállalkozásoktól \\
\hline 85 & Müködési célra átvett pénzeszközök háztartásoktól \\
\hline
\end{tabular}




\begin{tabular}{|c|c|}
\hline 86 & Müködési célra átvett pénzeszközök non-profit szervezetektől \\
\hline 87 & Működési célra átvett pénzeszközök nemzetközi szervezetektől \\
\hline 88 & Müködési célra átvett pénzeszközök egyéb külföldi forrásból \\
\hline 89 & Egyéb működési célú pénzeszközátvétel, bevételek $(79+\ldots . .88)$ \\
\hline 90 & Felhamozási célú pénzeszközátvétel a TB. alapoktól és kezelöitől \\
\hline 91 & Felhamozási célú pénzeszközátvétel az elkülönített állami alapoktól \\
\hline 92 & Tárgyi eszközök, immateriális javak értékesítése \\
\hline 93 & Felhalmozási célú pénzeszközátvétel központi költségvetési szervtől \\
\hline 94 & Felhalmozási célú pénzeszközátvétel fejezei kezelésű előirányzattól \\
\hline 95 & Felhalmozási célú pénzeszközátvétel helyi önkormányzatoktól \\
\hline 96 & Felhalmozási célra átvett pénzeszközök vállalkozásoktól \\
\hline 97 & Felhalmozási célra átvett pénzeszközök pénzügyi vállalkozásoktól \\
\hline 98 & Felhalmozási célra átvett pénzeszközök háztartásoktól \\
\hline 99 & Felhalmozási célra átvett pénzeszközök non-profit szervezetektől \\
\hline 100 & Felhalmozási célra átvett pénzeszközök nemzetközi szervezetektöl \\
\hline 101 & Felhalmozási célra kapott juttatások EU-tól \\
\hline 102 & Felhalmozási célra kapott juttatások kormányoktól \\
\hline 103 & Felhalmozási célra kapott juttatások külföldről (nem nemzetközi szervtől) \\
\hline 104 & Felhalmozási célra átvett pénzeszközök külföldi forrásból $(100+\ldots+103)$ \\
\hline 105 & Garancia-,kezességvállalásból származó pénzeszköz átvétel államháztartáson kívül \\
\hline 106 & Garancia-,kezességvállalásból származó pénzeszköz átvétel államháztartáson belül \\
\hline 107 & Önkormányzati lakások, egyéb helyiségek értékesítése, cseréje \\
\hline 108 & Privatizációból származó bevételek \\
\hline 109 & Vállalatértékesítésből származó bevételek \\
\hline 110 & Vagyoni értékü jog értékesítéséből, egyéb vagyonhasznosításból származó bevétel \\
\hline 111 & Felhalmozási bevételek $(92+\ldots .99+104+\ldots .+110)$ \\
\hline 112 & Kölcsönök visszatérülése államháztartáson belülröl \\
\hline 113 & Kölcsönök visszatérülése államháztartáson kívülröl \\
\hline 114 & Kölcsönök igénybevétele államháztartáson belülről \\
\hline 115 & Osztalékok, üzemeltetési és koncessziós díjak \\
\hline 116 & Pénzügyi befektetések bevételeiből részesedések \\
\hline 117 & Saját bevételek $(58+. .62+71+\ldots .78+89+90+91+111+\ldots \ldots+116)$ \\
\hline 118 & Önkormányzat költségvetési támogatása \\
\hline 119 & Felügyeleti szervtöl kapott támogatás \\
\hline 120 & Tárgyévi kiadások és bevételek egyenlege ) ( 57-117-118-119) \\
\hline 121 & Előző évi előirányzat-maradvány, pénzmaradvány igénybevétele \\
\hline 122 & Rövid lejáratú hitelek törlesztése \\
\hline 123 & Hosszú lejáratú hitelek törlesztése \\
\hline 124 & Rövid lejáratú értékpapírok beváltása \\
\hline 125 & Rövid lejáratú értékpapírok vásárlása \\
\hline 126 & Hosszú lejáratú értékpapírok beváltása \\
\hline 127 & Hosszú lejáratú értékpapírok vásárlása \\
\hline 128 & Hosszú lejáratú külföldi értékpapírok beváltása \\
\hline 129 & Hiteltörlesztés külföldre \\
\hline 130 & Egyéb finanszírozás kiadásai \\
\hline 131 & Finanszírozási kiadások $(122+\ldots .130)$ \\
\hline 132 & Rövid lejáratú hitelek bevételei \\
\hline 133 & Hosszú lejáratú hitelek bevételei \\
\hline 134 & Rövid lejáratú értékpapírok kibocsátása \\
\hline 135 & Rövid lejáratú értékpapírok értékesítése \\
\hline 136 & Hosszú lejáratú belföldi értékpapírok kibocsátása \\
\hline 137 & Hosszú lejáratú értékpapírok értékesítése \\
\hline 138 & Hosszú lejárató külföldi értékpapírok kibocsátása \\
\hline 139 & Hitelfelvétel külföldröl \\
\hline 140 & Egyéb finanszírozás bevételei \\
\hline 141 & Finanszírozási bevételek $(132+\ldots . .+140)$ \\
\hline 142 & Finanszírozás összesen $(121-131+141)=(120)$ \\
\hline 143 & Pénzkészl/pénztár, bank, változása $(117+118+119+28-57-131+141)$ \\
\hline 144 & Pénzkészlet január 1-jén1 \\
\hline 145 & Pénzkészlet a tárgyidőszak végén $(143+144)$ \\
\hline 146 & Foglalkoztatottak létszáma (fö) - időszakra \\
\hline 147 & Munkajogi létszám a tárgyidőszak végén \\
\hline
\end{tabular}




\section{f) Költségvetési jelentés 2006 és 2007 (azonos szerkezetben)}

\begin{tabular}{|c|c|}
\hline 01 & Rendszeres személyi juttatás \\
\hline 02 & Nem rendszeres személyi juttatás \\
\hline 03 & Külső személyi juttatások \\
\hline 04 & Személyi juttatások \\
\hline 05 & TB., munkaadói járulék, és táppénz-hozzájárulás \\
\hline 06 & Egészségügyi hozzájárulás \\
\hline 07 & Dologi kiadások ÁFA nélkül \\
\hline 08 & Dologi kiadások ÁFÁ-ja \\
\hline 9 & Egyéb folyó kiadások (kamatkiadások, előző évi maradvány visszafizetése nélkül) \\
\hline 10 & Elöző évi maradvány visszafizetése \\
\hline 11 & Támogatásértékủ müködési kiadás központi költségvetési szervnek \\
\hline 12 & Támogatásértékủ müködési kiadás fejezeti kezelésű előirányzatnak \\
\hline 13 & Támogatásértékủ müködési kiadás társadalombiztosítási alapok kezelőinek \\
\hline 14 & Támogatásértékű működési kiadás elkülönített állami pénzalapnak \\
\hline 15 & Támogatásértékủ működési kiadás helyi önkormányzatoknak és költségvetési szerveinek \\
\hline 16 & Támogatásértékű működési kiadás többcélú kistérségi társulásnak \\
\hline 17 & Garancia- és kezességvállalásból származó kifizetés államháztartáson belülre \\
\hline 18 & Támogatásértékủ működési kiadások összesen $(11+\ldots .+17)$ \\
\hline 19 & Előző évi elöirányzat-maradvány, pénzmaradvány átadás \\
\hline 20 & Működési célú pénzeszköz átadás Római sz. 87. cikk önkormányzati többségi tulajdonú egyéb vállalkozásoknak \\
\hline 21 & Működési célú pénzeszköz átadás Római sz. 87. cikk nem önkormányzati többségi tulajdonú egyéb vállalkozásoknak \\
\hline 22 & Működési célú pénzeszköz átadás Római Szerződés 87. cikkének egyéb vállalkozásoknak(20+21) \\
\hline 23 & Müködési célú pénzeszköz átadás önkormányzati többségi tulajdonú egyéb vállalkozásoknak (nem 20. sor alatt) \\
\hline 24 & Müködési célú pénzeszköz átadás nem önkormányzati többségi tulajdonú egyéb vállalkozásoknak (nem 21. sor alatt) \\
\hline 25 & Müködési célú pénzeszközátadás egyéb vállalkozásoknak $(22+23+24)$ \\
\hline 26 & Múködési célú pénzeszközátadás pénzügyi vállalkozásoknak \\
\hline 27 & Működési célú pénzeszközátadás háztartásoknak \\
\hline 28 & Müködési célú pénzeszközátadás non-profit szervezeteknek \\
\hline 29 & Müködési célú pénzeszközátadás külförldre \\
\hline 30 & Müködési célú pénzeszköz átadás EU költségvetésnek \\
\hline 31 & Államháztartáson kívüli működési pénzeszközátadások összesen $(25+30)$ \\
\hline 32 & Garancia- és kezességvállalásból származó kifizetés államháztartáson kívülre \\
\hline 33 & Társadalom-és szociálpolitikai és egyéb juttatás, támogatás \\
\hline 34 & Ellátottak pénzbeli juttatásai \\
\hline 35 & Pénzforgalom nélküli kiadások \\
\hline 36 & Egyéb működési célú támogatások, kiadások $(18+31+\ldots . .35)$ \\
\hline 37 & Kamatkiadások \\
\hline 38 & Müködési kiadások összesen $(04+\ldots+10+36+37)$ \\
\hline 39 & Felújítás \\
\hline 40 & Intézményi beruházási kiadások ÁFA nélkül \\
\hline 41 & Beruházások ÁFÁ-ja \\
\hline 42 & Támogatásértékü felhalmozási kiadás központi költségvetési szervnek \\
\hline 43 & Támogatásértékü felhalmozási kiadás fejezeti kezelésủ előirányzatnak \\
\hline 44 & Támogatásértékű felhalmozási kiadás társadalombiztosítási alapok kezelőinek \\
\hline 45 & Támogatásértékủ felhalmozási kiadás elkülönített állami pénzalapnak \\
\hline 46 & Támogatásértékű felhalmozási kiadás helyi önkormányzatoknak és költségvetési szerveinek \\
\hline 47 & Támogatásértékű felhalmozási kiadás többcélú kistérségi társulásnak \\
\hline 48 & Támogatásértékű felhalmozási kiadás összesen $(42+\ldots+47)$ \\
\hline 49 & $\begin{array}{l}\text { Felhalmozási célú pénzeszköz átadás Római Szerződés 87. cikkének önkormányzati többségi tulajdonú egyéb } \\
\text { vállalkozásoknak }\end{array}$ \\
\hline 50 & $\begin{array}{l}\text { Felhalmozási célú pénzeszköz átadás Római Szerződés 87. cikkének nem önkormányzati többségi tulajdonú egyéb } \\
\text { vállalkozásoknak }\end{array}$ \\
\hline 51 & Felhalmozási célú pénzeszköz átadás Római Szerződés 87. cikkének egyéb vállalkozásoknak (49+50) \\
\hline 52 & Felhalmozási célú pénzeszköz átadás önkormányzati többségi tulajdonú egyéb vállalkozásoknak (49. sor nélkül) \\
\hline 53 & Felhalmozási célú pénzeszköz átadás nem önkormányzati többségi tulajdonú egyéb vállalkozásoknak (50. sor nélkül) \\
\hline 54 & Felhalmozási célú pénzeszközátadásegyéb vállalkozásoknak \\
\hline 55 & Felhalmozási célú pénzeszközátadás pénzügyi vállalkozásoknak \\
\hline 56 & Felhalmozási célú pénzeszközátadás háztartásoknak \\
\hline 57 & Felhalmozási célú pénzeszközátadás non-profit szervezeteknek \\
\hline 58 & Felhalmozási célú pénzeszközátadás külföldre \\
\hline 59 & Felhalmozási célú pénzeszközátadás EU költségvetésnek \\
\hline 60 & Államháztartáson kívüli pénzeszközátadások összesen $(54+\ldots+59)$ \\
\hline 61 & Felhalmozási kiadások $(39+40+41+48+60)$ \\
\hline 62 & Kölcsönök nyújtása államháztartáson belülre \\
\hline 63 & Kölcsönök nyújtása államháztartáson kívülre \\
\hline 64 & Kölcsönök törlesztése államháztartáson belülre \\
\hline 65 & Pénzügyi befektetések kiadásaiból részesedések vásárlása \\
\hline 66 & Felügyelet alá tartozó költségvetési szerveknek folyósított támogatás \\
\hline 67 & KIADÁSOK $(04+\ldots \ldots+11+29+30+51+\ldots \ldots .56)$ \\
\hline 68 & Hatósági jogkörhöz köthető müködési bevétel \\
\hline 69 & Egyéb saját bevétel \\
\hline 70 & ÁFA bevételek, visszatérülések \\
\hline 71 & Hozam- és kamatbevételek \\
\hline 72 & Gépjármüadó \\
\hline 73 & Luxusadó \\
\hline 74 & Helyi adók \\
\hline 75 & - helyi adóból: Építményadó \\
\hline 76 & - helyi adóból: Telekadó \\
\hline 77 & - helyi adóból: Vállalkozók kommunális adója \\
\hline 78 & - helyi adóból: Magánszemélyek kommunális adója \\
\hline 79 & - helyi adóból: Idegenforgalmi adó tartózkodás után \\
\hline 80 & - helyi adóból: Idegenforgalmi adó épület után \\
\hline 81 & - helyi adóból: Iparüzési adó állandó jelleggel végzett iparüzési tevékenység után \\
\hline 82 & - helyi adóból: Iparüzési adó ideiglenes jelleggel végzett iparüzési tevékenység után \\
\hline 83 & Illetékek \\
\hline
\end{tabular}




\begin{tabular}{|c|c|}
\hline 84 & Személyi jövedelemadó \\
\hline 85 & Termőföld bérbeadásából származó jövedelemadó \\
\hline 86 & Átengedett adók, adójellegü bevételek \\
\hline 87 & Talajterhelési díj \\
\hline 88 & Helyi adókhoz kapcsolódó pótlékok, bírságok, önkormányzatokat megillető bírságok és egyéb sajátos bevételek \\
\hline 89 & Költségvetési kiegészítések, visszatérülések \\
\hline 90 & Előző évi elöirányzat-maradvány, pénzmaradvány átvétel \\
\hline 91 & Támogatásértékü müködési bevétel központi költségvetési szervtől \\
\hline 92 & Támogatásértékü müködési bevétel fejezeti kezelésű előirányzattól \\
\hline 93 & Támogatásértékủ múködési bevétel társadalombiztosítási alaptól \\
\hline 94 & Támogatásértékü müködési bevétel elkülönített állami pénzalaptól \\
\hline 95 & Támogatásértékű működési bevétel helyi önkormányzatoktól és költségvetési szerveitől \\
\hline 96 & Támogatásértékü müködési bevétel többcélú kistérségi társulástól \\
\hline 97 & Garancia- és kezességvállalásból származó visszatérülések, bevételek \\
\hline 98 & Támogatásértékű müködési bevételek összesen $(91+\ldots+971 ́)$ \\
\hline 99 & Müködési célú pénzeszközátvételek államháztartáson kívülről \\
\hline 100 & Garancia- és kezességvállalásból származó megtérülések államháztartáson kívülről \\
\hline 101 & Tárgyi eszközök, immateriális javak értékesítése \\
\hline 102 & Támogatásértékủ felhalmozási bevétel központi költségvetési szervtől \\
\hline 103 & Támogatásértékủ felhalmozási bevétel fejezeti kezelésű előirányzattól \\
\hline 104 & Támogatásértékủ felhalmozási bevétel társadalombiztosítási alaptól \\
\hline 105 & Támogatásértékủ felhalmozási bevétel elkülönített állami pénzalaptól \\
\hline 106 & Támogatásértékü felhalmozási bevétel helyi önkormányzatoktól és költségvetési szerveitől \\
\hline 107 & Támogatásértékű felhalmozási bevétel többcélú kistérségi társulástól \\
\hline 108 & Támogatásértékü felhalmozási bevétel összesen $(102+\ldots+107)$ \\
\hline 109 & Felhalmozási célú pénzeszközátvétel államháztartáson kívülről \\
\hline 110 & ebből: átvett pénzeszközök EU költségvetésböl \\
\hline 111 & Önkormányzati lakások, egyéb helyiségek értékesítése, cseréje \\
\hline 112 & Privatizációból származó bevételek \\
\hline 113 & Vállalatértékesítésből származó bevételek \\
\hline 114 & Vagyoni értékü jog értékesítéséből, egyéb vagyonhasznosításból származó bevétel \\
\hline 115 & Felhalmozási bevételek $(101+108+109+111+\ldots+114)$ \\
\hline 116 & Kölcsönök visszatérülése államháztartáson belülröl \\
\hline 117 & Kölcsönök visszatérülése államháztartáson kívülröl \\
\hline 118 & Támogatási kölcsönök igénybevétele államháztartáson belülről \\
\hline 119 & Osztalékok, üzemeltetési és koncessziós díjak \\
\hline 120 & Pénzügyi befektetések bevételeiből részesedések \\
\hline 121 & Saját bevételek $(68+\ldots+74+83+. .+89+90+98+99+100+115+\ldots+120)$ \\
\hline 122 & Önkormányzat költségvetési támogatása \\
\hline 123 & Felügyeleti szervtől kapott támogatás \\
\hline 124 & Tárgyévi kiadások és bevételek egyenlege (67-121-122-123) \\
\hline 125 & Pénzforgalom nélküli bevételek \\
\hline 126 & Rövid lejáratú hitelek törlesztése \\
\hline 127 & Likvid hitelek törlesztése \\
\hline 128 & Hosszú lejáratú hitelek törlesztése \\
\hline 129 & Rövid lejáratú értékpapírok beváltása \\
\hline 130 & Rövid lejáratú értékpapírok vásárlása \\
\hline 131 & Hosszú lejáratú belföldi értékpapírok beváltása \\
\hline 132 & Hosszú lejáratú értékpapírok vásárlása \\
\hline 133 & Hosszú lejáratú külföldi értékpapírok beváltása \\
\hline 134 & Hiteltörlesztés külföldre \\
\hline 135 & Egyéb finanszírozás kiadásai \\
\hline 136 & Finanszírozási kiadások $(126+\ldots+135)$ \\
\hline 137 & Rövid lejáratú hitelek felvétele \\
\hline 138 & Likvid hitelek felvétele \\
\hline 139 & Hosszú lejáratú hitelek felvétele \\
\hline 140 & Forgatási célú értékpapírok kibocsátása \\
\hline 141 & Forgatási célú értékpapírok értékesítése \\
\hline 142 & Befektetési célú belföldi értékpapírok kibocsátása \\
\hline 143 & Hosszú lejáratú értékpapírok értékesítése \\
\hline 144 & Hosszú lejáratú külföldi értékpapírok kibocsátása \\
\hline 145 & Hitelfelvétel külföldröl \\
\hline 146 & Egyéb finanszírozás bevételei \\
\hline 147 & Finanszírozási bevételek $(137+\ldots+146)$ \\
\hline 148 & Finanszírozás összesen $(125-136+147)=124)$ \\
\hline 149 & Államháztartáson belülről kapott továbbadási célú kiadás összesen \\
\hline 150 & Államháztartáson kívülről kapott továbbadási célú kiadás összesen \\
\hline 151 & Államháztartáson belülröl kapott továbbadási célú bevétel összesen \\
\hline 152 & Államháztartáson kívülről kapott továbbadási célú bevétel összesen \\
\hline 153 & Pénzkészlet változása $(121+\ldots+123+35-67-136+147-149-150+151+152)$ \\
\hline 154 & Pénzkészlet január 1-jén \\
\hline 155 & Pénzkészlet a tárgyidőszak végén \\
\hline 156 & Foglalkoztatottak létszáma (fö) - időszakra \\
\hline 157 & Munkajogi létszám a tárgyidőszak végén \\
\hline
\end{tabular}


g) Költségvetési jelentés 2008

\begin{tabular}{|c|c|}
\hline 01 & Rendszeres személyi juttatás \\
\hline 02 & Nem rendszeres személyi juttatás \\
\hline 03 & Külső személyi juttatások \\
\hline 04 & Személyi juttatások \\
\hline 05 & TB., munkaadói járulék, és táppénz-hozzájárulás \\
\hline 06 & Egészségügyi hozzájárulás \\
\hline 07 & Dologi kiadások ÁFA nélkül \\
\hline 08 & Dologi kiadások ÁFÁ-ja \\
\hline 09 & Egyéb folyó kiadások (kamatkiadások, előző évi maradvány visszafizetése nélkül) \\
\hline 10 & Előző évi maradvány visszafizetése \\
\hline 11 & Támogatásértékű működési kiadás központi költségvetési szervnek \\
\hline 12 & Támogatásértékü müködési kiadás fejezeti kezelésű elöirányzatnak \\
\hline 13 & Támogatásértékủ mủködési kiadás társadalombiztosítási alapok kezelöinek \\
\hline 14 & Támogatásértékủ müködési kiadás elkülönített állami pénzalapnak \\
\hline 15 & Támogatásértékủ működési kiadás helyi önkormányzatoknak és költségvetési szerveinek \\
\hline 16 & Támogatásértékủ müködési kiadás többcélú kistérségi társulásnak \\
\hline 17 & Támogatásértékủ müködési kiadás országos kisebbségi önkormányzatoknak \\
\hline 18 & Garancia- és kezességvállalásból származó kifizetés államháztartáson belülre \\
\hline 19 & Támogatásértékü müködési kiadások összesen $(11+\ldots+18)$ \\
\hline 20 & Előző évi előirányzat-maradvány, pénzmaradvány átadás \\
\hline 21 & Müködési célú pénzeszköz átadás Római sz. 87. cikk önkormányzati többségi tulajdonú egyéb vállalkozásoknak \\
\hline 22 & Müködési célú pénzeszköz átadás Római sz. 87 . cikk nem önkormányzati többségi tulajdonú egyéb vállalkozásoknak \\
\hline 23 & Mủködési célú pénzeszköz átadás Római Szerződés 87. cikkének egyéb vállalkozásoknak(21+22) \\
\hline 24 & Müködési célú pénzeszköz átadás önkormányzati többségi tulajdonú egyéb vállalkozásoknak (nem 21. sor alatt) \\
\hline 25 & Müködési célú pénzeszköz átadás nem önkormányzati többségi tulajdonú egyéb vállalkozásoknak (nem 22. sor alatt) \\
\hline 26 & Müködési célú pénzeszközátadás egyéb vállalkozásoknak $(23+24+25)$ \\
\hline 27 & Müködési célú pénzeszközátadás pénzügyi vállalkozásoknak \\
\hline 28 & Müködési célú pénzeszközátadás háztartásoknak \\
\hline 29 & Működési célú pénzeszközátadás non-profit szervezeteknek \\
\hline 30 & Müködési célú pénzeszközátadás külförldre \\
\hline 31 & Működési célú pénzeszköz átadás EU költségvetésnek \\
\hline 32 & Államháztartáson kívüli müködési pénzeszközátadások összesen $(26+31)$ \\
\hline 33 & Garancia- és kezességvállalásból származó kifizetés államháztartáson kívülre \\
\hline 34 & Társadalom-és szociálpolitikai és egyéb juttatás, támogatás \\
\hline 35 & Ellátottak pénzbeli juttatásai \\
\hline 36 & Pénzforgalom nélküli kiadások \\
\hline 37 & Egyéb müködési célú támogatások, kiadások $(19+32+\ldots . .36)$ \\
\hline 38 & Kamatkiadások \\
\hline 39 & Követelés elengedés, tartozásátvállalás kiadásai \\
\hline 40 & Müködési kiadások összesen $(04+\ldots+10+37+39)$ \\
\hline 41 & Felújítás \\
\hline 42 & Intézményi beruházási kiadások ÁFA nélkül \\
\hline 43 & Beruházások ÁFÁ-ja \\
\hline 44 & Támogatásértékü felhalmozási kiadás központi költségvetési szervnek \\
\hline 45 & Támogatásértékủ felhalmozási kiadás fejezeti kezelésű előirányzatnak \\
\hline 46 & Támogatásértékủ felhalmozási kiadás társadalombiztosítási alapok kezelöinek \\
\hline 47 & Támogatásértékü felhalmozási kiadás elkülönített állami pénzalapnak \\
\hline 48 & Támogatásértékü felhalmozási kiadás helyi önkormányzatoknak és költségvetési szerveinek \\
\hline 49 & Támogatásértékủ felhalmozási kiadás többcélú kistérségi társulásnak \\
\hline 50 & Támogatásértékü felhalmozási kiadás országos kisebbségi önkormányzatoknak \\
\hline 51 & Támogatásértékü felhalmozási kiadás összesen $(44+\ldots+50)$ \\
\hline 52 & $\begin{array}{l}\text { Felhalmozási célú pénzeszköz átadás Római Szerződés 87. cikkének önkormányzati többségi tulajdonú egyéb } \\
\text { vállalkozásoknak }\end{array}$ \\
\hline 53 & $\begin{array}{l}\text { Felhalmozási célú pénzeszköz átadás Római Szerződés } 87 \text {. cikkének nem önkormányzati többségi tulajdonú egyéb } \\
\text { vállalkozásoknak }\end{array}$ \\
\hline 54 & Felhalmozási célú pénzeszköz átadás Római Szerződés 87. cikkének egyéb vállalkozásoknak (52+53) \\
\hline 55 & Felhalmozási célú pénzeszköz átadás önkormányzati többségi tulajdonú egyéb vállalkozásoknak (52. sor nélkül) \\
\hline 56 & Felhalmozási célú pénzeszköz átadás nem önkormányzati többségi tulajdonú egyéb vállalkozásoknak (53. sor nélkül) \\
\hline 57 & Felhalmozási célú pénzeszközátadásegyéb vállalkozásoknak \\
\hline 58 & Felhalmozási célú pénzeszközátadás pénzügyi vállalkozásoknak \\
\hline 59 & Felhalmozási célú pénzeszközátadás háztartásoknak \\
\hline 60 & Felhalmozási célú pénzeszközátadás non-profit szervezeteknek \\
\hline 61 & Felhalmozási célú pénzeszközátadás külföldre \\
\hline 62 & Felhalmozási célú pénzeszközátadás EU költségvetésnek \\
\hline 63 & Államháztartáson kívüli pénzeszközátadások összesen $(57+\ldots+62)$ \\
\hline 64 & Felhalmozási kiadások $(41+\ldots+43+51+63)$ \\
\hline 65 & Kölcsönök nyújtása államháztartáson belülre \\
\hline 66 & Kölcsönök nyújtása államháztartáson kívülre \\
\hline 67 & Kölcsönök törlesztése államháztartáson belülre \\
\hline 68 & Pénzügyi befektetések kiadásaiból részesedések vásárlása \\
\hline 69 & Felügyelet alá tartozó költségvetési szerveknek folyósított támogatás \\
\hline 70 & KIADÁSOK $(20+40+64+\ldots+69)$ \\
\hline 71 & Hatósági jogkörhöz köthető müködési bevétel \\
\hline 72 & Egyéb saját bevétel \\
\hline 73 & ÁFA bevételek, visszatérülések \\
\hline 74 & Hozam- és kamatbevételek \\
\hline 75 & Gépjármüadó \\
\hline 76 & Luxusadó \\
\hline 77 & Helyi adók \\
\hline 78 & - helyi adóból: Építményadó \\
\hline 79 & - helyi adóból: Telekadó \\
\hline 80 & - helyi adóból: Vállalkozók kommunális adója \\
\hline 81 & - helyi adóból: Magánszemélyek kommunális adója \\
\hline 82 & - helyi adóból: Idegenforgalmi adó tartózkodás után \\
\hline 83 & - helyi adóból: Idegenforgalmi adó épület után \\
\hline
\end{tabular}




\begin{tabular}{|c|c|}
\hline 84 & - helyi adóból: Iparüzési adó állandó jelleggel végzett iparüzési tevékenység után \\
\hline 85 & - helyi adóból: Iparüzési adó ideiglenes jelleggel végzett iparüzési tevékenység után \\
\hline 86 & Illetékek \\
\hline 87 & Személyi jövedelemadó \\
\hline 88 & Termőföld bérbeadásából származó jövedelemadó \\
\hline 89 & Átengedett adók, adójellegü bevételek \\
\hline 90 & Talajterhelési díj \\
\hline 91 & Helyi adókhoz kapcsolódó pótlékok, bírságok, önkormányzatokat megillető bírságok és egyéb sajátos bevételek \\
\hline 92 & Költségvetési kiegészítések, visszatérülések \\
\hline 93 & Előző évi előirányzat-maradvány, pénzmaradvány átvétel \\
\hline 94 & Támogatásértékü müködési bevétel központi költségvetési szervtől \\
\hline 95 & Támogatásértékü müködési bevétel fejezeti kezelésű előirányzattól \\
\hline 96 & Támogatásértékű mủködési bevétel társadalombiztosítási alaptól \\
\hline 97 & Támogatásértékủ müködési bevétel elkülönített állami pénzalaptól \\
\hline 98 & Támogatásértékű működési bevétel helyi önkormányzatoktól és költségvetési szerveitől \\
\hline 99 & Támogatásértékü működési bevétel többcélú kistérségi társulástól \\
\hline 100 & Támogatásértékü müködési bevétel országos kisebbségi önkormányzatoktól \\
\hline 101 & Garancia- és kezességvállalásból származó visszatérülések, bevételek \\
\hline 102 & Támogatásértékü müködési bevételek összesen $(94+\ldots+101 I ́)$ \\
\hline 103 & Müködési célú pénzeszközátvételek államháztartáson kívülről \\
\hline 104 & Garancia- és kezességvállalásból származó megtérülések államháztartáson kívülről \\
\hline 105 & Tárgyi eszközök, immateriális javak értékesítése \\
\hline 106 & Támogatásértékủ felhalmozási bevétel központi költségvetési szervtől \\
\hline 107 & Támogatásértékủ felhalmozási bevétel fejezeti kezelésű elöirányzattól \\
\hline 108 & Támogatásértékủ felhalmozási bevétel társadalombiztosítási alaptól \\
\hline 109 & Támogatásértékű felhalmozási bevétel elkülönített állami pénzalaptól \\
\hline 110 & Támogatásértékü felhalmozási bevétel helyi önkormányzatoktól és költségvetési szerveitöl \\
\hline 111 & Támogatásértékü felhalmozási bevétel többcélú kistérségi társulástól \\
\hline 112 & Támogatásértékü felhalmozási bevétel országos kisebbségi önkormányzatoktól \\
\hline 113 & Támogatásértékü felhalmozási bevétel összesen $(106+\ldots+112)$ \\
\hline 114 & Felhalmozási célú pénzeszközátvétel államháztartáson kívülről \\
\hline 115 & ebböl: átvett pénzeszközök EU költségvetésböl \\
\hline 116 & Önkormányzati lakások, egyéb helyiségek értékesítése, cseréje \\
\hline 117 & Privatizációból származó bevételek \\
\hline 118 & Vállalatértékesítésből származó bevételek \\
\hline 119 & Vagyoni értékủ jog értékesítéséből, egyéb vagyonhasznosításból származó bevétel \\
\hline 120 & Felhalmozási bevételek $(105+113+114+116+\ldots+119)$ \\
\hline 121 & Kölcsönök visszatérülése államháztartáson belülröl \\
\hline 122 & Kölcsönök visszatérülése államháztartáson kívülröl \\
\hline 123 & Támogatási kölcsönök igénybevétele államháztartáson belülről \\
\hline 124 & Osztalékok, üzemeltetési és koncessziós díjak \\
\hline 125 & Pénzügyi befektetések bevételeiből részesedések \\
\hline 126 & Saját bevételek $(71+\ldots+77+86+\ldots+93+102+\ldots+104+120+\ldots+125)$ \\
\hline 127 & Önkormányzat költségvetési támogatása \\
\hline 128 & Felügyeleti szervtől kapott támogatás \\
\hline 129 & Tárgyévi kiadások és bevételek egyenlege (70-126-127-128) \\
\hline 130 & Pénzforgalom nélküli bevételek \\
\hline 131 & Rövid lejáratú hitelek törlesztése \\
\hline 132 & Likvid hitelek törlesztése \\
\hline 133 & Hosszú lejáratú hitelek törlesztése \\
\hline 134 & Rövid lejáratú értékpapírok beváltása \\
\hline 135 & Rövid lejáratú értékpapírok vásárlása \\
\hline 136 & Hosszú lejáratú belföldi értékpapírok beváltása \\
\hline 137 & Hosszú lejáratú értékpapírok vásárlása \\
\hline 138 & Hosszú lejáratú külföldi értékpapírok beváltása \\
\hline 139 & Hiteltörlesztés külföldre \\
\hline 140 & Egyéb finanszírozás kiadásai \\
\hline 141 & Finanszírozási kiadások $(131+\ldots .+140)$ \\
\hline 142 & Rövid lejáratú hitelek felvétele \\
\hline 143 & Likvid hitelek felvétele \\
\hline 144 & Hosszú lejáratú hitelek felvétele \\
\hline 145 & Forgatási célú értékpapírok kibocsátása \\
\hline 146 & Forgatási célú értékpapírok értékesítése \\
\hline 147 & Befektetési célú belföldi értékpapírok kibocsátása \\
\hline 148 & Hosszú lejáratú értékpapírok értékesítése \\
\hline 149 & Hosszú lejáratú külföldi értékpapírok kibocsátása \\
\hline 150 & Hitelfelvétel külföldröl \\
\hline 151 & Egyéb finanszírozás bevételei \\
\hline 152 & Finanszírozási bevételek $(142+\ldots+151)$ \\
\hline 153 & Finanszírozás összesen $(130-141+152)=129)$ \\
\hline 154 & Államháztartáson belülről kapott továbbadási célú kiadás összesen \\
\hline 155 & Államháztartáson kívülröl kapott továbbadási célú kiadás összesen \\
\hline 156 & Államháztartáson belülről kapott továbbadási célú bevétel összesen \\
\hline 157 & Államháztartáson kívülről kapott továbbadási célú bevétel összesen \\
\hline 158 & Pénzkészlet változása $(126+\ldots+128+36-70-141+152-154-155+156+157)$ \\
\hline 159 & Pénzkészlet január 1-jén \\
\hline 160 & Pénzkészlet a tárgyidőszak végén \\
\hline 161 & Foglalkoztatottak létszáma (fö) - időszakra \\
\hline 162 & Munkajogi létszám a tárgyidőszak végén \\
\hline
\end{tabular}


9. a) számú melléklet: A Központi Statisztikai Hivatal honlapjától letöltött adatok köre

1. Lakónépesség száma az év közepén (a népszámlálás végleges adataiból továbbszámított adat) 2004

2. Állandó népesség száma 2004

3. Lakónépesség száma az év közepén (a népszámlálás végleges adataiból továbbszámított adat) 2005

4. Állandó népesség száma 2005

5. Lakónépesség száma az év közepén (a népszámlálás végleges adataiból továbbszámított adat) 2006

6. Állandó népesség száma 2006

7. Lakónépesség száma az év közepén (a népszámlálás végleges adataiból továbbszámított adat) 2007

8. Állandó népesség száma 2007

9. Lakónépesség száma az év közepén (a népszámlálás végleges adataiból továbbszámított adat) 2008

10. Állandó népesség száma 2008

Az adatok településenkénti és megyei bontásban álltak rendelkezésre. 
9. b) számú melléklet: A Nemzeti Fejlesztési Ügynökség EMIR NFT adatbázisának kutatás szempontjából releváns változói

\begin{tabular}{|l|l|}
\hline \multicolumn{1}{|c|}{ Változó megnevezése } & Változó típusa \\
\hline Gazdasági forma & ordinális \\
\hline Székhely régió & ordinális \\
\hline Székhely megye & ordinális \\
\hline Székhely kistérség & ordinális \\
\hline Székhely település & ordinális \\
\hline 2004 évi kifizetés & arányskála \\
\hline 2005 évi kifizetés & arányskála \\
\hline 2006 évi kifizetés & arányskála \\
\hline 2007 évi kifizetés & arányskála \\
\hline 2008 évi kifizetés & arányskála \\
\hline 2009 évi kifizetés & arányskála \\
\hline 2010 évi kifizetés & arányskála \\
\hline 2011 évi kifizetés & arányskála \\
\hline 2012 évi kifizetés & arányskála \\
\hline
\end{tabular}


10. számú melléklet: Az adatbázis feltárásához kapcsolódó adatok

a)Az állandó népesség átlaga, szórása, ferdesége és csúcsossága

\begin{tabular}{|l|r|r|r|r|r|}
\hline \multicolumn{7}{|c|}{ Leíró statis ztika } \\
\hline & Darabszám & \multicolumn{1}{|c|}{ Átlag } & \multicolumn{1}{c|}{ Szórás } & Ferdeség & Csúcsosság \\
\hline $\begin{array}{l}\text { Állandó_népesség_száma } \\
2008\end{array}$ & 3151 & 2688,14 & 9239,37 & 12,32 & 198,68 \\
\hline
\end{tabular}

\begin{tabular}{|l|r|r|r|c|}
\hline \multicolumn{5}{|c|}{ Korrigált átlagok (M-Estimators) } \\
\hline & $\begin{array}{c}\text { Huber's M- } \\
\text { Estimator }\end{array}$ & $\begin{array}{c}\text { Tukey's } \\
\text { Biweight }\end{array}$ & $\begin{array}{c}\text { Hampel's M- } \\
\text { Estimator }\end{array}$ & $\begin{array}{c}\text { Andrews' } \\
\text { Wave }\end{array}$ \\
\hline $\begin{array}{l}\text { Állandó_népesség_száma } \\
2008\end{array}$ & 993,955 & 802,339 & 915,473 & 800,327 \\
\hline
\end{tabular}

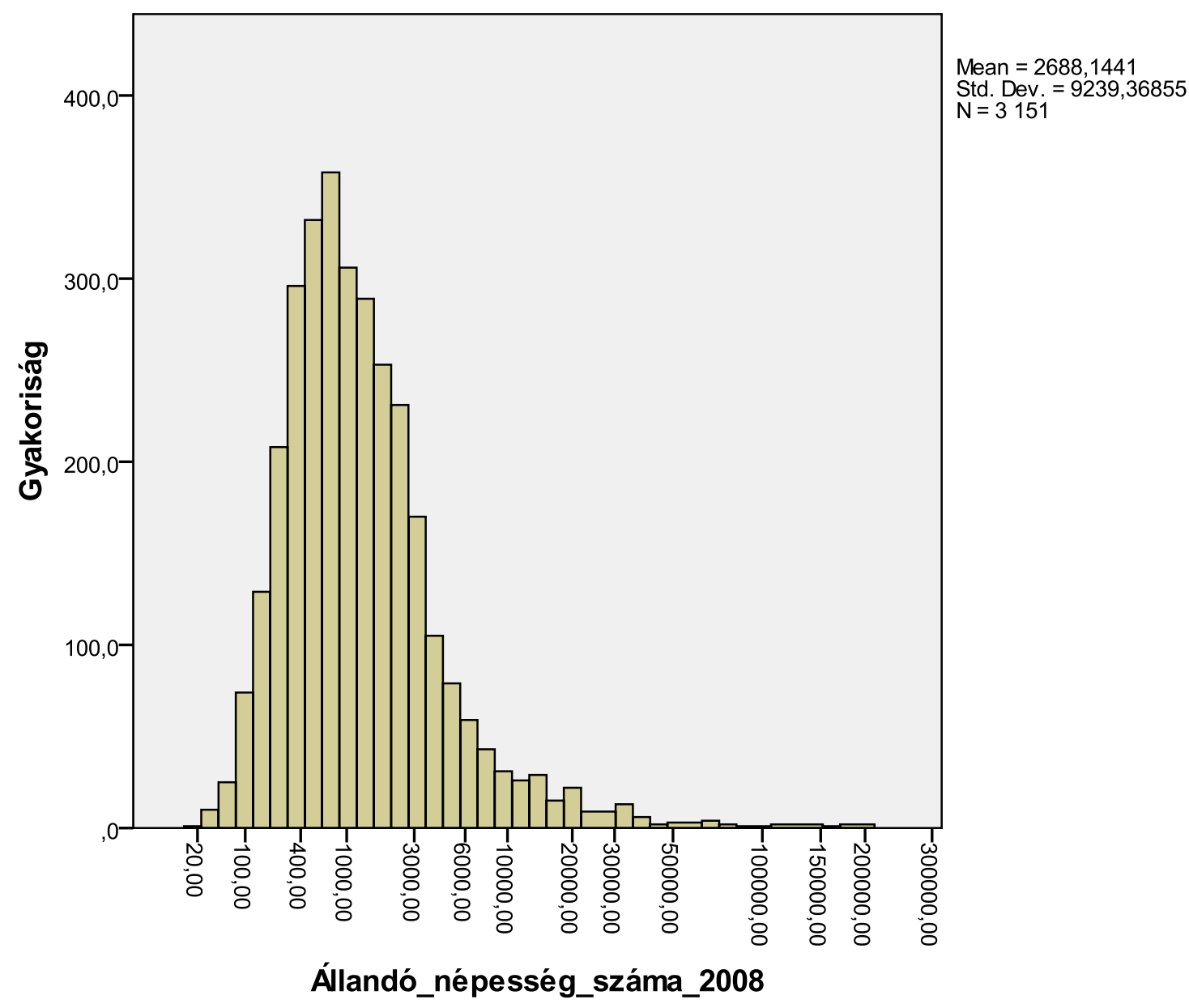


b) NUTS szintek összefüggései Magyarországon

\begin{tabular}{|l|l|l|l|}
\hline \multicolumn{1}{|c|}{ Ssz. } & \multicolumn{1}{|c|}{ NUTS1 } & \multicolumn{1}{c|}{ NUTS 2 } & \multicolumn{1}{c|}{ NUTS 3 (megyék) } \\
\hline 1. & Közép-Magyarország & Közép-Magyarország & Budapest és Pest megye \\
\hline \multirow{4}{*}{2.} & \multirow{3}{*}{ Dunántúl } & Közép-Dunántúl & $\begin{array}{l}\text { Fejér, Komárom- } \\
\text { Esztergom, Veszprém }\end{array}$ \\
\cline { 3 - 4 } & & Nyugat-Magyarország & $\begin{array}{l}\text { Győr-Moson-Sopron, } \\
\text { Vas, Zala) }\end{array}$ \\
\cline { 3 - 4 } & Dél-Dunántúl & $\begin{array}{l}\text { Baranya, Somogy, Tolna } \\
\text { Borsos-Abaúj-Zemplén, } \\
\text { Heves, Nógrád }\end{array}$ \\
\hline \multirow{3}{*}{3.} & Észak-Magyarország & $\begin{array}{l}\text { Hajdú-Bihar, Szabolcs- } \\
\text { Szatmár-Bereg, Jász- } \\
\text { Nagykun-Szolnok }\end{array}$ \\
\cline { 3 - 4 } & Alföld és Észak & Észak-Alföld & $\begin{array}{l}\text { Bács-Kiskun, Békés, } \\
\text { Csongrád }\end{array}$ \\
\cline { 3 - 4 } & & Dél-Alföld & \\
\cline { 3 - 4 } & & &
\end{tabular}

c1) Magyarország nagyrégiói (NUTS1)

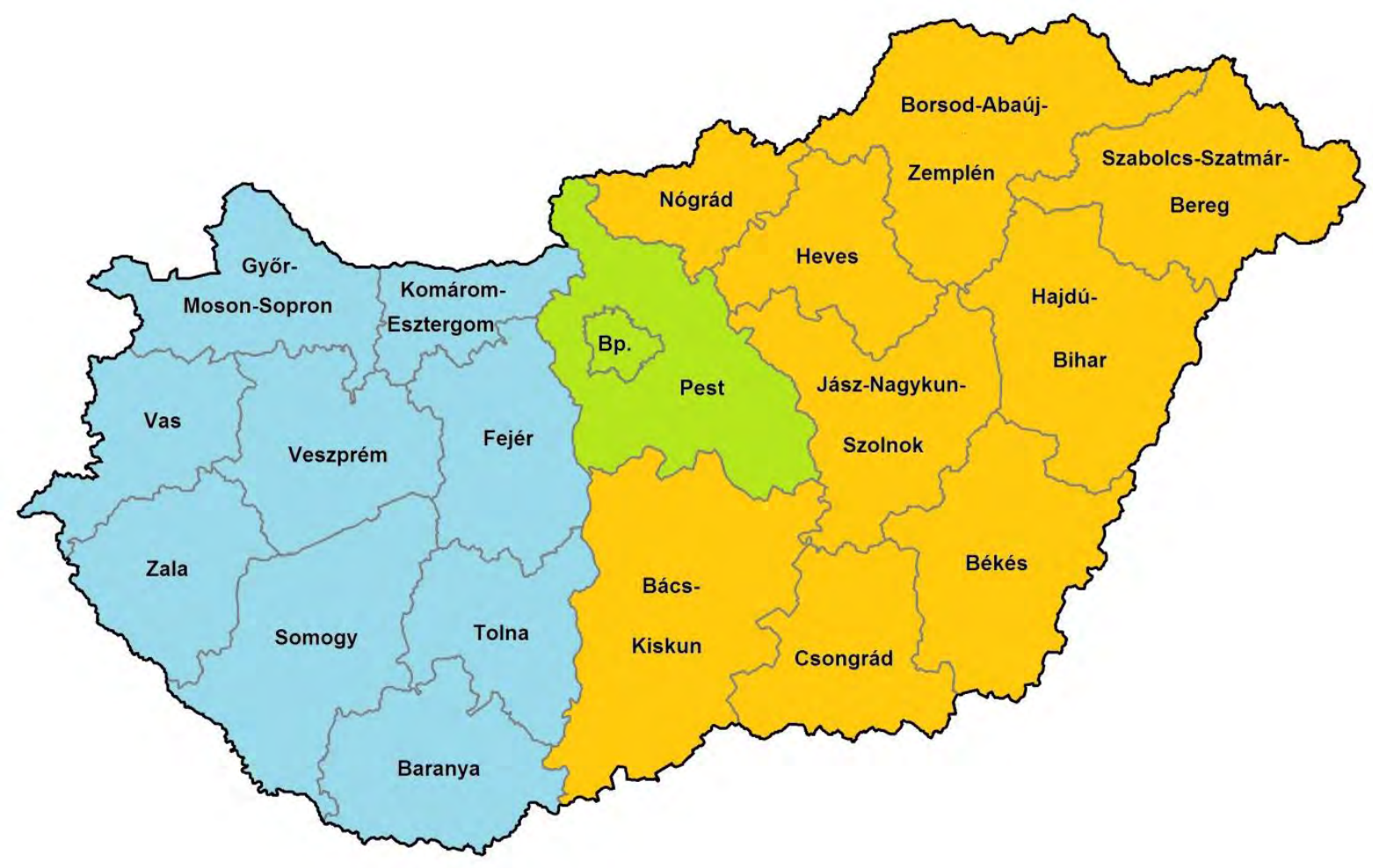

\begin{tabular}{|l|}
\hline Dunántúl \\
\hline Alföld és Észak \\
\hline Közép-Magyarország \\
\hline
\end{tabular} 
c2) Magyarország régiói (NUTS2) és megyéi (NUTS3)

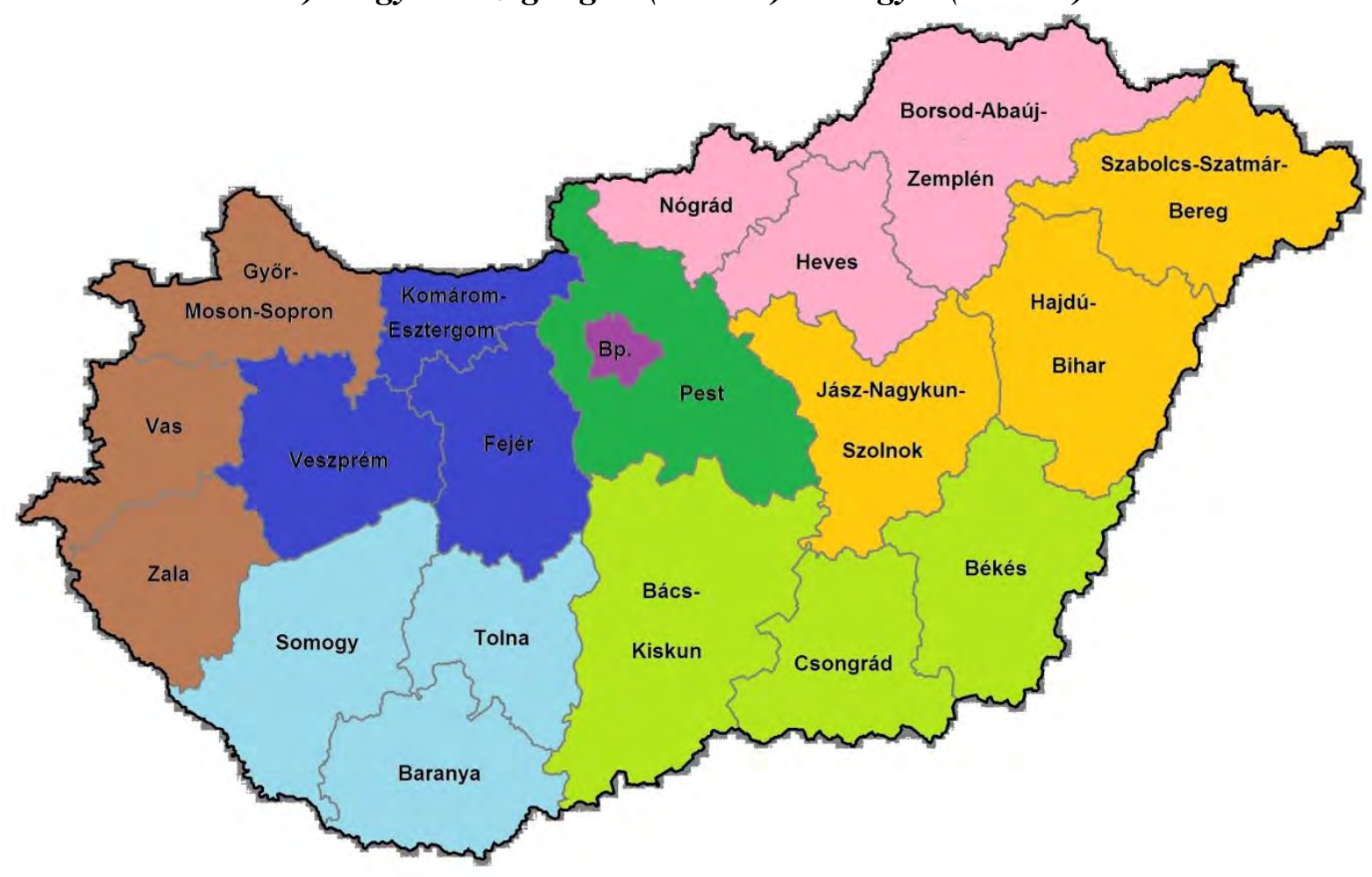

\begin{tabular}{|l|l|}
\hline $\begin{array}{l}\text { Közép-Magyarország } \\
\text { (Budapest) }\end{array}$ & $\begin{array}{l}\text { Közép-Magyarország } \\
\text { (Pest megye) }\end{array}$ \\
\hline $\begin{array}{l}\text { Közép-Dunántúl } \\
\text { (Fejér megye, Komárom-Esztergom megye, Veszprém megye) }\end{array}$ \\
\hline $\begin{array}{l}\text { Nyugat-Magyarország } \\
\text { (Győr-Moson-Sopron megye, Vas megye, Zala megye) }\end{array}$ \\
\hline $\begin{array}{l}\text { Dél-Dunántúl } \\
\text { (Baranya megye, Somogy megye, Tolna megye) }\end{array}$ \\
\hline $\begin{array}{l}\text { Észak-Magyarország } \\
\text { (Borsod-Abaúj-Zemplén megye, Heves megye, Nógrád megye) }\end{array}$ \\
\hline $\begin{array}{l}\text { Észak-Alföld } \\
\text { (Hajdú-Bihar megye, Szabolcs-Szatmár-Bereg megye, Jász-Nagykun-Szolnok megye) }\end{array}$ \\
\hline $\begin{array}{l}\text { Dél-Alföld } \\
\text { (Bács-Kiskun megye, Békés megye, Csongrád megye) }\end{array}$ \\
\hline
\end{tabular}


d)Településszerkezet NUTS1 nagyrégiónként (lélekszám-nagyrégió bontásban)

\begin{tabular}{|l|l|r|r|}
\hline Léle kszám & Nagyrégió (NUTS1) & Darabszám & \multicolumn{1}{|c|}{ Arány } \\
\hline \multirow{4}{*}{500 fö alatt } & Közép-Magyarország & 6 & $0,6 \%$ \\
\cline { 2 - 4 } & Dunántúl & 785 & $75,8 \%$ \\
\cline { 2 - 4 } & Alföld és Észak & 245 & $23,6 \%$ \\
\hline \multirow{3}{*}{$500-4999$ fö } & Közép-Magyarország & 114 & $6,2 \%$ \\
\cline { 2 - 4 } & Dunántúl & 848 & $46,4 \%$ \\
\cline { 2 - 4 } & Alföld és Észak & 864 & $47,3 \%$ \\
\hline \multirow{3}{*}{$10000-49999$ fő } & Közép-Magyarország & 29 & $20,1 \%$ \\
\cline { 2 - 4 } & Konzántúl & 33 & $22,9 \%$ \\
\cline { 2 - 4 } & Alföld és Észak & 82 & $56,9 \%$ \\
\cline { 2 - 4 } & Dunántúl & 37 & $29,6 \%$ \\
\cline { 2 - 4 } & Alföld és Észak & 34 & $27,2 \%$ \\
\hline \multirow{3}{*}{50000 fó felett } & Közép-Magyarország & 1 & $43,2 \%$ \\
\cline { 2 - 4 } & Dunántúl & 11 & $5,0 \%$ \\
\cline { 2 - 4 } & Alföld és Észak & 8 & $40,0 \%$ \\
\hline
\end{tabular}

e)Településszerkezet NUTS1 nagyrégiónként (nagyrégió- lélekszám bontásban)

\begin{tabular}{|c|c|c|c|}
\hline Nagyrégió (NUTS1) & Lélekszám & Darabszám & Arány \\
\hline \multirow{5}{*}{ Közép-Magyarország } & 500 fö alatt & 6 & $3,2 \%$ \\
\hline & 500-4999 fö & 114 & $61,0 \%$ \\
\hline & 5000-9999 fó & 29 & $15,5 \%$ \\
\hline & 10000-49999 fö & 37 & $19,8 \%$ \\
\hline & 50000 fö felett & 1 &, $5 \%$ \\
\hline \multirow{5}{*}{ Dunántúl } & 500 fö alatt & 785 & $45,9 \%$ \\
\hline & 500-4999 fö & 848 & $49,6 \%$ \\
\hline & \begin{tabular}{|l}
$5000-9999$ fö \\
\end{tabular} & 33 & $1,9 \%$ \\
\hline & 10000-49999 fö & 34 & $2,0 \%$ \\
\hline & 50000 fó felett & 11 &, $6 \%$ \\
\hline \multirow{5}{*}{ Alföld és Észak } & 500 fö alatt & 245 & $19,6 \%$ \\
\hline & 500-4999 fö & 864 & $69,0 \%$ \\
\hline & \begin{tabular}{|l}
$5000-9999$ fó \\
\end{tabular} & 82 & $6,5 \%$ \\
\hline & \begin{tabular}{|l|l}
$10000-49999$ fö \\
\end{tabular} & 54 & $4,3 \%$ \\
\hline & 50000 fö felett & 8 & ,6\% \\
\hline
\end{tabular}


f1) Megyék saját besorolása feltáró elemzés alapján

\begin{tabular}{|c|c|}
\hline Besorolás & Érintett megyék \\
\hline \multirow{6}{*}{ Nyugat } & Baranya \\
\hline & Győr-Moson-Sopron \\
\hline & Somogy \\
\hline & Vas \\
\hline & Veszprém \\
\hline & Zala \\
\hline \multirow{7}{*}{ Közép } & Borsod-Abaúj-Zemplén \\
\hline & Fejér \\
\hline & Heves \\
\hline & Komárom-Esztergom \\
\hline & Nógrád \\
\hline & Pest \\
\hline & Tolna \\
\hline \multirow{6}{*}{ Kelet } & Bács-Kiskun \\
\hline & Békés \\
\hline & Csongrád \\
\hline & Hajdú-Bihar \\
\hline & Szabolcs-Szatmár-Bereg \\
\hline & Jász-Nagykun-Szolnok \\
\hline
\end{tabular}


f2) Megyék saját besorolása feltáró elemzés alapján, térképes megjelenítés

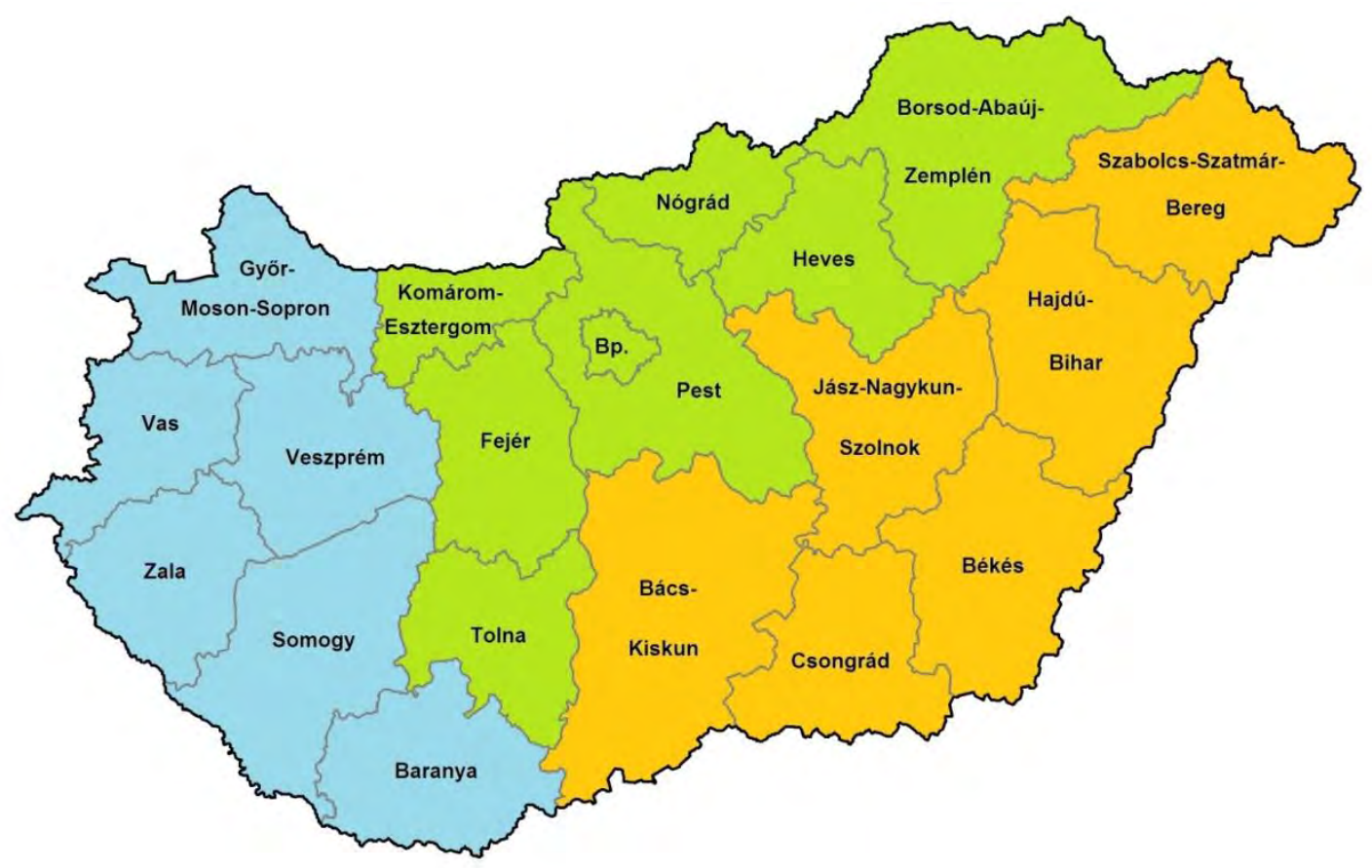

\begin{tabular}{|l|}
\hline Nyugat \\
\hline Közép \\
\hline Kelet \\
\hline
\end{tabular}


g)Településszerkezet saját besorolás szerint (lélekszám-területi elhelyezkedés)

\begin{tabular}{|l|l|r|r|}
\hline Léle kszám & Saját be sorolás & Darab & \multicolumn{1}{c|}{ Arány } \\
\hline \multirow{3}{*}{500 fö alatt } & Nyugat & 747 & $72,1 \%$ \\
\cline { 2 - 4 } & Közép & 226 & $21,8 \%$ \\
\cline { 2 - 4 } & Kelet & 63 & $6,1 \%$ \\
\hline \multirow{3}{*}{$500-4999$ fö } & Nyugat & 626 & $34,3 \%$ \\
\cline { 2 - 4 } & Közép & 734 & $40,2 \%$ \\
\cline { 2 - 4 } & Kelet & 466 & $25,5 \%$ \\
\hline \multirow{3}{*}{ 5000-9999 fö } & Nyugat & 16 & $11,1 \%$ \\
\cline { 2 - 4 } & Közép & 60 & $41,7 \%$ \\
\cline { 2 - 4 } & Kelet & 68 & $47,2 \%$ \\
\hline \multirow{3}{*}{$50000-49999$ fö fö felett } & Nyugat & 21 & $16,8 \%$ \\
\cline { 2 - 4 } & Közép & 64 & $51,2 \%$ \\
\cline { 2 - 4 } & Kelet & 40 & $32,0 \%$ \\
\hline & Nyugat & 8 & $40,0 \%$ \\
\cline { 2 - 4 } & Közép & 6 & $30,0 \%$ \\
\cline { 2 - 4 } & Kelet & 6 & $30,0 \%$ \\
\hline
\end{tabular}

h)Településszerkezet saját besorolás szerint (területi elhelyezkedés-lélekszám)

\begin{tabular}{|l|l|r|r|}
\hline Besorolás & \multicolumn{1}{|c|}{ Léle ks zám } & \multicolumn{1}{c|}{ Darab } & \multicolumn{1}{c|}{ Arány } \\
\hline \multirow{4}{*}{ Nyugat } & 500 fö alatt & 747 & $52,7 \%$ \\
\cline { 2 - 4 } & $500-4999$ fö & 626 & $44,1 \%$ \\
\cline { 2 - 4 } & $5000-9999$ fö & 16 & $1,1 \%$ \\
\cline { 2 - 4 } & $10000-49999$ fó & 21 & $1,5 \%$ \\
\cline { 2 - 4 } & 50000 fö felett & 8 &, $6 \%$ \\
\hline \multirow{5}{*}{ özép } & 500 fó alatt & 226 & $20,7 \%$ \\
\cline { 2 - 4 } & $500-4999$ fö & 734 & $67,3 \%$ \\
\cline { 2 - 4 } & $5000-9999$ fö & 60 & $5,5 \%$ \\
\cline { 2 - 4 } & $10000-49999$ fö & 64 & $5,9 \%$ \\
\cline { 2 - 4 } & 50000 fö felett & 6 &, $6 \%$ \\
\hline \multirow{5}{*}{ Kelet } & 500 fö alatt & 63 & $9,8 \%$ \\
\cline { 2 - 4 } & $500-4999$ fö & 466 & $72,5 \%$ \\
\cline { 2 - 4 } & $5000-9999$ fö & 68 & $10,6 \%$ \\
\cline { 2 - 4 } & $10000-49999$ fó & 40 & $6,2 \%$ \\
\cline { 2 - 4 } & 50000 fó felett & 6 &, $9 \%$ \\
\hline
\end{tabular}




\section{i) Településszerkezet és európai uniós támogatások összefüggései, NUTS régiók szerinti}

bontásban

\begin{tabular}{|c|c|c|c|c|c|}
\hline $\begin{array}{l}\text { Nagyrégió } \\
\text { (NUTS1) }\end{array}$ & Régió (NUTS2) & Léle ks zám & $\begin{array}{c}\text { Támogatásban } \\
\text { részes ült-e }\end{array}$ & Darabszám & Arány \\
\hline \multirow{10}{*}{ Közép-Magyarország } & \multirow{10}{*}{ Közép-Magyarország } & \multirow{2}{*}{500 fó alatt } & Nem kapott & 6 & $100,0 \%$ \\
\hline & & & Részesült & 0 &, $0 \%$ \\
\hline & & \multirow{2}{*}{ 500-4999 fö } & Nem kapott & 84 & $73,7 \%$ \\
\hline & & & Részesült & 30 & $26,3 \%$ \\
\hline & & \multirow{2}{*}{ 5000-9999 fó } & Nem kapott & 17 & $58,6 \%$ \\
\hline & & & Részesült & 12 & $41,4 \%$ \\
\hline & & \multirow{2}{*}{ 10000-49999 fö } & Nem kapott & 12 & $32,4 \%$ \\
\hline & & & Részesült & 25 & $67,6 \%$ \\
\hline & & \multirow{2}{*}{50000 fö felett } & Nem kapott & 0 &, $0 \%$ \\
\hline & & & Részesült & 1 & $100,0 \%$ \\
\hline \multirow{30}{*}{ Dunántúl } & \multirow{10}{*}{ Közép-Dunántúl } & \multirow{2}{*}{500 fó alatt } & Nem kapott & 97 & $88,2 \%$ \\
\hline & & & Részesült & 13 & $11,8 \%$ \\
\hline & & \multirow{2}{*}{ 500-4999 fö } & Nem kapott & 166 & $65,1 \%$ \\
\hline & & & Részesült & 89 & $34,9 \%$ \\
\hline & & \multirow{2}{*}{ 5000-9999 fö } & Nem kapott & 5 & $26,3 \%$ \\
\hline & & & Részesült & 14 & $73,7 \%$ \\
\hline & & \multirow{2}{*}{ 10000-49999 fö } & Nem kapott & 2 & $15,4 \%$ \\
\hline & & & Részesült & 11 & $84,6 \%$ \\
\hline & & \multirow{2}{*}{50000 fö felett } & Nem kapott & 0 &, $0 \%$ \\
\hline & & & Részesültt & 4 & $100,0 \%$ \\
\hline & \multirow{10}{*}{$\begin{array}{l}\text { Nyugat- } \\
\text { Magyarország }\end{array}$} & \multirow{2}{*}{500 fö alatt } & Nem kapott & 260 & $78,1 \%$ \\
\hline & & & Részesült & 73 & $21,9 \%$ \\
\hline & & \multirow{2}{*}{ 500-4999 fö } & Nem kapott & 201 & $66,1 \%$ \\
\hline & & & Részesült & 103 & $33,9 \%$ \\
\hline & & \multirow{2}{*}{ 5000-9999 fö } & Nem kapott & 2 & $40,0 \%$ \\
\hline & & & Részesült & 3 & $60,0 \%$ \\
\hline & & \multirow{2}{*}{ 10000-49999 fó } & Nem kapott & 4 & $50,0 \%$ \\
\hline & & & Részesült & 4 & $50,0 \%$ \\
\hline & & \multirow{2}{*}{50000 fö felett } & Nem kapott & 0 &, $0 \%$ \\
\hline & & & Részesült & 5 & $100,0 \%$ \\
\hline & \multirow{10}{*}{ Dél-Dunántúl } & \multirow{2}{*}{500 fó alatt } & Nem kapott & 301 & $88,0 \%$ \\
\hline & & & Részesült & 41 & $12,0 \%$ \\
\hline & & \multirow{2}{*}{ 500-4999 fö } & Nem kapott & 181 & $62,6 \%$ \\
\hline & & & Részesült & 108 & $37,4 \%$ \\
\hline & & \multirow{2}{*}{ 5000-9999 fö } & Nem kapott & 3 & $33,3 \%$ \\
\hline & & & Részesült & 6 & $66,7 \%$ \\
\hline & & \multirow{2}{*}{ 10000-49999 fö } & Nem kapott & 3 & $23,1 \%$ \\
\hline & & & Részesült & 10 & $76,9 \%$ \\
\hline & & \multirow{2}{*}{50000 fó felett } & Nem kapott & 0 &, $0 \%$ \\
\hline & & & Részesült & 2 & $100,0 \%$ \\
\hline
\end{tabular}




\begin{tabular}{|c|c|c|c|c|c|}
\hline $\begin{array}{c}\text { Nagyrégió } \\
\text { (NUTS1) }\end{array}$ & Régió (NUTS2) & Léle kszám & $\begin{array}{l}\text { Támogatás ban } \\
\text { része sült-e }\end{array}$ & Darabszám & Arány \\
\hline \multirow{30}{*}{ Alföld és Észak } & \multirow{10}{*}{ Észak-Magyarország } & \multirow{2}{*}{500 fó alatt } & Nem kapott & 151 & $83,0 \%$ \\
\hline & & & Részesültt & 31 & $17,0 \%$ \\
\hline & & \multirow{2}{*}{ 500-4999 fö } & Nem kapott & 245 & $61,6 \%$ \\
\hline & & & Részesültt & 153 & $38,4 \%$ \\
\hline & & \multirow{2}{*}{ 5000-9999 fó } & Nem kapott & 5 & $35,7 \%$ \\
\hline & & & Részesült & 9 & $64,3 \%$ \\
\hline & & \multirow{2}{*}{ 10000-49999 fó } & Nem kapott & 1 & $7,1 \%$ \\
\hline & & & Részesült & 13 & $92,9 \%$ \\
\hline & & \multirow{2}{*}{50000 fö felett } & Nem kapott & 0 &, $0 \%$ \\
\hline & & & Részesült & 2 & $100,0 \%$ \\
\hline & \multirow{10}{*}{ Észak-Alföld } & \multirow{2}{*}{500 fö alatt } & Nem kapott & 36 & $81,8 \%$ \\
\hline & & & Részesült & 8 & $18,2 \%$ \\
\hline & & \multirow{2}{*}{ 500-4999 fó } & Nem kapott & 137 & $48,6 \%$ \\
\hline & & & Részesült & 145 & $51,4 \%$ \\
\hline & & \multirow{2}{*}{ 5000-9999 fö } & Nem kapott & 7 & $17,9 \%$ \\
\hline & & & Részesült & 32 & $82,1 \%$ \\
\hline & & \multirow{2}{*}{ 10000-49999 fó } & Nem kapott & 1 & $4,8 \%$ \\
\hline & & & Részesült & 20 & $95,2 \%$ \\
\hline & & \multirow{2}{*}{50000 fö felett } & Nem kapott & 0 &, $0 \%$ \\
\hline & & & Részesült & 3 & $100,0 \%$ \\
\hline & \multirow{10}{*}{ Dél-Alföld } & \multirow{2}{*}{500 fö alatt } & Nem kapott & 15 & $78,9 \%$ \\
\hline & & & Részesült & 4 & $21,1 \%$ \\
\hline & & \multirow{2}{*}{ 500-4999 fö } & Nem kapott & 96 & $52,2 \%$ \\
\hline & & & Részesült & 88 & $47,8 \%$ \\
\hline & & \multirow{2}{*}{ 5000-9999 fó } & Nem kapott & 2 & $6,9 \%$ \\
\hline & & & Részesült & 27 & $93,1 \%$ \\
\hline & & \multirow{2}{*}{ 10000-49999 fó } & Nem kapott & 3 & $15,8 \%$ \\
\hline & & & Részesült & 16 & $84,2 \%$ \\
\hline & & \multirow{2}{*}{50000 fö felett } & Nem kapott & 0 &, $0 \%$ \\
\hline & & & Részesült & 3 & $100,0 \%$ \\
\hline
\end{tabular}

j)Támogatásban részesült települések NUTS1 nagyrégiók szerinti bontásban

\begin{tabular}{|l|l|r|r|}
\hline $\begin{array}{c}\text { Támogatás ban } \\
\text { részes ült-e }\end{array}$ & \multicolumn{1}{|c|}{$\begin{array}{c}\text { Nagyrégió } \\
\text { (NUTS1) }\end{array}$} & Darab & \multicolumn{1}{c|}{ Arány } \\
\hline \multirow{3}{*}{ Nem kapott } & Közép-Magyarország & 119 & $5,8 \%$ \\
\cline { 2 - 4 } & Dunántúl & 1225 & $60,0 \%$ \\
\cline { 2 - 4 } & Alföld és Észak & 699 & $34,2 \%$ \\
\hline \multirow{3}{*}{ Részesültt } & Közép-Magyarország & 68 & $6,1 \%$ \\
\cline { 2 - 4 } & Dunántúl & 486 & $43,9 \%$ \\
\cline { 2 - 4 } & Alföld és Észak & 554 & $50,0 \%$ \\
\hline
\end{tabular}


k)Településszerkezet és európai uniós támogatások összefüggései (saját bontásban)

\begin{tabular}{|c|c|c|c|c|}
\hline Saját bes orolás & Léle ks zám & \begin{tabular}{|c|}
$\begin{array}{c}\text { Támogatás ban } \\
\text { része sült-e }\end{array}$ \\
\end{tabular} & Darab & Arány \\
\hline \multirow{10}{*}{ Nyugat } & \multirow{2}{*}{500 fó alatt } & Nem kapott & 630 & $84,3 \%$ \\
\hline & & Részesült & 117 & $15,7 \%$ \\
\hline & \multirow{2}{*}{ 500-4999 fö } & Nem kapott & 418 & $66,8 \%$ \\
\hline & & Részesült & 208 & $33,2 \%$ \\
\hline & \multirow{2}{*}{ 5000-9999 fö } & Nem kapott & 6 & $37,5 \%$ \\
\hline & & Részesült & 10 & $62,5 \%$ \\
\hline & \multirow{2}{*}{ 10000-49999 fö } & Nem kapott & 6 & $28,6 \%$ \\
\hline & & Részesült & 15 & $71,4 \%$ \\
\hline & \multirow{2}{*}{50000 fő felett } & Nem kapott & 0 &, $0 \%$ \\
\hline & & Részesült & 8 & $100,0 \%$ \\
\hline \multirow{10}{*}{ Közép } & \multirow{2}{*}{500 fó alatt } & Nem kapott & 185 & $81,9 \%$ \\
\hline & & Részesült & 41 & $18,1 \%$ \\
\hline & \multirow{2}{*}{ 500-4999 fö } & Nem kapott & 460 & $62,7 \%$ \\
\hline & & Részesült & 274 & $37,3 \%$ \\
\hline & \multirow{2}{*}{ 5000-9999 fö } & Nem kapott & 26 & $43,3 \%$ \\
\hline & & Részesült & 34 & $56,7 \%$ \\
\hline & \multirow{2}{*}{ 10000-49999 fö } & Nem kapott & 16 & $25,0 \%$ \\
\hline & & Részesült & 48 & $75,0 \%$ \\
\hline & \multirow{2}{*}{50000 fö felett } & Nem kapott & 0 &, $0 \%$ \\
\hline & & Részesült & 6 & $100,0 \%$ \\
\hline \multirow{10}{*}{ Kelet } & \multirow{2}{*}{500 fö alatt } & Nem kapott & 51 & $81,0 \%$ \\
\hline & & Részesült & 12 & $19,0 \%$ \\
\hline & \multirow{2}{*}{ 500-4999 fö } & Nem kapott & 232 & $49,8 \%$ \\
\hline & & Részesült & 234 & $50,2 \%$ \\
\hline & \multirow{2}{*}{ 5000-9999 fö } & Nem kapott & 9 & $13,2 \%$ \\
\hline & & Részesült & 59 & $86,8 \%$ \\
\hline & \multirow{2}{*}{ 10000-49999 fó } & Nem kapott & 4 & $10,0 \%$ \\
\hline & & Részesült & 36 & $90,0 \%$ \\
\hline & \multirow{2}{*}{50000 fö felett } & Nem kapott & 0 &, $0 \%$ \\
\hline & & Részesült & 6 & $100,0 \%$ \\
\hline
\end{tabular}


l)Támogatásban részesüllt települések saját bontás szerint

\begin{tabular}{|l|l|r|r|}
\hline $\begin{array}{c}\text { Támogatás ban } \\
\text { részes ült-e }\end{array}$ & $\begin{array}{c}\text { Saját } \\
\text { besorolás }\end{array}$ & Darab & \multicolumn{1}{c|}{ Arány } \\
\hline \multirow{3}{*}{ Nem kapott } & Nyugat & 1060 & $51,9 \%$ \\
\cline { 2 - 4 } & Közép & 687 & $33,6 \%$ \\
\cline { 2 - 4 } & Kelet & 296 & $14,5 \%$ \\
\hline \multirow{3}{*}{ Részesült } & Nyugat & 358 & $32,3 \%$ \\
\cline { 2 - 4 } & Közép & 403 & $36,4 \%$ \\
\cline { 2 - 4 } & Kelet & 347 & $31,3 \%$ \\
\hline
\end{tabular}


m) A helyi önkormányzatoknak juttatott európai uniós támogatás NUTS1 régiók szerinti bontásban

\begin{tabular}{|c|c|c|c|}
\hline \multirow{2}{*}{\multicolumn{2}{|c|}{ Régió NUTS 1}} & \multicolumn{2}{|c|}{ Helyi önkormányzatnak juttatott európai uniós támogatás } \\
\hline & & Támogatás összege & Ele ms zám \\
\hline \multirow{3}{*}{$\begin{array}{l}\text { Közé p- } \\
\text { Magyarország }\end{array}$} & Nem kapott & - & 119 \\
\hline & Részesült & 13042966888 & 68 \\
\hline & Összesen & 13042966888 & 187 \\
\hline \multirow{3}{*}{ Dunántúl } & Nem kapott & - & 1225 \\
\hline & Részesült & 49668416600 & 486 \\
\hline & Összesen & 49668416600 & 1711 \\
\hline \multirow{3}{*}{ Alföld és Észak } & Nem kapott & - & 699 \\
\hline & Részesült & 97494872642 & 554 \\
\hline & Összesen & 97494872642 & 1253 \\
\hline \multirow{3}{*}{ Összesen } & Nem kapott & - & 2043 \\
\hline & Részesült & 160206256129 & 1108 \\
\hline & Összesen & 160206256129 & 3151 \\
\hline
\end{tabular}


n)A helyi önkormányzatoknak juttatott európai uniós támogatás NUTS2 régiók szerinti bontásban

\begin{tabular}{|c|c|c|c|}
\hline \multirow{2}{*}{\multicolumn{2}{|c|}{ Régió NUTS 2}} & \multicolumn{2}{|c|}{ Helyi önkormányzatnak juttatott e urópai uniós támogatás } \\
\hline & & Támogatás összege & Elemszám \\
\hline \multirow{3}{*}{$\begin{array}{l}\text { Közép- } \\
\text { Magyarország }\end{array}$} & Nem kapott & - & 119 \\
\hline & Részesült & 13042966888 & 68 \\
\hline & Összesen & 13042966888 & 187 \\
\hline \multirow{3}{*}{ Közép-Dunántúl } & Nem kapott & - & 270 \\
\hline & Részesült & 19866711006 & 131 \\
\hline & Összesen & 19866711006 & 401 \\
\hline \multirow{3}{*}{$\begin{array}{l}\text { Nyugat- } \\
\text { Magyarország }\end{array}$} & Nem kapott & - & 467 \\
\hline & Részesült & 10489634654 & 188 \\
\hline & Összesen & 10489634654 & 655 \\
\hline \multirow{3}{*}{ Dél-Dunántúl } & Nem kapott & - & 488 \\
\hline & Részesült & 19312070940 & 167 \\
\hline & Összesen & 19312070940 & 655 \\
\hline \multirow{3}{*}{$\begin{array}{l}\text { Észak- } \\
\text { Magyarország }\end{array}$} & Nem kapott & - & 402 \\
\hline & Részesült & 34724652570 & 208 \\
\hline & Összesen & 34724652570 & 610 \\
\hline \multirow{3}{*}{ Észak-Alföld } & Nem kapott & - & 181 \\
\hline & Részesültt & 34476545492 & 208 \\
\hline & Összesen & 34476545492 & 389 \\
\hline \multirow{3}{*}{ Dél-Alföld } & Nem kapott & - & 116 \\
\hline & Részesült & 28293674580 & 138 \\
\hline & Összesen & 28293674580 & 254 \\
\hline \multirow{3}{*}{ Összesen } & Nem kapott & - & 2043 \\
\hline & Részesült & 160206256129 & 1108 \\
\hline & Összesen & 160206256129 & 3151 \\
\hline
\end{tabular}


o)A helyi önkormányzatoknak juttatott európai uniós támogatás NUTS3 megye szerinti bontásban

\begin{tabular}{|c|c|c|c|}
\hline \multirow{2}{*}{\multicolumn{2}{|c|}{ Megye NUTS 3}} & \multicolumn{2}{|c|}{ Helyi önkormányzatnak juttatott e urópai uniós támogatás } \\
\hline & & Támogatás összege & Ele mszám \\
\hline \multirow{3}{*}{ Baranya } & Nem kapott & - & 244 \\
\hline & Részesült & 8850264627 & 57 \\
\hline & Összesen & 8850264627 & 301 \\
\hline \multirow{3}{*}{ Bács-Kis kun } & Nem kapott & - & 58 \\
\hline & Részesültt & 8865672290 & 61 \\
\hline & Összesen & 8865672290 & 119 \\
\hline \multirow{3}{*}{ Békés } & Nem kapott & - & 33 \\
\hline & Részesült & 11201059251 & 42 \\
\hline & Összesen & 11201059251 & 75 \\
\hline \multirow{3}{*}{$\begin{array}{l}\text { Borsod-Abaúj- } \\
\text { Zemplén }\end{array}$} & Nem kapott & - & 233 \\
\hline & Részesült & 18913886802 & 125 \\
\hline & Összesen & 18913886802 & 358 \\
\hline \multirow{3}{*}{ Cs ongrád } & Nem kapott & - & 24 \\
\hline & \begin{tabular}{|l|} 
Részesültt \\
\end{tabular} & 8247806220 & 36 \\
\hline & Összesen & 8247806220 & 60 \\
\hline \multirow{3}{*}{ Fejér } & Nem kapott & - & 52 \\
\hline & Részesült & 10606152232 & 56 \\
\hline & Összesen & 10606152232 & 108 \\
\hline \multirow{3}{*}{$\begin{array}{l}\text { Győr-Moson- } \\
\text { Sopron }\end{array}$} & Nem kapott & - & 142 \\
\hline & Részesült & 2833997734 & 40 \\
\hline & Összesen & 2833997734 & 182 \\
\hline \multirow{3}{*}{ Hajdú-Bihar } & Nem kapott & - & 30 \\
\hline & Részesült & 11430672702 & 52 \\
\hline & Összesen & 11430672702 & 82 \\
\hline \multirow{3}{*}{ Heves } & Nem kapott & - & 71 \\
\hline & Részesült & 12489074532 & 50 \\
\hline & Összesen & 12489074532 & 121 \\
\hline \multirow{3}{*}{$\begin{array}{l}\text { Komárom- } \\
\text { Esztergom }\end{array}$} & Nem kapott & - & 48 \\
\hline & Részesült & 4967036295 & 28 \\
\hline & Összesen & 4967036295 & 76 \\
\hline \multirow{3}{*}{ Nógrád } & Nem kapott & - & 99 \\
\hline & Részesült & 3302451669 & 32 \\
\hline & Összesen & 3302451669 & 131 \\
\hline \multirow{3}{*}{ Pest } & Nem kapott & - & 120 \\
\hline & Részesült & 13040059888 & 67 \\
\hline & Összesen & 13040059888 & 187 \\
\hline
\end{tabular}




\begin{tabular}{|c|c|c|c|}
\hline \multirow{2}{*}{\multicolumn{2}{|c|}{ Megye NUTS 3}} & \multicolumn{2}{|c|}{ Helyi önkormányzatnak juttatott e urópai uniós támogatás } \\
\hline & & Támogatás összege & Elems zám \\
\hline \multirow{3}{*}{ Somogy } & Nem kapott & - & 180 \\
\hline & Részesült & 6394014392 & 65 \\
\hline & Összesen & 6394014392 & 245 \\
\hline \multirow{3}{*}{$\begin{array}{l}\text { Szabolcs-Szatmár- } \\
\text { Bereg }\end{array}$} & Nem kapott & - & 117 \\
\hline & Részesült & 15021270599 & 112 \\
\hline & Összesen & 15021270599 & 229 \\
\hline \multirow{3}{*}{$\begin{array}{l}\text { Jász-Nagykun- } \\
\text { Szolnok }\end{array}$} & Nem kapott & - & 34 \\
\hline & Részesült & 8006646010 & 44 \\
\hline & Összesen & 8006646010 & 78 \\
\hline \multirow{3}{*}{ Tolna } & Nem kapott & - & 64 \\
\hline & Részesült & 4067791921 & 45 \\
\hline & Összesen & 4067791921 & 109 \\
\hline \multirow{3}{*}{ Vas } & Nem kapott & - & 164 \\
\hline & Részesült & 3167804471 & 52 \\
\hline & Összesen & 3167804471 & 216 \\
\hline \multirow{3}{*}{ Veszprém } & Nem kapott & - & 169 \\
\hline & Részesült & 4308022449 & 48 \\
\hline & Összesen & 4308022449 & 217 \\
\hline \multirow{3}{*}{ Zala } & Nem kapott & - & 161 \\
\hline & Részesült & 4492572046 & 96 \\
\hline & Összesen & 4492572046 & 257 \\
\hline \multirow{3}{*}{ Összesen } & Nem kapott & - & 2043 \\
\hline & Részesült & 160206256129 & 1108 \\
\hline & Összesen & 160206256129 & 3151 \\
\hline
\end{tabular}


p)A helyi önkormányzatoknak juttatott európai uniós támogatás saját kategorizálás szerint

\begin{tabular}{|c|c|c|c|}
\hline \multirow{2}{*}{\multicolumn{2}{|c|}{ Saját bontás }} & Helyi önkormányzatnak juttatott & \\
\hline & & Támogatás összege & Ele ms zám \\
\hline \multirow{3}{*}{ Nyugat } & Nem kapott & - & 1060 \\
\hline & Részesült & 30046675719 & 358 \\
\hline & Összesen & 30046675719 & 1418 \\
\hline \multirow{3}{*}{ Közép } & Nem kapott & - & 687 \\
\hline & Részesült & 67386453339 & 403 \\
\hline & Összesen & 67386453339 & 1090 \\
\hline \multirow{3}{*}{ Kelet } & Nem kapott & - & 296 \\
\hline & \begin{tabular}{|l|} 
Részesültt \\
\end{tabular} & 62773127072 & 347 \\
\hline & Összesen & 62773127072 & 643 \\
\hline \multirow{3}{*}{ Összesen } & Nem kapott & - & 2043 \\
\hline & Részesült & 160206256129 & 1108 \\
\hline & Összesen & 160206256129 & 3151 \\
\hline
\end{tabular}




\section{q) Allandó népesség száma különféle területi bontásban, box-plot ábrázolással}

A box-plot ábrázolás értelmezése a következő: a dobozban a megfigyelések 50\%-a található, annak alja $25 \%$, teteje $75 \%$ percentilis. A doboz közepében lévő vízszintes vonal a medián. A függőleges vonalak hossza legfeljebb másfél interkvartilis. A záró vonalon kívül eső elemek kör jelöléssel kilógó elemek, a csillaggal jelöltek pedig extrémen kilógók. (Kovács 2009)

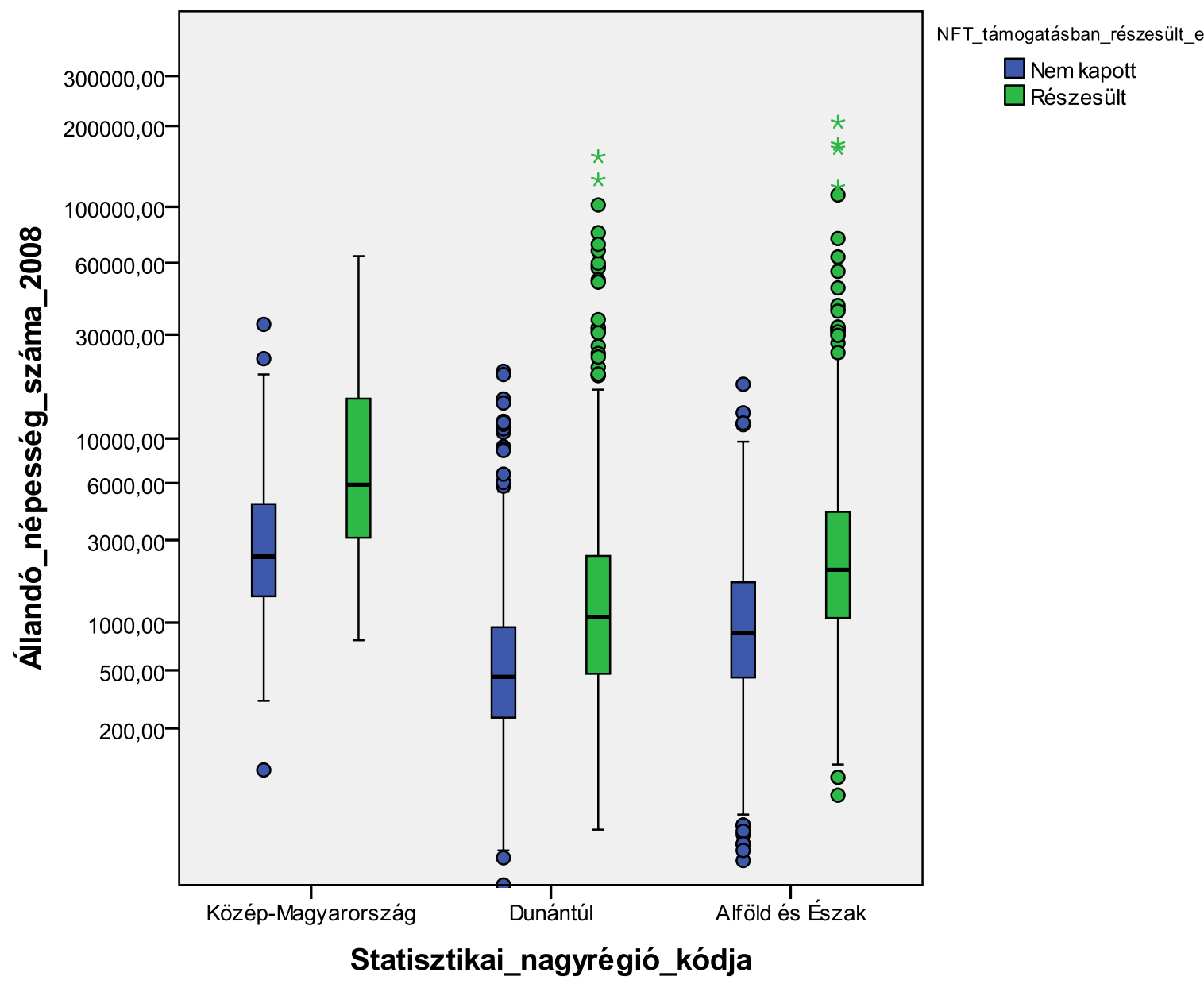



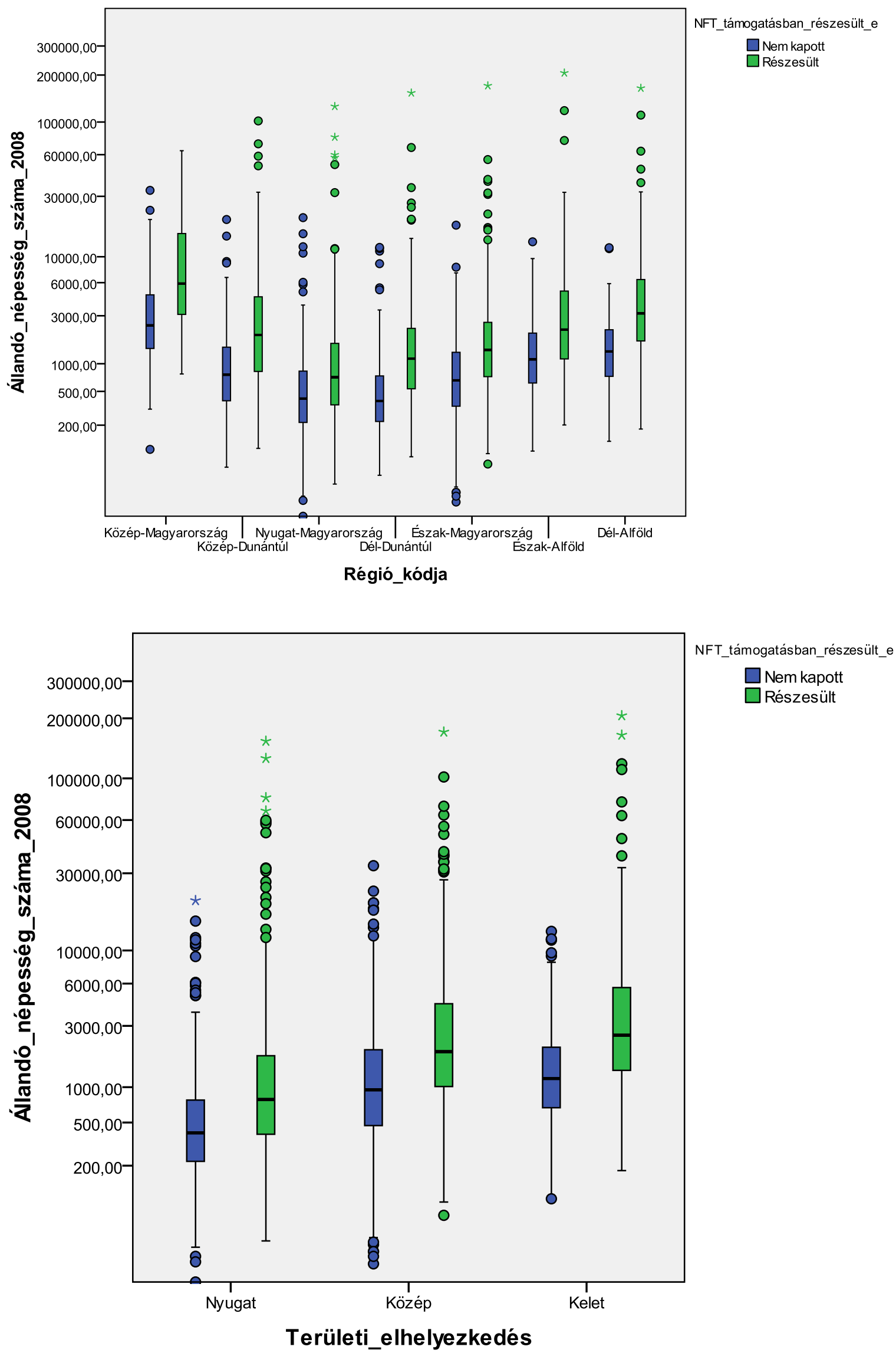
11. számú melléklet: A H2 hipotézis tesztelésének eredményei a1) Az állandó népesség száma és a felújítás és beruházásra fordított
önkormányzati kiadások kapcsolata

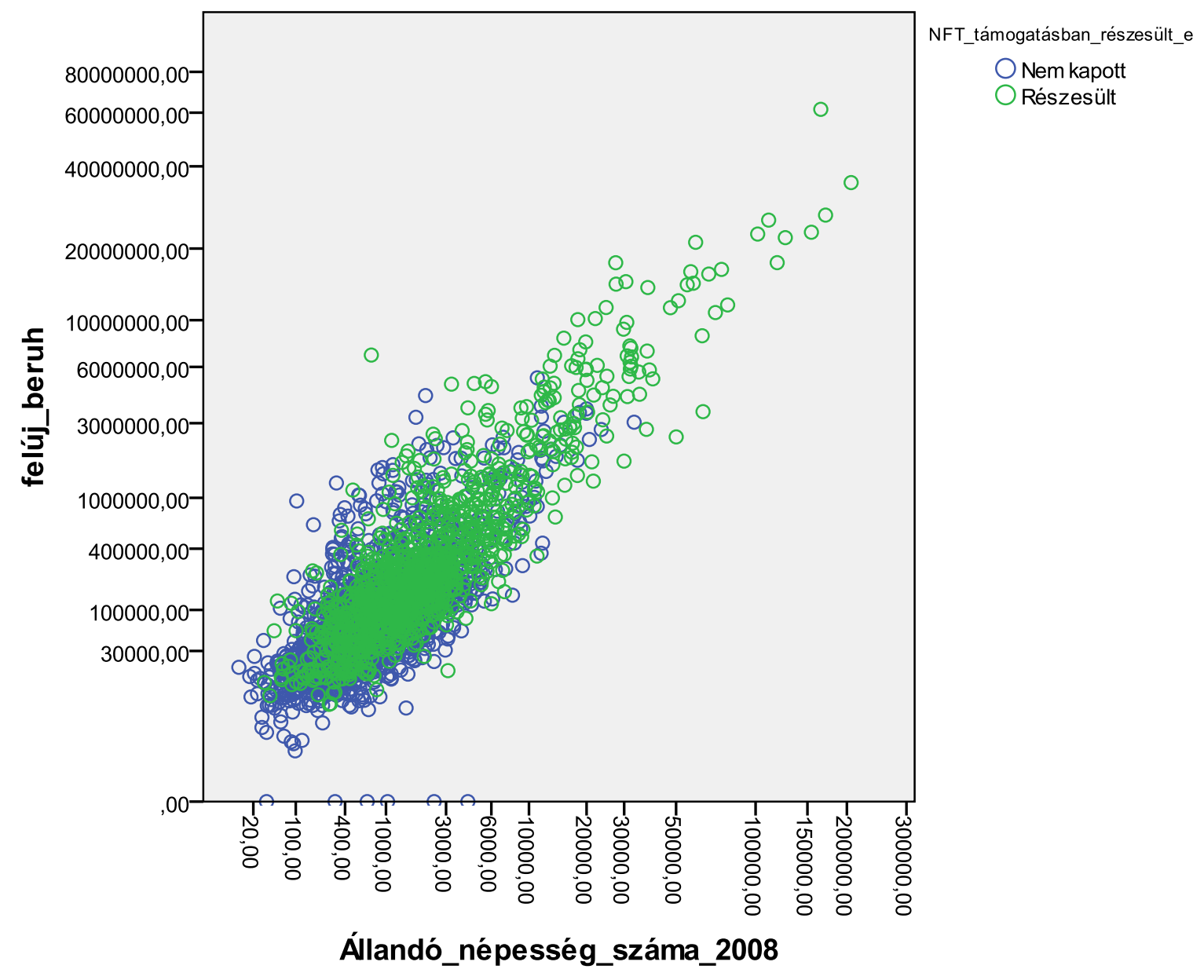


a2) Az állandó népesség száma és a helyi önkormányzat részére folyósított európai uniós támogatások kapcsolata

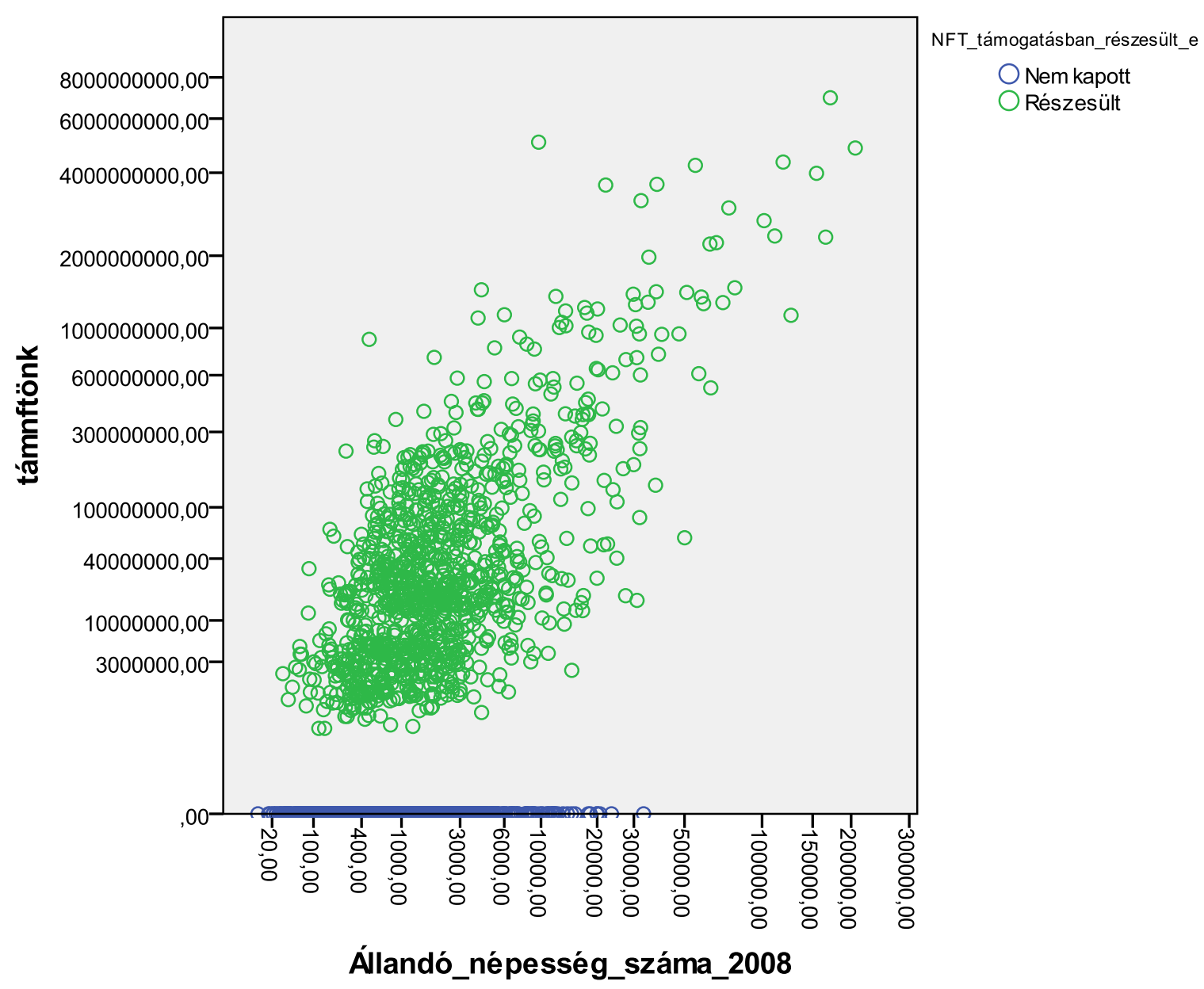


a3) A felújítás és beruházásra fordított önkormányzati kiadások és a folyósított európai uniós támogatások kapcsolata

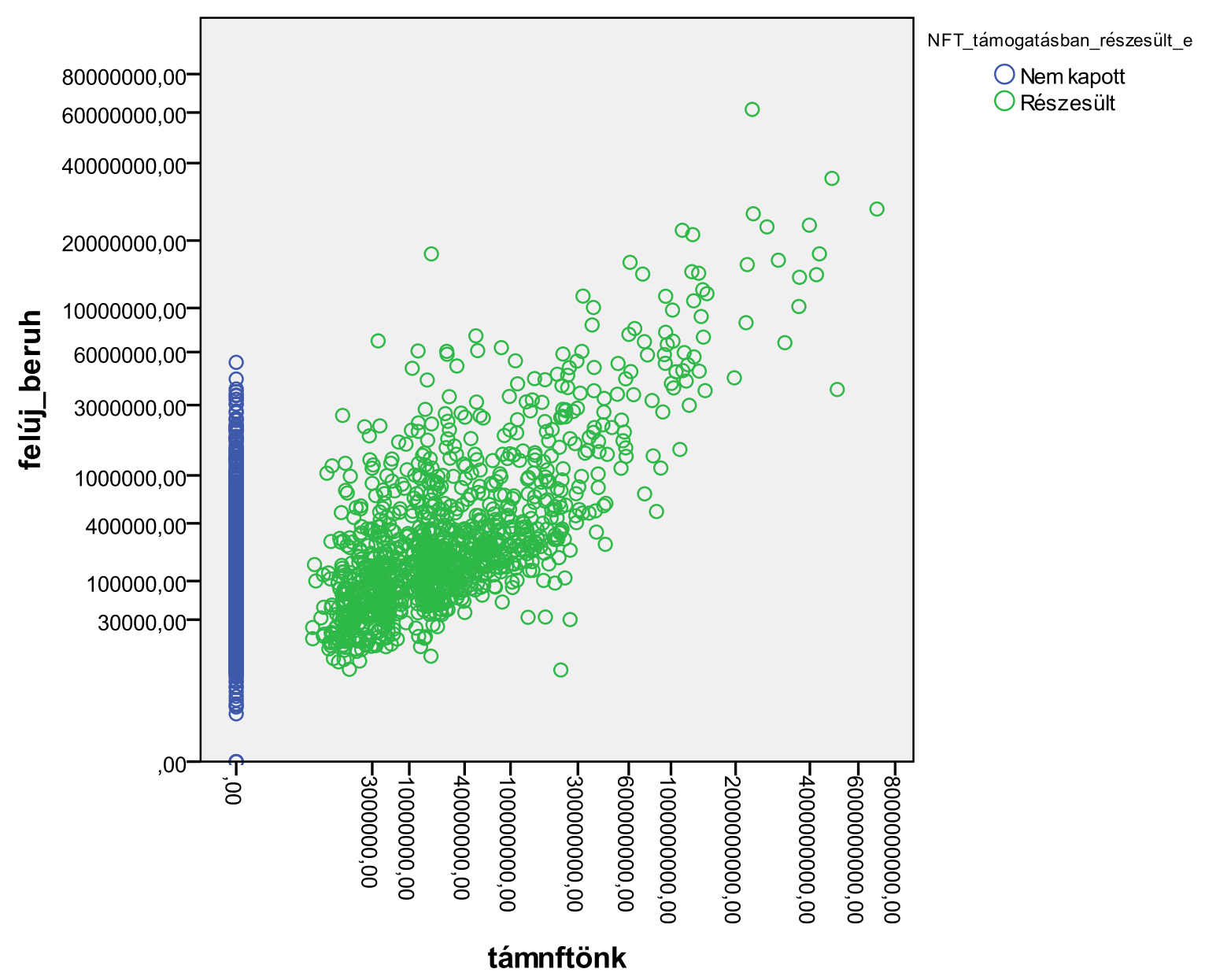


b1) A folyósított európai uniós támogatások, a felújítás és beruházásra fordított önkormányzati kiadások és a lélekszám közötti korreláció országos szinten

\begin{tabular}{|r|r|r|r|}
\hline \multicolumn{4}{|c|}{ Korre láció } \\
\hline & támnftönk & felúj_beruh & Állandó_népesség_száma_2008 \\
\hline támnftönk & 1,000 & 0,726 & 0,776 \\
\hline
\end{tabular}

b2) A folyósított európai uniós támogatások, a felújitás és beruházásra fordított önkormányzati kiadások és a lélekszám közötti korreláció megyék szerinti bontásban

\begin{tabular}{|l|r|r|r|}
\hline \multicolumn{4}{|c|}{ Korreláció } \\
\hline Megye & támnftönk & felúj_beruh & Állandó_népesség_száma_2008 \\
\hline Baranya & 1,000 & 0,938 & 0,946 \\
\hline Bács-Kiskun & 1,000 & 0,925 & 0,894 \\
\hline Békés & 1,000 & 0,768 & 0,813 \\
\hline Borsod-Abaúj-Zemplén & 1,000 & 0,928 & 0,931 \\
\hline Csongrád & 1,000 & 0,848 & 0,841 \\
\hline Fejér & 1,000 & 0,564 & 0,468 \\
\hline Györ-Moson-Sopron & 1,000 & 0,968 & 0,971 \\
\hline Hajdú-Bihar & 1,000 & 0,977 & 0,978 \\
\hline Heves & 1,000 & 0,941 & 0,868 \\
\hline Komárom-Esztergom & 1,000 & 0,921 & 0,818 \\
\hline Nógrád & 1,000 & 0,910 & 0,836 \\
\hline Pest & 1,000 & 0,521 & 0,499 \\
\hline Somogy & 1,000 & 0,826 & 0,883 \\
\hline Szabolcs-Szatmár-Bereg & 1,000 & 0,937 & 0,936 \\
\hline Jász-Nagykun-Szolnok & 1,000 & 0,810 & 0,894 \\
\hline Tolna & 1,000 & 0,722 & 0,770 \\
\hline Vas & 1,000 & 0,897 & 0,923 \\
\hline Veszprém & 1,000 & 0,932 & 0,874 \\
\hline Zala & 1,000 & 0,899 & 0,942 \\
\hline
\end{tabular}


c1) A folyósított európai uniós támogatások, a felújítás és beruházásra forditott önkormányzati kiadások és a lélekszám közötti korreláció országos szinten, a lélekszám mint kontroll változó figyelembe vételével

\begin{tabular}{|c|c|c|c|c|c|}
\hline \multicolumn{6}{|c|}{ Korreláció } \\
\hline \multicolumn{3}{|l|}{ Kontroll változó } & támnftönk & felúj_beruh & Állandó_népesség_száma_2008 \\
\hline \multirow{9}{*}{ Nincs } & \multirow{3}{*}{ támnftönk } & Korreláció & 1,000 & 0,726 & 0,776 \\
\hline & & Szignifikancia & & 0,000 & 0,000 \\
\hline & & df & & 3143 & 3143 \\
\hline & \multirow{3}{*}{ felúj_beruh } & Korreláció & 0,726 & 1,000 & 0,900 \\
\hline & & Szignifikancia & 0,000 & & 0,000 \\
\hline & & $\mathrm{df}$ & 3143,000 &, 000 & 3143,000 \\
\hline & \multirow{3}{*}{$\begin{array}{l}\text { Állandó_népesség_száma } \\
2008\end{array}$} & Korreláció & ,776 & ,900 & 1,000 \\
\hline & & Szignifikancia &, 000 &, 000 & \\
\hline & & df & 3143 & 3143 & \\
\hline \multirow{6}{*}{$\begin{array}{l}\text { Állandó_népesség_száma } \\
\text { _2008 }\end{array}$} & \multirow{3}{*}{ támnftönk } & Korreláció & 1,000 & 0,101 & \\
\hline & & Szignifikancia & & 0,000 & \\
\hline & & df & & 3142 & \\
\hline & \multirow{3}{*}{ felúj_beruh } & Korreláció & 0,101 & 1,000 & \\
\hline & & Szignifikancia & 0,000 & & \\
\hline & & df & 3142 & & \\
\hline
\end{tabular}

c2) A folyósított európai uniós támogatások, a felújítás és beruházásra fordított önkormányzati kiadások és a lélekszám közötti korreláció megyénkénti bontásban, a lélekszám mint kontroll változó figyelembe vételével

\begin{tabular}{|c|c|c|c|c|c|c|}
\hline \multicolumn{7}{|c|}{ Korreláció } \\
\hline Megye & \multicolumn{3}{|l|}{ Kontroll változó } & támnftönk & felúj_beruh & $\begin{array}{c}\text { Állandó_népesség_ } \\
\text { száma_2008 }\end{array}$ \\
\hline \multirow{15}{*}{ Baranya } & \multirow{9}{*}{ Nincs } & \multirow{3}{*}{ támnftönk } & Korreláció & 1,000 & 0,938 & 0,946 \\
\hline & & & Szignifikancia & . & 0,000 & 0,000 \\
\hline & & & $\mathrm{df}$ & 0 & 299 & 299 \\
\hline & & \multirow{3}{*}{ felúj_beruh } & Korreláció & 0,938 & 1,000 & 0,973 \\
\hline & & & Szignifikancia & 0,000 & . & 0,000 \\
\hline & & & df & 299 & 0 & 299 \\
\hline & & \multirow{3}{*}{$\begin{array}{l}\text { Állandó_népesség_ } \\
\text { száma_2008 }\end{array}$} & Korreláció & 0,946 & 0,973 & 1,000 \\
\hline & & & Szignifikancia & 0,000 & 0,000 & \\
\hline & & & $\mathrm{df}$ & 299 & 299 & 0 \\
\hline & \multirow{6}{*}{$\begin{array}{l}\text { Állandó_népesség } \\
\text { _száma_2008 }\end{array}$} & \multirow{3}{*}{ támnftönk } & Korreláció & 1,000 & 0,231 & \\
\hline & & & Szignifikancia & & 0,000 & \\
\hline & & & $\mathrm{df}$ & 0 & 298 & \\
\hline & & \multirow{3}{*}{ felúj_beruh } & Korreláció & 0,231 & 1,000 & \\
\hline & & & Szignifikancia & 0,000 & 1 & \\
\hline & & & $\mathrm{df}$ & 298 & 0 & \\
\hline
\end{tabular}




\begin{tabular}{|c|c|c|c|c|c|c|}
\hline \multicolumn{7}{|c|}{ Korreláció } \\
\hline Megye & \multicolumn{3}{|l|}{ Kontroll változó } & támnftönk & felúj_beruh & $\begin{array}{c}\text { Állandó_népesség } \\
\text { száma_2008 }\end{array}$ \\
\hline \multirow{15}{*}{$\begin{array}{l}\text { Bács- } \\
\text { Kiskun }\end{array}$} & \multirow{9}{*}{ Nincs } & \multirow{3}{*}{ támnftönk } & Korreláció & 1,000 & 0,925 & 0,894 \\
\hline & & & Szignifikancia & . & 0,000 & 0,000 \\
\hline & & & df & 0 & 117 & 117 \\
\hline & & \multirow{3}{*}{ felúj_beruh } & Korreláció & 0,925 & 1,000 & 0,962 \\
\hline & & & Szignifikancia & 0,000 & . & 0,000 \\
\hline & & & $\mathrm{df}$ & 117 & 0 & 117 \\
\hline & & \multirow{3}{*}{$\begin{array}{l}\text { Állandó_népesség_ } \\
\text { száma_2008 }\end{array}$} & Korreláció & 0,894 & 0,962 & 1,000 \\
\hline & & & Szignifikancia & 0,000 & 0,000 & \\
\hline & & & $\mathrm{df}$ & 117 & 117 & 0 \\
\hline & \multirow{6}{*}{$\begin{array}{l}\text { Állandó_népesség } \\
\text { _száma_2008 }\end{array}$} & \multirow{3}{*}{ támnftönk } & Korreláció & 1,000 & 0,531 & \\
\hline & & & Szignifikancia & . & 0,000 & \\
\hline & & & $\mathrm{df}$ & 0 & 116 & \\
\hline & & \multirow{3}{*}{ felúj_beruh } & Korreláció & 0,531 & 1,000 & \\
\hline & & & Szignifikancia & 0,000 &. & \\
\hline & & & df & 116 & 0 & \\
\hline \multirow{15}{*}{ Békés } & \multirow{9}{*}{ Nincs } & \multirow{3}{*}{ támnftönk } & Korreláció & 1,000 & 0,768 & 0,813 \\
\hline & & & Szignifikancia & . & 0,000 & 0,000 \\
\hline & & & $\mathrm{df}$ & 0 & 73 & 73 \\
\hline & & \multirow{3}{*}{ felúj_beruh } & Korreláció & 0,768 & 1,000 & 0,878 \\
\hline & & & Szignifikancia & 0,000 & . & 0,000 \\
\hline & & & $\mathrm{df}$ & 73 & 0 & 73 \\
\hline & & \multirow{3}{*}{$\begin{array}{l}\text { Állandó_népesség_ } \\
\text { száma_2008 }\end{array}$} & Korreláció & 0,813 & 0,878 & 1,000 \\
\hline & & & Szignifikancia & 0,000 & 0,000 & \\
\hline & & & $\mathrm{df}$ & 73 & 73 & 0 \\
\hline & \multirow{6}{*}{$\begin{array}{l}\text { Állandó_népesség } \\
\text { _száma_2008 }\end{array}$} & \multirow{3}{*}{ támnftönk } & Korreláció & 1,000 & 0,192 & \\
\hline & & & Szignifikancia & $\cdot 1$ & 0,101 & \\
\hline & & & $\mathrm{df}$ & 0 & 72 & \\
\hline & & \multirow{3}{*}{ felúj_beruh } & Korreláció & 0,192 & 1,000 & \\
\hline & & & Szignifikancia & 0,101 &. & \\
\hline & & & $\mathrm{df}$ & 72 & 0 & \\
\hline
\end{tabular}




\begin{tabular}{|c|c|c|c|c|c|c|}
\hline \multicolumn{7}{|c|}{ Korreláció } \\
\hline Megye & Kontroll változó & & & támnftönk & felúj_beruh & $\begin{array}{c}\text { Állandó_népesség } \\
\text { száma_2008 }\end{array}$ \\
\hline \multirow{15}{*}{$\begin{array}{l}\text { Borsod- } \\
\text { Abaúj- } \\
\text { Zemplén }\end{array}$} & \multirow{9}{*}{ Nincs } & \multirow{3}{*}{ támnftönk } & Korreláció & 1,000 & 0,928 & 0,931 \\
\hline & & & Szignifikancia & & 0,000 & 0,000 \\
\hline & & & $\mathrm{df}$ & 0 & 355 & 355 \\
\hline & & \multirow{3}{*}{ felúj_beruh } & Korreláció & 0,928 & 1,000 & 0,952 \\
\hline & & & Szignifikancia & 0,000 & & 0,000 \\
\hline & & & df & 355 & 0 & 355 \\
\hline & & \multirow{3}{*}{$\begin{array}{l}\text { Állandó_népesség_ } \\
\text { száma_2008 }\end{array}$} & Korreláció & 0,931 & 0,952 & 1,000 \\
\hline & & & Szignifikancia & 0,000 & 0,000 & \\
\hline & & & df & 355 & 355 & 0 \\
\hline & \multirow{6}{*}{$\begin{array}{l}\text { Állandó_népesség } \\
\text { _száma_2008 }\end{array}$} & \multirow{3}{*}{ támnftönk } & Korreláció & 1,000 & 0,370 & \\
\hline & & & Szignifikancia & & 0,000 & \\
\hline & & & $\mathrm{df}$ & 0 & 354 & \\
\hline & & \multirow{3}{*}{ felúj_beruh } & Korreláció & 0,370 & 1,000 & \\
\hline & & & Szignifikancia & 0,000 & & \\
\hline & & & $\mathrm{df}$ & 354 & 0 & \\
\hline \multirow{15}{*}{ Csongrád } & \multirow{9}{*}{ Nincs } & \multirow{3}{*}{ támnftönk } & Korreláció & 1,000 & 0,848 & 0,841 \\
\hline & & & Szignifikancia & & 0,000 & 0,000 \\
\hline & & & df & 0 & 58 & 58 \\
\hline & & \multirow{3}{*}{ felúj_beruh } & Korreláció & 0,848 & 1,000 & 0,989 \\
\hline & & & Szignifikancia & 0,000 & & 0,000 \\
\hline & & & $\mathrm{df}$ & 58 & 0 & 58 \\
\hline & & \multirow{3}{*}{$\begin{array}{l}\text { Állandó_népesség_ } \\
\text { száma_2008 }\end{array}$} & Korreláció & 0,841 & 0,989 & 1,000 \\
\hline & & & Szignifikancia & 0,000 & 0,000 & \\
\hline & & & $\mathrm{df}$ & 58 & 58 & 0 \\
\hline & \multirow{6}{*}{$\begin{array}{l}\text { Állandó_népesség } \\
\text { _száma_2008 }\end{array}$} & \multirow{3}{*}{ támnftönk } & Korreláció & 1,000 & 0,197 & \\
\hline & & & Szignifikancia & & 0,134 & \\
\hline & & & $\mathrm{df}$ & 0 & 57 & \\
\hline & & \multirow{3}{*}{ felúj_beruh } & Korreláció & 0,197 & 1,000 & \\
\hline & & & Szignifikancia & 0,134 & & \\
\hline & & & $\mathrm{df}$ & 57 & 0 & \\
\hline
\end{tabular}




\begin{tabular}{|c|c|c|c|c|c|c|}
\hline \multicolumn{7}{|c|}{ Korreláció } \\
\hline Megye & \multicolumn{3}{|l|}{ Kontroll változó } & támnftönk & felúj_beruh & $\begin{array}{c}\text { Állandó_népesség_ } \\
\text { száma_2008 }\end{array}$ \\
\hline \multirow{15}{*}{ Fejér } & \multirow{9}{*}{ Nincs } & \multirow{3}{*}{ támnftönk } & Korreláció & 1,000 & 0,564 & 0,468 \\
\hline & & & Szignifikancia & & 0,000 & 0,000 \\
\hline & & & $\mathrm{df}$ & 0 & 106 & 106 \\
\hline & & \multirow{3}{*}{ felúj_beruh } & Korreláció & 0,564 & 1,000 & 0,894 \\
\hline & & & Szignifikancia & 0,000 & & 0,000 \\
\hline & & & $\mathrm{df}$ & 106 & 0 & 106 \\
\hline & & \multirow{3}{*}{$\begin{array}{l}\text { Állandó_népesség_ } \\
\text { száma_2008 }\end{array}$} & Korreláció & 0,468 & 0,894 & 1,000 \\
\hline & & & Szignifikancia & 0,000 & 0,000 & \\
\hline & & & $\mathrm{df}$ & 106 & 106 & 0 \\
\hline & \multirow{6}{*}{$\begin{array}{l}\text { Állandó_népesség } \\
\text { _száma_2008 }\end{array}$} & \multirow{3}{*}{ támnftönk } & Korreláció & 1,000 & 0,368 & \\
\hline & & & Szignifikancia & & 0,000 & \\
\hline & & & $\mathrm{df}$ & 0 & 105 & \\
\hline & & \multirow{3}{*}{ felúj_beruh } & Korreláció & 0,368 & 1,000 & \\
\hline & & & Szignifikancia & 0,000 & & \\
\hline & & & $\mathrm{df}$ & 105 & 0 & \\
\hline \multirow{15}{*}{$\begin{array}{l}\text { Győr- } \\
\text { Moson- } \\
\text { Sopron }\end{array}$} & \multirow{9}{*}{ Nincs } & \multirow{3}{*}{ támnftönk } & Korreláció & 1,000 & 0,968 & 0,971 \\
\hline & & & Szignifikancia & & 0,000 & 0,000 \\
\hline & & & $\mathrm{df}$ & 0 & 180 & 180 \\
\hline & & \multirow{3}{*}{ felúj_beruh } & Korreláció & 0,968 & 1,000 & 0,974 \\
\hline & & & Szignifikancia & 0,000 & & 0,000 \\
\hline & & & $\mathrm{df}$ & 180 & 0 & 180 \\
\hline & & \multirow{3}{*}{$\begin{array}{l}\text { Állandó_népesség_ } \\
\text { száma_2008 }\end{array}$} & Korreláció & 0,971 & 0,974 & 1,000 \\
\hline & & & Szignifikancia & 0,000 & 0,000 & \\
\hline & & & $\mathrm{df}$ & 180 & 180 & 0 \\
\hline & \multirow{6}{*}{$\begin{array}{l}\text { Állandó_népesség } \\
\text { _száma_2008 }\end{array}$} & \multirow{3}{*}{ támnftönk } & Korreláció & 1,000 & 0,398 & \\
\hline & & & \begin{tabular}{|l|} 
Szignifikancia \\
\end{tabular} & & 0,000 & \\
\hline & & & $\mathrm{df}$ & 0 & 179 & \\
\hline & & \multirow{3}{*}{ felúj_beruh } & Korreláció & 0,398 & 1,000 & \\
\hline & & & Szignifikancia & 0,000 & & \\
\hline & & & $\mathrm{df}$ & 179 & 0 & \\
\hline
\end{tabular}




\begin{tabular}{|c|c|c|c|c|c|c|}
\hline \multicolumn{7}{|c|}{ Korreláció } \\
\hline Megye & Kontroll változó & & & támnftönk & felúj_beruh & $\begin{array}{c}\text { Állandó_népesség _ } \\
\text { száma_2008 }\end{array}$ \\
\hline \multirow{15}{*}{$\begin{array}{l}\text { Hajdú- } \\
\text { Bihar }\end{array}$} & \multirow{9}{*}{ Nincs } & \multirow{3}{*}{ támnftönk } & Korreláció & 1,000 & 0,977 & 0,978 \\
\hline & & & \begin{tabular}{|l} 
Szignifikancia \\
\end{tabular} & & 0,000 & 0,000 \\
\hline & & & $\mathrm{df}$ & 0 & 80 & 80 \\
\hline & & \multirow{3}{*}{ felúj_beruh } & Korreláció & 0,977 & 1,000 & 0,989 \\
\hline & & & Szignifikancia & 0,000 & . & 0,000 \\
\hline & & & $\mathrm{df}$ & 80 & 0 & 80 \\
\hline & & \multirow{3}{*}{$\begin{array}{l}\text { Állandó_népesség_ } \\
\text { száma_2008 }\end{array}$} & Korreláció & 0,978 & 0,989 & 1,000 \\
\hline & & & \begin{tabular}{|l} 
Szignifikancia \\
\end{tabular} & 0,000 & 0,000 & \\
\hline & & & $\mathrm{df}$ & 80 & 80 & 0 \\
\hline & \multirow{6}{*}{$\begin{array}{l}\text { Állandó_népesség } \\
\text { _száma_2008 }\end{array}$} & \multirow{3}{*}{ támnftönk } & Korreláció & 1,000 & 0,309 & \\
\hline & & & Szignifikancia & . & 0,005 & \\
\hline & & & $\mathrm{df}$ & 0 & 79 & \\
\hline & & \multirow{3}{*}{ felúj_beruh } & Korreláció & 0,309 & 1,000 & \\
\hline & & & \begin{tabular}{|l} 
Szignifikancia \\
\end{tabular} & 0,005 & . & \\
\hline & & & df & 79 & 0 & \\
\hline \multirow{15}{*}{ Heves } & \multirow{9}{*}{ Nincs } & \multirow{3}{*}{ támnftönk } & Korreláció & 1,000 & 0,941 & 0,868 \\
\hline & & & \begin{tabular}{|l} 
Szignifikancia \\
\end{tabular} & . & 0,000 & 0,000 \\
\hline & & & df & 0 & 118 & 118 \\
\hline & & \multirow{3}{*}{ felúj_beruh } & Korreláció & 0,941 & 1,000 & 0,943 \\
\hline & & & Szignifikancia & 0,000 &. & 0,000 \\
\hline & & & $\mathrm{df}$ & 118 & 0 & 118 \\
\hline & & \multirow{3}{*}{$\begin{array}{l}\text { Állandó_népesség_ } \\
\text { száma_2008 }\end{array}$} & Korreláció & 0,868 & 0,943 & 1,000 \\
\hline & & & Szignifikancia & 0,000 & 0,000 & \\
\hline & & & $\mathrm{df}$ & 118 & 118 & 0 \\
\hline & \multirow{6}{*}{$\begin{array}{l}\text { Állandó_népesség } \\
\text { _száma_2008 }\end{array}$} & \multirow{3}{*}{ támnftönk } & Korreláció & 1,000 & 0,741 & \\
\hline & & & \begin{tabular}{|l} 
Szignifikancia \\
\end{tabular} & & 0,000 & \\
\hline & & & $\mathrm{df}$ & 0 & 117 & \\
\hline & & \multirow{3}{*}{ felúj_beruh } & Korreláció & 0,741 & 1,000 & \\
\hline & & & Szignifikancia & 0,000 &. & \\
\hline & & & $\mathrm{df}$ & 117 & 0 & \\
\hline
\end{tabular}




\begin{tabular}{|c|c|c|c|c|c|c|}
\hline \multicolumn{7}{|c|}{ Korreláció } \\
\hline Megye & \multicolumn{3}{|l|}{ Kontroll változó } & támnftönk & felúj_beruh & $\begin{array}{c}\text { Állandó_népesség_ } \\
\text { száma_2008 }\end{array}$ \\
\hline \multirow{15}{*}{$\begin{array}{l}\text { Komárom- } \\
\text { Esztergom }\end{array}$} & \multirow{9}{*}{ Nincs } & \multirow{3}{*}{ támnftönk } & Korreláció & 1,000 & 0,921 & 0,818 \\
\hline & & & Szignifikancia & & 0,000 & 0,000 \\
\hline & & & $\mathrm{df}$ & 0 & 74 & 74 \\
\hline & & \multirow{3}{*}{ felúj_beruh } & Korreláció & 0,921 & 1,000 & 0,841 \\
\hline & & & Szignifikancia & 0,000 & & 0,000 \\
\hline & & & $\mathrm{df}$ & 74 & 0 & 74 \\
\hline & & \multirow{3}{*}{$\begin{array}{l}\text { Állandó_népesség_ } \\
\text { száma_2008 }\end{array}$} & Korreláció & 0,818 & 0,841 & 1,000 \\
\hline & & & Szignifikancia & 0,000 & 0,000 & \\
\hline & & & $\mathrm{df}$ & 74 & 74 & 0 \\
\hline & \multirow{6}{*}{$\begin{array}{l}\text { Állandó_népesség } \\
\text { _száma_2008 }\end{array}$} & \multirow{3}{*}{ támnftönk } & Korreláció & 1,000 & 0,750 & \\
\hline & & & Szignifikancia & & 0,000 & \\
\hline & & & $\mathrm{df}$ & 0 & 73 & \\
\hline & & \multirow{3}{*}{ felúj_beruh } & Korreláció & 0,750 & 1,000 & \\
\hline & & & Szignifikancia & 0,000 & & \\
\hline & & & $\mathrm{df}$ & 73 & 0 & \\
\hline \multirow{15}{*}{ Nógrád } & \multirow{9}{*}{ Nincs } & \multirow{3}{*}{ támnftönk } & Korreláció & 1,000 & 0,910 & 0,836 \\
\hline & & & \begin{tabular}{|l} 
Szignifikancia \\
\end{tabular} & & 0,000 & 0,000 \\
\hline & & & $\mathrm{df}$ & 0 & 127 & 127 \\
\hline & & \multirow{3}{*}{ felúj_beruh } & Korreláció & 0,910 & 1,000 & 0,805 \\
\hline & & & Szignifikancia & 0,000 & & 0,000 \\
\hline & & & $\mathrm{df}$ & 127 & 0 & 127 \\
\hline & & \multirow{3}{*}{$\begin{array}{l}\text { Állandó_népesség_ } \\
\text { száma_2008 }\end{array}$} & Korreláció & 0,836 & 0,805 & 1,000 \\
\hline & & & Szignifikancia & 0,000 & 0,000 & \\
\hline & & & $\mathrm{df}$ & 127 & 127 & 0 \\
\hline & \multirow{6}{*}{$\begin{array}{l}\text { Állandó_népesség } \\
\text { _száma_2008 }\end{array}$} & \multirow{3}{*}{ támnftönk } & Korreláció & 1,000 & 0,728 & \\
\hline & & & \begin{tabular}{|l|} 
Szignifikancia \\
\end{tabular} & & 0,000 & \\
\hline & & & $\mathrm{df}$ & 0 & 126 & \\
\hline & & \multirow{3}{*}{ felúj_beruh } & Korreláció & 0,728 & 1,000 & \\
\hline & & & Szignifikancia & 0,000 & & \\
\hline & & & $\mathrm{df}$ & 126 & 0 & \\
\hline
\end{tabular}




\begin{tabular}{|c|c|c|c|c|c|c|}
\hline \multicolumn{7}{|c|}{ Korreláció } \\
\hline Megye & \multicolumn{3}{|l|}{ Kontroll változó } & támnftönk & felúj_beruh & $\begin{array}{c}\text { Állandó_népesség _ } \\
\text { száma_2008 }\end{array}$ \\
\hline \multirow{15}{*}{ Pest } & \multirow{9}{*}{ Nincs } & \multirow{3}{*}{ támnftönk } & Korreláció & 1,000 & 0,521 & 0,499 \\
\hline & & & \begin{tabular}{|l} 
Szignifikancia \\
\end{tabular} & & 0,000 & 0,000 \\
\hline & & & $\mathrm{df}$ & 0 & 184 & 184 \\
\hline & & \multirow{3}{*}{ felúj_beruh } & Korreláció & 0,521 & 1,000 & 0,678 \\
\hline & & & Szignifikancia & 0,000 & . & 0,000 \\
\hline & & & $\mathrm{df}$ & 184 & 0 & 184 \\
\hline & & \multirow{3}{*}{$\begin{array}{l}\text { Állandó_népesség_ } \\
\text { száma_2008 }\end{array}$} & Korreláció & 0,499 & 0,678 & 1,000 \\
\hline & & & \begin{tabular}{|l} 
Szignifikancia \\
\end{tabular} & 0,000 & 0,000 & \\
\hline & & & $\mathrm{df}$ & 184 & 184 & 0 \\
\hline & \multirow{6}{*}{$\begin{array}{l}\text { Állandó_népesség } \\
\text { _száma_2008 }\end{array}$} & \multirow{3}{*}{ támnftönk } & Korreláció & 1,000 & 0,286 & \\
\hline & & & Szignifikancia & . & 0,000 & \\
\hline & & & $\mathrm{df}$ & 0 & 183 & \\
\hline & & \multirow{3}{*}{ felúj_beruh } & Korreláció & 0,286 & 1,000 & \\
\hline & & & \begin{tabular}{|l} 
Szignifikancia \\
\end{tabular} & 0,000 & . & \\
\hline & & & df & 183 & 0 & \\
\hline \multirow{15}{*}{ Somogy } & \multirow{9}{*}{ Nincs } & \multirow{3}{*}{ támnftönk } & Korreláció & 1,000 & 0,826 & 0,883 \\
\hline & & & \begin{tabular}{|l} 
Szignifikancia \\
\end{tabular} & . & 0,000 & 0,000 \\
\hline & & & df & 0 & 243 & 243 \\
\hline & & \multirow{3}{*}{ felúj_beruh } & Korreláció & 0,826 & 1,000 & 0,943 \\
\hline & & & Szignifikancia & 0,000 &. & 0,000 \\
\hline & & & $\mathrm{df}$ & 243 & 0 & 243 \\
\hline & & \multirow{3}{*}{$\begin{array}{l}\text { Állandó_népesség_ } \\
\text { száma_2008 }\end{array}$} & Korreláció & 0,883 & 0,943 & 1,000 \\
\hline & & & Szignifikancia & 0,000 & 0,000 & \\
\hline & & & $\mathrm{df}$ & 243 & 243 & 0 \\
\hline & \multirow{6}{*}{$\begin{array}{l}\text { Állandó_népesség } \\
\text { _száma_2008 }\end{array}$} & \multirow{3}{*}{ támnftönk } & Korreláció & 1,000 & $-0,045$ & \\
\hline & & & \begin{tabular}{|l} 
Szignifikancia \\
\end{tabular} & & 0,481 & \\
\hline & & & $\mathrm{df}$ & 0 & 242 & \\
\hline & & \multirow{3}{*}{ felúj_beruh } & Korreláció & $-0,045$ & 1,000 & \\
\hline & & & Szignifikancia & 0,481 &. & \\
\hline & & & $\mathrm{df}$ & 242 & 0 & \\
\hline
\end{tabular}




\begin{tabular}{|c|c|c|c|c|c|c|}
\hline \multicolumn{7}{|c|}{ Korreláció } \\
\hline Megye & \multicolumn{3}{|l|}{ Kontroll változó } & támnftönk & felúj_beruh & $\begin{array}{c}\text { Állandó_népesség_ } \\
\text { száma_2008 }\end{array}$ \\
\hline \multirow{15}{*}{$\begin{array}{l}\text { Szabolcs- } \\
\text { Szatmár- } \\
\text { Bereg }\end{array}$} & \multirow{9}{*}{ Nincs } & \multirow{3}{*}{ támnftönk } & Korreláció & 1,000 & 0,937 & 0,936 \\
\hline & & & Szignifikancia & & 0,000 & 0,000 \\
\hline & & & $\mathrm{df}$ & 0 & 227 & 227 \\
\hline & & \multirow{3}{*}{ felúj_beruh } & Korreláció & 0,937 & 1,000 & 0,963 \\
\hline & & & Szignifikancia & 0,000 & & 0,000 \\
\hline & & & $\mathrm{df}$ & 227 & 0 & 227 \\
\hline & & \multirow{3}{*}{$\begin{array}{l}\text { Állandó_népesség_ } \\
\text { száma_2008 }\end{array}$} & Korreláció & 0,936 & 0,963 & 1,000 \\
\hline & & & Szignifikancia & 0,000 & 0,000 & \\
\hline & & & df & 227 & 227 & 0 \\
\hline & \multirow{6}{*}{$\begin{array}{l}\text { Állandó_népesség } \\
\text { _száma_2008 }\end{array}$} & \multirow{3}{*}{ támnftönk } & Korreláció & 1,000 & 0,384 & \\
\hline & & & Szignifikancia & & 0,000 & \\
\hline & & & $\mathrm{df}$ & 0 & 226 & \\
\hline & & \multirow{3}{*}{ felúj_beruh } & Korreláció & 0,384 & 1,000 & \\
\hline & & & Szignifikancia & 0,000 & & \\
\hline & & & $\mathrm{df}$ & 226 & 0 & \\
\hline \multirow{15}{*}{$\begin{array}{l}\text { Jász- } \\
\text { Nagykun- } \\
\text { Szolnok }\end{array}$} & \multirow{9}{*}{ Nincs } & \multirow{3}{*}{ támnftönk } & Korreláció & 1,000 & 0,810 & 0,894 \\
\hline & & & Szignifikancia & & 0,000 & 0,000 \\
\hline & & & $\mathrm{df}$ & 0 & 76 & 76 \\
\hline & & \multirow{3}{*}{ felúj_beruh } & Korreláció & 0,810 & 1,000 & 0,911 \\
\hline & & & Szignifikancia & 0,000 & & 0,000 \\
\hline & & & $\mathrm{df}$ & 76 & 0 & 76 \\
\hline & & \multirow{3}{*}{$\begin{array}{l}\text { Állandó_népesség_ } \\
\text { száma_2008 }\end{array}$} & Korreláció & 0,894 & 0,911 & 1,000 \\
\hline & & & Szignifikancia & 0,000 & 0,000 & \\
\hline & & & $\mathrm{df}$ & 76 & 76 & 0 \\
\hline & \multirow{6}{*}{$\begin{array}{l}\text { Állandó_népesség } \\
\text { _száma_2008 }\end{array}$} & \multirow{3}{*}{ támnftönk } & Korreláció & 1,000 & $-0,022$ & \\
\hline & & & Szignifikancia & & 0,852 & \\
\hline & & & $\mathrm{df}$ & 0 & 75 & \\
\hline & & \multirow{3}{*}{ felúj_beruh } & Korreláció & $-0,022$ & 1,000 & \\
\hline & & & Szignifikancia & 0,852 & & \\
\hline & & & $\mathrm{df}$ & 75 & 0 & \\
\hline
\end{tabular}




\begin{tabular}{|c|c|c|c|c|c|c|}
\hline \multicolumn{7}{|c|}{ Korreláció } \\
\hline Megye & \multicolumn{3}{|l|}{ Kontroll változó } & támnftönk & felúj_beruh & $\begin{array}{c}\text { Állandó_népesség_ } \\
\text { száma_2008 }\end{array}$ \\
\hline \multirow{15}{*}{ Tolna } & \multirow{9}{*}{ Nincs } & \multirow{3}{*}{ támnftönk } & Korreláció & 1,000 & 0,722 & 0,770 \\
\hline & & & \begin{tabular}{|l} 
Szignifikancia \\
\end{tabular} & & 0,000 & 0,000 \\
\hline & & & $\mathrm{df}$ & 0 & 106 & 106 \\
\hline & & \multirow{3}{*}{ felúj_beruh } & Korreláció & 0,722 & 1,000 & 0,941 \\
\hline & & & Szignifikancia & 0,000 & . & 0,000 \\
\hline & & & $\mathrm{df}$ & 106 & 0 & 106 \\
\hline & & \multirow{3}{*}{$\begin{array}{l}\text { Állandó_népesség_ } \\
\text { száma_2008 }\end{array}$} & Korreláció & 0,770 & 0,941 & 1,000 \\
\hline & & & Szignifikancia & 0,000 & 0,000 & \\
\hline & & & $\mathrm{df}$ & 106 & 106 & 0 \\
\hline & \multirow{6}{*}{$\begin{array}{l}\text { Állandó_népesség } \\
\text { _száma_2008 }\end{array}$} & \multirow{3}{*}{ támnftönk } & Korreláció & 1,000 & $-0,011$ & \\
\hline & & & Szignifikancia & 4 & 0,912 & \\
\hline & & & $\mathrm{df}$ & 0 & 105 & \\
\hline & & \multirow{3}{*}{ felúj_beruh } & Korreláció & $-0,011$ & 1,000 & \\
\hline & & & \begin{tabular}{|l} 
Szignifikancia \\
\end{tabular} & 0,912 & . & \\
\hline & & & df & 105 & 0 & \\
\hline \multirow{15}{*}{ Vas } & \multirow{9}{*}{ Nincs } & \multirow{3}{*}{ támnftönk } & Korreláció & 1,000 & 0,897 & 0,923 \\
\hline & & & \begin{tabular}{|l} 
Szignifikancia \\
\end{tabular} & . & 0,000 & 0,000 \\
\hline & & & $\mathrm{df}$ & 0 & 214 & 214 \\
\hline & & \multirow{3}{*}{ felúj_beruh } & Korreláció & 0,897 & 1,000 & 0,939 \\
\hline & & & Szignifikancia & 0,000 &. & 0,000 \\
\hline & & & $\mathrm{df}$ & 214 & 0 & 214 \\
\hline & & \multirow{3}{*}{$\begin{array}{l}\text { Állandó_népesség_ } \\
\text { száma_2008 }\end{array}$} & Korreláció & 0,923 & 0,939 & 1,000 \\
\hline & & & Szignifikancia & 0,000 & 0,000 & \\
\hline & & & $\mathrm{df}$ & 214 & 214 & 0 \\
\hline & \multirow{6}{*}{$\begin{array}{l}\text { Állandó_népesség } \\
\text { _száma_2008 }\end{array}$} & \multirow{3}{*}{ támnftönk } & Korreláció & 1,000 & 0,228 & \\
\hline & & & \begin{tabular}{|l} 
Szignifikancia \\
\end{tabular} & & 0,001 & \\
\hline & & & $\mathrm{df}$ & 0 & 213 & \\
\hline & & \multirow{3}{*}{ felúj_beruh } & Korreláció & 0,228 & 1,000 & \\
\hline & & & Szignifikancia & 0,001 &. & \\
\hline & & & $\mathrm{df}$ & 213 & 0 & \\
\hline
\end{tabular}




\begin{tabular}{|c|c|c|c|c|c|c|}
\hline \multicolumn{7}{|c|}{ Korreláció } \\
\hline Megye & \multicolumn{3}{|l|}{ Kontroll változó } & támnftönk & felúj_beruh & $\begin{array}{c}\text { Állandó_népesség_ } \\
\text { száma_2008 }\end{array}$ \\
\hline \multirow{15}{*}{ Veszprém } & \multirow{9}{*}{ Nincs } & \multirow{3}{*}{ támnftönk } & Korreláció & 1,000 & 0,932 & 0,874 \\
\hline & & & Szignifikancia & & 0,000 & 0,000 \\
\hline & & & df & 0 & 215 & 215 \\
\hline & & \multirow{3}{*}{ felúj_beruh } & Korreláció & 0,932 & 1,000 & 0,951 \\
\hline & & & Szignifikancia & 0,000 & & 0,000 \\
\hline & & & $\mathrm{df}$ & 215 & 0 & 215 \\
\hline & & \multirow{3}{*}{$\begin{array}{l}\text { Állandó_népesség_ } \\
\text { száma_2008 }\end{array}$} & Korreláció & 0,874 & 0,951 & 1,000 \\
\hline & & & Szignifikancia & 0,000 & 0,000 & \\
\hline & & & $\mathrm{df}$ & 215 & 215 & 0 \\
\hline & \multirow{6}{*}{$\begin{array}{l}\text { Állandó_népesség } \\
\text { _száma_2008 }\end{array}$} & \multirow{3}{*}{ támnftönk } & Korreláció & 1,000 & 0,668 & \\
\hline & & & Szignifikancia & & 0,000 & \\
\hline & & & $\mathrm{df}$ & 0 & 214 & \\
\hline & & \multirow{3}{*}{ felúj_beruh } & Korreláció & 0,668 & 1,000 & \\
\hline & & & \begin{tabular}{|l|} 
Szignifikancia \\
\end{tabular} & 0,000 & & \\
\hline & & & df & 214 & 0 & \\
\hline \multirow{15}{*}{ Zala } & \multirow{9}{*}{ Nincs } & \multirow{3}{*}{ támnftönk } & Korreláció & 1,000 & 0,899 & 0,942 \\
\hline & & & \begin{tabular}{|l|} 
Szignifikancia \\
\end{tabular} & & 0,000 & 0,000 \\
\hline & & & $\mathrm{df}$ & 0 & 255 & 255 \\
\hline & & \multirow{3}{*}{ felúj_beruh } & Korreláció & 0,899 & 1,000 & 0,927 \\
\hline & & & Szignifikancia & 0,000 & & 0,000 \\
\hline & & & df & 255 & 0 & 255 \\
\hline & & \multirow{3}{*}{$\begin{array}{l}\text { Állandó_népesség_ } \\
\text { száma_2008 }\end{array}$} & Korreláció & 0,942 & 0,927 & 1,000 \\
\hline & & & Szignifikancia & 0,000 & 0,000 & \\
\hline & & & $\mathrm{df}$ & 255 & 255 & 0 \\
\hline & \multirow{6}{*}{$\begin{array}{l}\text { Állandó_népesség } \\
\text { _száma_2008 }\end{array}$} & \multirow{3}{*}{ támnftönk } & Korreláció & 1,000 & 0,203 & \\
\hline & & & Szignifikancia & & 0,001 & \\
\hline & & & df & 0 & 254 & \\
\hline & & \multirow{3}{*}{ felúj_beruh } & Korreláció & 0,203 & 1,000 & \\
\hline & & & Szignifikancia & 0,001 & & \\
\hline & & & $\mathrm{df}$ & 254 & 0 & \\
\hline
\end{tabular}


d) Az európai uniós támogatásban részesült, illetve nem részesült települlések gyakorisága településkategóriánként

\begin{tabular}{|c|c|c|}
\hline Kategorizálás & $\begin{array}{c}\text { Európai uniós } \\
\text { támogatás ban } \\
\text { részes ült-e }\end{array}$ & Darabszám \\
\hline \multirow{2}{*}{200 fó alatt } & Nem kapott & 294 \\
\hline & Részesült & 39 \\
\hline \multirow{2}{*}{ 200-499 fő } & Nem kapott & 572 \\
\hline & Részesült & 131 \\
\hline \multirow{2}{*}{ 500-999 fö } & Nem kapott & 490 \\
\hline & Részesült & 186 \\
\hline \multirow{2}{*}{ 1000-4999 fö } & Nem kapott & 620 \\
\hline & Részesült & 530 \\
\hline \multirow{2}{*}{ 5000-9999 fö } & Nem kapott & 41 \\
\hline & Részesült & 103 \\
\hline \multirow{2}{*}{ 10000-49999 fö } & Nem kapott & 26 \\
\hline & Részesült & 99 \\
\hline \multirow{2}{*}{50000 fó felett } & Nem kapott & 0 \\
\hline & Részesült & 20 \\
\hline
\end{tabular}


e1) Az egy före jutó beruházási és fejlesztési kiadások átlaga és szórása a támogatásban részesült, illetve nem részesült helyi önkormányzatok viszonylatában, méret szerinti rétegezés figyelembe vételével

\begin{tabular}{|c|c|c|c|c|c|}
\hline $\begin{array}{l}\text { Méret szerinti } \\
\text { rétegezés }\end{array}$ & $\begin{array}{c}\text { Európai uniós } \\
\text { támogatás ban } \\
\text { rés zes ült-e }\end{array}$ & Darabszám & Átlag & Szórás & $\begin{array}{c}\text { Standard } \\
\text { átlagos elté rés }\end{array}$ \\
\hline \multirow{2}{*}{200 fó alatt } & Nem kapott & 294 & 262,235 & 628,824 & 36,674 \\
\hline & Részesült & 39 & 376,724 & 507,846 & 81,320 \\
\hline \multirow{2}{*}{ 200-499 fö } & Nem kapott & 572 & 172,380 & 293,732 & 12,282 \\
\hline & Részesült & 131 & 187,881 & 267,062 & 23,333 \\
\hline \multirow{2}{*}{ 500-999 fö } & Nem kapott & 490 & 137,768 & 241,847 & 10,926 \\
\hline & Részesült & 186 & 226,351 & 693,048 & 50,817 \\
\hline \multirow{2}{*}{ 1000-4999 fö } & Nem kapott & 620 & 128,056 & 195,545 & 7,853 \\
\hline & Részesült & 530 & 165,495 & 210,778 & 9,156 \\
\hline \multirow{2}{*}{ 5000-9999 fö } & Nem kapott & 41 & 129,626 & 100,784 & 15,740 \\
\hline & Részesült & 103 & 172,403 & 152,444 & 15,021 \\
\hline \multirow{2}{*}{ 10000-49999 fö } & Nem kapott & 26 & 155,122 & 92,831 & 18,206 \\
\hline & Részesült & 99 & 229,884 & 128,656 & 12,930 \\
\hline \multirow{2}{*}{50000 fö felett } & Nem kapott & 0 & & & \\
\hline & Részesült & 20 & 199,733 & 83,227 & 18,610 \\
\hline
\end{tabular}


e2) Az egy före jutó helyi önkormányzat részére juttatott európai uniós támogatás méret szinti bontásban

\begin{tabular}{|l|r|c|}
\hline \multirow{2}{*}{$\begin{array}{c}\text { Méret sze rinti } \\
\text { ré te gezés }\end{array}$} & \multicolumn{2}{|c|}{ támnftönk_fo } \\
\cline { 2 - 3 } & \multicolumn{1}{|c|}{ Darabszám } & \multicolumn{1}{c|}{ Átlag } \\
\hline 200 fö alatt & 39 & 61023,40 \\
\hline 200-499 fo' & 131 & 50126,80 \\
\hline 500-999 fö & 186 & 46108,16 \\
\hline 1000-4999 fó & 530 & 27629,46 \\
\hline 5000-9999 fó & 103 & 26193,30 \\
\hline 10000-49999 fö & 99 & 24445,12 \\
\hline 50000 fö felett & 20 & 25584,68 \\
\hline
\end{tabular}


e3) Az európai uniós támogatásban részesült, illetve nem részesült helyi önkormányzatok egy före jutó beruházási és fejlesztési kiadásai egyenlöségének tesztelése, méret szerinti rétegezés figyelembe vételével (t-próba)

\begin{tabular}{|c|c|c|c|c|c|c|c|c|c|c|}
\hline \multirow{3}{*}{\multicolumn{2}{|c|}{ Méret sze rinti rétegezés }} & \multicolumn{2}{|c|}{$\begin{array}{c}\text { Levene's tesztje a } \\
\text { szórások } \\
\text { egyezőségére }\end{array}$} & \multicolumn{7}{|c|}{ t-próba az átlagok egyenlőségére } \\
\hline & & \multirow[t]{2}{*}{$\mathbf{F}$} & \multirow[t]{2}{*}{ Szignifikancia } & \multirow[t]{2}{*}{$\mathbf{t}$} & \multirow[t]{2}{*}{ df } & \multirow{2}{*}{$\begin{array}{c}\text { Szzignifikancia } \\
\text { (két farkú) }\end{array}$} & \multirow{2}{*}{$\begin{array}{l}\text { Átlagos } \\
\text { eltérés }\end{array}$} & \multirow{2}{*}{$\begin{array}{c}\text { Standard } \\
\text { hiba elté rés }\end{array}$} & \multicolumn{2}{|c|}{$\begin{array}{c}\text { A különbséghez tartozó 90\%- } \\
\text { os konfidencia intervallum }\end{array}$} \\
\hline & & & & & & & & & alsó érték & felső érték \\
\hline \multirow{2}{*}{200 fö alatt } & $\begin{array}{l}\text { Egyenlő szórást } \\
\text { feltételezve }\end{array}$ & 1,681 & 0,196 & $-1,090$ & 331 & 0,276 & $-114,489$ & 105,002 & $-287,687$ & 58,709 \\
\hline & $\begin{array}{l}\text { Egyenlő szórásokat nem } \\
\text { feltételezve }\end{array}$ & & & $-1,283$ & 54,735 & 0,205 & $-114,489$ & 89,208 & $-263,749$ & 34,771 \\
\hline \multirow{2}{*}{ 200-499 fö } & $\begin{array}{l}\text { Egyenlö szórást } \\
\text { feltételezve }\end{array}$ & 0,024 & 0,878 & $-0,554$ & 701 & 0,580 & $-15,501$ & 27,990 & $-61,601$ & 30,599 \\
\hline & $\begin{array}{l}\text { Egyenlő szórásokat nem } \\
\text { feltételezve }\end{array}$ & & & $-0,588$ & 208,369 & 0,557 & $-15,501$ & 26,368 & $-59,066$ & 28,064 \\
\hline \multirow{2}{*}{ 500-999 fő } & $\begin{array}{l}\text { Egyenlő szórást } \\
\text { feltételezve }\end{array}$ & 3,861 & 0,050 & $-2,464$ & 674 & 0,014 & $-88,583$ & 35,953 & $-147,802$ & $-29,365$ \\
\hline & $\begin{array}{l}\text { Egyenlő szórásokat nem } \\
\text { feltételezve }\end{array}$ & & & $-1,704$ & 202,335 & 0,090 & $-88,583$ & 51,978 & $-174,473$ & $-2,694$ \\
\hline \multirow{2}{*}{$1000-4999$} & $\begin{array}{l}\text { Egyenlő szórást } \\
\text { feltételezve }\end{array}$ & 2,260 & 0,133 & $-3,122$ & 1148 & 0,002 & $-37,439$ & 11,992 & $-57,180$ & $-17,699$ \\
\hline & $\begin{array}{l}\text { Egyenlő szórásokat nem } \\
\text { feltételezve }\end{array}$ & & & $-3,104$ & 1089,677 & 0,002 & $-37,439$ & 12,062 & $-57,297$ & $-17,582$ \\
\hline \multirow{2}{*}{ 5000-9999 } & $\begin{array}{l}\text { Egyenlő szórást } \\
\text { feltételezve }\end{array}$ & 1,172 & 0,281 & $-1,657$ & 142 & 0,100 & $-42,778$ & 25,822 & $-85,530$ & $-0,025$ \\
\hline & $\begin{array}{l}\text { Egyenlö szórásokat nem } \\
\text { feltételezve }\end{array}$ & & & $-1,966$ & 110,193 & 0,052 & $-42,778$ & 21,757 & $-78,868$ & $-6,687$ \\
\hline \multirow{2}{*}{$10000-49999$} & $\begin{array}{l}\text { Egyenlő szórást } \\
\text { feltételezve }\end{array}$ & 5,849 & 0,017 & $-2,776$ & 123 & 0,006 & $-74,762$ & 26,935 & $-119,403$ & $-30,122$ \\
\hline & $\begin{array}{l}\text { Egyenlő szórásokat nem } \\
\text { feltételezve }\end{array}$ & & & $-3,348$ & 53,134 & 0,002 & $-74,762$ & 22,330 & $-112,144$ & $-37,381$ \\
\hline
\end{tabular}


f) A 200 és 500 fö közötti települlések egy före jutó beruházási és fejlesztési kiadásainak ábrázolása a lakosság függvényében

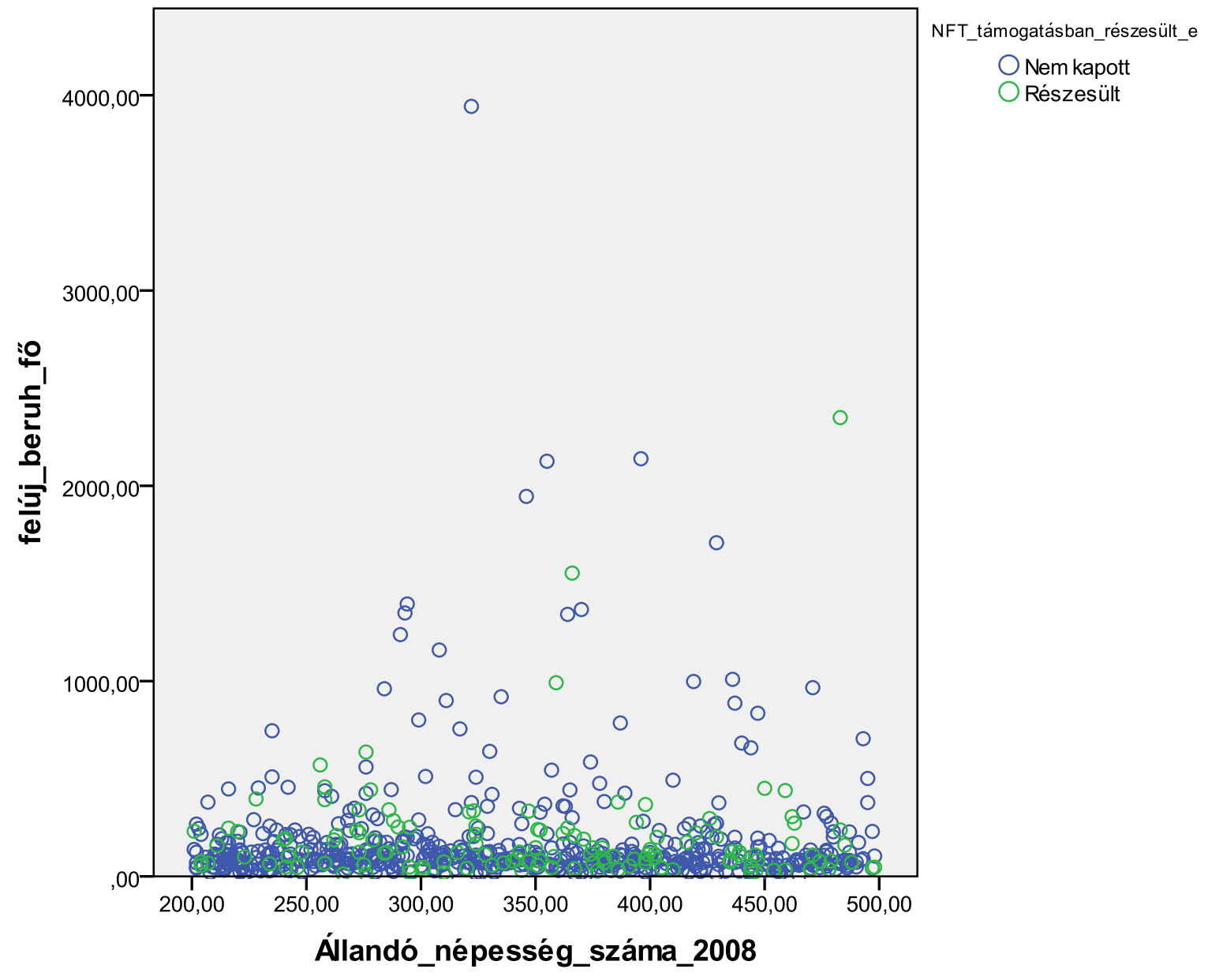


g) Az európai uniós támogatásban részesült, illetve nem részesült helyi önkormányzatok egy före jutó beruházási és fejlesztési kiadásai egyenlöségének tesztelése, a 200 -500 fö közötti rétegben, az extrém elemek elhagyásával

\begin{tabular}{|c|c|r|r|r|r|}
\hline & $\begin{array}{c}\text { Európai uniós } \\
\text { támogatás ban } \\
\text { részesült-e }\end{array}$ & Darabszám & Átlag & \multicolumn{1}{c|}{ Szórás } & \multicolumn{1}{c|}{$\begin{array}{c}\text { Standard } \\
\text { átlagos } \\
\text { eltérés }\end{array}$} \\
\hline felúj_beruh_fó & Nem kapott & 541 & 117,265 & 93,824 & 4,034 \\
\cline { 2 - 6 } & Részesült & 126 & 146,914 & 110,674 & 9,860 \\
\hline
\end{tabular}

\begin{tabular}{|c|c|c|c|c|c|c|c|c|c|c|}
\hline & & \multicolumn{2}{|c|}{$\begin{array}{c}\text { Levene's tesztje a szórások } \\
\text { egyezöségére }\end{array}$} & \multicolumn{7}{|c|}{ t-próba az átlagok egyenlőségére } \\
\hline & & \multirow[t]{2}{*}{$\mathbf{F}$} & \multirow[t]{2}{*}{ Szignifikancia } & \multirow[t]{2}{*}{$\mathbf{t}$} & \multirow[t]{2}{*}{ df } & \multirow{2}{*}{$\begin{array}{l}\text { Szignifikanci } \\
\text { a (két farkú) }\end{array}$} & \multirow{2}{*}{$\begin{array}{l}\text { Átlagos } \\
\text { elté rés }\end{array}$} & \multirow{2}{*}{$\begin{array}{c}\text { Standard hiba } \\
\text { eltérés }\end{array}$} & \multicolumn{2}{|c|}{$\begin{array}{c}\text { A különbséghez tartozó } \\
\begin{array}{c}95 \% \text {-os konfidencia } \\
\text { intervallum }\end{array} \\
\end{array}$} \\
\hline & & & & & & & & & alsó érték & felső érték \\
\hline \multirow{2}{*}{ felúj_beruh_fö } & $\begin{array}{l}\text { Egyenlő szórást } \\
\text { feltételezve }\end{array}$ & 13,695 & 0,000 & $-3,083$ & 665 & 0,002 & $-29,650$ & 9,616 & $-48,532$ & $-10,768$ \\
\hline & $\begin{array}{l}\text { Egyenlö szórásokat nem } \\
\text { feltételezve }\end{array}$ & & & $-2,783$ & 169,250 & 0,006 & $-29,650$ & 10,653 & $-50,679$ & $-8,620$ \\
\hline
\end{tabular}




\section{2. számú melléklet: A H3 hipotézis tesztelésének eredményei}

a) A saját bevétel és az európai uniós támogatások összefüggései országos szinten

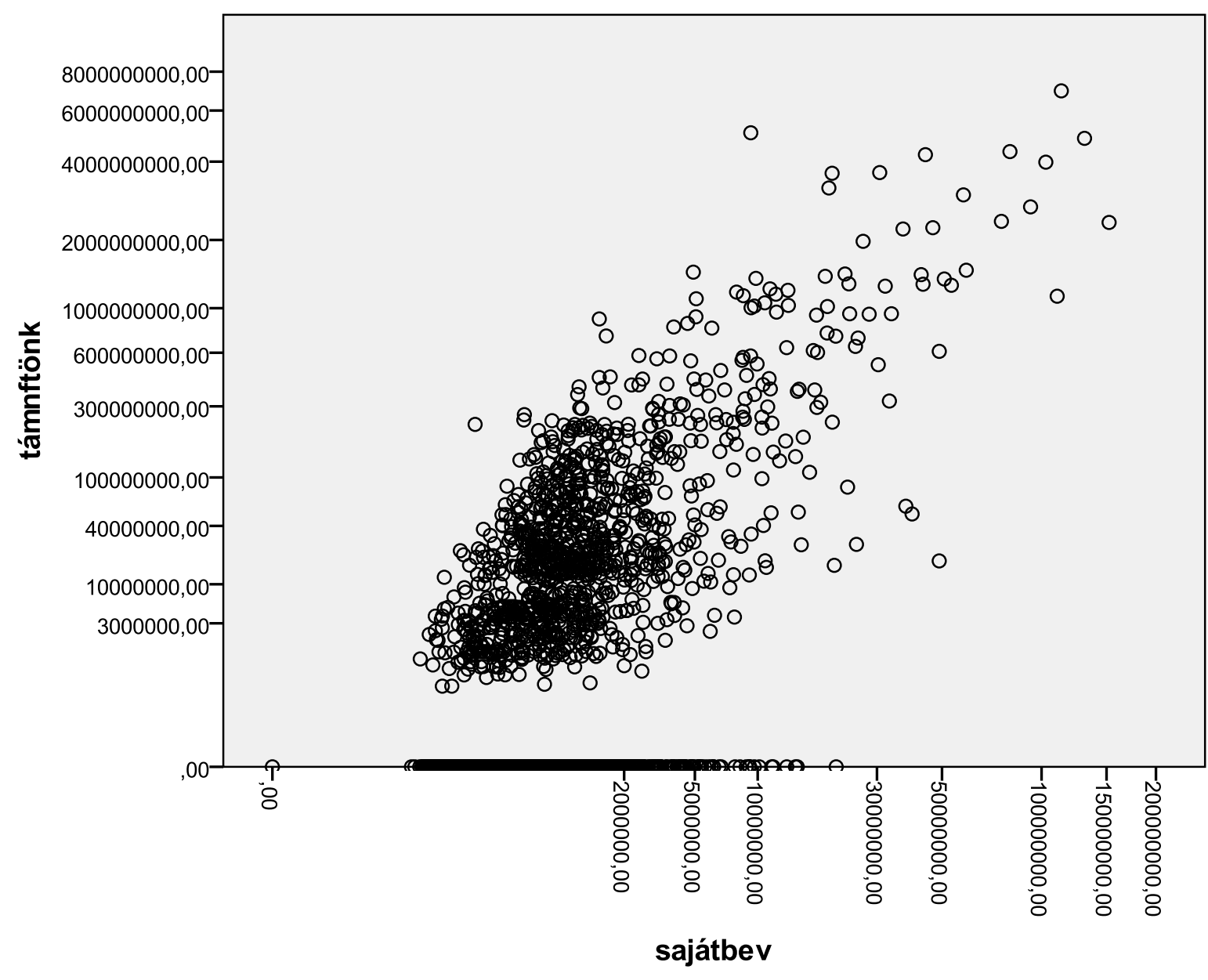


b1) A saját bevétel és az európai uniós támogatások összefüggései nagyrégiók (NUTS1) szerint

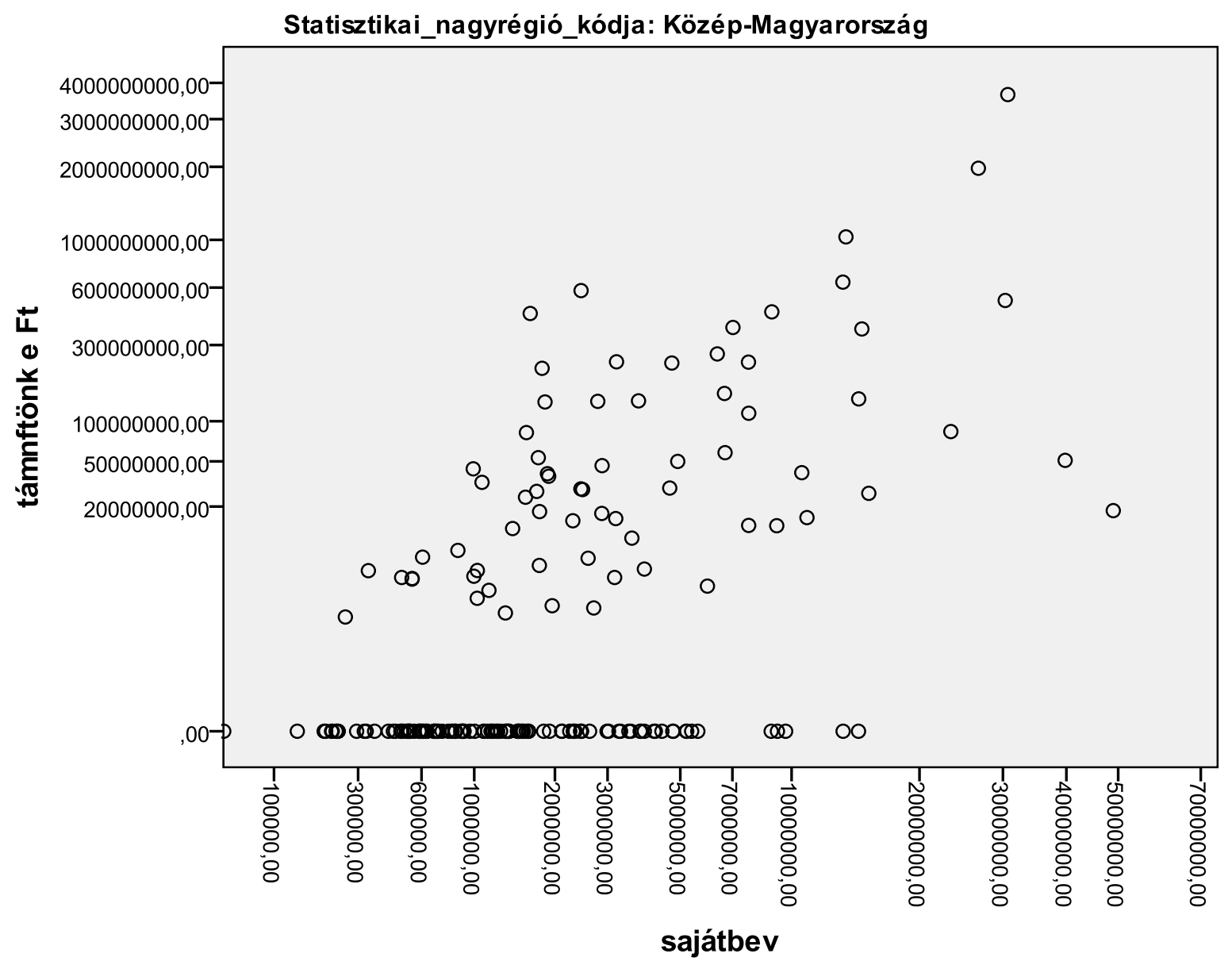


b2) A saját bevétel és az európai uniós támogatások összefüggései nagyrégiók (NUTS1) szerint

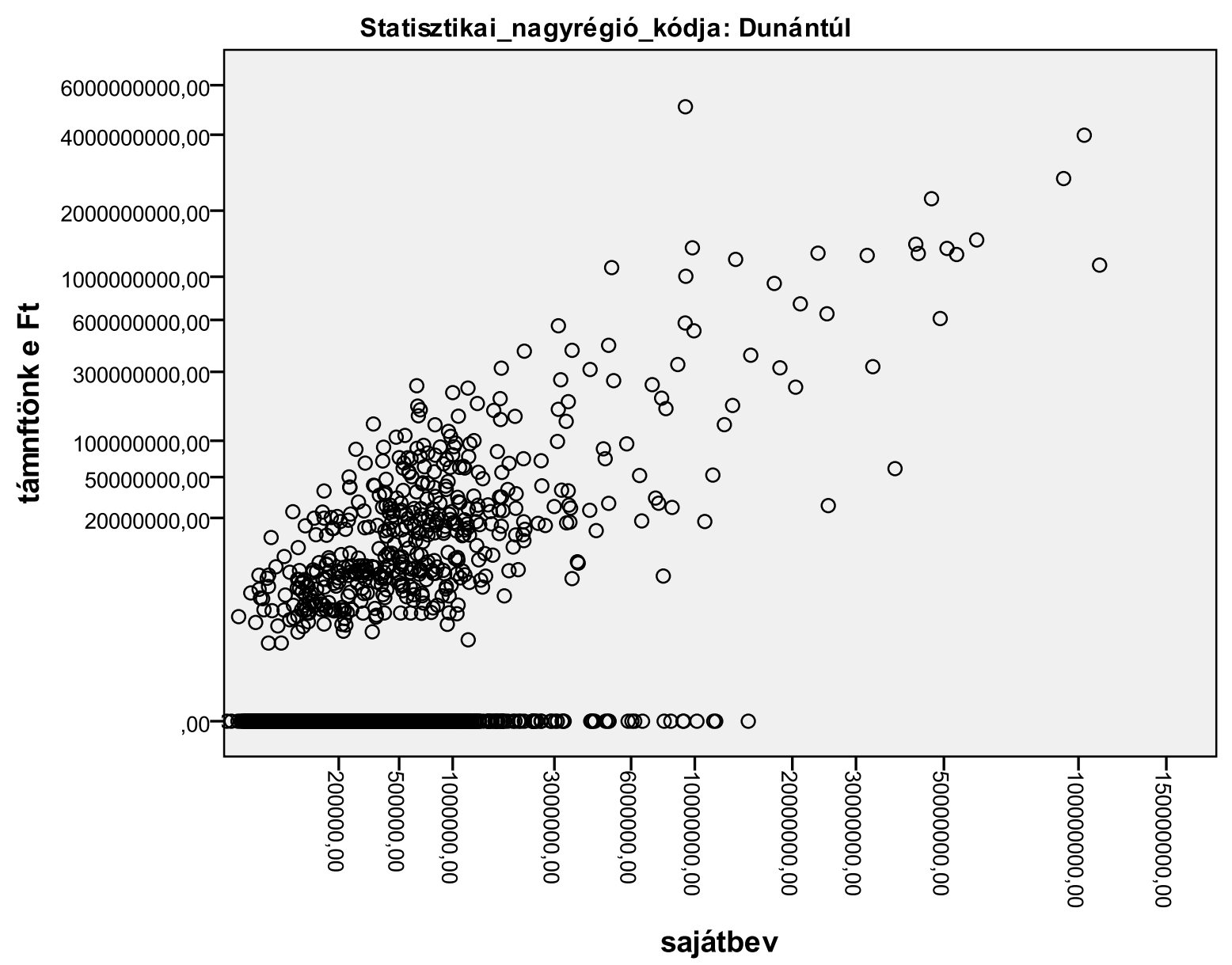


b3) A saját bevétel és az európai uniós támogatások összefüggései nagyrégiók (NUTS1) szerint

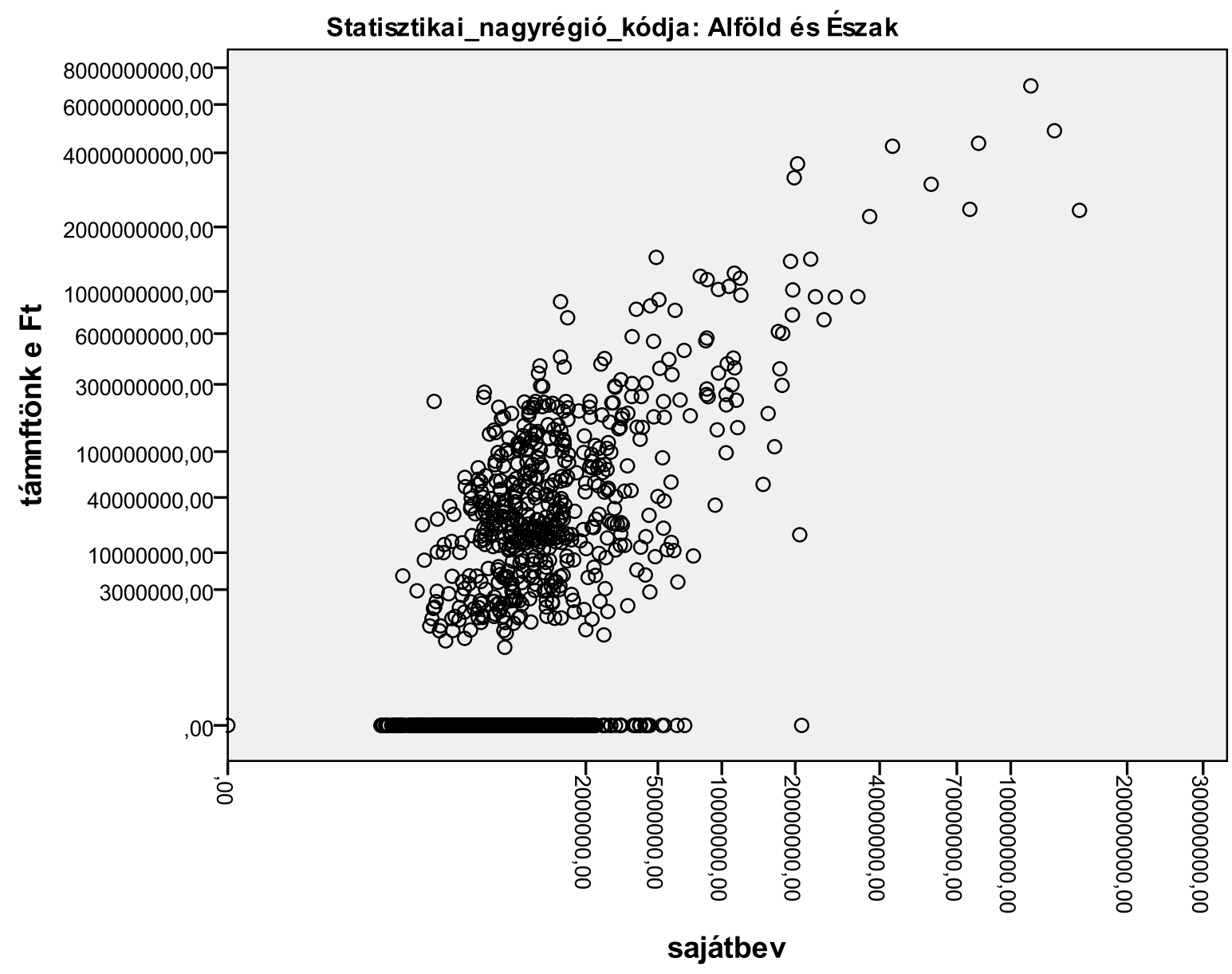


c1) A saját bevétel és az európai uniós támogatások összefüggései régiók (NUTS2) szerint

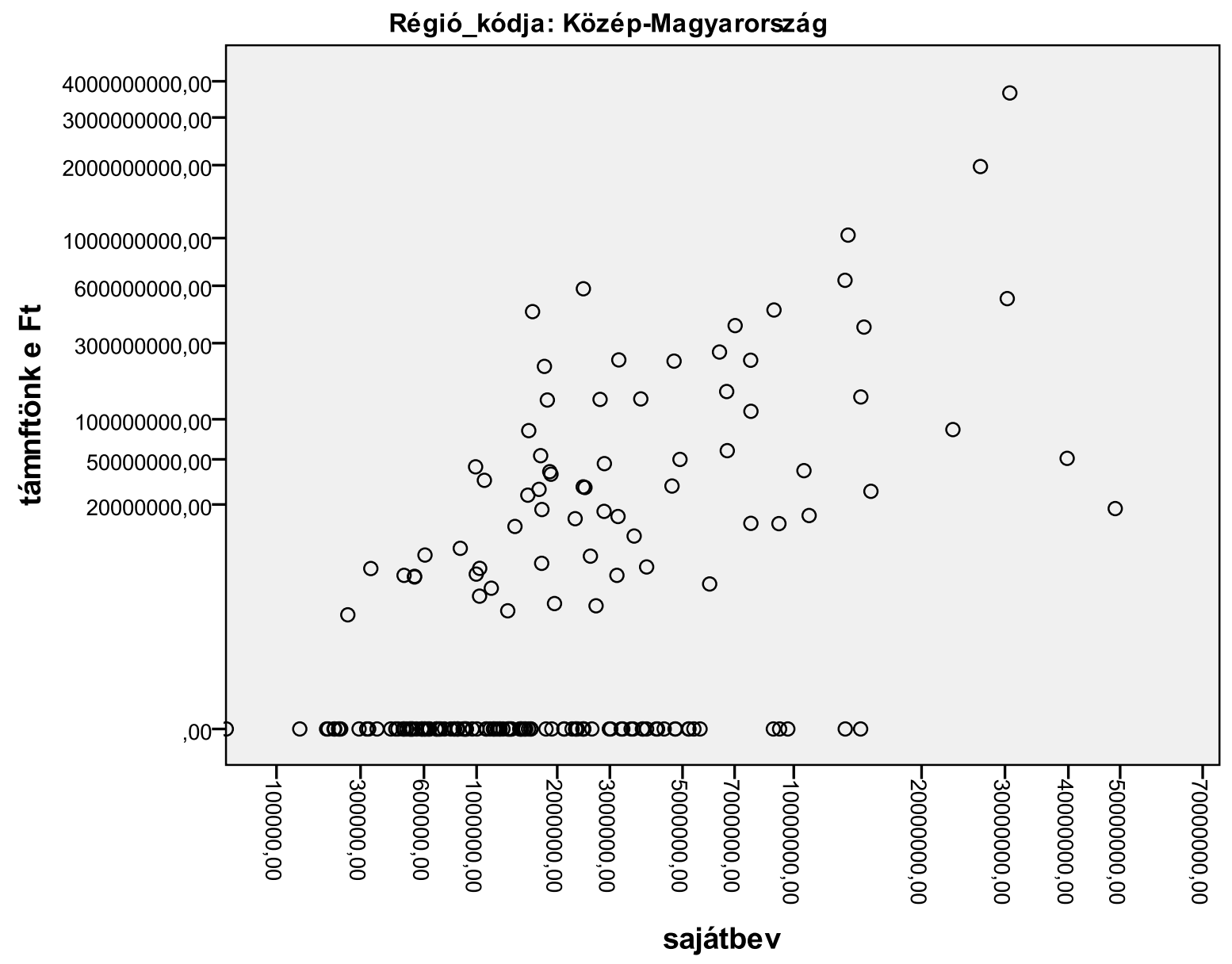


c2) A saját bevétel és az európai uniós támogatások összefüggései régiók (NUTS2) szerint

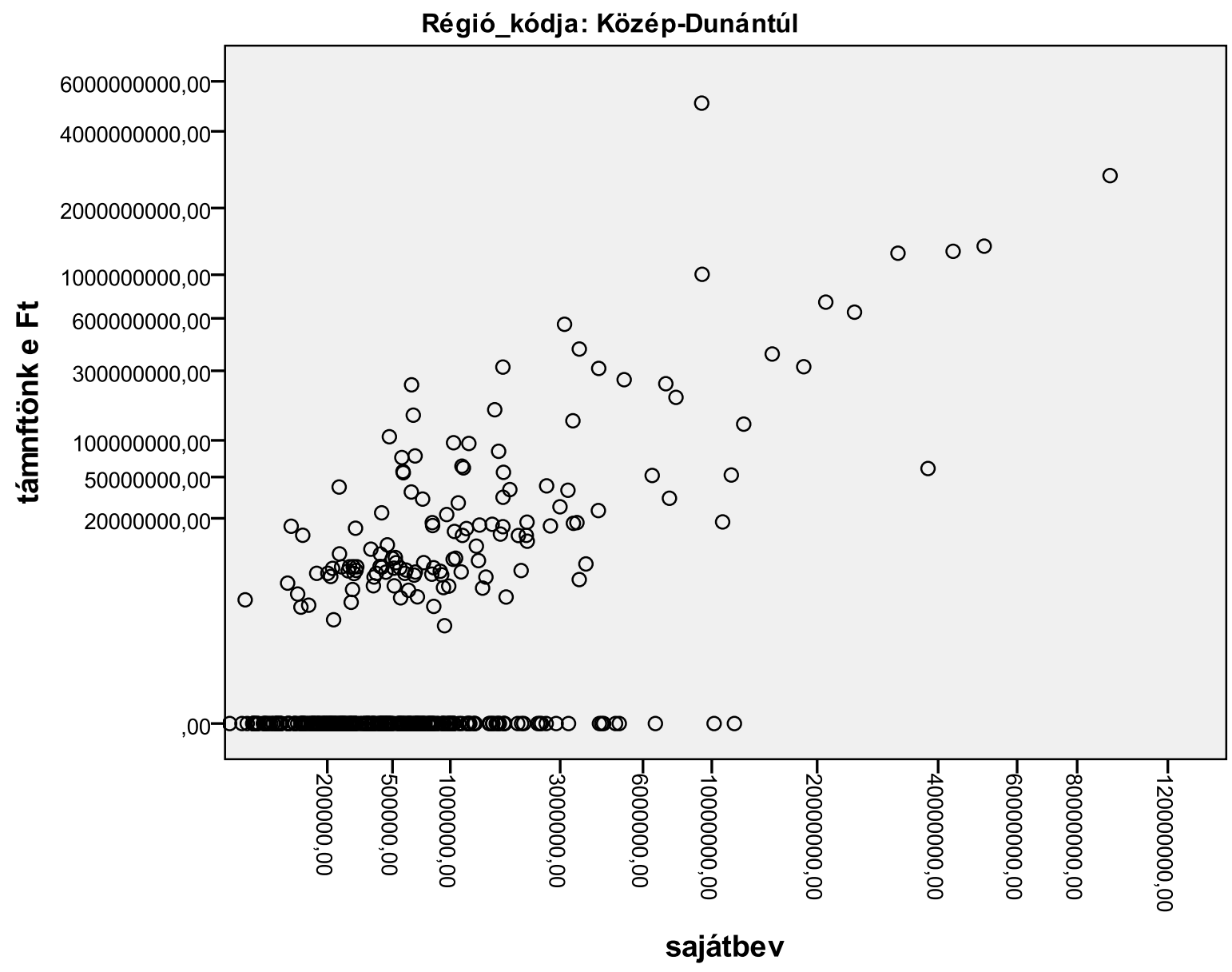


c3) A saját bevétel és az európai uniós támogatások összefüggései régiók (NUTS2) szerint

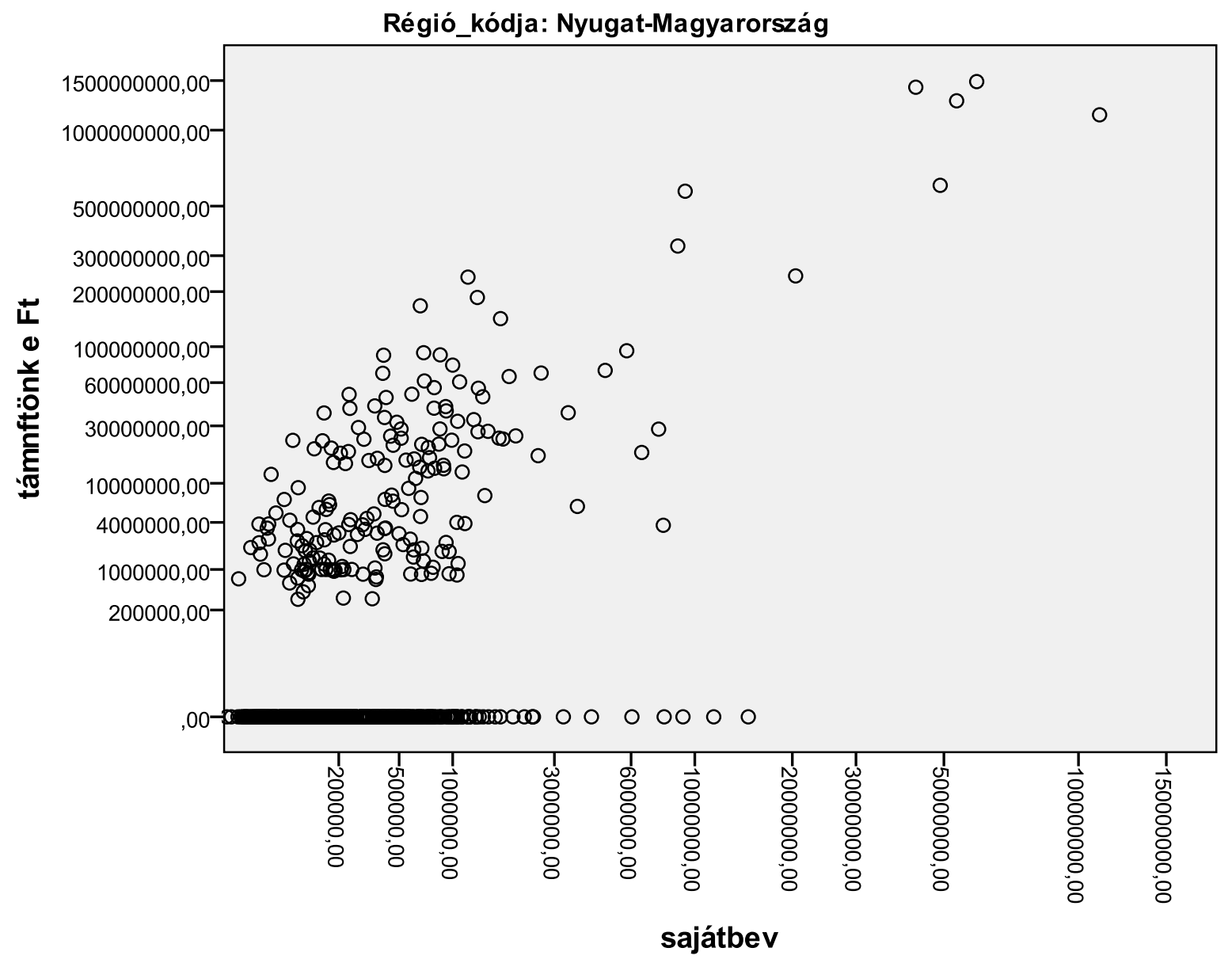


c4) A saját bevétel és az európai uniós támogatások összefüggései régiók (NUTS2) szerint

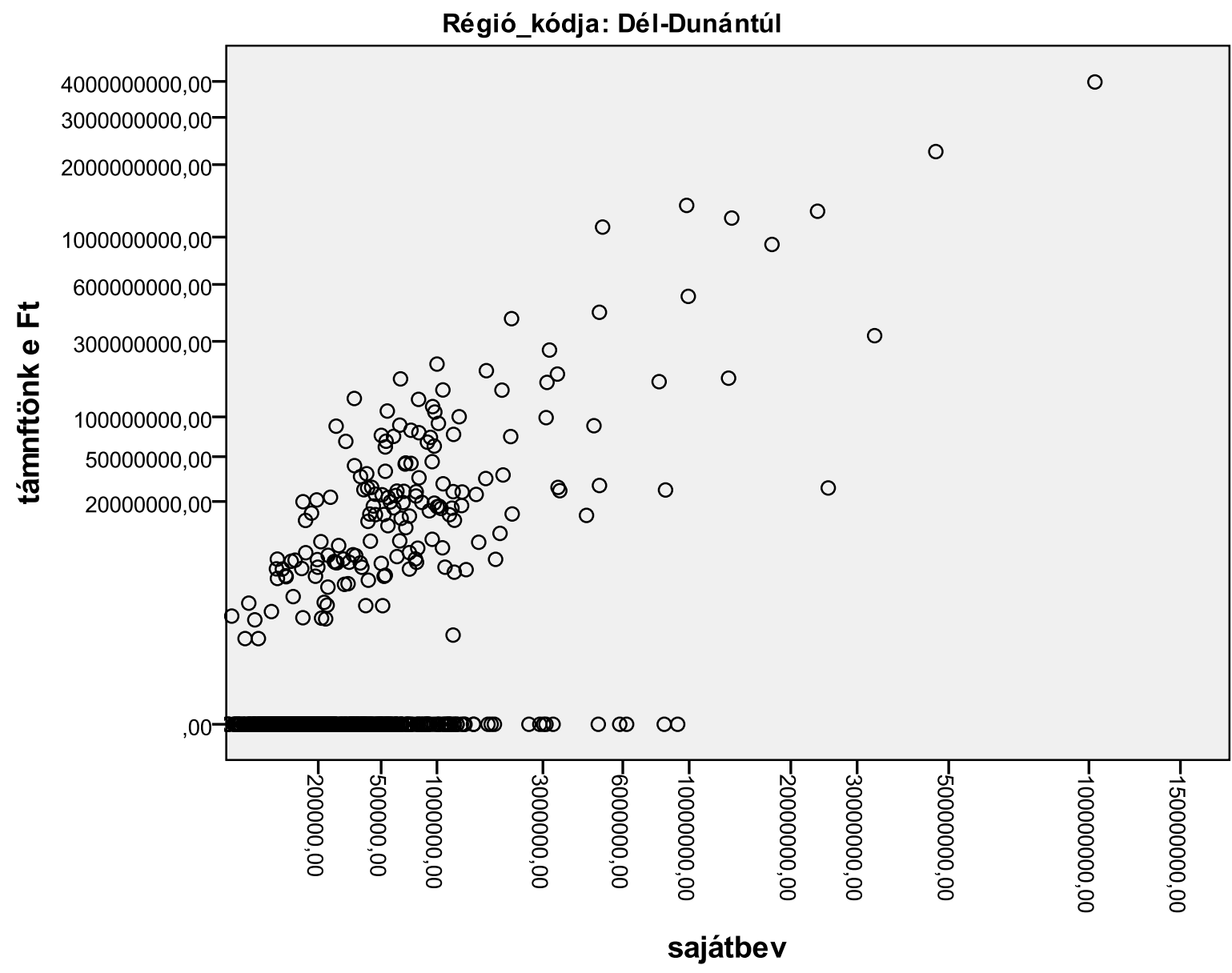


c5) A saját bevétel és az európai uniós támogatások összefüggései régiók (NUTS2) szerint

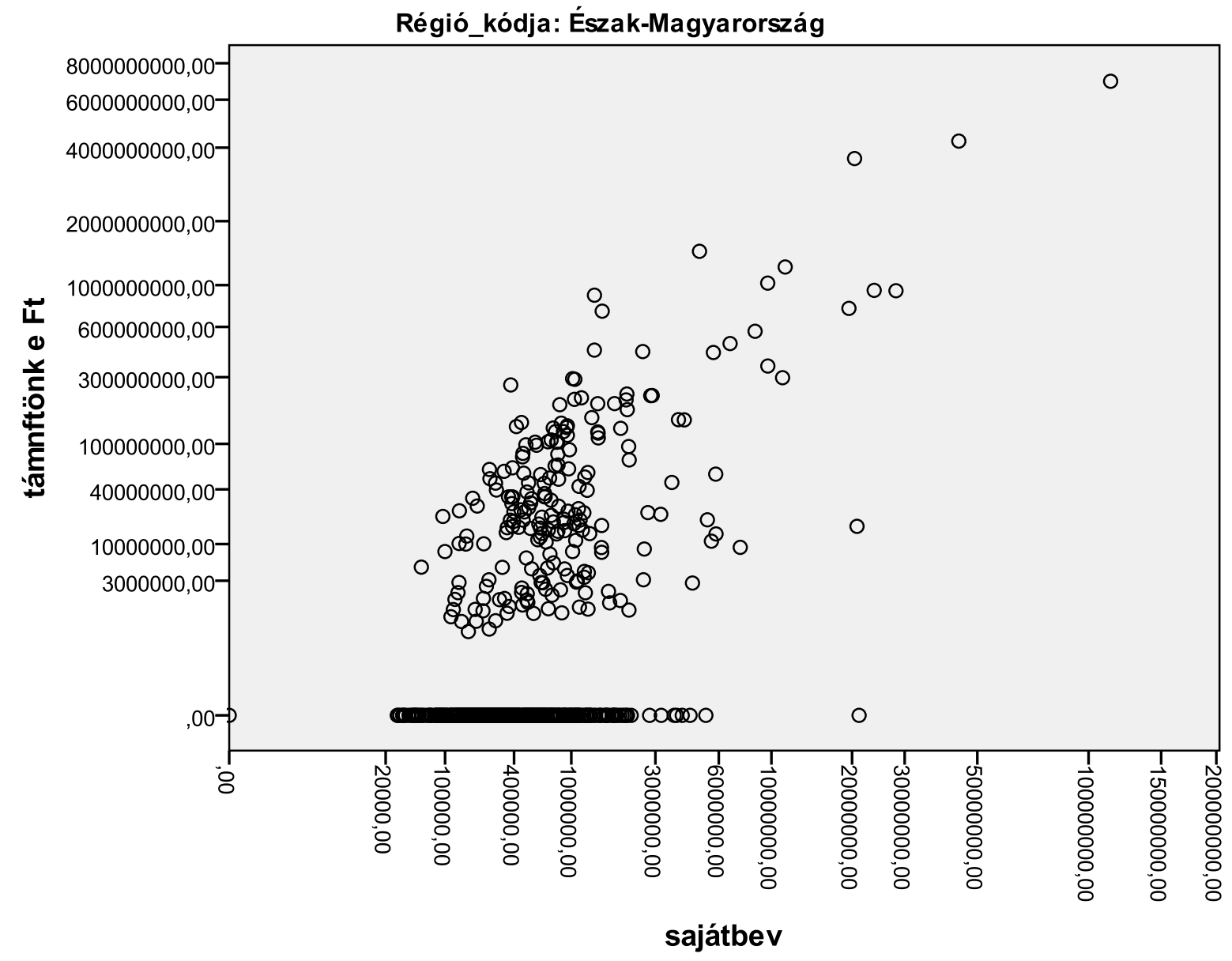


c6) A saját bevétel és az európai uniós támogatások összefüggései régiók (NUTS2) szerint

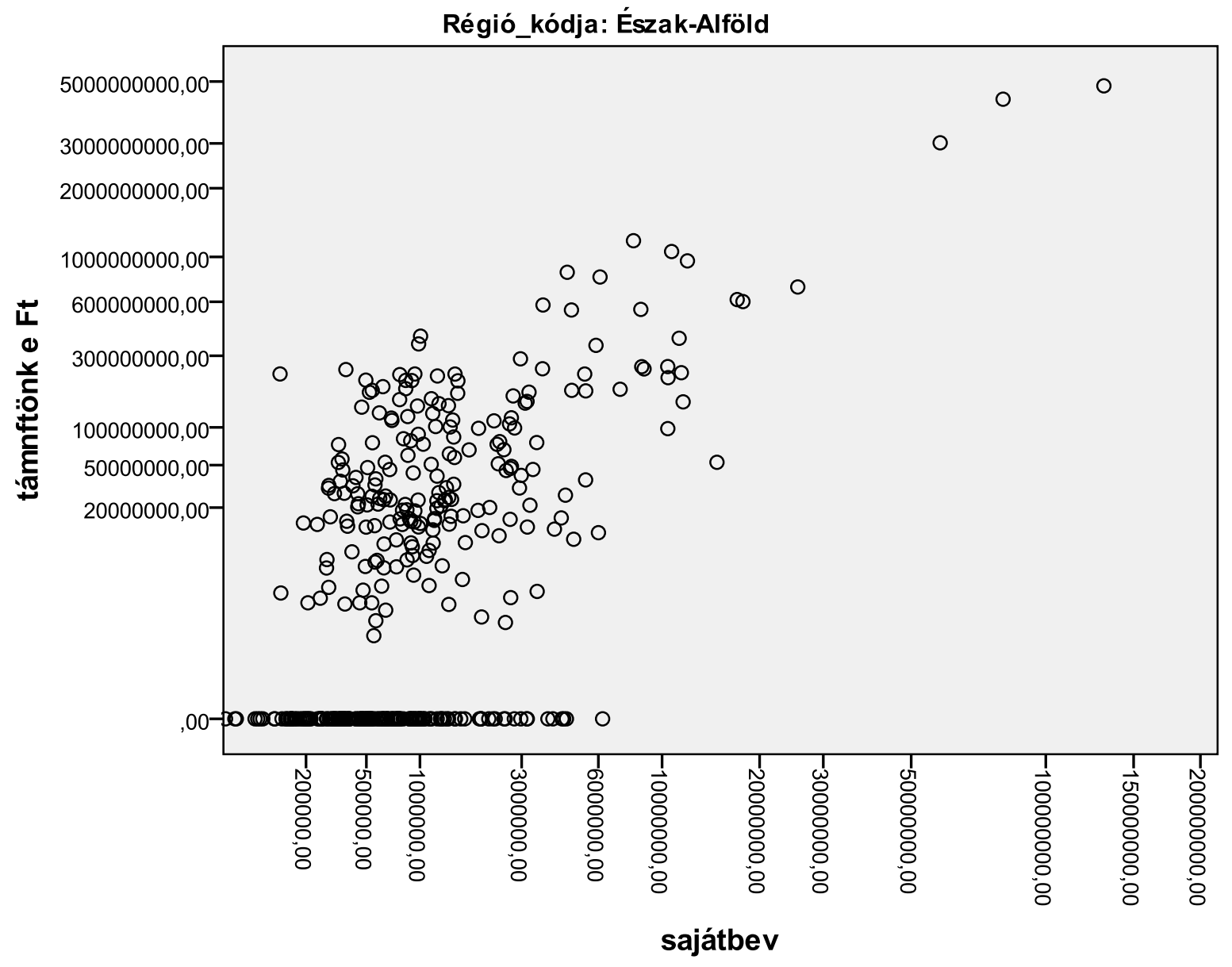


c7) A saját bevétel és az európai uniós támogatások összefüggései régiók (NUTS2) szerint

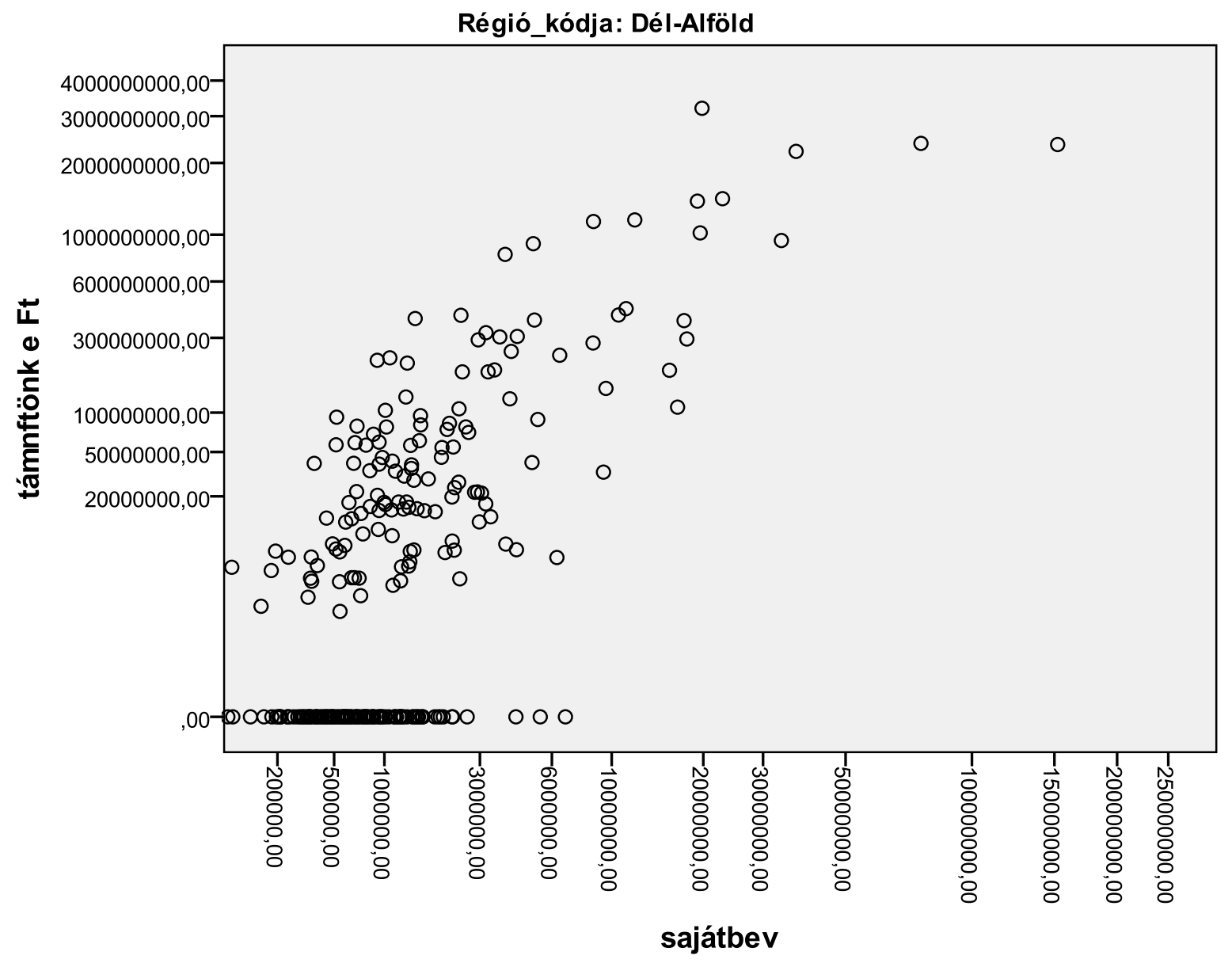


d1) A saját bevétel és az európai uniós támogatások összefüggései saját területi bontás szerint

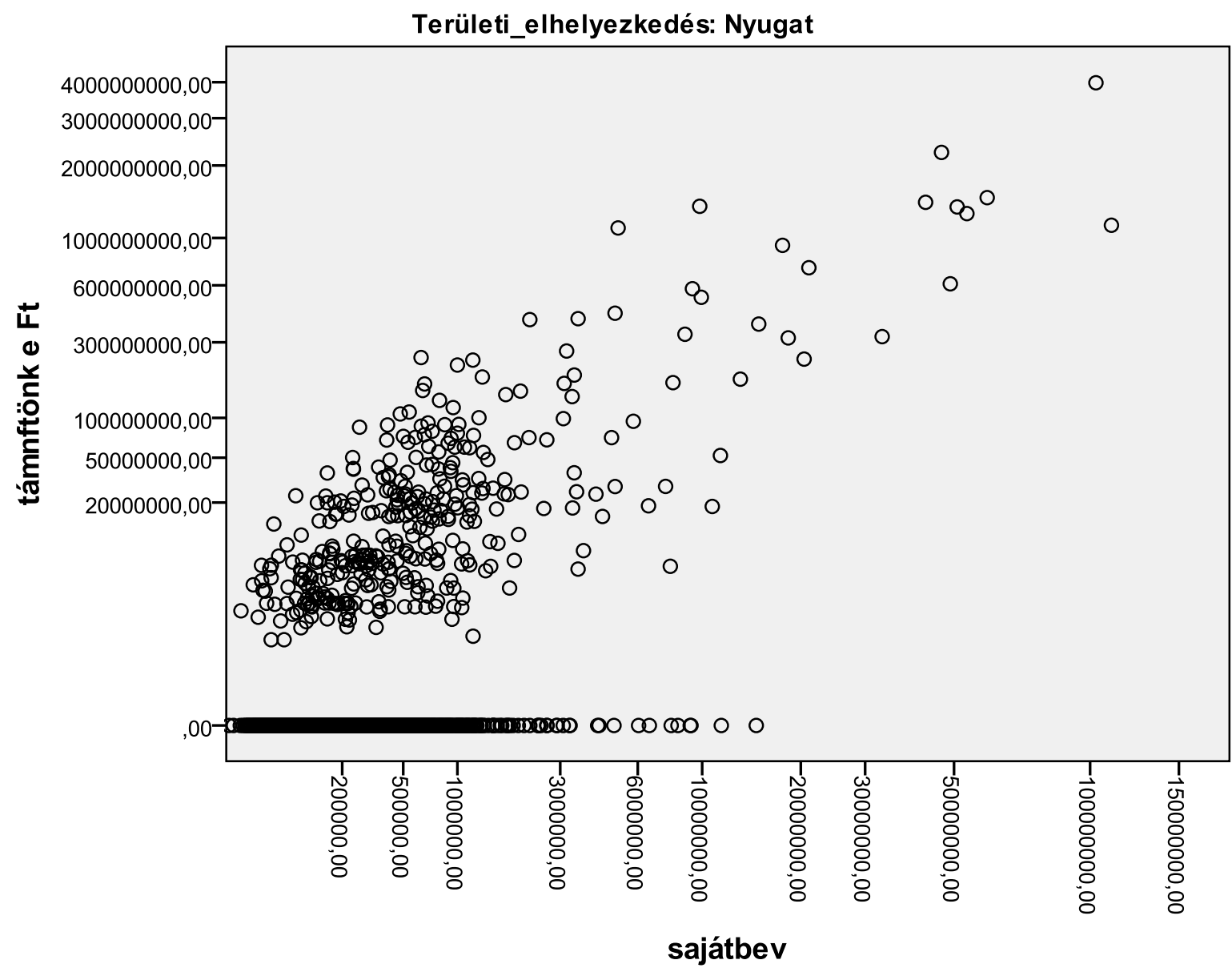


d2) A saját bevétel és az európai uniós támogatások összefüggései saját területi bontás szerint

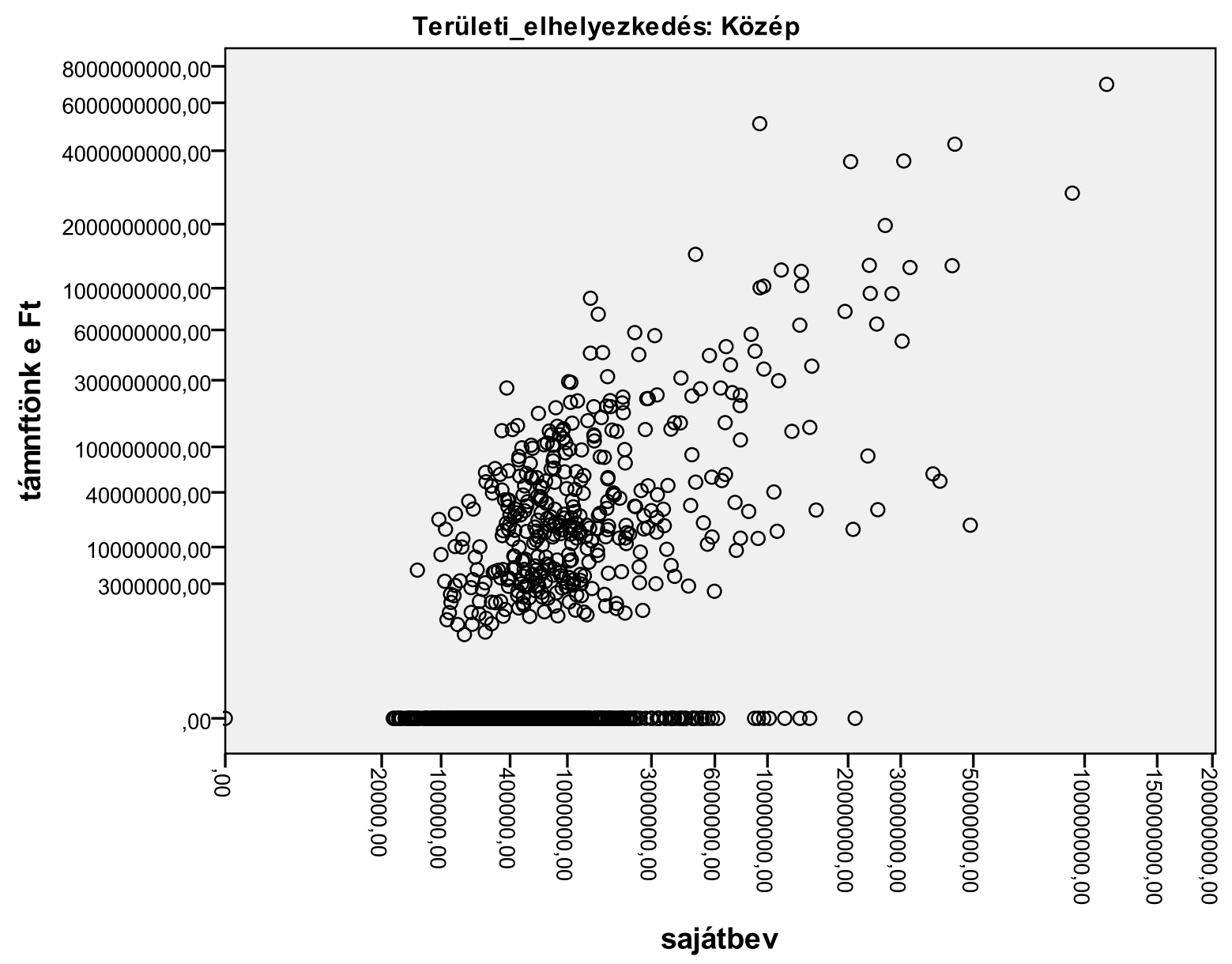


d3) A saját bevétel és az európai uniós támogatások összefüggései saját területi bontás szerint

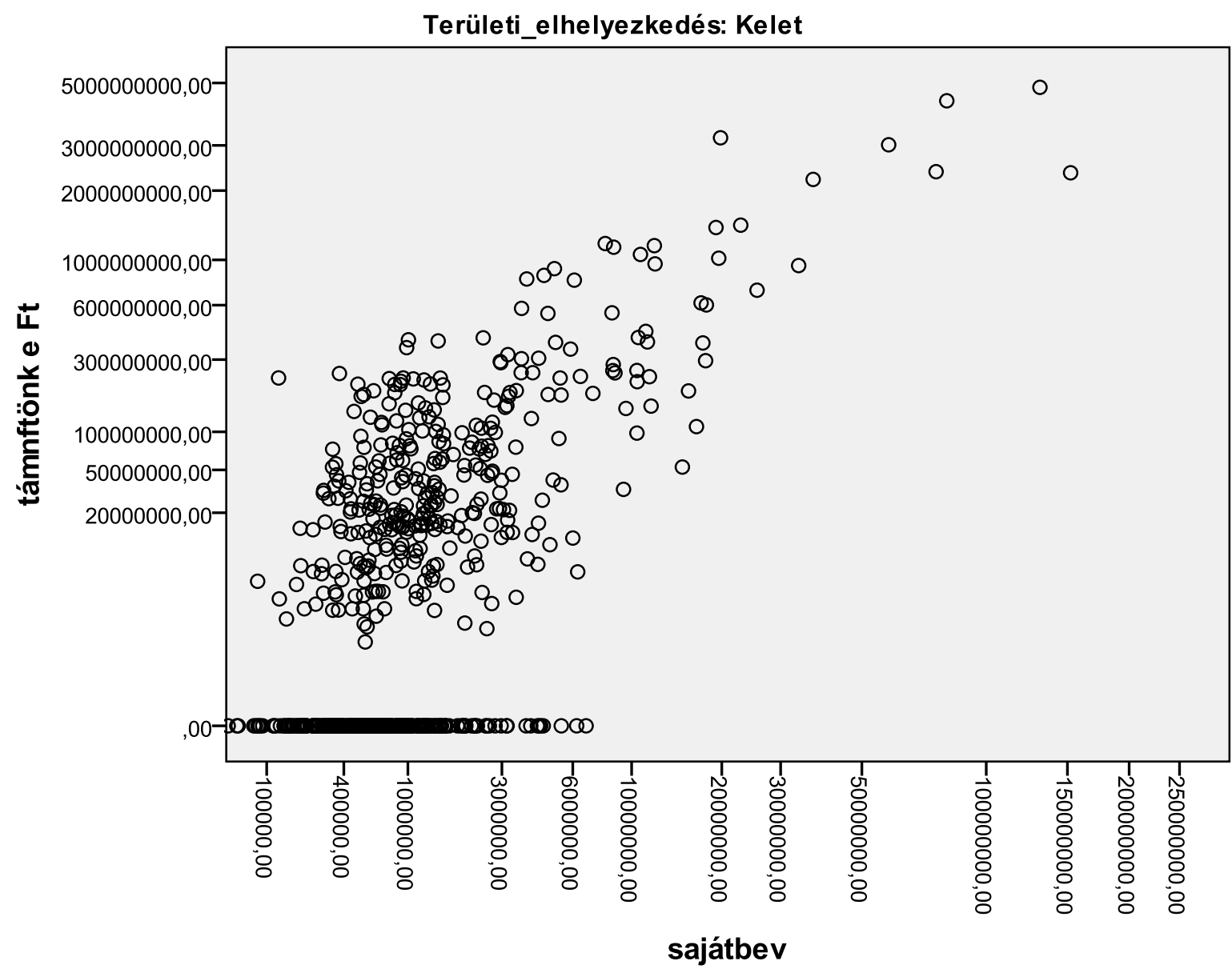


e) A finanszírozás egyenlege és az európai uniós támogatások összefüggései országos szinten, nulla körüli elemekre szükítve

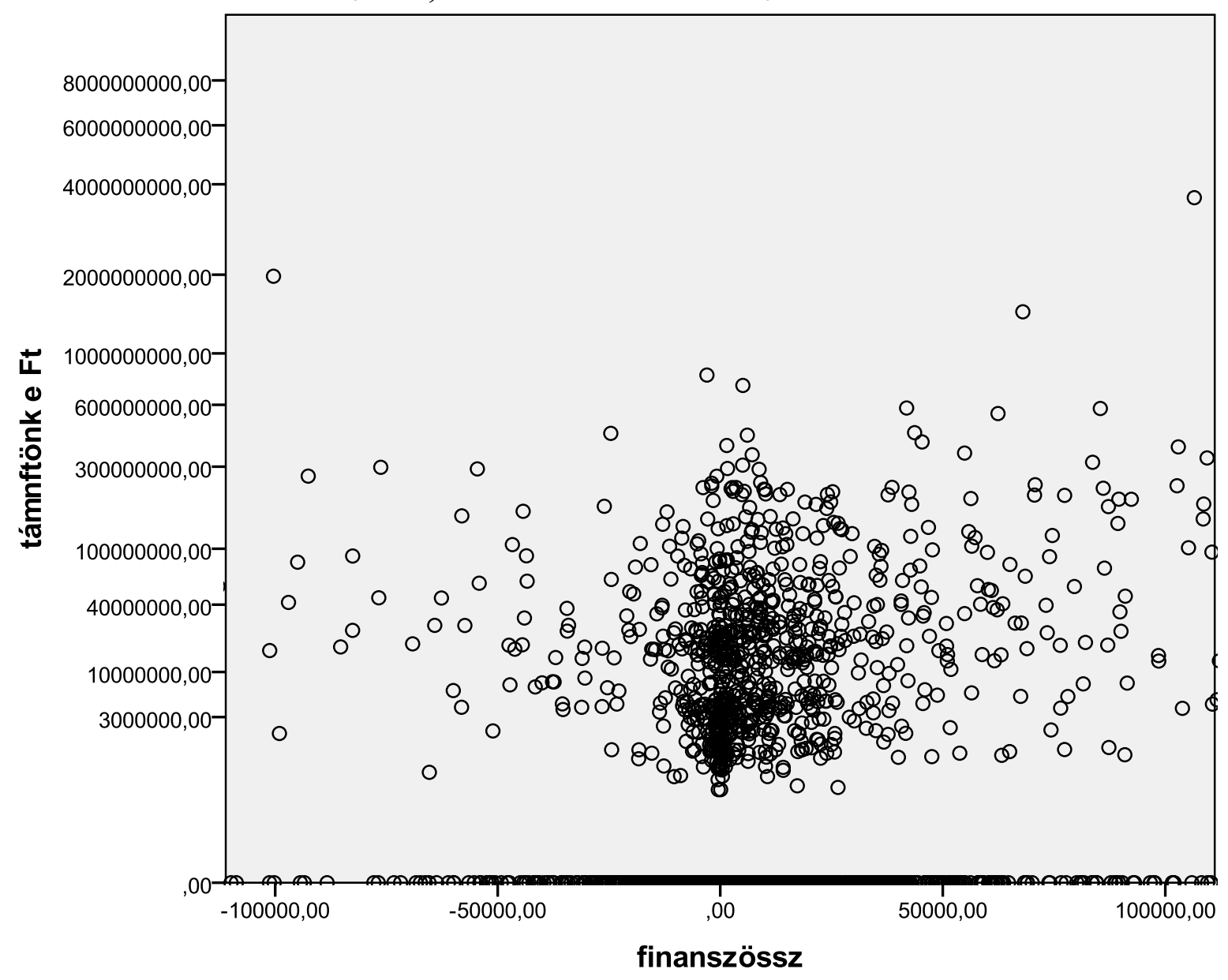

\begin{tabular}{|l|r|r|}
\hline & Gyakoriság & $\%$ \\
\hline Nem kapott & 1934 & 69,4 \\
\hline Részesült & 853 & 30,6 \\
\hline Összesen & 2787 & 100,0 \\
\hline
\end{tabular}


f1) Korreláció a helyi önkormányzatnak nyújtott támogatás és a saját bevétel, valamint a finanszírozás egyenlege között, országos bontásban

\begin{tabular}{|l|r|r|r|c|}
\hline \multirow{2}{*}{} & \multicolumn{3}{|c|}{ Támogatás ban részesültek } & \multicolumn{2}{c|}{ Valamennyi helyi önkormányzat } \\
\cline { 2 - 5 } & saját bevétel & $\begin{array}{c}\text { finanszírozás } \\
\text { egyenlege }\end{array}$ & saját bevétel & $\begin{array}{c}\text { finanszírozás } \\
\text { egyenlege }\end{array}$ \\
\hline Országos & 0,757 & 0,684 & 0,753 & 0,683 \\
\hline
\end{tabular}

f2) Korreláció a helyi önkormányzatnak nyújtott támogatás és a saját bevétel, valamint a finanszírozás egyenlege között, nagyrégió (NUTS1) szintü bontásban

\begin{tabular}{|l|r|r|r|r|}
\hline \multirow{2}{*}{ NUTS1 } & \multicolumn{3}{|c|}{ Támogatás ban részes ültek } & \multicolumn{2}{c|}{ Valamennyi helyi önkormányzat } \\
\cline { 2 - 5 } & saját bevétel & $\begin{array}{c}\text { finanszírozás } \\
\text { egyenlege }\end{array}$ & saját bevétel & $\begin{array}{c}\text { finanszírozás } \\
\text { egyenlege }\end{array}$ \\
\hline Közép-Magyarország & 0,484 & 0,291 & 0,449 & 0,268 \\
\hline Dunántúl & 0,708 & 0,672 & 0,703 & 0,670 \\
\hline Alföld és Észak & 0,821 & 0,774 & 0,819 & 0,769 \\
\hline
\end{tabular}

f3) Korreláció a helyi önkormányzatnak nyújtott támogatás és a saját bevétel, valamint a finanszírozás egyenlege között, régió (NUTS2) szintü bontásban

\begin{tabular}{|l|r|r|r|r|}
\hline \multirow{2}{*}{ NUTS2 } & \multicolumn{3}{|c|}{ Támogatás ban részesültek } & \multicolumn{2}{c|}{ Valamennyi helyi önkormányzat } \\
\cline { 2 - 5 } & saját bevétel & $\begin{array}{c}\text { finanszírozás } \\
\text { egyenlege }\end{array}$ & saját bevétel & $\begin{array}{c}\text { finanszírozás } \\
\text { egyenlege }\end{array}$ \\
\hline Közép-Magyarország & 0,484 & 0,291 & 0,449 & 0,268 \\
\hline Közép-Dunántúl & 0,595 & 0,439 & 0,579 & 0,419 \\
\hline Nyugat-Magyarország & 0,865 & 0,801 & 0,873 & 0,820 \\
\hline Dél-Dunántúl & 0,895 & 0,872 & 0,899 & 0,879 \\
\hline Észak-Magyarország & 0,894 & 0,807 & 0,905 & 0,807 \\
\hline Észak-Alföld & 0,940 & 0,920 & 0,942 & 0,921 \\
\hline Dél-Alföld & 0,724 & 0,649 & 0,713 & 0,632 \\
\hline
\end{tabular}


f4) Korreláció a helyi önkormányzatnak nyújtott támogatás és a saját bevétel, valamint a finanszírozás egyenlege között, megye (NUTS3) szintü bontásban

\begin{tabular}{|l|r|r|r|r|}
\hline \multirow{2}{*}{ Megye } & \multicolumn{2}{|c|}{$\begin{array}{c}\text { Támogatás ban } \\
\text { rés ze ülttek }\end{array}$} & \multicolumn{2}{c|}{$\begin{array}{c}\text { Valame nnyi helyi } \\
\text { önkormányzat }\end{array}$} \\
\cline { 2 - 5 } & $\begin{array}{c}\text { saját } \\
\text { bevétel }\end{array}$ & $\begin{array}{c}\text { finanszírozás } \\
\text { egyenlege }\end{array}$ & $\begin{array}{c}\text { saját } \\
\text { bevétel }\end{array}$ & $\begin{array}{c}\text { finanszírozás } \\
\text { egyenlege }\end{array}$ \\
\hline Baranya & 0,964 & 0,949 & 0,960 & 0,945 \\
\hline Bács-Kiskun & 0,906 & 0,876 & 0,903 & 0,881 \\
\hline Békés & 0,803 & 0,808 & 0,819 & 0,823 \\
\hline Borsod-Abaúj-Zemplén & 0,949 & 0,948 & 0,933 & 0,947 \\
\hline Csongrád & 0,829 & 0,665 & 0,833 & 0,681 \\
\hline Fejér & 0,488 & 0,351 & 0,497 & 0,359 \\
\hline Györ-Moson-Sopron & 0,978 & 0,824 & 0,974 & 0,828 \\
\hline Hajdú-Bihar & 0,984 & 0,948 & 0,982 & 0,947 \\
\hline Heves & 0,905 & 0,709 & 0,902 & 0,705 \\
\hline Komárom-Esztergom & 0,898 & 0,752 & 0,892 & 0,760 \\
\hline Nógrád & 0,840 & 0,830 & 0,849 & 0,733 \\
\hline Pest & 0,447 & 0,266 & 0,484 & 0,291 \\
\hline Somogy & 0,822 & 0,904 & 0,816 & 0,891 \\
\hline Szabolcs-Szatmár-Bereg & 0,949 & 0,949 & 0,945 & 0,947 \\
\hline Jász-Nagykun-Szolnok & 0,907 & 0,865 & 0,908 & 0,867 \\
\hline Tolna & 0,657 & 0,708 & 0,661 & 0,614 \\
\hline Vas & 0,958 & 0,926 & 0,932 & 0,858 \\
\hline Veszprém & 0,918 & 0,697 & 0,914 & 0,718 \\
\hline Zala & 0,970 & 0,954 & 0,941 & 0,949 \\
\hline
\end{tabular}

f5) Korreláció a helyi önkormányzatnak nyújtott támogatás és a saját bevétel, valamint a finanszírozás egyenlege között, saját területi besorolás szerint

\begin{tabular}{|l|r|r|r|r|}
\hline \multirow{2}{*}{ Saját bontás } & \multicolumn{3}{|c|}{ Támogatás ban részesültek } & \multicolumn{2}{c|}{ Valamennyi helyi önkormányzat } \\
\cline { 2 - 5 } & saját bevétel & \multicolumn{1}{c|}{$\begin{array}{c}\text { finanszírozás } \\
\text { egyenlege }\end{array}$} & saját bevétel & $\begin{array}{c}\text { finanszírozás } \\
\text { egyenlege }\end{array}$ \\
\hline Nyugat & 0,835 & 0,860 & 0,838 & 0,867 \\
\hline Közép & 0,711 & 0,596 & 0,713 & 0,600 \\
\hline Kelet & 0,832 & 0,765 & 0,828 & 0,758 \\
\hline
\end{tabular}


g) A saját bevétel és a finanszírozás egyenlegének együttes értéke és az európai uniós támogatások viszonya országosan

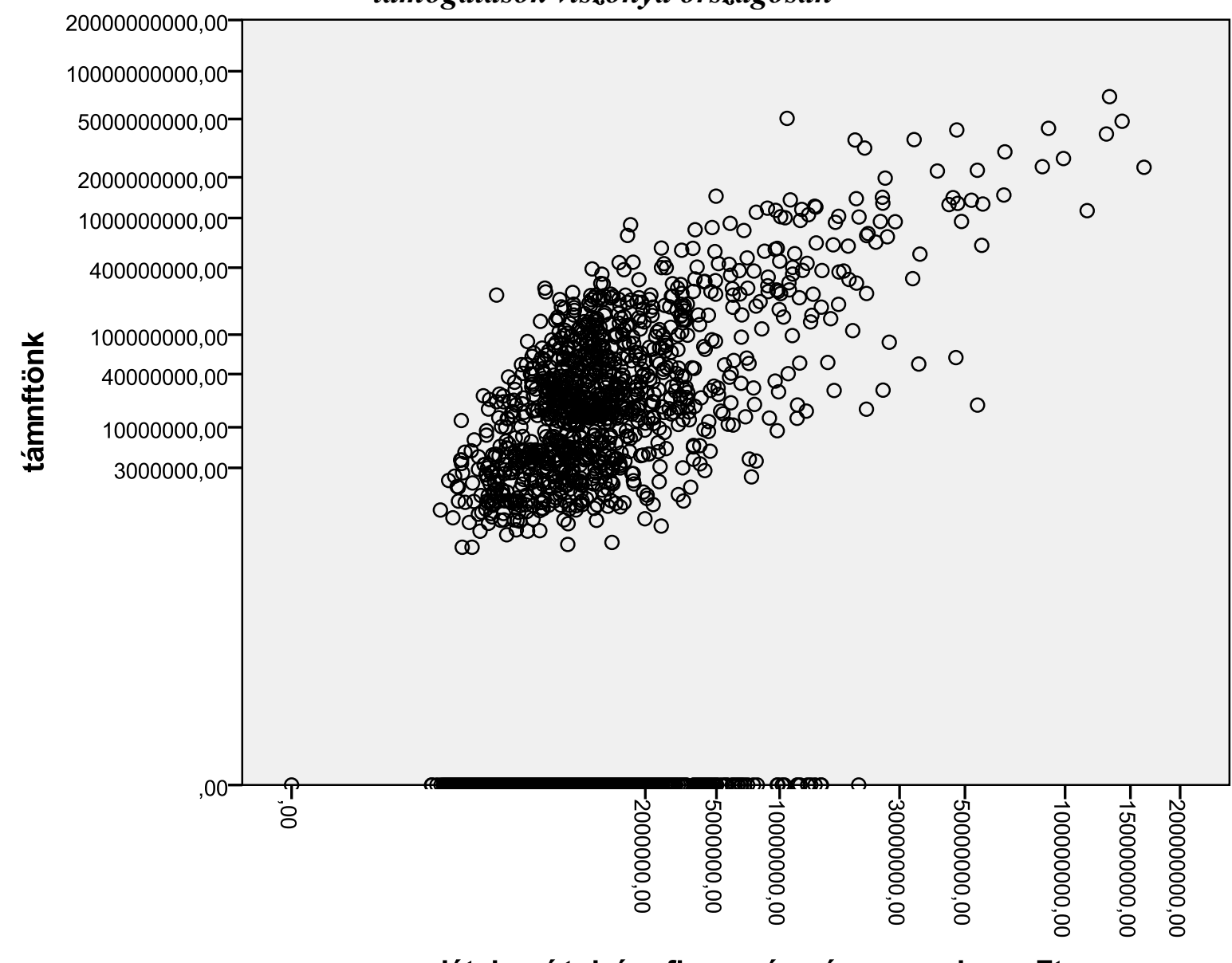

saját_bevétel_és_finanszírozás_egyenleg e Ft 
h1) A saját bevétel és a finanszírozás egyenlegének együttes értéke és az európai uniós támogatások viszonya nagyrégiók (NUTS1) szerinti bontásban

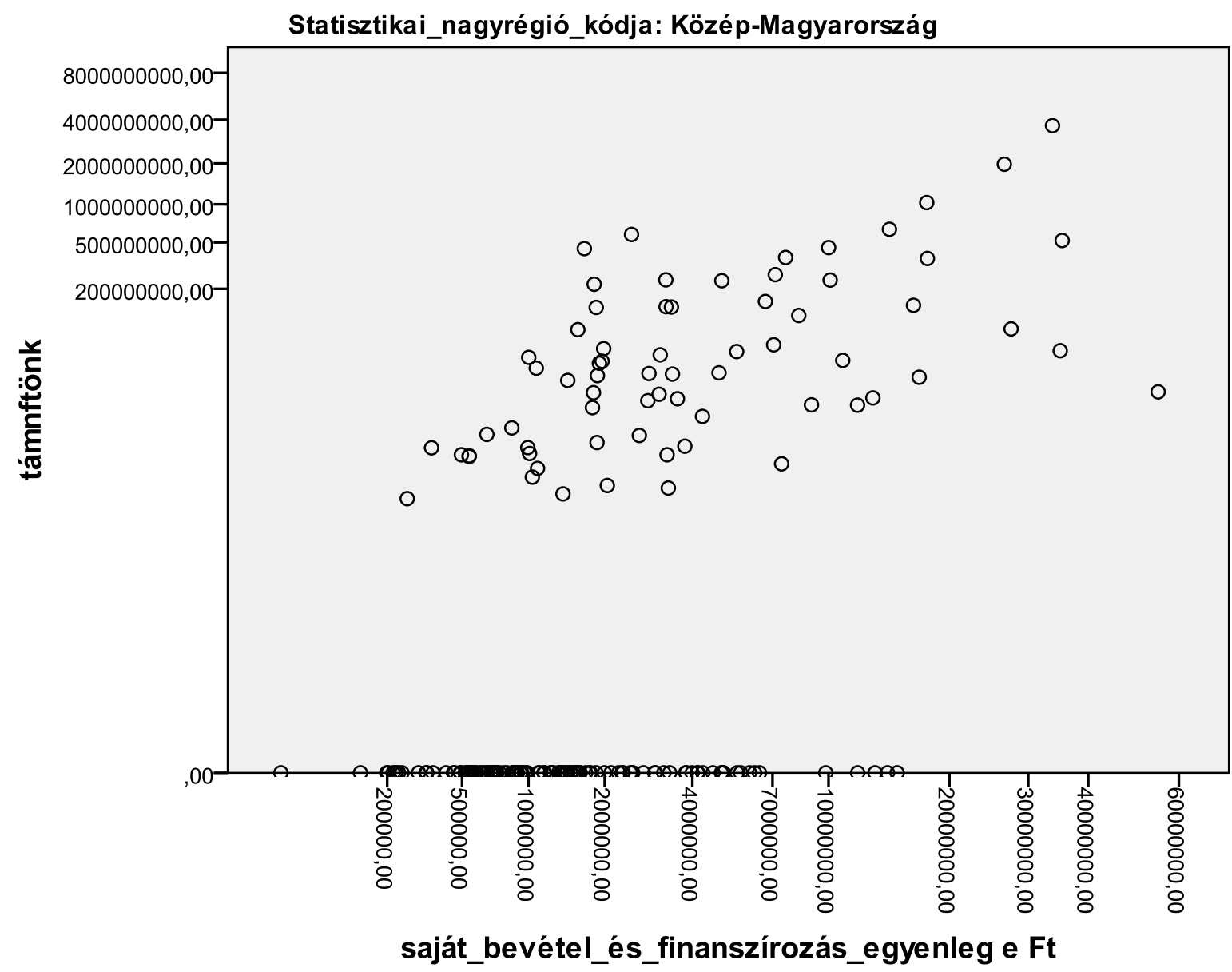


h2) A saját bevétel és a finanszirozás egyenlegének együttes értéke és az európai uniós támogatások viszonya nagyrégiók (NUTS1) szerinti bontásban

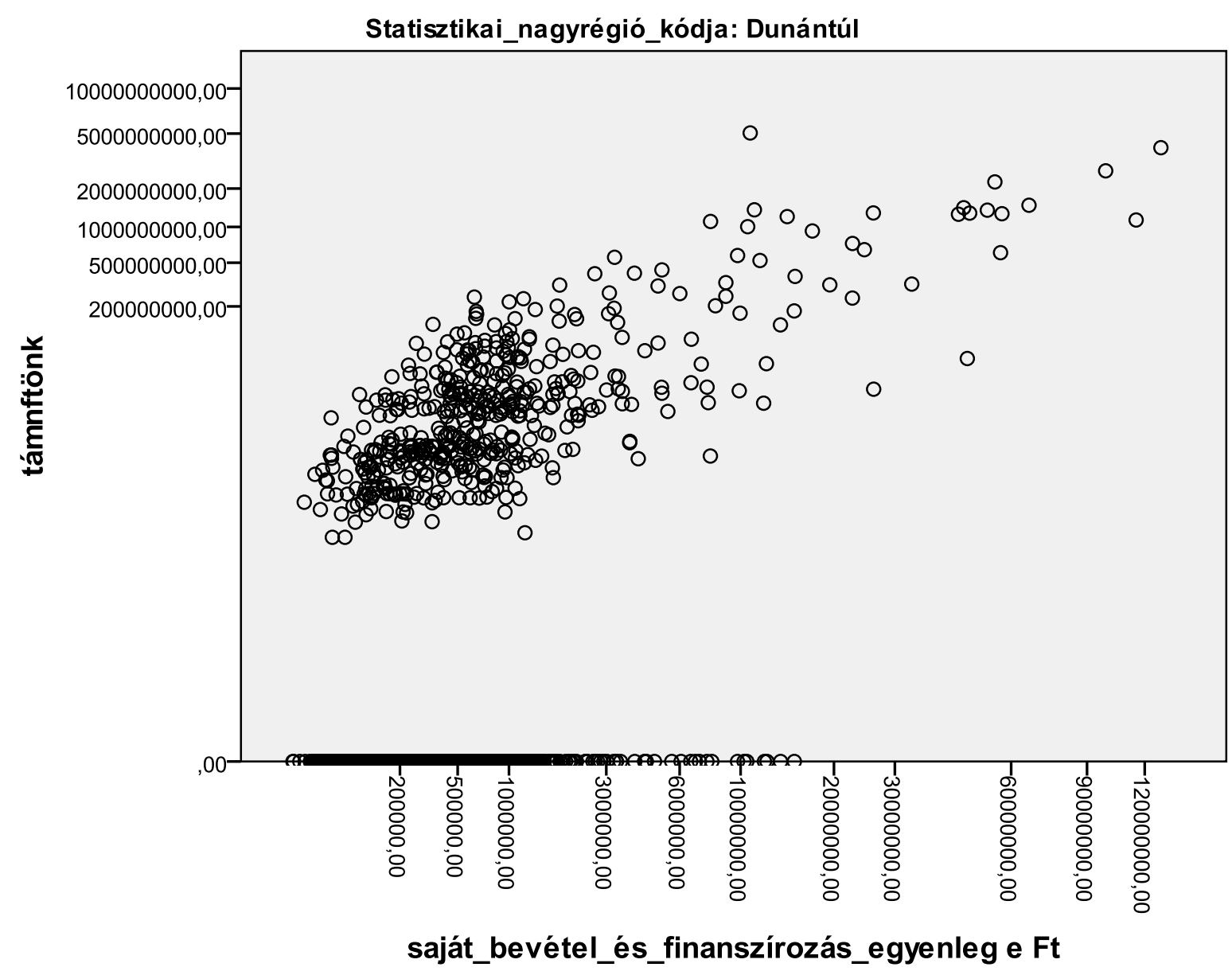


h3) A saját bevétel és a finanszirozás egyenlegének együttes értéke és az európai uniós támogatások viszonya nagyrégiók (NUTS1) szerinti bontásban

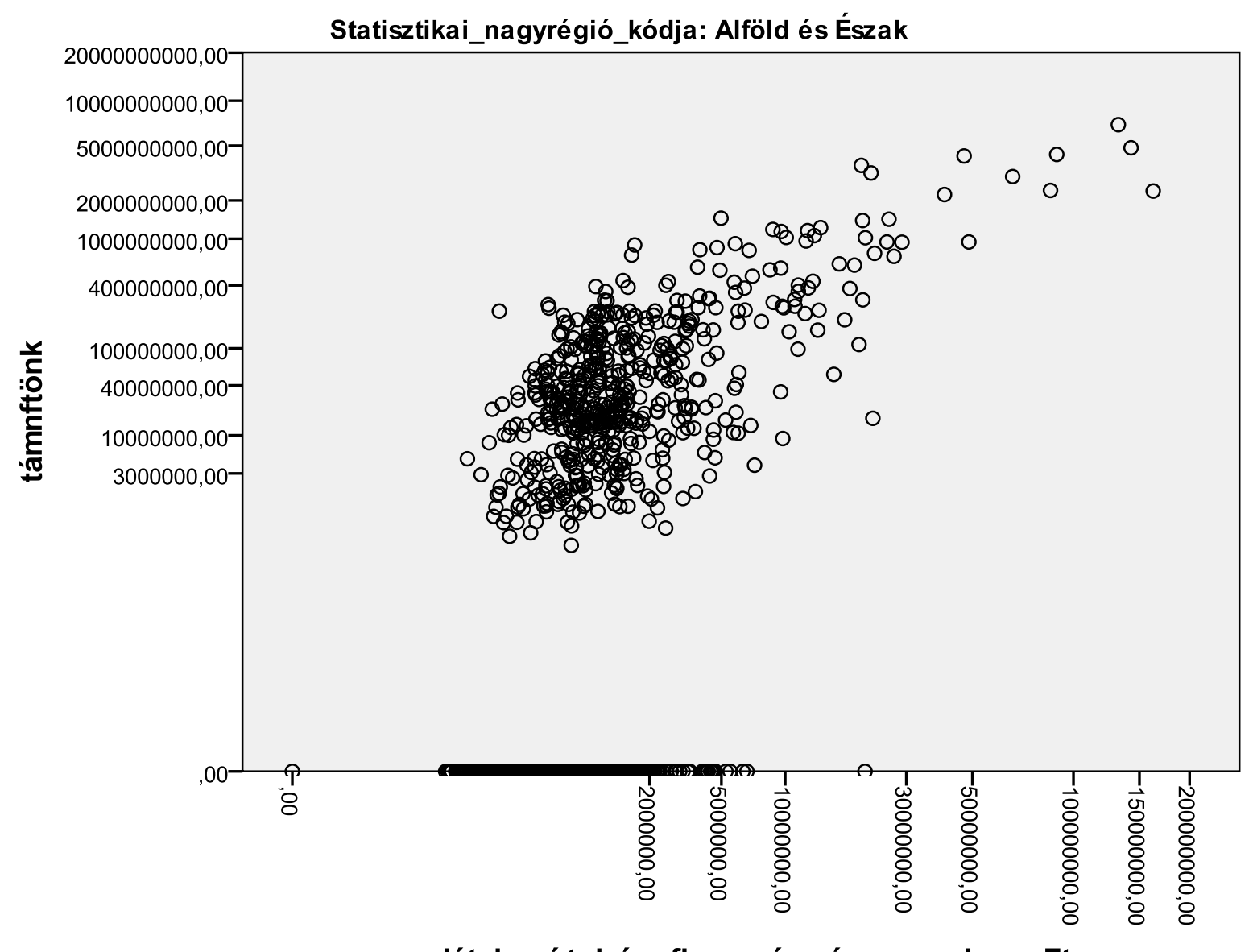

saját_bevétel_és_finanszírozás_egyenleg e Ft 
i1) A saját bevétel és a finanszírozás egyenlegének együttes értéke és az európai uniós támogatások viszonya régiók (NUTS2) szerinti bontásban

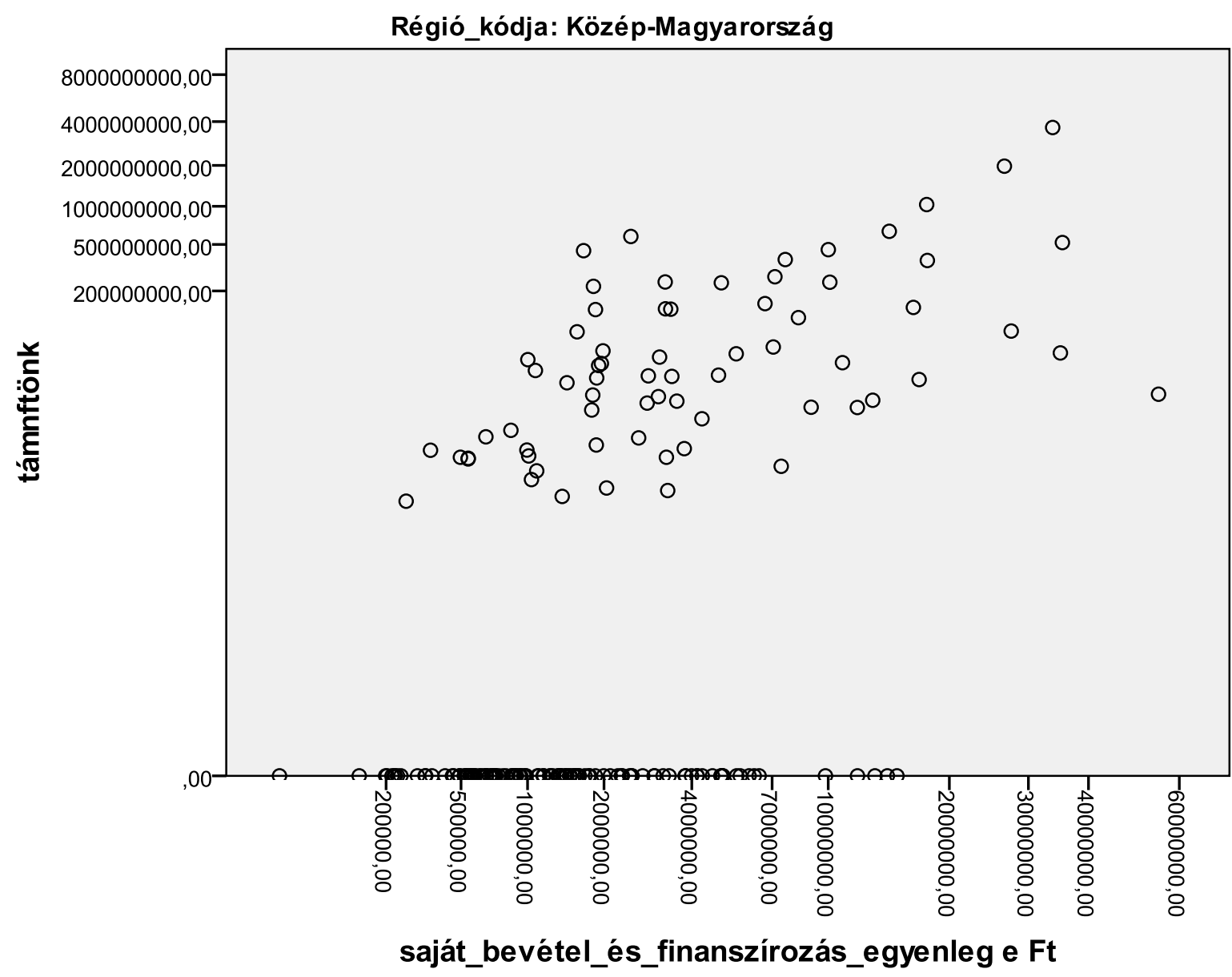


i2) A saját bevétel és a finanszirozás egyenlegének együttes értéke és az európai uniós támogatások viszonya régiók (NUTS2) szerinti bontásban

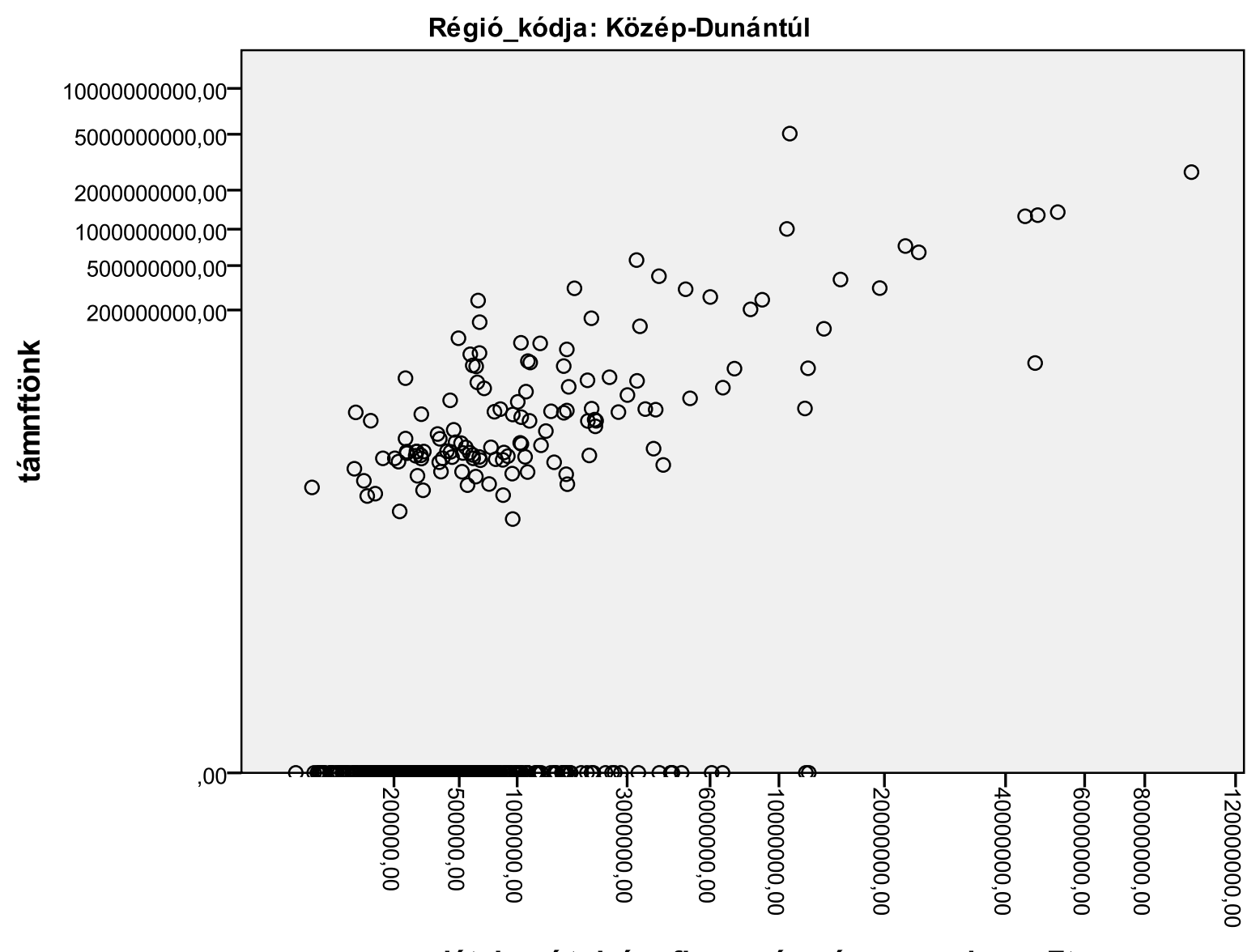

saját_bevétel_és_finanszírozás_egyenleg e Ft 
i3) A saját bevétel és a finanszírozás egyenlegének együttes értéke és az európai uniós támogatások viszonya régiók (NUTS2) szerinti bontásban

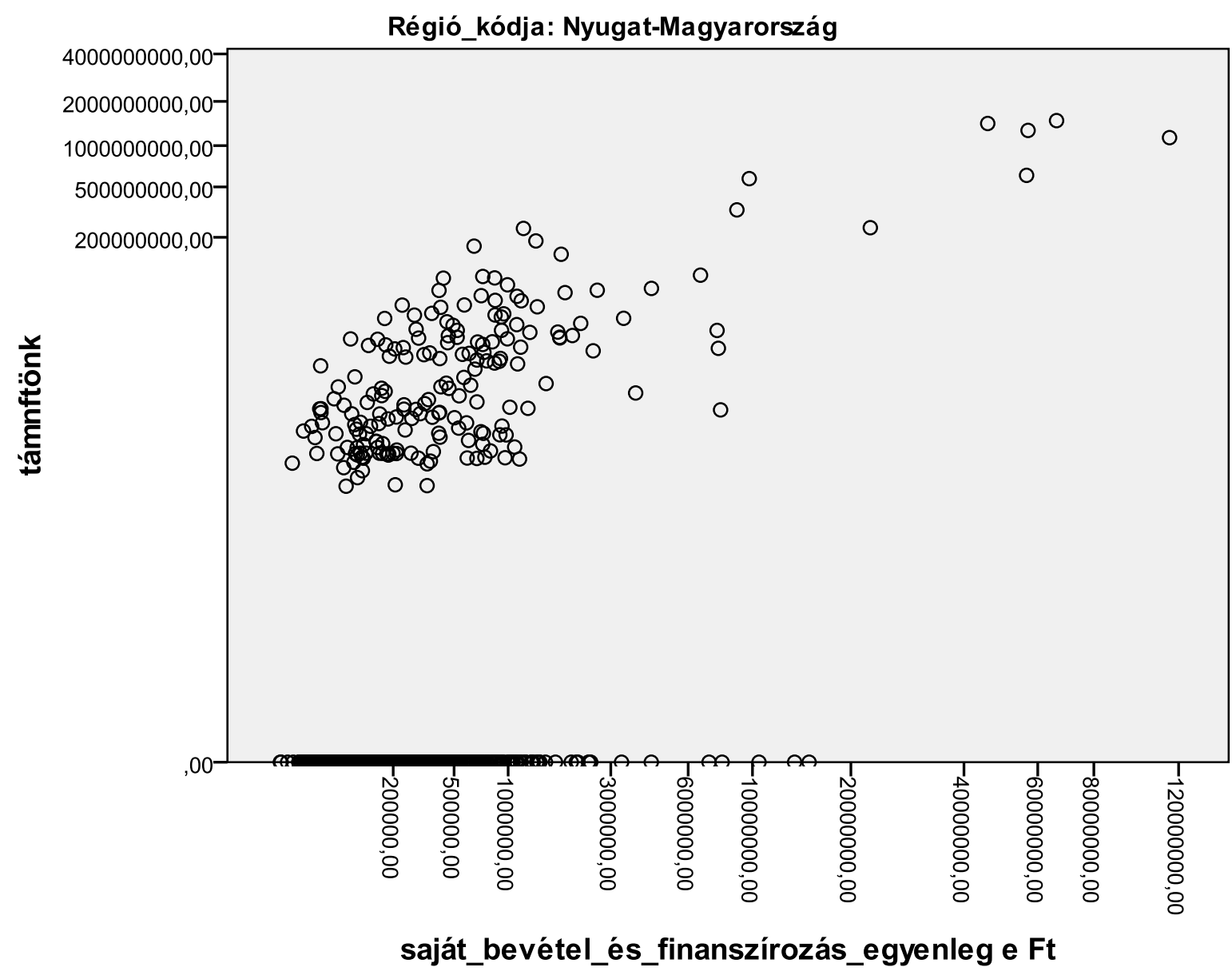


i4) A saját bevétel és a finanszirozás egyenlegének együttes értéke és az európai uniós támogatások viszonya régiók (NUTS2) szerinti bontásban

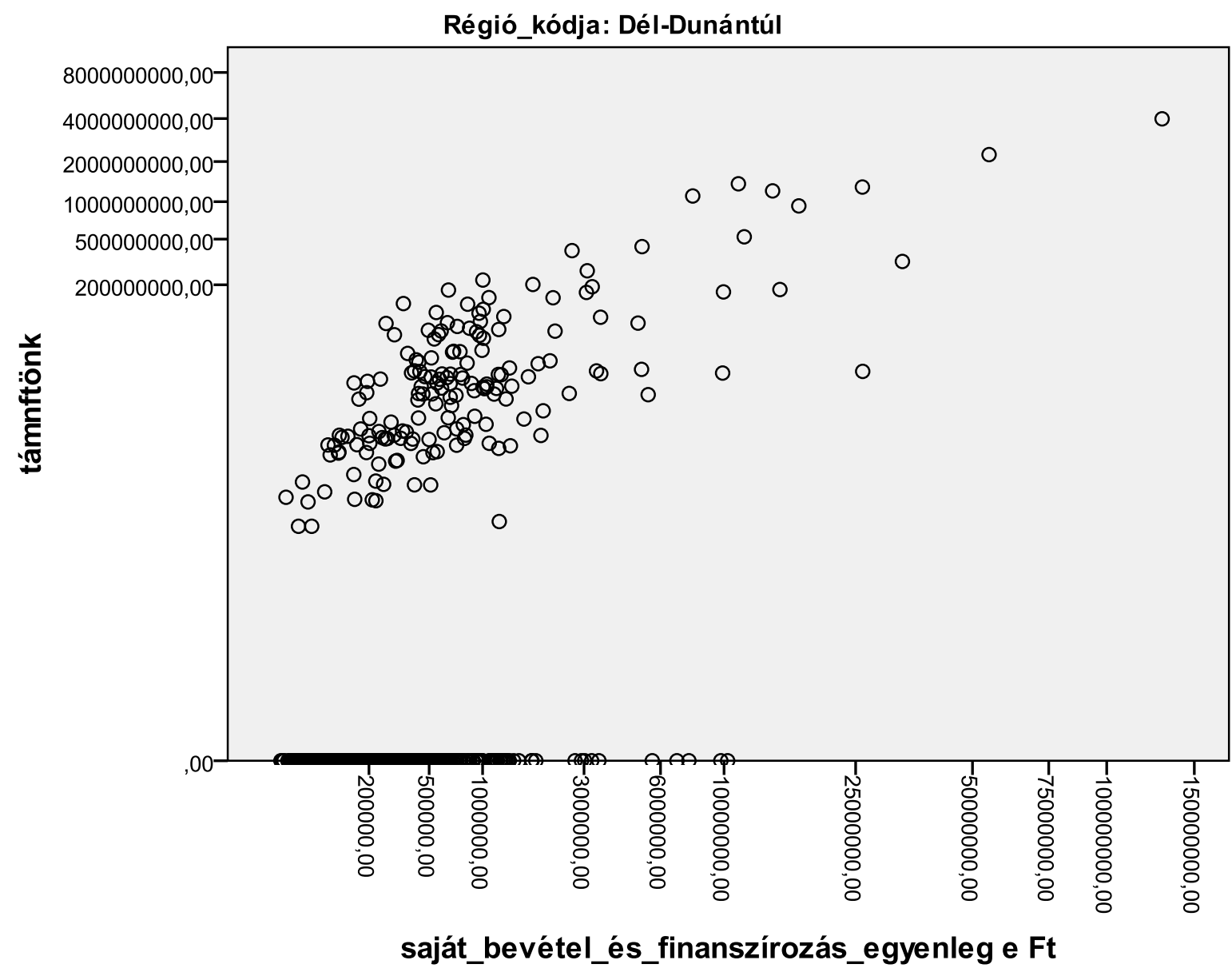


i5) A saját bevétel és a finanszírozás egyenlegének együttes értéke és az európai uniós támogatások viszonya régiók (NUTS2) szerinti bontásban

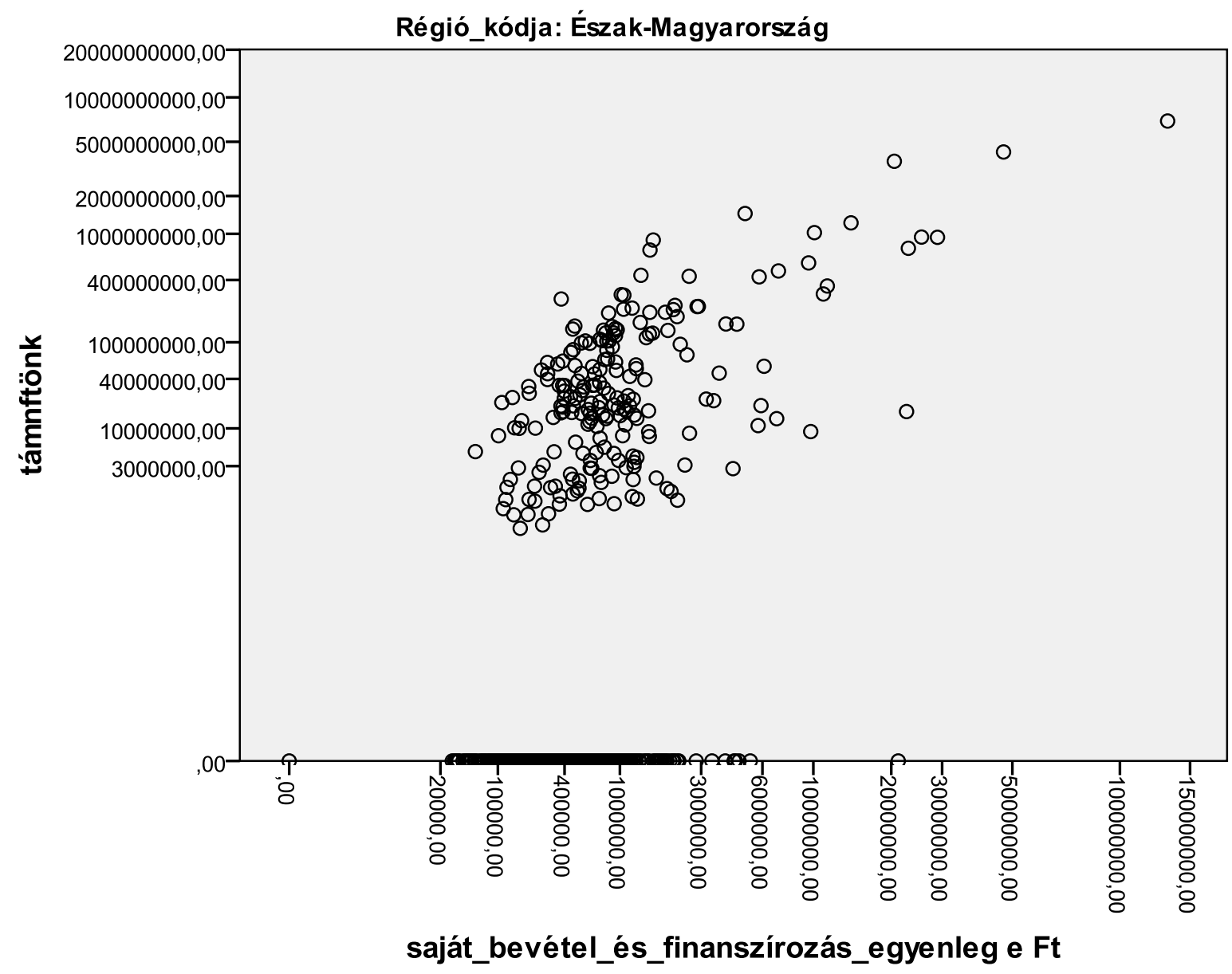


i6) A saját bevétel és a finanszirozás egyenlegének együttes értéke és az európai uniós támogatások viszonya régiók (NUTS2) szerinti bontásban

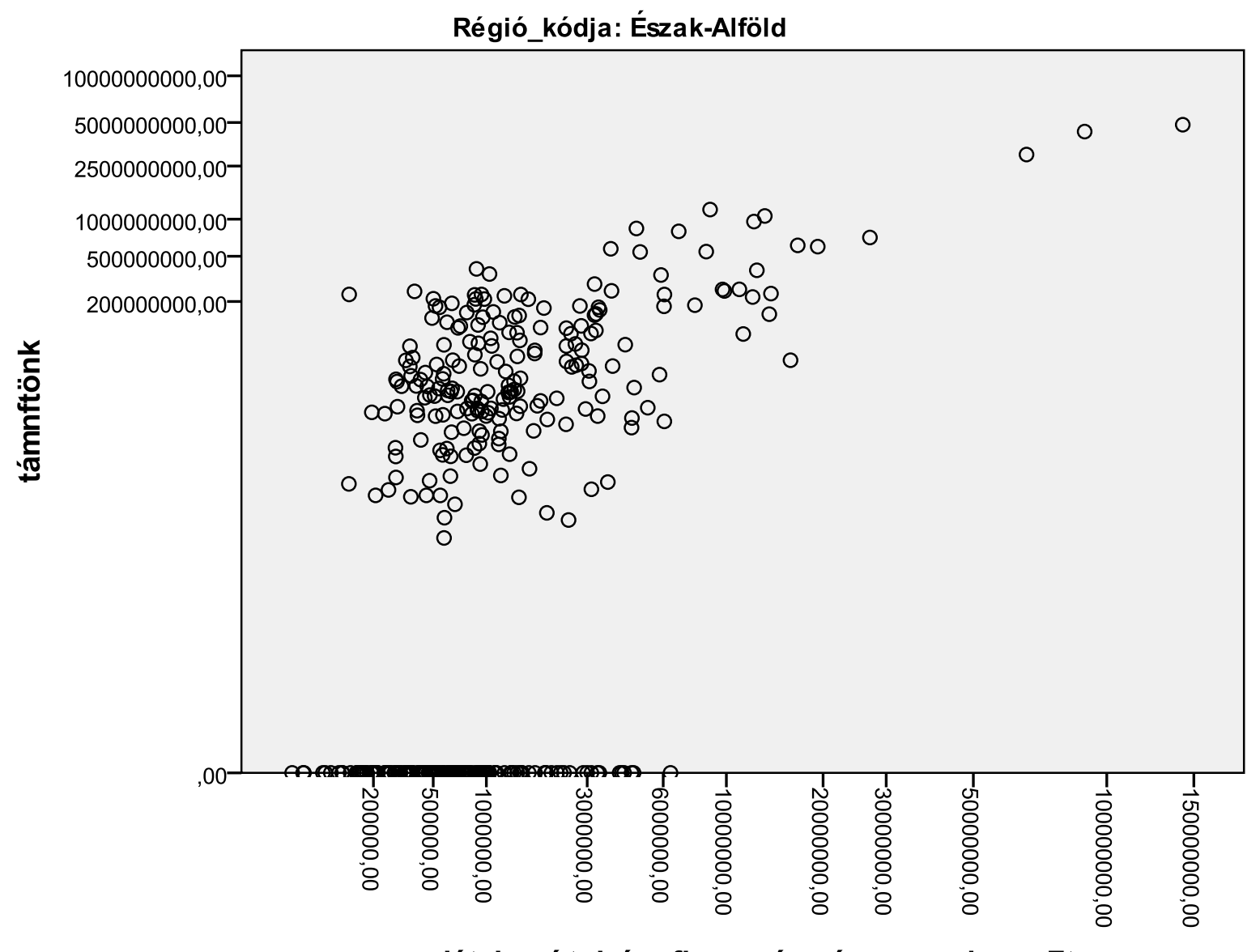

saját_bevétel_és_finanszírozás_egyenleg e Ft 
i7) A saját bevétel és a finanszírozás egyenlegének együttes értéke és az európai uniós támogatások viszonya régiók (NUTS2) szerinti bontásban

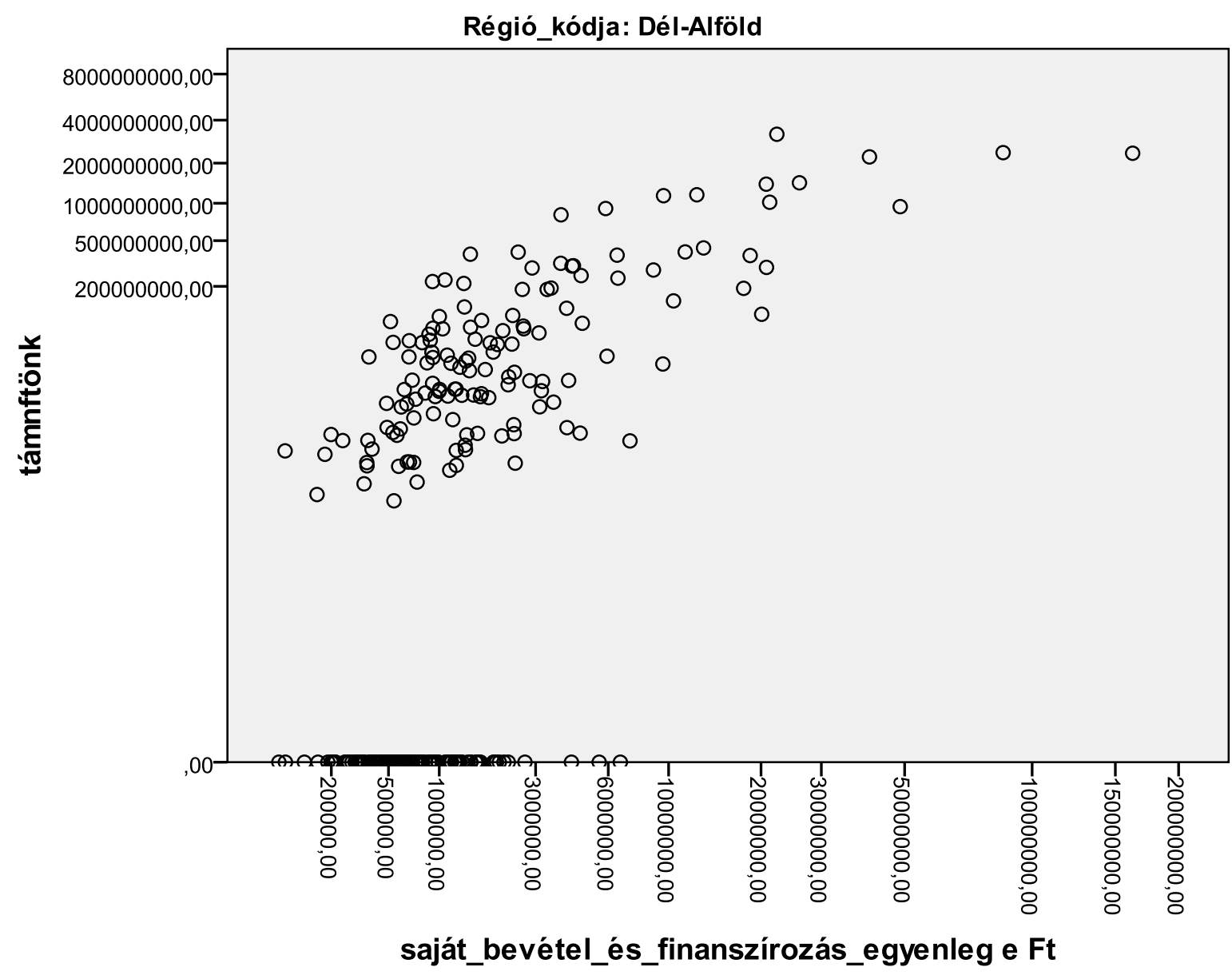


j1) A saját bevétel és a finanszírozás egyenlegének együttes értéke és az európai uniós támogatások viszonya saját területi bontás szerint

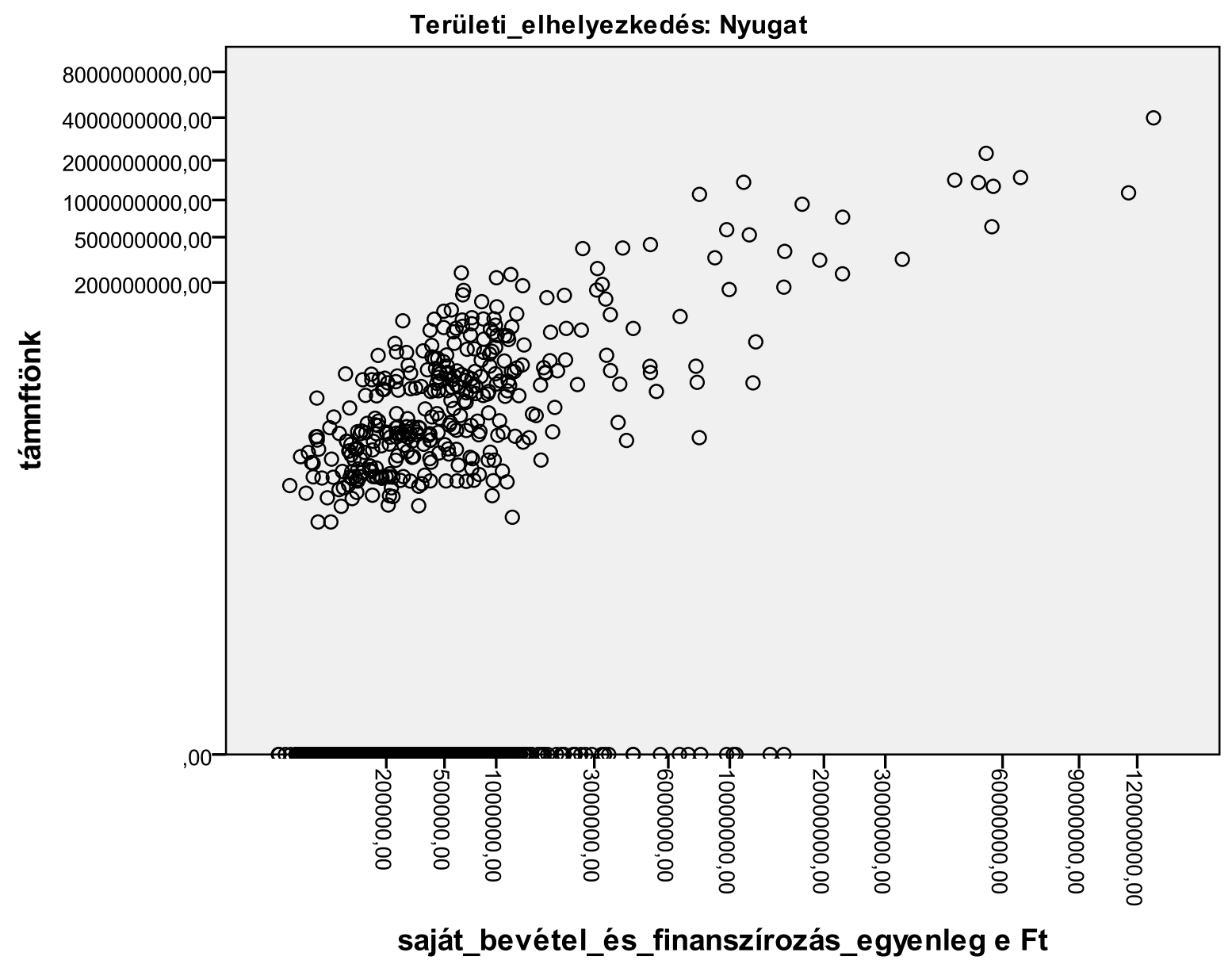


j2) A saját bevétel és a finanszirozás egyenlegének együttes értéke és az európai uniós támogatások viszonya saját terïleti bontás szerint

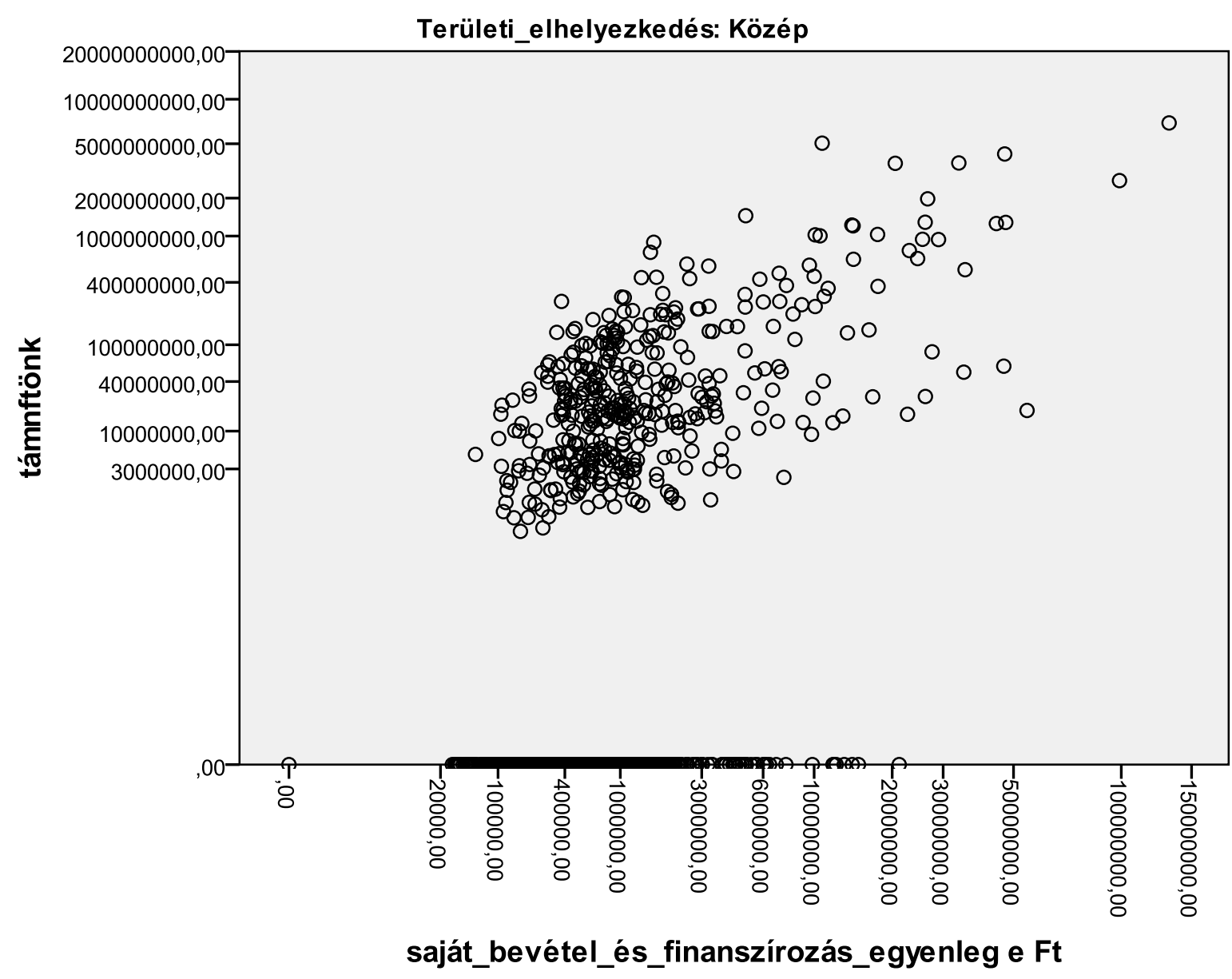


j3) A saját bevétel és a finanszírozás egyenlegének együttes értéke és az európai uniós támogatások viszonya saját területi bontás szerint

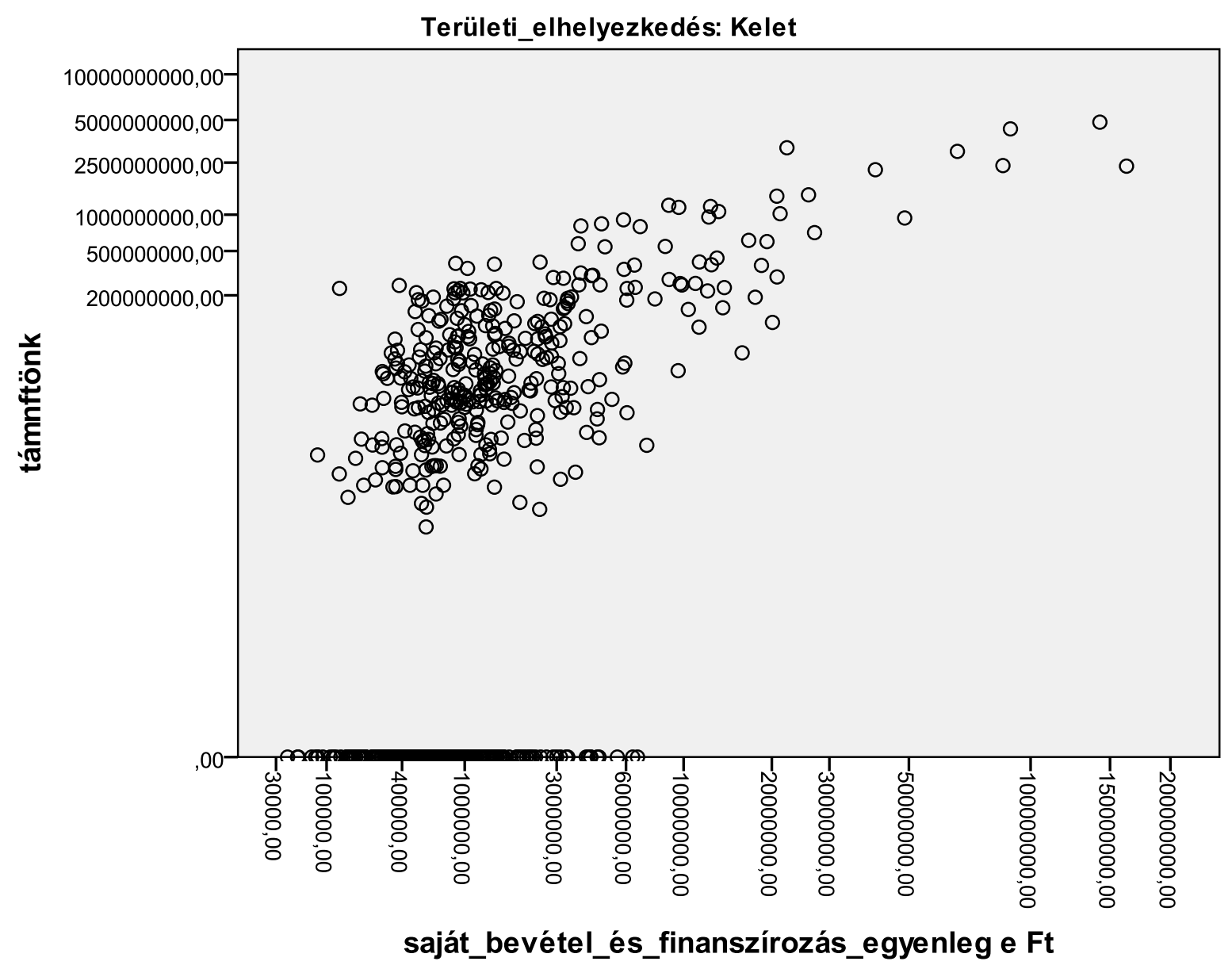


k1) Korreláció a helyi önkormányzatnak nyújtott támogatás és a saját bevétel valamint a finanszírozás egyenlegének együttese között, országos bontásban

\begin{tabular}{|l|r|r|}
\hline \multirow{7}{*}{} & $\begin{array}{c}\text { Támogatás ban } \\
\text { részes ültek }\end{array}$ & $\begin{array}{c}\text { Valamennyi helyi } \\
\text { önkormányzat }\end{array}$ \\
\cline { 2 - 3 } & $\begin{array}{c}\text { saját bevétel és } \\
\text { finanszírozás } \\
\text { bevétele együttesen }\end{array}$ & $\begin{array}{c}\text { saját bevétel és } \\
\text { finanszírozás } \\
\text { bevétele együttesen }\end{array}$ \\
\hline Országos & 0,764 & 0,761 \\
\hline
\end{tabular}

k2) Korreláció a helyi önkormányzatnak nyújtott támogatás és a saját bevétel valamint a finanszirrozás egyenlegének együttese között, nagyrégió (NUTS1) szintü bontásban

\begin{tabular}{|l|r|r|}
\hline \multirow{2}{*}{ NUTS1 } & $\begin{array}{c}\text { Támogatás ban } \\
\text { részes ültek }\end{array}$ & $\begin{array}{c}\text { Valame nnyi helyi } \\
\text { önkormányzat }\end{array}$ \\
\cline { 2 - 3 } & $\begin{array}{c}\text { saját bevétel és } \\
\text { finanszírozás } \\
\text { bevétele együttesen }\end{array}$ & $\begin{array}{c}\text { saját bevétel és } \\
\text { finanszírozás } \\
\text { bevétele együttesen }\end{array}$ \\
\hline Közép-Magyarország & 0,486 & 0,454 \\
\hline Dunántúl & 0,722 & 0,718 \\
\hline Alföld és Észak & 0,827 & 0,824 \\
\hline
\end{tabular}

k3) Korreláció a helyi önkormányzatnak nyújtott támogatás és a saját bevétel valamint a finanszírozás egyenlegének együttese között, régió (NUTS2) szintü bontásban

\begin{tabular}{|l|r|r|}
\hline \multirow{2}{*}{ NUTS2 } & $\begin{array}{c}\text { Támogatás ban } \\
\text { részes ültek }\end{array}$ & $\begin{array}{c}\text { Valame nnyi helyi } \\
\text { önkormányzat }\end{array}$ \\
\cline { 2 - 3 } & $\begin{array}{c}\text { saját bevétel és } \\
\text { finanszírozás } \\
\text { bevétele együttesen }\end{array}$ & $\begin{array}{c}\text { saját bevétel és } \\
\text { finanszírozás } \\
\text { bevétele együttesen }\end{array}$ \\
\hline Közép-Magyarország & 0,486 & 0,454 \\
\hline Közép-Dunántúl & 0,595 & 0,579 \\
\hline Nyugat-Magyarország & 0,869 & 0,878 \\
\hline Dél-Dunántúl & 0,902 & 0,907 \\
\hline Észak-Magyarország & 0,890 & 0,899 \\
\hline Észak-Alföld & 0,943 & 0,944 \\
\hline Dél-Alföld & 0,731 & 0,72 \\
\hline
\end{tabular}


k4) Korreláció a helyi önkormányzatnak nyújtott támogatás és a saját bevétel valamint a finanszírozás egyenlegének együttese között, megye (NUTS3) szintü bontásban

\begin{tabular}{|l|r|r|}
\hline \multirow{1}{*}{ NUTS3 } & $\begin{array}{c}\text { Támogatás ban } \\
\text { rés se sülte k }\end{array}$ & $\begin{array}{c}\text { Valamennyi helyi } \\
\text { önkormányzat }\end{array}$ \\
\cline { 2 - 3 } & $\begin{array}{c}\text { saját bevétel és } \\
\text { finanszírozás } \\
\text { bevétele együttesen }\end{array}$ & $\begin{array}{c}\text { saját bevétel és } \\
\text { finanszírozás } \\
\text { bevétele együttesen }\end{array}$ \\
\hline Baranya & 0,961 & 0,964 \\
\hline Bács-Kiskun & 0,903 & 0,904 \\
\hline Békés & 0,824 & 0,808 \\
\hline Borsod-Abaúj-Zemplén & 0,938 & 0,950 \\
\hline Csongrád & 0,840 & 0,835 \\
\hline Fejér & 0,492 & 0,483 \\
\hline Györ-Moson-Sopron & 0,976 & 0,979 \\
\hline Hajdú-Bihar & 0,981 & 0,983 \\
\hline Heves & 0,895 & 0,897 \\
\hline Komárom-Esztergom & 0,909 & 0,914 \\
\hline Nógrád & 0,852 & 0,843 \\
\hline Pest & 0,486 & 0,452 \\
\hline Somogy & 0,842 & 0,849 \\
\hline Szabolcs-Szatmár- & 0,948 & 0,951 \\
\hline Bereg & 0,912 & 0,911 \\
\hline Jász-Nagykun-Szolnok & 0,667 & 0,668 \\
\hline Tolna & 0,928 & 0,958 \\
\hline Vas & 0,913 & 0,944 \\
\hline Veszprém & & \\
\hline Zala & 0,972 \\
\hline
\end{tabular}

k3) Korreláció a helyi önkormányzatnak nyújtott támogatás és a saját bevétel valamint a finanszírozás egyenlegének együttese között, saját területi besorolás szerint

\begin{tabular}{|l|r|r|}
\hline \multirow{1}{*}{ Saját bontás } & $\begin{array}{c}\text { Támogatás ban } \\
\text { részesültek }\end{array}$ & $\begin{array}{c}\text { Valamennyi helyi } \\
\text { önkormányzat }\end{array}$ \\
\cline { 2 - 3 } & $\begin{array}{c}\text { saját bevétel és } \\
\text { finanszírozás } \\
\text { bevétele együttesen }\end{array}$ & $\begin{array}{c}\text { saját bevétel és } \\
\text { finanszírozás } \\
\text { bevétele együttesen }\end{array}$ \\
\hline Nyugat & 0,860 & 0,864 \\
\hline Közép & 0,714 & 0,716 \\
\hline Kelet & 0,836 & 0,833 \\
\hline
\end{tabular}




\section{3. számú melléklet: A H3.1 hipotézis tesztelésének eredményei}

A mellékletben szereplő valamennyi ábra, diagram, táblázat csak az európai uniós támogatásban részesült helyi önkormányzatok alapján készült, mivel a hipotézis tesztelése szempontjából az tekinthető relevánsnak.

\section{a) Képzett változók definiálása}

1. kül hosszú lejáratú kölcsön: a hosszú lejáratra kapott kölcsönök változása

2. kül_fejlesztési_célú_kötvénykibocsátás: a fejlesztési célú kötvénykibocsátások különbözete

3. kül_müködési_célú_kötvénykibocsátás: a müködési célú kötvénykibocsátások különbözete

4. kül beruházási és fejlesztési hitelek: a beruházási és fejlesztési hitelek különbözete

5. kül_müködési_célú_hosszú_lejáratú_hitelek: a müködési célú hosszú lejáratú hitelek különbözete

6. kül_egyéb_hosszú_lejáratú_kötelezettségek: az egyéb hosszú lejáratú kötelezettségek különbözete

7. kül rövid lejáratú kölcsön: a rövid lejáratra kapott kölcsönök változása

8. kül_rövid_lejáratú_hitelek: a rövid lejáratú hitelek különbözete

9. kül_szálló: az áruvásárlásból és szolgáltatásból származó szállítói kötelezettségek különbözete

10. kül_egyéb_rövid_lejáratú_kötelezettségek: az egyéb rövid lejáratú kötelezettségek különbözete

11. kül_törlesztés_hosszú_lejáratú_kölcsön: a hosszú lejáratú kölcsönök törlesztése miatti, következő évben esedékes rövid lejáratú kötelezettségek

12. kül törlesztés fejlesztési célú kötvénykibocsátás: a fejlesztési célú kötvénykibocsátások törlesztése miatti, következő évben esedékes rövid lejáratú kötelezettségek

13. kül törlesztés müködési célú kötvénykibocsátás: a müködési célú kötvénykibocsátások törlesztése miatti, következő évben esedékes rövid lejáratú kötelezettségek

14. kül_törlesztés_beruházási_és_fejlesztési_hitel: a beruházási és fejlesztési hitelek törlesztése miatti, következő évben esedékes rövid lejáratú kötelezettségek

15. kül_törlesztés_müködési_célú_hosszú_lejáratú_hitel: a müködési célú hosszú lejáratú hitelek törlesztése miatti, következő évben esedékes rövid lejáratú kötelezettségek

16. kül_törlesztés_egyéb_hosszú_kötelezettség: az egyéb hosszú lejáratú kötelezettségek törlesztése miatti, következő évben esedékes rövid lejáratú kötelezettségek 
Korreláció vizsgálat

b1) Korreláció vizsgálat a helyi önkormányzat részére folyósított európai uniós támogatással országos szinten, NUTS1 nagyrégiónként és saját területi bontásban

\begin{tabular}{|c|c|c|c|c|c|c|c|}
\hline \multirow[b]{2}{*}{ Változó megnevezése } & \multirow[b]{2}{*}{ Országos } & \multicolumn{3}{|c|}{ Nagyrégió NUTS1 } & \multicolumn{3}{|c|}{ Saját területi } \\
\hline & & \begin{tabular}{|c|} 
Közép- \\
Magyarország
\end{tabular} & Dunántúl & \begin{tabular}{|c|}
$\begin{array}{c}\text { Alföld és } \\
\text { Észak }\end{array}$ \\
\end{tabular} & Nyugat & Közép & Kelet \\
\hline $\begin{array}{l}\text { különbözet hosszú } \\
\text { lejáratú kölcsön }\end{array}$ & $-0,09$ & 0,06 & $-0,05$ & $-0,41$ & $-0,07$ & $-0,01$ & $-0,59$ \\
\hline $\begin{array}{l}\text { különbözet fejles ztési célú } \\
\text { kötvény-kibocsátás }\end{array}$ & 0,53 & 0,39 & 0,51 & 0,56 & 0,66 & 0,49 & 0,56 \\
\hline $\begin{array}{l}\text { különbözet müködési célú } \\
\text { kötvény-kibocsátás }\end{array}$ & 0,10 & 0,08 & 0,51 & 0,01 & 0,72 & 0,04 & 0,01 \\
\hline $\begin{array}{l}\text { különbözet beruházási és } \\
\text { fejlesztési hitelek }\end{array}$ & 0,54 & $-0,05$ & 0,53 & 0,68 & 0,83 & 0,46 & 0,60 \\
\hline $\begin{array}{l}\text { különbözet működési célú } \\
\text { hosszú lejáratú hitelek }\end{array}$ & 0,18 & 0,20 & 0,57 & 0,17 & 0,19 & 0,24 & 0,23 \\
\hline $\begin{array}{l}\text { különbözet egyéb hosszú } \\
\text { lejáratú kötelezettségek }\end{array}$ & 0,14 & $-0,02$ & 0,23 & 0,11 & 0,34 & 0,16 & 0,01 \\
\hline $\begin{array}{l}\text { különbözet rövid lejáratú } \\
\text { kölcsönök }\end{array}$ & $-0,01$ & 0,04 & 0,00 & $-0,05$ & 0,00 & 0,01 & $-0,08$ \\
\hline $\begin{array}{l}\text { különbözet rövid lejáratú } \\
\text { hitelek }\end{array}$ & 0,37 & 0,01 & 0,07 & 0,53 & 0,16 & 0,45 & 0,46 \\
\hline különbözet szállító & 0,20 & 0,01 & 0,14 & 0,26 & 0,37 & $-0,05$ & 0,46 \\
\hline $\begin{array}{l}\text { különbözet egyéb rövid } \\
\text { lejáratú kötelezettségek }\end{array}$ & 0,29 & 0,08 & 0,09 & 0,43 & 0,15 & 0,09 & 0,58 \\
\hline $\begin{array}{l}\text { különbözet törlesztés } \\
\text { hosszú lejáratú kölcsön }\end{array}$ & 0,07 & $-0,04$ & 0,14 & 0,04 & 0,21 & $-0,02$ & 0,13 \\
\hline $\begin{array}{l}\text { különbözet törles ztés } \\
\text { fejles ztési célú } \\
\text { kötvénykibocsátás }\end{array}$ & 0,31 & NA & 0,17 & 0,37 & 0,18 & 0,07 & 0,52 \\
\hline $\begin{array}{l}\text { különbözet törles ztés } \\
\text { müködési célú } \\
\text { kötvénykibocsátás }\end{array}$ & 0,02 & $-0,05$ & 0,05 & 0,01 & 0,07 & $-0,01$ & 0,02 \\
\hline $\begin{array}{l}\text { különbözet törlesztés } \\
\text { beruházási és fejlesztési } \\
\text { hitel }\end{array}$ & 0,22 & $-0,01$ & 0,08 & 0,34 & 0,69 & $-0,12$ & 0,54 \\
\hline $\begin{array}{l}\text { különbözet törles ztés } \\
\text { müködési célú hoss zú } \\
\text { lejáratú hitelek }\end{array}$ & 0,20 & $-0,04$ & 0,53 & 0,14 & 0,20 & 0,24 & 0,21 \\
\hline $\begin{array}{l}\text { különbözet törlesztés } \\
\text { egyéb hosszú } \\
\text { kötelezettség }\end{array}$ & 0,15 & 0,16 & 0,15 & 0,16 & 0,09 & 0,10 & 0,23 \\
\hline
\end{tabular}


b2) Korreláció vizsgálat a helyi önkormányzat részére folyósított európai uniós támogatással régió (NUTS2) szinten

\begin{tabular}{|c|c|c|c|c|c|c|c|}
\hline \multirow[b]{2}{*}{ Változó megnevezése } & \multicolumn{7}{|c|}{ Régió (NUTS2) } \\
\hline & \begin{tabular}{c|} 
Közép- \\
Magyarország
\end{tabular} & \begin{tabular}{c|} 
Közép- \\
Dunántúl
\end{tabular} & $\begin{array}{c}\text { Nyugat- } \\
\text { Magyarország }\end{array}$ & \begin{tabular}{c|} 
Dél- \\
Dunántúl
\end{tabular} & $\begin{array}{c}\text { Észak- } \\
\text { Magyarország }\end{array}$ & $\begin{array}{l}\text { Észak- } \\
\text { Alföld } \\
\end{array}$ & Dél-Alföld \\
\hline $\begin{array}{l}\text { különbözet hosszú } \\
\text { lejáratú kölcsön }\end{array}$ & 0,06 & $-0,06$ & $-0,01$ & 0,00 & $-0,02$ & $-0,73$ & $-0,24$ \\
\hline $\begin{array}{l}\text { különbözet fejlesztési célú } \\
\text { kötvény-kibocsátás }\end{array}$ & 0,39 & 0,43 & 0,18 & 0,79 & 0,64 & 0,57 & 0,56 \\
\hline $\begin{array}{l}\text { különbözet müködési célú } \\
\text { kötvény-kibocsátás }\end{array}$ & 0,08 & 0,01 & $-0,01$ & 0,85 & 0,06 & 0,01 & 0,01 \\
\hline $\begin{array}{l}\text { különbözet beruházási és } \\
\text { fejlesztési hitelek }\end{array}$ & $-0,05$ & $-0,01$ & 0,88 & 0,80 & 0,82 & 0,65 & 0,52 \\
\hline $\begin{array}{l}\text { különbözet müködési célú } \\
\text { hosszú lejáratú hitelek }\end{array}$ & 0,20 & 0,78 & 0,44 & 0,01 & 0,00 & 0,03 & 0,38 \\
\hline $\begin{array}{l}\text { különbözet egyéb hosszú } \\
\text { lejáratú kötelezettségek }\end{array}$ & $-0,02$ & 0,24 & 0,37 & 0,39 & 0,21 & 0,08 & 0,01 \\
\hline $\begin{array}{l}\text { különbözet rövid lejáratú } \\
\text { kölcsönök }\end{array}$ & 0,04 & $-0,03$ & 0,02 & $-0,05$ & $-0,01$ & 0,00 & $-0,12$ \\
\hline $\begin{array}{l}\text { különbözet rövid lejáratú } \\
\text { hitelek }\end{array}$ & 0,01 & 0,13 & 0,20 & $-0,12$ & 0,81 & 0,54 & 0,45 \\
\hline különbözet szállító & 0,01 & 0,02 & 0,01 & 0,55 & $-0,22$ & 0,67 & 0,11 \\
\hline $\begin{array}{l}\text { különbözet egyéb rövid } \\
\text { lejáratú kötelezettségek }\end{array}$ & 0,08 & 0,01 & $-0,09$ & 0,81 & 0,18 & 0,72 & 0,56 \\
\hline $\begin{array}{l}\text { különbözet törlesztés } \\
\text { hosszú lejáratú kölcsön }\end{array}$ & $-0,04$ & 0,02 & 0,44 & $-0,02$ & $-0,01$ & 0,01 & 0,21 \\
\hline $\begin{array}{l}\text { különbözet törlesztés } \\
\text { fejlesztési célú } \\
\text { kötvénykibocsátás }\end{array}$ & NA & 0,18 & 0,20 & 0,24 & 0,07 & 0,66 & 0,01 \\
\hline $\begin{array}{l}\text { különbözet törlesztés } \\
\text { müködési célú } \\
\text { kötvénykibocsátás }\end{array}$ & $-0,05$ & 0,01 & NA & 0,08 & NA & 0,01 & 0,03 \\
\hline $\begin{array}{l}\text { különbözet törlesztés } \\
\text { beruházási és fejlesztési } \\
\text { hitel }\end{array}$ & $-0,01$ & $-0,24$ & 0,84 & 0,67 & $-0,08$ & 0,64 & 0,47 \\
\hline $\begin{array}{l}\text { különbözet törlesztés } \\
\text { müködési célú hosszú } \\
\text { lejáratú hitelek }\end{array}$ & $-0,04$ & 0,78 & 0,44 & 0,00 & 0,02 & 0,01 & 0,38 \\
\hline $\begin{array}{l}\text { különbözet törlesztés } \\
\text { egyéb hosszú } \\
\text { kötelezettség }\end{array}$ & 0,16 & 0,12 & 0,44 & 0,41 & 0,00 & $-0,09$ & 0,38 \\
\hline
\end{tabular}




\section{b3) Korreláció vizsgálat a helyi önkormányzat részére folyósított európai uniós támogatással megye (NUTS3) szinten}

\begin{tabular}{|c|c|c|c|c|c|c|c|c|c|c|c|c|c|c|c|c|c|c|c|}
\hline Változó megnevezése & Baranya & $\begin{array}{c}\text { Bács- } \\
\text { Kiskun }\end{array}$ & Békés & \begin{tabular}{|c|} 
Borsod- \\
Abaúj- \\
Zemplén
\end{tabular} & Csongrád & Fejér & \begin{tabular}{|c|} 
Györ- \\
Moson- \\
Sopron
\end{tabular} & $\begin{array}{l}\text { Hajdú- } \\
\text { Bihar }\end{array}$ & Heves & $\begin{array}{l}\text { Komárom- } \\
\text { Esztergom }\end{array}$ & Nógrád & Pest & Somogy & \begin{tabular}{|c|} 
Szabolcs- \\
Szatmár- \\
Bereg
\end{tabular} & \begin{tabular}{|c|} 
Jász- \\
Nagykun- \\
Szolnok \\
\end{tabular} & Tolna & Vas & Veszprém & Zala \\
\hline \begin{tabular}{|l} 
különbözet hosszú \\
lejáratú kölcsön
\end{tabular} & $-0,07$ & $-0,02$ & 0,17 & 0,02 & $-0,73$ & $|-0,01|$ & NA & $-0,96$ & $-0,69$ & $-0,11$ & $-0,04$ & 0,06 & $-0,04$ & 0,02 & $-0,91$ & 0,04 & $|-0,01|$ & $-0,27$ & NA \\
\hline $\begin{array}{l}\text { különbözet fejlesztési célú } \\
\text { kötvény-kibocsátás }\end{array}$ & 0,81 & 0,88 & 0,71 & 0,84 & 0,31 & 0,42 & 0,40 & $-0,50$ & $-0,07$ & 0,51 & $-0,04$ & 0,39 & 0,90 & 0,93 & 0,87 & 0,57 & $|-0,02|$ & 0,34 & 0,03 \\
\hline $\begin{array}{l}\text { különbözet működési célú } \\
\text { kötvény-kibocsátás }\end{array}$ & 0,91 & $\mathrm{NA}$ & $-0,07$ & 0,08 & 0,05 & 0,00 & $-0,04$ & 0,01 & $\mathrm{NA}$ & $\mathrm{NA}$ & 0,04 & 0,08 & 0,73 & 0,00 & 0,01 & 0,71 & $\mathrm{NA}$ & $\mathrm{NA}$ & NA \\
\hline \begin{tabular}{|l|} 
különbözet beruházási és \\
fejlesztési hitelek
\end{tabular} & 0,93 & 0,53 & 0,51 & 0,95 & 0,78 & $-0,43$ & 0,97 & 0,96 & 0,71 & 0,86 & 0,32 & $-0,05$ & 0,88 & $-0,32$ & 0,76 & 0,09 & 0,91 & 0,77 & 0,93 \\
\hline $\begin{array}{l}\text { különbözet müködési célú } \\
\text { hosszú lejáratú hitelek }\end{array}$ & $-0,04$ & 0,77 & $\mathrm{NA}$ & $-0,01$ & $-0,04$ & 0,86 & NA & $\mathrm{NA}$ & $-0,02$ & $\mathrm{NA}$ & 0,04 & 0,20 & $-0,03$ & 0,08 & $-0,07$ & 0,07 & $\mathrm{NA}$ & $\mathrm{NA}$ & 0,66 \\
\hline $\begin{array}{l}\text { különbözet egyéb hosszú } \\
\text { lejáratú kötelezettségek }\end{array}$ & $-0,12$ & $-0,01$ & 0,02 & 0,30 & 0,56 & 0,44 & $-0,11$ & 0,04 & 0,09 & 0,57 & $-0,04$ & $-0,02$ & 0,83 & 0,24 & 0,04 & 0,28 & $0,20 \mid$ & $-0,57$ & 0,54 \\
\hline $\begin{array}{l}\text { különbözet rövid lejáratú } \\
\text { kölcsönök }\end{array}$ & 0,04 & $-0,01$ & $\mathrm{NA}$ & 0,01 & $-0,24$ & $-0,04$ & NA & $-0,04$ & $\mathrm{NA}$ & $-0,07$ & $-0,45$ & 0,04 & $-0,14$ & 0,00 & 0,02 & $-0,04$ & $\mathrm{NA}$ & $\mathrm{NA}$ & 0,02 \\
\hline $\begin{array}{l}\text { különbözet rövid lejáratú } \\
\text { hitelek }\end{array}$ & 0,12 & 0,48 & $-0,40$ & 0,91 & 0,88 & $-0,18$ & 0,46 & $-0,01$ & 0,68 & 0,63 & 0,66 & 0,01 & $-0,13$ & 0,92 & 0,34 & $\mid-0,68$ & 0,11 & 0,78 & $-0,19$ \\
\hline különbözet szállitó & 0,92 & $-0,09$ & $-0,05$ & $-0,21$ & 0,25 & 0,00 & 0,45 & 0,71 & $-0,30$ & 0,45 & 0,22 & 0,01 & $-0,07$ & 0,87 & 0,67 & 0,16 & $-0,82$ & 0,16 & 0,04 \\
\hline $\begin{array}{l}\text { különbözet egyéb rövid } \\
\text { lejáratú kötelezettségek }\end{array}$ & 0,93 & 0,80 & 0,67 & 0,01 & 0,75 & $-0,38$ & $-0,76$ & 0,96 & 0,74 & 0,84 & $-0,05$ & 0,08 & 0,86 & 0,39 & 0,64 & 0,24 & $0,87 \mid$ & 0,22 & 0,76 \\
\hline \begin{tabular}{|l|} 
különbözet törlesztés \\
hosszú lejáratú kölcsön
\end{tabular} & $-0,04$ & $-0,04$ & 0,05 & 0,00 & 0,40 & $-0,06$ & NA & 0,01 & $-0,05$ & $-0,04$ & $\mathrm{NA}$ & $-0,04$ & NA & $\mathrm{NA}$ & $\mathrm{NA}$ & $\mathrm{NA}$ & $\mathrm{NA}$ & 0,15 & 0,66 \\
\hline $\begin{array}{l}\text { különbözet törlesztés } \\
\text { fejlestzési célú } \\
\text { kötvénykibocsátás }\end{array}$ & $\mathrm{NA}$ & 0,05 & $-0,09$ & 0,10 & $\mathrm{NA}$ & $\mathrm{NA}$ & 0,43 & 0,96 & $\mathrm{NA}$ & 0,56 & $\mathrm{NA}$ & NA & 0,49 & $\mathrm{NA}$ & 0,91 & $\mathrm{NA}$ & $\mathrm{NA}$ & $\mathrm{NA}$ & NA \\
\hline $\begin{array}{l}\text { különbözet törlesztés } \\
\text { működési célú } \\
\text { kötvénykibocsátás }\end{array}$ & $\mathrm{NA}$ & $\mathrm{NA}$ & $-0,07$ & $\mathrm{NA}$ & 0,05 & 0,00 & NA & $\mathrm{NA}$ & $\mathrm{NA}$ & $\mathrm{NA}$ & $\mathrm{NA}$ & $-0,05$ & 0,16 & $\mathrm{NA}$ & 0,02 & $\mathrm{NA}$ & $\mathrm{NA}$ & $\mathrm{NA}$ & NA \\
\hline $\begin{array}{l}\text { különbözet törlesztés } \\
\text { beruházási és fejlesztési } \\
\text { hitel }\end{array}$ & 0,92 & 0,28 & 0,53 & $-0,61$ & 0,70 & $-0,44$ & 0,96 & 0,95 & 0,59 & 0,69 & 0,17 & $-0,01 \mid$ & $-0,22$ & 0,06 & 0,42 & $-0,15$ & $|0,92|$ & 0,40 & 0,85 \\
\hline $\begin{array}{l}\text { különbözet törlesztés } \\
\text { müködési célú hosszú } \\
\text { lejáratú hitelek }\end{array}$ & $-0,04$ & 0,77 & $\mathrm{NA}$ & 0,09 & $-0,04$ & 0,86 & NA & $-0,05$ & $-0,05$ & $\mathrm{NA}$ & 0,04 & $-0,05$ & $-0,03$ & 0,08 & $-0,07$ & 0,07 & $\mathrm{NA}$ & $\mathrm{NA}$ & 0,66 \\
\hline $\begin{array}{l}\text { különbözet törlesztés } \\
\text { egyéb hosszú } \\
\text { kötelezettség }\end{array}$ & 0,15 & 0,03 & $-0,04$ & $-0,01$ & 0,73 & 0,05 & $-0,39$ & 0,08 & $-0,07$ & 0,57 & 0,53 & 0,16 & 0,79 & 0,87 & $-0,83$ & 0,31 & 0,01 & $-0,22$ & 0,66 \\
\hline
\end{tabular}


Faktoranalízis

c1) Fökomponens elemzés eredménye varimax rotációval országos szinten

\begin{tabular}{|l|r|r|r|r|r|r|}
\hline \multicolumn{1}{|c|}{ Változó megne vezés e } & \multicolumn{6}{c|}{ Faktorok } \\
\cline { 2 - 7 } & $\mathbf{1}$ & $\mathbf{2}$ & $\mathbf{3}$ & $\mathbf{4}$ & \multicolumn{1}{c|}{$\mathbf{5}$} & \multicolumn{1}{c|}{$\mathbf{6}$} \\
\hline támnftönk & 0,24 & 0,39 & 0,21 & 0,52 & 0,37 & $-0,01$ \\
\hline kül_hosszú_lejáratú_kölcsön & 0,04 & $-0,29$ & 0,07 & $-0,15$ & 0,23 & $-0,49$ \\
\hline kül_fejlesztési_célú_kötvénykibocsátás & 0,04 & 0,08 & 0,24 & 0,83 & 0,20 & $-0,06$ \\
\hline kül_müködési_célú_kötvénykibocsátás & $-0,11$ & 0,13 & $-0,01$ & 0,00 & 0,62 & $-0,14$ \\
\hline kül_beruházási_és_fejlesztési_hitelek & 0,37 & 0,62 & 0,05 & 0,14 & 0,33 & 0,00 \\
\hline kül_müködési_célú_hosszú_lejáratú_hitelek & 0,03 & $-0,01$ & 0,95 & 0,09 & $-0,02$ & $-0,03$ \\
\hline kül_egyéb_hosszú_lejáratú_kötelezettségek & 0,19 & $-0,17$ & $-0,07$ & 0,06 & 0,60 & 0,34 \\
\hline kül_rövid_lejáratú_kölcsönök & 0,02 & 0,04 & 0,09 & $-0,47$ & 0,27 & $-0,17$ \\
\hline kül_rövid_lejáratú_hitelek & 0,71 & 0,02 & $-0,08$ & 0,44 & $-0,09$ & $-0,11$ \\
\hline kül_szálító & $-0,06$ & 0,58 & $-0,10$ & 0,38 & $-0,02$ & 0,02 \\
\hline kül_egyéb_rövid_lejáratún_kötelezettségek & 0,75 & 0,29 & 0,26 & $-0,02$ & 0,10 & 0,16 \\
\hline kül_törlesztés_hosszú_lejáratú_kölcsön & 0,05 & $-0,04$ & 0,12 & $-0,04$ & 0,09 & 0,80 \\
\hline kül_törlesztés_fejlesztési_célú_kötvénykibocsátás & 0,06 & 0,84 & 0,02 & $-0,09$ & $-0,01$ & 0,06 \\
\hline kül_törlesztés_beruházási_és_fejlesztési_hitel & 0,65 & 0,50 & 0,04 & $-0,18$ & $-0,08$ & 0,05 \\
\hline kül_törlesztés_múködési_célú_hosszú_lejáratú_hitelek & 0,03 & $-0,01$ & 0,95 & 0,05 & $-0,01$ & 0,11 \\
\hline kül_törlesztés_egyéb_hosszú_kötelezettség & 0,87 & $-0,12$ & $-0,06$ & $-0,01$ & 0,06 & 0,01 \\
\hline
\end{tabular}

\begin{tabular}{|l|r|r|}
\hline \multicolumn{3}{|c|}{ Kommunalitások } \\
\hline & Initial & Extraction \\
\hline támnftönk & 1,00 & 0,67 \\
\hline kül_hosszú_lejáratú_kölcsön & 1,00 & 0,40 \\
\hline kül_fejlesztési_célú_kötvénykibocsátás & 1,00 & 0,79 \\
\hline kül_müködési_célú_kötvénykibocsátás & 1,00 & 0,43 \\
\hline kül_beruházási_és_fejlesztési_hitelek & 1,00 & 0,65 \\
\hline kül_müködési_célú_hosszú_lejáratú_hitelek & 1,00 & 0,91 \\
\hline kül_egyéb_hosszú_lejáratú_kötelezettségek & 1,00 & 0,55 \\
\hline kül_rövid_lejáratú_kölcsönök & 1,00 & 0,34 \\
\hline kül_rövid_lejáratú_hitelek & 1,00 & 0,73 \\
\hline kül_szállító & 1,00 & 0,50 \\
\hline kül_egyéb_rövid_lejáratú_kötelezettségek & 1,00 & 0,75 \\
\hline kül_törlesztés_hosszú_lejáratú_kölcsön & 1,00 & 0,67 \\
\hline kül_törlesztés_fejlesztési_célú_kötvénykibocsátás & 1,00 & 0,73 \\
\hline kül_törlesztés_beruházási_és_fejlesztési_hitel & 1,00 & 0,71 \\
\hline kül_törlesztés_müködési_célú_hosszú_lejáratú hitelek & 1,00 & 0,92 \\
\hline kül_törlesztés_egyéb_hosszú_kötelezettség & 1,00 & 0,79 \\
\hline
\end{tabular}


c2) Fökomponens elemzés eredménye varimax rotációval Baranya megye

\begin{tabular}{|l|r|r|r|r|r|}
\hline \multirow{2}{*}{ Válttozó megnevezése } & \multicolumn{5}{c|}{ Faktorok } \\
\cline { 2 - 6 } & \multicolumn{1}{|c|}{$\mathbf{1}$} & \multicolumn{1}{c|}{$\mathbf{2}$} & \multicolumn{1}{c|}{$\mathbf{3}$} & \multicolumn{1}{c|}{$\mathbf{4}$} & \multicolumn{1}{c|}{$\mathbf{5}$} \\
\hline támnftönk & 0,97 & $-0,02$ & 0,07 & 0,15 & $-0,05$ \\
\hline kül_hosszú_lejáratú_kölcsön & $-0,01$ & 0,03 & $-0,03$ & $-0,12$ & 0,84 \\
\hline kül_fejlesztési_célú_kötvénykibocsátás & 0,79 & $-0,02$ & 0,44 & 0,22 & 0,04 \\
\hline kül_müködési_célú_kötvénykibocsátás & 0,97 & $-0,01$ & 0,10 & $-0,20$ & 0,02 \\
\hline kül_beruházási_és_fejlesztési_hitelek & 0,99 & $-0,01$ & $-0,08$ & $-0,06$ & 0,02 \\
\hline kül_müködési_célú_hosszú_lejáratú_hitelek & $-0,02$ & 1,00 & $-0,02$ & $-0,01$ & $-0,01$ \\
\hline kül_egyéb_hosszú_lejáratú_kötelezettségek & $-0,08$ & $-0,02$ & 0,79 & $-0,54$ & $-0,02$ \\
\hline kül_rövid_lejáratú_kölcsönök & 0,03 & 0,04 & $-0,04$ & $-0,11$ & $-0,56$ \\
\hline kül_rövid_lejáratú_hitelek & 0,04 & $-0,02$ & 0,96 & $-0,07$ & 0,05 \\
\hline kül_szállító & 0,90 & 0,00 & 0,11 & 0,35 & $-0,05$ \\
\hline kül_egyéb_rövid_lejáratú_kötelezettségek & 0,98 & $-0,01$ & $-0,14$ & $-0,04$ & $-0,03$ \\
\hline kül_törlesztés_hosszú_lejáratú_kölcsön & $-0,01$ & 0,96 & $-0,01$ & $-0,01$ & $-0,01$ \\
\hline kül_törlesztés_beruházási_és_fejlesztési_hitel & 0,97 & $-0,01$ & $-0,19$ & $-0,07$ & $-0,07$ \\
\hline kül_törlesztés_müködési_célúl_hosszú_lejáratú_hitelek & $-0,02$ & 0,97 & $-0,02$ & $-0,01$ & $-0,01$ \\
\hline kül_törlesztés_egyéb_hosszú_kötelezettség & 0,04 & $-0,04$ & $-0,24$ & 0,95 & 0,04 \\
\hline
\end{tabular}

\begin{tabular}{|l|r|r|}
\hline \multicolumn{3}{|c|}{ Kommunalitás ok } \\
\hline & Initial & Extraction \\
\hline támnftönk & 1,00 & 0,97 \\
\hline kül_hosszú_lejáratú_kölcsön & 1,00 & 0,72 \\
\hline kül_fejlesztési_célú_kötvénykibocsátás & 1,00 & 0,87 \\
\hline kül_müködési_célú_kötvénykibocsátás & 1,00 & 0,99 \\
\hline kül_beruházási_és_fejlesztési_hitelek & 1,00 & 0,99 \\
\hline kül_müködési_célú_hosszú_lejáratú_hitelek & 1,00 & 1,00 \\
\hline kül_egyéb_hosszú_lejáratú_kötelezettségek & 1,00 & 0,92 \\
\hline kül_rövid_lejáratú_kölcsönök & 1,00 & 0,33 \\
\hline kül_rövid_lejáratú_hitelek & 1,00 & 0,93 \\
\hline kül_szállitó & 1,00 & 0,95 \\
\hline kül_egyéb_rövid_lejáratú_kötelezettségek & 1,00 & 0,98 \\
\hline kül_törlesztés_hosszú_lejáratú_kölcsön & 1,00 & 0,92 \\
\hline kül_törlesztés_beruházási_és_fejlesztési_hitel & 1,00 & 0,99 \\
\hline kül_törlesztés_múködési_célú_hosszú_lejáratú_hitelek & 1,00 & 0,95 \\
\hline kül_törlesztés_egyéb_hosszú_kötelezettség & 1,00 & 0,96 \\
\hline
\end{tabular}


c3) Fökomponens elemzés eredménye varimax rotációval Bács-Kiskun megye

\begin{tabular}{|c|c|c|c|c|c|c|}
\hline \multirow{2}{*}{ Változó megnevezése } & \multicolumn{6}{|c|}{ Faktorok } \\
\hline & 1 & 2 & 3 & 4 & 5 & 6 \\
\hline támnftönk & 0,86 & 0,05 & 0,24 & $-0,07$ & $-0,08$ & $-0,15$ \\
\hline kül_hosszú_lejáratú_kölcsön & 0,00 & 0,03 & $-0,07$ & 0,82 & 0,10 & $-0,25$ \\
\hline kül_fejlesztési_célú_kötvénykibocsátás & 0,92 & $-0,14$ & 0,19 & 0,01 & $-0,17$ & $-0,09$ \\
\hline kül_beruházási_és_fejlesztési_hitelek & 0,73 & $-0,44$ & 0,22 & 0,01 & 0,20 & 0,19 \\
\hline kül_müködési_célú_hosszú_lejáratú_hitelek & 0,98 & 0,04 & $-0,11$ & 0,04 & 0,00 & 0,04 \\
\hline kül_egyéb_hosszú_lejáratú_kötelezettségek & $-0,03$ & 0,96 & 0,02 & $-0,01$ & 0,03 & 0,01 \\
\hline kül_rövid_lejáratú_kölcsönök & 0,03 & $-0,04$ & $-0,01$ & 0,83 & $-0,11$ & 0,12 \\
\hline kül_rövid_lejáratú_hitelek & 0,11 & 0,07 & 0,83 & $-0,10$ & $-0,32$ & $-0,16$ \\
\hline kül_szállító & $-0,13$ & 0,08 & 0,05 & 0,08 & 0,90 & 0,03 \\
\hline kül_egyéb_rövid_lejáratú_kötelezettségek & 0,98 & 0,08 & $-0,03$ & $-0,04$ & 0,13 & 0,00 \\
\hline kül_törlesztés_hosszú_lejáratú_kölcsön & $-0,01$ & 0,06 & $-0,03$ & $-0,07$ & $-0,05$ & 0,90 \\
\hline kül_törlesztés_fejlesztési_célú_kötvénykibocsátás & 0,03 & $-0,03$ & 0,88 & 0,02 & 0,21 & 0,10 \\
\hline kül_törlesztés_beruházási_és_fejlesztési_hitel & 0,31 & $-0,03$ & $-0,17$ & $-0,35$ & 0,56 & $-0,20$ \\
\hline kül_törlesztés_müködési_célú_hosszú_lejáratú_hitelek & 0,98 & 0,04 & $-0,11$ & 0,04 & 0,01 & 0,04 \\
\hline kül_törlesztés_egyéb_hosszú_kötelezettség & 0,03 & 0,95 & 0,02 & 0,00 & 0,05 & 0,07 \\
\hline
\end{tabular}

\begin{tabular}{|l|r|r|}
\hline \multicolumn{3}{|c|}{ Kommunalitások } \\
\hline & Initial & Extraction \\
\hline támnftönk & 1,00 & 0,84 \\
\hline kül_hosszú_lejáratú_kölcsön & 1,00 & 0,76 \\
\hline kül_fejlesztési_célú_kötvénykibocsátás & 1,00 & 0,95 \\
\hline kül_beruházási_és_fejlesztési_hitelek & 1,00 & 0,84 \\
\hline kül_müködési_célú_hosszú_lejáratú_hitelek & 1,00 & 0,97 \\
\hline kül_egyéb_hosszzúlejáratú_kötelezettségek & 1,00 & 0,92 \\
\hline kül_rövid_lejáratú_kölcsönök & 1,00 & 0,73 \\
\hline kül_rövid_lejáratú_hitelek & 1,00 & 0,85 \\
\hline kül_szállitó & 1,00 & 0,85 \\
\hline kül_egyéb_rövid_lejáratú_kötelezettségek & 1,00 & 0,99 \\
\hline kül_törlesztés_hosszú_lejáratú_kölcsön & 1,00 & 0,83 \\
\hline kül_törlesztés_fejlesztési_célú_kötvénykibocsátás & 1,00 & 0,83 \\
\hline kül_törlesztés_beruházási_és_fejlesztési_hitel & 1,00 & 0,60 \\
\hline kül_törlesztés_múködési_célú_hosszú_lejáratú_hitelek & 1,00 & 0,97 \\
\hline kül_törlesztés_egyéb_hosszú_kötelezettség & 1,00 & 0,91 \\
\hline
\end{tabular}


c4) Fökomponens elemzés eredménye varimax rotációval Békés megye

\begin{tabular}{|l|r|r|r|r|r|}
\hline \multicolumn{1}{|c|}{ Változó megnevezése } & \multicolumn{5}{c|}{ Faktorok } \\
\cline { 2 - 6 } & \multicolumn{1}{|c|}{$\mathbf{1}$} & \multicolumn{1}{c|}{$\mathbf{2}$} & \multicolumn{1}{c|}{$\mathbf{4}$} & \multicolumn{1}{c|}{$\mathbf{5}$} \\
\hline támnftönk & 0,80 & 0,29 & $-0,06$ & $-0,14$ & $-0,11$ \\
\hline kül_hosszú_lejáratú_kölcsön & 0,21 & $-0,04$ & $-0,96$ & 0,07 & 0,01 \\
\hline kül_fejlesztési_célú_kötvénykibocsátás & 0,89 & 0,23 & $-0,03$ & $-0,07$ & 0,00 \\
\hline kül_müködési_célú_kötvénykibocsátás & $-0,04$ & $-0,01$ & $-0,02$ & 0,07 & 0,77 \\
\hline kül_beruházási_és_fejlesztési_hitelek & 0,86 & $-0,10$ & 0,01 & 0,02 & 0,15 \\
\hline kül_egyéb_hosszú_lejáratú_kötelezettségek & $-0,04$ & 0,82 & 0,04 & 0,03 & $-0,01$ \\
\hline kül_rövid_lejáratú_hitelek & $-0,23$ & $-0,21$ & 0,10 & 0,81 & 0,12 \\
\hline kül_szállító & $-0,05$ & $-0,22$ & 0,21 & $-0,80$ & 0,02 \\
\hline kül_egyéb_rövid_lejáratú_kötelezettségek & 0,58 & 0,78 & $-0,03$ & $-0,07$ & 0,11 \\
\hline kül_törlesztés_hosszú_lejáratú_kölcsön & 0,15 & $-0,07$ & 0,98 & $-0,04$ & 0,00 \\
\hline kül_törlesztés_fejlesztési_célú_kötvénykibocsátás & $-0,05$ & 0,02 & $-0,04$ & 0,06 & 0,76 \\
\hline kül_törlesztés_beruházási_és_fejlesztési_hitel & 0,22 & 0,92 & $-0,07$ & 0,02 & 0,04 \\
\hline kül_törlesztés_egyéb_hosszú_kötelezettség & $-0,20$ & $-0,05$ & $-0,06$ & 0,06 & $-0,29$ \\
\hline
\end{tabular}

\begin{tabular}{|l|r|r|}
\hline \multicolumn{3}{|c|}{ Kommunalitások } \\
\hline \multicolumn{3}{|c|}{} \\
\hline támnftönk & Initial & Extraction \\
\hline kül_hosszú_lejáratú_kölcsön & 1,00 & 0,76 \\
\hline kül_fejlesztési_célú_kötvénykibocsátás & 1,00 & 0,97 \\
\hline kül_müködési_célú_kötvénykibocsátás & 1,00 & 0,85 \\
\hline kül_beruházási_és_fejlesztési_hitelek & 1,00 & 0,59 \\
\hline kül_egyéb_hosszú_lejáratú_kötelezettségek & 1,00 & 0,78 \\
\hline kül_rövid_lejáratú_hitelek & 1,00 & 0,67 \\
\hline kül_szállító & 1,00 & 0,78 \\
\hline kül_egyéb_rövid_lejáratú_kötelezettségek & 1,00 & 0,74 \\
\hline kül_törlesztés_hosszú_lejáratú_kölcsön & 1,00 & 0,96 \\
\hline kül_törlesztés_fejlesztési_célú_kötvénykibocsátás & 1,00 & 0,99 \\
\hline kül_törlesztés_beruházási_és_fejlesztési_hitel & 1,00 & 0,59 \\
\hline kül_törlesztés_egyéb_hosszú_kötelezettség & 1,00 & 0,90 \\
\hline
\end{tabular}


c5) Fökomponens elemzés eredménye varimax rotációval Borsod-Abaúj-Zemplén megye

\begin{tabular}{|c|c|c|c|c|c|c|}
\hline \multirow{2}{*}{ Változó megnevezése } & \multicolumn{6}{|c|}{ Faktorok } \\
\hline & 1 & 2 & 3 & 4 & 5 & 6 \\
\hline támnftönk & 0,96 & 0,08 & $-0,02$ & 0,01 & 0,07 & 0,03 \\
\hline kül_hosszú_lejáratú_kölcsön & 0,00 & 0,00 & 0,01 & 0,95 & 0,00 & 0,01 \\
\hline kül_fejlesztési_célú_kötvénykibocsátás & 0,88 & $-0,01$ & 0,19 & $-0,06$ & 0,18 & $-0,02$ \\
\hline kül_müködési_célú_kötvénykibocsátás & 0,07 & $-0,01$ & 0,94 & $-0,03$ & 0,03 & $-0,04$ \\
\hline kül_beruházási_és_fejlesztési_hitelek & 0,97 & $-0,01$ & $-0,04$ & 0,00 & 0,13 & 0,02 \\
\hline kül_müködési_célú_hosszú_lejáratú_hitelek & $-0,02$ & 0,01 & $-0,03$ & $-0,01$ & 0,02 & $-0,34$ \\
\hline kül_egyéb_hosszú_lejáratú_kötelezettségek & 0,27 & $-0,04$ & $-0,09$ & 0,01 & 0,64 & 0,00 \\
\hline kül_rövid_lejáratú_kölcsönök & $-0,02$ & 0,00 & 0,01 & $-0,02$ & 0,04 & 0,94 \\
\hline kül_rövid_lejáratú_hitelek & 0,94 & $-0,02$ & $-0,08$ & 0,02 & 0,09 & 0,07 \\
\hline kül_szállító & $-0,20$ & $-0,03$ & 0,89 & 0,10 & 0,04 & 0,16 \\
\hline kül_egyéb_rövid_lejáratú_kötelezettségek & 0,10 & 0,25 & 0,26 & $-0,03$ & 0,45 & 0,02 \\
\hline kül_törlesztés_hosszú_lejáratú_kölcsön & $-0,01$ & $-0,01$ & 0,04 & 0,95 & 0,00 & 0,00 \\
\hline kül_törlesztés_fejlesztési_célú_kötvénykibocsátás & 0,01 & 0,97 & $-0,05$ & 0,00 & 0,02 & $-0,01$ \\
\hline kül_törlesztés_beruházási_és_fejlesztési_hitel & $-0,75$ & 0,00 & 0,25 & $-0,03$ & 0,35 & 0,11 \\
\hline kül_törlesztés_müködési_célú_hosszú_lejáratú_hitelek & 0,00 & 0,96 & 0,01 & 0,00 & 0,02 & $-0,01$ \\
\hline kül_törlesztés_egyéb_hosszú_kötelezettség & $-0,10$ & $-0,03$ & 0,02 & 0,01 & 0,76 & $-0,03$ \\
\hline
\end{tabular}

\begin{tabular}{|l|r|r|}
\hline \multicolumn{3}{|c|}{ Kommunalitások } \\
\hline & Initial & Extraction \\
\hline támnftönk & 1,00 & 0,93 \\
\hline kül_hosszú_lejáratú_kölcsön & 1,00 & 0,91 \\
\hline kül_fejlesztési_célú_kötvénykibocsátás & 1,00 & 0,85 \\
\hline kül_müködési_célú_kötvénykibocsátás & 1,00 & 0,89 \\
\hline kül_beruházási_és_fejlesztési_hitelek & 1,00 & 0,96 \\
\hline kül_müködési_célú_hosszú_lejáratú_hitelek & 1,00 & 0,12 \\
\hline kül_egyéb_hosszú_lejáratú_kötelezettségek & 1,00 & 0,49 \\
\hline kül_rövid_lejáratú_kölcsönök & 1,00 & 0,88 \\
\hline kül_rövid_lejáratú_hitelek & 1,00 & 0,90 \\
\hline kül_szállitó & 1,00 & 0,86 \\
\hline kül_egyéb_rövid_lejáratú_kötelezettségek & 1,00 & 0,34 \\
\hline kül_törlesztés_hosszú_lejáratú_kölcsön & 1,00 & 0,91 \\
\hline kül_törlesztés_fejlesztési_célú_kötvénykibocsátás & 1,00 & 0,94 \\
\hline kül_törlesztés_beruházási_és_fejlesztési_hitel & 1,00 & 0,75 \\
\hline kül_törlesztés_müködési_célú_hosszú_lejáratú_hitelek & 1,00 & 0,93 \\
\hline kül_törlesztés_egyéb_hosszú_kötelezettség & 1,00 & 0,59 \\
\hline
\end{tabular}


c6) Fökomponens elemzés eredménye varimax rotációval Csongrád megye

\begin{tabular}{|l|r|r|r|r|}
\hline \multicolumn{1}{|c|}{ Válttozó megnevezése } & \multicolumn{4}{c|}{ Faktorok } \\
\cline { 2 - 5 } & \multicolumn{1}{|c|}{$\mathbf{1}$} & \multicolumn{1}{c|}{$\mathbf{2}$} & \multicolumn{1}{c|}{$\mathbf{3}$} & \multicolumn{1}{c|}{$\mathbf{4}$} \\
\hline támnftönk & 0,84 & 0,24 & $-0,01$ & 0,22 \\
\hline kül_hosszú_lejáratú_kölcsön & $-0,96$ & 0,08 & 0,02 & 0,06 \\
\hline kül_fejlesztési_célú_kötvénykibocsátás & 0,04 & 0,96 & $-0,03$ & 0,04 \\
\hline kül_müködési_célú_kötvénykibocsátás & $-0,05$ & 0,00 & $-0,02$ & 0,92 \\
\hline kül_beruházási_és_fejlesztési_hitelek & 0,94 & 0,29 & $-0,04$ & $-0,04$ \\
\hline kül_müködési_célú_hosszú_lejáratú_hitelek & $-0,02$ & $-0,02$ & 1,00 & $-0,01$ \\
\hline kül_egyéb_hosszú_lejáratú_kötelezettségek & 0,48 & $-0,08$ & 0,00 & 0,30 \\
\hline kül_rövid_lejáratú_kölcsönök & $-0,04$ & $-0,99$ & 0,01 & 0,04 \\
\hline kül_rövid_lejáratú_hitelek & 0,96 & 0,14 & $-0,01$ & 0,14 \\
\hline kül_szállító & 0,03 & 0,99 & $-0,01$ & $-0,01$ \\
\hline kül_egyéb_rövid_lejáratú_kötelezettségek & 0,98 & 0,07 & $-0,01$ & $-0,14$ \\
\hline kül_törlesztés_hossźn_lejáratú_kölcsön & 0,25 & 0,96 & $-0,01$ & $-0,05$ \\
\hline kül_törlesztés_beruházási_és_fejlesztési_hitel & 0,90 & 0,20 & $-0,01$ & $-0,38$ \\
\hline kül_törlesztés_müködési_célú_hosszú_lejáratú_hitelek & $-0,02$ & $-0,02$ & 1,00 & $-0,01$ \\
\hline kül_törlesztés_egyéb_hosszú_kötelezettség & 0,98 & $-0,07$ & $-0,01$ & $-0,06$ \\
\hline
\end{tabular}

\begin{tabular}{|l|r|r|}
\hline \multicolumn{3}{|c|}{ Kommunalitás ok } \\
\hline & Initial & Extraction \\
\hline támnftönk & 1,00 & 0,81 \\
\hline kül_hosszú_lejáratú_kölcsön & 1,00 & 0,93 \\
\hline kül_fejlesztési_célú_kötvénykibocsátás & 1,00 & 0,93 \\
\hline kül_müködési_célú_kötvénykibocsátás & 1,00 & 0,84 \\
\hline kül_beruházási_és_fejlesztési_hitelek & 1,00 & 0,97 \\
\hline kül_müködési_célú_hosszú_lejáratú_hitelek & 1,00 & 1,00 \\
\hline kül_egyéb_hosszú_lejáratú_kötelezettségek & 1,00 & 0,32 \\
\hline kül_rövid_lejáratú_kölcsönök & 1,00 & 0,99 \\
\hline kül_rövid_lejáratú_hitelek & 1,00 & 0,96 \\
\hline kül_szállitó & 1,00 & 0,98 \\
\hline kül_egyéb_rövid_lejáratú_kötelezettségek & 1,00 & 0,98 \\
\hline kül_törlesztés_hosszú_lejáratú_kölcsön & 1,00 & 0,99 \\
\hline kül_törlesztés_beruházási_és_fejlesztési_hitel & 1,00 & 0,99 \\
\hline kül_törlesztés_mǘködési_célú_hosszú_lejáratú_hitelek & 1,00 & 1,00 \\
\hline kül_törlesztés_egyéb_hosszú_kötelezettség & 1,00 & 0,96 \\
\hline
\end{tabular}


c7) Fökomponens elemzés eredménye varimax rotációval Fejér megye

\begin{tabular}{|l|r|r|r|r|r|r|}
\hline \multicolumn{1}{|c|}{ Változó megnevezése } & \multicolumn{6}{c|}{ Faktorok } \\
\cline { 2 - 7 } & \multicolumn{1}{|c|}{$\mathbf{1}$} & \multicolumn{1}{c|}{$\mathbf{2}$} & \multicolumn{1}{c|}{$\mathbf{3}$} & \multicolumn{1}{c|}{$\mathbf{5}$} & \multicolumn{1}{c|}{$\mathbf{6}$} \\
\hline támnftönk & $-0,41$ & 0,90 & $-0,01$ & 0,02 & 0,00 & $-0,02$ \\
\hline kül_hosszú_lejáratú_kölcsön & $-0,06$ & $-0,03$ & 0,97 & 0,05 & $-0,01$ & 0,02 \\
\hline kül_fejlesztési_célú_kötvénykibocsátás & $-0,79$ & 0,11 & $-0,06$ & 0,01 & 0,48 & $-0,09$ \\
\hline kül_müködési_célú_kötvénykibocsátás & 0,07 & $-0,02$ & 0,04 & 0,30 & $-0,19$ & $-0,05$ \\
\hline kül_beruházási_és_fejlesztési_hitelek & 0,97 & $-0,05$ & 0,06 & $-0,03$ & 0,13 & 0,01 \\
\hline kül_müködési_célú_hosszú_lejáratú_hitelek & 0,06 & 0,99 & 0,05 & $-0,01$ & 0,01 & 0,00 \\
\hline kül_egyéb_hosszú_lejáratú_kötelezettségek & $-0,97$ & 0,03 & $-0,05$ & $-0,04$ & 0,01 & $-0,01$ \\
\hline kül_rövid_lejáratú_kölcsönök & 0,02 & $-0,03$ & 0,04 & $-0,12$ & $-0,04$ & 0,92 \\
\hline kül_rövid_lejáratú_hitelek & 0,48 & $-0,02$ & 0,17 & $-0,14$ & 0,79 & $-0,06$ \\
\hline kül_szállító & $-0,27$ & $-0,14$ & $-0,91$ & $-0,02$ & $-0,10$ & $-0,01$ \\
\hline kül_egyéb_rövid_lejáratú_kötelezettségek & 0,86 & $-0,02$ & 0,08 & 0,02 & 0,39 & $-0,05$ \\
\hline kül_törlesztés_hosszú_lejáratú_kölcsön & 0,06 & $-0,06$ & 0,10 & $-0,71$ & $-0,31$ & $-0,37$ \\
\hline kül_törlesztés_beruházási_és_fejlesztési_hitel & 0,98 & $-0,04$ & 0,05 & 0,03 & 0,10 & $-0,01$ \\
\hline kül_törlesztés_müködési_célú_hosszú_lejáratú_hitelek & 0,06 & 0,99 & 0,05 & $-0,01$ & 0,01 & $-0,01$ \\
\hline kül_törlesztés_egyéb_hosszú_kötelezettség & $-0,03$ & 0,00 & 0,08 & 0,77 & $-0,09$ & $-0,25$ \\
\hline
\end{tabular}

\begin{tabular}{|l|r|r|}
\hline \multicolumn{3}{|c|}{ Kommunalitások } \\
\hline \multicolumn{2}{|c|}{} \\
\hline támnftönk & Initial & Extraction \\
\hline kül_hosszú_lejáratú_kölcsön & 1,00 & 0,97 \\
\hline kül_fejlesztési_célú_kötvénykibocsátás & 1,00 & 0,96 \\
\hline kül_müködési_célú_kötvénykibocsátás & 1,00 & 0,88 \\
\hline kül_beruházási_és_fejlesztési_hitelek & 1,00 & 0,13 \\
\hline kül_müködési_célú_hosszú_lejáratú_hitelek & 1,00 & 0,97 \\
\hline kül_egyéb_hosszzúlejáratú_kötelezettségek & 1,00 & 0,99 \\
\hline kül_rövid_lejáratú_kölcsönök & 1,00 & 0,95 \\
\hline kül_rövid_lejáratú_hitelek & 1,00 & 0,86 \\
\hline kül_szállitó & 1,00 & 0,90 \\
\hline kül_egyéb_rövid_lejáratú_kötelezettségek & 1,00 & 0,94 \\
\hline kül_törlesztés_hosszú_lejáratú_kölcsön & 1,00 & 0,90 \\
\hline kül_törlesztés_beruházási_és_fejlesztési_hitel & 1,00 & 0,76 \\
\hline kül_törlesztés_müködési_célú_hosszú_lejáratú_hitelek & 1,00 & 0,98 \\
\hline kül_törlesztés_egyéb_hosszú_kötelezettség & 1,00 & 1,00 \\
\hline
\end{tabular}


c8) Fökomponens elemzés eredménye varimax rotációval Györ-Moson-Sopron megye

\begin{tabular}{|l|r|r|r|}
\hline \multicolumn{2}{|c|}{ Változó megnevezése } & \multicolumn{3}{c|}{ Faktorok } \\
\cline { 2 - 4 } & \multicolumn{1}{|c|}{$\mathbf{1}$} & \multicolumn{1}{c|}{$\mathbf{2}$} & \multicolumn{1}{c|}{$\mathbf{3}$} \\
\hline támnftönk & 0,29 & 0,94 & $-0,02$ \\
\hline kül_fejlesztési_célú_kötvénykibocsátás & 0,93 & 0,15 & 0,29 \\
\hline kül_müködési_célú_kötvénykibocsátás & $-0,01$ & $-0,02$ & 1,00 \\
\hline kül_beruházási_és_fejlesztési_hitelek & 0,41 & 0,90 & $-0,01$ \\
\hline kül_egyéb_hosszú_lejáratú_kötelezettségek & $-0,29$ & $-0,03$ & 0,04 \\
\hline kül_rövid_lejáratú_hitelek & 0,97 & 0,18 & $-0,03$ \\
\hline kül_szállító & 0,89 & 0,19 & $-0,08$ \\
\hline kül_egyéb_rövid_lejáratú_kötelezettségek & 0,36 & $-0,93$ & 0,02 \\
\hline kül_törlesztés_fejlesztési_célú_kötvénykibocsátás & 0,96 & 0,17 & 0,00 \\
\hline kül_törlesztés_beruházási_és_fejlesztési_hitel & 0,40 & 0,90 & 0,01 \\
\hline kül_törlesztés_egyéb_hosszú_kötelezettség & $-0,86$ & $-0,15$ & $-0,01$ \\
\hline
\end{tabular}

\begin{tabular}{|l|r|r|}
\hline \multicolumn{3}{|c|}{ Kommunalitás ok } \\
\hline & Initial & Extraction \\
\hline támnftönk & 1,00 & 0,98 \\
\hline kül_fejlesztési_célú_kötvénykibocsátás & 1,00 & 0,96 \\
\hline kül_müködési_célú_kötvénykibocsátás & 1,00 & 0,99 \\
\hline kül_beruházási_és_fejlesztési_hitelek & 1,00 & 0,99 \\
\hline kül_egyéb_hosszú_lejáratú_kötelezettségek & 1,00 & 0,09 \\
\hline kül_rövid_lejáratú_hitelek & 1,00 & 0,97 \\
\hline kül_szállító & 1,00 & 0,84 \\
\hline kül_egyéb_rövid_lejáratú_kötelezettségek & 1,00 & 0,99 \\
\hline kül_törlesztés_fejlesztési_célú_kötvénykibocsátás & 1,00 & 0,95 \\
\hline kül_törlesztés_beruházási_és_fejlesztési_hitel & 1,00 & 0,98 \\
\hline kül_törlesztés_egyéb_hosszú_kötelezettség & 1,00 & 0,76 \\
\hline
\end{tabular}


c9) Fökomponens elemzés eredménye varimax rotációval Hajdú-Bihar megye

\begin{tabular}{|l|r|r|r|r|r|}
\hline \multirow{2}{*}{ Változó megnevezése } & \multicolumn{5}{c|}{ Faktorok } \\
\cline { 2 - 6 } & \multicolumn{1}{|c|}{$\mathbf{1}$} & \multicolumn{1}{c|}{$\mathbf{2}$} & \multicolumn{1}{c|}{$\mathbf{3}$} & \multicolumn{1}{c|}{$\mathbf{4}$} & \multicolumn{1}{c|}{$\mathbf{5}$} \\
\hline támnftönk & 0,97 & 0,01 & $-0,06$ & 0,10 & 0,02 \\
\hline kül_hosszú_lejáratú_kölcsön & $-0,99$ & 0,05 & $-0,05$ & 0,01 & 0,06 \\
\hline kül_fejlesztési_célú_kötvénykibocsátás & $-0,54$ & 0,76 & 0,08 & 0,03 & 0,04 \\
\hline kül_müködési_célú_kötvénykibocsátás & 0,04 & 0,72 & $-0,18$ & $-0,05$ & 0,01 \\
\hline kül_beruházási_és_fejlesztési_hitelek & 0,99 & 0,03 & 0,06 & 0,03 & 0,01 \\
\hline kül_egyéb_hosszú_lejáratú_kötelezettségek & 0,17 & $-0,14$ & 0,49 & $-0,07$ & $-0,13$ \\
\hline kül_rövid_lejáratú_kölcsönök & $-0,02$ & $-0,11$ & $-0,20$ & $-0,71$ & 0,34 \\
\hline kül_rövid_lejáratú_hitelek & $-0,02$ & 0,92 & 0,03 & 0,02 & 0,02 \\
\hline kül_szállító & 0,81 & $-0,21$ & 0,07 & $-0,08$ & $-0,02$ \\
\hline kül_egyéb_rövid_lejáratú_kötelezettségek & 0,99 & $-0,06$ & 0,06 & 0,02 & 0,01 \\
\hline kül_törlesztés_hosszú_lejáratú_kölcsön & $-0,01$ & $-0,05$ & $-0,06$ & 0,01 & $-0,86$ \\
\hline kül_törlesztés_fejlesztési_célú_kötvénykibocsátás & 1,00 & $-0,05$ & 0,06 & $-0,01$ & 0,00 \\
\hline kül_törlesztés_beruházási_és_fejlesztési_hitel & 0,99 & $-0,09$ & 0,06 & $-0,02$ & $-0,01$ \\
\hline kül_törlesztés_müködési_célú_hosszú_lejáratú_hitelek & $-0,06$ & 0,04 & 0,81 & 0,07 & 0,19 \\
\hline kül_törlesztés_egyéb_hosszú_kötelezettség & 0,00 & $-0,14$ & $-0,24$ & 0,71 & 0,33 \\
\hline
\end{tabular}

\begin{tabular}{|l|r|r|}
\hline \multicolumn{3}{|c|}{ Kommunalitások } \\
\hline & Initial & Extraction \\
\hline támnftönk & 1,00 & 0,95 \\
\hline kül_hosszú_lejáratú_kölcsön & 1,00 & 1,00 \\
\hline kül_fejlesztési_célú_kötvénykibocsátás & 1,00 & 0,88 \\
\hline kül_müködési_célú_kötvénykibocsátás & 1,00 & 0,56 \\
\hline kül_beruházási_és_fejlesztési_hitelek & 1,00 & 0,98 \\
\hline kül_egyéb_hosszú_lejáratú_kötelezettségek & 1,00 & 0,30 \\
\hline kül_rövid_lejáratú_kölcsönök & 1,00 & 0,67 \\
\hline kül_rövid_lejáratú_hitelek & 1,00 & 0,85 \\
\hline kül_szállitó & 1,00 & 0,71 \\
\hline kül_egyéb_rövid_lejáratú_kötelezettségek & 1,00 & 0,99 \\
\hline kül_törlesztés_hosszú_lejáratú_kölcsön & 1,00 & 0,75 \\
\hline kül_törlesztés_fejlesztési_célú_kötvénykibocsátás & 1,00 & 1,00 \\
\hline kül_törlesztés_beruházási_és_fejlesztési_hitel & 1,00 & 0,99 \\
\hline kül_törlesztés_müköódésicélú_hosszú_lejáratú_hitelek & 1,00 & 0,70 \\
\hline kül_törlesztés_egyéb_hosszú_kötelezettség & 1,00 & 0,68 \\
\hline
\end{tabular}


c10) Fökomponens elemzés eredménye varimax rotációval Heves megye

\begin{tabular}{|l|r|r|r|r|}
\hline \multicolumn{1}{|c|}{ Változó megnevezése } & \multicolumn{4}{c|}{ Faktorok } \\
\cline { 2 - 5 } & \multicolumn{1}{|c|}{$\mathbf{1}$} & \multicolumn{1}{c|}{$\mathbf{2}$} & \multicolumn{1}{c|}{$\mathbf{3}$} & \multicolumn{1}{c|}{$\mathbf{4}$} \\
\hline támnftönk & 0,80 & $-0,08$ & 0,00 & $-0,05$ \\
\hline kül_hosszú_lejáratú_kölcsön & $-0,89$ & 0,23 & 0,36 & 0,01 \\
\hline kül_fejlesztési_célú_kötvénykibocsátás & $-0,11$ & 0,71 & $-0,06$ & $-0,06$ \\
\hline kül_beruházási_és_fejlesztési_hitelek & 0,97 & $-0,13$ & 0,01 & 0,01 \\
\hline kül_müködési_célú_hosszú_lejáratú_hitelek & $-0,01$ & $-0,01$ & 0,00 & 0,74 \\
\hline kül_egyéb_hosszú_lejáratú_kötelezettségek & 0,23 & 0,89 & 0,02 & $-0,02$ \\
\hline kül_rövid_lejáratú_hitelek & 0,93 & 0,34 & 0,01 & $-0,01$ \\
\hline kül_szállító & $-0,42$ & 0,45 & 0,04 & 0,09 \\
\hline kül_egyéb_rövid_lejáratú_kötelezettségek & 0,91 & 0,36 & 0,05 & $-0,01$ \\
\hline kül_törlesztés_hosszú_lejáratú_kölcsön & $-0,05$ & $-0,03$ & 1,00 & $-0,03$ \\
\hline kül_törlesztés_beruházási_és_fejlesztési_hitel & 0,91 & $-0,02$ & 0,02 & 0,02 \\
\hline kül_törlesztés_müködési_célú_hosszú_lejáratú_hitelek & $-0,02$ & $-0,02$ & $-0,02$ & 0,75 \\
\hline kül_törlesztés_egyéb_hosszú_kötelezettség & 0,07 & 0,94 & 0,03 & 0,00 \\
\hline
\end{tabular}

\begin{tabular}{|l|r|r|}
\hline \multicolumn{3}{|c|}{ Kommunalitás ok } \\
\hline \multicolumn{2}{|c|}{} \\
\hline támnftönk & Initial & Extraction \\
\hline kül_hosszú_lejáratú_kölcsön & 1,00 & 0,64 \\
\hline kül_fejlesztési_célú_kötvénykibocsátás & 1,00 & 0,99 \\
\hline kül_beruházási_és_fejlesztési_hitelek & 1,00 & 0,52 \\
\hline kül_müködési_célú_hosszú_lejáratú_hitelek & 1,00 & 0,96 \\
\hline kül_egyéb_hosszú_lejáratú_kötelezettségek & 1,00 & 0,55 \\
\hline kül_rövid_lejáratú_hitelek & 1,00 & 0,85 \\
\hline kül_szállító & 1,00 & 0,98 \\
\hline kül_egyéb_rövid_lejáratú_kötelezettségek & 1,00 & 0,39 \\
\hline kül_törlesztés_hosszú_lejáratú_kölcsön & 1,00 & 0,95 \\
\hline kül_törlesztés_beruházási_és_fejlesztési_hitel & 1,00 & 0,99 \\
\hline kül_törlesztés_müködési_célú_hosszú_lejáratú_hitelek & 1,00 & 0,84 \\
\hline kül_törlesztés_egyéb_hosszú_kötelezettség & 1,00 & 0,56 \\
\hline
\end{tabular}


c11) Fökomponens elemzés eredménye varimax rotációval Komárom-Esztergom megye

\begin{tabular}{|l|r|r|r|r|}
\hline \multicolumn{2}{|c|}{ Változó megnevezés e } & \multicolumn{4}{c|}{ Faktorok } \\
\cline { 2 - 5 } & \multicolumn{1}{|c|}{$\mathbf{1}$} & \multicolumn{1}{c|}{$\mathbf{2}$} & \multicolumn{1}{c|}{$\mathbf{3}$} & \multicolumn{1}{c|}{$\mathbf{4}$} \\
\hline támnftönk & 0,54 & 0,70 & $-0,06$ & 0,03 \\
\hline kül_hosszú_lejáratú_kölcsön & 0,02 & $-0,01$ & 0,83 & $-0,06$ \\
\hline kül_fejlesztési_célú_kötvénykibocsátás & 0,89 & 0,05 & $-0,02$ & 0,38 \\
\hline kül_beruházási_és_fejlesztési_hitelek & 0,51 & 0,85 & $-0,04$ & $-0,08$ \\
\hline kül_egyéb_hosszú_lejáratú_kötelezettségek & $-0,11$ & 0,98 & $-0,01$ & $-0,02$ \\
\hline kül_rövid_lejáratú_kölcsönök & $-0,04$ & $-0,05$ & $-0,04$ & 0,97 \\
\hline kül_rövid_lejáratú_hitelek & 0,97 & 0,08 & $-0,02$ & $-0,02$ \\
\hline kül_szállitó & 0,89 & 0,07 & $-0,01$ & $-0,37$ \\
\hline kül_egyéb_rövid_lejáratú_kötelezettségek & 0,31 & 0,91 & $-0,03$ & $-0,01$ \\
\hline kül_törlesztés_hosszú_lejáratú_kölcsön & $-0,07$ & $-0,05$ & 0,82 & 0,02 \\
\hline kül_törlesztés_fejlesztési_célú_kötvénykibocsátás & 0,99 & 0,07 & $-0,02$ & 0,00 \\
\hline kül_törlesztés_beruházási_és_fejlesztési_hitel & 0,80 & 0,52 & $-0,01$ & $-0,12$ \\
\hline kül_törlesztés_egyéb_hosszú_kötelezettség & $-0,11$ & 0,98 & $-0,01$ & $-0,02$ \\
\hline
\end{tabular}

\begin{tabular}{|l|r|r|}
\hline \multicolumn{3}{|c|}{ Kommunalitás ok } \\
\hline \multicolumn{3}{|c|}{} \\
\hline támnftönk & \multicolumn{1}{|c|}{ Initial } & Extraction \\
\hline kül_hosszú_lejáratú_kölcsön & 1,00 & 0,79 \\
\hline kül_fejlesztési_célú_kötvénykibocsátás & 1,00 & 0,69 \\
\hline kül_beruházási_és_fejlesztési_hitelek & 1,00 & 0,94 \\
\hline kül_egyéb_hosszú_lejáratú_kötelezettségek & 1,00 & 0,98 \\
\hline kül_rövid_lejáratú_kölcsönök & 1,00 & 0,98 \\
\hline kül_rövid_lejáratú_hitelek & 1,00 & 0,95 \\
\hline kül_szállító & 1,00 & 0,95 \\
\hline kül_egyéb_rövid_lejáratú_kötelezettségek & 1,00 & 0,94 \\
\hline kül_törlesztés_hosszú_lejáratú_kölcsön & 1,00 & 0,92 \\
\hline kül_törlesztés_fejlesztési_célú_kötvénykibocsátás & 1,00 & 0,68 \\
\hline kül_törlesztés_beruházási_és_fejlesztési_hitel & 1,00 & 0,98 \\
\hline kül_törlesztés_egyéb_hosszú_kötelezettség & 1,00 & 0,93 \\
\hline
\end{tabular}


c12) Fökomponens elemzés eredménye varimax rotációval Nógrád megye

\begin{tabular}{|l|r|r|r|r|}
\hline \multicolumn{1}{|c|}{ Változó megnevezése } & \multicolumn{4}{c|}{ Faktorok } \\
\cline { 2 - 5 } & \multicolumn{1}{|c|}{$\mathbf{1}$} & \multicolumn{1}{c|}{$\mathbf{2}$} & \multicolumn{1}{c|}{$\mathbf{3}$} & \multicolumn{1}{c|}{$\mathbf{4}$} \\
\hline támnftönk & 0,34 & 0,10 & $-0,15$ & 0,88 \\
\hline kül_hosszú_lejáratú_kölcsön & 0,03 & 0,04 & 0,32 & $-0,06$ \\
\hline kül_fejlesztési_célú_kötvénykibocsátás & $-0,11$ & 0,19 & 0,16 & 0,01 \\
\hline kül_müködési_célú_köttvénykibocsátás & 0,01 & 0,99 & 0,01 & $-0,06$ \\
\hline kül_beruházási_és_fejlesztési_hitelek & 0,82 & $-0,07$ & 0,36 & 0,19 \\
\hline kül_müködési_célú_hosszú_lejáratú_hitelek & 0,01 & 0,99 & 0,01 & $-0,06$ \\
\hline kül_egyéb_hosszú_lejáratú_kötelezettségek & $-0,41$ & $-0,02$ & $-0,85$ & 0,00 \\
\hline kül_rövid_lejáratú_kölcsönök & $-0,81$ & $-0,02$ & 0,18 & $-0,22$ \\
\hline kül_rövid_lejáratú_hitelek & 0,26 & $-0,47$ & 0,13 & 0,77 \\
\hline kül_szállító & $-0,17$ & $-0,10$ & 0,78 & 0,51 \\
\hline kül_egyéb_rövid_lejáratú_kötelezettségek & 0,35 & 0,04 & 0,90 & $-0,04$ \\
\hline kül_törlesztés_beruházási_és_fejlesztési_hitel & 0,87 & 0,00 & 0,46 & $-0,07$ \\
\hline kül_törlesztés_müködési_célú_hosszú_lejáratú_hitelek & 0,01 & 0,99 & 0,01 & $-0,06$ \\
\hline kül_törlesztés_egyéb_hosszú_kötelezettség & 0,88 & $-0,08$ & 0,19 & 0,25 \\
\hline
\end{tabular}

\begin{tabular}{|l|r|r|}
\hline \multicolumn{3}{|c|}{ Kommunalitás ok } \\
\hline & Initial & Extraction \\
\hline támnftönk & 1,00 & 0,93 \\
\hline kül_hosszú_lejáratú_kölcsön & 1,00 & 0,11 \\
\hline kül_fejlesztési_célú_kötvénykibocsátás & 1,00 & 0,07 \\
\hline kül_müködési_célú_kötvénykibocsátás & 1,00 & 0,99 \\
\hline kül_beruházási_és_fejlesztési_hitelek & 1,00 & 0,84 \\
\hline kül_müködési_célú_hosszú_lejáratú_hitelek & 1,00 & 0,99 \\
\hline kül_egyéb_hosszú_lejáratú_kötelezettségek & 1,00 & 0,90 \\
\hline kül_rövid_lejáratú_kölcsönök & 1,00 & 0,74 \\
\hline kül_rövid_lejáratú_hitelek & 1,00 & 0,90 \\
\hline kül_szállító & 1,00 & 0,90 \\
\hline kül_egyéb_rövid_lejáratúdkötelezettségek & 1,00 & 0,94 \\
\hline kül_törlesztés_beruházási_és_fejlesztési_hitel & 1,00 & 0,97 \\
\hline kül_törlesztés_müködési_célú_hosszú_lejáratú_hitelek & 1,00 & 0,99 \\
\hline kül_törlesztés_egyéb_hosszú_kötelezettség & 1,00 & 0,88 \\
\hline
\end{tabular}


c13) Fökomponens elemzés eredménye varimax rotációval Pest megye

\begin{tabular}{|c|c|c|c|c|c|c|}
\hline \multirow{2}{*}{ Változó megnevezése } & \multicolumn{6}{|c|}{ Faktorok } \\
\hline & 1 & 2 & 3 & 4 & 5 & 6 \\
\hline támnftönk & 0,03 & 0,03 & 0,00 & $-0,01$ & 0,76 & 0,32 \\
\hline kül_hosszú_lejáratú_kölcsön & 0,77 & $-0,03$ & 0,04 & $-0,41$ & 0,16 & $-0,18$ \\
\hline kül_fejlesztési_célú_kötvénykibocsátás & 0,01 & $-0,27$ & 0,62 & 0,20 & 0,52 & 0,05 \\
\hline kül_müködési_célú_kötvénykibocsátás & 0,24 & 0,04 & $-0,03$ & $-0,02$ & $-0,05$ & 0,73 \\
\hline kül_beruházási_és_fejlesztési_hitelek & $-0,87$ & 0,02 & 0,05 & 0,26 & $-0,02$ & $-0,01$ \\
\hline kül_müködési_célú_hosszú_lejáratú_hitelek & 0,01 & 0,03 & 0,17 & 0,09 & 0,71 & $-0,21$ \\
\hline kül_egyéb_hosszú_lejáratú_kötelezettségek & $-0,16$ & 0,06 & 0,91 & $-0,16$ & $-0,09$ & 0,03 \\
\hline kül_rövid_lejáratú_kölcsönök & 0,06 & 0,99 & $-0,02$ & 0,10 & 0,01 & $-0,01$ \\
\hline kül_rövid_lejáratú_hitelek & 0,59 & $-0,11$ & 0,24 & 0,53 & $-0,20$ & 0,13 \\
\hline kül_szállító & 0,76 & 0,19 & $-0,01$ & 0,09 & $-0,01$ & 0,14 \\
\hline kül_egyéb_rövid_lejáratú_kötelezettségek & $-0,17$ & 0,29 & $-0,07$ & 0,89 & 0,11 & 0,08 \\
\hline kül_törlesztés_hosszú_lejáratú_kölcsön & $-0,05$ & $-0,99$ & 0,02 & $-0,10$ & 0,00 & 0,00 \\
\hline kül_törlesztés_beruházási_és_fejlesztési_hitel & $-0,27$ & 0,00 & $-0,31$ & 0,66 & 0,16 & $-0,27$ \\
\hline kül_törlesztés_müködési_célú_hosszú_lejáratú_hitelek & 0,11 & 0,04 & 0,00 & 0,00 & $-0,07$ & $-0,54$ \\
\hline kül_törlesztés_egyéb_hosszú_kötelezettség & 0,20 & $-0,02$ & 0,81 & $-0,09$ & 0,28 & $-0,10$ \\
\hline
\end{tabular}

\begin{tabular}{|l|r|r|}
\hline \multicolumn{3}{|c|}{ Kommunalitások } \\
\hline & Initial & Extraction \\
\hline támnftönk & 1,00 & 0,68 \\
\hline kül_hosszú_lejáratú_kölcsön & 1,00 & 0,83 \\
\hline kül_fejlesztési_célú_kötvénykibocsátás & 1,00 & 0,77 \\
\hline kül_müködési_célú_kötvénykibocsátás & 1,00 & 0,60 \\
\hline kül_beruházási_és_fejlesztési_hitelek & 1,00 & 0,83 \\
\hline kül_müködési_célú _hosszú_lejáratú_hitelek & 1,00 & 0,58 \\
\hline kül_egyéb_hosszú_lejáratú_kötelezettségek & 1,00 & 0,89 \\
\hline kül_rövid_lejáratú_kölcsönök & 1,00 & 0,99 \\
\hline kül_rövid_lejáratú_hitelek & 1,00 & 0,76 \\
\hline kül_szállító & 1,00 & 0,64 \\
\hline kül_egyéb_rövid_lejáratú_kötelezettségek & 1,00 & 0,92 \\
\hline kül_törlesztés_hosszú_lejáratú_kölcsön & 1,00 & 0,99 \\
\hline kül_törlesztés_beruházási_és_fejlesztési_hitel & 1,00 & 0,70 \\
\hline kül_törlesztés_múködési_célú_hosszú_lejáratú_hitelek & 1,00 & 0,31 \\
\hline kül_törlesztés_egyéb_hosszú_kötelezettség & 1,00 & 0,80 \\
\hline
\end{tabular}


c14) Fökomponens elemzés eredménye varimax rotációval Somogy megye

\begin{tabular}{|c|c|c|c|c|c|}
\hline \multirow{2}{*}{ Változó megnevezése } & \multicolumn{5}{|c|}{ Faktorok } \\
\hline & 1 & 2 & 3 & 4 & 5 \\
\hline támnftönk & 0,93 & $-0,02$ & 0,31 & $-0,08$ & $-0,06$ \\
\hline kül_hosszú_lejáratú_kölcsön & 0,02 & 0,02 & $-0,17$ & $-0,07$ & 0,54 \\
\hline kül_fejlesztési_célú_kötvénykibocsátás & 0,97 & $-0,01$ & 0,01 & 0,07 & $-0,13$ \\
\hline kül_müködési_célú_kötvénykibocsátás & 0,80 & $-0,02$ & 0,08 & 0,49 & 0,15 \\
\hline kül_beruházási_és_fejlesztési_hitelek & 0,98 & $-0,01$ & $-0,04$ & $-0,02$ & 0,02 \\
\hline kül_müködési_célú_hosszú_lejáratú_hitelek & $-0,01$ & 1,00 & $-0,01$ & 0,00 & 0,02 \\
\hline kül_egyéb_hosszú_lejáratú_kötelezettségek & 0,97 & $-0,01$ & $-0,20$ & 0,03 & $-0,05$ \\
\hline kül_rövid_lejáratú_kölcsönök & $-0,01$ & 0,01 & $-0,63$ & $-0,13$ & 0,26 \\
\hline kül_rövid_lejáratú_hitelek & $-0,03$ & 0,00 & $-0,12$ & 0,96 & 0,04 \\
\hline kül_szállító & 0,01 & 0,01 & $-0,09$ & 0,19 & 0,76 \\
\hline kül_egyéb_rövid_lejáratú_kötelezettségek & 0,84 & 0,02 & 0,34 & $-0,22$ & 0,22 \\
\hline kül_törlesztés_fejlesztési_célú_kötvénykibocsátás & 0,15 & 0,00 & 0,76 & $-0,29$ & $-0,26$ \\
\hline kül_törlesztés_beruházási_és_fejlesztési_hitel & $-0,43$ & 0,00 & 0,63 & $-0,29$ & 0,44 \\
\hline kül_törlesztés_müködési_célú_hosszú_lejáratú_hitelek & $-0,01$ & 1,00 & $-0,01$ & 0,00 & 0,02 \\
\hline kül_törlesztés_egyéb_hosszú_kötelezettség & 0,94 & $-0,01$ & $-0,24$ & $-0,01$ & $-0,04$ \\
\hline
\end{tabular}

\begin{tabular}{|l|r|r|}
\hline \multicolumn{3}{|c|}{ Kommunalitás ok } \\
\hline \multicolumn{2}{|c|}{} \\
\hline támnftönk & Initial & Extraction \\
\hline kül_hosszú_lejáratú_kölcsön & 1,00 & 0,96 \\
\hline kül_fejlesztési_célú_kötvénykibocsátás & 1,00 & 0,32 \\
\hline kül_müködési_célú_kötvénykibocsátás & 1,00 & 0,96 \\
\hline kül_beruházási_és_fejlesztési_hitelek & 1,00 & 0,92 \\
\hline kül_müködési_célú_hosszú_lejáratú_hitelek & 1,00 & 0,97 \\
\hline kül_egyéb_hosszú_lejáratú_kötelezettségek & 1,00 & 1,00 \\
\hline kül_rövid_lejáratú_kölcsönök & 1,00 & 0,98 \\
\hline kül_rövid_lejáratú_hitelek & 1,00 & 0,48 \\
\hline kül_szállitó & 1,00 & 0,94 \\
\hline kül_egyéb_rövid_lejáratú_kötelezettségek & 1,00 & 0,62 \\
\hline kül_törlesztés_fejlesztési_célú_kötvénykibocsátás & 1,00 & 0,92 \\
\hline kül_törlesztés_beruházási_és_fejlesztési_hitel & 1,00 & 0,75 \\
\hline kül_törlesztés_müködési_célú_hosszú_lejáratú_hitelek & 1,00 & 0,85 \\
\hline kül_törlesztés_egyéb_hosszú_kötelezettség & 1,00 & 1,00 \\
\hline
\end{tabular}


c15) Fökomponens elemzés eredménye varimax rotációval Szabolcs-Szatmár-Bereg megye

\begin{tabular}{|l|r|r|r|r|r|}
\hline \multicolumn{1}{|c|}{ Változó megnevezés e } & \multicolumn{5}{c|}{ Faktorok } \\
\cline { 2 - 6 } & \multicolumn{1}{|c|}{$\mathbf{1}$} & \multicolumn{1}{c|}{$\mathbf{2}$} & \multicolumn{1}{c|}{$\mathbf{4}$} & \multicolumn{1}{c|}{$\mathbf{5}$} \\
\hline támnftönk & 0,94 & 0,10 & $-0,01$ & 0,14 & 0,01 \\
\hline kül_hosszú_lejáratú_kölcsön & 0,10 & 0,02 & $-0,09$ & $-0,32$ & 0,76 \\
\hline kül_fejlesztési_célú_kötvénykibocsátás & 0,95 & 0,04 & 0,03 & 0,16 & $-0,01$ \\
\hline kül_müködési_célú_kötvénykibocsátás & 0,05 & $-0,02$ & $-0,79$ & $-0,10$ & 0,02 \\
\hline kül_beruházási_és_fejlesztési_hitelek & $-0,37$ & 0,16 & 0,09 & $-0,57$ & 0,06 \\
\hline kül_müködési_célú_hosszú_lejáratú_hitelek & $-0,03$ & 0,98 & $-0,07$ & 0,04 & $-0,01$ \\
\hline kül_egyéb_hosszú_lejáratú_kötelezettségek & 0,17 & 0,10 & $-0,01$ & 0,62 & $-0,05$ \\
\hline kül_rövid_lejáratú_kölcsönök & $-0,12$ & $-0,02$ & 0,11 & 0,48 & 0,66 \\
\hline kül_rövid_lejáratú_hitelek & 0,95 & 0,07 & 0,02 & 0,17 & 0,00 \\
\hline kül_szállító & 0,93 & 0,08 & 0,08 & 0,13 & 0,00 \\
\hline kül_egyéb_rövid_lejáratú_kötelezettségek & 0,38 & 0,77 & 0,20 & $-0,09$ & 0,02 \\
\hline kül_törlesztés_beruházási_és_fejlesztési_hitel & 0,15 & $-0,01$ & 0,82 & $-0,16$ & 0,01 \\
\hline kül_törlesztés_müköddési_célú_hosszú_lejáratú_hitelek & $-0,03$ & 0,97 & $-0,05$ & 0,03 & 0,00 \\
\hline kül_törlesztés_egyéb_hosszú_kötelezettség & 0,94 & 0,00 & 0,03 & 0,02 & 0,02 \\
\hline
\end{tabular}

\begin{tabular}{|l|r|r|}
\hline \multicolumn{3}{|c|}{ Kommunalitás ok } \\
\hline \multicolumn{3}{|c|}{} \\
\hline támnftönk & Initial & Extraction \\
\hline kül_hosszú_lejáratú_kölcsön & 1,00 & 0,91 \\
\hline kül_fejlesztési_célú_kötvénykibocsátás & 1,00 & 0,71 \\
\hline kül_müködési_célú_kötvénykibocsátás & 1,00 & 0,94 \\
\hline kül_beruházási_és_fejlesztési_hitelek & 1,00 & 0,63 \\
\hline kül_müködési_célú_hosszú_lejáratú_hitelek & 1,00 & 0,50 \\
\hline kül_egyéb_hosszú_lejáratú_kötelezettségek & 1,00 & 0,96 \\
\hline kül_rövid_lejáratú_kölcsönök & 1,00 & 0,43 \\
\hline kül_rövid_lejáratú_hitelek & 1,00 & 0,69 \\
\hline kül_szállitó & 1,00 & 0,93 \\
\hline kül_egyéb_rövid_lejáratú_kötelezettségek & 1,00 & 0,89 \\
\hline kül_törlesztés_beruházási_és_fejlesztési_hitel & 1,00 & 0,78 \\
\hline kül_törlesztés_müködési_célú_hosszú_lejáratú_hitelek & 1,00 & 0,72 \\
\hline kül_törlesztés_egyéb_hosszú_kötelezettség & 1,00 & 0,95 \\
\hline
\end{tabular}


c16) Fökomponens elemzés eredménye varimax rotációval Jász-Nagykun-Szolnok megye

\begin{tabular}{|l|r|r|r|r|}
\hline \multicolumn{2}{|c|}{ Változó megnevezése } & \multicolumn{4}{c|}{ Faktorok } \\
\cline { 2 - 5 } & \multicolumn{1}{c|}{$\mathbf{1}$} & \multicolumn{1}{c|}{$\mathbf{2}$} & \multicolumn{1}{c|}{$\mathbf{3}$} & \multicolumn{1}{c|}{$\mathbf{4}$} \\
\hline támnftönk & 0,94 & $-0,07$ & 0,07 & $-0,05$ \\
\hline kül_hosszú_lejáratú_kölcsön & $-0,97$ & 0,13 & $-0,01$ & $-0,01$ \\
\hline kül_fejlesztési_célú_kötvénykibocsátás & 0,94 & 0,09 & 0,17 & $-0,02$ \\
\hline kül_müködési_célú_kötvénykibocsátás & 0,03 & 0,87 & 0,04 & $-0,03$ \\
\hline kül_beruházási_és_fejlesztési_hitelek & 0,71 & 0,01 & 0,16 & $-0,10$ \\
\hline kül_müködési_célú_hosszú_lejáratú_hitelek & $-0,03$ & 0,01 & 0,10 & 0,80 \\
\hline kül_egyéb_hosszú_lejáratú_kötelezettségek & $-0,05$ & $-0,62$ & 0,04 & $-0,06$ \\
\hline kül_rövid_lejáratú_kölcsönök & 0,00 & 0,08 & 0,92 & 0,01 \\
\hline kül_rövid_lejáratú_hitelek & 0,34 & $-0,85$ & $-0,08$ & 0,12 \\
\hline kül_szállító & 0,65 & $-0,21$ & 0,66 & $-0,18$ \\
\hline kül_egyéb_rövid_lejáratú_kötelezettségek & 0,78 & 0,34 & $-0,17$ & $-0,04$ \\
\hline kül_törlesztés_fejlesztési_célú_kötvénykibocsátás & 0,97 & $-0,13$ & 0,01 & 0,01 \\
\hline kül_törlesztés_beruházási_és_fejlesztési_hitel & 0,54 & 0,45 & $-0,26$ & $-0,06$ \\
\hline kül_törlesztés_müködési_célú_hosszú_lejáratú_hitelek & $-0,04$ & $-0,05$ & $-0,15$ & 0,81 \\
\hline kül_törlesztés_egyéb_hosszú_kötelezettség & $-0,90$ & 0,11 & 0,00 & $-0,04$ \\
\hline
\end{tabular}

\begin{tabular}{|l|r|r|}
\hline \multicolumn{3}{|c|}{ Kommunalitás ok } \\
\hline & Initial & Extraction \\
\hline támnftönk & 1,00 & 0,90 \\
\hline kül_hosszú_lejáratú_kölcsön & 1,00 & 0,96 \\
\hline kül_fejlesztési_célú_kötvénykibocsátás & 1,00 & 0,92 \\
\hline kül_müködési_célú_kötvénykibocsátás & 1,00 & 0,75 \\
\hline kül_beruházási_és_fejlesztési_hitelek & 1,00 & 0,55 \\
\hline kül_müködési_célú_hosszú_lejáratú_hitelek & 1,00 & 0,64 \\
\hline kül_egyéb_hosszú_lejáratú_kötelezettségek & 1,00 & 0,39 \\
\hline kül_rövid_lejáratú_kölcsönök & 1,00 & 0,84 \\
\hline kül_rövid_lejáratú_hitelek & 1,00 & 0,85 \\
\hline kül_szállító & 1,00 & 0,94 \\
\hline kül_egyéb_rövid_lejáratú_kötelezettségek & 1,00 & 0,75 \\
\hline kül_törlesztés_fejlesztési_célú_kötvénykibocsátás & 1,00 & 0,96 \\
\hline kül_törlesztés_beruházási_és_fejlesztési_hitel & 1,00 & 0,57 \\
\hline kül_törlesztés_müködési_célú_hosszú_lejáratú_hitelek & 1,00 & 0,68 \\
\hline kül_törlesztés_egyéb_hosszú_kötelezettség & 1,00 & 0,82 \\
\hline
\end{tabular}


c17) Fökomponens elemzés eredménye varimax rotációval Tolna megye

\begin{tabular}{|l|r|r|r|r|r|r|}
\hline \multirow{2}{*}{\multicolumn{1}{c|}{ Változó megnevezése }} & \multicolumn{7}{c|}{ Faktorok } \\
\cline { 2 - 7 } & \multicolumn{1}{|c|}{$\mathbf{1}$} & \multicolumn{1}{c|}{$\mathbf{2}$} & $\mathbf{3}$ & \multicolumn{1}{c|}{$\mathbf{5}$} & \multicolumn{1}{c|}{$\mathbf{5}$} & \multicolumn{1}{c|}{$\mathbf{6}$} \\
\hline támnftönk & 0,86 & 0,06 & 0,08 & 0,11 & 0,06 & 0,06 \\
\hline kül_hosszú_lejáratú_kölcsön & 0,07 & 0,07 & 0,11 & $-0,27$ & 0,19 & 0,52 \\
\hline kül_fejlesztési_célú_kötvénykibocsátás & 0,55 & 0,69 & $-0,05$ & 0,14 & 0,41 & 0,05 \\
\hline kül_müködési_célú_kötvénykibocsátás & 0,94 & 0,00 & $-0,04$ & 0,18 & 0,02 & 0,07 \\
\hline kül_beruházási_és_fejlesztési_hitelek & 0,06 & $-0,12$ & $-0,08$ & $-0,06$ & $-0,38$ & 0,69 \\
\hline kül_müködési_célú_hosszú_lejáratú_hitelek & 0,00 & $-0,01$ & 0,99 & 0,04 & $-0,01$ & $-0,02$ \\
\hline kül_egyéb_hosszú_lejáratú_kötelezettségek & 0,17 & 0,11 & 0,06 & 0,91 & 0,03 & 0,01 \\
\hline kül_rövid_lejáratú_kölcsönök & $-0,08$ & 0,01 & $-0,03$ & 0,06 & 0,94 & 0,02 \\
\hline kül_rövid_lejáratú_hitelek & $-0,92$ & $-0,01$ & 0,06 & $-0,16$ & 0,27 & $-0,08$ \\
\hline kül_szállító & 0,26 & $-0,95$ & 0,01 & $-0,08$ & 0,00 & $-0,04$ \\
\hline kül_egyéb_rövid_lejáratú_kötelezettségek & 0,22 & 0,94 & 0,01 & 0,08 & $-0,06$ & $-0,05$ \\
\hline kül_törlesztés_beruházási_és_fejlesztési_hitel & $-0,08$ & $-0,06$ & 0,10 & $-0,40$ & $-0,13$ & $-0,69$ \\
\hline kül_törlesztés_müködési_célú_hosszú_lejáratú_hitelek & 0,00 & $-0,01$ & 0,99 & 0,04 & $-0,01$ & $-0,02$ \\
\hline kül_törlesztés_egyéb_hosszú_kötelezettség & 0,24 & 0,10 & 0,05 & 0,90 & 0,06 & $-0,04$ \\
\hline
\end{tabular}

\begin{tabular}{|l|r|r|}
\hline \multicolumn{3}{|c|}{ Kommunalitás ok } \\
\hline \multicolumn{3}{|c|}{} \\
\hline támnftönk & Initial & Extraction \\
\hline kül_hosszú_lejáratú_kölcsön & 1,00 & 0,76 \\
\hline kül_fejlesztési_célú_kötvénykibocsátás & 1,00 & 0,40 \\
\hline kül_müködési_célú_kötvénykibocsátás & 1,00 & 0,97 \\
\hline kül_beruházási_és_fejlesztési_hitelek & 1,00 & 0,93 \\
\hline kül_müködési_célú_hosszú_lejáratú _hitelek & 1,00 & 0,64 \\
\hline kül_egyéb_hosszú_lejáratú_kötelezettségek & 1,00 & 0,99 \\
\hline kül_rövid_lejáratú_kölcsönök & 1,00 & 0,88 \\
\hline kül_rövid_lejáratú_hitelek & 1,00 & 0,91 \\
\hline kül_szállító & 1,00 & 0,94 \\
\hline kül_egyéb_rövid_lejáratú_kötelezettségek & 1,00 & 0,98 \\
\hline kül_törlesztés_beruházási_és_fejlesztési_hitel & 1,00 & 0,95 \\
\hline kül_törlesztés_müködési_célú_hosszú_lejáratú_hitelek & 1,00 & 0,68 \\
\hline kül_törlesztés_egyéb_hosszú_kötelezettség & 1,00 & 0,99 \\
\hline
\end{tabular}


c18) Fökomponens elemzés eredménye varimax rotációval Vas megye

\begin{tabular}{|l|r|r|r|r|}
\hline \multicolumn{1}{|c|}{ Válttozó megnevezése } & \multicolumn{4}{c|}{ Faktorok } \\
\cline { 2 - 5 } & \multicolumn{1}{c|}{$\mathbf{1}$} & \multicolumn{1}{c|}{$\mathbf{2}$} & \multicolumn{1}{c|}{$\mathbf{3}$} & \multicolumn{1}{c|}{$\mathbf{4}$} \\
\hline támnftönk & 0,94 & $-0,01$ & 0,19 & $-0,03$ \\
\hline kül_hosszú_lejáratú_kölcsön & 0,01 & 0,01 & 0,01 & 1,00 \\
\hline kül_fejlesztési_célú_kötvénykibocsátás & 0,00 & 1,00 & $-0,05$ & 0,01 \\
\hline kül_beruházási_és_fejlesztési_hitelek & 0,99 & $-0,02$ & $-0,02$ & 0,03 \\
\hline kül_egyéb_hosszú_lejáratú_kötelezettségek & 0,04 & $-0,02$ & 0,87 & $-0,02$ \\
\hline kül_rövid_lejáratú_hitelek & $-0,02$ & 0,01 & 0,86 & 0,03 \\
\hline kül_szállító & $-0,91$ & $-0,32$ & 0,08 & $-0,04$ \\
\hline kül_egyéb_rövid_lejáratú_kötelezettségek & 0,96 & $-0,20$ & $-0,04$ & 0,04 \\
\hline kül_törlesztés_beruházási_és_fejlesztési_hitel & 0,99 & $-0,02$ & $-0,01$ & $-0,04$ \\
\hline kül_törlesztés_egyéb_hosszú_kötelezettség & 0,00 & 0,99 & 0,04 & 0,01 \\
\hline
\end{tabular}

\begin{tabular}{|l|r|r|}
\hline \multicolumn{3}{|c|}{ Kommunalitás ok } \\
\hline & Initial & Extraction \\
\hline támnftönk & 1,00 & 0,92 \\
\hline kül_hosszú_lejáratú_kölcsön & 1,00 & 1,00 \\
\hline kül_fejlesztési_célú_kötvénykibocsátás & 1,00 & 0,99 \\
\hline kül_beruházási_és_fejlesztési_hitelek & 1,00 & 0,99 \\
\hline kül_egyéb_hosszú_lejáratú_kötelezettségek & 1,00 & 0,76 \\
\hline kül_rövid_lejáratú_hitelek & 1,00 & 0,75 \\
\hline kül_szállító & 1,00 & 0,93 \\
\hline kül_egyéb_rövid_lejáratú_kötelezettségek & 1,00 & 0,97 \\
\hline kül_törlesztés_beruházási_és_fejlesztési_hitel & 1,00 & 0,99 \\
\hline kül_törlesztés_egyéb_hosszú_kötelezettség & 1,00 & 0,99 \\
\hline
\end{tabular}


c19) Fökomponens elemzés eredménye varimax rotációval Veszprém megye

\begin{tabular}{|l|r|r|r|r|}
\hline \multirow{2}{*}{ Változó megnevezés e } & \multicolumn{4}{c|}{ Faktorok } \\
\cline { 2 - 5 } & \multicolumn{1}{|c|}{$\mathbf{1}$} & \multicolumn{1}{c|}{$\mathbf{2}$} & \multicolumn{1}{c|}{$\mathbf{3}$} & \multicolumn{1}{c|}{$\mathbf{4}$} \\
\hline támnftönk & 0,89 & 0,05 & 0,14 & 0,06 \\
\hline kül_hosszú_lejáratú_kölcsön & $-0,19$ & 0,06 & $-0,97$ & $-0,03$ \\
\hline kül_fejlesztési_célú_kötvénykibocsátás & 0,10 & $-0,21$ & 0,23 & 0,68 \\
\hline kül_beruházási_és_fejlesztési_hitelek & 0,94 & 0,13 & 0,03 & 0,07 \\
\hline kül_egyéb_hosszú_lejáratú_kötelezettségek & $-0,76$ & 0,57 & $-0,09$ & 0,09 \\
\hline kül_rövid_lejáratú_hitelek & 0,92 & $-0,10$ & 0,12 & $-0,14$ \\
\hline kül_szállitó & 0,18 & 0,46 & $-0,02$ & 0,84 \\
\hline kül_egyéb_rövid_lejáratú_kötelezettségek & 0,21 & 0,96 & 0,12 & $-0,08$ \\
\hline kül_törlesztés_hosszú_lejáratú_kölcsön & 0,04 & $-0,05$ & 0,99 & 0,04 \\
\hline kül_törlesztés_beruházási_és_fejlesztési_hitel & 0,35 & 0,06 & 0,14 & $-0,82$ \\
\hline kül_törlesztés_egyéb_hosszú_kötelezettség & $-0,28$ & 0,91 & $-0,29$ & 0,05 \\
\hline
\end{tabular}

\begin{tabular}{|l|r|r|}
\hline \multicolumn{3}{|c|}{ Kommunalitás ok } \\
\hline & Initial & Extraction \\
\hline támnftönk & 1,00 & 0,82 \\
\hline kül_hosszú_lejáratú_kölcsön & 1,00 & 0,99 \\
\hline kül_fejlesztési_célú_kötvénykibocsátás & 1,00 & 0,58 \\
\hline kül_beruházási_és_fejlesztési_hitelek & 1,00 & 0,91 \\
\hline kül_egyéb_hosszú_lejáratú_kötelezettségek & 1,00 & 0,92 \\
\hline kül_rövid_lejáratú_hitelek & 1,00 & 0,90 \\
\hline kül_szállító & 1,00 & 0,95 \\
\hline kül_egyéb_rövid_lejáratú_kötelezettségek & 1,00 & 0,99 \\
\hline kül_törlesztés_hosszú_lejáratú_kölcsön & 1,00 & 0,99 \\
\hline kül_törlesztés_beruházási_és_fejlesztési_hitel & 1,00 & 0,82 \\
\hline kül_törlesztés_egyéb_hosszú_kötelezettség & 1,00 & 0,99 \\
\hline
\end{tabular}


c20) Fökomponens elemzés eredménye varimax rotációval Zala megye

\begin{tabular}{|l|r|r|r|r|}
\hline \multicolumn{1}{|c|}{ Változó megnevezése } & \multicolumn{4}{c|}{ Faktorok } \\
\cline { 2 - 5 } & \multicolumn{1}{|c|}{$\mathbf{1}$} & \multicolumn{1}{c|}{$\mathbf{2}$} & \multicolumn{1}{c|}{$\mathbf{3}$} & \multicolumn{1}{c|}{$\mathbf{4}$} \\
\hline támnftönk & 0,69 & $-0,08$ & 0,63 & 0,06 \\
\hline kül_fejlesztési_célú_kötvénykibocsátás & 0,03 & 0,95 & 0,00 & 0,03 \\
\hline kül_beruházási_és_fejlesztési_hitelek & 0,45 & $-0,11$ & 0,82 & 0,05 \\
\hline kül_müködési_célú_hosszú_lejáratú_hitelek & 0,99 & $-0,01$ & 0,01 & 0,00 \\
\hline kül_egyéb_hosszú_lejáratú_kötelezettségek & 0,85 & 0,00 & $-0,02$ & $-0,01$ \\
\hline kül_rövid_lejáratú_kölcsönök & 0,00 & 0,01 & $-0,01$ & 1,00 \\
\hline kül_rövid_lejáratú_hitelek & $-0,02$ & 0,96 & $-0,06$ & $-0,02$ \\
\hline kül_szállító & $-0,25$ & 0,03 & 0,68 & $-0,06$ \\
\hline kül_egyéb_rövid_lejáratú_kötelezettségek & 0,99 & 0,01 & 0,14 & 0,01 \\
\hline kül_törlesztés_hosszú_lejáratú_kölcsön & 0,99 & $-0,01$ & 0,01 & 0,00 \\
\hline kül_törlesztés_beruházási_és_fejlesztési_hitel & 0,90 & 0,06 & 0,37 & 0,03 \\
\hline kül_törlesztés_müködési_célú_hosszú_lejáratú_hitelek & 0,99 & $-0,01$ & 0,01 & 0,00 \\
\hline kül_törlesztés_egyéb_hosszú_kötelezettség & 0,99 & $-0,01$ & 0,01 & 0,00 \\
\hline
\end{tabular}

\begin{tabular}{|l|r|r|}
\hline \multicolumn{3}{|c|}{ Kommunalitások } \\
\hline & \multicolumn{2}{|c|}{} \\
\hline támnitial & Extraction \\
\hline kül_fejlesztési_célú_kötvénykibocsátás & 1,00 & 0,88 \\
\hline kül_beruházási_és_fejlesztési_hitelek & 1,00 & 0,90 \\
\hline kül_müködési_célú_hosszú_lejáratú_hitelek & 1,00 & 0,90 \\
\hline kül_egyéb_hosszúlejáratú_kötelezettségek & 1,00 & 0,98 \\
\hline kül_rövid_lejáratú_kölcsönök & 1,00 & 0,72 \\
\hline kül_rövid_lejáratú_hitelek & 1,00 & 0,99 \\
\hline kül_szállító & 1,00 & 0,94 \\
\hline kül_egyéb_rövid_lejáratú_kötelezettségek & 1,00 & 0,52 \\
\hline kül_törlesztés_hosszú_lejáratú_kölcsön & 1,00 & 0,99 \\
\hline kül_törlesztés_beruházási_és_fejlesztési_hitel & 1,00 & 0,98 \\
\hline kül_törlesztés_müködési_célú_hosszúllejáratú_hitelek & 1,00 & 0,95 \\
\hline kül_törlesztés_egyéb_hosszú_kötelezettség & 1,00 & 0,98 \\
\hline
\end{tabular}




\section{a) Klaszteranalízis}

d1) Klaszteranalizis országos szinten

Dendrogram using Average Linkage (Between Groups)

Rescaled Distance Cluster Combine

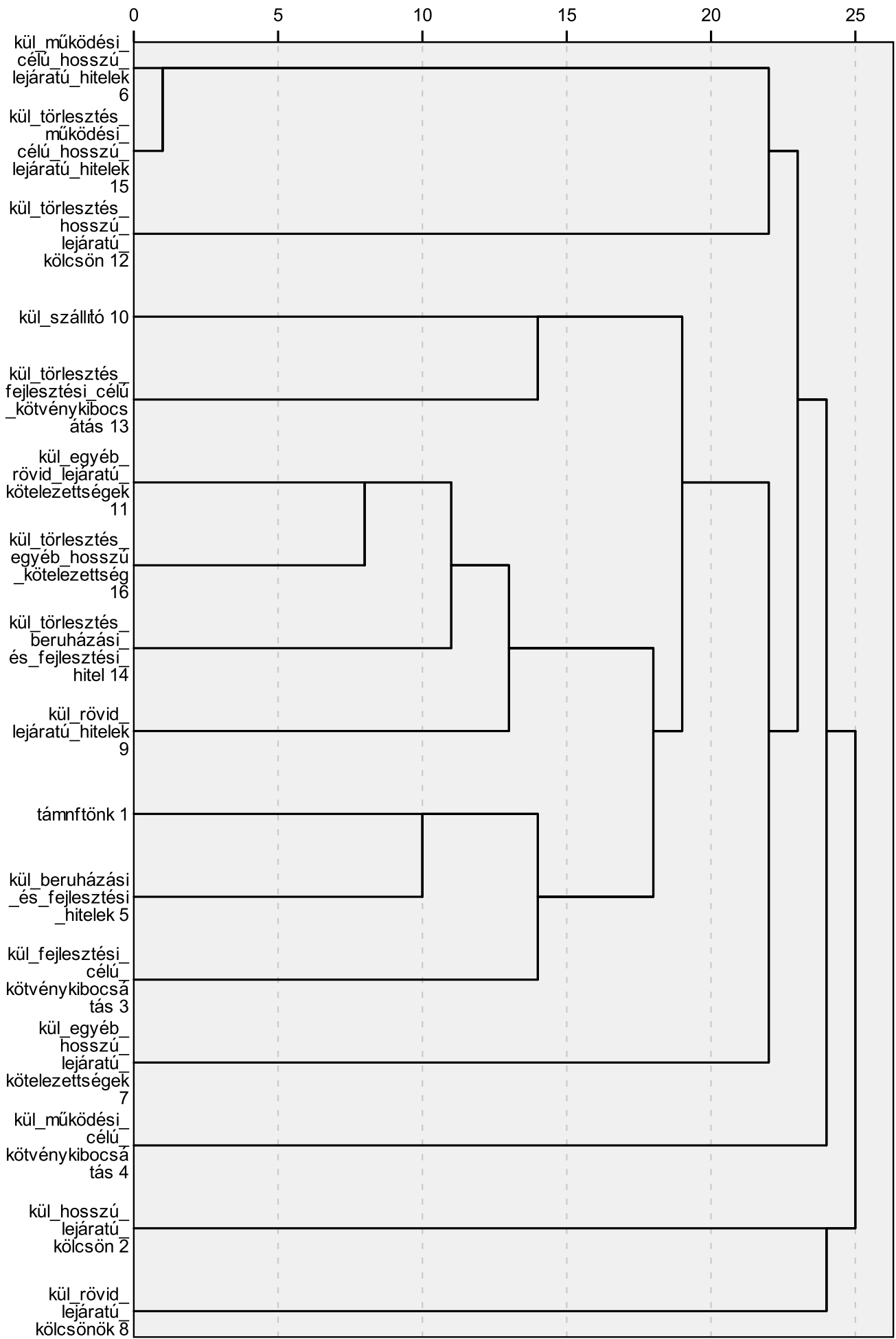


d2) Klaszteranalízis megye (NUTS3) szinten (Baranya)

Dendrogram using Average Linkage (Between Groups)

Rescaled Distance Cluster Combine

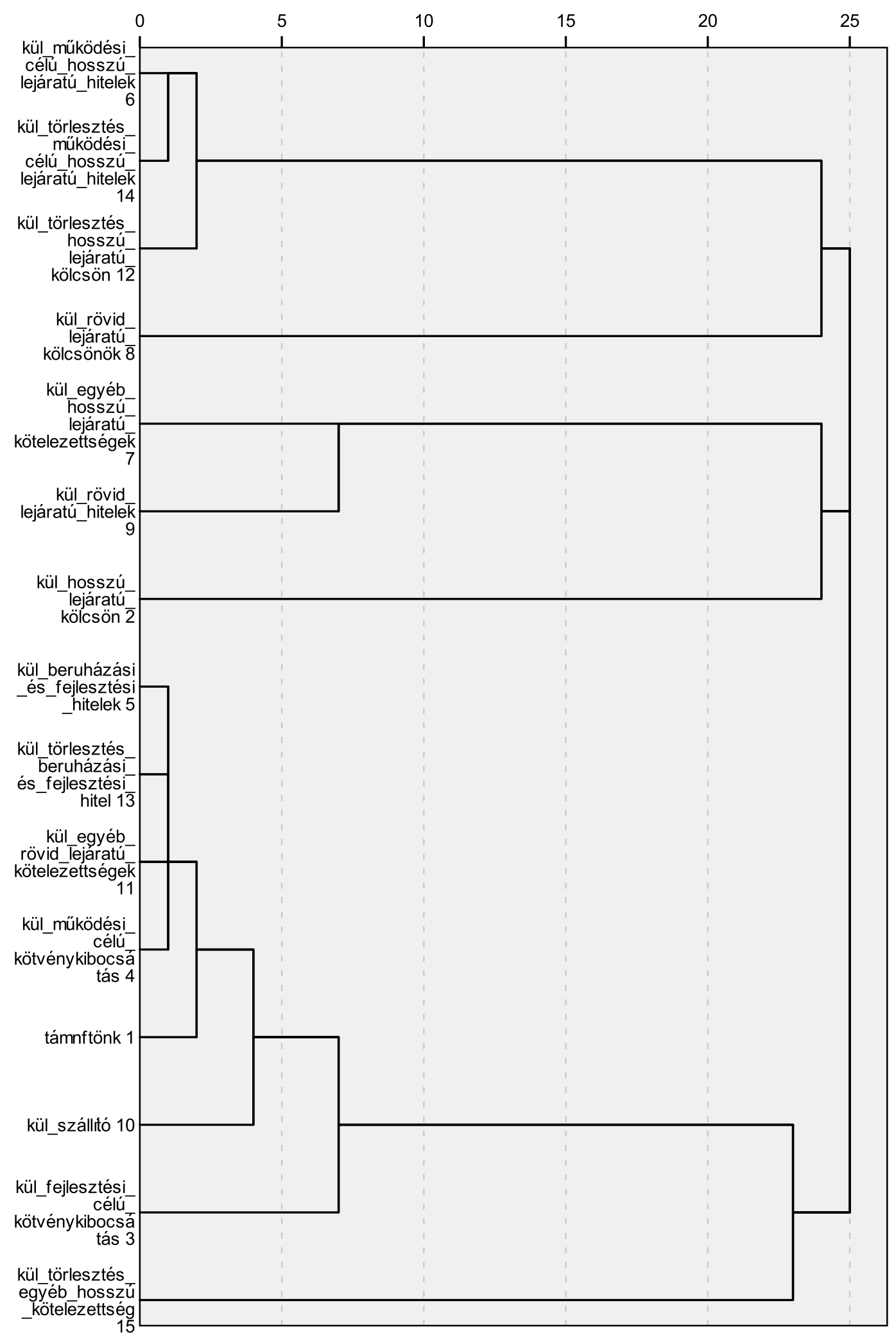


Klaszteranalízis megye (NUTS3) szinten (Bács-Kiskun)

Dendrogram using Average Linkage (Between Groups)

Rescaled Distance Cluster Combine

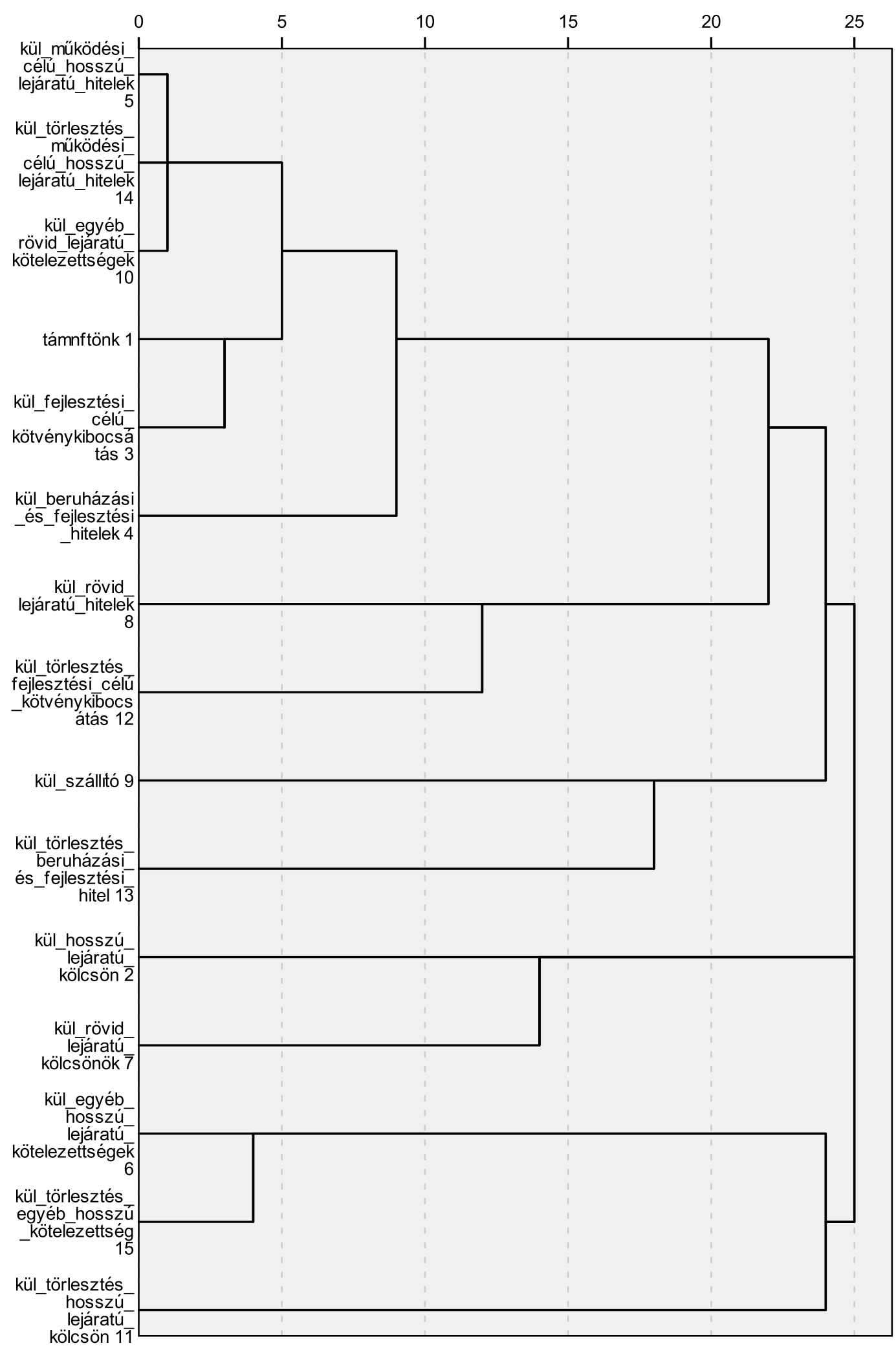




\section{Dendrogram using Average Linkage (Between Groups)}

Rescaled Distance Cluster Combine

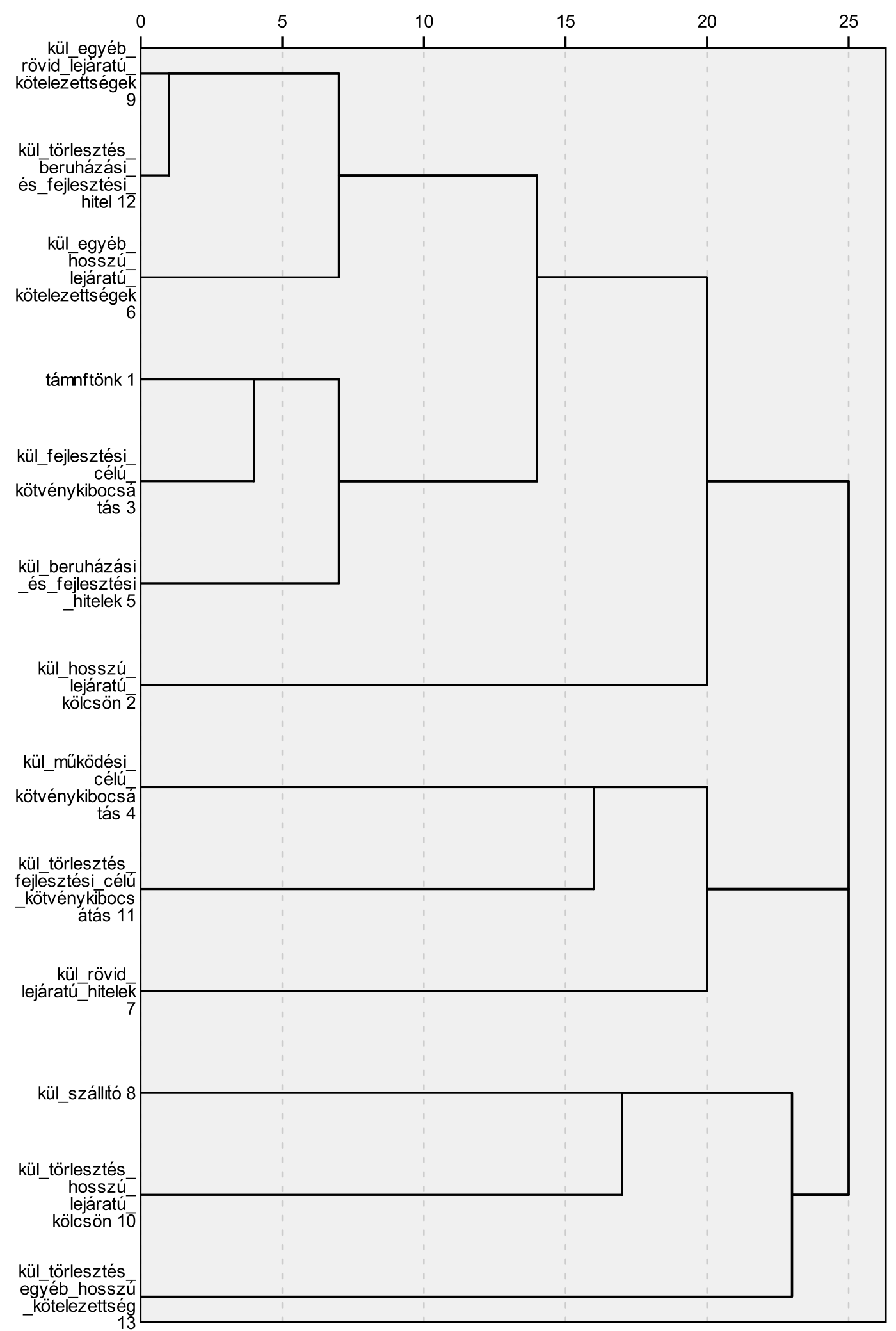


Klaszteranalízis megye (NUTS3) szinten (Borsod-Abaúj-Zemplén)

Dendrogram using Average Linkage (Between Groups)

Rescaled Distance Cluster Combine

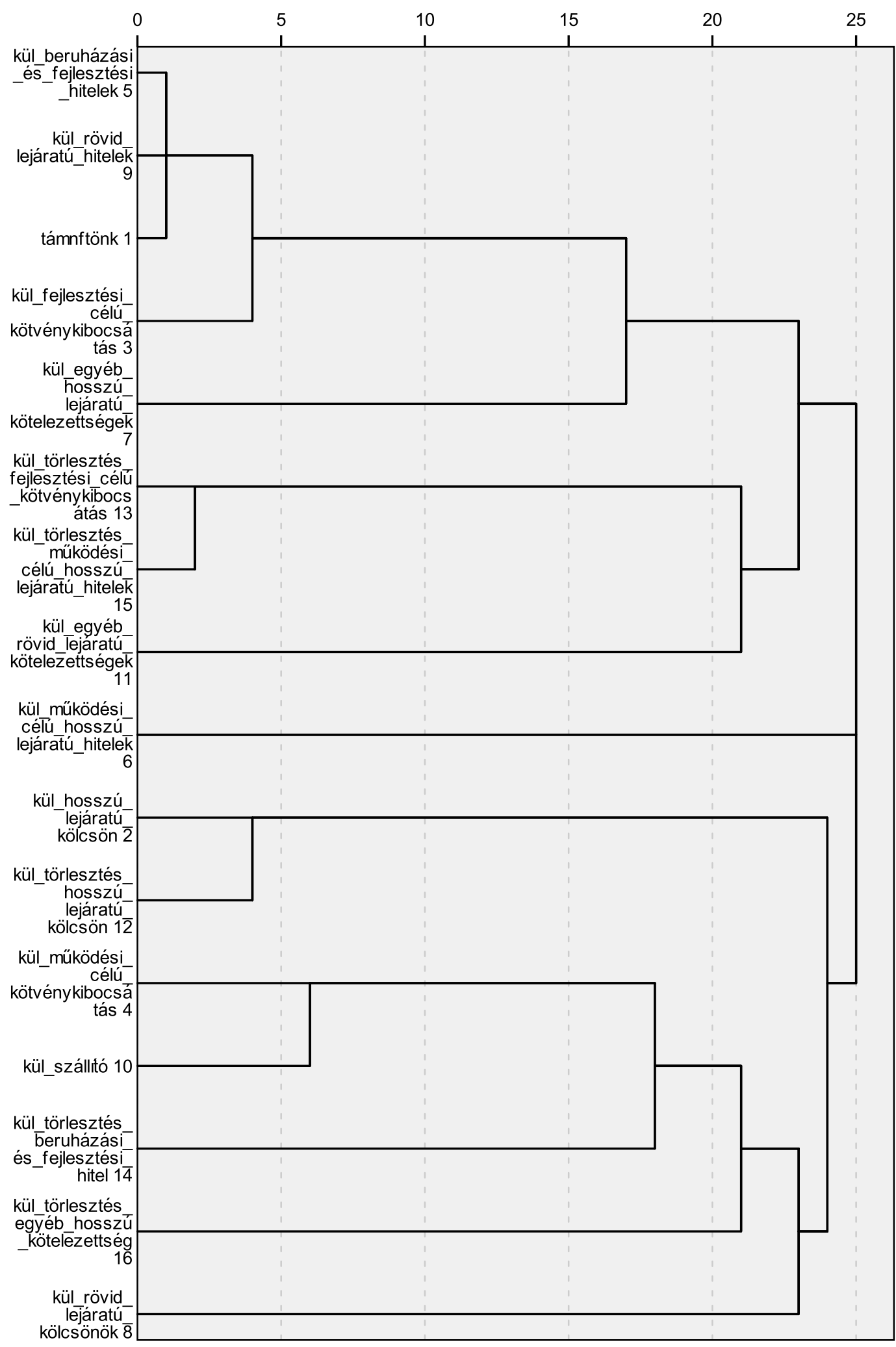


Dendrogram using Average Linkage (Between Groups)

Rescaled Distance Cluster Combine

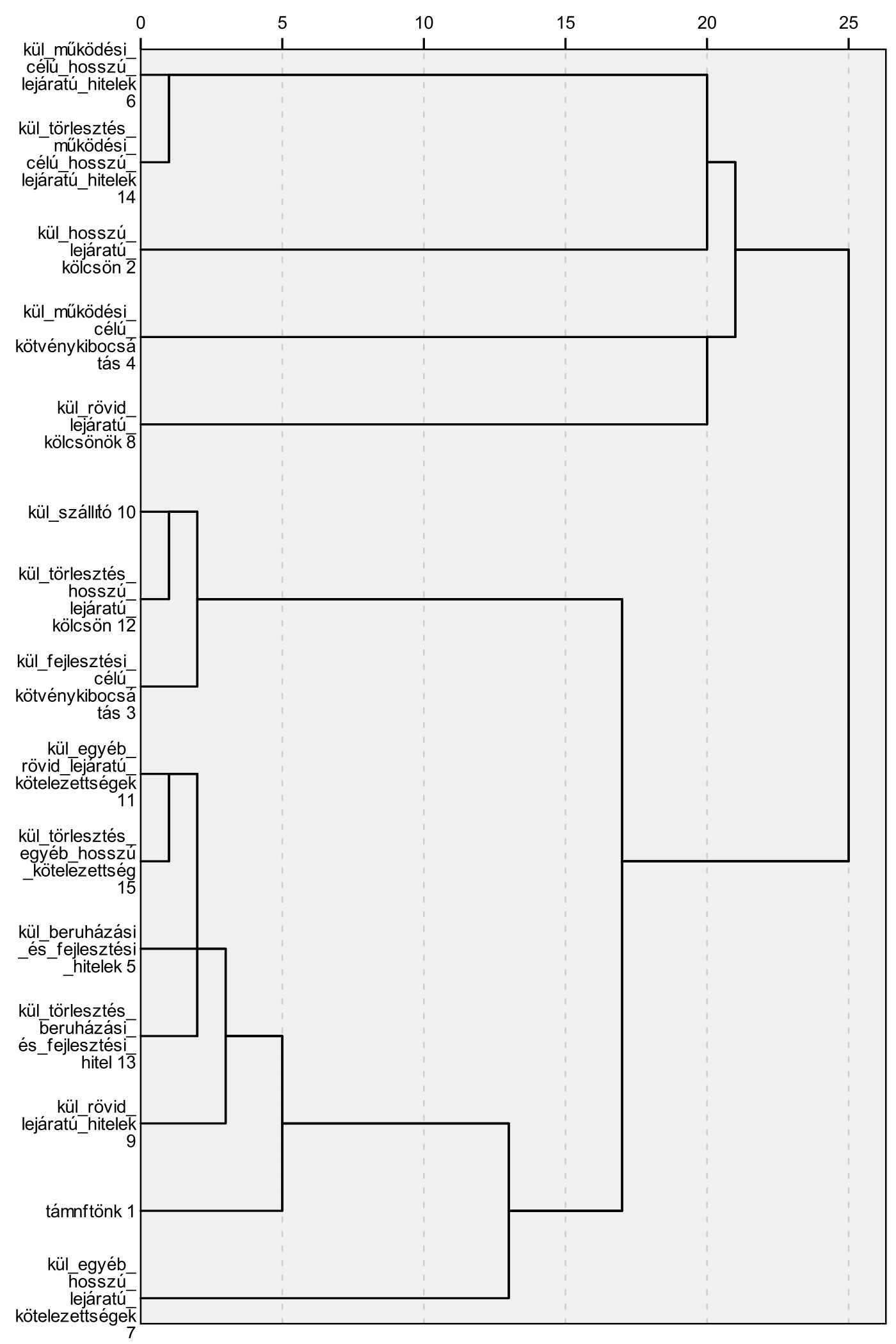


Klaszteranalízis megye (NUTS3) szinten (Fejér)

Dendrogram using Average Linkage (Between Groups)

\section{Rescaled Distance Cluster Combine}

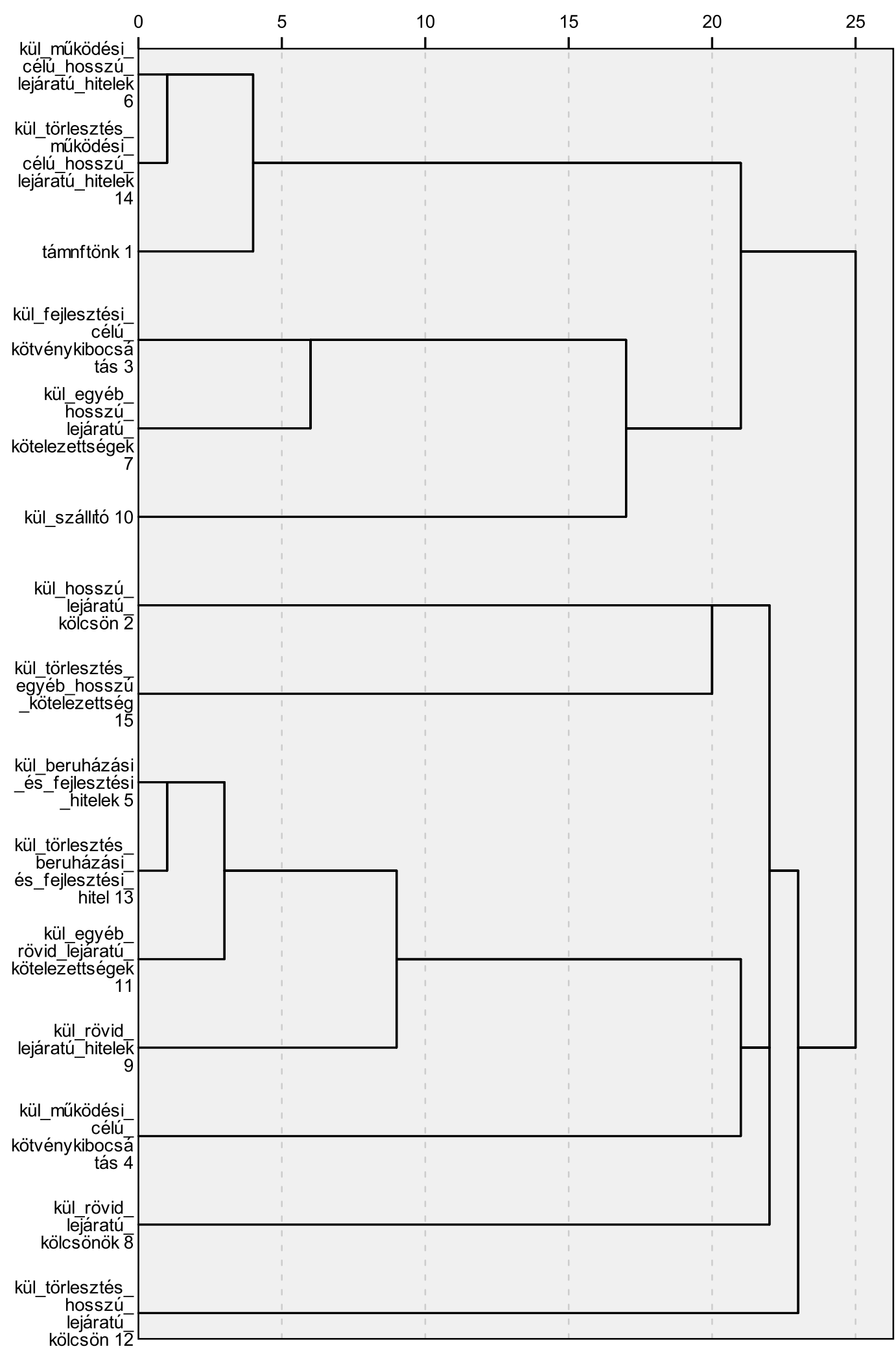


Klaszteranalizis megye (NUTS3) szinten (Györ-Moson-Sopron)

Dendrogram using Average Linkage (Between Groups)

Rescaled Distance Cluster Combine

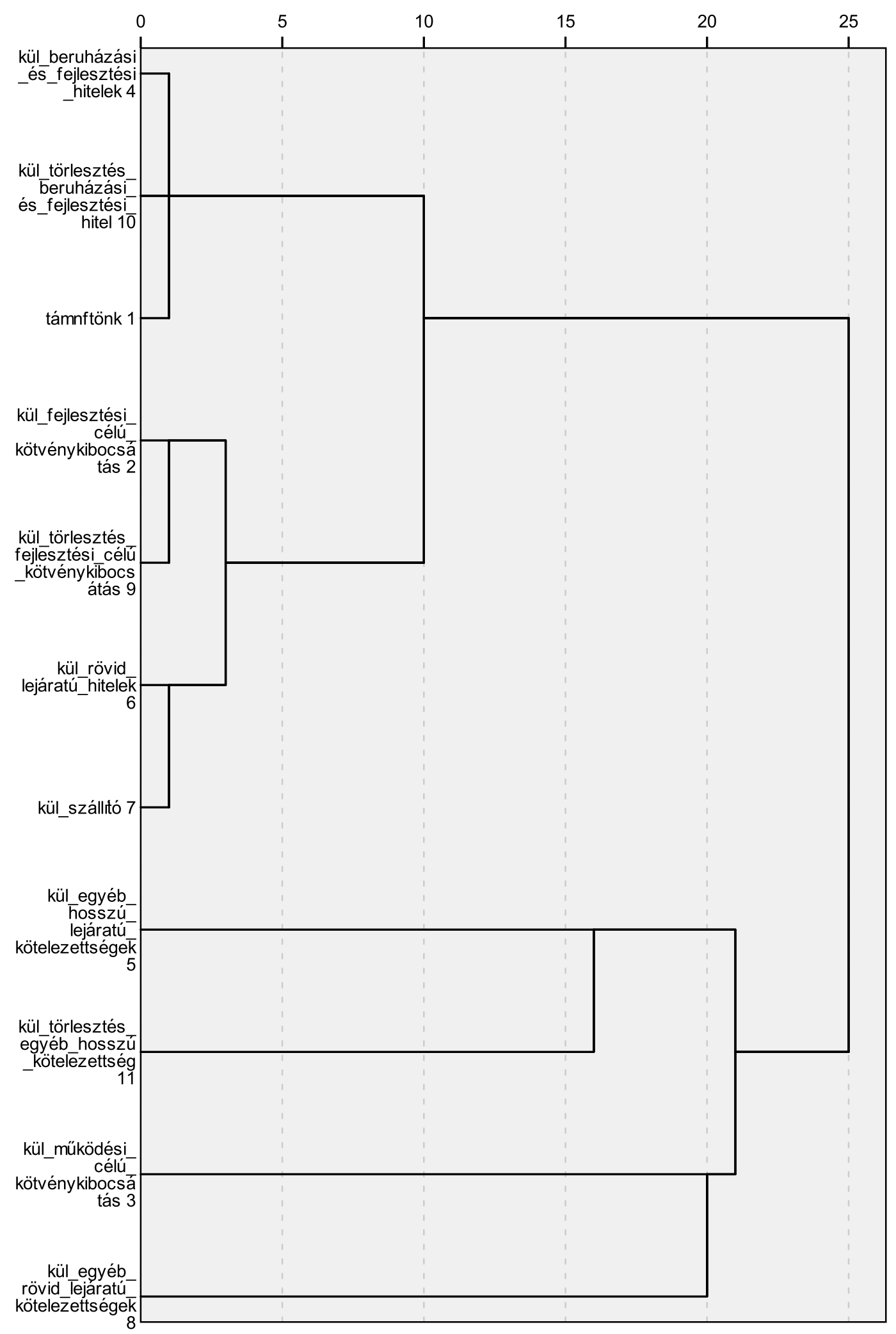


Klaszteranalízis megye (NUTS3) szinten (Hajdú-Bihar)

Dendrogram using Average Linkage (Between Groups)

Rescaled Distance Cluster Combine

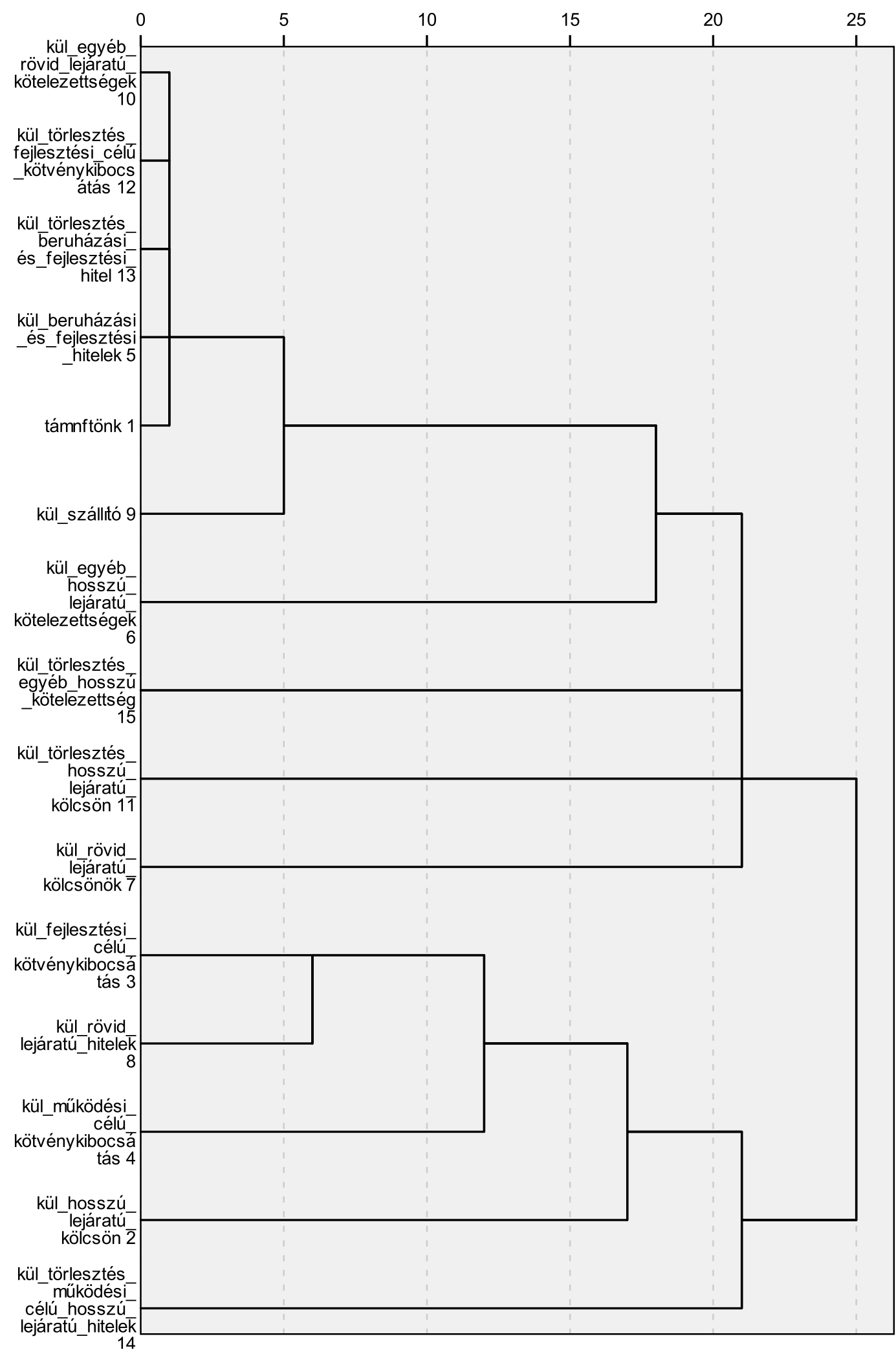


Dendrogram using Average Linkage (Between Groups)

Rescaled Distance Cluster Combine

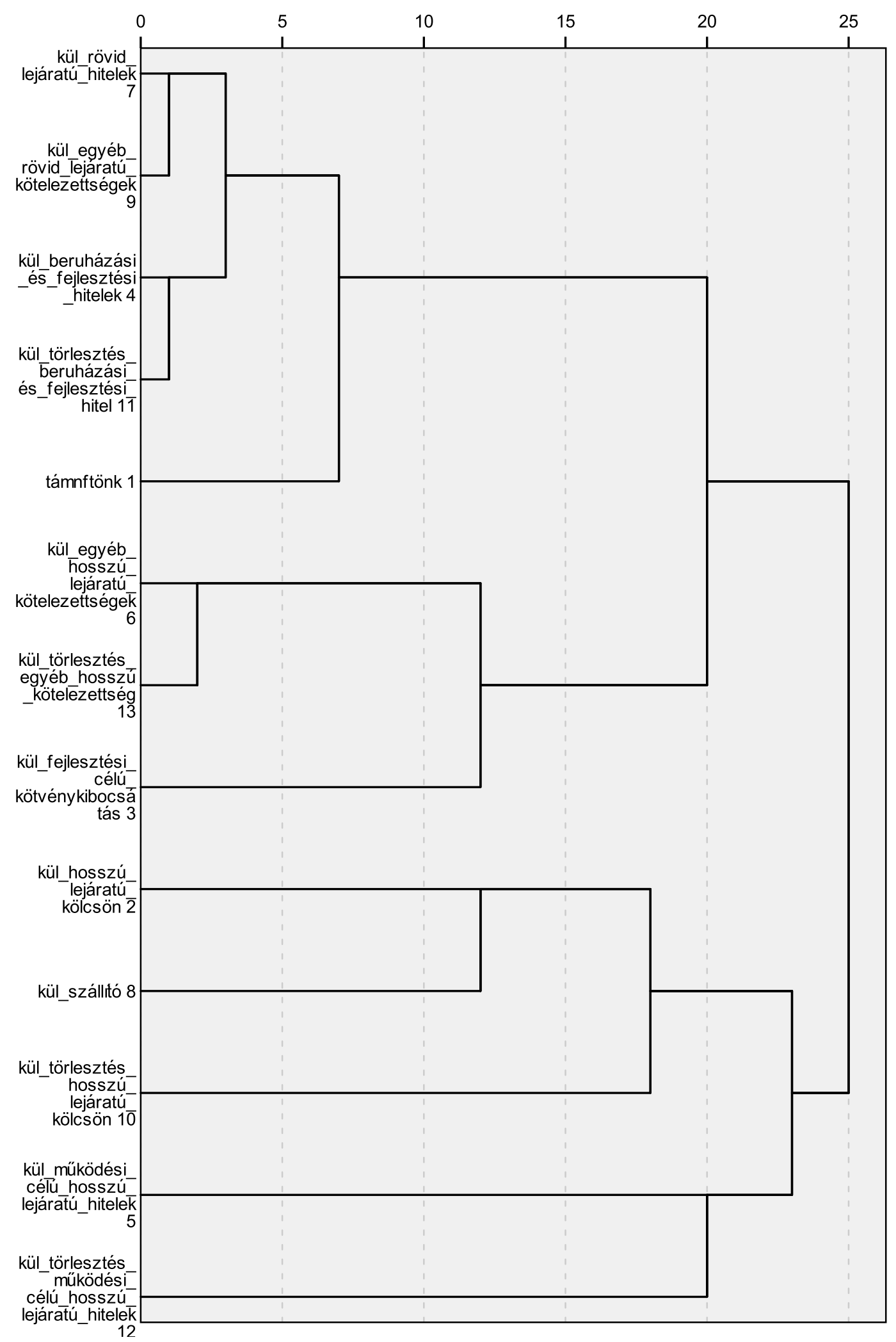


Klaszteranalízis megye (NUTS3) szinten (Komárom-Esztergom)

Dendrogram using Average Linkage (Between Groups)

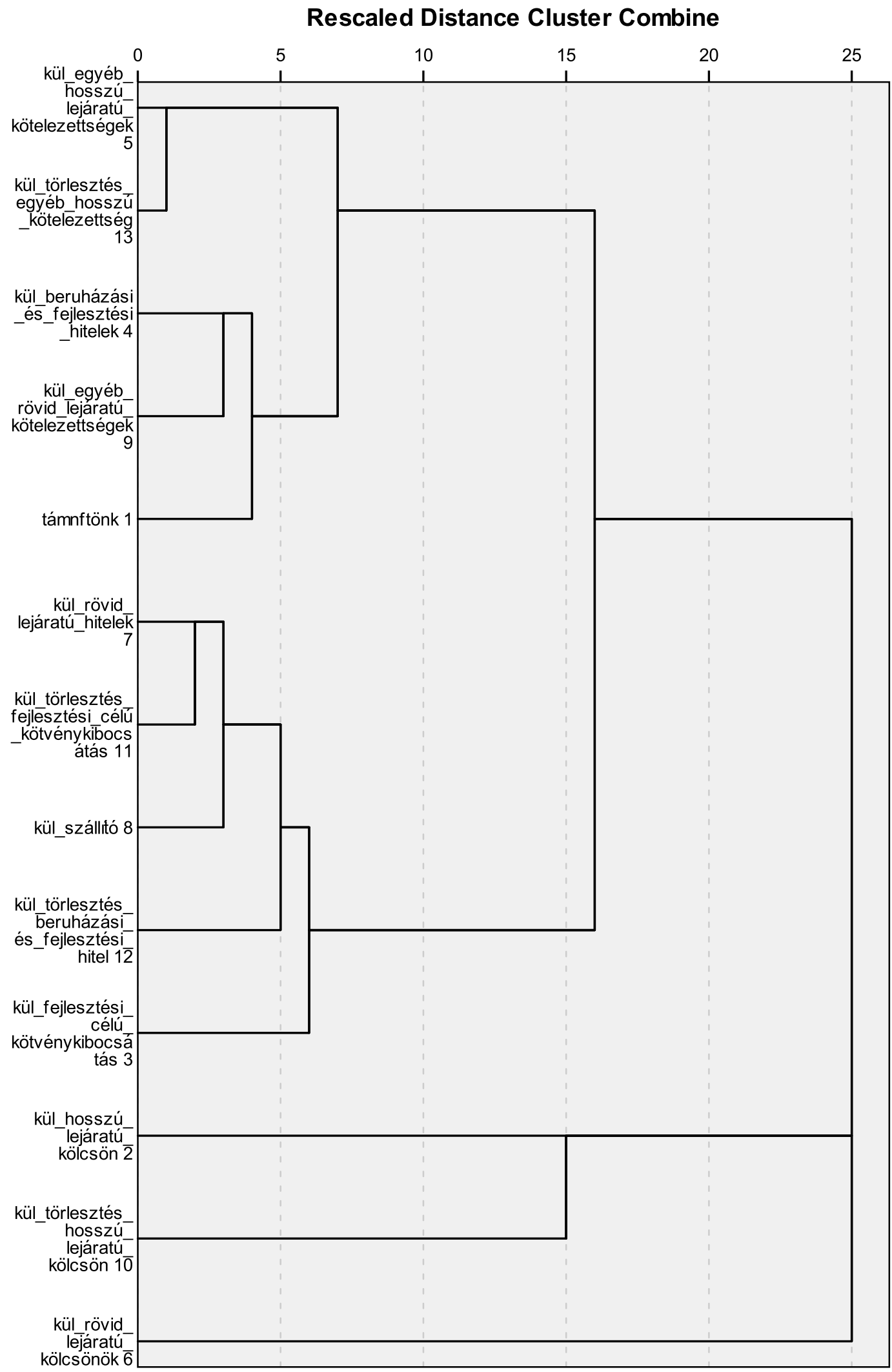


Klaszteranalízis megye (NUTS3) szinten (Nógrád)

Dendrogram using Average Linkage (Between Groups)

Rescaled Distance Cluster Combine

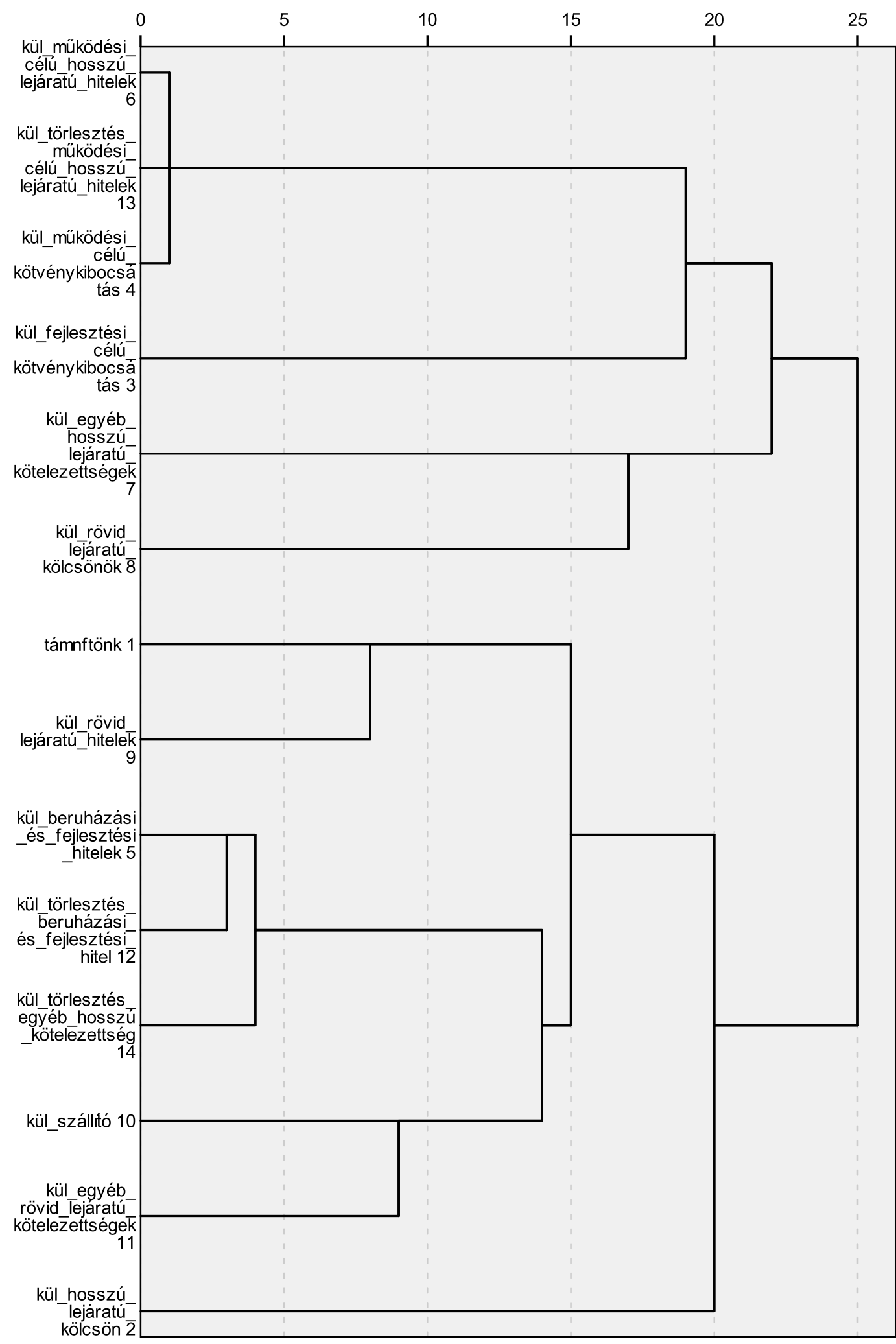


Klaszteranalízis megye (NUTS3) szinten (Pest)

Dendrogram using Average Linkage (Between Groups)

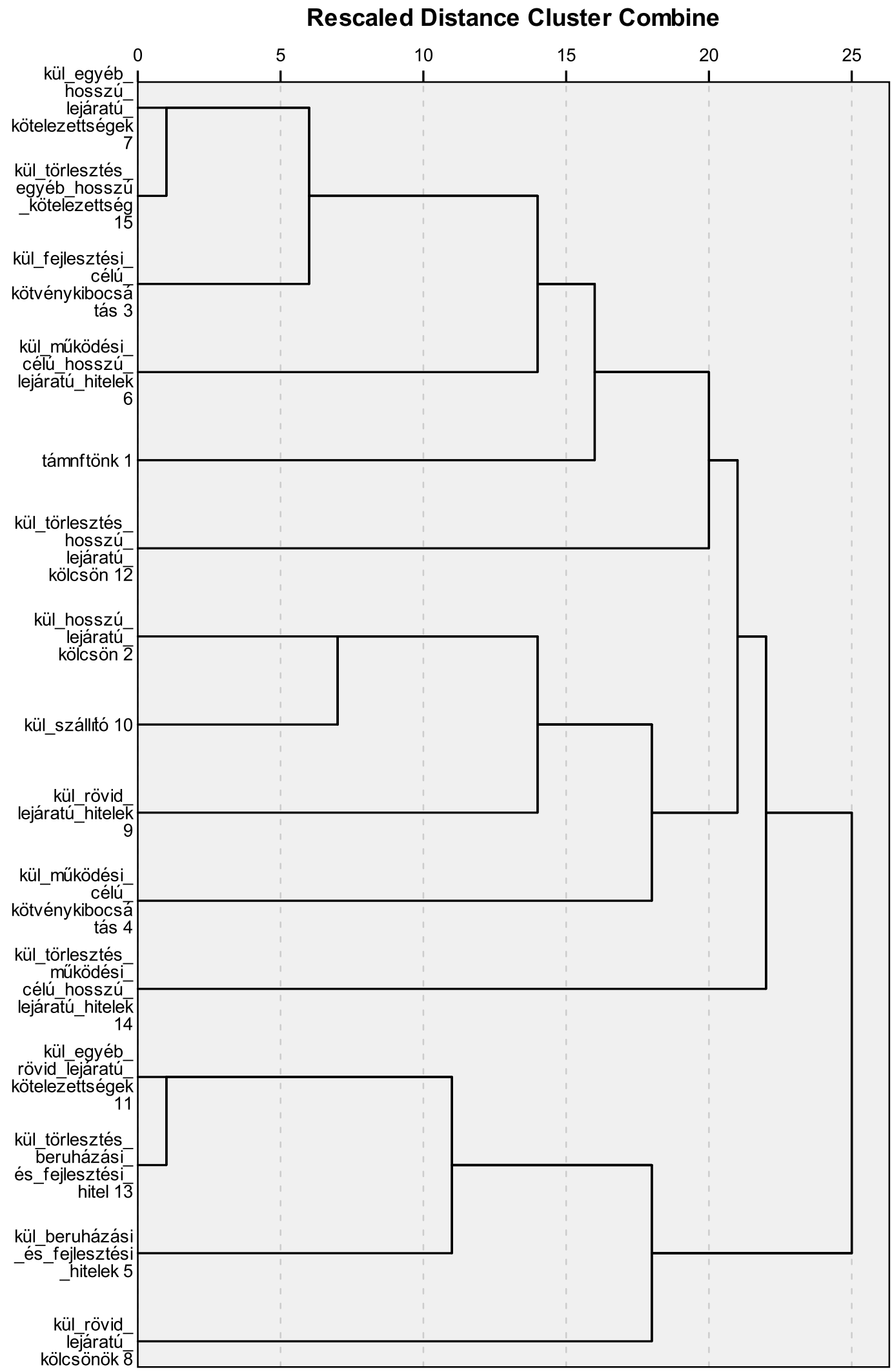


Dendrogram using Average Linkage (Between Groups)

Rescaled Distance Cluster Combine

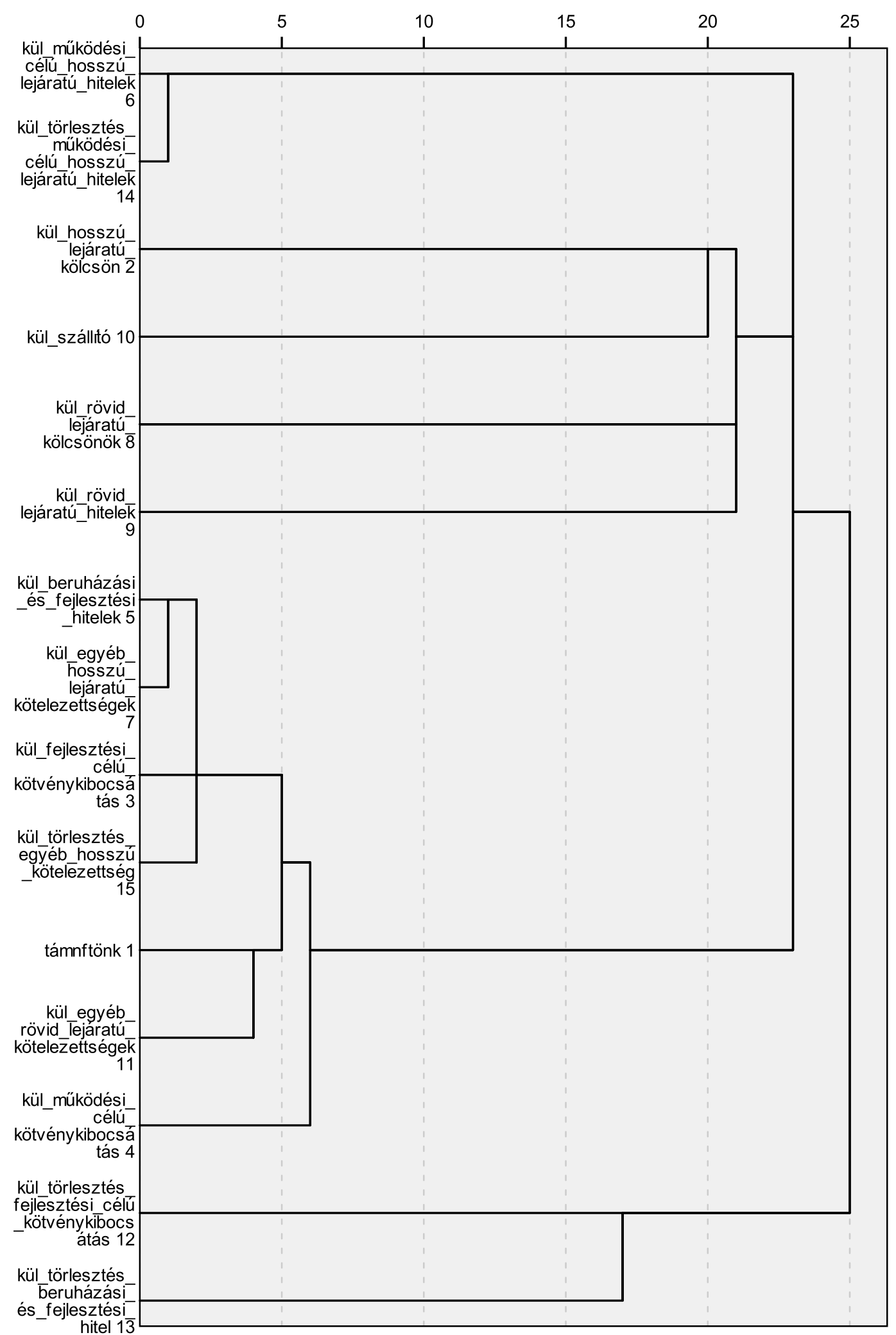


Klaszteranalizis megye (NUTS3) szinten (Szabolcs-Szatmár-Bereg)

Dendrogram using Average Linkage (Between Groups)

Rescaled Distance Cluster Combine

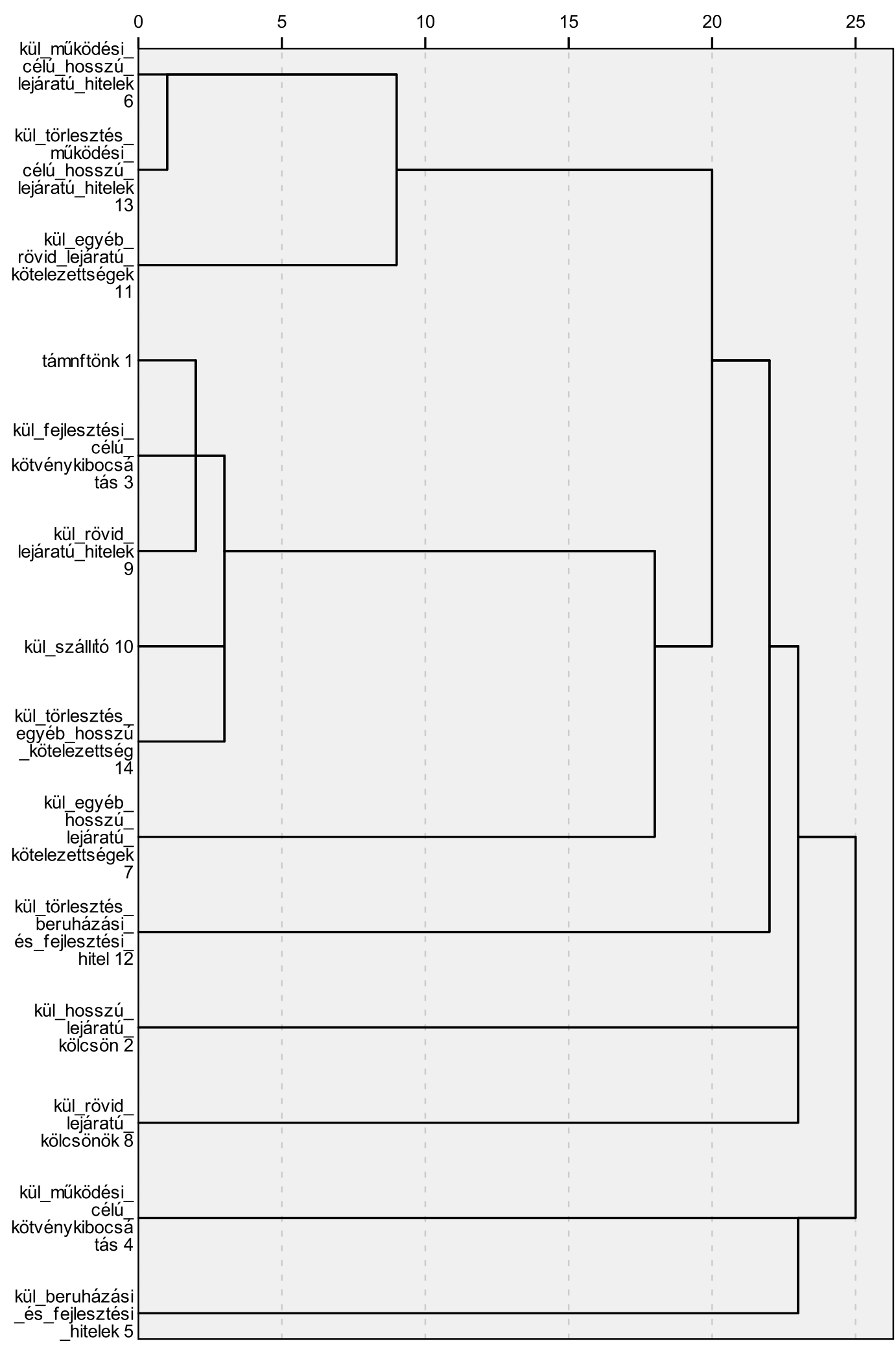


Klaszteranalizis megye (NUTS3) szinten (Jász-Nagykun-Szolnok)

Dendrogram using Average Linkage (Between Groups)

Rescaled Distance Cluster Combine

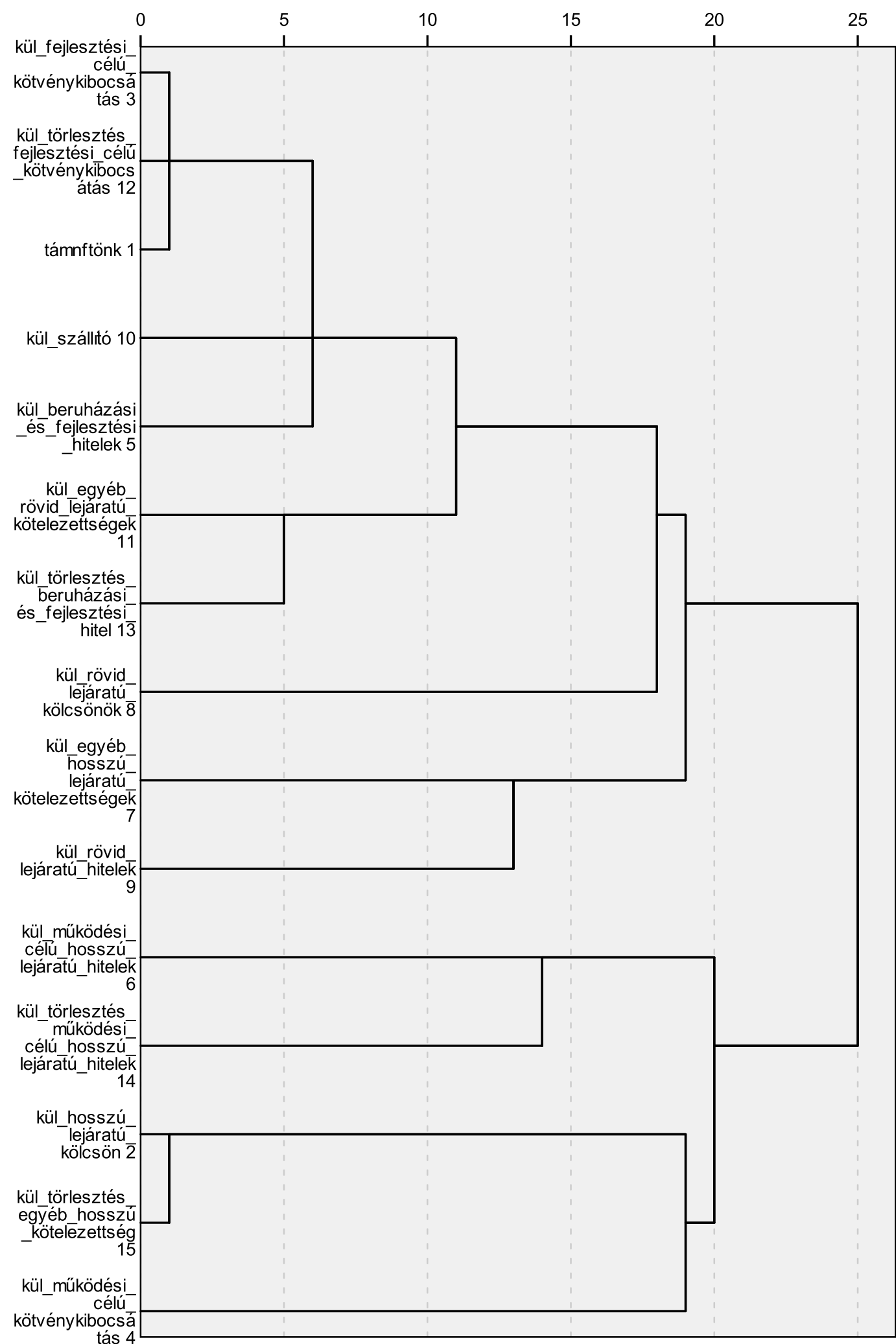


Klaszteranalízis megye (NUTS3) szinten (Tolna)

Dendrogram using Average Linkage (Between Groups)

Rescaled Distance Cluster Combine

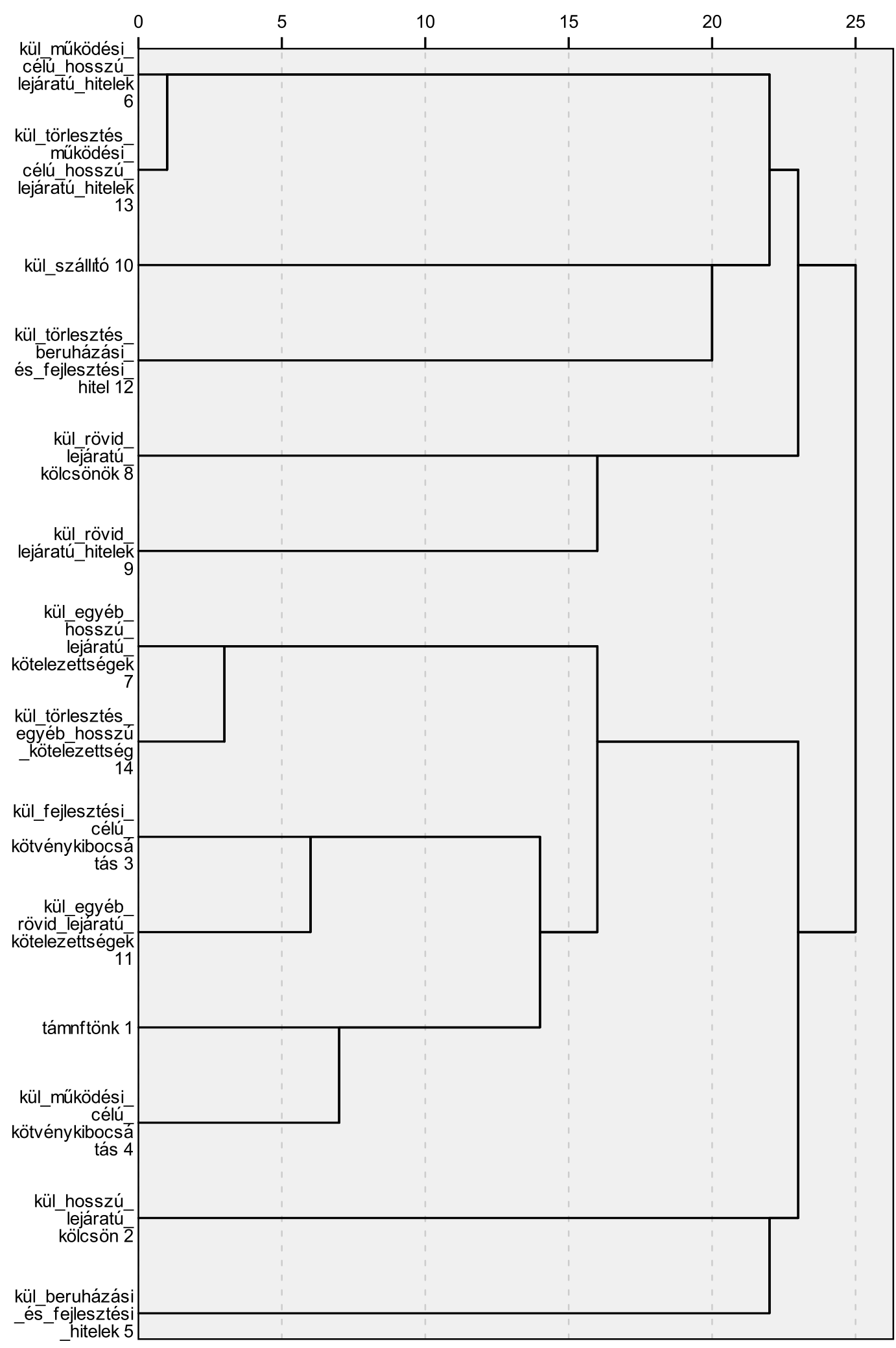


Klaszteranalízis megye (NUTS3) szinten (Vas)

Dendrogram using Average Linkage (Between Groups)

Rescaled Distance Cluster Combine

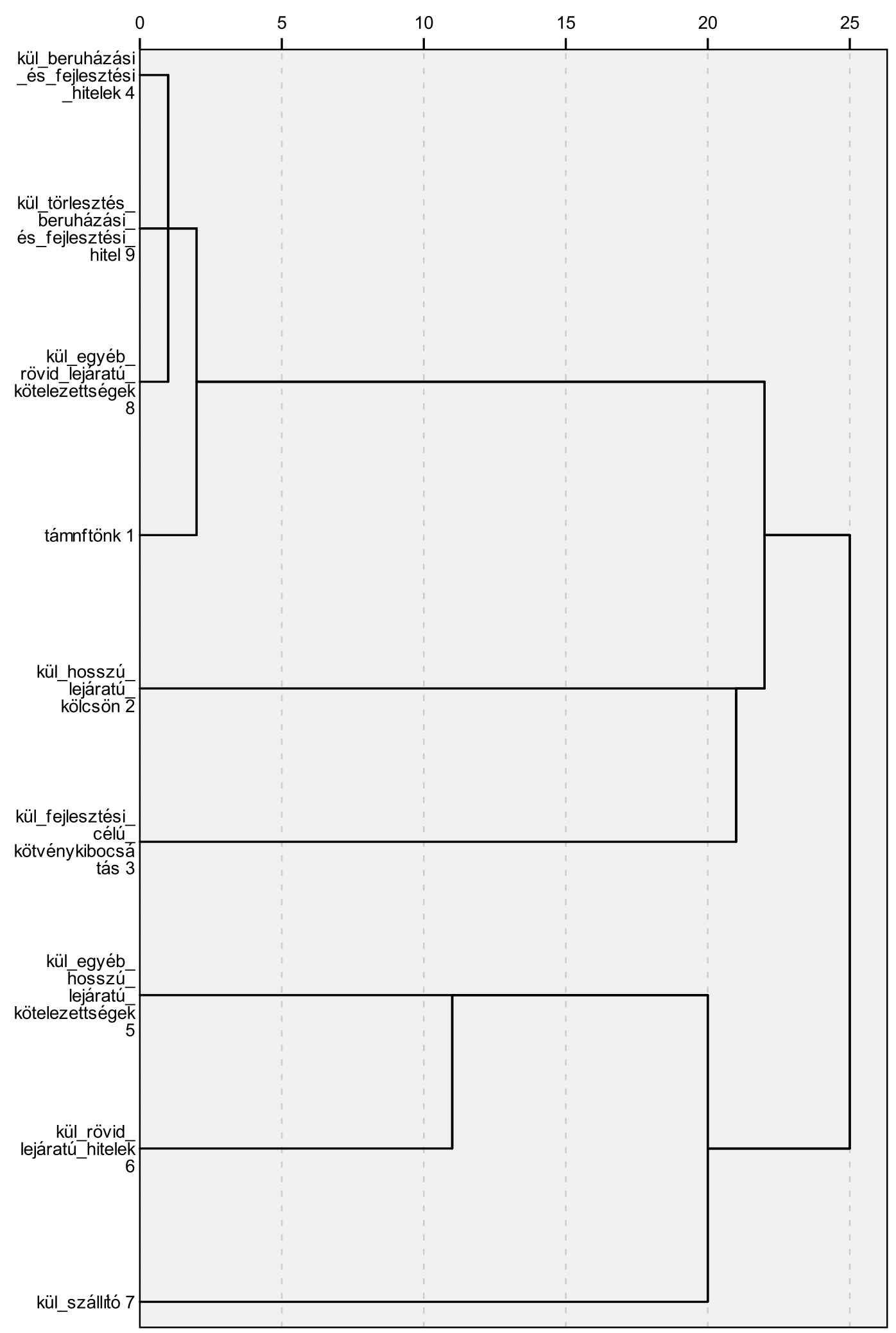


Klaszteranalizis megye (NUTS3) szinten (Veszprém)

Dendrogram using Average Linkage (Between Groups)

Rescaled Distance Cluster Combine

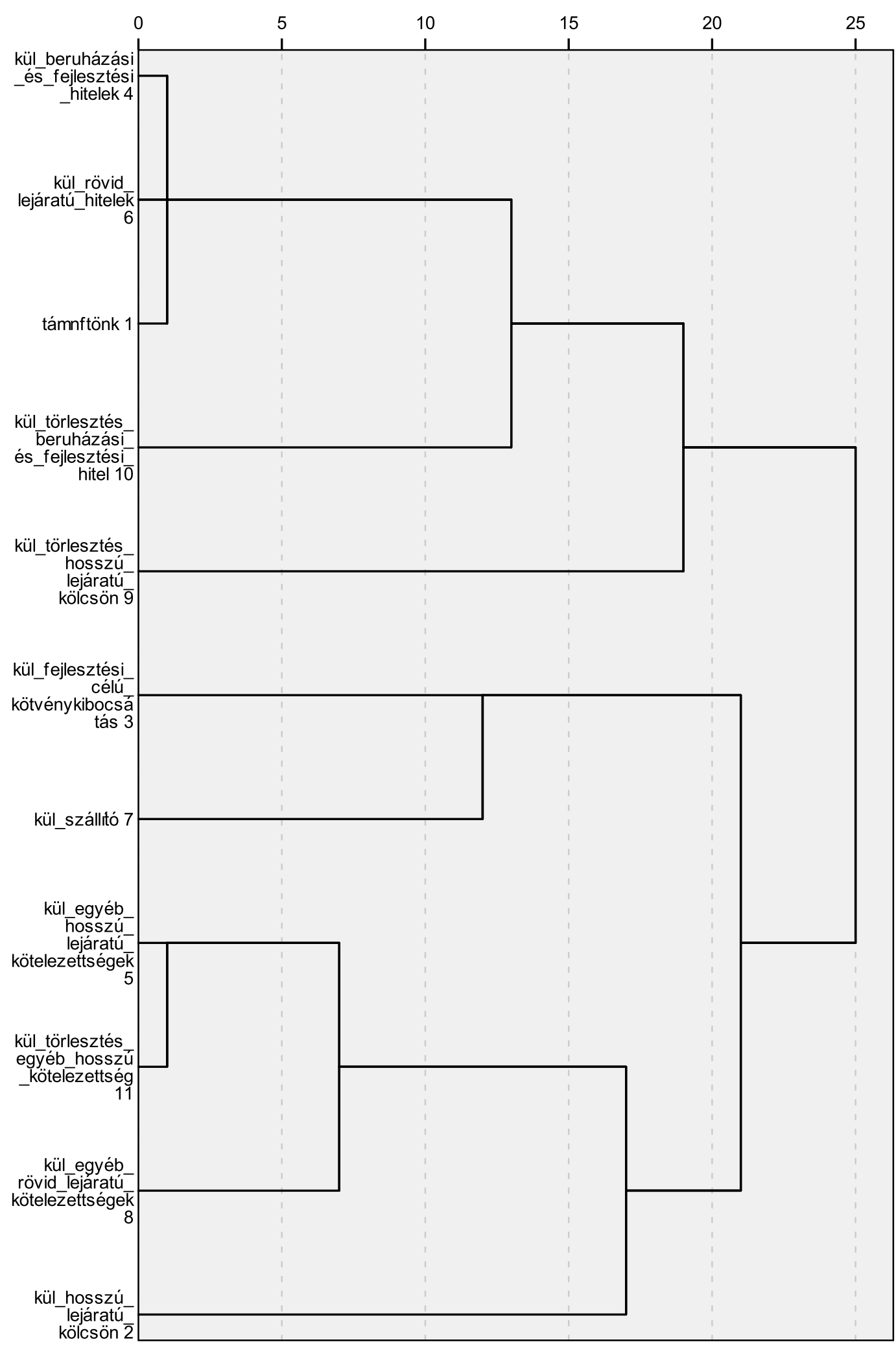


Dendrogram using Average Linkage (Between Groups)

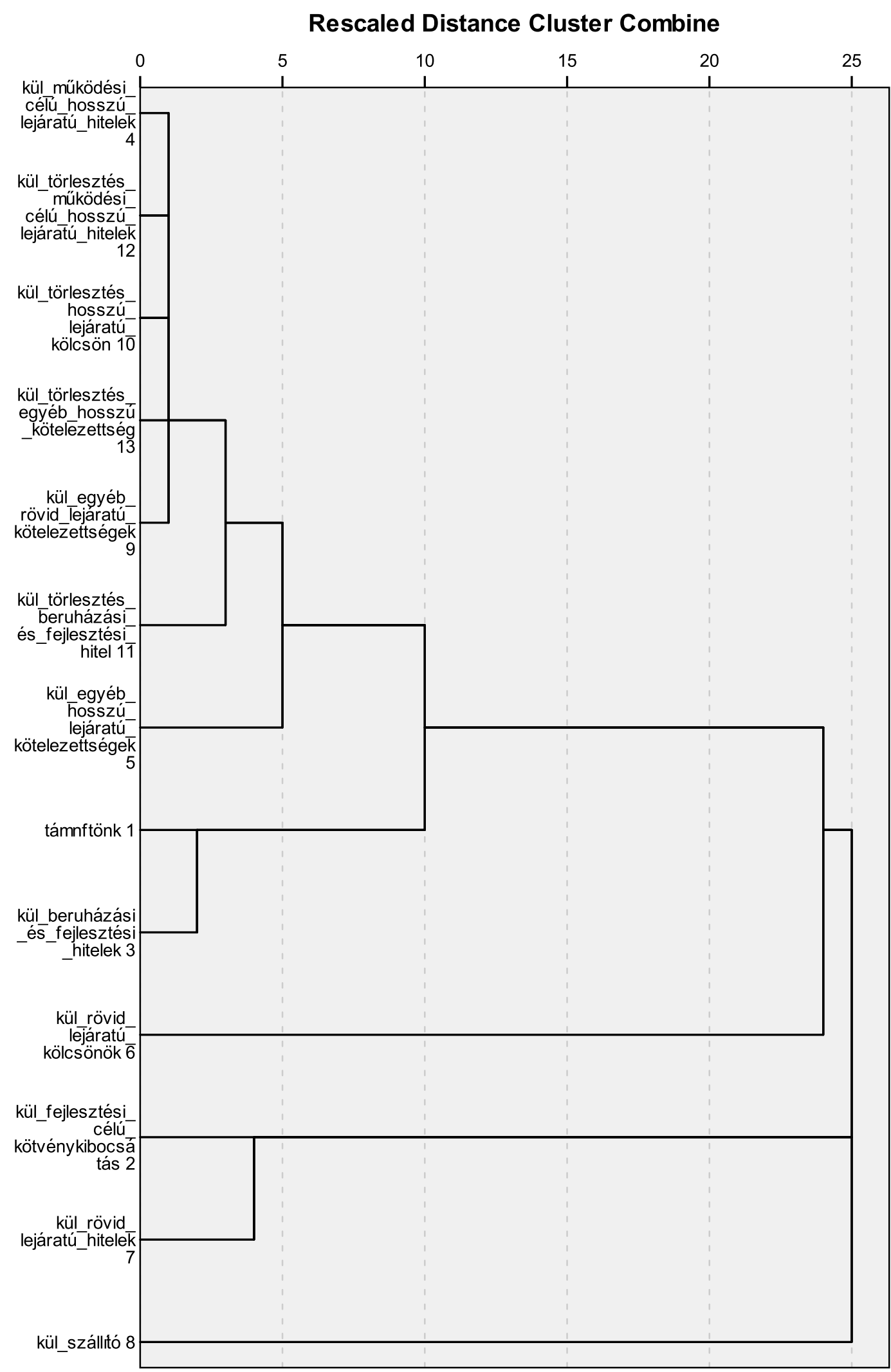




\section{4. számú melléklet: A H4 hipotézis tesztelésének eredményei}

\section{a) Pearson korreláció vizsgálat helyi önkormányzatra}

\begin{tabular}{|c|c|c|c|c|c|c|c|c|c|c|c|c|}
\hline \multicolumn{13}{|c|}{ Pearson korreláció országos szinten } \\
\hline Országos an & $\begin{array}{c}\text { Állandó_népess } \\
\text { ég_száma_2008 }\end{array}$ & pénzkészlet & $\begin{array}{c}\text { költségvetési_tá } \\
\mathrm{m}\end{array}$ & szja & teért & sajátbev & helyiadoossz & IPAössz & adóbírság & kamatbev & rövidhitel & hosszúhitel \\
\hline Állandó_népesség_száma & 1 & 0,852 & 0,977 & 0,968 & 0,849 & 0,974 & 0,886 & 0,866 & 0,782 & 0,727 & 0,556 & 0,87 \\
\hline
\end{tabular}

\begin{tabular}{|c|c|c|c|c|c|c|c|c|c|c|c|c|c|}
\hline \multicolumn{14}{|c|}{ Pearson korreláció nagyrégió (NUTS1) szinten } \\
\hline \multicolumn{2}{|c|}{ Statisztikai nagyrégió } & Állandó_népess & pénzkészlet & költségvetési_tá & szja & teért & sajátbev & helyiadoossz & IPAössz & adóbírság & kamatbev & rövidhitel & hosszúhitel \\
\hline Közép-Magyarország & \multirow{3}{*}{$\begin{array}{c}\text { Állandó_népesség_száma_2 } \\
008\end{array}$} & 1 & 0,561 & 0,946 & 0,89 & 0,679 & 0,827 & 0,565 & 0,539 & 0,753 & 0,384 & 0,471 & 0,771 \\
\hline Dunántúl & & 1 & 0,895 & 0,986 & 0,966 & 0,877 & 0,982 & 0,934 & 0,919 & 0,786 & 0,784 & 0,672 & 0,855 \\
\hline Alföld és Észak & & 1 & 0,885 & 0,984 & 0,983 & 0,901 & 0,984 & 0,964 & 0,96 & 0,806 & 0,843 & 0,533 & 0,891 \\
\hline
\end{tabular}




\begin{tabular}{|c|c|c|c|c|c|c|c|c|c|c|c|c|c|}
\hline \multicolumn{14}{|c|}{ Pearson korreláció régió (NUTS2) szinten } \\
\hline & Régió & $\begin{array}{c}\text { Állandó_népess } \\
\text { ég száma } 2008\end{array}$ & pénzkészlet & $\begin{array}{c}\text { költségvetési_tá } \\
\mathrm{m}\end{array}$ & szja & teért & sajátbev & helyiadoossz & IPAössz & adóbírság & kamatbev & rövidhitel & hosszúhitel \\
\hline Közép-Magyarország & \multirow{7}{*}{$\begin{array}{c}\text { Állandó_népesség_száma_2 } \\
008\end{array}$} & 1 & 0,561 & 0,946 & 0,89 & 0,679 & 0,827 & 0,565 & 0,539 & 0,753 & 0,384 & 0,471 & 0,771 \\
\hline Közép-Dunántúl & & 1 & 0,81 & 0,981 & 0,975 & 0,84 & 0,976 & 0,943 & 0,917 & 0,916 & 0,626 & 0,36 & 0,815 \\
\hline Nyugat-Magyarország & & 1 & 0,929 & 0,994 & 0,966 & 0,909 & 0,993 & 0,971 & 0,976 & 0,708 & 0,868 & 0,742 & 0,857 \\
\hline Dél-Dunántúl & & 1 & 0,939 & 0,984 & 0,977 & 0,947 & 0,983 & 0,934 & 0,942 & 0,849 & 0,885 & 0,812 & 0,952 \\
\hline Észak-Magyarország & & 1 & 0,887 & 0,991 & 0,987 & 0,927 & 0,989 & 0,923 & 0,913 & 0,788 & 0,93 & 0,41 & 0,959 \\
\hline Észak-Alföld & & 1 & 0,915 & 0,987 & 0,987 & 0,927 & 0,994 & 0,979 & 0,977 & 0,75 & 0,854 & 0,51 & 0,913 \\
\hline Dél-Alföld & & 1 & 0,845 & 0,989 & 0,983 & 0,864 & 0,981 & 0,979 & 0,976 & 0,91 & 0,849 & 0,649 & 0,818 \\
\hline
\end{tabular}

\begin{tabular}{|c|c|c|c|c|c|c|c|c|c|c|c|c|c|}
\hline \multicolumn{14}{|c|}{ Pearson korreláció megye (NUTS3) szinten } \\
\hline \multicolumn{2}{|c|}{ Megye } & $\mid \begin{array}{c}\text { Állandónnépess } \\
\text { ég }\end{array}$ & pénzkészlet & költségvetési_tá & szja & teért & sajátbev & helyiadoossz & IPAössz & adóbírság & kamatbev & rövidhitel & hosszúhitel \\
\hline Baranya & \multirow{19}{*}{$\begin{array}{c}\text { Állandó_népesség_száma_2 } \\
008\end{array}$} & 1 & 0,959 & 0,998 & 0,985 & 0,967 & 0,997 & 0,991 & 0,988 & 0,986 & 0,913 & 0,935 & 0,963 \\
\hline Bács-Kiskun & & 1 & 0,885 & 0,983 & 0,974 & 0,941 & 0,994 & 0,978 & 0,976 & 0,894 & 0,934 & 0,456 & 0,966 \\
\hline Békés & & 1 & 0,86 & 0,977 & 0,99 & 0,669 & 0,987 & 0,955 & 0,941 & 0,896 & 0,935 & 0,755 & 0,966 \\
\hline Borsod-Abaúj-Zemplén & & 1 & 0,914 & 0,996 & 0,991 & 0,982 & 0,992 & 0,919 & 0,909 & 0,972 & 0,96 & 0,348 & 0,98 \\
\hline Csongrád & & 1 & 0,835 & 0,999 & 0,992 & 0,984 & 0,995 & 0,989 & 0,985 & 0,981 & 0,873 & 0,769 & 0,729 \\
\hline Fejér & & 1 & 0,978 & 0,992 & 0,981 & 0,908 & 0,992 & 0,988 & 0,986 & 0,985 & 0,865 & 0,223 & 0,974 \\
\hline Györ-Moson-Sopron & & 1 & 0,974 & 0,994 & 0,968 & 0,976 & 0,997 & 0,984 & 0,98 & 0,606 & 0,945 & 0,818 & 0,834 \\
\hline Hajdú-Bihar & & 1 & 0,984 & 0,995 & 0,992 & 0,982 & 0,999 & 0,99 & 0,99 & 0,995 & 0,983 & 0,118 & 0,984 \\
\hline Heves & & 1 & 0,896 & 0,985 & 0,986 & 0,82 & 0,988 & 0,964 & 0,959 & 0,9 & 0,873 & 0,574 & 0,937 \\
\hline Komárom-Es ztergom & & 1 & 0,654 & 0,983 & 0,984 & 0,758 & 0,952 & 0,881 & 0,835 & 0,975 & 0,639 & 0,378 & 0,67 \\
\hline Nógrád & & 1 & 0,94 & 0,959 & 0,993 & 0,476 & 0,994 & 0,966 & 0,972 & 0,885 & 0,942 & 0,908 & 0,889 \\
\hline Pest & & 1 & 0,56 & 0,946 & 0,89 & 0,679 & 0,827 & 0,565 & 0,539 & 0,752 & 0,384 & 0,471 & 0,771 \\
\hline Somogy & & 1 & 0,956 & 0,976 & 0,992 & 0,908 & 0,964 & 0,942 & 0,971 & 0,937 & 0,966 & 0,25 & 0,937 \\
\hline Szabolcs-Szatmár-Bereg & & 1 & 0,77 & 0,985 & 0,99 & 0,976 & 0,997 & 0,98 & 0,98 & 0,977 & 0,735 & 0,937 & 0,942 \\
\hline Jász-Nagykun-Szolnok & & 1 & 0,815 & 0,992 & 0,97 & 0,372 & 0,984 & 0,931 & 0,922 & 0,868 & 0,929 & 0,685 & 0,933 \\
\hline Tolna & & 1 & 0,726 & 0,97 & 0,935 & 0,849 & 0,943 & 0,709 & 0,741 & 0,828 & 0,561 & 0,815 & 0,947 \\
\hline Vas & & 1 & 0,897 & 0,995 & 0,989 & 0,898 & 0,997 & 0,986 & 0,987 & 0,954 & 0,69 & 0,388 & 0,981 \\
\hline Veszprém & & 1 & 0,729 & 0,978 & 0,987 & 0,851 & 0,978 & 0,94 & 0,922 & 0,898 & 0,77 & 0,503 & 0,892 \\
\hline Zala & & 1 & 0,885 & 0,995 & 0,972 & 0,917 & 0,989 & 0,985 & 0,985 & 0,782 & 0,831 & 0,887 & 0,886 \\
\hline
\end{tabular}




\begin{tabular}{|c|c|c|c|c|c|c|c|c|c|c|c|c|c|}
\hline \multicolumn{14}{|c|}{ Pearson korreláció területi elhelyezkedés (saját kategória) } \\
\hline \multicolumn{2}{|r|}{ Területi_elhelyezkedés } & Állandó_népess & pénzkészlet & költségvetési_tá & szja & teért & sajátbev & helyiadoossz & IPAössz & adóbírság & kamatbev & rövidhitel & hosszúhitel \\
\hline Nyugat & \multirow{3}{*}{$\begin{array}{c}\text { Állandó_népesség_száma_2 } \\
008\end{array}$} & 1 & 0,924 & 0,988 & 0,966 & 0,901 & 0,986 & 0,95 & 0,951 & 0,745 & 0,877 & 0,759 & 0,876 \\
\hline Közép & & 1 & 0,777 & 0,954 & 0,952 & 0,782 & 0,95 & 0,791 & 0,76 & 0,817 & 0,557 & 0,411 & 0,876 \\
\hline Kelet & & 1 & 0,886 & 0,987 & 0,985 & 0,9 & 0,983 & 0,979 & 0,976 & 0,818 & 0,832 & 0,573 & 0,867 \\
\hline
\end{tabular}




\section{b) Pearson korreláció vizsgálat a támogatásban részesült helyi önkormányzatokra}

\begin{tabular}{|c|c|c|c|c|c|c|c|c|c|c|c|c|}
\hline \multicolumn{13}{|c|}{ Pearson korreláció országos szinten támogatás ban részesültek } \\
\hline & $\begin{array}{r}\text { Állandó_népess } \\
\text { ég_száma_2008 }\end{array}$ & pénzkészlet & $\begin{array}{c}\text { költségvetési_tá } \\
\mathrm{m}\end{array}$ & szja & teért & sajátbev & helyiadoossz & IPAössz & adóbírság & kamatbev & rövidhitel & hosszúhitel \\
\hline $\begin{array}{l}\text { Állandó_népesség_száma_2 } \\
008\end{array}$ & 1 & 0,851 & 0,979 & 0,969 & 0,859 & 0,975 & 0,89 & 0,87 & 0,783 & 0,737 & 0,559 & 0,893 \\
\hline
\end{tabular}

\begin{tabular}{|c|c|c|c|c|c|c|c|c|c|c|c|c|c|}
\hline \multicolumn{14}{|c|}{ Pearson korreláció nagyrégió (NUTS1) szinten támogatásban részesültek } \\
\hline \multicolumn{2}{|c|}{ Statisztikai nagyrégió } & Állandó_népess & pénzkészlet & $\begin{array}{c}\text { költségvetési_tá } \\
\mathrm{m}\end{array}$ & szja & teért & sajátbev & helyiadoossz & IPAössz & adóbírság & kamatbev & rövidhitel & hosszúhitel \\
\hline Közép-Magyarország & \multirow{3}{*}{$\begin{array}{c}\text { Állandó_népesség_száma_2 } \\
008\end{array}$} & 1 & 0,485 & 0,938 & 0,874 & 0,69 & 0,791 & 0,503 & 0,48 & 0,746 & 0,324 & 0,456 & 0,76 \\
\hline Dunántúl & & 1 & 0,896 & 0,987 & 0,967 & 0,889 & 0,982 & 0,935 & 0,922 & 0,781 & 0,792 & 0,661 & 0,853 \\
\hline Alföld és Észak & & 1 & 0,895 & 0,985 & 0,984 & 0,907 & 0,985 & 0,98 & 0,978 & 0,809 & 0,896 & 0,526 & 0,936 \\
\hline
\end{tabular}

\begin{tabular}{|c|c|c|c|c|c|c|c|c|c|c|c|c|c|}
\hline \multicolumn{14}{|c|}{ Pearson korreláció régió (NUTS2) szinten támogatás banrészesültek } \\
\hline & Régió & $\begin{array}{c}\text { Állandó_népess } \\
\text { ég száma } 2008\end{array}$ & pénzkészlet & $\underset{\mathrm{m}}{\text { költségvetési_tá }}$ & szja & teért & sajátbev & helyiadoossz & IPAössz & adóbírság & kamatbev & rövidhitel & hosszúhitel \\
\hline Közép-Magyarország & \multirow{7}{*}{$\begin{array}{c}\text { Állandó_népesség_száma_2 } \\
008\end{array}$} & 1 & 0,485 & 0,938 & 0,874 & 0,69 & 0,791 & 0,503 & 0,48 & 0,746 & 0,324 & 0,456 & 0,76 \\
\hline Közép-Dunántúl & & 1 & 0,79 & 0,982 & 0,974 & 0,868 & 0,975 & 0,942 & 0,914 & 0,914 & 0,638 & 0,256 & 0,787 \\
\hline Nyugat-Magyarország & & 1 & 0,935 & 0,995 & 0,976 & 0,954 & 0,995 & 0,976 & 0,981 & 0,703 & 0,875 & 0,747 & 0,865 \\
\hline Dél-Dunántúl & & 1 & 0,942 & 0,985 & 0,978 & 0,953 & 0,984 & 0,936 & 0,944 & 0,852 & 0,884 & 0,81 & 0,958 \\
\hline Észak-Magyarország & & 1 & 0,889 & 0,993 & 0,991 & 0,949 & 0,994 & 0,975 & 0,974 & 0,786 & 0,94 & 0,397 & 0,965 \\
\hline Észak-Alföld & & 1 & 0,916 & 0,988 & 0,988 & 0,932 & 0,995 & 0,983 & 0,981 & 0,772 & 0,853 & 0,497 & 0,914 \\
\hline Dél-Alföld & & 1 & 0,888 & 0,989 & 0,984 & 0,86 & 0,982 & 0,983 & 0,981 & 0,914 & 0,941 & 0,746 & 0,956 \\
\hline
\end{tabular}




\begin{tabular}{|c|c|c|c|c|c|c|c|c|c|c|c|c|c|}
\hline \multicolumn{14}{|c|}{ Pearson korreláció megye (NUTS3) szinten támogatás ban részesültek } \\
\hline & egye & $\begin{array}{l}\text { Állandó_népess } \\
\text { ég_száma_2008 }\end{array}$ & pénzkészlet & $\begin{array}{c}\text { költségvetési_tá } \\
\mathrm{m}\end{array}$ & szja & teért & sajátbev & helyiadoossz & IPAössz & adóbírság & kamatbev & rövidhitel & hosszúhitel \\
\hline Baranya & \multirow{19}{*}{$\begin{array}{c}\text { Állandó_népesség_száma_2 } \\
008\end{array}$} & 1 & 0,959 & 0,999 & 0,987 & 0,969 & 0,997 & 0,993 & 0,991 & 0,988 & 0,912 & 0,938 & 0,962 \\
\hline Bács-Kiskun & & 1 & 0,889 & 0,983 & 0,974 & 0,95 & 0,996 & 0,984 & 0,983 & 0,894 & 0,945 & 0,426 & 0,976 \\
\hline Békés & & 1 & 0,846 & 0,976 & 0,99 & 0,648 & 0,986 & 0,961 & 0,948 & 0,904 & 0,936 & 0,763 & 0,97 \\
\hline Borsod-Abaúj-Zemplén & & 1 & 0,923 & 0,997 & 0,996 & 0,988 & 0,996 & 0,985 & 0,988 & 0,976 & 0,975 & 0,335 & 0,986 \\
\hline Csongrád & & 1 & 0,926 & 0,999 & 0,996 & 0,995 & 0,997 & 0,991 & 0,989 & 0,989 & 0,978 & 0,898 & 0,978 \\
\hline Fejér & & 1 & 0,987 & 0,993 & 0,983 & 0,985 & 0,995 & 0,99 & 0,988 & 0,987 & 0,974 & 0,023 & 0,988 \\
\hline Györ-Moson-Sopron & & 1 & 0,98 & 0,995 & 0,971 & 0,984 & 0,998 & 0,988 & 0,984 & 0,588 & 0,95 & 0,812 & 0,827 \\
\hline Hajdú-Bihar & & 1 & 0,987 & 0,996 & 0,994 & 0,985 & 0,999 & 0,993 & 0,994 & 0,996 & 0,985 & 0,086 & 0,987 \\
\hline Heves & & 1 & 0,896 & 0,987 & 0,988 & 0,901 & 0,994 & 0,971 & 0,966 & 0,908 & 0,875 & 0,573 & 0,947 \\
\hline Komárom-Es ztergom & & 1 & 0,638 & 0,981 & 0,983 & 0,718 & 0,946 & 0,869 & 0,82 & 0,982 & 0,617 & 0,336 & 0,635 \\
\hline Nógrád & & 1 & 0,946 & 0,963 & 0,996 & 0,45 & 0,999 & 0,977 & 0,985 & 0,897 & 0,949 & 0,936 & 0,914 \\
\hline Pest & & 1 & 0,482 & 0,938 & 0,873 & 0,688 & 0,789 & 0,501 & 0,478 & 0,744 & 0,322 & 0,453 & 0,758 \\
\hline Somogy & & 1 & 0,971 & 0,977 & 0,993 & 0,911 & 0,962 & 0,947 & 0,974 & 0,952 & 0,978 & 0,168 & 0,963 \\
\hline Szabolcs-Szatmár-Bereg & & 1 & 0,766 & 0,985 & 0,991 & 0,983 & 0,998 & 0,986 & 0,985 & 0,983 & 0,732 & 0,944 & 0,945 \\
\hline Jász-Nagykun-Szolnok & & 1 & 0,804 & 0,993 & 0,969 & 0,306 & 0,987 & 0,934 & 0,923 & 0,946 & 0,936 & 0,664 & 0,937 \\
\hline Tolna & & 1 & 0,702 & 0,975 & 0,924 & 0,871 & 0,946 & 0,711 & 0,745 & 0,816 & 0,533 & 0,82 & 0,97 \\
\hline Vas & & 1 & 0,963 & 0,997 & 0,993 & 0,987 & 0,998 & 0,99 & 0,99 & 0,976 & 0,827 & 0,33 & 0,991 \\
\hline Veszprém & & 1 & 0,759 & 0,98 & 0,988 & 0,852 & 0,979 & 0,943 & 0,927 & 0,898 & 0,806 & 0,463 & 0,893 \\
\hline Zala & & 1 & 0,896 & 0,998 & 0,994 & 0,978 & 0,992 & 0,995 & 0,994 & 0,83 & 0,826 & 0,97 & 0,912 \\
\hline
\end{tabular}

\begin{tabular}{|c|c|c|c|c|c|c|c|c|c|c|c|c|c|}
\hline \multicolumn{14}{|c|}{ Pearson korreláció területi elhelyezkedés támogatásban részesültek (saját kategória) } \\
\hline \multicolumn{2}{|r|}{ Területi elhelyezkedés } & Állandó_népess & pénzkészlet & költségvetési_tá & szja & teért & sajátbev & helyiadoossz & IPAössz & adóbírság & kamatbev & rövidhitel & hosszúhitel \\
\hline Nyugat & \multirow{3}{*}{$\begin{array}{c}\text { Állandó_népesség_száma_2 } \\
008\end{array}$} & 1 & 0,929 & 0,989 & 0,969 & 0,909 & 0,986 & 0,952 & 0,955 & 0,742 & 0,886 & 0,757 & 0,881 \\
\hline Közép & & 1 & 0,757 & 0,96 & 0,955 & 0,798 & 0,951 & 0,783 & 0,749 & 0,819 & 0,542 & 0,396 & 0,88 \\
\hline Kelet & & 1 & \begin{tabular}{l|l|}
0,9 \\
\end{tabular} & \begin{tabular}{|c|}
0,987 \\
\end{tabular} & 0,986 & \begin{tabular}{l|l|}
0,902 \\
\end{tabular} & \begin{tabular}{|c|}
0,983 \\
\end{tabular} & 0,983 & 0,981 & 0,825 & 0,889 & 0,582 & 0,927 \\
\hline
\end{tabular}




\section{c) Lineáris regresszió eredményei}

I. Valamennyi települési önkormányzat vizsgálata, terülleti elhelyezkedés figyelembe vétele nélkül

\begin{tabular}{|c|c|c|}
\hline \multicolumn{3}{|c|}{ Modell eredmény } \\
\hline $\begin{array}{c}\text { Iterációk } \\
\text { száma }\end{array}$ & $\mathrm{R}$ & $\mathrm{R}^{2}$ \\
\hline 6 & 0,808 & 0,653 \\
\hline
\end{tabular}

Közelitő egyenlet együtthatói

\begin{tabular}{|c|c|c|c|c|c|c|}
\hline \multirow{2}{*}{$\begin{array}{c}\text { Iterációk } \\
\text { száma }\end{array}$} & \multirow{2}{*}{ Változók } & \multirow{2}{*}{$\begin{array}{c}\text { Együttható } \\
\text { B }\end{array}$} & \multirow{2}{*}{$\begin{array}{l}\text { Standard } \\
\text { hiba }\end{array}$} & \multirow{2}{*}{\begin{tabular}{|c|}
$\begin{array}{c}\text { Standardizált } \\
\text { együttható }\end{array}$ \\
Beta \\
\end{tabular}} & \multirow[t]{2}{*}{$\mathbf{t}$} & \multirow{2}{*}{ Sig. } \\
\hline & & & & & & \\
\hline \multirow{7}{*}{6} & (Constant) & $-14909192,59$ & 3451163,21 & & $-4,320$ & ,000 \\
\hline & költségvetési_tám & 37,720 & 4,415 & ,493 & 8,544 & 000 \\
\hline & szja & 44,433 & 9,007 & ,239 & 4,933 & ,000 \\
\hline & teért & 123,992 & 16,333 & , 160 & 7,592 &, 000 \\
\hline & helyiadoossz & $-22,404$ & 3,141 &,- 188 & $-7,132$ &, 000 \\
\hline & hosszúhitel & 20,153 & 6,372 &, 072 & 3,163 &, 002 \\
\hline & adóbírság & 88,145 & 29,635 &, 052 & 2,974 & ,003 \\
\hline
\end{tabular}




\section{II. a) Eredmények statisztikai nagyrégiók (NUTS1) szerinti bontásban}

\begin{tabular}{|l|c|r|r|}
\hline \multicolumn{4}{|c|}{ Modell eredmények } \\
\hline $\begin{array}{l}\text { Nagyrégió } \\
\text { megnevezése }\end{array}$ & $\begin{array}{c}\text { Iterációk } \\
\text { száma }\end{array}$ & \multicolumn{1}{c|}{$\mathrm{R}$} & \multicolumn{1}{c|}{$\mathrm{R}^{2}$} \\
\hline $\begin{array}{l}\text { Közép- } \\
\text { Magyarország }\end{array}$ & 5 & 0,837 & 0,700 \\
\hline Dunántúl & 9 & 0,783 & 0,613 \\
\hline Alföld és Észak & 7 & 0,872 & 0,761 \\
\hline
\end{tabular}

Közelitö egyenlet együtthatói

\begin{tabular}{|c|c|c|c|c|c|c|c|}
\hline \multirow{2}{*}{$\begin{array}{c}\text { Nagyrégió } \\
\text { megnevezése }\end{array}$} & \multirow{2}{*}{$\begin{array}{l}\text { Iterációk } \\
\text { száma }\end{array}$} & \multirow[t]{2}{*}{ Változók } & Együttható & \multirow[t]{2}{*}{ Standard hiba } & \begin{tabular}{|c|}
$\begin{array}{c}\text { Standardizált } \\
\text { együttható }\end{array}$ \\
\end{tabular} & \multirow[t]{2}{*}{$\mathbf{t}$} & \multirow[t]{2}{*}{ Sig. } \\
\hline & & & B & & Beta & & \\
\hline \multirow{6}{*}{$\begin{array}{l}\text { Közép- } \\
\text { Magyarország }\end{array}$} & \multirow{6}{*}{5} & (Constant) & $-46986285,97$ & 15372745,51 & & $-3,056$ & ,003 \\
\hline & & adóbírság & 3458,514 & 204,107 & 1,022 & 16,945 &, 000 \\
\hline & & kamatbev & $-740,639$ & 79,738 &,- 554 & $-9,288$ & ,000 \\
\hline & & pénzkészlet & $-24,685$ & 10,864 &,- 126 & $-2,272$ & ,024 \\
\hline & & teért & 310,275 & 74,642 & ,265 & 4,157 &, 000 \\
\hline & & hosszúhitel & $-48,310$ & 16,693 &,- 166 & $-2,894$ &, 004 \\
\hline \multirow{8}{*}{ Dunántúl } & \multirow{8}{*}{9} & (Constant) & $-290174,39$ & 3556695,50 & &,- 082 & ,935 \\
\hline & & teért & 203,160 & 18,404 & ,387 & 11,039 &, 000 \\
\hline & & hosszúhitel & 61,014 & 7,402 & ,257 & 8,243 &, 000 \\
\hline & & rövidhitel & 62,627 & 18,585 & ,074 & 3,370 & ,001 \\
\hline & & szja & $-40,009$ & 13,507 &,- 211 & $-2,962$ & ,003 \\
\hline & & költségvetési_tám & 21,282 & 5,944 & ,312 & 3,581 & ,000 \\
\hline & & sajátbev & 21,971 & 5,151 & ,599 & 4,265 &, 000 \\
\hline & & helyiadoossz & $-56,690$ & 7,901 &,- 623 & $-7,175$ &, 000 \\
\hline
\end{tabular}




\begin{tabular}{|c|c|c|c|c|c|c|c|}
\hline \multirow{2}{*}{$\begin{array}{l}\text { Nagyrégió } \\
\text { megnevezése }\end{array}$} & \multirow{2}{*}{$\begin{array}{c}\text { Iterációk } \\
\text { száma }\end{array}$} & \multirow[t]{2}{*}{ Változók } & Együttható & \multirow[t]{2}{*}{ Standard hiba } & $\begin{array}{c}\text { Standardizált } \\
\text { együittható }\end{array}$ & \multirow[t]{2}{*}{$\mathbf{t}$} & \multirow[t]{2}{*}{ Sig. } \\
\hline & & & B & & Beta & & \\
\hline \multirow{8}{*}{ Alföld és Észak } & \multirow{8}{*}{7} & (Constant) & $-7128132,02$ & 6240678,24 & & $-1,142$ & ,254 \\
\hline & & adóbírság & 473,592 & 58,186 & 239 & 8,139 &, 000 \\
\hline & & kamatbev & $-1111,161$ & 147,028 &,- 363 & $-7,557$ &, 000 \\
\hline & & pénzkészlet & 98,280 & 11,119 & ,317 & 8,839 &, 000 \\
\hline & & hosszúhitel & 75,364 & 14,563 & 244 & 5,175 &, 000 \\
\hline & & szja & $-37,750$ & 16,784 &,- 206 & $-2,249$ &, 025 \\
\hline & & költségvetési_tám & 65,940 & 7,915 & 845 & 8,331 & ,000 \\
\hline & & sajátbev & $-8,296$ & 3,493 &,- 175 & $-2,375$ & ,018 \\
\hline
\end{tabular}




\section{II. b) Eredmények Statisztikai régiók (NUTS2) szerinti bontásban}

\begin{tabular}{|l|c|c|c|}
\hline \multicolumn{4}{|c|}{ Modell eredmények } \\
\hline Régió megnevezése & $\begin{array}{c}\text { Iterációk } \\
\text { száma }\end{array}$ & \multicolumn{1}{c|}{$\mathrm{R}$} & \multicolumn{1}{c|}{$\mathrm{R}^{2}$} \\
\hline $\begin{array}{l}\text { Közép- } \\
\text { Magyarország }\end{array}$ & 5 & 0,837 & 0,700 \\
\hline Közép-Dunántúl & 4 & 0,688 & 0,473 \\
\hline $\begin{array}{l}\text { Nyugat- } \\
\text { Magyarország }\end{array}$ & 9 & 0,964 & 0,929 \\
\hline Dél-Dunántúl & 10 & 0,945 & 0,894 \\
\hline Észak-Magyarország & 9 & 0,927 & 0,859 \\
\hline Észak-Alföld & 11 & 0,960 & 0,922 \\
\hline Dél-Alföld & 6 & 0,826 & 0,681 \\
\hline
\end{tabular}

Közelitő egyenlet együtthatói

\begin{tabular}{|c|c|c|c|c|c|c|c|}
\hline \multirow[t]{2}{*}{ Régió megnevezése } & \multirow{2}{*}{$\begin{array}{l}\text { Iterációk } \\
\text { száma }\end{array}$} & \multirow[t]{2}{*}{ Változók } & Együttható & \multirow{2}{*}{$\begin{array}{l}\text { Standard } \\
\text { hiba }\end{array}$} & \begin{tabular}{|c|}
$\begin{array}{c}\text { Standardizált } \\
\text { együittható }\end{array}$ \\
\end{tabular} & \multirow[t]{2}{*}{$\mathbf{t}$} & \multirow[t]{2}{*}{ Sig. } \\
\hline & & & B & & Beta & & \\
\hline \multirow{6}{*}{$\begin{array}{l}\text { Közép- } \\
\text { Magyarország }\end{array}$} & \multirow{6}{*}{5} & (Constant) & $-46986285,97$ & 15372745,51 & & $-3,056$ & ,003 \\
\hline & & adóbírság & 3458,514 & 204,107 & 1,022 & 16,945 & ,000 \\
\hline & & kamatbev & $-740,639$ & 79,738 &,- 554 & $-9,288$ & ,000 \\
\hline & & pénzkészlet & $-24,685$ & 10,864 &,- 126 & $-2,272$ & ,024 \\
\hline & & teért & 310,275 & 74,642 & ,265 & 4,157 &, 000 \\
\hline & & hosszúhitel & $-48,310$ & 16,693 &,- 166 & $-2,894$ & ,004 \\
\hline
\end{tabular}




\begin{tabular}{|c|c|c|c|c|c|c|c|}
\hline \multirow{2}{*}{ Régió megnevezése } & \multirow{2}{*}{$\begin{array}{c}\text { Iterációk } \\
\text { száma }\end{array}$} & \multirow{2}{*}{ Változók } & Együttható & \multirow{2}{*}{$\begin{array}{l}\text { Standard } \\
\text { hiba }\end{array}$} & \begin{tabular}{|c|}
$\begin{array}{c}\text { Standardizált } \\
\text { együittható }\end{array}$ \\
\end{tabular} & \multirow[t]{2}{*}{$\mathbf{t}$} & \multirow{2}{*}{ Sig. } \\
\hline & & & B & & Beta & & \\
\hline \multirow{5}{*}{ Közép-Dunántúl } & \multirow{5}{*}{4} & (Constant) & $-14497555,47$ & 12348681,17 & & $-1,174$ & ,241 \\
\hline & & teért & 474,613 & 48,053 & ,788 & 9,877 &, 000 \\
\hline & & rövidhitel & 438,787 & 72,671 & ,244 & 6,038 &, 000 \\
\hline & & IPAössz & $-118,904$ & 31,603 & $-1,303$ & $-3,762$ &, 000 \\
\hline & & helyiadoossz & 112,207 & 35,582 & 1,073 & 3,153 & ,002 \\
\hline \multirow{8}{*}{$\begin{array}{l}\text { Nyugat- } \\
\text { Magyarország }\end{array}$} & \multirow{8}{*}{9} & (Constant) & $-3075584,46$ & 1299677,18 & & $-2,366$ & ,018 \\
\hline & & adóbírság & $-40,516$ & 11,815 &,- 074 & $-3,429$ & ,001 \\
\hline & & kamatbev & $-209,765$ & 72,436 &,- 124 & $-2,896$ &, 004 \\
\hline & & pénzkészlet & $-85,733$ & 9,147 &,- 687 & $-9,373$ &, 000 \\
\hline & & teért & $-52,801$ & 13,618 &,- 125 & $-3,877$ & ,000 \\
\hline & & IPAössz & 128,977 & 8,076 & 2,881 & 15,970 & ,000 \\
\hline & & helyiadoossz & $-155,115$ & 8,483 & $-3,402$ & $-18,286$ &, 000 \\
\hline & & sajátbev & 42,371 & 1,740 & 2,291 & 24,354 & ,000 \\
\hline \multirow{9}{*}{ Dél-Dunántúl } & \multirow{9}{*}{10} & (Constant) & $-2549261,38$ & 3096598,04 & &,- 823 & ,411 \\
\hline & & kamatbev & 876,479 & 186,862 & 237 & 4,691 & ,000 \\
\hline & & pénzkészlet & $-52,138$ & 14,654 &,- 237 & $-3,558$ &, 000 \\
\hline & & teért & 93,098 & 19,945 & , 193 & 4,668 & ,000 \\
\hline & & hosszúhitel & 79,251 & 11,225 & ,371 & 7,060 &, 000 \\
\hline & & rövidhitel & 89,460 & 17,411 & , 139 & 5,138 &, 000 \\
\hline & & IPAössz & $-53,913$ & 5,989 &,- 422 & $-9,002$ & ,000 \\
\hline & & költségvetési_tám & 75,626 & 6,790 & 1,106 & 11,137 & ,000 \\
\hline & & szja & $-72,162$ & 14,637 &,- 423 & $-4,930$ & ,000 \\
\hline
\end{tabular}




\begin{tabular}{|c|c|c|c|c|c|c|c|}
\hline \multirow{2}{*}{ Régió megnevezése } & \multirow{2}{*}{$\begin{array}{l}\text { Iterációk } \\
\text { száma }\end{array}$} & \multirow{2}{*}{ Változók } & Együttható & \multirow{2}{*}{$\begin{array}{l}\text { Standard } \\
\text { hiba }\end{array}$} & \multirow{2}{*}{\begin{tabular}{|c|}
$\begin{array}{c}\text { Standardizált } \\
\text { együ̈ttható }\end{array}$ \\
Beta
\end{tabular}} & \multirow[t]{2}{*}{$\mathbf{t}$} & \multirow[t]{2}{*}{ Sig. } \\
\hline & & & $\mathbf{B}$ & & & & \\
\hline \multirow{10}{*}{ Észak-Magyarország } & \multirow{10}{*}{9} & (Constant) & $-37818763,41$ & 6620212,65 & & $-5,713$ &, 000 \\
\hline & & adóbírság & $-258,046$ & 81,754 &,- 108 & $-3,156$ &, 002 \\
\hline & & kamatbev & $-971,183$ & 478,944 &,- 172 & $-2,028$ &, 043 \\
\hline & & pénzkészlet & 114,975 & 27,166 & ,286 & 4,232 &, 000 \\
\hline & & teért & $-182,892$ & 85,329 &,- 109 & $-2,143$ & ,032 \\
\hline & & rövidhitel & $-81,801$ & 22,708 &,- 073 & $-3,602$ &, 000 \\
\hline & & IPAössz & 270,571 & 76,184 & 1,233 & 3,552 & ,000 \\
\hline & & helyiadoossz & $-517,366$ & 78,294 & $-2,400$ & $-6,608$ &, 000 \\
\hline & & sajátbev & 225,947 & 12,653 & 3,244 & 17,857 &, 000 \\
\hline & & szja & $-258,992$ & 20,858 & $-1,144$ & $-12,417$ & ,000 \\
\hline \multirow{8}{*}{ Észak-Alföld } & \multirow{8}{*}{11} & (Constant) & $-2019073,00$ & 7037453,06 & &,- 287 & ,774 \\
\hline & & kamatbev & 1160,913 & 156,072 & ,368 & 7,438 & ,000 \\
\hline & & pénzkészlet & $-144,097$ & 15,647 &,- 541 & $-9,209$ &, 000 \\
\hline & & teért & 408,433 & 52,330 & ,492 & 7,805 & ,000 \\
\hline & & IPAössz & $-124,091$ & 18,495 &,- 930 & $-6,710$ & ,000 \\
\hline & & költségvetési_tám & 34,945 & \begin{tabular}{l|l}
11,511 \\
\end{tabular} & ,501 & 3,036 & ,003 \\
\hline & & sajátbev & 79,532 & 9,068 & 1,783 & 8,771 &, 000 \\
\hline & & szja & $-120,114$ & 28,525 &,- 717 & $-4,211$ &, 000 \\
\hline \multirow{5}{*}{ Dél-Alföld } & \multirow{5}{*}{6} & (Constant) & $-45141153,08$ & 15652889,82 & & $-2,884$ & ,004 \\
\hline & & kamatbev & $-1227,144$ & 269,429 &,- 673 & $-4,555$ & ,000 \\
\hline & & pénzkészlet & 105,529 & 29,157 & ,404 & 3,619 & ,000 \\
\hline & & rövidhitel & 104,387 & \begin{tabular}{|l|}
51,052 \\
\end{tabular} & ,163 & 2,045 & ,042 \\
\hline & & szja & 138,392 & 11,499 & ,918 & 12,035 &, 000 \\
\hline
\end{tabular}




\section{II. c) Saját besorolás szerinti bontásban}

\begin{tabular}{|l|c|c|c|}
\hline \multicolumn{4}{|c|}{ Modell eredmények } \\
\hline $\begin{array}{l}\text { Saját bontás (területi } \\
\text { elhelyezkedés) }\end{array}$ & $\begin{array}{c}\text { Iterációk } \\
\text { száma }\end{array}$ & $\mathrm{R}$ & $\mathrm{R}^{2}$ \\
\hline Nyugat & 8 & 0,946 & 0,895 \\
\hline Közép & 10 & 0,841 & 0,707 \\
\hline Kelet & 3 & 0,884 & 0,781 \\
\hline
\end{tabular}

Közelítő egyenlet együtthatói

\begin{tabular}{|c|c|c|c|c|c|c|c|}
\hline \multirow{2}{*}{$\begin{array}{l}\text { Nagyrégió } \\
\text { megnevezése }\end{array}$} & \multirow{2}{*}{$\begin{array}{c}\text { Iterációk } \\
\text { száma }\end{array}$} & \multirow[t]{2}{*}{ Változók } & Együttható & \multirow{2}{*}{ Standard hiba } & $\begin{array}{c}\begin{array}{c}\text { Standardizált } \\
\text { együittható }\end{array} \\
\end{array}$ & \multirow[t]{2}{*}{$\mathbf{t}$} & \multirow[t]{2}{*}{ Sig. } \\
\hline & & & B & & Beta & & \\
\hline \multirow{9}{*}{ Nyugat } & \multirow{9}{*}{8} & (Constant) & 1813175,44 & 1590467,99 & & 1,140 & ,254 \\
\hline & & hosszúhitel & 107,652 & 5,392 & ,516 & 19,965 &, 000 \\
\hline & & teért & 148,210 & 11,940 & ,332 & 12,413 &, 000 \\
\hline & & költségvetési_tám & 59,044 & 2,922 & 1,100 & 20,210 & ,000 \\
\hline & & helyiadoossz & $-48,804$ & 4,671 &,- 618 & $-10,448$ &, 000 \\
\hline & & szja & $-70,246$ & 6,783 &,- 475 & $-10,356$ & ,000 \\
\hline & & pénzkészlet & $-45,730$ & 4,439 &,- 255 & $-10,302$ &, 000 \\
\hline & & adóbírság & $-85,230$ & 16,083 &,- 088 & $-5,299$ & ,000 \\
\hline & & sajátbev & 11,329 & 2,723 & ,385 & 4,161 &, 000 \\
\hline
\end{tabular}




\begin{tabular}{|c|c|c|c|c|c|c|c|}
\hline \multirow{2}{*}{$\begin{array}{l}\text { Nagyrégió } \\
\text { megnevezése }\end{array}$} & \multirow{2}{*}{$\begin{array}{c}\text { Iterációk } \\
\text { száma }\end{array}$} & \multirow{2}{*}{ Változók } & Együttható & \multirow{2}{*}{ Standard hiba } & $\begin{array}{c}\text { Standardizált } \\
\text { együttható }\end{array}$ & \multirow[t]{2}{*}{$\mathbf{t}$} & \multirow{2}{*}{ Sig. } \\
\hline & & & B & & Beta & & \\
\hline \multirow{9}{*}{ Közép } & \multirow{9}{*}{10} & (Constant) & $-53224897,23$ & 6917231,70 & & $-7,695$ &, 000 \\
\hline & & hosszúhitel & $-82,851$ & 12,008 &,- 243 & $-6,900$ &, 000 \\
\hline & & költségvetési_tám & 30,825 & 7,548 & ,305 & 4,084 &, 000 \\
\hline & & helyiadoossz & $-79,957$ & 26,778 &,- 603 & $-2,986$ &, 003 \\
\hline & & szja & $-244,687$ & 20,357 & $-1,024$ & $-12,020$ & ,000 \\
\hline & & pénzkészlet & 93,140 & 11,710 & 307 & 7,954 &, 000 \\
\hline & & adóbírság & $-169,515$ & 75,152 &,- 072 & $-2,256$ &, 024 \\
\hline & & sajátbev & 188,541 & 8,274 & 3,165 & 22,788 &, 000 \\
\hline & & IPAössz & $-173,671$ & 23,747 & $-1,442$ & $-7,313$ &, 000 \\
\hline \multirow{4}{*}{ Kelet } & \multirow{4}{*}{3} & (Constant) & $-14182002,33$ & 7553153,07 & & $-1,878$ & ,061 \\
\hline & & \begin{tabular}{|l|} 
hosszúhitel \\
\end{tabular} & 99,841 & 14,066 & ,387 & 7,098 & ,000 \\
\hline & & költségvetési_tám & 52,772 & 2,544 & ,770 & 20,742 & ,000 \\
\hline & & kamatbev & $-671,713$ & 112,673 &,- 283 & $-5,962$ & ,000 \\
\hline
\end{tabular}




\begin{tabular}{|c|c|c|}
\hline \multicolumn{3}{|c|}{ Modell eredmény } \\
\hline $\begin{array}{c}\text { Iterációk } \\
\text { száma }\end{array}$ & $\mathrm{R}$ & $\mathrm{R}^{2}$ \\
\hline 5 & 0,807 & 0,652 \\
\hline
\end{tabular}

Közelitö egyenlet együtthatói

\begin{tabular}{|c|c|c|c|c|c|c|}
\hline \multirow{2}{*}{$\begin{array}{c}\text { Iterációk } \\
\text { száma }\end{array}$} & \multirow{2}{*}{ Változók } & Együttható & \multirow{2}{*}{$\begin{array}{l}\text { Standard } \\
\text { hiba }\end{array}$} & \begin{tabular}{|c|}
$\begin{array}{c}\text { Standardizált } \\
\text { együttható }\end{array}$ \\
\end{tabular} & \multirow[t]{2}{*}{$\mathbf{t}$} & \multirow[t]{2}{*}{ Sig. } \\
\hline & & $\mathbf{B}$ & & Beta & & \\
\hline \multirow{6}{*}{5} & (Constant) & 2652786,80 & 9708292,87 & & ,273 &, 785 \\
\hline & szja & 68,175 & 15,247 & ,359 & 4,471 &, 000 \\
\hline & teért & 154,596 & 28,469 & ,200 & 5,430 &, 000 \\
\hline & költségvetési_tám & 28,698 & 7,679 &, 372 & 3,737 &, 000 \\
\hline & IPAössz & $-19,266$ & 4,988 &,- 170 & $-3,862$ &, 000 \\
\hline & adóbírság & 108,380 & 49,682 & ,064 & 2,181 & ,029 \\
\hline
\end{tabular}




\section{Csak a támogatást elnyert települési önkormányzatok vizsgálata a területi elhelyezkedés figyelembe vételével}

\section{IV. a) Statisztikai nagyrégiók (NUTS1) szerinti bontásban}

\begin{tabular}{|l|c|r|r|}
\hline \multicolumn{4}{|c|}{ Modell eredmények } \\
\hline $\begin{array}{l}\text { Nagyrégió } \\
\text { megnevezése }\end{array}$ & $\begin{array}{c}\text { Iterációk } \\
\text { száma }\end{array}$ & $\mathrm{R}$ & $\mathrm{R}^{2}$ \\
\hline $\begin{array}{l}\text { Közép- } \\
\text { Magyarország }\end{array}$ & 4 & 0,864 & 0,747 \\
\hline Dunántúl & 5 & 0,788 & 0,621 \\
\hline Alföld és Észak & 6 & 0,870 & 0,757 \\
\hline
\end{tabular}

Közelítö egyenlet együtthatói

\begin{tabular}{|c|c|c|c|c|c|c|c|}
\hline \multirow{2}{*}{$\begin{array}{c}\text { Nagyrégió } \\
\text { megnevezése }\end{array}$} & \multirow{2}{*}{$\begin{array}{c}\text { Iterációk } \\
\text { száma }\end{array}$} & \multirow[t]{2}{*}{ Változók } & Együttható & \multirow[t]{2}{*}{ Standard hiba } & \begin{tabular}{|c|}
$\begin{array}{c}\text { Standardizált } \\
\text { együttható }\end{array}$ \\
\end{tabular} & \multirow[t]{2}{*}{$\mathbf{t}$} & \multirow[t]{2}{*}{ Sig. } \\
\hline & & & B & & Beta & & \\
\hline \multirow{5}{*}{$\begin{array}{l}\text { Közép- } \\
\text { Magyarország }\end{array}$} & \multirow{5}{*}{4} & (Constant) & $-43798016,85$ & 41258426,79 & & $-1,062$ & ,292 \\
\hline & & adóbírság & 3853,900 & 331,362 & 1,067 & 11,630 & ,000 \\
\hline & & kamatbev & $-903,157$ & 119,094 &,- 682 & $-7,584$ &, 000 \\
\hline & & hosszúhitel & $-92,623$ & 28,562 &,- 271 & $-3,243$ &, 002 \\
\hline & & teért & 369,111 & 130,087 & ,288 & 2,837 & ,006 \\
\hline \multirow{6}{*}{ Dunántúl } & \multirow{6}{*}{5} & (Constant) & 20510244,92 & 11793742,52 & & 1,739 & ,083 \\
\hline & & hosszúhitel & 55,977 & 13,135 & ,234 & 4,262 & ,000 \\
\hline & & teért & 262,216 & 34,586 & ,495 & 7,582 & ,000 \\
\hline & & rövidhitel & 76,539 & 34,804 &, 088 & 2,199 & ,028 \\
\hline & & IPAössz & $-39,295$ & 9,105 &,- 463 & $-4,316$ &, 000 \\
\hline & & sajátbev & 16,888 & 4,928 & ,456 & 3,427 & ,001 \\
\hline
\end{tabular}




\begin{tabular}{|c|c|c|c|c|c|c|c|}
\hline \multirow{2}{*}{$\begin{array}{l}\text { Nagyrégió } \\
\text { megnevezése }\end{array}$} & \multirow{2}{*}{$\begin{array}{c}\text { Iterációk } \\
\text { száma }\end{array}$} & \multirow{2}{*}{ Változók } & Együttható & \multirow{2}{*}{ Standard hiba } & $\begin{array}{c}\text { Standardizált } \\
\text { együttható }\end{array}$ & \multirow[t]{2}{*}{$\mathbf{t}$} & \multirow{2}{*}{ Sig. } \\
\hline & & & B & & Beta & & \\
\hline \multirow{7}{*}{ Alföld és Észak } & \multirow{7}{*}{6} & (Constant) & 24947414,68 & 14056282,19 & & 1,775 &, 076 \\
\hline & & adóbírság & 441,149 & 86,617 & ,225 & 5,093 &, 000 \\
\hline & & kamatbev & $-1276,355$ & 202,363 &,- 421 & $-6,307$ &, 000 \\
\hline & & hosszúhitel & 83,504 & 21,522 & ,273 & 3,880 & ,000 \\
\hline & & költségvetési_tám & 64,345 & 11,017 & 824 & 5,840 & ,000 \\
\hline & & pénzkészlet & 104,255 & 17,023 & ,336 & 6,125 & ,000 \\
\hline & & szja & $-63,230$ & 28,194 &,- 342 & $-2,243$ & ,025 \\
\hline
\end{tabular}




\section{IV. b) Statisztikai régiók (NUTS2) szerinti bontásban}

\begin{tabular}{|l|c|r|r|}
\hline \multicolumn{4}{|c|}{ Modell eredmények } \\
\hline Régió megnevezése & $\begin{array}{c}\text { Iterációk } \\
\text { száma }\end{array}$ & \multicolumn{1}{c|}{$\mathrm{R}$} & \multicolumn{1}{|c|}{$\mathrm{R}^{2}$} \\
\hline $\begin{array}{l}\text { Közép- } \\
\text { Magyarország }\end{array}$ & 4 & 0,864 & 0,747 \\
\hline Közép-Dunántúl & 4 & 0,698 & 0,487 \\
\hline $\begin{array}{l}\text { Nyugat- } \\
\text { Magyarország }\end{array}$ & 11 & 0,972 & 0,945 \\
\hline Dél-Dunántúl & 5 & 0,955 & 0,911 \\
\hline Észak-Magyarország & 7 & 0,948 & 0,899 \\
\hline Észak-Alföld & 4 & 0,956 & 0,914 \\
\hline Dél-Alföld & 2 & 0,807 & 0,652 \\
\hline
\end{tabular}

Közelitő egyenlet együtthatói

\begin{tabular}{|c|c|c|c|c|c|c|c|}
\hline \multirow[t]{2}{*}{ Régió megnevezése } & \multirow{2}{*}{$\begin{array}{c}\text { Iterációk } \\
\text { száma }\end{array}$} & \multirow[t]{2}{*}{ Változók } & \multirow{2}{*}{$\begin{array}{c}\text { Együittható } \\
\text { B }\end{array}$} & \multirow{2}{*}{$\begin{array}{l}\text { Standard } \\
\text { hiba }\end{array}$} & \multirow{2}{*}{\begin{tabular}{|c|}
$\begin{array}{c}\text { Standardizált } \\
\text { együttható }\end{array}$ \\
Beta
\end{tabular}} & \multirow[t]{2}{*}{$\mathbf{t}$} & \multirow[t]{2}{*}{ Sig. } \\
\hline & & & & & & & \\
\hline \multirow{5}{*}{$\begin{array}{l}\text { Közép- } \\
\text { Magyarország }\end{array}$} & \multirow{5}{*}{4} & (Constant) & $-43798016,85$ & 41258426,79 & & $-1,062$ & 292 \\
\hline & & adóbírság & 3853,900 & 331,362 & 1,067 & 11,630 & 000 \\
\hline & & kamatbev & $-903,157$ & 119,094 &,- 682 & $-7,584$ & 000 \\
\hline & & hosszúhitel & $-92,623$ & 28,562 &,- 271 & $-3,243$ & ,002 \\
\hline & & teért & 369,111 & 130,087 & ,288 & 2,837 & ,006 \\
\hline \multirow{5}{*}{ Közép-Dunántúl } & \multirow{5}{*}{4} & (Constant) & $-2904781,87$ & 38502283,75 & &,- 075 & 940 \\
\hline & & teért & 538,638 & 87,973 & ,890 & 6,123 & 000 \\
\hline & & rövidhitel & 509,825 & 136,218 & ,260 & 3,743 & 000 \\
\hline & & IPAössz & $-151,670$ & 57,855 & $-1,655$ & $-2,622$ & ,010 \\
\hline & & helyiadoossz & 139,127 & 64,368 & 1,318 & 2,161 & 033 \\
\hline
\end{tabular}




\begin{tabular}{|c|c|c|c|c|c|c|c|}
\hline \multirow[t]{2}{*}{ Régió megnevezése } & \multirow{2}{*}{$\begin{array}{c}\text { Iterációk } \\
\text { száma }\end{array}$} & \multirow[t]{2}{*}{ Változók } & \multirow{2}{*}{\begin{tabular}{c|} 
Együttható \\
B
\end{tabular}} & \multirow{2}{*}{$\begin{array}{l}\text { Standard } \\
\text { hiba }\end{array}$} & \multirow{2}{*}{\begin{tabular}{|c|}
$\begin{array}{c}\text { Standardizált } \\
\text { együ̈ttható }\end{array}$ \\
Beta
\end{tabular}} & \multirow[t]{2}{*}{$\mathbf{t}$} & \multirow[t]{2}{*}{ Sig. } \\
\hline & & & & & & & \\
\hline \multirow{6}{*}{$\begin{array}{l}\text { Nyugat- } \\
\text { Magyarország }\end{array}$} & \multirow{6}{*}{11} & (Constant) & 7323127,86 & 3906319,30 & & 1,875 & ,062 \\
\hline & & kamatbev & $-232,207$ & 114,365 &,- 133 & $-2,030$ &, 044 \\
\hline & & IPAössz & 166,042 & 15,086 & 3,737 & 11,006 &, 000 \\
\hline & & helyiadoossz & $-184,068$ & 14,042 & $-4,068$ & $-13,108$ &, 000 \\
\hline & & pénzkészlet & $-82,481$ & 13,410 &,- 651 & $-6,151$ & ,000 \\
\hline & & sajátbev & 35,480 & 2,763 & 1,920 & 12,843 & ,000 \\
\hline \multirow{6}{*}{ Dél-Dunántúl } & \multirow{6}{*}{5} & (Constant) & 11066520,41 & 10450716,70 & & 1,059 & ,291 \\
\hline & & hosszúhitel & 145,990 & 19,919 & ,683 & 7,329 &, 000 \\
\hline & & helyiadoossz & $-49,207$ & 13,647 &,- 385 & $-3,606$ &, 000 \\
\hline & & pénzkészlet & $-64,125$ & 18,387 &,- 293 & $-3,488$ & ,001 \\
\hline & & sajátbev & 17,279 & 7,668 & ,408 & 2,253 & ,026 \\
\hline & & költségvetési_tám & 35,048 & 8,662 & ,510 & 4,046 & ,000 \\
\hline \multirow{8}{*}{ Észak-Magyarország } & \multirow{8}{*}{7} & (Constant) & $-8515454,65$ & 16866337,24 & &,- 505 & ,614 \\
\hline & & adóbírság & $-389,836$ & 111,557 &,- 164 & $-3,494$ & ,001 \\
\hline & & rövidhitel & $-80,675$ & 29,562 &,- 072 & $-2,729$ & ,007 \\
\hline & & IPAössz & 583,593 & 119,522 & 2,437 & 4,883 & ,000 \\
\hline & & helyiadoossz & $-797,290$ & 115,149 & $-3,433$ & $-6,924$ & ,000 \\
\hline & & szja & $-252,642$ & 42,604 & $-1,112$ & $-5,930$ &, 000 \\
\hline & & sajátbev & 262,912 & 25,391 & 3,737 & 10,354 & ,000 \\
\hline & & költségvetési_tám & $-57,586$ & 23,875 &,- 604 & $-2,412$ & ,017 \\
\hline
\end{tabular}




\begin{tabular}{|c|c|c|c|c|c|c|c|}
\hline \multirow{2}{*}{ Régió megnevezése } & \multirow{2}{*}{$\begin{array}{l}\text { Iterációk } \\
\text { száma }\end{array}$} & \multirow{2}{*}{ Változók } & Együittható & \multirow{2}{*}{$\begin{array}{l}\text { Standard } \\
\text { hiba }\end{array}$} & $\begin{array}{c}\text { Standardizált } \\
\text { együittható }\end{array}$ & \multirow[t]{2}{*}{$\mathbf{t}$} & \multirow{2}{*}{ Sig. } \\
\hline & & & B & & Beta & & \\
\hline \multirow{5}{*}{ Észak-Alföld } & \multirow{5}{*}{4} & (Constant) & 18529049,67 & 13830128,10 & & 1,340 & , 182 \\
\hline & & adóbírság & 755,772 & 113,762 & ,324 & 6,643 &, 000 \\
\hline & & teért & 172,575 & 57,780 & ,212 & 2,987 &, 003 \\
\hline & & IPAössz & $-46,553$ & 17,581 &,- 354 & $-2,648$ & ,009 \\
\hline & & sajátbev & 36,995 & 6,812 & ,836 & 5,431 & ,000 \\
\hline \multirow{3}{*}{ Dél-Alföld } & \multirow{3}{*}{2} & (Constant) & $-25907221,86$ & 30115343,80 & &,- 860 & ,391 \\
\hline & & szja & 180,343 & 24,194 & 1,195 & 7,454 & ,000 \\
\hline & & sajátbev & $-13,460$ & 5,139 &,- 420 & $-2,619$ &, 010 \\
\hline
\end{tabular}




\section{$I V$. c) Saját besorolás szerinti bontásban}

\begin{tabular}{|l|c|c|c|}
\hline \multicolumn{4}{|c|}{ Modell eredmények } \\
\hline $\begin{array}{l}\text { Saját bontás (területi } \\
\text { elhelyezkedés) }\end{array}$ & $\begin{array}{c}\text { Iterációk } \\
\text { száma }\end{array}$ & $\mathrm{R}$ & $\mathrm{R}^{2}$ \\
\hline Nyugat & 8 & 0,958 & 0,918 \\
\hline Közép & 9 & 0,865 & 0,748 \\
\hline Kelet & 7 & 0,894 & 0,799 \\
\hline
\end{tabular}

Közelitő egyenlet együtthatói

\begin{tabular}{|c|c|c|c|c|c|c|c|}
\hline \multirow{2}{*}{$\begin{array}{l}\text { Nagyrégió } \\
\text { megnevezése }\end{array}$} & \multirow{2}{*}{$\begin{array}{c}\text { Iterációk } \\
\text { száma }\end{array}$} & \multirow[t]{2}{*}{ Változók } & Együttható & \multirow{2}{*}{ Standard hiba } & $\begin{array}{c}\begin{array}{c}\text { Standardizált } \\
\text { együittható }\end{array} \\
\end{array}$ & \multirow[t]{2}{*}{$\mathbf{t}$} & \multirow[t]{2}{*}{ Sig. } \\
\hline & & & B & & Beta & & \\
\hline \multirow{9}{*}{ Nyugat } & \multirow{9}{*}{8} & (Constant) & 17881199,16 & 5425919,83 & & 3,296 &, 001 \\
\hline & & hosszúhitel & 106,119 & 11,057 & ,506 & 9,597 &, 000 \\
\hline & & teért & 169,458 & 22,381 & 375 & 7,572 & ,000 \\
\hline & & költségvetési_tám & 70,233 & 5,899 & 1,304 & 11,907 & ,000 \\
\hline & & helyiadoossz & $-37,976$ & 4,737 &,- 484 & $-8,017$ & ,000 \\
\hline & & pénzkészlet & $-75,804$ & 10,848 &,- 418 & $-6,988$ & ,000 \\
\hline & & szja & $-58,945$ & 12,431 &,- 389 & $-4,742$ & ,000 \\
\hline & & adóbírság & $-92,469$ & 30,936 &,- 097 & $-2,989$ & ,003 \\
\hline & & kamatbev & 302,983 & 128,543 &, 111 & 2,357 & ,019 \\
\hline
\end{tabular}




\begin{tabular}{|c|c|c|c|c|c|c|c|}
\hline \multirow{2}{*}{$\begin{array}{l}\text { Nagyrégió } \\
\text { megnevezése }\end{array}$} & \multirow{2}{*}{$\begin{array}{c}\text { Iterációk } \\
\text { száma }\end{array}$} & \multirow{2}{*}{ Változók } & Együttható & \multirow{2}{*}{ Standard hiba } & \begin{tabular}{|c|}
$\begin{array}{c}\text { Standardizált } \\
\text { együittható }\end{array}$ \\
\end{tabular} & \multirow[t]{2}{*}{$\mathbf{t}$} & \multirow[t]{2}{*}{ Sig. } \\
\hline & & & B & & Beta & & \\
\hline \multirow{8}{*}{ Közép } & \multirow{8}{*}{9} & (Constant) & $-58405407,75$ & 16914781,308 & & $-3,453$ & ,001 \\
\hline & & hosszúhitel & $-104,119$ & 19,548 &,- 298 & $-5,326$ &, 000 \\
\hline & & pénzkészlet & 119,297 & 18,317 & ,384 & 6,513 &, 000 \\
\hline & & szja & $-291,245$ & 28,024 & $-1,192$ & $-10,393$ &, 000 \\
\hline & & adóbírság & $-387,047$ & 118,564 &,- 164 & $-3,264$ & ,001 \\
\hline & & kamatbev & $-301,540$ & 118,125 &,- 102 & $-2,553$ & ,011 \\
\hline & & sajátbev & 245,800 & 14,004 & 4,034 & 17,553 & ,000 \\
\hline & & IPAössz & $-295,461$ & 18,112 & $-2,401$ & $-16,313$ &, 000 \\
\hline \multirow{6}{*}{ Kelet } & \multirow{6}{*}{7} & (Constant) & 17325007,06 & 15917549,87 & & 1,088 & ,277 \\
\hline & & \begin{tabular}{|l} 
helyiadoossz \\
\end{tabular} & 413,833 & 75,582 & 3,224 & 5,475 &, 000 \\
\hline & & szja & 153,658 & 15,492 & ,953 & 9,919 & , 000 \\
\hline & & adóbírság & 507,494 & 106,508 & 295 & 4,765 &, 000 \\
\hline & & sajátbev & $-43,059$ & 7,331 & $-1,126$ & $-5,873$ & ,000 \\
\hline & & IPAössz & $-305,841$ & 73,350 & $-2,428$ & $-4,170$ & ,000 \\
\hline
\end{tabular}




\section{5. számú melléklet: A H5 hipotézis tesztelésének eredményei}

a) Településszerkezet és európai uniós támogatások összefüggései nagyrégiónként

\begin{tabular}{|c|c|c|c|c|}
\hline $\begin{array}{c}\text { Nagyrégió } \\
\text { (NUTS1) }\end{array}$ & Lélekszám & \begin{tabular}{|c|}
$\begin{array}{c}\text { Támogatás ban } \\
\text { rés ze sült-e }\end{array}$ \\
\end{tabular} & Darab & Arány \\
\hline \multirow{10}{*}{ Közép-Magyarország } & \multirow{2}{*}{500 fö alatt } & Nem kapott & 6 & $100,0 \%$ \\
\hline & & Részesült & 0 &, $0 \%$ \\
\hline & \multirow{2}{*}{ 500-4999 fö } & Nem kapott & 84 & $73,7 \%$ \\
\hline & & Részesült & 30 & $26,3 \%$ \\
\hline & \multirow{2}{*}{ 5000-9999 fö } & Nem kapott & 17 & $58,6 \%$ \\
\hline & & Részesült & 12 & $41,4 \%$ \\
\hline & \multirow{2}{*}{ 10000-49999 fö } & Nem kapott & 12 & $32,4 \%$ \\
\hline & & Részesült & 25 & $67,6 \%$ \\
\hline & \multirow{2}{*}{50000 fö felett } & Nem kapott & 0 &, $0 \%$ \\
\hline & & Részesült & 1 & $100,0 \%$ \\
\hline \multirow{10}{*}{ Dunántúl } & \multirow{2}{*}{500 fö alatt } & Nem kapott & 658 & $83,8 \%$ \\
\hline & & Részesült & 127 & $16,2 \%$ \\
\hline & \multirow{2}{*}{ 500-4999 fö } & Nem kapott & 548 & $64,6 \%$ \\
\hline & & Részesült & 300 & $35,4 \%$ \\
\hline & \multirow{2}{*}{ 5000-9999 fö } & Nem kapott & 10 & $30,3 \%$ \\
\hline & & Részesült & 23 & $69,7 \%$ \\
\hline & \multirow{2}{*}{ 10000-49999 fö } & Nem kapott & 9 & $26,5 \%$ \\
\hline & & Részesült & 25 & $73,5 \%$ \\
\hline & \multirow{2}{*}{50000 fö felett } & Nem kapott & 0 & $0 \%$ \\
\hline & & Részesült & 11 & $100,0 \%$ \\
\hline \multirow{10}{*}{ Alföld és Észak } & \multirow{2}{*}{500 fö alatt } & Nem kapott & 202 & $82,4 \%$ \\
\hline & & Részesült & 43 & $17,6 \%$ \\
\hline & \multirow{2}{*}{ 500-4999 fö } & Nem kapott & 478 & $55,3 \%$ \\
\hline & & Részesült & 386 & $44,7 \%$ \\
\hline & \multirow{2}{*}{ 5000-9999 fö } & Nem kapott & 14 & $17,1 \%$ \\
\hline & & Részesült & 68 & $82,9 \%$ \\
\hline & \multirow{2}{*}{ 10000-49999 fö } & Nem kapott & 5 & $9,3 \%$ \\
\hline & & Részesült & 49 & $90,7 \%$ \\
\hline & \multirow{2}{*}{50000 fö felett } & Nem kapott & 0 &, $0 \%$ \\
\hline & & Részesült & 8 & $100,0 \%$ \\
\hline
\end{tabular}


Pénzkészlet a tárgyidőszak végén (pénzkészlet)
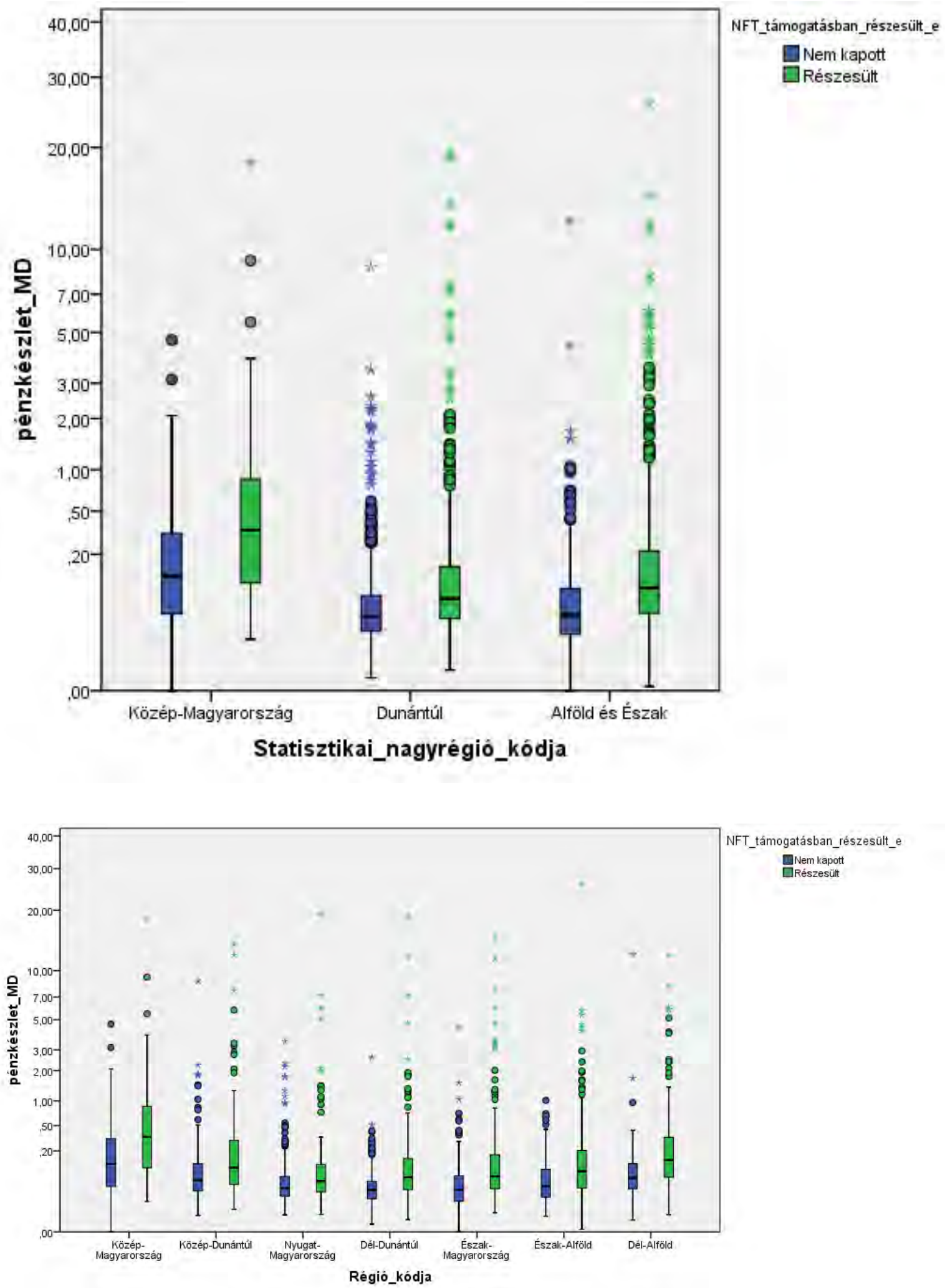


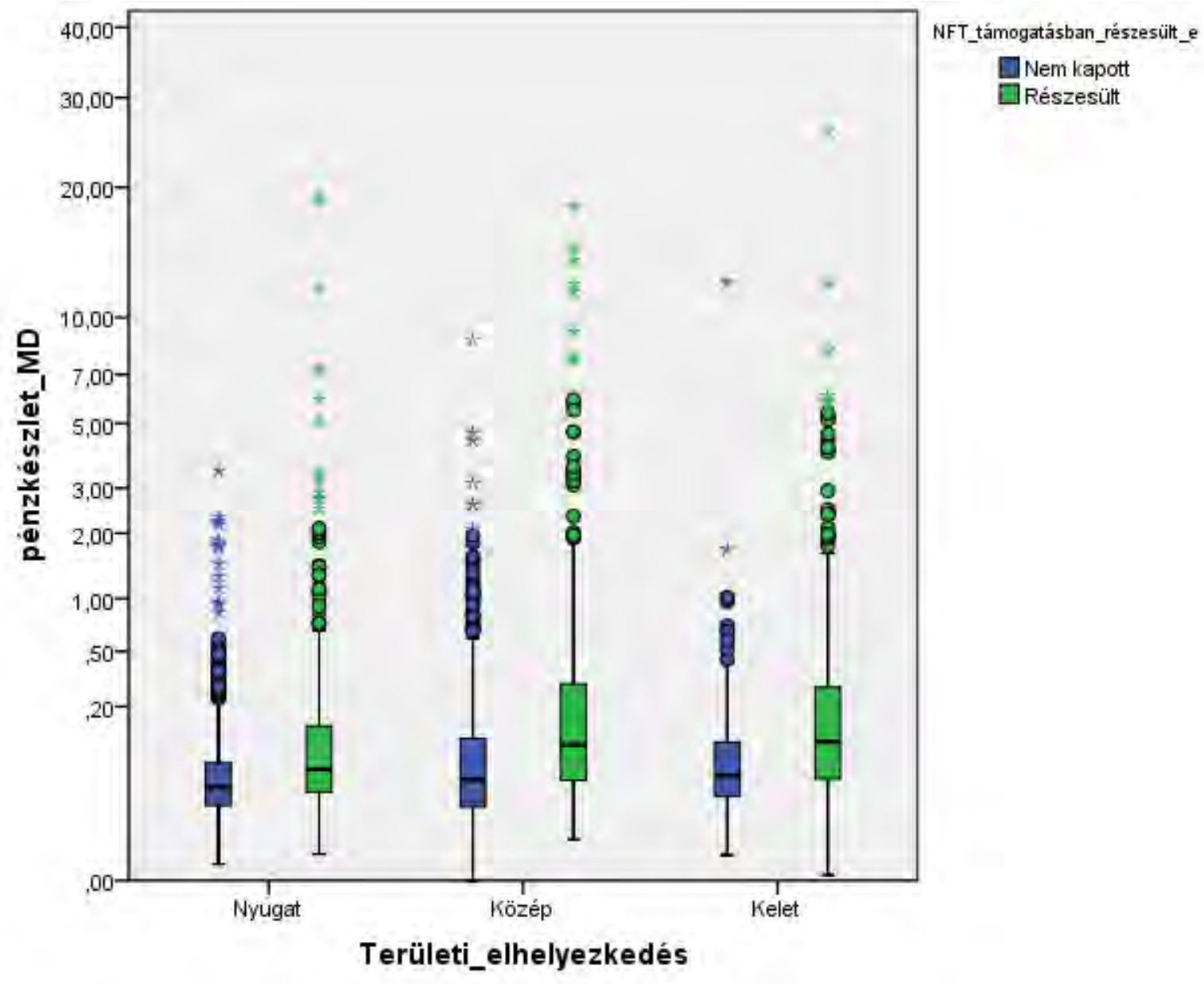



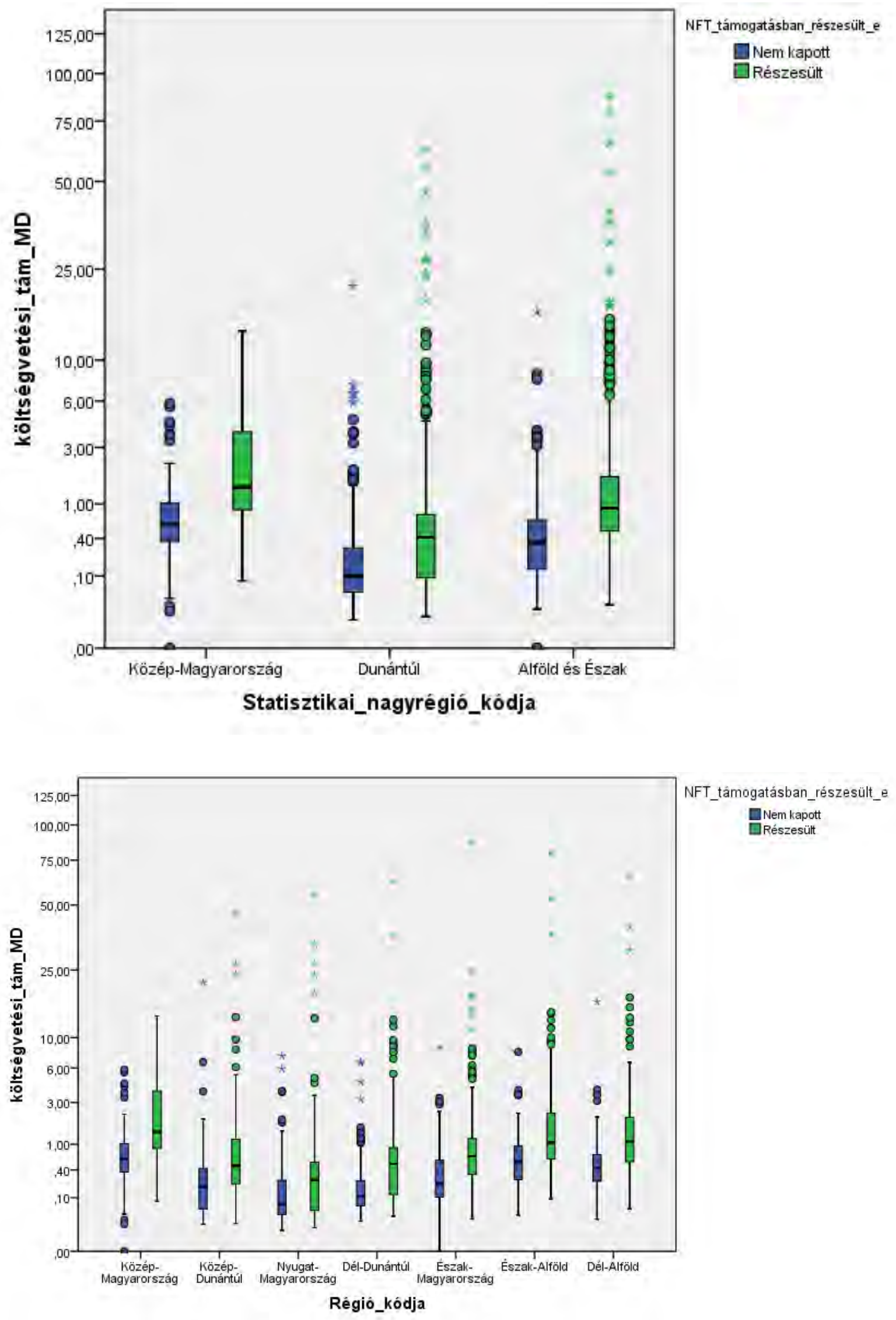


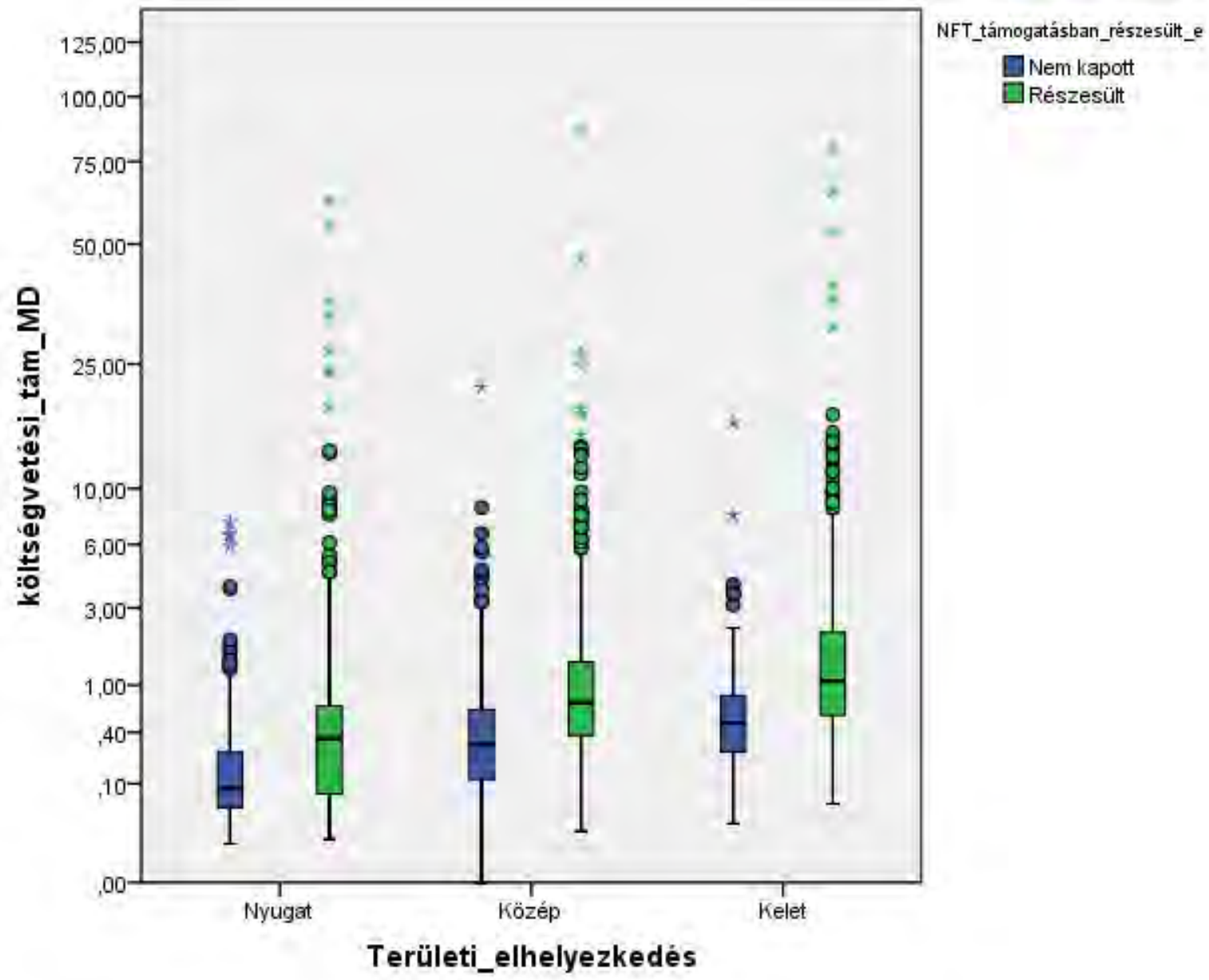


Személyi jövedelemadó bevételek (SzJA)

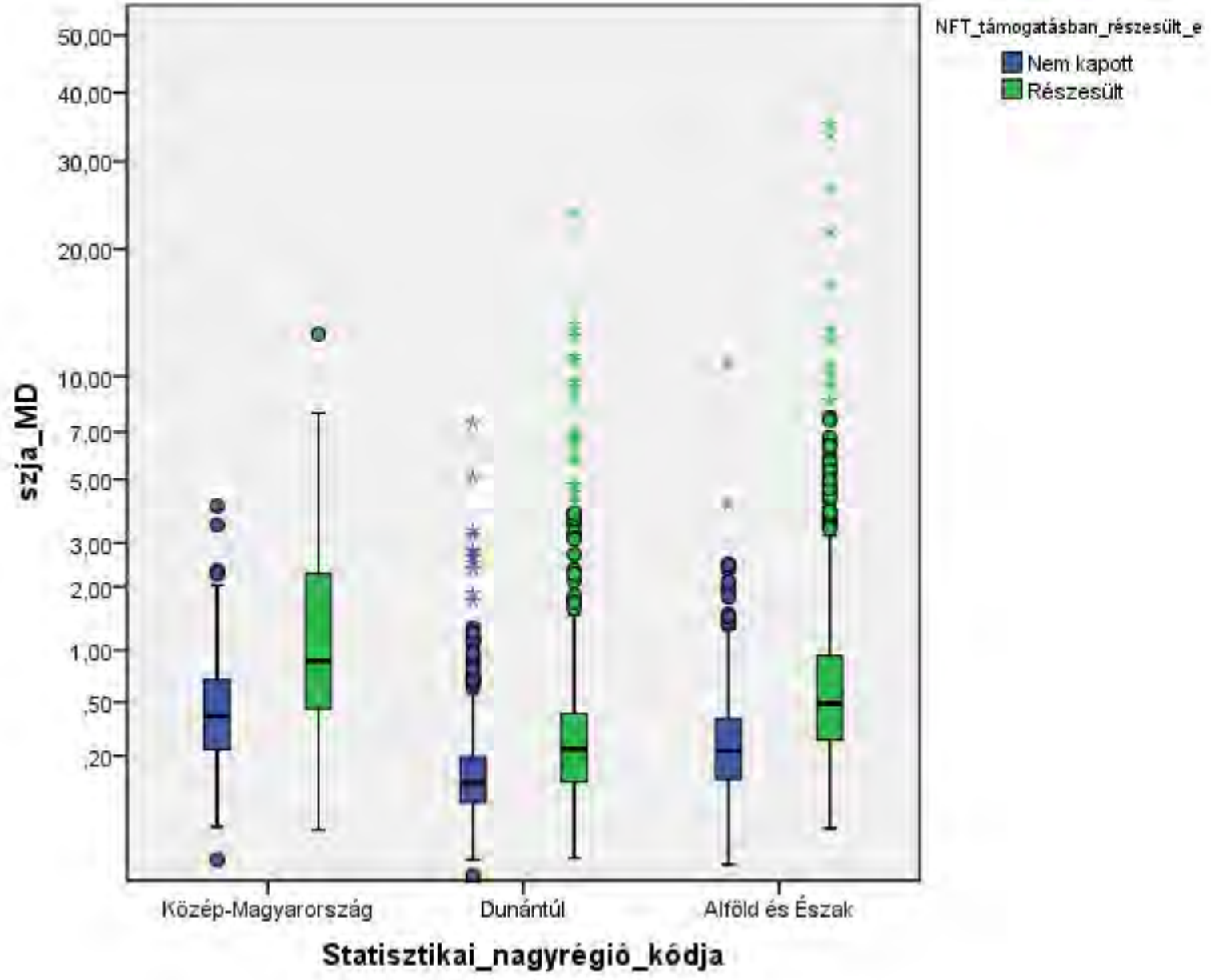



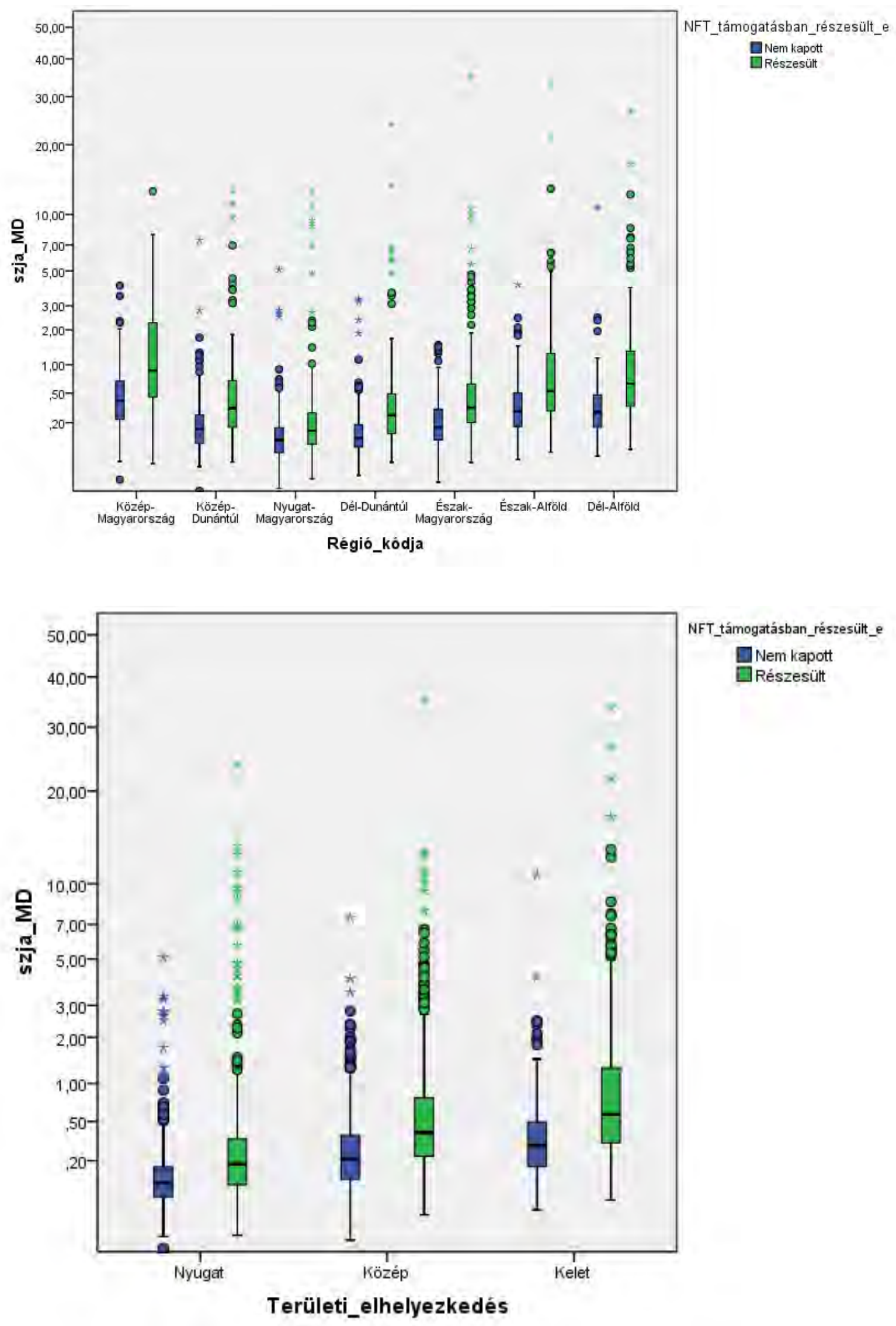
Tárgyi eszközök, immateriális javak értékesitése (teért)
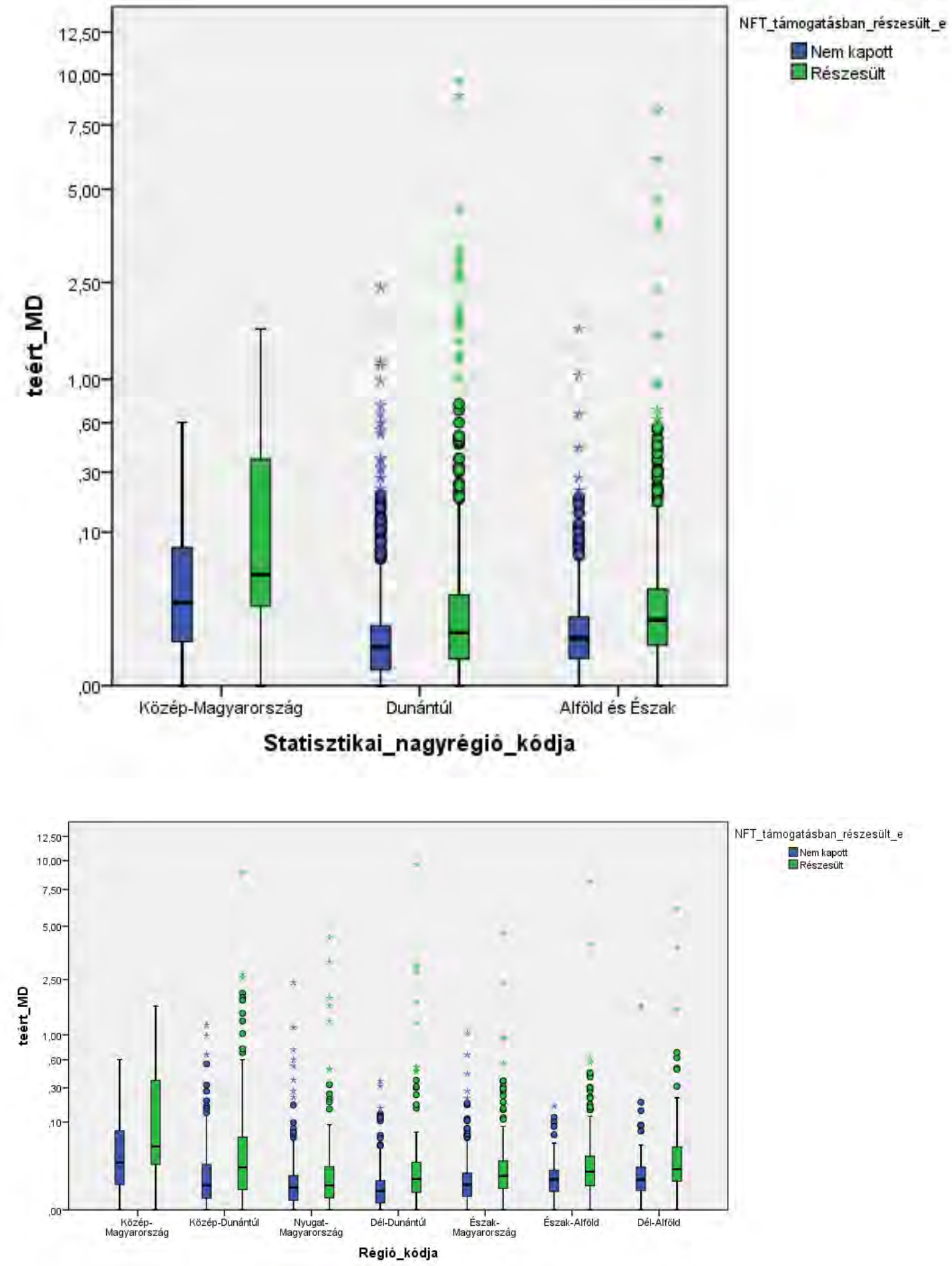


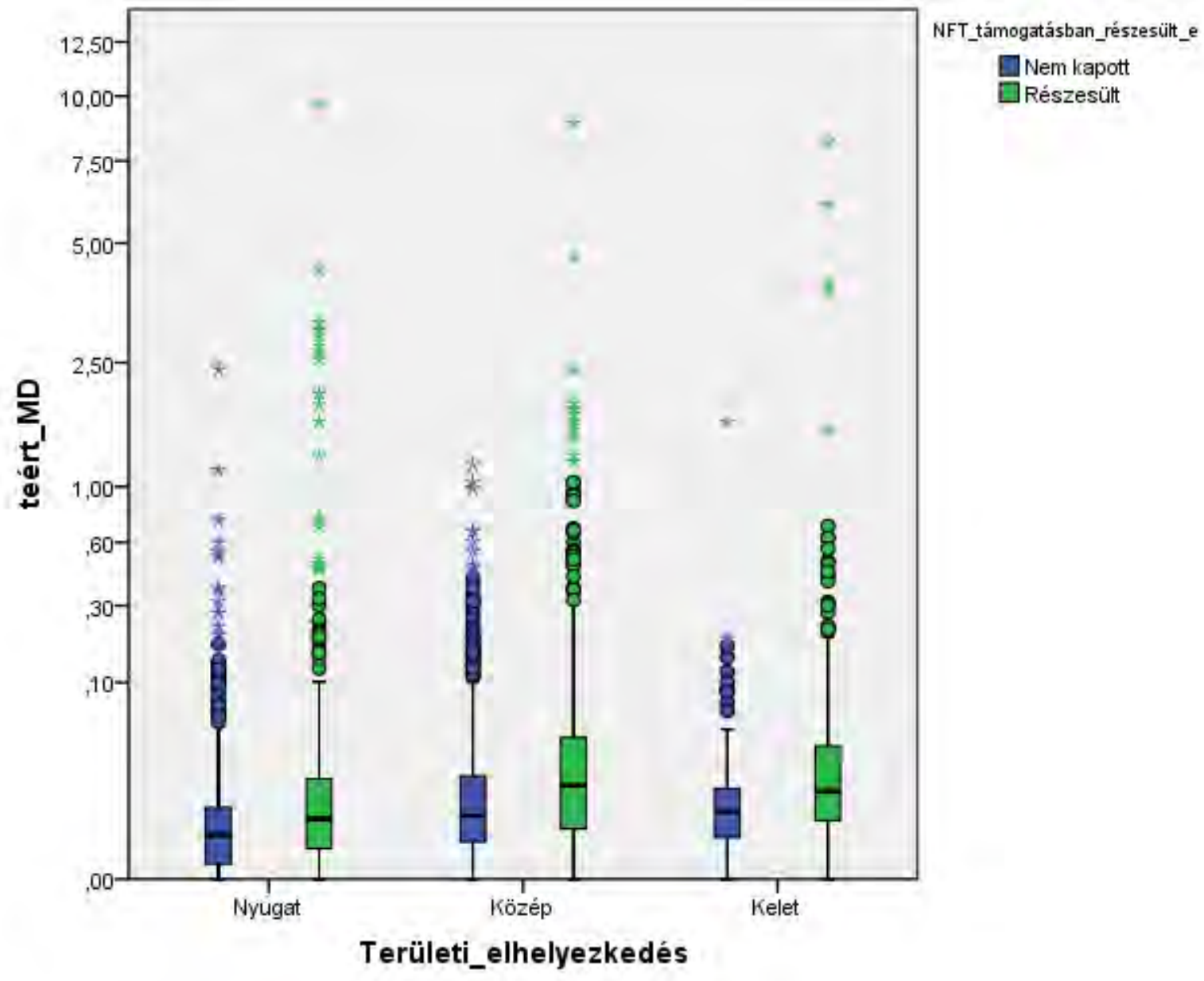


Saját bevételek összesen (sajátbev)

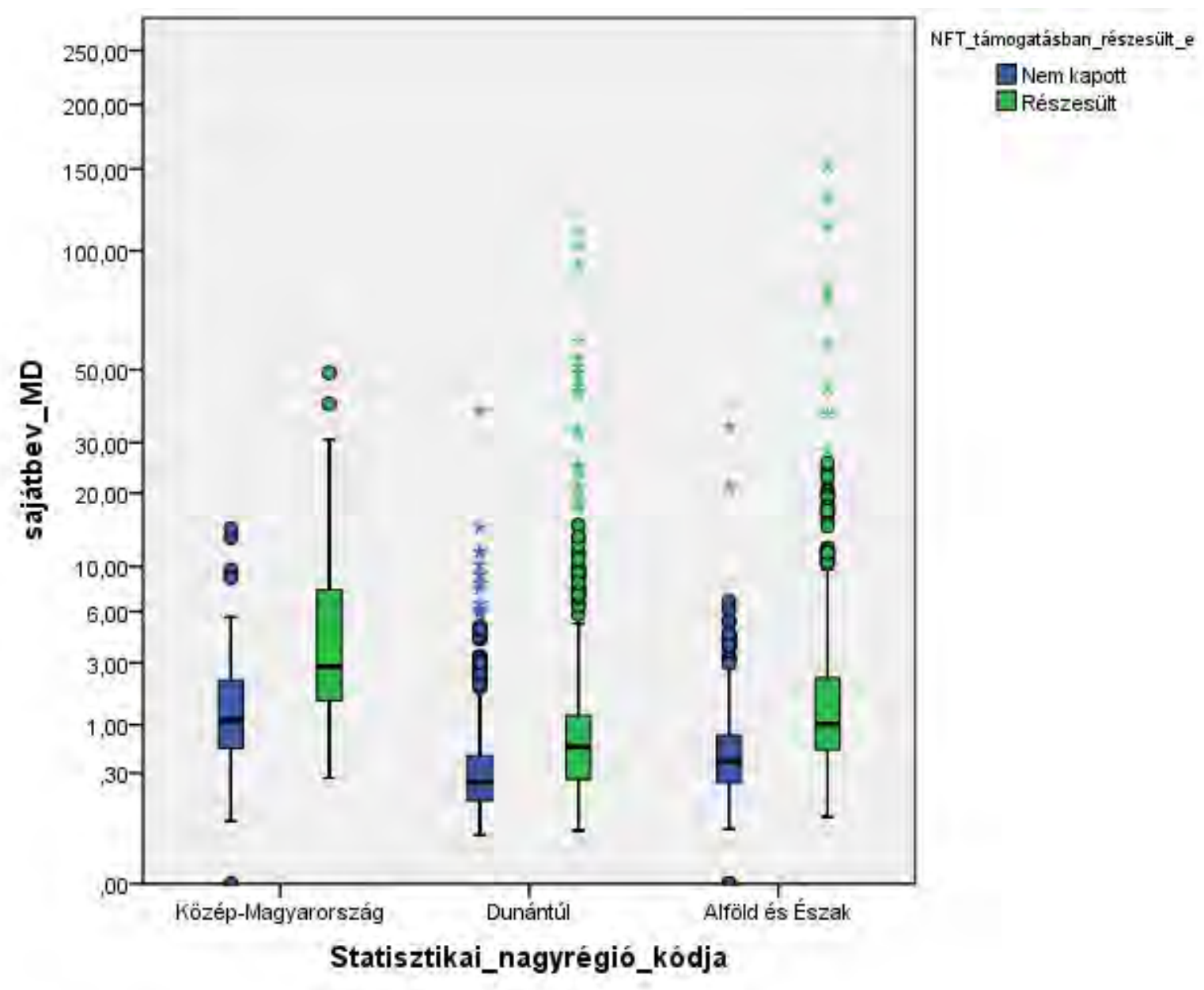



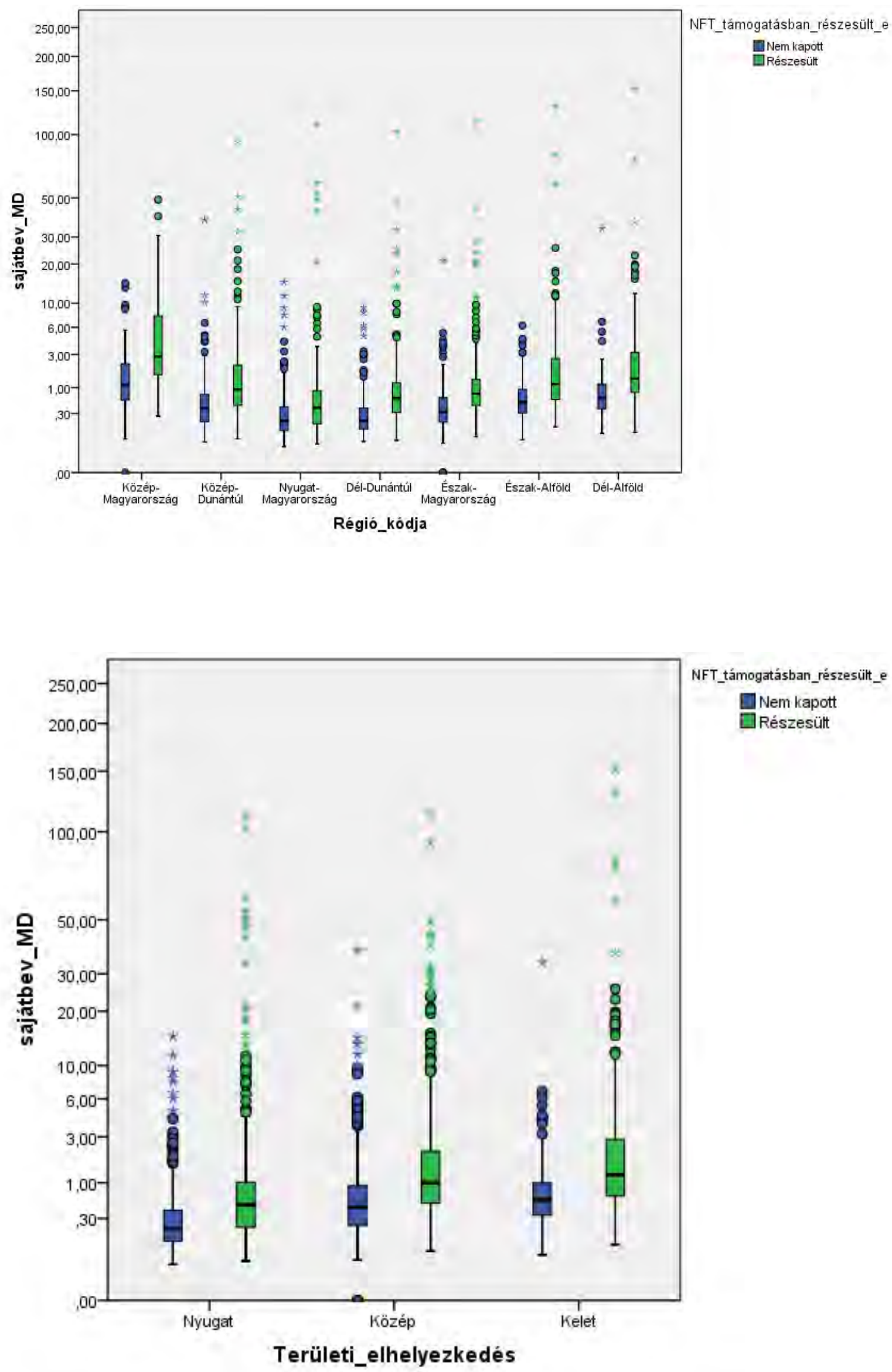
Helyi adók (helyiadoossz) ${ }^{174}$
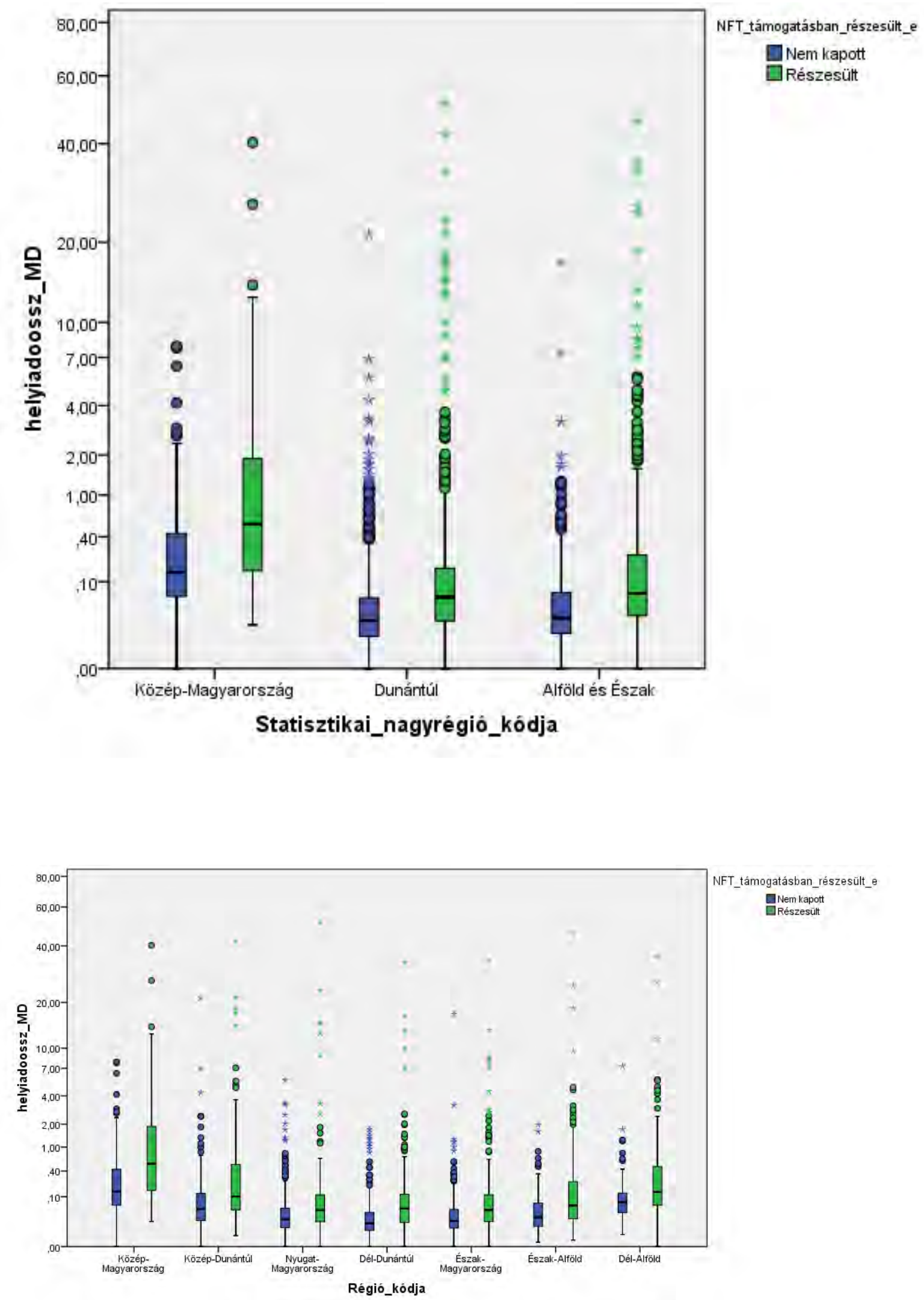

${ }^{174}$ Csak a pozitív helyi adóval rendelkező települések szerepelnek az ábrán. 


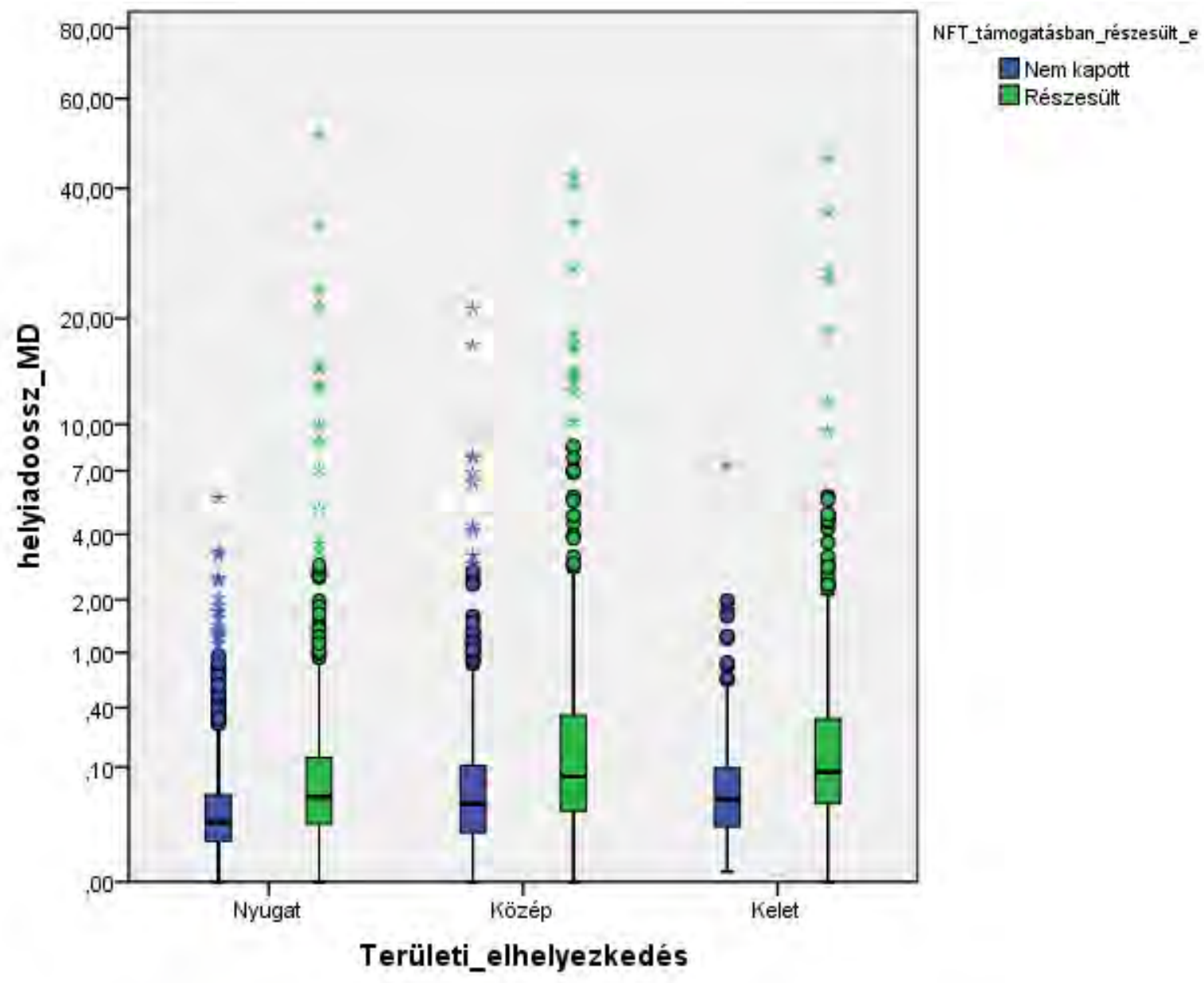


Iparüzési adó (IPAössz)
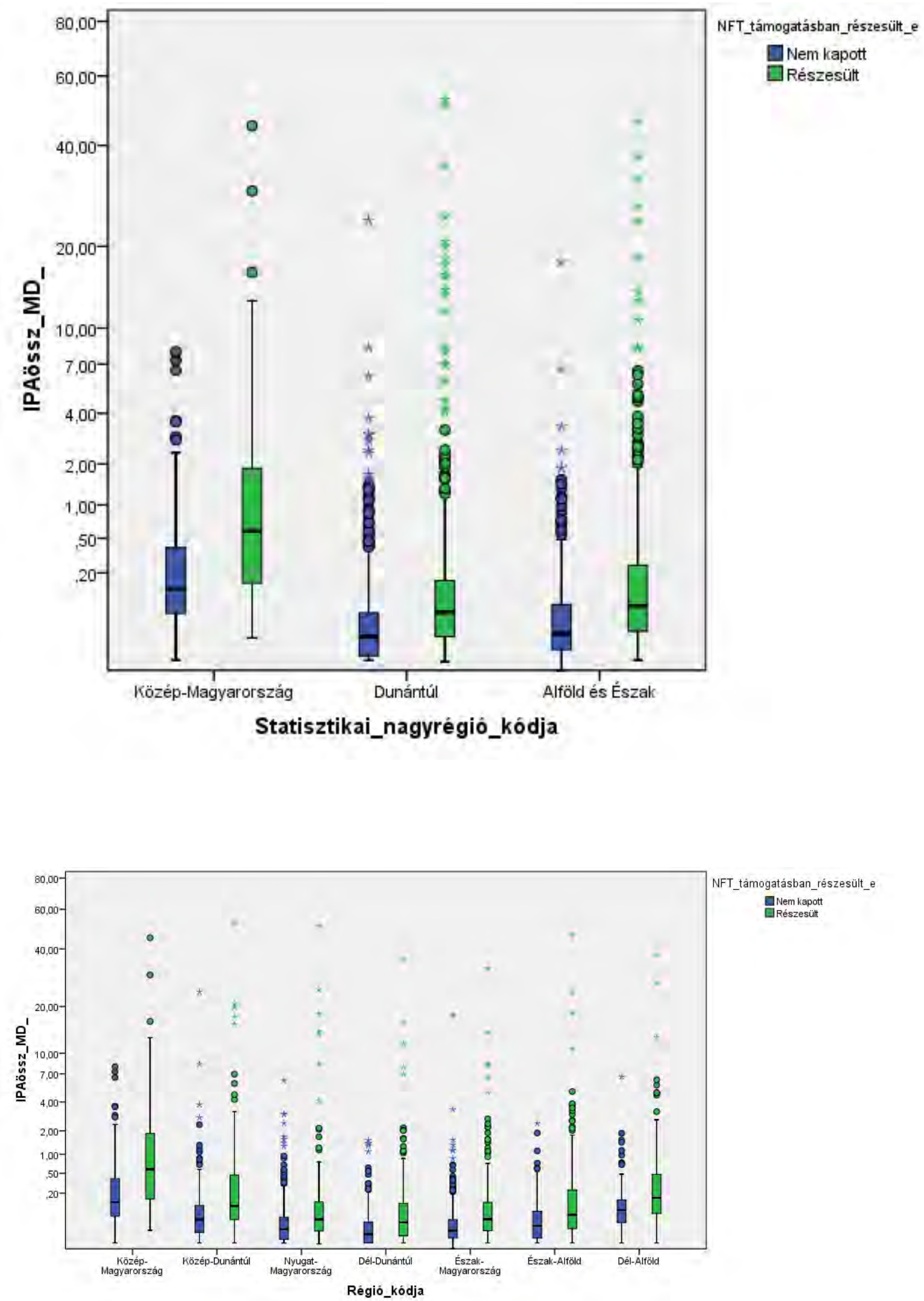


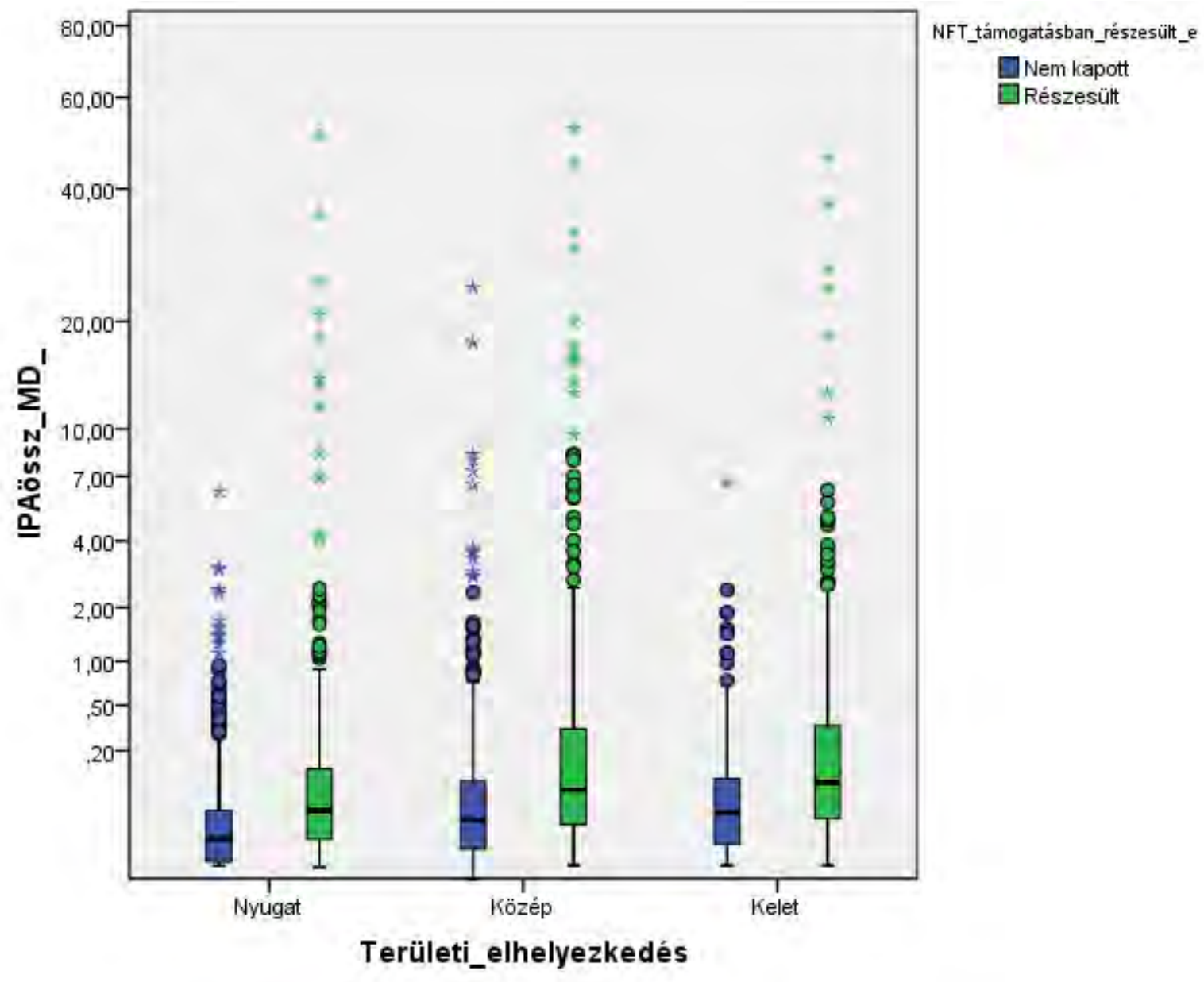



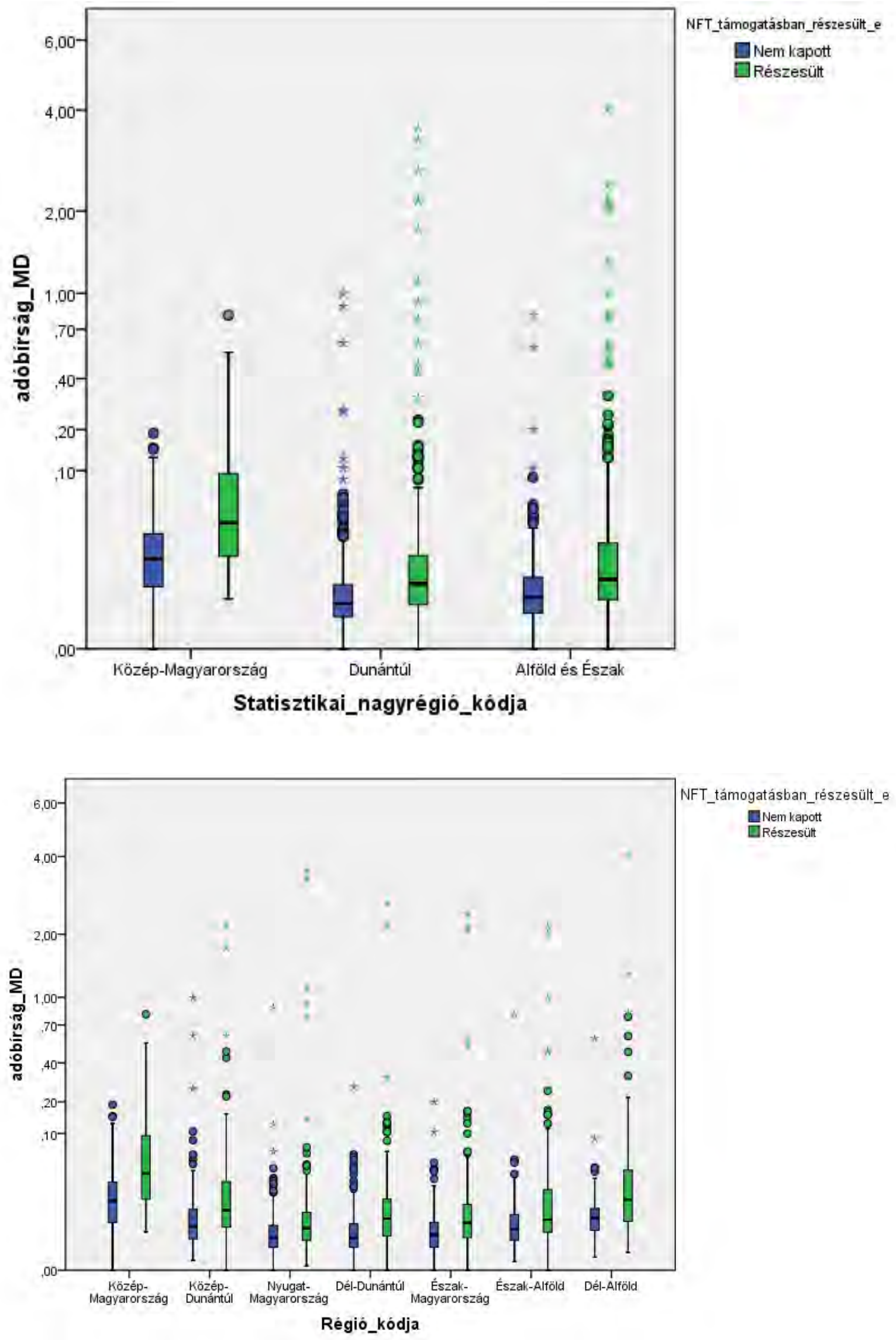


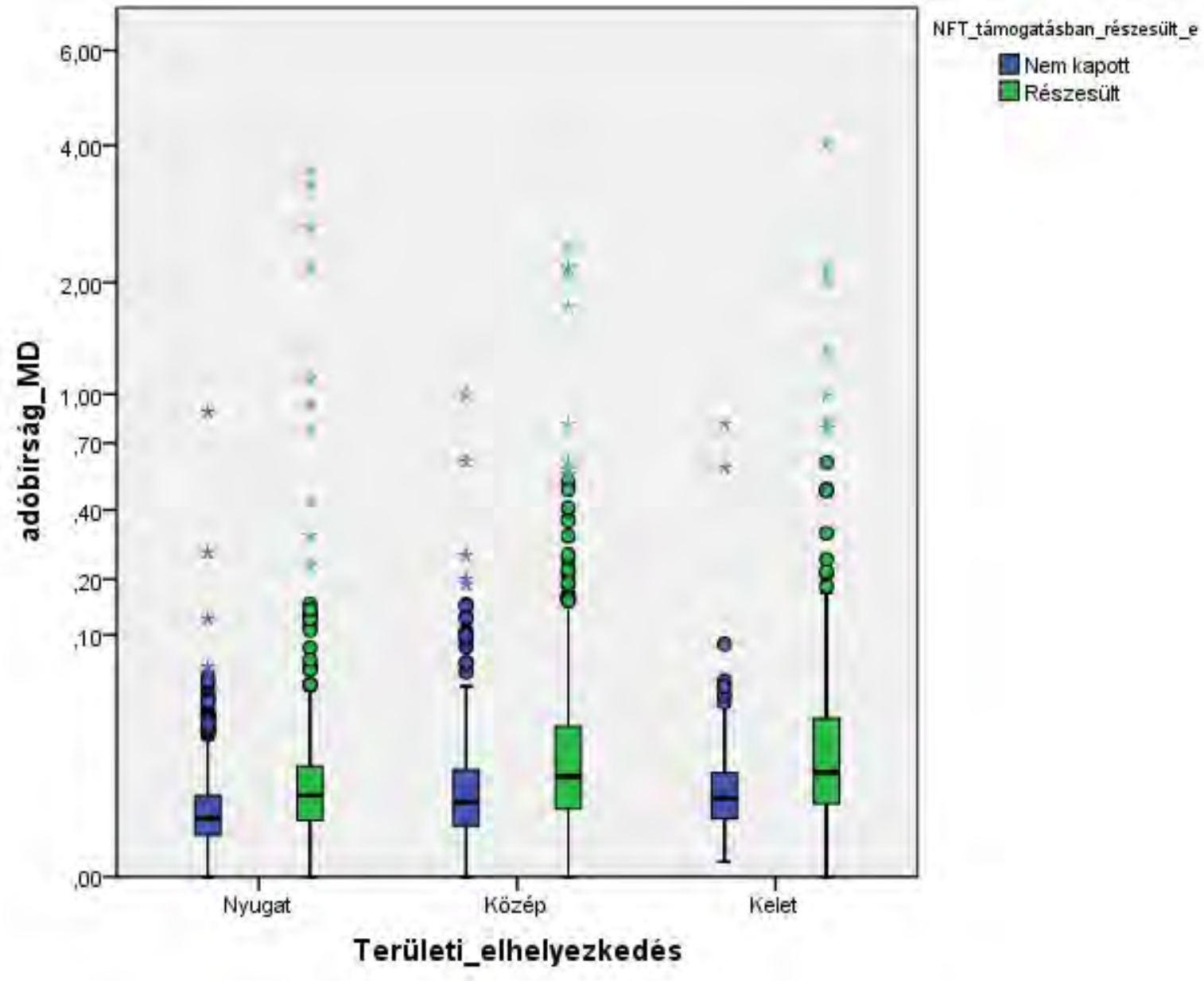


Kamatbevétel (kamatbevétel)
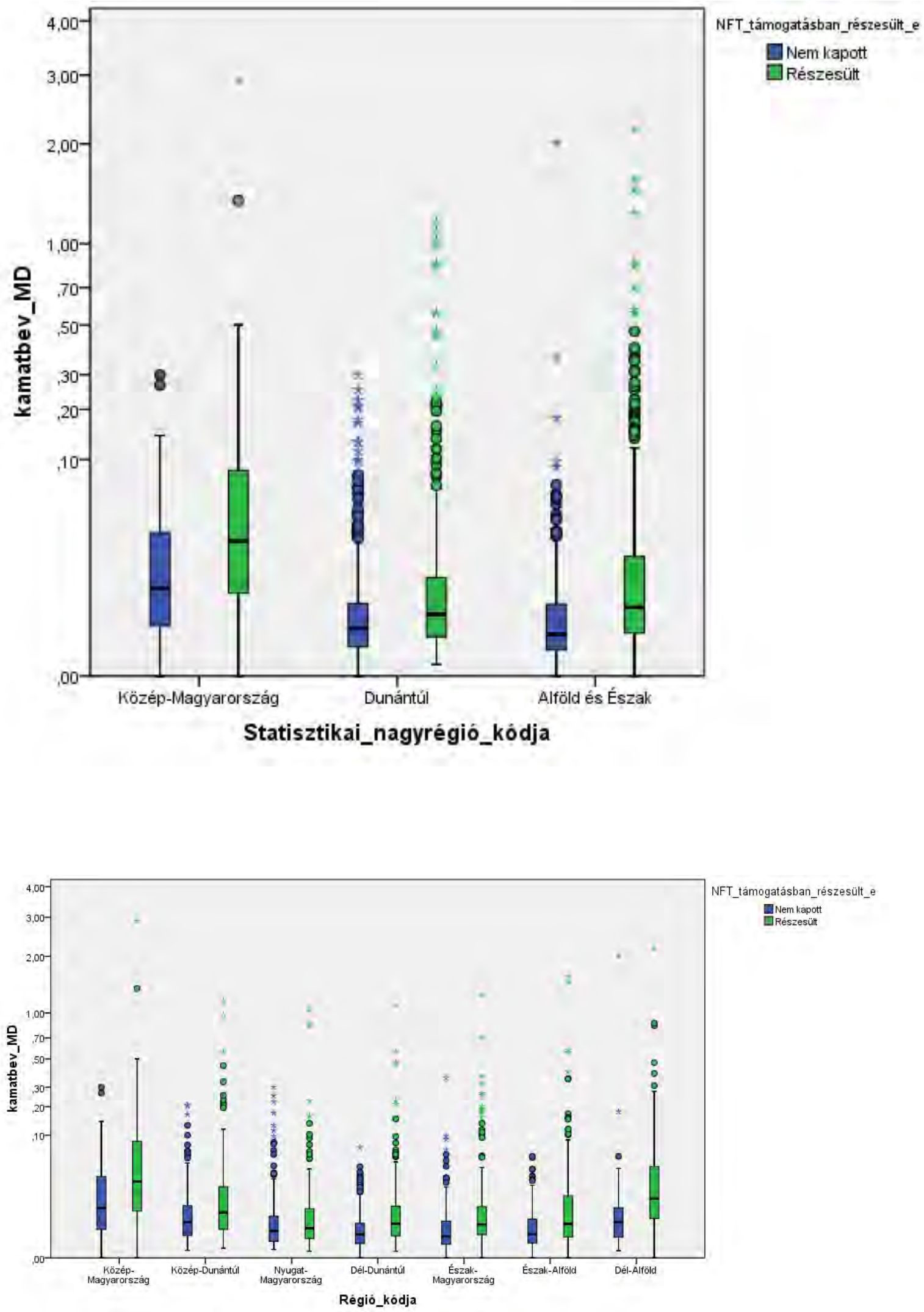


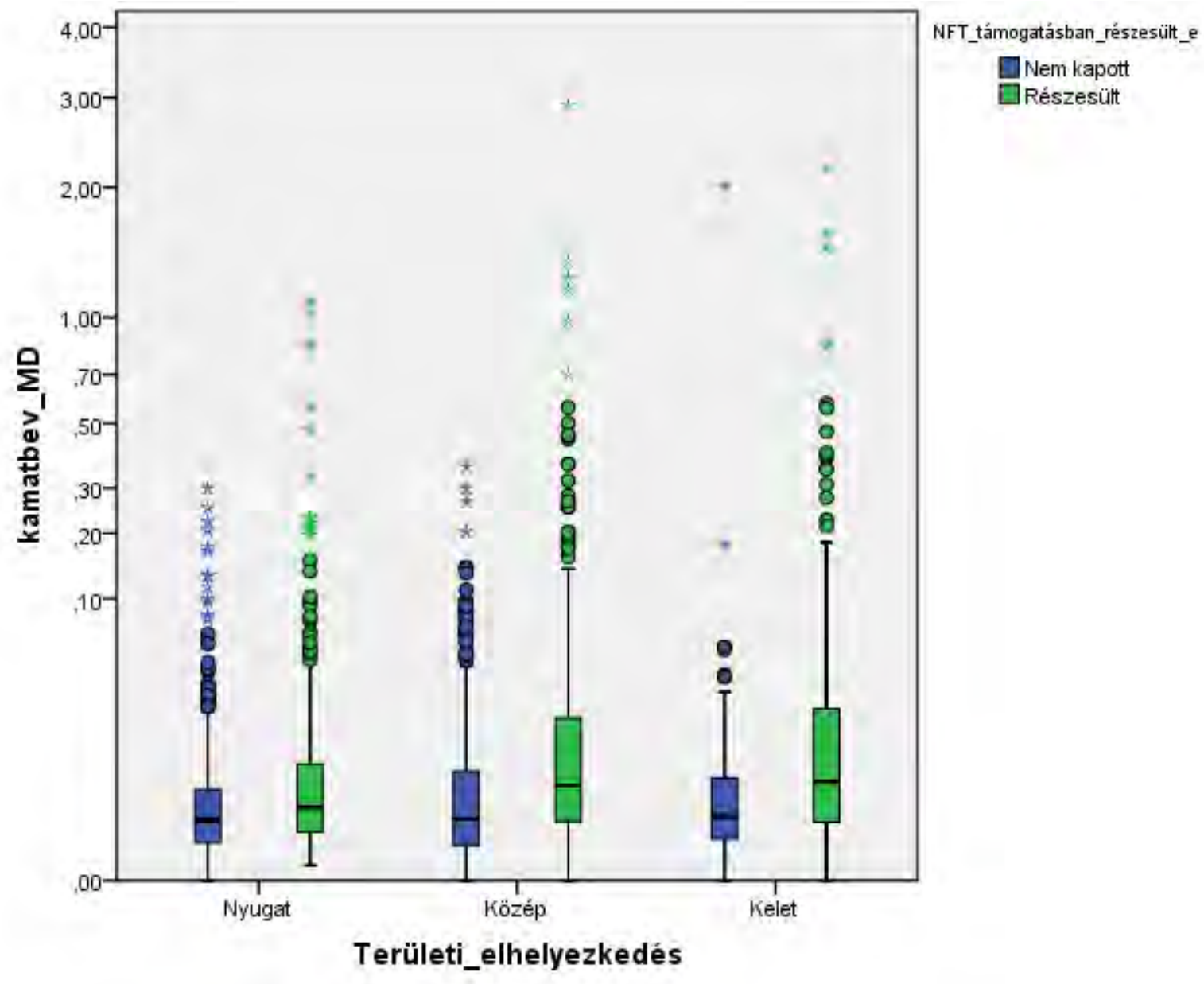


Rövid lejáratú és likvid hitelek felvétele, forgatási célú értékpapírok kibocsátása és értékesítése (rövidhitel)
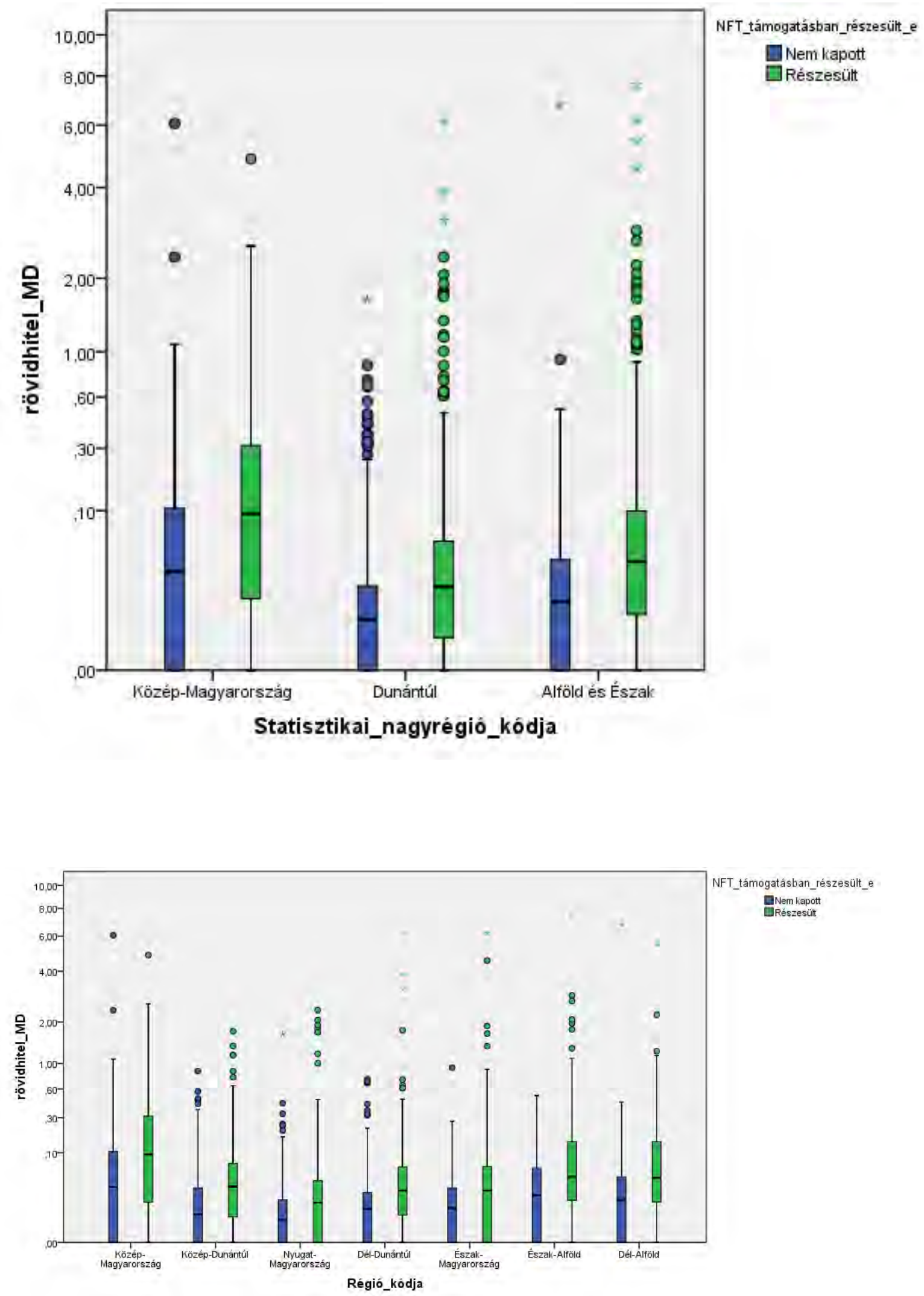


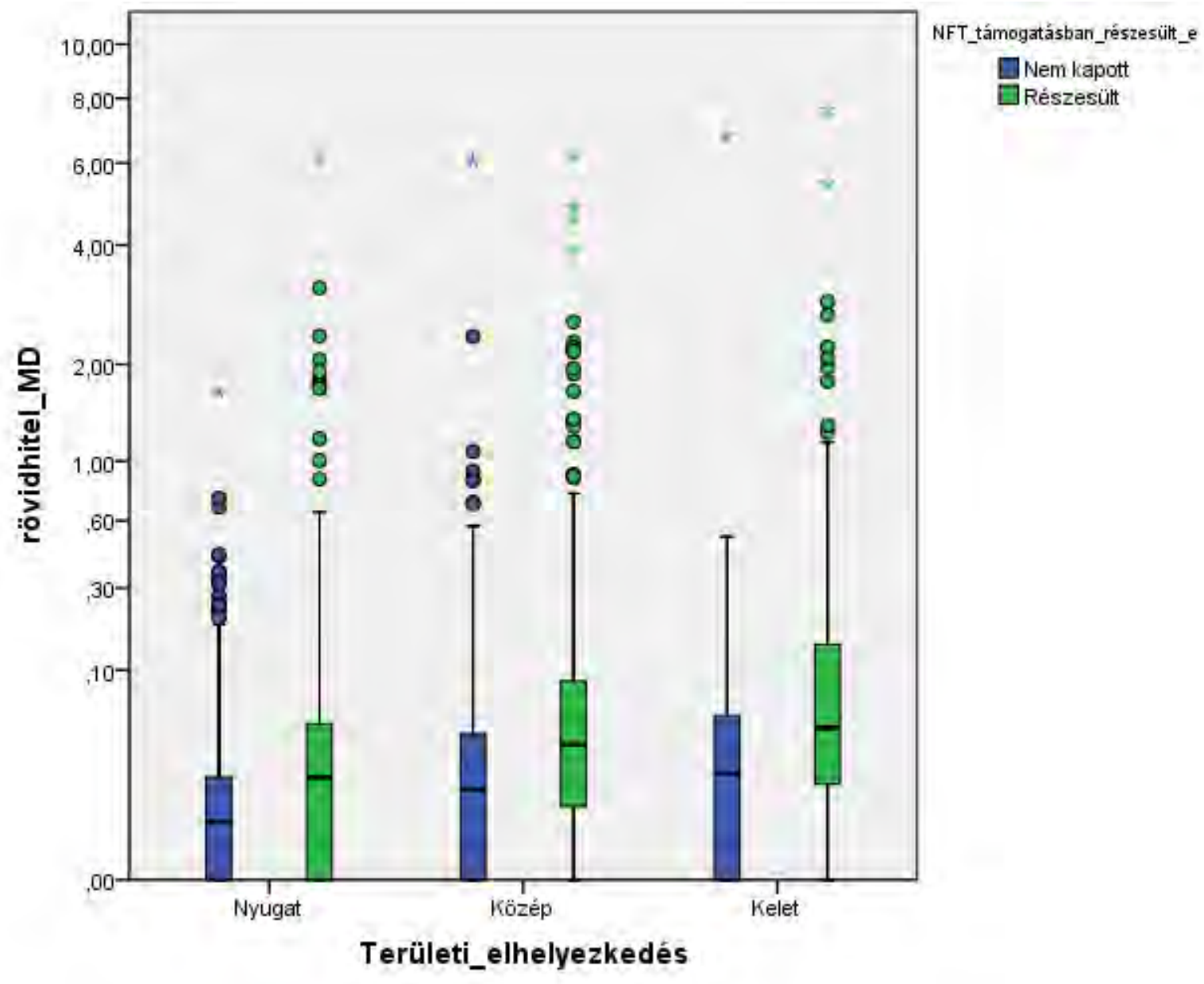


Hosszú lejáratú hitelek felvétele, hosszú lejáratú értékpapírok értékesítése és kibocsátása, befektetési célú értékpapírok kibocsátása (hosszúhitel)
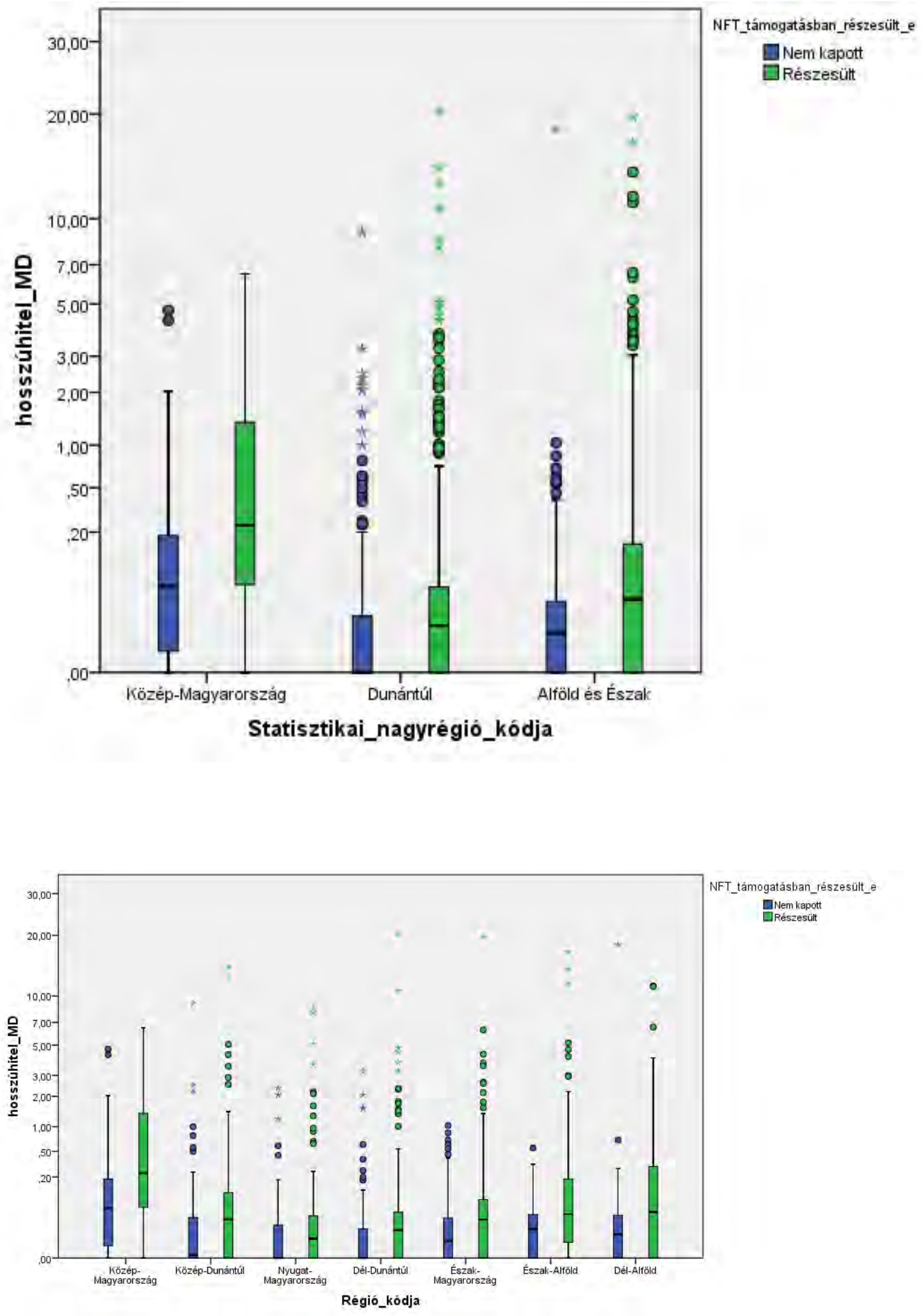


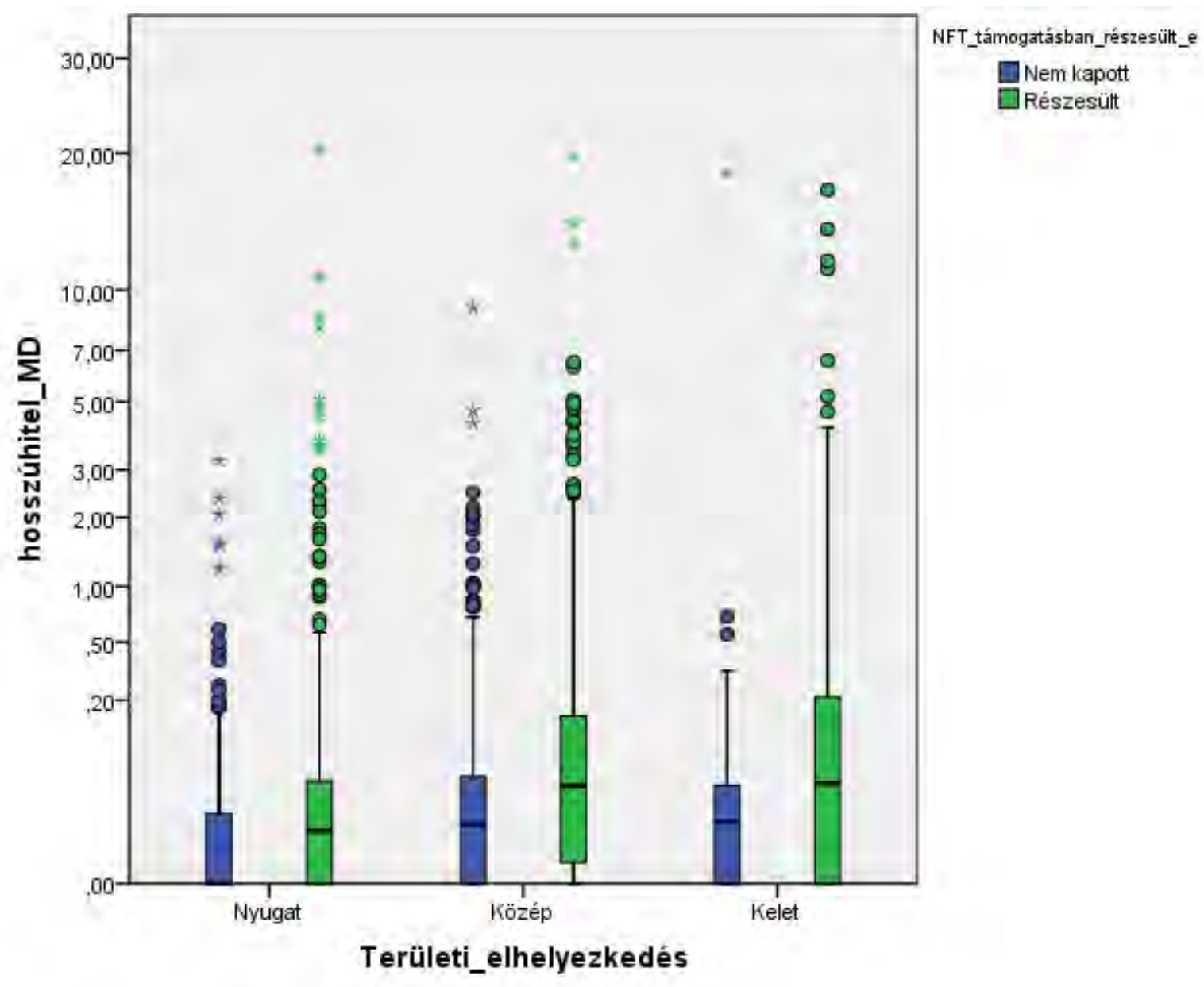


c1) A vizsgált változók átlaga és szórása a támogatásban részesült, illetve nem részesült helyi önkormányzatok viszonylatában, országos szinten

\begin{tabular}{|l|l|r|r|r|r|}
\hline \multirow{2}{*}{ Válttozó megnevezés e e } & $\begin{array}{c}\text { Európai uniós } \\
\text { támogatás ban } \\
\text { részesüllt-e }\end{array}$ & Darabs zám & Átlag & Szórás & $\begin{array}{c}\text { Standard } \\
\text { átlagos } \\
\text { elté rés }\end{array}$ \\
\hline \multirow{2}{*}{ helyiadoossz_MD } & Nem kapott & 2043 & 0,124 & 0,592 & 0,013 \\
\cline { 2 - 6 } & Részesült & 1108 & 0,968 & 4,100 & 0,123 \\
\hline \multirow{2}{*}{ költségvetési_tám_MD } & Nem kapott & 2043 & 0,391 & 0,666 & 0,015 \\
\cline { 2 - 6 } & Részesült & 1108 & 2,196 & 6,349 & 0,191 \\
\hline \multirow{2}{*}{ adóbírság_MD } & Nem kapott & 2043 & 0,006 & 0,033 & 0,001 \\
\cline { 2 - 6 } & Részesült & 1108 & 0,059 & 0,290 & 0,009 \\
\hline \multirow{2}{*}{ sajátbev_MD } & Nem kapott & 2043 & 0,639 & 1,224 & 0,027 \\
\cline { 2 - 6 } & Részesült & 1108 & 3,570 & 11,180 & 0,336 \\
\hline \multirow{2}{*}{ pénzkészlet_MD } & Nem kapott & 2043 & 0,094 & 0,273 & 0,006 \\
\cline { 2 - 6 } & Részesült & 1108 & 0,528 & 1,858 & 0,056 \\
\hline \multirow{2}{*}{ IPAössz_MD } & Nem kapott & 2043 & 0,117 & 0,609 & 0,013 \\
\cline { 2 - 6 } & Részesült & 1108 & 0,989 & 4,323 & 0,130 \\
\hline \multirow{2}{*}{ szja_MD } & Nem kapott & 2043 & 0,246 & 0,360 & 0,008 \\
\cline { 2 - 6 } & Részesült & 1108 & 1,053 & 2,580 & 0,077 \\
\hline \multirow{2}{*}{ teért_MD } & Nem kapott & 2043 & 0,017 & 0,089 & 0,002 \\
\cline { 2 - 6 } & Részesült & 1108 & 0,128 & 0,634 & 0,019 \\
\hline \multirow{2}{*}{ kamatbev_MD } & Nem kapott & 2043 & 0,006 & 0,022 & 0,000 \\
\cline { 2 - 6 } & Részesült & 1108 & 0,043 & 0,183 & 0,006 \\
\hline \multirow{2}{*}{ rövidhitel_MD } & Nem kapott & 2043 & 0,032 & 0,166 & 0,004 \\
\cline { 2 - 6 } & Részesült & 1108 & 0,172 & 0,595 & 0,018 \\
\hline \multirow{2}{*}{ hosszúhitel_MD } & Nem kapott & 2043 & 0,043 & 0,233 & 0,005 \\
\cline { 2 - 6 } & Részesült & 1108 & 0,455 & 1,729 & 0,052 \\
\hline \multirow{2}{*}{ IPAössz_MD_ } & Nem kapott & 2043 & 0,118 & 0,609 & 0,013 \\
\cline { 2 - 6 } & Részesült & 1108 & 0,990 & 4,323 & 0,130 \\
\hline & & & & \\
& & & & \\
& & & &
\end{tabular}




\section{c2) Az európai uniós támogatásban részesült, illetve nem részesült helyi önkormányzatok tekintetében a vizsgált változók közötti egyenlőségének tesztelése, országos szinten (t-próba)}

\begin{tabular}{|c|c|c|c|c|c|c|c|c|c|c|}
\hline \multirow{3}{*}{\multicolumn{2}{|c|}{ Változók }} & \multicolumn{2}{|c|}{$\begin{array}{c}\text { Levene's tesztje a } \\
\text { szórások } \\
\text { egyezóségére }\end{array}$} & \multicolumn{7}{|c|}{ t-próba az átlagok egyenlőségére } \\
\hline & & \multirow{2}{*}{$\mathbf{F}$} & \multirow{2}{*}{ Szignifikancia } & \multirow{2}{*}{$\mathbf{t}$} & \multirow{2}{*}{ df } & \multirow{2}{*}{$\begin{array}{c}\text { Szignifikancia } \\
\text { (két farkú) }\end{array}$} & \multirow{2}{*}{$\begin{array}{l}\text { Átlagos } \\
\text { eltérés }\end{array}$} & \multirow{2}{*}{\begin{tabular}{|c|}
$\begin{array}{c}\text { Standard hiba } \\
\text { eltérés }\end{array}$ \\
\end{tabular}} & \multicolumn{2}{|c|}{ A különbséghez tartozó } \\
\hline & & & & & & & & & alsó érték & felső érték \\
\hline \multirow{2}{*}{ helyiadoossz_MD } & \begin{tabular}{|l} 
Egyenlő szórást \\
feltételezve
\end{tabular} & 231,107 & 0,000 & $-9,133$ & 3149,000 & 0,000 & $-0,844$ & 0,092 & $-0,996$ & $-0,692$ \\
\hline & $\begin{array}{l}\text { Egyenlő szórásokat nem } \\
\text { feltételezve }\end{array}$ & & & $-6,814$ & 1132,055 & 0,000 & $-0,844$ & 0,124 & $-1,048$ & $-0,640$ \\
\hline \multirow{2}{*}{ költségvetési_tám_MD } & $\begin{array}{l}\text { Egyenlő szórást } \\
\text { feltételezve }\end{array}$ & 290,473 & 0,000 & $-12,719$ & 3149,000 & 0,000 & $-1,804$ & 0,142 & $-2,038$ & $-1,571$ \\
\hline & $\begin{array}{l}\text { Egyenlö szórásokat nem } \\
\text { feltételezve }\end{array}$ & & & $-9,432$ & 1120,233 & 0,000 & $-1,804$ & 0,191 & $-2,119$ & $-1,489$ \\
\hline \multirow{2}{*}{ adóbírság_MD } & $\begin{array}{l}\text { Egyenlő szórást } \\
\text { feltételezve }\end{array}$ & 177,275 & 0,000 & $-8,107$ & 3149,000 & 0,000 & $-0,053$ & 0,006 & $-0,063$ & $-0,042$ \\
\hline & $\begin{array}{l}\text { Egyenlő szórásokat nem } \\
\text { feltételezve }\end{array}$ & & & $-6,019$ & 1122,665 & 0,000 & $-0,053$ & 0,009 & $-0,067$ & $-0,038$ \\
\hline \multirow{2}{*}{ sajátbev_MD } & $\begin{array}{l}\text { Egyenlő szórást } \\
\text { feltételezve }\end{array}$ & 281,739 & 0,000 & $-11,721$ & 3149,000 & 0,000 & $-2,931$ & 0,250 & $-3,342$ & $-2,519$ \\
\hline & $\begin{array}{l}\text { Egyenlö szórásokat nem } \\
\text { feltételezve }\end{array}$ & & & $-8,697$ & 1121,403 & 0,000 & $-2,931$ & 0,337 & $-3,485$ & $-2,376$ \\
\hline \multirow{2}{*}{ pénzkészlet_MD } & $\begin{array}{l}\text { Egyenlő szórást } \\
\text { feltételezve }\end{array}$ & 268,391 & 0,000 & $-10,369$ & 3149,000 & 0,000 & $-0,435$ & 0,042 & $-0,503$ & $-0,366$ \\
\hline & $\begin{array}{l}\text { Egyenlö szórásokat nem } \\
\text { feltételezve }\end{array}$ & & & $-7,741$ & 1133,021 & 0,000 & $-0,435$ & 0,056 & $-0,527$ & $-0,342$ \\
\hline \multirow{2}{*}{ IPAössz_MD } & $\begin{array}{l}\text { Egyenlő szórást } \\
\text { feltételezve }\end{array}$ & 223,739 & 0,000 & $-8,954$ & 3149,000 & 0,000 & $-0,872$ & 0,097 & $-1,032$ & $-0,712$ \\
\hline & $\begin{array}{l}\text { Egyenlő szórásokat nem } \\
\text { feltételezve }\end{array}$ & & & $-6,677$ & 1130,906 & 0,000 & $-0,872$ & 0,131 & $-1,087$ & $-0,657$ \\
\hline \multirow{2}{*}{ szja_MD } & $\begin{array}{l}\text { Egyenlő szórást } \\
\text { feltételezve }\end{array}$ & 352,771 & 0,000 & $-13,886$ & 3149,000 & 0,000 & $-0,807$ & 0,058 & $-0,902$ & $-0,711$ \\
\hline & $\begin{array}{l}\text { Egyenlő szórásokat nem } \\
\text { feltételezve }\end{array}$ & & & $-10,353$ & 1130,481 & 0,000 & $-0,807$ & 0,078 & $-0,935$ & $-0,678$ \\
\hline \multirow{2}{*}{ teért_MD } & $\begin{array}{l}\text { Egyenlő szórást } \\
\text { feltételezve }\end{array}$ & 179,093 & 0,000 & $-7,814$ & 3149,000 & 0,000 & $-0,111$ & 0,014 & $-0,135$ & $-0,088$ \\
\hline & $\begin{array}{l}\begin{array}{l}\text { Egyenlő szórásokat nem } \\
\text { feltételezve }\end{array} \\
\end{array}$ & & & $-5,826$ & 1130,537 & 0,000 & $-0,111$ & 0,019 & $-0,143$ & $-0,080$ \\
\hline \multirow{2}{*}{ kamatbev_MD } & \begin{tabular}{|l|} 
Egyenlő szórást \\
feltételezve
\end{tabular} & 224,331 & 0,000 & $-9,054$ & 3149,000 & 0,000 & $-0,037$ & 0,004 & $-0,044$ & $-0,030$ \\
\hline & $\begin{array}{l}\begin{array}{l}\text { Egyenlő szórásokat nem } \\
\text { feltételezve }\end{array} \\
\end{array}$ & & & $-6,727$ & 1124,091 & 0,000 & $-0,037$ & 0,006 & $-0,046$ & $-0,028$ \\
\hline \multirow{2}{*}{ rövidhitel_MD } & $\begin{array}{l}\text { Egyenlő szórást } \\
\text { feltételezve }\end{array}$ & 231,359 & 0,000 & $-9,935$ & 3149,000 & 0,000 & $-0,140$ & 0,014 & $-0,163$ & $-0,117$ \\
\hline & $\begin{array}{l}\text { Egyenlő szórásokat nem } \\
\text { feltételezve }\end{array}$ & & & $-7,661$ & 1200,859 & 0,000 & $-0,140$ & 0,018 & $-0,170$ & $-0,110$ \\
\hline \multirow{2}{*}{ hosszúhitel_MD } & \begin{tabular}{|l|} 
Egyenlő szórást \\
feltételezve \\
\end{tabular} & 324,594 & 0,000 & $-10,585$ & 3149,000 & 0,000 & $-0,412$ & 0,039 & $-0,476$ & $-0,348$ \\
\hline & $\begin{array}{l}\text { Egyenlő szórásokat nem } \\
\text { feltételezve }\end{array}$ & & & $-7,885$ & 1128,893 & 0,000 & $-0,412$ & 0,052 & $-0,498$ & $-0,326$ \\
\hline \multirow{2}{*}{ IPAössz_MD_ } & \begin{tabular}{|l|}
$\begin{array}{l}\text { Egyenlő szórást } \\
\text { feltételezve }\end{array}$ \\
\end{tabular} & 223,739 & 0,000 & $-8,954$ & 3149,000 & 0,000 & $-0,872$ & 0,097 & $-1,032$ & $-0,712$ \\
\hline & $\begin{array}{l}\text { Egyenlő szórásokat nem } \\
\text { feltételezve }\end{array}$ & & & $-6,677$ & 1130,906 & 0,000 & $-0,872$ & 0,131 & $-1,087$ & $-0,657$ \\
\hline
\end{tabular}


d1) Logisztikus regresszió eredményei országos szinten

\begin{tabular}{|r|r|r|r|r|}
\hline \multicolumn{5}{|c|}{ Ors zágos (ne mek) } \\
\hline \multicolumn{1}{|c|}{ Talált } & Ne m talált & Összesen & Találati pontos ság & Vágópont \\
\hline 1921 & 779 & 2700 & $71,15 \%$ & 0,5 \\
\hline 1461 & 352 & 1813 & $80,58 \%$ & 0,3 \\
\hline 1575 & 423 & 1998 & $78,83 \%$ & 0,32 \\
\hline 1512 & 383 & 1895 & $79,79 \%$ & 0,31 \\
\hline \multicolumn{5}{|c|}{ Ors zágos (ige nek) } \\
\hline Talált & Ne m talált & Össze sen n & Találati pontos ság & Vágópont \\
\hline 329 & 122 & 451 & $72,95 \%$ & 0,5 \\
\hline 232 & 54 & 286 & $81,12 \%$ & 0,65 \\
\hline 246 & 65 & 311 & $79,10 \%$ & 0,61 \\
\hline 240 & 61 & 301 & $79,73 \%$ & 0,63 \\
\hline 238 & 56 & 294 & $80,95 \%$ & 0,64 \\
\hline & & & & \\
\hline Összes en & $\mathbf{1 6 9 9}$ & & & \\
\hline
\end{tabular}


d2) Logisztikus regresszió becslöfüggvénye országos szinten

\begin{tabular}{|l|r|r|r|r|r|r|}
\hline & $\begin{array}{c}\text { Logisztikus } \\
\text { együttható (B) }\end{array}$ & $\begin{array}{c}\text { Standard } \\
\text { hiba }\end{array}$ & $\begin{array}{c}\text { Wald- } \\
\text { statisztika }\end{array}$ & df & Szignifikancia & Exp(B) \\
\hline helyiadoossz_MD & $-2,03$ & 0,51 & 16,01 & 1 & 0,00 & 0,13 \\
\hline költségvetési_tám_MD & 0,79 & 0,15 & 27,01 & 1 & 0,00 & 2,20 \\
\hline adóbírság_MD & $-4,52$ & 1,86 & 5,89 & 1 & 0,02 & 0,01 \\
\hline sajátbev_MD & 0,88 & 0,15 & 34,90 & 1 & 0,00 & 2,41 \\
\hline IPAössz_MD & 0,85 & 0,41 & 4,39 & 1 & 0,04 & 2,34 \\
\hline szja_MD & $-1,00$ & 0,31 & 10,71 & 1 & 0,00 & 0,37 \\
\hline teért_MD & $-2,44$ & 0,63 & 15,25 & 1 & 0,00 & 0,09 \\
\hline Constant & $-1,31$ & 0,06 & 542,07 & 1 & 0,00 & 0,27 \\
\hline
\end{tabular}


e1) Logisztikus regresszió eredményei NUTS1 szinten

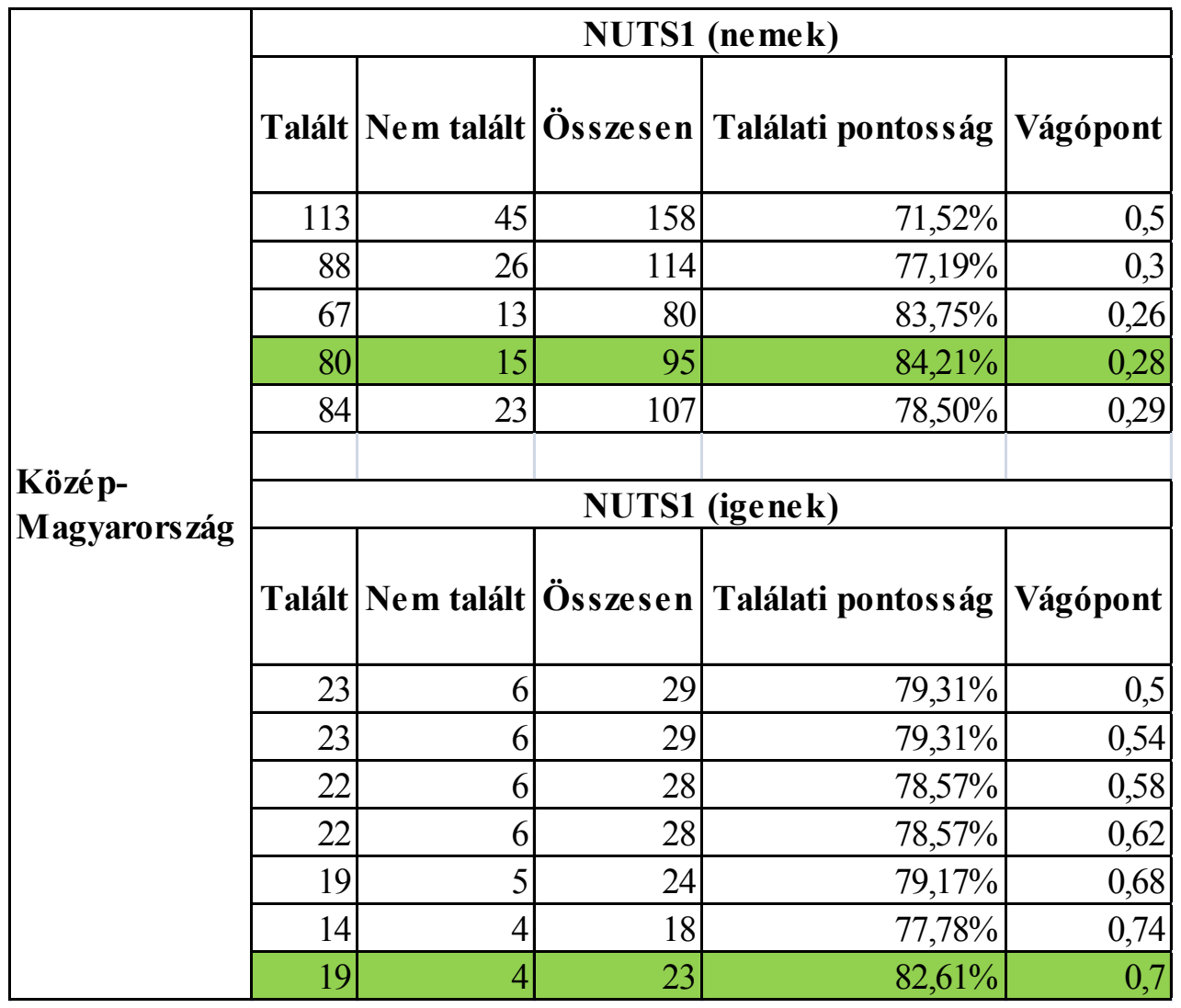

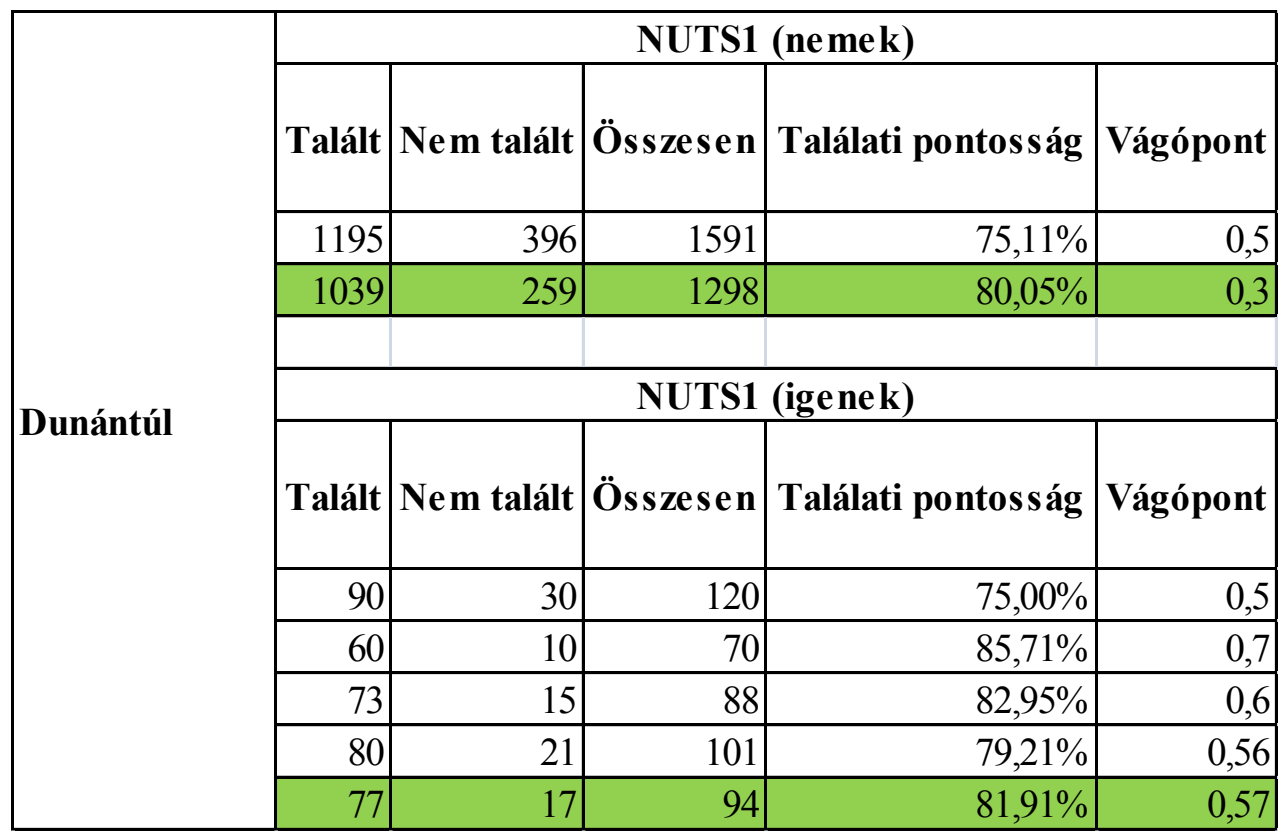




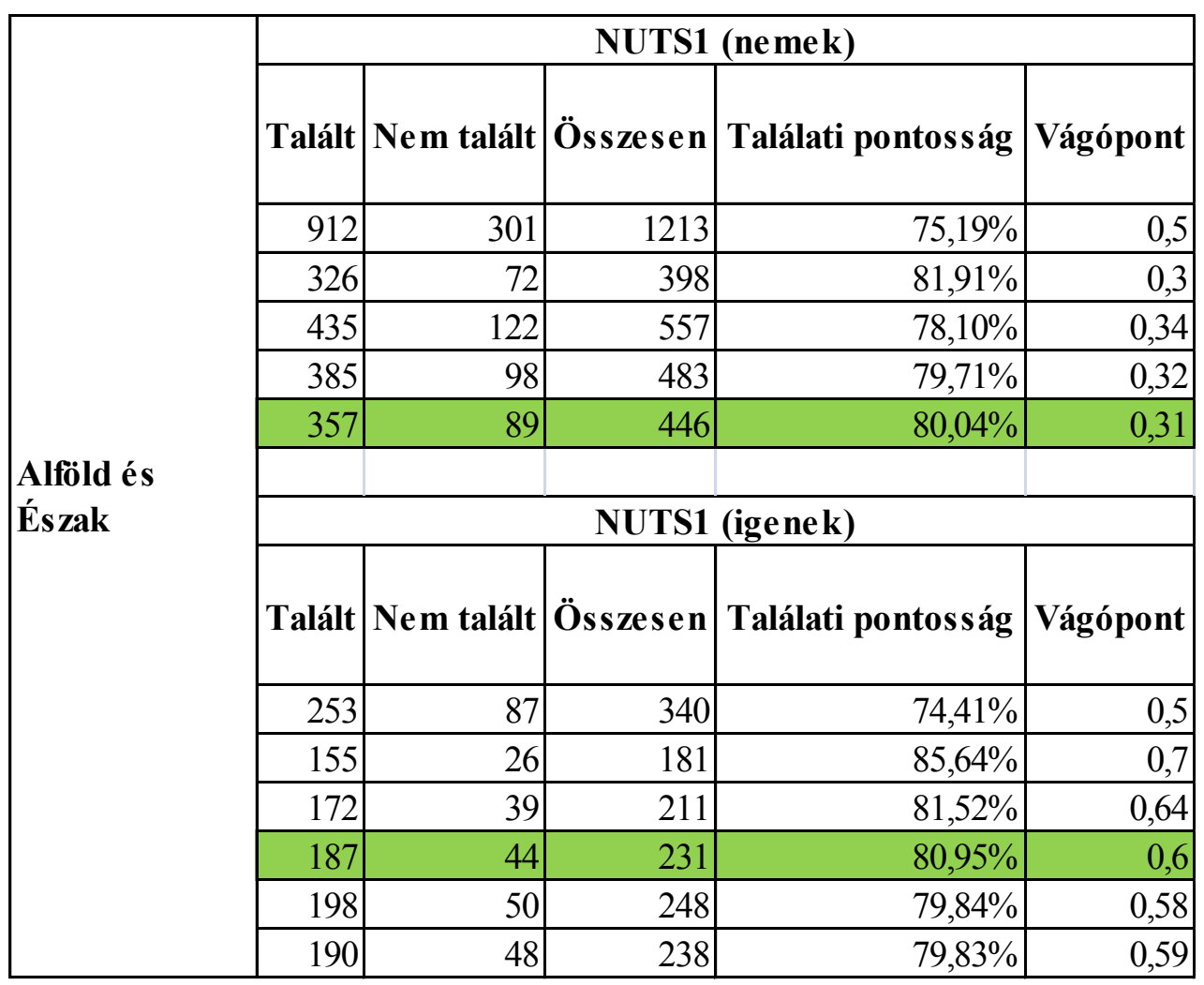


e2) Logisztikus regresszió becslöfüggvénye NUTS1 szinten

\begin{tabular}{|c|c|c|c|c|c|c|}
\hline \multicolumn{7}{|c|}{ Közép-Magyarors zág } \\
\hline & Logisztikus együttható (B) & Standard hiba & Wald-statisztika & $\mathrm{df}$ & Szignifikancia & $\operatorname{Exp}(B)$ \\
\hline költségvetési_tám_MD & 0,62 & 0,13 & 21,51 & 1 & 0,00 & 1,86 \\
\hline Constant & $-1,48$ & 0,24 & 37,54 & 1 & 0,00 & 0,23 \\
\hline \multicolumn{7}{|c|}{ Dunántúl } \\
\hline & Logisztikus együttható (B) & Standard hiba & Wald-statisztika & $\mathrm{df}$ & Szignifikancia & $\operatorname{Exp}(B)$ \\
\hline helyiadoossz_MD & $-0,82$ & 0,22 & 14,41 & 1 & 0,00 & 0,44 \\
\hline költségvetési_tám_MD & 0,55 & 0,22 & 6,52 & 1 & 0,01 & 1,74 \\
\hline adóbírság_MD & $-4,84$ & 2,38 & 4,12 & 1 & 0,04 & 0,01 \\
\hline sajátbev_MD & 0,76 & 0,18 & 17,45 & 1 & 0,00 & 2,14 \\
\hline teért_MD & $-2,96$ & 0,80 & 13,55 & 1 & 0,00 & 0,05 \\
\hline hosszúhitel_MD & $-0,47$ & 0,21 & 5,12 & 1 & 0,02 & 0,63 \\
\hline Constant & $-1,48$ & 0,08 & 372,03 & 1 & 0,00 & 0,23 \\
\hline
\end{tabular}

\begin{tabular}{|c|c|c|c|c|c|c|}
\hline \multicolumn{7}{|c|}{ Alföld és Észak } \\
\hline & Logisztikus együttható (B) & Standard hiba & Wald-statisztika & df & Szignifikancia & $\operatorname{Exp}(B)$ \\
\hline helyiadoossz_MD & $-1,83$ & 0,44 & 17,69 & 1 & 0,00 & 0,16 \\
\hline költségvetési_tám_MD & 0,89 & 0,27 & 10,98 & 1 & 0,00 & 2,44 \\
\hline adóbírság_MD & $-4,88$ & 3,13 & 2,42 & 1 & 0,12 & 0,01 \\
\hline sajátbev_MD & 1,03 & 0,28 & 13,27 & 1 & 0,00 & 2,80 \\
\hline szja_MD & $-1,39$ & 0,55 & 6,45 & 1 & 0,01 & 0,25 \\
\hline teért_MD & $-7,71$ & 1,88 & 16,87 & 1 & 0,00 & 0,00 \\
\hline kamatbev_MD & 15,06 & 5,63 & 7,14 & 1 & 0,01 & 3470770,10 \\
\hline rövidhitel_MD & 1,54 & 0,78 & 3,86 & 1 & 0,05 & 4,65 \\
\hline Constant & $-1,19$ & 0,10 & 143,90 & 1 & 0,00 & 0,30 \\
\hline
\end{tabular}


f1) Logisztikus regresszió eredményei NUTS2 szinten

\begin{tabular}{|c|c|c|c|c|c|}
\hline \multirow{17}{*}{$\begin{array}{c} \\
\text { Közép- } \\
\text { Magyarország }\end{array}$} & \multicolumn{5}{|c|}{ NUTS2 (nemek) } \\
\hline & Talált & Nem talált & Összesen & $\begin{array}{c}\text { Találati } \\
\text { pontos ság }\end{array}$ & Vágópont \\
\hline & 113 & 45 & 158 & $71,52 \%$ & 0,5 \\
\hline & 88 & 26 & 114 & $77,19 \%$ & 0,3 \\
\hline & 67 & 13 & 80 & $83,75 \%$ & 0,26 \\
\hline & 80 & 15 & 95 & $84,21 \%$ & 0,28 \\
\hline & 84 & 23 & 107 & $78,50 \%$ & 0,29 \\
\hline & & & & & \\
\hline & \multicolumn{5}{|c|}{ NUTS2 (igenek) } \\
\hline & Talált & Nem talált & Összesen & $\begin{array}{c}\text { Találati } \\
\text { pontos ság }\end{array}$ & Vágópont \\
\hline & 23 & 6 & 29 & $79,31 \%$ & 0,5 \\
\hline & 23 & 6 & 29 & $79,31 \%$ & 0,54 \\
\hline & 22 & 6 & 28 & $78,57 \%$ & 0,58 \\
\hline & 22 & 6 & 28 & $78,57 \%$ & 0,62 \\
\hline & 19 & 5 & 24 & $79,17 \%$ & 0,68 \\
\hline & 14 & 4 & 18 & $77,78 \%$ & 0,74 \\
\hline & 19 & 4 & 23 & $82,61 \%$ & 0,7 \\
\hline
\end{tabular}

\begin{tabular}{|c|c|c|c|c|c|}
\hline \multirow{16}{*}{$\begin{array}{c} \\
\text { Közép- } \\
\text { Dunántúl }\end{array}$} & \multicolumn{5}{|c|}{ NUTS2 (ne mek) } \\
\hline & Talált & Nem talált & Összesen & $\begin{array}{c}\text { Találati } \\
\text { pontos ság }\end{array}$ & Vágópont \\
\hline & 254 & 89 & 343 & $74,05 \%$ & 0,5 \\
\hline & 242 & 78 & 320 & $75,63 \%$ & 0,4 \\
\hline & 247 & 86 & 333 & $74,17 \%$ & 0,44 \\
\hline & 203 & 56 & 259 & $78,38 \%$ & 0,3 \\
\hline & 155 & 31 & 186 & $83,33 \%$ & 0,24 \\
\hline & 170 & 38 & 208 & $81,73 \%$ & 0,26 \\
\hline & 177 & 46 & 223 & $79,37 \%$ & 0,27 \\
\hline & & & & & \\
\hline & \multicolumn{5}{|c|}{ NUTS2 (igenek) } \\
\hline & Talált & Nem talált & Összesen & $\begin{array}{c}\text { Találati } \\
\text { pontos ság }\end{array}$ & Vágópont \\
\hline & 42 & 16 & 58 & $72,41 \%$ & 0,5 \\
\hline & 29 & 3 & 32 & $90,63 \%$ & 0,7 \\
\hline & 35 & 9 & 44 & $79,55 \%$ & 0,6 \\
\hline & 32 & 8 & 40 & $80,00 \%$ & 0,62 \\
\hline
\end{tabular}




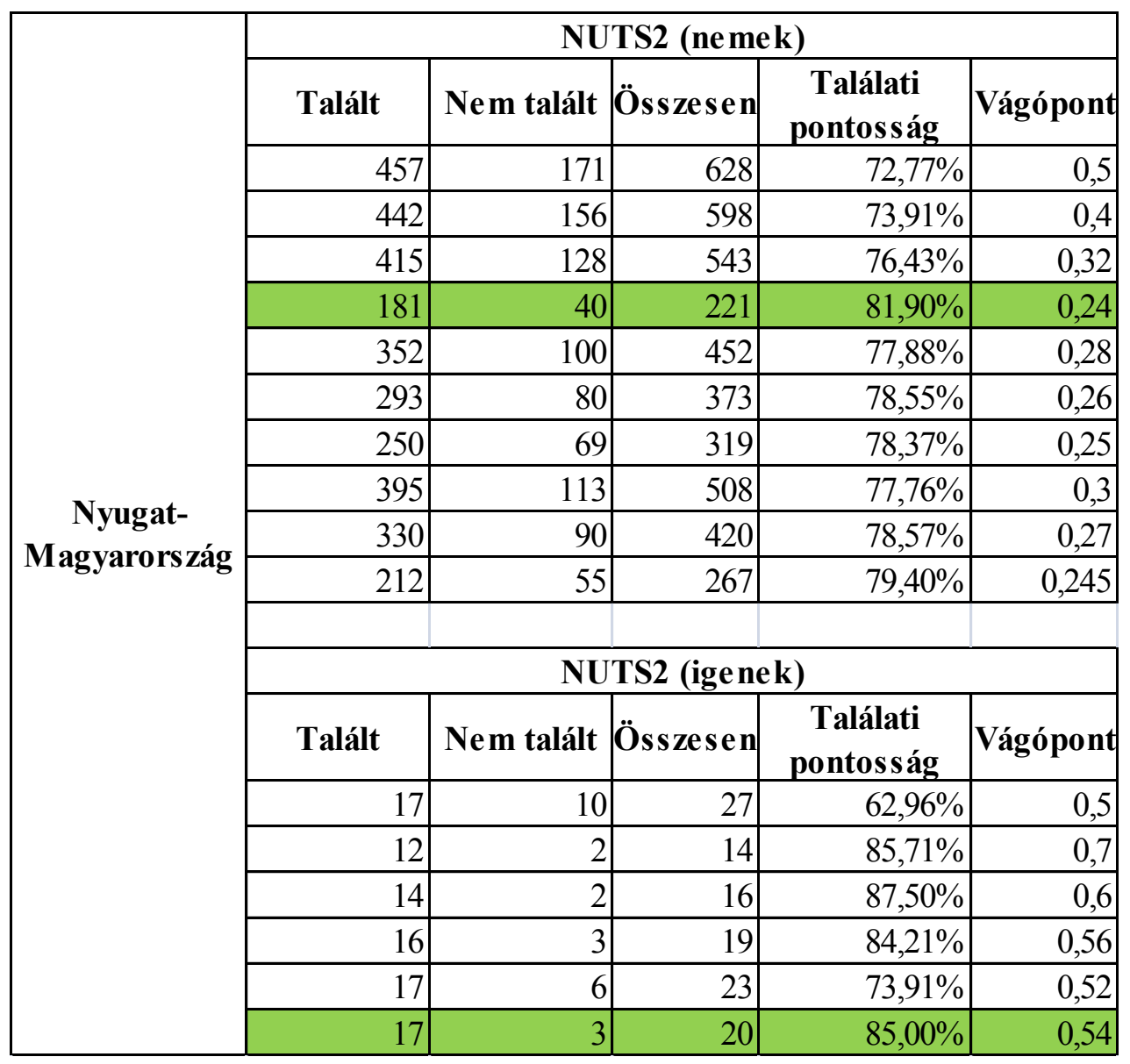

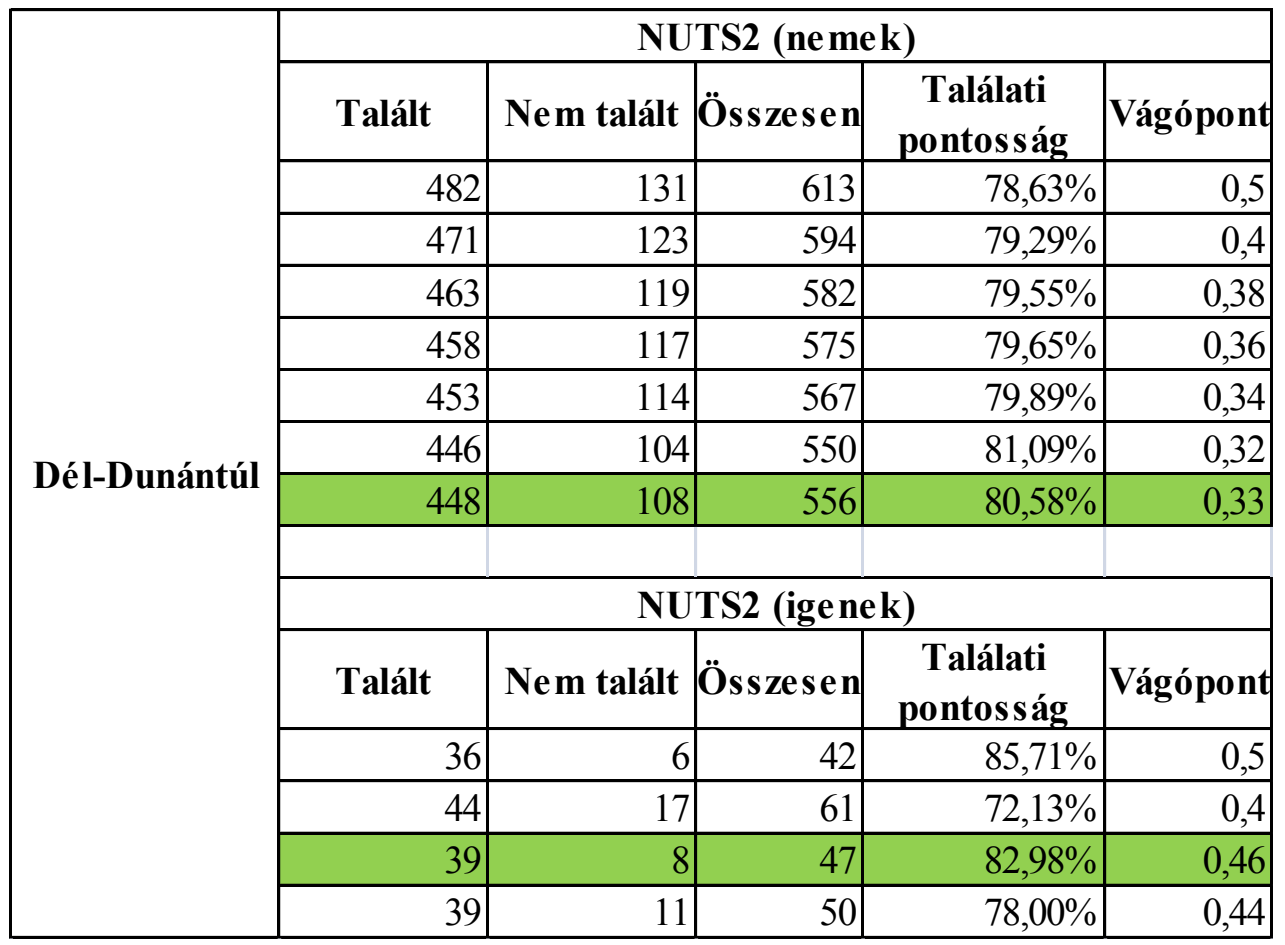




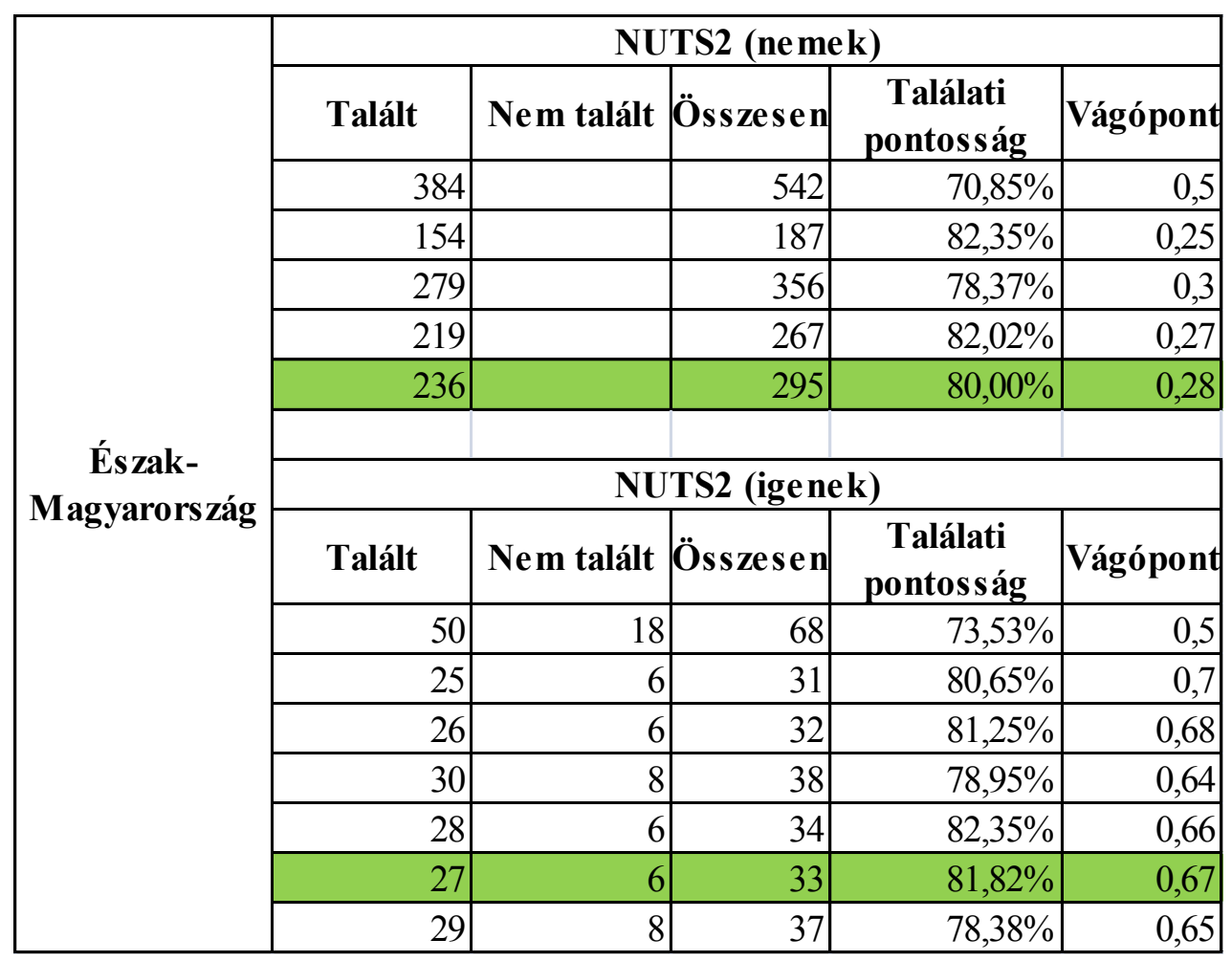

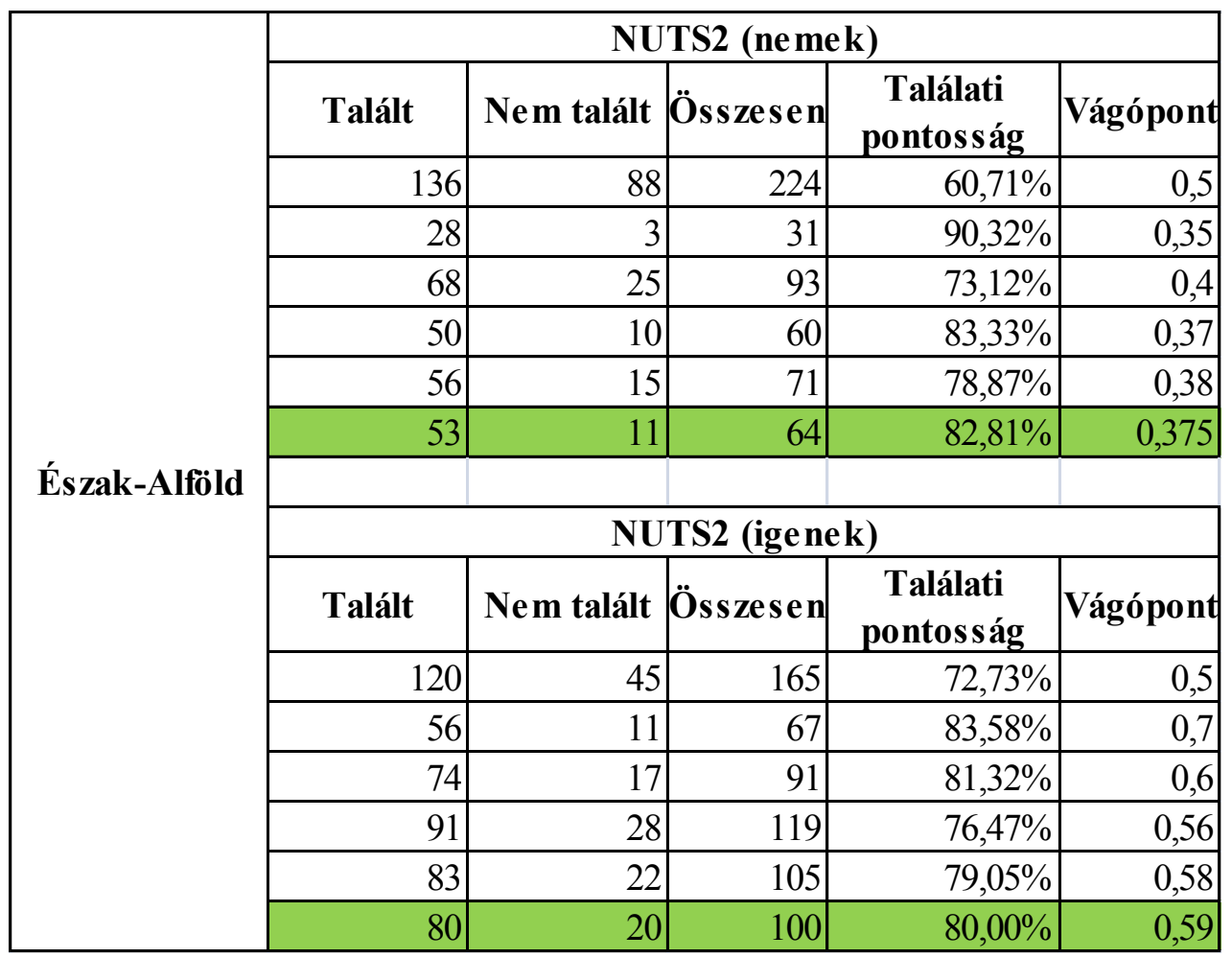




\begin{tabular}{|c|c|c|c|c|c|}
\hline \multirow{14}{*}{ Dél-Alföld } & \multicolumn{5}{|c|}{ NUTS2 (nemek) } \\
\hline & Talált & Nem talált & Ös szesen & $\begin{array}{c}\text { Találati } \\
\text { pontosság }\end{array}$ & Vágópont \\
\hline & 93 & 53 & 146 & $63,70 \%$ & 0,5 \\
\hline & 70 & 30 & 100 & $70,00 \%$ & 0,4 \\
\hline & 6 & 2 & 8 & $75,00 \%$ & 0,3 \\
\hline & 1 & 2 & 3 & $33,33 \%$ & 0,26 \\
\hline & & & & & \\
\hline & \multicolumn{5}{|c|}{ NUTS2 (igenek) } \\
\hline & Talált & Nem talált & Ös szesen & $\begin{array}{c}\text { Találati } \\
\text { pontosság }\end{array}$ & Vágópont \\
\hline & 85 & 23 & 108 & $78,70 \%$ & 0,5 \\
\hline & 66 & 11 & 77 & $85,71 \%$ & 0,6 \\
\hline & 73 & 17 & 90 & $81,11 \%$ & 0,54 \\
\hline & 77 & 19 & 96 & $80,21 \%$ & 0,52 \\
\hline & 81 & 21 & 102 & $79,41 \%$ & 0,51 \\
\hline
\end{tabular}


f2) Logisztikus regresszió becslöfüggvénye NUTS2 szinten

\begin{tabular}{|l|r|r|r|r|r|r|}
\hline \multicolumn{9}{|c|}{ Közép-Magyarország } \\
\hline & Logisztikus együttható (B) & Standard hiba & Wald-statisztika & df & Szignifikancia & Exp(B) \\
\hline költségvetési_tám_MD & 0,62 & 0,13 & 21,51 & 1 & 0,00 & 1,86 \\
\hline Constant & $-1,48$ & 0,24 & 37,54 & 1 & 0,00 & 0,23 \\
\hline
\end{tabular}

\begin{tabular}{|c|c|c|c|c|c|c|}
\hline \multicolumn{7}{|c|}{ Közép-Dunántúl } \\
\hline & Logisztikus együttható (B) & Standard hiba & Wald-statisztika & df & Szignifikancia & $\operatorname{Exp}(\mathrm{B})$ \\
\hline költségvetési_tám_MD & 1,17 & 0,44 & 7,05 & 1 & 0,01 & 3,21 \\
\hline adóbírság_MD & $-16,35$ & 4,54 & 12,95 & 1 & 0,00 & 0,00 \\
\hline pénzkészlet_MD & $-0,35$ & 0,20 & 3,17 & 1 & 0,07 & 0,70 \\
\hline szja_MD & 1,56 & 0,68 & 5,24 & 1 & 0,02 & 4,74 \\
\hline Constant & $-1,59$ & 0,17 & 84,52 & 1 & 0,00 & 0,20 \\
\hline
\end{tabular}

\begin{tabular}{|l|r|r|r|r|r|r|}
\hline \multicolumn{9}{|c|}{ Nyugat-Magyarország } \\
\hline & Logisztikus együttható (B) & Standard hiba & Wald-statisztika & df & Szignifikancia & Exp(B) \\
\hline szja_MD & 2,22 & 0,55 & 16,47 & 1 & 0,00 & 9,17 \\
\hline teért_MD & $-7,71$ & 2,01 & 14,70 & 1 & 0,00 & 0,00 \\
\hline rövidhitel_MD & 4,67 & 2,21 & 4,47 & 1 & 0,03 & 106,34 \\
\hline Constant & $-1,32$ & 0,12 & 114,39 & 1 & 0,00 & 0,27 \\
\hline
\end{tabular}

\begin{tabular}{|c|c|c|c|c|c|c|}
\hline \multicolumn{7}{|c|}{ Dél-Dunántúl } \\
\hline & Logisztikus együttható (B) & Standard hiba & Wald-statisztika & df & Szignifikancia & $\operatorname{Exp}(\mathrm{B})$ \\
\hline költségvetési_tám_MD & 1,12 & 0,24 & 20,85 & 1 & 0,00 & 3,05 \\
\hline pénzkészlet_MD & 2,31 & 1,15 & 4,03 & 1 & 0,04 & 10,02 \\
\hline IPAössz_MD & $-1,04$ & 0,36 & 8,52 & 1 & 0,00 & 0,35 \\
\hline Constant & $-1,67$ & 0,13 & 170,21 & 1 & 0,00 & 0,19 \\
\hline
\end{tabular}

\begin{tabular}{|l|r|r|r|r|r|r|}
\hline \multicolumn{9}{|c|}{ Észak-Magyarors zág } \\
\hline & Logisztikus együttható (B) & Standard hiba & Wald-statisztika & df & Szignifikancia & Exp(B) \\
\hline szja_MD & 2,17 & 0,36 & 36,21 & 1 & 0,00 & 8,79 \\
\hline Constant & $-1,40$ & 0,14 & 97,44 & 1 & 0,00 & 0,25 \\
\hline
\end{tabular}

\begin{tabular}{|l|r|r|r|r|r|r|}
\hline \multicolumn{9}{|c|}{ Észak-Alföld } \\
\hline & Logisztikus együttható (B) & Standard hiba & Wald-statisztika & df & Szignifikancia & Exp(B) \\
\hline költségvetési_tám_MD & 1,48 & 0,41 & 13,22 & 1 & 0,00 & 4,37 \\
\hline szja_MD & $-1,49$ & 0,72 & 4,25 & 1 & 0,04 & 0,23 \\
\hline Constant & $-0,64$ & 0,17 & 14,62 & 1 & 0,00 & 0,53 \\
\hline
\end{tabular}

\section{Dél-Alföld}

\begin{tabular}{|l|r|r|r|r|r|r|}
\hline \multicolumn{9}{|c|}{ Dél-Alföld } \\
\hline & Logisztikus együttható (B) & Standard hiba & Wald-statisztika & df & Szignifikancia & Exp(B) \\
\hline szja_MD & 1,68 & 0,42 & 16,34 & 1 & 0,00 & 5,36 \\
\hline teért_MD & $-12,71$ & 3,70 & 11,79 & 1 & 0,00 & 0,00 \\
\hline hosszúhitel_MD & 4,79 & 1,77 & 7,28 & 1 & 0,01 & 119,88 \\
\hline Constant & $-0,91$ & 0,23 & 15,95 & 1 & 0,00 & 0,40 \\
\hline
\end{tabular}


g1) Logisztikus regresszió eredményei saját területi bontás szerint

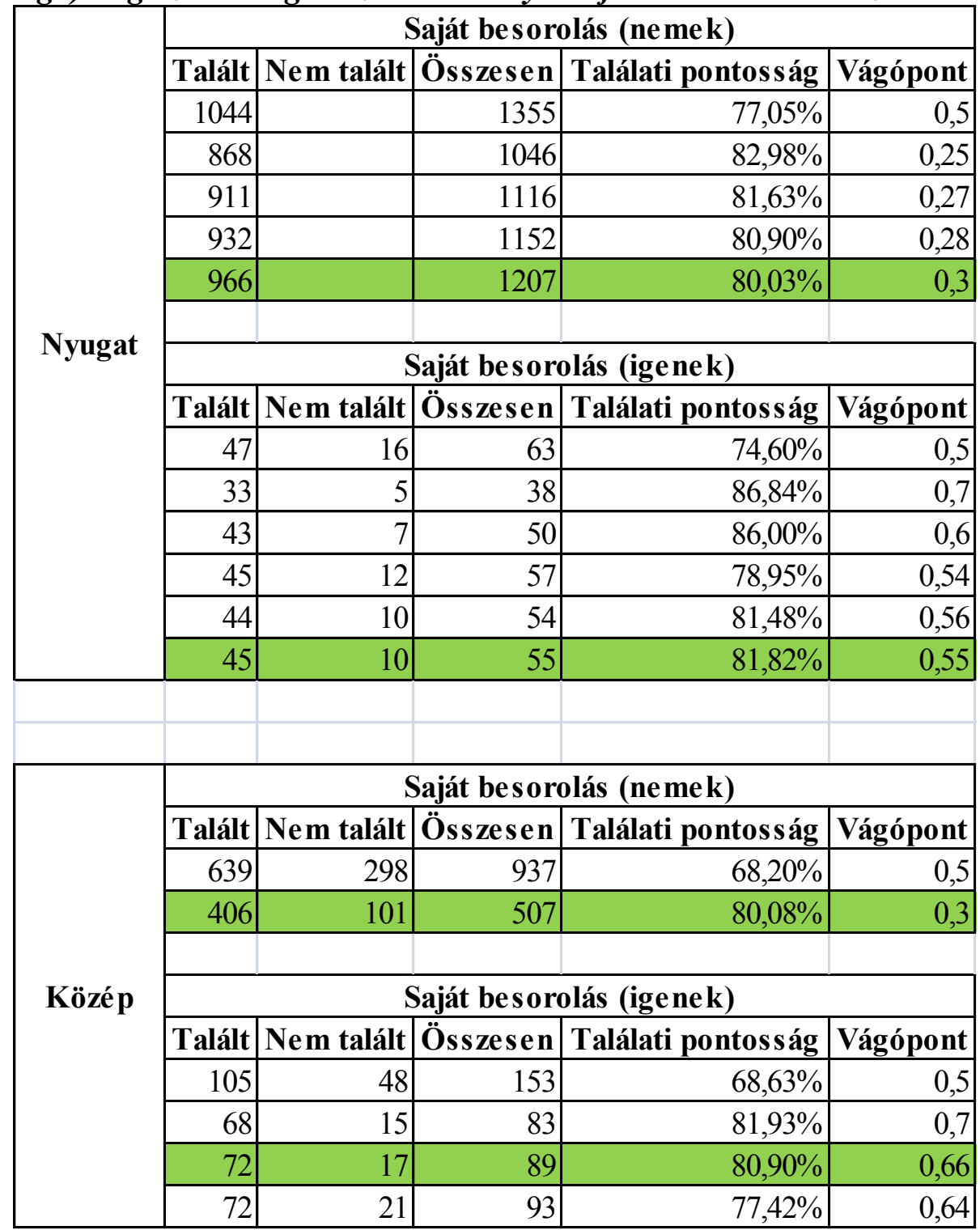




\begin{tabular}{|c|c|c|c|c|c|}
\hline \multirow{16}{*}{ Kelet } & \multicolumn{5}{|c|}{ Saját besorolás (nemek) } \\
\hline & Talált & Nem talált & Összesen & Találati pontos ság & \begin{tabular}{|l|} 
Vágópont \\
\end{tabular} \\
\hline & 236 & 158 & 394 & $59,90 \%$ & 0,5 \\
\hline & 118 & 45 & 163 & $72,39 \%$ & 0,4 \\
\hline & 44 & 10 & 54 & $81,48 \%$ & 0,36 \\
\hline & 60 & 19 & 79 & $75,95 \%$ & 0,37 \\
\hline & 51 & 13 & 64 & $79,69 \%$ & 0,365 \\
\hline & \multicolumn{5}{|c|}{ Saját besorolás (igenek) } \\
\hline & \begin{tabular}{|l|} 
Talált \\
\end{tabular} & Nem talált & Összesen & Találati pontos ság & \begin{tabular}{|l|} 
Vágópont \\
\end{tabular} \\
\hline & 189 & 60 & 249 & $75,90 \%$ & 0,5 \\
\hline & 134 & 26 & 160 & $83,75 \%$ & 0,6 \\
\hline & 124 & 22 & 146 & $84,93 \%$ & 0,64 \\
\hline & 150 & 29 & 179 & $83,80 \%$ & 0,56 \\
\hline & 166 & 39 & 205 & $80,98 \%$ & 0,54 \\
\hline & 176 & 46 & 222 & $79,28 \%$ & 0,52 \\
\hline & 171 & 40 & 211 & $81,04 \%$ & 0,53 \\
\hline
\end{tabular}


g2) Logisztikus regresszió becslöfüggvénye saját területi bontás szerint

\begin{tabular}{|l|r|r|r|r|r|r|}
\hline \multicolumn{1}{|c|}{ Nyugat } \\
\hline & Logisztikus együttható (B) & Standard hiba & Wald-statisztika & df & Szignifikancia & Exp(B) \\
\hline költségvetési_tám_MD & 1,19 & 0,17 & 51,76 & 1 & 0,00 & 3,29 \\
\hline teért_MD & $-2,35$ & 0,64 & 13,64 & 1 & 0,00 & 0,10 \\
\hline Constant & $-1,48$ & 0,08 & 352,41 & 1 & 0,00 & 0,23 \\
\hline
\end{tabular}

\begin{tabular}{|l|r|r|r|r|r|r|}
\hline \multicolumn{9}{|c|}{ Közép } \\
\hline & Logisztikus együttható (B) & Standard hiba & Wald-statisztika & df & Szignifikancia & Exp(B) \\
\hline helyiadoossz_MD & $-0,47$ & 0,14 & 11,93 & 1 & 0,00 & 0,63 \\
\hline költségvetési_tám_MD & 0,51 & 0,16 & 10,58 & 1 & 0,00 & 1,66 \\
\hline sajátbev_MD & 0,36 & 0,12 & 8,46 & 1 & 0,00 & 1,43 \\
\hline hosszúhitel_MD & $-0,50$ & 0,18 & 7,42 & 1 & 0,01 & 0,61 \\
\hline Constant & $-1,22$ & 0,10 & 159,88 & 1 & 0,00 & 0,30 \\
\hline
\end{tabular}

\begin{tabular}{|l|r|r|r|r|r|r|}
\hline \multicolumn{9}{|c|}{ Kelet } \\
\hline & Logisztikus együttható (B) & Standard hiba & Wald-statisztika & df & Szignifikancia & Exp(B) \\
\hline költségvetési_tám_MD & 0,59 & 0,14 & 18,44 & 1 & 0,00 & 1,80 \\
hosszúhitel_MD & 3,22 & 1,09 & 8,71 & 1 & 0,00 & 25,11 \\
\hline Constant & $-0,67$ & 0,13 & 25,40 & 1 & 0,00 & 0,51 \\
\hline
\end{tabular}


h) Az európai uniós támogatásban részesült települések gyakorisága nagyság szerinti rétegezésben

\begin{tabular}{|c|c|c|c|}
\hline $\begin{array}{l}\text { Méret sze rinti } \\
\text { rétegezés }\end{array}$ & $\begin{array}{c}\text { Európai uniós } \\
\text { támogatásban } \\
\text { rés zes ültt-e }\end{array}$ & Gyakoriság & $\%$ \\
\hline \multirow{3}{*}{500 fó alatt } & Nem kapott & 866 & 83,6 \\
\hline & Részesült & 170 & 16,4 \\
\hline & Összesen & 1036 & 100,0 \\
\hline \multirow{3}{*}{ 500-4999 fö } & Nem kapott & 1110 & 60,8 \\
\hline & Részesült & 716 & 39,2 \\
\hline & Összesen & 1826 & 100,0 \\
\hline \multirow{3}{*}{ 5000-9999 fö } & Nem kapott & 41 & 28,5 \\
\hline & Részesült & 103 & 71,5 \\
\hline & Összesen & 144 & 100,0 \\
\hline \multirow{3}{*}{ 10000-49999 fö } & Nem kapott & 26 & 20,8 \\
\hline & Részesült & 99 & 79,2 \\
\hline & Összesen & 125 & 100,0 \\
\hline 50000 fö felett & Részesült & 20 & 100,0 \\
\hline
\end{tabular}


i) Logisztikus regresszió eredményei 500-999 fó és 1000 - 4999 fö lélekszámú települések esetében

\begin{tabular}{|c|c|c|c|c|c|}
\hline \multirow{13}{*}{$\begin{array}{l}\text { 500-999 fó } \\
\text { léle ks zámú } \\
\text { te le pülés e k }\end{array}$} & \multicolumn{5}{|c|}{ Saját besorolás (ne mek) } \\
\hline & Talált & Nem talált & Összesen & Találati pontosság & Vágópont \\
\hline & 985 & 515 & 1500 & $65,67 \%$ & 0,5 \\
\hline & 307 & 76 & 383 & $80,16 \%$ & 0,28 \\
\hline & 363 & 97 & 460 & $78,91 \%$ & 0,29 \\
\hline & 332 & 89 & 421 & $78,86 \%$ & 0,285 \\
\hline & & & & & \\
\hline & \multicolumn{5}{|c|}{ Saját besorolás (ige nek) } \\
\hline & Talált & Nem talált & Összesen & Találati pontosság & Vágópont \\
\hline & 201 & 125 & 326 & $61,66 \%$ & 0,5 \\
\hline & 60 & 21 & 81 & $74,07 \%$ & 0,7 \\
\hline & 40 & 19 & 59 & $67,80 \%$ & 0,75 \\
\hline & 28 & 10 & 38 & $73,68 \%$ & 0,8 \\
\hline & & & & & \\
\hline \multirow{10}{*}{$\begin{array}{c}1000 \text { - } 4999 \text { fö } \\
\text { léle kszámú } \\
\text { te le pülés s k }\end{array}$} & \multicolumn{5}{|c|}{ Saját besorolás (nemek) } \\
\hline & Talált & Nem talált & Összesen & Találati pontosság & Vágópont \\
\hline & 3 & 3 & 6 & $50,00 \%$ & 0,5 \\
\hline & & & & & \\
\hline & \multicolumn{5}{|c|}{ Saját besorolás (igenek) } \\
\hline & Talált & Nem talált & Összesen & Találati pontosság & Vágópont \\
\hline & 100 & 38 & 138 & $72,46 \%$ & 0,5 \\
\hline & 84 & 26 & 110 & $76,36 \%$ & 0,6 \\
\hline & 78 & 19 & 97 & $80,41 \%$ & 0,64 \\
\hline & 79 & 20 & 99 & $79,80 \%$ & 0,63 \\
\hline
\end{tabular}

